\title{
Joan Roís de Corella, la seua vida i el seu entorn: noves dades per a la història de la cultura en la València del segle XV
}

\author{
Jaume J. Chiner Gimeno \\ Biblioteca Valenciana - Generalitat Valenciana \\ chiner jai@gva.es \\ http://orcid.org/OOOO-OOO3-2I6I-75I2 \\ Rebut 08/oI/20I4; acceptat 25/o6/20I4 \\ DOI Io.7203/MCLM.I.3934
}

\section{Joan Roís de Corella, his life and his associates: New data for the history of culture in fifteenth-century Valencia}

Abstract

This article offers a full updating of the biographical records of the writer Joan Roís de Corella (I435-I497) and his family: his great-grandparents, grandparents, parents, siblings and children. All data are presented in a systematic way, generation by generation, and a new vision of the writer himself is offered. In its documentary section, 432 documents are transcribed or summarised, dating from I373 to I5 16 . A broad range of new archival data is presented; other previously known data are corrected or improved.

Some examples: Joan Roís de Corella had four children: Magdalena (born I459), Maria, Joan and Estefania, the latter two by Isabel Martínez de Vera. Joan Roís de Corella was widely known and respected amongst the citizens of Valencia; he was frequently sought out for positions of trust, such as being the executor of wills. New documents testify to the long period over which Corella preached, and details are given of this, particularly his preaching activities in his last years. Further data are given on his relationship with the Borja family. Magdalena Roís de Corella, his daughter, was married to another writer, son of the notary Pero Pérez: Miquel Pérez -who, therefore, turns out to be Corella’s son-in-law. Miquel Pérez's library had more than 75 books, among which several new Italian titles stand out. New documentation is given of business transactions by Isabel Martínez de Vera regarding copies of Joan Roís de Corella’s translation of the Vita Christi by Ludolph of Saxony. The date on which jurats of the city of Valencia licensed Joan Roís de Corella, the writer's son, to print a "Passis" is also modified. Finally, an exact localization is given for the respective houses in which Joan Roís de Corella, Dalfina Roís de Corella and Isabel Martínez de Vera and her children lived.

In a significant part of this documentation, new information is provided which affects our knowledge of other important characters in fifteenth-century Valencia, such as Bernat Fenollar, Joan Escrivà, Berenguer Mercader, Jaume Roig, Lluís de Castellví, Guillem Ramon de Vila-rasa and Elionor Flors de Vallterra.

KEYWORDS

Joan Roís de Corella; literary biography; Miquel Pérez; Ludolph of Saxony; Vita Christi; late medieval translations of religious texts; fifteenth-century preaching; late medieval libraries; medieval hospitals; medieval preaching; non-priestly preachers; fifteenth- and sixteenth-century printing trade; Valencia city; archives; Crown of Aragon; fifteenth- and sixteenth-century.

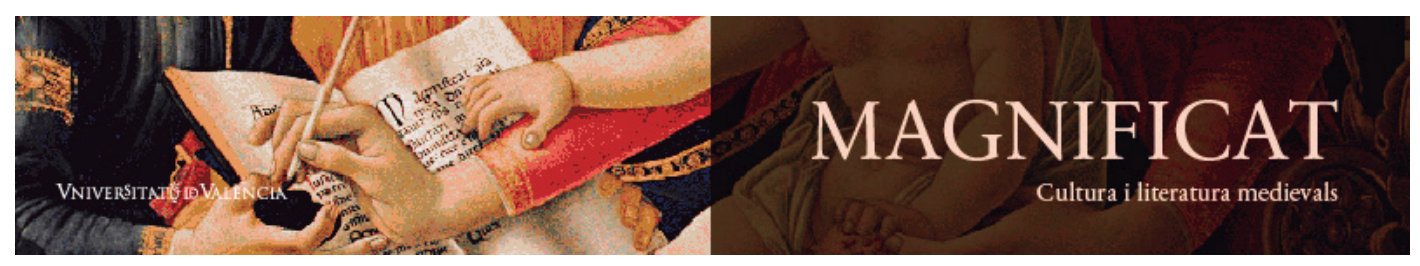

Magnificat Cultura i Literatura Medievals I, 20I4, III-377. http://ojs.uv.es/index.php/MCLM

ISSN 2386-8295 
RESUM

Aquest estudi fa un àmplia actualització de dades biogràfiques sobre l'escriptor Joan Roís de Corella (I435-I497) i la seua família, els seus besavis, avis, pares, germans i fills. L'article presenta les dades de manera sistemàtica, generació per generació, i ofereix una nova visió del propi escriptor. A la secció documental, es regesten o es transcriuen 432 documents, datats entre els anys I373 і I5 6 . S'hi presenta una extensa bateria de noves dades d'arxiu; se'n corregeixen o precisen d'altres prèviament conegudes.

Alguns exemples: Joan Roís de Corella tenia quatre fills: Magdalena (nascuda en I459), Maria, Joan i Estefania; els dos darrers, més joves, d’Isabel Martínez de Vera. Joan Roís de Corella apareix com a persona molt coneguda i respectada entre els seus conciutadans, i freqüentment rep encàrrecs de confiança, com fer de marmessor. Nous documents testimonien el llarg arc de temps en què Corella va predicar, i se’n donen detalls particularment de la predicació en els últims anys de la seua vida. També es donen dades sobre la seua relació amb la família Borja. Magdalena Roís de Corella, filla de l’escriptor, va casar amb un altre escriptor, fill del notari Pero Pérez: Miquel Pérez - que, per tant, resulta ser gendre de Corella. La biblioteca de Miquel Pérez tenia més de setanta-cinc llibres, d'entre els quals destaquen, per novedosos, els títols italians. Nova documentació sobre transaccions comercials d’Isabel Martínez de Vera amb exemplars del Cartoixà de Joan Roís de Corella. Es modifica la data en què els jurats de la ciutat de València van donar llicència d'impressió al fill de Joan Roís de Corella per a imprimir “un Passis”. Així mateix, s’ofereix localització exacta de les cases respectives de Joan Roís de Corella, de Dalfina Roís de Corella, i d’Isabel Martínez de Vera i fills.

En una part significativa d'aquesta documentació, es donen notícies que afecten altres importants personatges de la València del xv, com Bernat Fenollar; Joan Escrivà, Berenguer Mercader, Jaume Roig, Lluís de Castellví, Guillem Ramon de Vila-rasa i Elionor Flors de Vallterra.

PARAULES CLAU

Joan Roís de Corella; biografia literària; Miquel Pérez; Miquel Peres; Ludolf de Saxònia; Vita Christi; traduccions de textos religiosos; Cartoixà; predicació al s. Xv; biblioteques medievals; hospitals medievals; predicació medieval; predicadors no capellans; negoci de la impremta als segles XV-XVI; ciutat de València; arxius; Corona d’Aragó; segles $\mathrm{XV}-\mathrm{XVI}$

Jaume J. Chiner Gimeno, 20I4, “Joan Roís de Corella, la seua vida i el seu entorn: noves dades per a la història de la cultura en la València del segle Xv", Magnificat Cultura i Literatura Medievals I, III-377. (c) BY

TABLA DE CONTENIDOS

I Els orígens familiars i la cort ducal de Gandia: els Cabrera i els Roís de Corella - II4

I.I Els Cabrera. - II4

I.2 Els Roís de Corella - I2I

${ }_{2}$ D'Ausiàs Roís de Corella a Dalfina: els pares i germans de l'escriptor - I27

2.I Ausiàs Roús de Corella i Aldonça de Cabrera, els pares - I27

2.2 Fra Manuel, sor Aldonça, Lluís i Dalfina Roís de Corella, els germans - 140

2.2.I Fra Manuel, cavaller de l'orde de Montesa - I4O

2.2.2 Sor Aldonça, monja de la Trinitat de València - I45

2.2.3. Lluís Roís de Corella - I48

2.2.4 Dalfina Roís de Corella - I5O

3 El cavaller i mestre en teologia Joan Roís de Corella: vida pública, vida privada - I57

3.I Joan Roís de Corella, cavaller i mestre en teologia - 157

3.2 De Maria a Estefania: La descendència de l'escriptor - 199

3.2.I Maria Roís de Corella - I99

3.2.2 Magdalena Roís de Corella, esposa de Miquel Pérez - 200

3.2.3 Isabel Martínez de Vera i els seus fills, Joan i Estefania - 208

4 Secció documental -220

5 Arbres genealògics - 366

5.I Arbre genealògic Joan Roís de Corella, cavaller i mestre en teologia - 366

5.2 Arbre genealogic família Pere Roís de Corella-Saura d'Esplugues - 367

5.3 Arbre genealògic família Figuerola-Roís de Corella - 368

5.4 Arbre genealogic Isabel Martínez de Vera - 369

5.5 Arbre genealògic Miquel Pérez-Magdalena Roús de Corella - 370

6 Obres citades $-37 \mathrm{I}$

Magnificat CLM I,20I4, III-377. ISSN 2386-8295 


\section{ə*⿻}

A don Martí de Riquer, in memoriam

$\mathrm{P}$ er les venes del cavaller i mestre en teologia Joan Roís de Corella fluïa la sang de dues famílies de la noblesa menor valenciana: els Cabrera, senyors d'Almiserà i de Ròtova, i els Roís de Corella, senyors de Benieto i de Miraflor, amb càrrecs en la cort ducal de Gandia i forts llaços familiars amb els March. ${ }^{1}$

Nascut el 28 de setembre de I435, Roís de Corella és el més important escriptor de la València de finals del s. XV. La seua biografia era incerta fins que don Martí de Riquer ens va proporcionar dades genealògiques segures en I964, al tercer volum de la seua Història de la literatura catalana. Posteriorment, diversos treballs nostres publicats en I994 i 1997 aportaren noves dades biogràfiques sobre Joan Roís de Corella i, especialment, sobre els seus progenitors, avis i besavis.

Al llarg dels anys d'investigació destinats a la realització de la nostra antiga tesi doctoral, havíem reunit un ample repertori documental, sobre Corella i altres escriptors valencians de l'època, que proporcionava noves dades biogràfiques sobre l'autor de la Tragèdia de Caldesa; dades en alguns casos molt sorprenents, i que iluminaven fortament la trajectoria vital d'aquest escriptor. Aquestes dades no s'inclogueren en la versió final de la nostra tesi; tan sols consideràrem oportú esbossarles mínimament en la breu biografia de Roís de Corella que realitzàrem en l'abril de 20r3 per a la Biblioteca Virtual Miguel de Cervantes (Chiner 20I3). En aquesta breu biografia, moltes de les dades velles i noves que avui publiquem eren absents, tant per raons de l'espai donat -que, per altra banda, és el lògic en el tipus d'article demanat per al format de biblioteca virtual- com per raons personals referides a l'oportunitat temporal de donar-ne a conéixer la majoria en aquell moment; ho fem ara, amb aquest article.

En la primera part parlarem detalladament de les famílies Cabrera i Roís de Corella, seguint d'una manera molt propera el tipus de redacció donat a Chiner 1997, i aprofitem per corregir-ne les errates que hi apareixien. Ara, a més, proporcionem abundants notícies arxivístiques importants, abans desconegudes, i rectifiquem dades prèviament publicades, quan els nous documents localitzats ens han portat a fer-ho.

I. Aquest extens treball no es pot entendre ni ser la realitat que avui és, sense l'ajuda i el suport d'una sèrie de persones al llarg del temps i, per això, està dedicat a elles:

A don Martí de Riquer, savi entre els savis i millor persona, per la seua constant ajuda cada volta que a ell vaig acudir des de València, pel seu constant ànim i comprensió malgrat que moltes vegades les dades que li exposava o consultava modificaven les seues. Ell em va mostrar que, dins de la universitat, l’inteligència i la saviesa no estaven en contradicció amb la bondad personal i el suport sense amagats interessos. Sense ell i el seu esperit, la nostra història de la literatura sempre estarà òrfena i jo també.

Al personal i responsables de tots els arxius consultats -que vull representar en les persones del Rev. Juan José Garrido, del Reial Col-legi Seminari del Corpus Christi de València, i de Francesc Torres, de l’Arxiu del Regne de València- per les facilitats que sempre he tingut per accedir a la documentació que s’hi custodia.

A Rosanna Cantavella, professora de la Universitat de València, en qui sempre he trobat un port segur on acudir en demanda d'ajuda i consell. Sense la seua pacència, ànim i comprensió aquest article avui no veuria la llum. 
En la segona part, aprofundirem en les biografies del pares i germans de Joan Roís de Corella, i en les relacions d'aquests amb el prosista i poeta; unes relacions que, en algun cas com el de la seua gemana Dalfina, són clau per a veure, amb nova llum, alguns dels aspectes més foscos per a la crítica literària de la biografia de Corella.

Per últim, en la tercera part ens centrarem en la biografia de l'escriptor, i en la seua trajectòria vital i anímica, que portarà l'escriptor a centrar-se en els aspectes socials de la seua vocació de predicador i a ser conegut, en la València de finals del XV, sobretot com a mestre en teologia. En aquesta biografia exposarem una sèrie de nous documents que ens parlaran, amb noves perspectives, de Corella i dels seus fills- alguns d'ells desconeguts fins ara-, dels seus amors, dels seus lligams amb altres lletraferits valencians, de les raons que motivaren que el prosista i poeta no fera esment en el seu darrer testament de la seua amistançada, Isabel Martínez de Vera, i dels seus fills.

Conclourem amb una secció documental on regestem o transcrivim 432 documents d'entre els anys I373 і I5I6; si bé, al llarg de l'article, aportem més de 5 oo documents diferents relacionats amb Joan Roís de Corella

\section{Els orígens familiars i la cort ducal de Gandia: els Cabrera i els Roís de Corella}

\section{I.I Els Cabrera.}

Un dels primers documents que coneixem sobre Joan de Cabrera, habitant de Gandia i avi matern de l'autor de la Tragèdia de Caldesa, és un pacte establit el 30 d'abril de I373 entre ell i el notari de la vila ducal Bertomeu Dalmau per a la recuperació per aquest darrer de 450 sous censals que, anteriorment, el notari i la seua esposa havien venut a Cabrera, i que estaven carregats sobre els béns dels moros de l'alqueria de "Rafal d'en Síscar". ${ }^{2}$ D’aquest document es pot deduir que, en aquesta data, Joan de Cabrera ja tenia més de 20 anys, que és l'edat legal, segons els Furs, per a tenir capacitat individual jurídica plena per a contractar i realitzar accions comercials.

Ja en I379 el trobem lligat a la cort del marqués de Villena, qui li abonarà I2.240 sous "per preu d'aquells MXX sous que.l senyor marqués li fahia de cens mort cascun any" (doc. 3 ) i 200 sous com a salari anual pel "seu ofici de procurador de Pere March, procurador general del marqués" (doc. 5).

En octubre de 1387 , Joan de Cabrera figura com a testimoni en un document de Pere March, senyor de Beniarjó i pare del poeta Ausiàs March (doc. Io). Pere March era cosí de Joan de Cabrera, segons declara el senyor de Beniarjó al seu testament del 9 de desembre de I4IO. ${ }^{3}$ El pare d'Ausiàs l'elegí com a marmessor al costat de Joan Roís de Corella, avi de l'escriptor homònim i també cosí de Pere March (docs. 46 i 53), tal com també havia fet ja el I396 Joan March, fill del poeta Pere March i germanastre d’Ausiàs (doc. 24). ${ }^{4}$ A més a més, Joan de Cabrera tindrà un paper força important en els primers anys de la vida d'Ausiàs March atés que, d'acord amb el document de la seua emancipació, ell serà el tutor judicial d'Ausiàs l'any I409 (docs. 44 i 45).

Lògicament, la relació entre Joan de Cabrera, senyor d'Almiserà, ${ }^{5}$ i els March no es reduirà tan

2. AHN, clero secular regular, carpeta 3І63, no. 5. Aquest document s'establí davant el notari Ramon Dalmau i figura com a testimoni el veí de Gandia Arnau March.

3. Sobre Ausiàs March i la seua família, vid. Chiner i997.

4. Com a marmessors testamentaris de Joan March, Joan Roís de Corella i Joan de Cabrera realitzaran diferents pagaments en I398 a servidors de March i al prior del monestir de Cotalba (docs. 28, 29, 30 i 3I).

5. Consta com a senyor al doc. 67 , si bé desconeixem des de quina data ho era. Segons el doc. II3, el lloc d'Almiserà 
sols a tasques de tipus testamentari. En aquest sentit, cal assenyalar que, el 3 de novembre de I386, a Gandia, Joan de Cabrera, com a procurador del referit Joan March, reconeix haver rebut de Francesc Cerola, despenser de la vila, 250 sous deguts de la paga de Tots Sants per raó d’un censal de 5 OO sous pagadors en dues meitats. ${ }^{6}$ Cabrera figurarà com a testimoni en un altre document, datat a Gandia el 8 d'abril de I396, on Violant March, com a procuradora del seu marit segons constava en escriptura davant el notari Gonçalbo Caplana feta a Gandia el iz de gener de i387, reconeix a Roseta, vídua del cavaller Pere de Thous, el lliurament de 484 sous d'aquells 968 sous censals anuals que feien al seu espòs (doc. 25).

Anys després, el I3 de desembre de I4OI, Joan de Cabrera figura com a procurador d’Aldonça, vídua de Ramon Castellà -menor de dies-i hereua universal de la seua mare Violant March -vídua de Bonafonat de Vallebrera i germana de Pere March-, reconeixent haver rebut de Bertomeu Martí, despenser i clavari de la vila de Gandia, 200 sous deguts de la paga del mes de novembre d'un censal. $^{7}$

Així mateix, la seua estreta relació amb Pere March el farà exercir el càrrec de lloctinent d'aquest procurador general ducal. El veiem en aquesta funció en gener de I392, en juliol de I398 (docs. 20 i 32), i, també, el I8 de març de I4O4 quan, a Gandia en presència seua i dels jurats de la vila ducal, el marqués de Villena dictà una sentència referent a diferents debats i qüestions sobre el camí del barranc anomenat de Benirrugat i sobre les terres "heremes" del dit barranc. ${ }^{8}$ Fins i tot serà el propi Joan de Cabrera qui dictarà sentència, per ordre del marqués i com a lloctinent de Pere March, en les diferències entre Pere Celler, habitant de Polop, i el notari de Callosa Jaume Ivarç (doc. 39).

En I4O7 Joan de Cabrera tenia un lloc destacat a la cort de Gandia, tal com mostra el fet que, en aquesta data, serà ell una de les persones esmentades, al costat de Pere March, pel marqués de Villena per a rebre certes quantitats degudes a la vila de Gandia en un moment de conflicte amb el comte de Dénia (doc. 42).

Alamanda, l'esposa de Joan de Cabrera, era filla del mercader de la ciutat de València Pere de Montsant (doc. 73). A banda d'Ausiàs de Cabrera i d'Aldonça -la mare de Joan Roís de Corella-, d'aquest matrimoni seu va tenir, almenys, una filla que casà amb Mateu de Bondia, també mercader de València, i que donà a llum un nen, Joan de Bondia, abans d'octubre de I420. ${ }^{9}$

El 25 d'agost de I4I4, el cavaller Joan de Cabrera encara es trobava viu i cobrava un censal de mans del despenser de Gandia (doc. 5I). Hi testà davant el notari Ramon Agualada el I8 d'abril de I4I4, i establí un codicil rebut pel notari Pere Pugeriol el I8 de juliol següent (doc. 6o). Morí al voltant del I8 de setembre de I4I4, dia en què es publicaren les seues darreres voluntats per mort del testador a la mateixa vila (doc. II2). Al seu testament, Cabrera elegí com a marmessors l'esmentat notari Agualada i el prevere Guillem Pons. Hi nomenà hereu universal el seu fill Ausiàs, qui estaria sotmés a la tutoria i curadoria dels marmessors testamentaris fins arribar als vint anys d'edat.

estava dins el terme de Palma, i afrontava amb el territori de Llutxent, Castellonet, Alfauir i Ròtova.

6. L’escriptura de procuració va ser signada per Joan March, davant el notari Guerau Utal, en Biar el 3o d'octubre de I386 (doc. 9). L'anterior 9 d'octubre figura com a testimoni d'una àpoca atorgada per Ramon de Fontcuberta (ARV, Batlia, pergamins, no. I5I).

7. Doc. 34. L'acte de procuració de Joan de Cabrera va ser signat davant el notari Bertomeu Bonet a València el Io de desembre de I397.

8. Doc. 36. Tant Pere March com els jurats havien estat comissionats pel duc de Gandia per a entendre en els debats i reconéixer personalment el camí i terres en disputa. Joan de Cabrera figurarà, uns mesos després, com a testimoni d'altra sentència del marqués de Villena (doc. 37 ).

9. Doc. 73. El Io d'octubre de I420, Alamanda va lliurar al seu nét totes les quantitats que els mercaders Pere i Joan Bas devien al seu pare Pere de Montsant. Desconeixem en quina data exacta va nàixer Joan de Bondia. 
Entre els treballs més significatius d'aquesta marmessoria, cal assenyalar la contractació per Ramon Agualada, el 3 d'abril de I4I5, del pintor de la ciutat de València Antoni Pérez per a la realització d'un retaule per a la capella de Joan de Cabrera. ${ }^{10}$ Desconeixem si aquesta capella és la mateixa que Cabrera contractà construir a l'església de Xàtiva el ı2 de juliol de I399 amb el pedrapiquer Bertomeu Rufes, de la mateixa ciutat de l'actual comarca de la Costera, per i2o florins d'Aragó. ${ }^{11}$

Prop d'un any després, el 7 de gener de I_16, el prevere Mateu Roís de Corella reconeix haver rebut dels marmessors testamentaris de Cabrera -el prevere Guillem Pons i el notari Ramon Agualada - certa quantitat de diners, un missal, uns draps i certes peces de tela per a la capella del difunt (doc. 55). El mateix dia, aquest prevere, com a beneficiat d'un benifet instituït pel difunt, també reconeixia a Agualada el lliurament d'un calze d'argent, una patena, un “vestimentum album et rubeis" i un missal (doc. $\left.5^{6}\right)$.

Com a tutor dels fills de Joan de Cabrera, Ramon Agualada anualment lliurava als fills del difunt 4.ooo sous dividits en quatre pagues iguals. ${ }^{12}$ Així mateix, en el exercici del seu càrrec testamentari, l'hem trobat repetides vegades en relació amb la compra i venda de censals lligats, bé a particulars, ${ }^{13}$ bé als representants institucionals de llocs com Palma ${ }^{14}$ i Gata. ${ }^{15}$

En la seua condició de tutor i curador, va signar un acord on participà Ausiàs March, que ens permet relacionar, per primera volta, els Cabrera amb un lloc-Ròtova- del qual després seran senyors. El 26 de setembre de I4I8, Joan de Flovià -senyor de Ròtova i ciutadà de València, prometé a Ramon Agualada, com a curador dels fills del senyor d'Almiserà, que l'aigua de la font anomenada Baclamala, que ell volia portar a Ròtova, després d'ésser "engranada" a la séquia del Balancar "no cubrirà ans la portarà descuberta per ço que el senyor i moros de Almicerà, hayan servitut en aquella per seu obs i necesitat, abrevar besties, etc" (doc. 67).

En morir aquest notari, la tutoria i curadoria dels fills de Joan de Cabrera l'exercí Guillem Pons, marmessor amb ell del darrer testament de Cabrera, ${ }^{16}$ qui va dur a terme aquest càrrec d'una manera semblant a Agualada fins que Ausiàs, fill i hereu de Joan de Cabrera, arribà als vint anys. ${ }^{17}$

IO. El I7 de juny de I4I6, el pintor de la ciutat de València Antoni Pérez li reconeix el pagament dels i.ooo sous acordats per fer un retaule per a la capella del difunt, així com el lliurament de 2 florins d'or "quibus emi les polseres" del retaule i d'altres 5 sous, 6 diners que costà adaptar "staginum dicti retabli" (doc. 59). Figura, erròniament, el dia 3 de juliol en Chiner I998, I7.

II. Doc. 33. Aquest document es va establir a Gandia.

I2. Un d'aquests pagaments, el féu el I7 d'agost de I4I8 a Guillem Pons, prevere de l'església de Gandia, comarmessor amb ell i procurador d’Alamanda Cabrera -vídua de Joan- (doc. 66). Desconeixem si té relació amb aquests pagaments anuals un document segons el qual, el dia 24 de febrer de I4I9, Alamanda de Cabrera reconeix a Ramon Agualada, com a tutor i curador dels fills d'ella, el lliurament de 45 florins d'or d'Aragó (doc. 69).

I3. El 23 de gener de I4I6, a Gandia, Violant de Vilarig, vídua de Joan March, li vengué, en sengles escriptures, Ioo i I83 sous, 4 diners censals (docs. 57 i 5 8.); l'i d'agost de I4I7, Agualada ven a Joan Sànchez Munyoz, cavaller de casa del duc de Gandia i habitant de la vila, 5 O sous censals per 30 lliures (doc. 62).

I4. El 3I de juliol de I4I6, a Gandia, Domènec Belsa i Bernat Mascarell, sindic i jurat del lloc de Palma, entregaren al notari 3.749 sous i II diners per pagues degudes d'un censal (doc. 6o).

I5. El I2 de setembre de I4I7 va reconéixer a l'alamí i jurats del lloc de Gata el lliurament de 5oo sous, part d'aquells I.ooo que l'aljama responia a l'esmentada tutela (doc. 63). El 2 de novembre següent tornà a fer-ho, però per 29I sous i 8 diners (doc. 64).

I6. Així figura en una escriptura de l'iı d'octubre de ı420, on va reconéixer al noble Lluís d’Abella, cavaller i senyor de Gata, i a l'alamí i jurats del referit lloc, el pagament de 5 oo sous (doc. 74).

I7. Sabem que el 28 de febrer de I425 el notari gandià Lluc Pous li vengué a Guillem Pons, com a tutor i curador, 5 OO sous censals per preu de 5 oo lliures (doc. 85). El i5 de maig de I427 el cavaller de Gandia Galceran de Vich reconegué a Pons, com a tutor dels fill de Cabrera, el lliurament de i8 lliures i 8 sous (doc. 96). 
Després de la mort de Joan, sabem que la seua esposa, Alamanda, es preocupà per millorar el senyoriu. Prova d'aixó és la petició de II5 sous i I5 diners al tutor dels seus fills per a fer-hi diverses obres (doc. 68) i, també, l'escriptura d'arrendament del senyoriu signada el 2I de març de I426 per ella i Guillem Pons a Domènec Belsa, Bernat Bono, Antoni Matamala i Miquel Ros, veïns d'Ador, per 3 oo florins d'or d'Aragó anuals (doc. 92).

Traspassat el seu marit, Alamanda de Cabrera també administrà directament els seus béns. Així la veiem comprant i venent censals bé sola, ${ }^{18}$ bé conjuntament amb el seu fill Ausiàs de Cabrera; ${ }^{19}$ ratificant vendes d'esclaus seus; ${ }^{20}$ arrendant el lloc d'Almiserà (doc. 92); comprant el de Ròtova, etc. Desconeixem si una casa, a la parròquia de Sant Andreu de València, venuda en I427, formava part dels béns del seu marit o si era pròpia d'Alamanda (doc. 99).

Entre la gran quantitat de censals que coneixem relacionats amb Alamanda, en destaca, pels personatges intervinents, el de 66 sous i 8 diners censals que, a Gandia el I 4 de setembre de I425 i davant el notari Lluc Pous, Elionor Ripoll i Ausiàs March vengueren a Alamanda de Cabrera. Aquest censal va ser venut per Alamanda al veí de Gandia Joan Mateu i a Teresa, la seua esposa, el 28 de setembre de I $428 .{ }^{21}$

Alamanda de Cabrera figura entre els integrants de la confraria de Nostra Senyora de Santa Maria de la vila de Gandia en I440 (doc. I62) i degué morir un poc abans del i6 de setembre de I447. En aquesta data i a Gandia, el seu fill Ausiàs lliurà certa quantitat monetària a Bernat de Sabrera, escuder seu, d'acord amb el manament testamentari en aquest sentit fet per la seua mare (doc. I80).

Si Joan de Cabrera figura lligat a Pere i Joan March en importants documents, el mateix succeirà entre Ausiàs March i Ausiàs de Cabrera, el fill i hereu de Joan. Ausiàs de Cabrera va nàixer un poc abans del 22 de sesembre de I409, atés que, en eixa data però de I429, ja actua com a major d'edat $-2 \mathrm{O}$ anys- (doc. II2).

El primer document on hem trobat Ausiàs de Cabrera administrant el seu propi patrimoni -fet que, en determinades circumstàncies, podien fer els majors de quinze anys -és d'abril de I 427 (doc. 95). Un any i mig després, el 20 d'octubre de I428, a Beniarjó, Ausiàs March -en el seu nom propi i també com a procurador d'Ausiàs de Cabrera $-{ }^{22}$, mossén Guillem Pons - prevere i curador d’Ausiàs de Cabrera-, Alamanda i Ausiàs de Cabrera, d'una part, i, de l'altra, Joan de Flovià -senyor de Ròtova-i el seu fill homònim Joan de Flovià -cavaller-acordaren nomenar com a àrbitres $\mathrm{i}$

I8. El I8 de setembre de I422, els jurats de Gandia li abonen 25 sous a ella deguts en raó de la pensió -corresponent al Io de març- d'un censal de I.5oo sous carregat per Bernat de Garrigas sobre els seus béns a "obs de la obra de la ecclésia de la dita vila” (doc. 77). El I7 d'abril de I425, Alamanda reconeix a Guerarda, esposa del notari Lluc Pous, i a Joan Martí, com a successors en els béns del difunt Bernat Garrigas, el pagament de i25 sous que a ella li feien de cens (doc. 86). El I9 de febrer de I426, el notari Lluc Pous i la seua esposa Guerarda venen a Alamanda Cabrera 68 sous i 4 diners per preu de $4 \mathrm{I}$ lliures (docs. 88 i 89). El I9 de març següent, Alamanda reconeix als hereus del difunt notari Bernat de Garrigas, el lliurament de I25 sous censals per mans de Guillem Balaguer, de la dita vila (doc. 9I). El I2 de gener de I429 vengué a Pere Verdeguer -menor de dies-, veí de Gandia, cinquanta sous censals anuals per preu de trenta lliures (doc. I2O).

I9. El I2 d'abril de I434 Alamanda i Ausiàs de Cabrera, el seu fill, venen a Damiata de Mota, de la ciutat de València, diferents censals per preu de 6r lliures (doc. I36). Deu dies després, feren el mateix per idéntica quantitat a Ausiàs Roís de Corella (doc. I37). El I5 de febrer de I435 la vídua, juntament amb Ausiàs de Cabrera i amb la seua esposa Damiata, tots ells habitants de Gandia, vengueren a Joan Gascó, prevere canonge de la Seu de València i rector de l'església de Gandia, diverses quantitats i censals (doc. I44).

20. L'II de juliol de I426, a Gandia, Alamanda aprovava la venda feta per Guillem Jordà, de la ciutat de València, d'un sarraí esclau i servent seu negre, anomenat Pere de Trullàs, al mercader Joan Alegre de València per IIo sous (doc. 93).

2I. Aquesta segona venda es féu a Gandia i va ser rebut el corresponent document notarial per Pere Belsa (doc. I2I).

22. La procuració es va fer davant el notari Bertomeu Torrella l'anterior cinc d'octubre (doc. IO4). 
amigables componedors el cavaller habitant de Gandia mossén Joan Cifre, i Francesc del Bosch, de Xàtiva, per a l'establiment d'un important compromís sobre la venda del lloc de Ròtova (doc. IO4).

La convinença seria sobre

la venda del loch de Ròtova e territori de aquell e drets de aquell, cubs, gerres, deutes de moros e altres aparellaments axí de fer oli com vi, etc fahedora per los dits honorables en Johan de Flovià e na Úrsula, muller de aquell, e mossén Johan de Flovià, son fill, als honorables mossén Ausiàs March, a madona Alamanda de Cabrera e a mossén Guillem Ponz, curador del dit honorable n’Ausiàs de Cabrera, e per quin preu e en quina manera lo dit preu serà pagat e altres coses tocants a la dita venda, etc. E encara sobre la pau e treua fahedora entre les dites parts, e encara sobre [...] de clams e qualsevol questions o debats civils e criminals que entre nos dites parts sien o-s speren ésser entre nos dites parts de tot lo temps passat en tro en lo present dia de huy, etc (doc. IO4).

Aquest acord es respectaria sota pena de 3 .ooo florins, i duraria fins al següent dimarts. ${ }^{23}$ Cal assenyalar que, per a detenir les bregues entre els Flovià i els Cabrera, va intervenir fins i tot Alfons el Magnànim, tal com mostra un document del I8 de setembre de I 428 on el monarca reitera el mandat realitzat al seu alguatzir, el cavaller Pere Pardo de la Casta, perquè detinga Ausiàs March, Ausiàs de Cabrera i a les altres persones que van participar en la brega i ferides causades al cavaller Joan de Flovià a Gandia (doc. IO3).

Abans d'arribar a la data fixada, i dos dies després de la data anterior, s'establí de nou l'acord en els mateixos termes que a la precedent escriptura notarial. El motiu, pensem, és la variació hi existent en un dels arbitres i amigables componedors: Joan Gascó -rector de Gandia- apareix ara al costat de Joan Cifre -cavaller habitant de Gandia. ${ }^{24}$ Ausiàs March signà aquesta vegada a Vilallonga (doc. IO5).

El dimarts acordat, 26 d'octubre de I428, a l'alqueria del comanador de Montalbà, situada al terme de Gandia, Joan Cifre i Joan Gascó dictaren l'esperada sentència (doc. Io6). No en coneixem el text exacte, però sabem que, entre el 27 i el 29 d'aquell mateix mes, totes les parts implicades acceptaren el seu contingut mitjançant dues escriptures notarials diferents: el 28 d'octubre acceptaren la sentència arbitral Alamanda de Cabrera i mossén Guillem Pons, com a curador d'Ausiàs de Cabrera (doc. IO7); el poeta Ausiàs March i el seu homònim de la família Cabrera ho feren davant els testimonis Antoni Garcia -prevere d'Oliva- i Miquel Valls -veí de Gandia- el 29 d'octubre "in vico quo tendit de Beniarjo a Vilallonga, termini ville Olive" (doc. Io8).

El referit dia 29, a Ròtova, Joan de Flovià, cavaller i senyor d’aquell lloc després de la mort del seu pare, nomenà com a procurador seu el notari Benet de Vilaur per a totes les qüestions relacionades amb el compromís firmat amb Ausiàs March i els Cabrera (doc. Iog). Al dia següent, al terme de Palma, en el lloc on era el molló que dividia el seu terme del de Vilallonga, un important grup de persones firmaren una treva i pau per espai de cent anys d'acord amb la sentència arbitral donada per Gascó i Cifre. ${ }^{25}$ Els dos grups enfrontats eren, d'una part, els Floviàa ${ }^{26}$ i, d'altra, un grup format pel cavaller i senyor de Beniarjó Ausiàs March, els donzells Ausiàs de Cabrera i Joan de Monpalau

23. Doc. IO4. Com a testimonis figuren, entre d'altres, el metge de València Gabriel Garcia, Miquel Valls, Gabriel Martí i fra Joan Puig, del monestir de San Jeroni de Cotalba.

24. Alguns anys després, el 4 d'abril de I434, a Gandia, Ausiàs de Cabrera va cedir a Pere de Saraus, a conseqüència de certes quantitats que li devia, I66 sous censals que Joan Cifre devia a Cabrera (doc. I35).

25. Doc. пro. Com a testimonis figuren el notari Lluc Pous, Miquel Valls, Joan Belsa, i Simó Mascarell, menor de dies.

26. Concretament eren Joan de Flovià -cavaller i habitant de València-i Joan de Sent Martí -escuder seu- (doc. IIO).

Sent Martí procedia de Daroca, segons un testament seu que trobem a AHN, Osuna, llig. I280, no. II, not. Pere Pugeriol (2O d'octubre de I428). 
i trenta-tres persones més. ${ }^{27}$ Així mateix, Úrsula -vídua de Joan Flovià, senyor de Ròtova- i el seu fill Joan, en el seu nom propi i com a curador de la seua germana Isabel, renunciaren a continuar amb els plets que contra Ausiàs March i els anteriors havien posat davant les cúries del procurador general del rei de Navarra i duc de Gandia, del justícia de Palma, del rei d’Aragó i de diversos oficials seus, etc. ${ }^{28}$

El 20 de desembre de I428 a Ròtova, Alamanda i Ausiàs de Cabrera, i Galceran Cirera, de Gandia, vengueren als Flovià I.384 sous, 4 diners i òbol censals per preu de I8.ooo sous (doc. II8). Aquests censals, carregats en la seua major part sobre el lloc d'Almiserà, propietat d'Ausiàs, varen ser lliurats pels Cabrera com a part del preu de venda de Ròtova -83.0oo sous- (doc. II2). A més a més, també els vengueren per idèntic motiu un bon grapat de censals venuts als Cabrera per diferens persones de Gata, Dénia, Valldigna, Oliva, València, Pego i Gandia. En total varen ser I.82I sous i 8 diners censals i anuals, per preu de 2r.86o sous. ${ }^{29} \mathrm{El}$ més antic d'aquests censals correspon als 5 o sous que es podien redimir per preu de 3 o lliures i que restaven d'aquells 83 sous i 4 diners venuts per l'hebreu Usua Cabelmale a Joan de Cabrera per escriptura feta a Gandia davant el notari Esteve Corts el 3i de març de I39ז. Des del punt de vista d'aquest article, els més interesants d'ells són els Ioo sous censals venuts per Violant de Vilarig, l'esposa de Joan March -germanastre del poeta Ausiàs March-, a la tutela i curatela d'Ausiàs de Cabrera el 23 de gener de I4I6 (doc. 57).

El mateix dia, el cavaller Joan de Flovià i la seua mare Úrsula nomenaren el cirurgià Jaume Lorenz, veí de Gandia, com a procurador seu per a la presa de possessió del lloc de Ròtova que anaven a realitzar Alamanda, Ausiàs de Cabrera, Guillem Pons -com a tutor i curador d'Ausiàs- i Galceran Cirera (doc. II4). També prometé l'esmentat cavaller eixir del seu antic senyoriu quan els Cabrera hagueren realitzat el referit acte administratiu (doc. II)). Per la seua part, els suara esmentats compradors de Ròtova es comprometeren notarialment, d'acord amb el text de la sentència arbitral, a quitar en l'espai de quatre anys i sota pena de Ioo lliures els censals que sobre aquest lloc els Flovià havien carregat (doc. II5).

Així mateix, els Flovià i els Cabrera nomenaren misser Joan Gascó com a àrbitre i amigable componedor, i es comprometeren a acceptar les seues decisions

sobre qualsevol duptes, debats e questions que sien o s'esperen ésser o sortir entre les dites parts axí per via del compromés fermat entre les dites parts a XXII de octubre del present any com de la sentència donada per los dits àrbitres a XXV [sic] dies del dit mes e declaració de aquella, etc, com encara de la compra e venda del dit loch de Ròtova e pagaments del dit loch e altres totes e sengles coses tocants o devallants de les dites coses, incidens, dependents e emergents de aquelles, etc. E en totes altres e qualsevol questions e debats civils e criminals que entre nos dites parts dien o.s speren ésser de tot lo temps passat tro en lo present dia de huy entre nos dites parts.

Aquest compromís tindria una duració d'un any a partir del dia de Nadal de I428, i el seu trencament estaria penat amb 300 florins d'or (doc. II6).

Atés que, en aquest moment, Ausiàs de Cabrera era menor de 20 anys i restava obligat en totes aquestes vendes i compromisos donada l'actuació dels seus representants, calia -des del punt de vista legal- que, en el moment que Ausiàs complira la majoria d'edat -els vint anys-acceptara

27. En el llistat de partidaris figuren veïns de Gandia, d'Oliva i de València (doc. IIO).

28. Doc. III. En dues altres escriptures d'aquest mateix notari (2O desembre I428) és Úrsula la que figura com a tutora i curadora d'Isabel. Segons una altra de la mateixa data, el testament del pare de Joan Flovià es publicà el 22 de novembre de I 428.

29. Doc. II3. En una altra escriptura d'aquest protocol corresponent al 23 de desembre figura en lloc d'aquesta xifra la de I.860 sous. 
explícitament tot allò que en el seu nom s'havia fet. El 23 de desembre de I428 Ausiàs March, senyor de Beniarjó, i el propi Ausiàs de Cabrera, ambdós cavallers habitants de Gandia, així ho prometeren a Joan de Flovià (doc. IIg). La participació d'Ausiàs March en aquest document s'entén si recordem la seua condició de procurador de Cabrera. L'acceptació del compromís per Ausiàs de Cabrera es realitzà el 22 de desembre de I429 (doc. II2).

Amb la majoria d'edat, Ausiàs de Cabrera realitzarà diversos actes que afectaven el seu patrimoni. En juliol de I 432 reclamarà el pagament de censals als representants de Gata; ${ }^{30}$ en setembre de I432, rebrà I2 lliures, Io sous del clavari de la Generalitat per la pensió deguda de 5 Oo sous que Cabrera rebia anualment sobre els béns de la Generalitat (doc. I28); en abril de I433, ell, la seua mare i Galceran Cirera nomenaren procurador seu el notari Bernat Sanç perquè els representara en qualsevol tipus de demandes judicials (doc. I3I).

Però l'acte més important que farà Ausiàs de Cabrera, com a cap de la família, serà l'establiment de l'acord matrimonial de la seua germana Aldonça amb el cavaller de Gandia Ausiàs Roís de Corella en I433 (docs. I29 i I3O). Ells seran els pares del cavaller, mestre en teologia i escriptor Joan Roís de Corella.

Després d'haver-se realitzat el casament d'Ausiàs Roís de Corella i d'Aldonça de Cabrera i d'haver-li traspassat diversos censals en pagament del dot, Alamanda de Cabrera, vídua de Joan de Cabrera, i el seu fill, vengueren, el 22 d'abril de I434, diversos censals per preu de 6r lliures al cavaller Ausiàs Roís de Corella, habitant de Gandia com ells (docs. I36 i ı37). Aquell mateix dia, Ausiàs Roís de Corella reconeixia a sa sogra el lliurament de 2.220 sous restants d'aquells 3.00o sous constituïts a ell pel seu matrimoni amb Aldonça, filla d'Alamanda (doc. I38).

Uns mesos després, el cavaller i habitant de Gandia Ausiàs Roís de Corella, com a cessionari d’Ausiàs i d'Alamanda de Cabrera, va reconéixer a Bertomeu Renart, veí de Dénia, el lliurament de 3 I lliures, IO sous degudes per ell als referits Cabrera (doc. I43).

A aquesta època es refereixen dos nomenaments de procuradors judicials d'Ausiàs de Cabrera: la designació a Gandia el 5 de maig de I 436 d’Antoni Ferrer, veí d'Oliva, per a l'execució que Cabrera realitzava contra els béns de Joan Ferrando, també d’Oliva (doc. I46), i el nomenament com a procurador seu del notari Pere Rubiols, per a intervenir en un plet amb Galceran de Vilanova, el 4 d'abril de I $438 .{ }^{31}$

$\mathrm{El}_{4}$ de desembre de I 430 ja era casat el donzell Ausiàs de Cabrera, oncle de Joan Roís de Corella, amb Damiata de Celma (doc. I24), qui tenia vincles familiars amb l'esposa del cavaller de la ciutat de València Joan Roca. ${ }^{32}$ Ara per ara, desconeixem amb total seguretat -encara que opinem que sí- si Damiata de Celma és parenta de Caterina de Celma, esposa en segones núpcies de Martí Joan de Galba, l'editor del Tirant lo Blanc. ${ }^{33}$

El I5 de febrer de I435 Damiata de Celma, amb el seu marit, va vendre diversos censals al canonge de la seu de València i rector de Gandia Joan Gascó (doc. I44). Al costat del seu marit i de la seua sogra, Damiata vengué 5 Oo sous censals al mercader Mateu Cardona (doc. I52). Anys després, el

30. Doc. I27. En les seues reclamacions judicials contra els representants de les aljames de Gata i Gorgos va arribar a reclamar la subhasta pública dels béns de les referides aljames (doc. I67).

3I. Doc. I54. Aquest document es va signar a València.

32. Així es pot hipotèticament deduir d'una escriptura del 7 de maig de $\mathrm{I} 436$, on ordenà procurador seu a Joan Caposa, notari de València. Hi figura qualificada d'hereua universal de l'esposa del cavaller valencià Joan Roca (doc. I47).

33. Sobre Martí Joan de Galba i el seu matrimoni amb Caterina de Celma, vídua de Guillem de Siurana, vid. Chiner I993, г54-66. 
30 d'octubre de I444, Damiata i el seu marit vengueren a Francesca, muller de Joan Agostí -veí de Cullera-, una esclava anomenada Lícia, de 25 anys de edat, per 66 lliures (doc. I76).

El ı2 de maig de I436, Damiata de Celma testà deixant com a hereus llurs fills Joan i Jaume (doc. I48).

Per la seua part, Ausiàs de Cabrera ho va fer el I9 d'agost de I436 a Gandia (doc. I5O):

Elegeix com a marmessors mossén Mateu de Corella, prevere de Gandia, Alamanda de Cabrera, la seua mare, i Damiata, la seua esposa.

* Ordena que siguen destinats 2.0oo sous dels seus béns per a fer la seua sepultura i aniversaris i, a més, que siguen lliurats 300 sous als frares de Sant Jeroni de Cotalba en raó de 300 misses de rèquiem que hauràn de fer. Si sobrava cap quantitat d'aquests 2.ooo sous, calia lliurar-la per a casar òrfenes i per als pobres vergonyants.

Al seu fill Jaume, llega I.ooo florins que haurà de cobrar el dia que complisca 20 anys.

A Elionor, filla seua, llega 5oo florins, que se li lliuraran en casar-se.

* Nomena usufructuària dels seus béns Damiata, la seua esposa, sempre i quan no es casàs, designant-la així mateix com a tutora i curadora de llurs fills amb dues condicions: la primera, no poder vendre cap bé de l'herència sense el consell dels altres marmessors testamentaris; la segona, que en cas de morir o de casar-se ella abans que llurs fills foren majors d'edat, la tutoria i curadoria passaria a mans d'Alamanda de Cabrera i de Mateu de Corella.

Elegeix el seu fill Joan com a hereu universal amb el vincle i condició que, en cas de morir sense fills nascuts de legítim matrimoni, l'hereu en seria Jaume i, si aquest també moria sense fills legítims, ho seria Elionor.

Quant a la data del traspàs de l'oncle de l'escriptor Joan Roís de Corella cal dir que, si bé segons una nota marginal del llistat de confrares que l'any I 440 integraven la confraria de Nostra Senyora de Santa Maria de la vila de Gandia Ausiàs de Cabrera morí el 20 de setembre de I $43^{8}$ (doc. I59), sabem que assistí a les sessions de les corts de I443-I 445 i que encara vivia el 23 d'agost de I448. ${ }^{34}$ Consta com a ja mort el i6 de desembre de I45I (ARV, Governació, no. 228I, mà I, f. Iorv) i, uns mesos després, el 2I de gener de I $45^{2}$, la seua esposa, Damiata de Celma, figura com a tutora i curadora dels seus fills. ${ }^{35}$

\section{I.2 Els Roís de Corella}

Respecte als Roís de Corella, a més dels documents que acabem d'esmentar en parlar de la família Cabrera, hem localitzat diversa documentació referida exclusivament a ells.

El besavi patern de l'escriptor Joan Roís de Corella s’anomenava Pere, i era membre de la casa del marqués de Villena, com ho serà també el seu fill Joan. En aquest sentit, cal assenyalar que, el I373, rebia una compensació monetària pel seu servei amb dues bèsties (doc. I) i, en juliol-setembre de I379, com a alcaid del castell de Gallinera, rebrà I5OO sous per la retinença del dit castell (doc. 2). En eixe mateix any de I379, sabem que Pere Roís de Corella cobrà, per ordre del marqués de Villena,

34. En aquesta data, Ausiàs de Cabrera, donzell i senyor de Ròtova, reconeix a Jaume Roca, cavaller i batle general de la vila d'Oriola, que d'aquells 22 lliures i ro sous que a ell li feia, li ha lliurat Ir lliures, 5 sous (doc. I8I). En cas que l'Ausiàs de Cabrera membre de la confraria siga l'oncle de l'escriptor, podem plantejar com a hipòtesi que l'error siga producte d'una confusió: I 438 en lloc de I448.

35. ARV, Governació, no. 228I, mà I, f. I8rv i mà 3, ff. I8r-I9v. Damiata vendrà, el 20 de maig de I452, un censal a Pere Minyana, veí del castell de Palma, amb qui va tenir també relacions censalistes el poeta Ausiàs March (doc. I88). 
I.Ooo sous "los quals lo senyor marqués li fa cascun any rendals, los quals són carregats sobre l'alqueria del Patró de la vall de Gallinera" (doc. 4.).

Es va casar amb Saura d'Esplugues, germana de Guillemona d'Esplugues -mare del poeta Pere March. Al matrimoni, Saura aportà un dot de 30.000 sous (doc. II).

Pere Roís de Corella testà a Gandia l'iı de febrer de r384 davant Jaume Vilavella, notari de Gandia, vila on, mot probablement, es produí el seu traspàs entre aquesta data i el 20 de juny de 1388 dia en què ja sabem que havia faltat (doc. II). Nomenà el seu fill Joan com a hereu universal i, també, com a curador i tutor testamentari de Pere, Alfons, Manuel i Joana, els altres fills seus. Aquests encara estaven el 20 de juny de I388 sota la tutoria i curadoria de Joan Roís de Corella (doc. II). Un fet que ens indica que, en la referida data, en necessitar la cura i tutela legal del seu germà, tots ells tenien menys de I5 anys, mentre que Joan Roís de Corella ja en tenia almenys 20, car era necessari tenir aquesta edat per ésser nomenat tutor i curador d'algú. Aquestes informacions ens permeten deduir un terme ad quem per al naixement de l'avi del futur escriptor: l'iı de febrer de i364, i el període ı369-I373 per als de Pere, Alfons, Manuel i Joana (doc. II).

En morir el seu marit, Saura va veure reconegut pel seu fill Joan Roís, hereu universal del seu pare, el dot per ella aportat al seu matrimoni -30.00o sous-i el creix corresponent-I5.Ooo sous. Com a paga i solució del seu dot, el seu fill li lliurà I.40o sous censals i anuals que al seu pare i a ell feien diverses persones. ${ }^{36}$

Una volta ja vídua, Saura comprà el 30 d'octubre de I388 a Gandia, del seus veïns Esteve Amat i la seua esposa Flor, 5 o sous anuals de violari durant la seua vida i la del seu fill Joan Roís de Corella per preu de 350 sous (doc. I4). Aquell mateix dia, Saura obligà els seus béns en raó d'aquest violari. L’i de desembre següent, farà el mateix, i pel preu referit, amb altres 5 o sous censals i rendals de violari adquirits al matrimoni format pel pescador de Gandia Castili Garberà i per Nicolasa (doc. I5).

Gairebé sis anys després, Saura signarà una àpoca a Ramon Castellà, fill de Ramon Castellà i d'Aldonça, per valor de 2.400 sous, preu pel qual aquest li havia venut un censal de 200 sous (doc. 22).

L’i de gener de I425 Saura testà a Gandia, i dos dies després afegí un codicil (docs. 8ı i 82). Hi nomenà com a marmessors el seu fill fra Manuel Roís de Corella -de l'orde de Montesa i comanador d'Onda- i Mateu Roís de Corella, prevere de l'església de Gandia. ${ }^{37}$ Elegeix com a hereu universal fra Manuel Roís de Corella i, en cas de mort d'aquest, el seu nét Ausiàs, fill del difunt Joan Roís de Corella i pare de l'autor de la traducció del Cartoixà.

Uns dies després, el I3 de gener, la vídua de Pere Roís de Corella reconegué a Pere Espinós, veí d'Alcoi, el pagament de 8 lliures, 6 sous i 8 diners censals anuals (doc. 83). Idèntica quantitat, perquè es tractara, potser, del mateix censal, va rebre el I2 de setembre de I427 d'un altre alcoià, Joan de Torragrosa (doc. IOI).

36. Doc. II. Tres dies després, Saura signà l’àpoca corresponent (doc. I2).

37. Sobre aquest prevere de Gandia, familiar de Saura d’Esplugues per part del seu marit, coneixem diversa documentació. Destaquem la següent:

(a) I 429, gener, 29. Gandia: Mateu Roís de Corella, prevere, habitant de Gandia, ven a Joan de Stanya, cavaller de Gandia, 83 sous i 4 diners censals anuals que a Mateu feia Arnau Riera com a tutor i curador de Guillem Riera (AHN, Osuna, llig. I323, no. Io, not. Joan Lorca).

(b) I45O, febrer, 9. Gandia: Mateu Roís de Corella, prevere de l'església de Gandia, ven a Joan de Tonia i la seua esposa Anastasia, veïns de Gandia, un tros de terra amb vinyes per preu de 26 lliures. El 26 de maig de ı452, Rodrigo Roís de Corella, hereu universal de Mateu Roís de Corella, cancel-là aquest deute (AHN, Osuna, llig. I2o6, no. I8, not. Pere Belsa). 
$\mathrm{El} 23$ de gener de $\mathrm{I}_{42}$, Saura dictà un altre testament ${ }^{38}$ on nomenà com a marmessors fra Manuel Roís de Corella, comanador d’Onda, i mossén Mateu Roís de Corella i elegí com a hereu universal Ausiàs Roís de Corella -nomenant com a usufructuari dels seus béns fra Manuel Roís de Corella. Establí un codicil a Gandia el I3 de juny de I430 segons el qual manava "que Marta, serventa e sclava mia, sia de l'honorable frare Manuel Roís de Corella a fer de aquella a ses plenes voluntats" (doc. I22).

Saura d'Esplugues tornà a testar sis anys després, el 2I de novembre de I436 (doc. I5I), deixant diversos legats al seu fill fra Manuel, ara comanador de Culla, a la seua serventa Marta i a mossén Mateu de Corella. Elegeix, novament, Ausiàs Roís de Corella com a hereu universal, atorgant l'usdefruit a fra Manuel, i ordena que no li siga donat res al seu nét Guerau Domènech, fill de Bernat Domènech i de Joana -filla de Saura d'Esplugues.

Tal com es desprén d'aquests testaments, la confiança de Saura d'Esplugues en el seu nét Ausiàs era gran. En aquest sentit cal dir que, el Io de febrer i el I5 de juliol de I434, ja Ausiàs Roís de Corella actuà com a procurador de la seua àvia en substituir Bernat Julià i Joan Bas, de Xàbia (docs. I33 i I40). Probablement, el va nomenar el 28 de gener de I 433 davant el notari Joan Sart (doc. I4I).

La seua vellesa, la seua residència permanent a la vila de Gandia i la seua relació amb els implicats varen ser els factors determinants perquè hom demanara a Saura d'Esplugues l'agost de I 436 el seu testimoniatge en un procés judicial a Gandia en què també declararen Beatriu, àvia de l'escriptor Joanot Martorell, i Bernat Escorna, futur sogre d'Ausiàs March. Es tracta de la demanda judicial de successió ab intestato presentada pel donzell Joan de Monpalau en raó dels béns jacents de mossén Berenguer Salelles, cavaller i oncle de Monpalau. ${ }^{39}$

La besàvia del futur escriptor encara era viva el ig d'abril de I439, dia en què reconegué al seu nét Ausiàs Roís de Corella estar completament pagada de certes quantitats degudes. ${ }^{40}$ Per un document tardà d'Isabel Martínez de Vera -l'amistançada del poeta Joan Roís de Corella-, sabem que va fer un darrer testament en I 440 en poder del notari Pere Belsa, dada que en permet deduir la seua mort al voltant d'eixe any (doc. 384).

Pere, Alfons i Joana, els altres fills esmentats en el testament de Pere Roís de Corella, sembla que han mort ja l'i de gener de I425, car Saura d'Esplugues no els esmenta al seu testament. És segur que la seua filla Joana ja era morta el 2I de novembre de I 436 , ja que, al testament de Saura d'Esplugues d'aquesta data, aquesta es preocupa molt per la no realització d'un "aniversari per la honorable dona na Johana, filla mia e muller de l'honorable mossén Bernat Domènech, cavaller, per ànima sua lexat e instituït en la ecclésia de la dita vila" (doc. I5I). ${ }^{41}$

Respecte de fra Manuel Roís de Corella, fill de Saura d’Esplugues i oncle del pare de l'escriptor Joan Roís de Corella, podem assenyalar aquestes dades:

* El I3 d'abril de I399 va assistir a la coronació del rei Martí l'Humà a Saragossa i va ser adobat cavaller eixe dia pel seu cosí i mestre de Montesa Berenguer March, germà dels poetes Jaume i Pere March. ${ }^{42}$

38. Doc. 84. Figura una còpia inclompleta a AHN, Osuna, llig. I206, no. I, not. Pere Belsa.

39. Doc. I 49, vid. Chiner r993, 67 .

40. AHN, Osuna, llig. ı2o6, no. Io, not. Pere Belsa. Per error, en aquesta escriptura notarial hom diu que era vídua del cavaller Pere d'Esplugues.

4I. Corregim així la dada donada en Chiner I997, 536, on havíem afirmat que, al testament del 2i de novembre de I436, Saura li havia fet diversos llegats testamentaris.

42. Llistat de nous cavallers a Samper (I669, 22I). Ferran (I926, 3O-3I) resumeix així les dades proporcionades 
El I7 de maig de I 403 consta com a majordom del mestre de Montesa Berenguer March. ${ }^{43}$

Era comanador de Borriana en agost de I III (doc. 47); d'Onda en I 42I, I 422 i I $425,{ }^{44}$ i consta com a comanador de Culla ja en I43I. ${ }^{45}$

Del seu tarannà pot ser bona mostra l'actitud que va prendre en I42I, en un episodi del tradicional conflicte de l'orde de Montesa amb la vila d'Onda per la seua jurisdicció. El 7 d'agost de I42I, Pere d’Anglesola, procurador fiscal reial, demana a mossén Vidal de Blanes que, com a conseller reial i governador del regne de València, protegisca els oficials reials d'Onda de les amenaces i agressions que a ells feia fra Manuel Roís de Corella, comanador d'Onda, qui

...crexent de jorn en jorn de scuders e companya, és vist devallar cascun jorn del castell de la dita vila e anar per aquella ab quatre, sis, huyt e deu scuders armats en molt desonesta manera ell e els dits scuders de cotes de malla, d'avantbraços, guantellets , cervelleres ab gualteres, calces flandeses, spases e broqués, e alguns d'ells ab arches en les mans, menaçant ell e els scuders dessús dits matar als officials reyals qui en la dita vila són per lo senyor rey [...]. Hoc encara etc [...] lo dit que·s diu comanador los scandalosos mals que ab los dits scuders e companya ha [...] de fer en atterrament e contra los dits officials reyals forneix e és vist fornir secretament cascun jorn lo dit castell fahenthi portar de altres parts càrregues de armes, forments, civades e altres forniments, e metent-hi més companya de altres parts per córrer, perseguir e guerrejar de aquell dit castell al dits officials reyals e als altres vehins e habitadors de la dita vila, qui per conservar de llur feeltat rahonablement favoreixen ço que en la dita vila pertany al senyor rey, los quals lo dit comanador diu ésser per la dita rahó inhimichs seus e de la dita orde. ${ }^{46}$

Desconeixem la data de la mort d'aquest fra Manuel Roís de Corella, i encara que no tenim plena seguretat, pensem que no es pot identificar amb ell "lo honorable Francesch Manuel de Corella, comanador" que contribuí a la fâbrica del monestir de la Santíssima Trinitat de València (Mata I99I, I3).

Ignorem si existeix alguna llunyana relació familiar entre el Joan Roís de Corella avi patern de l'escriptor, i el generós homònim, senyor d'Almussafes, ajusticiat el desembre de 1348 per ser partidari de la Unió (Rodrigo 1975, I58). El mateix ens ocorre amb el Joan Roís de Corella senyor de Pardines del Xúquer, el procurador del qual reconeix en I4O3 a l’aljama del jueus de Morvedre

per Samper: “...en I399, al realizarse la unión de la Orden de San Jorge de la Alfama con la de Montesa debida al celo e interés del rey D. Martín, el cual en el día de su coronación, armó caballero en Zaragoza a Frey Berenguer March, V Maestre de la Orden, queriendo así señalar día tan grande en la vida del reino; el Maestre de Montesa, que había andado algo reacio en esta mudanza, por no tener autorización del pontífice, accedió por fin y allí mismo en Zaragoza armó y dio el hábito a otros más caballeros, que le habían acompañado. [...] Los que armó caballeros en Zaragoza el Maestre March, fueron Frey D. Ramón del Jardín, Frey D. Ramón de Ribes, comendador de Burriana; Frey D. Guillén de Villafranca, comendador de las Cuevas; Frey D. Antonio de Tolosana, clavero; Frey D. Berenguer Dumenge; Frey don Gastón Colomer, Frey D. Alonso de Lloris, Frey D. Berenguer de Ferrer de Villafranca; Frey D. Ramón de Zaricera, Frey D. Nicolás de Proxita, Frey D. Juan de Núñez, Frey D. Romeu de Corbera, Frey D. Tomás Vives, Frey D. Miguel de Espejo, Frey D. Manuel de Corella”.

43. Doc. 35. Sobre Berenguer March, mort a Sant Mateu el 8 de març de I409, i la seua relació amb Jaume i Pere March, vid. Chiner 1997, 62-7.

44. Doc. 8I. ARV, Governació, no. 226, mà 20, f. 2r; ARV, Governació, no. 2227, f. 2orv; ARV, Governació, no. 2228 , mà I4, f. $44 \mathrm{rv}$.

45. El 29 de desembre de I43I, Manuel era ja comanador de Culla, i es trobava a Gandia, on nomenà com a procurador seu Antoni Sfano, mercader de la vila saforenca, per a rebre 4.68o sous que se li devien (doc. I25).

46. ARV, Governació, no. 2227, f. 2orv. Sobre aquest conflicte, vid. Guinot 1986. 
el lliurament de I5O sous d'aquells 3 Oo sous censals, rendals i anuals que a ell li feien. ${ }^{47}$ En canvi, pensem que sí que és l'avi de l'escriptor el membre de la casa del marqués de Villena que, l'any I38I, rebia una compensació monetària pels seus serveis en la cort del marqués (doc. 6); que, en febrer de I383, cobrava I8 sous i 9 diners "per messió (...) feta al senyor comte a Cullera anant a Gandia" (doc. 7) i, també, aquell que, el I9 de octubre de I388, nomenà procurador seu Pere Matern, àlies Cavila, resident a l'alqueria de Benieto, propietat de Corella, sobre la que el poeta Pere March havia diversos censals. ${ }^{48}$

Conjuntament amb la seua mare, Joan Roís de Corella reconeixia l'in de juny de ı39o, a Gandia, deure a Pere de la Rochella -barber del marqués de Villena- i a la seua esposa Celestina, 2.200 sous per l'adquisició d'una casa ubicada a Gandia (doc. I6). Consta també que aquest barber va vendre a Joan Roís de Corella una casa a la parròquia de Sant Joan del Mercat de València (doc. 192).

Molt probablement, amb la seua mare, Saura d'Esplugues, Joan Roís de Corella adquirí altra gran casa a Gandia. Així el podem deduir de l'elevat deute -I.Ooo sous- que, el 2 de març de I405, varen confessar tenir amb Jacmeta de Poblet, vídua del cavaller i habitant de València Pere Guillem Català, per la compra d'una casa a la vila saforenca (doc. 40).

Com a cap de la família, Joan Roís de Corella -sempre qualificat d’habitant de Gandia i de donzell-i la seua mare, acordaren el matrimoni el 7 de setembre de r39o de la seua germana Joana amb Bernat Domènech, fill de l'habitant d'Alcoi Guerau Domènech. Aportaren un dot de 2000 florins comuns d'Aragó - uns 22.0oo sous reials de València- i, en paga, li lliuraren els I.ooo sous censals que a Saura feia, sobre el lloc de Pedreguer, Bernat Escorna, pare de Joana Escorna -segona esposa del poeta Ausiàs March. Per la seua banda, Domènech es comprometia a atorgar a Joana IOoo florins comuns d'Aragó, probablement com a creix (doc. I7).

Un any després, el 25 de desembre de I39I, Bernat Domènech no havia cobrat íntegrament el dot establit. En aquesta data, Bernat reconeixia notarialment el lliurament del referit censal d'Escorna, però feia constar que encara se li devien 2.00o sous d'aquells 4.ooo que el marqués de Villena lliurà graciosament a Joana amb ocasió del matrimoni (doc. I9).

Hom pot llegir diversos assentaments comptables referits a aquest avi de l'autor de la Tragédia de Caldesa en la comptabilitat de la cort de Gandia (doc. 7). Com a membre de la casa ducal, amb una estreta relació de parentesc amb Pere March, procurador general del duc de Gandia, és lògic que el trobem gaudint d'un càrrec cortesà. Així, Joan Roís de Corella figura com a alcaid del castell de Gallinera en una àpoca signada, el 28 d'agost de I396, a Pere Martorell -oncle del pare de Joanot Martorell i col-lector dels drets senyorials del marqués de Villena entre els sarraïns del comtat de Dénia-, pel lliurament de 750 sous, part d'aquells i.50o sous que havia de donar-li de les rendes del castell. ${ }^{49}$ Aquesta alcaidia degué haver-la ocupada després del traspàs del seu pare car, en desembre

47. RCSCCV, protocols, no. 25863, not. Joan de Sant Feliu (7 d'agost de I4O3).

48. Doc. I3. Segons Sanchis Sivera (ı922, ıг6), Benieto era “una partida del término de Gandia, en tiempo de la Conquista, llamada en el Repartimiento Beniatons, de la que D. Jaime dió tierras a Bernardo Davis de Valmol, Berenguer de San Martín, Guillem de Entenza, Pereta de Moraton y su hijo Arnaldo, Domingo Sanz, Pedro Palacol, Ferrando de Dolçascarns, Juan de Rubio, Bertrán scriba, Domingo Eximeno, Justo de Teruel, Ricardo de Valmol, García de Montflorit, Pedro March, Ato de Valmol, Juan scriba, Mateo de Teurel, Eximeno de Cosio, Bartolomé de Maynar, Pedro Gómez i Domingo i Sancho Lop, en I3 de mayo de I248 i ı3 de agosto de i249. Formóse un caserío que, por compra, en I485, fué de Da María Enríquez, esposa de D. Pedro Luis Borja. Se desmembró de San José, del arrabal de Gandia, a cuya iglesia pertenecía desde I535, anexionándolo con Morera a Álmoines, al erigirse esta parroquia en tiempo del Beato Juan de Ribera, contando entonces 26 casas de cristianos nuevos: en el siglo XVII, dice Escolano que tenía go casas. En el perímetro que ocupa la ermita de San Vicente Ferrer, en término de Álmoines, se dice que estuvo la iglesia de este lugar, cuyo nombre lleva todavía la partida. Su desaparición se debe a la expulsión de los moriscos”.

49. Doc. 26. En octubre de I394, serà l'avi de Joanot Martorell qui, com a despenser del marqués de Villena, anotarà als seus llibres de comptes un pagament a Joan Roís pel seu servei com a membre de la casa del marqués (doc. 23). 
de I39I, Joan Roís de Corella pagà 3 sous i 4 diners per "mudar la carta de la alcaydia” (doc. I8). El 20 de desembre de 1397 continuava exercint aquest càrrec (doc. 27) i sembla ser que, també, l'ocupava en I4I2, any en què rep 688 sous, I diner a ell deguts en raó de "l'offici de procuració de la vila e vall d'Ayora. E, d'altra part, li era degut per retinença del castell de Gallinera qui certs dies lo havia tengut" (doc. 48).

De la seua estreta relació familiar amb els March es prova tant el seu nomenament com a marmessor dels testaments de Joan i Pere March, germanastre i pares d'Ausiàs March respectivament, com el fet que el 26 de juny de I4I3 inventariàs els béns del poeta procurador del duc de Gandia. ${ }^{50}$ Com a marmessor testamentari del pare d'Ausiàs March, l'avi del prosista i poeta Roís de Corella actuarà en diversos actes realitzats entre desembre de I4I3 i octubre de I4I4, entre els quals destaca l'abonament de 2I2 sous a Pere Balaguer -mestre de les obres de la catedral de València- per la realització d'una tomba de pedra dins la capella dels March a la Seu de València (docs. 76,50 i $\left.5^{2}\right)$.

En I4I5, Joan Roís de Corella -avi del futur escriptor homònim, cosí germà i marmessor del poeta i procurador ducal Pere March- tenia un lloc destacat a la cort de Gandia, tal com mostra el fet que, el I2 de març de I4I5, figure com a testimoni del contracte matrimonial establit entre el duc de Gandia Alfons el Jove i Aldonça March, filla de Violant de Vilarig i del difunt Joan March -fill del poeta Pere March i germanastre d'Ausiàs March- (doc. 54).

Coneixem diverses escriptures notarials relacionades amb censals de Joan Roís de Corella:

El I9 de març de i394 Joan Roís reconeix a Margarida, vídua de Francesc Seguí -de casa del marqués de Villena-, haver rebut 3000 sous, preu pel qual li va vendre 250 sous censals (doc. 2I).

: El 22 de setembre de I4O4, a Gandia, va reconéixer a Francesc Verderes, també com ell habitant de la vila, el lliurament de Ioo sous com a paga d'un censal (doc. $3^{8}$ ).

El 9 de setembre de I404, Berenguer Francesc de Pertusa, en nom de Lluís de Pertusa, va vendre a Joan Roís de Corella ioo sous censals per preu de 6o lliures amb el compromís que Lluís quitaria dit censal en el termini d'un any (doc. 4I).

* El 3I de gener de I4I3, el veí i síndic de Benissa Guillem Bartomeu va vendre a Joan Roís de Corella, tutor i curador dels seus germans, I.3oo sous reals de València davant el notari Francesc Dalmau. ${ }^{51}$

* El I8 d'agost de I4I6, el notari gandià Ramon Agualada vengué a Joan Roís de Corella, senyor de Miraflor, I25 sous restants d'aquells 625 sous censals i anuals venuts al difunt cavaller Guillem Martorell, aví de l'autor del Tirant lo Blanc, i que, posteriorment varen ser venuts al referit notari per Pere Martorell com a procurador de Guillem Martorell (doc. 6I).

El 28 de juny de I4I8, Joan Roís de Corella vengué a Joan Mateu 5O sous censals i anuals carregats sobre un camp anomenat de "domina Argilona"(doc. 65).

El I8 de maig de I4I9, comprà 4I sous i 8 diners censals a Miquel Sànchez, a Guillamona -la seua esposa- i a Joan Corts, veí de Pego (doc. 234).

Si en octubre de I388 Joan Roís de Corella consta com a senyor de l’alqueria de Benieto (doc. I3),

5o. Doc. 49. Joan Roís de Corella figura com a testimoni en un document de Joan March, fill de Pere March, del 26 d'octubre de I386 (doc. 8).

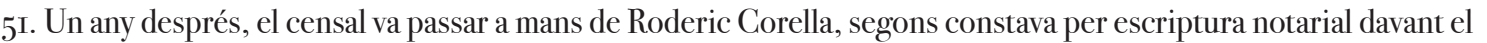
notari Francesc Dalmau feta a Gandia el I5 de gener de I4I4, qui va vendre el censal al referit notari a Gandia el 23 d'abril següent davant el notari Pere Pugeriol. Per aquest censal, el 3I de març de I427 Francesc Dalmau, qualificat ara de notari ciutadà de València, reconeixia a Francesc Cornet, també ciutadà d'ella, la restitució a ell d'aquests i3oo sous. (doc. 94). 
en agost de I4I6 figura com a senyor de Miraflor; però ignorem des de quina data exacta ho era (doc. 6I).

Tenim constància que el 8 de març i el 6 de juny de I4I9 assistí als consells generals de Gandia (docs. 7O i 7I), i que figura al costat de Roderic Roís de Corella entre els consellers de la vila de l'any I420 (doc. 72).

Ara com ara, desconeixem el nom de la seua esposa i la data de seu casament; però d'algunes dades referides al seu fill Ausiàs Roís de Corella, pare de l'escriptor, podem deduir que ja era casat a finals de I400 o principis de I4OI.

El testament de l'avi de l'autor de la Tragèdia de Caldesa va ser redactat davant el notari Lucas Pous el 7 de maig de I 422 i publicat pel mateix notari el 4 de juliol d'eixe mateix any (doc. 347). Per tant, Joan Roís de Corella morí entre el 7 de maig i el 4 de juliol de I 422.

\section{D’Ausiàs Roís de Corella a Dalfina: els pares i germans de l'escriptor}

\section{I Ausiàs Roís de Corella i Aldonça de Cabrera, els pares}

Les primeres voltes que hem trobat documentat Ausiàs Roís de Corella, pare de l'escriptor Joan Roís de Corella i cosí prim d’Ausiàs March, són en relació amb la venda i compra d'un violari: Ausiàs Roís de Corella vengué a Gandia 200 sous de violari per preu de 95 lliures a Aldonça, esposa del notari i veí de Gandia Jaume Pérez de Culla, el I4 de setembre de I42I (doc. 75). Açò ens indicaria que podria ser ja major de vint anys en aquesta data i que, per tant, va nàixer abans del I 4 de setembre de I4OI. ${ }^{52}$

L'any I 423 ja figura com a cavaller, i és conseller de la vila de Gandia al costat d'Ausiàs March (doc. 78). Torna a ser elegit per ocupar aquest càrrec municipal el 26 de maig de I 425 (doc. 87 ).

La major part de la documentació que hem localitzat sobre el pare del cavaller i mestre en teologia Joan Roís de Corella es refereix a la compra i venda de censals i violaris:

* El 29 de juliol de I423, a Gandia, Ausiàs Roís de Corella ven a Joan de Lorca, notari, 5 O sous censals (doc. 79).

* El 4 de desembre de I423 farà el mateix amb Ioo sous censals però a Guillem de Vilarig, membre de la important família de Gandia emparentada estretament amb els March (doc. 8o).

* El I2 de març de I426, Ausiàs va reconéixer a Bernat d'Esplugues, cavaller habitant de València, l'abonament de r.ooo sous que ell feia de cens anual el 7 d'octubre (doc. 9o). L'any següent, Bernat, ara resident a Dénia, tornarà a pagar-li la referida quantitat, actuant com a testimonis de l'acte notarial el prevere de l'església de Gandia Guillem Pons, antic marmessor del poeta Pere March, i Joan de Monpalau, menor de dies, habitant de Gandia. ${ }^{53}$

52. Corregim, en uns mesos, la data de naixement proporcionada en Chiner 1997, 539.

53. Doc. 97. En I434, Esplugues encara habitava a Dénia, segons consta en una altra escriptura de pagament de I.ooo sous a Corella (doc. I39). Hem localitzat diverses escriptures notarials de persones cognomenades Esplugues, entre ells aquest Bernat, si bé no tenim cap dada documental que en permeta emparentar, en una gran part dels casos, a la majoria d'aquestes persones. Tampoc podem establir amb certesa cap vincle de sang segur entre ells i les germanes Guillemona d'Esplugues -àvia d'Ausiàs March-i Saura d'Esplugues -besàvia de l'escriptor Joan Roís de Corella. Aquestes en són dades rellevants:

* En una escriptura notarial feta a Gandia el ı6 d'abril de ı39o, hom esmenta Joan d'Esplugues com a senyor de 
* El I7 d'agost de I427, Ausiàs Roís de Corella, cavaller i habitant de València, signa una àpoca a Bernat Martí, de Dénia, pel lliurament dels 293 sous, 4 diners que Martí i altres li feien. Figura com a testimoni Joan de Monpalau, donzell (doc. IOO).

El 24 de juliol de I430 Ausiàs, que es refereix a si mateix com a habitant de la capital del Túria, accepta el pagament pels jurats de Dénia de 29I sous, 8 diners que a ell feien de cens anual (doc. I23).

* L’i de maig de I434, a Gandia, el matrimoni format per Aldonça de Cabrera i Ausiàs Roís de Corella vengueren a Miquel Ros, veí d’Ador, diversos censals per preu de 2.0oo sous (doc. I40).

El 29 d'octubre de I434, el pare de l'escriptor, com a cessionari de la seua sogra i del seu cunyat Ausiàs de Cabrera, reconeix a Bertomeu Renart, veí de Dénia, el lliurament de 3I lliures, Io sous degudes a Alamanda i Ausiàs de Cabrera (doc. I43).

* El I9 d'abril de I436, Ausiàs Roís de Corella va admetre en escriptura notarial que Pere Martí, de Gandia, li havia entregat 5 oo sous que a ell feia de violari (doc. I45).

El 22 d'octubre de I444, davant el notari Joan Sart, Violant March, mossén Ausiàs March i mossén Pere Guillem Lançol varen carregar a Ausiàs Roís de Corella i als seus 265 sous censals (doc. 235).

Al llarg de tots aquests anys, el veurem en relació amb altres habitants de la vila ducal lligats en determinats moments a la vida del lletraferit Joanot Martorell. Així, el 6 de juny de I427, Ausiàs Roís de Corella nomenarà els habitants de Gandia Joan de Monpalau -major de dies-i Joan Cifre com a procuradors seus, ${ }^{54}$ el 3 d'octubre de I $_{42} 7$ figura com a testimoni en un document on l'escuder Fernando de Burgos promet servir Joan de Monpalau -menor- per un salari de 25 florins d'or comuns d’Aragó (doc. IO2); en I43I Ausiàs Roís de Corella establirà diverses escriptures amb els Abelló -la família de la mare de Joanot Martorell- (AHN, Osuna, llig. I27O, no. 2, not. Pere Pugeriol ), etc.

Així mateix, les relacions en aquests moments amb Ausiàs March són constants, tal com mostren diverses escriptures notarials establides entre ells en I436 (AHN, Osuna, llig. I323, no. I5, not. Joan Lorca) o la presència com a testimoni d'Ausiàs Roís de Corella tant en una sentència arbitral donada pel poeta el I 4 de gener de I 434 en un plet entre diversos veïns de Gandia (doc. I33), com en un nomenament de procurador fet per March l'any I $43^{8}$ (doc. I55), o el fet que el pare del traductor del Cartoixà siga un dels testimonis de les capitulacions matrimonials entre Ausiàs March i Joana Escorna en I443 (doc. I7O), entre altres actuacions.

¿Quan es varen casar Ausiàs Roís de Corella i Aldonça de Cabrera, els pares de l'escriptor Joan Roís de Corella?

Benicolet (AHN, Osuna, llig. II36, no. 6 , not. Francesc Fiscal)

; El I7 d'agost de I4OI el mercader Francesc d'Esplugues s'aveïna a València per espai de deu anys. El seu fiador fou el notari Jaume Pérez (Piles i978, 55).

El ı2 de desembre de ı409, Bernat d'Esplugues s'aveïna a la parròquia de San Nicolau de la capital del Túria per espai de 7 anys (Piles i978, пाо).

* El I2 de desembre de I422, Úrsula, esposa de Jaume d'Esplugues, i Bertomeua, esposa de Bernat d'Esplugues, nomenen llur procurador el notari Bertomeu Loret (RCSCGV, protocols, no. 22595, not. Joan de Plasència).

El I8 de setembre de I448, a Gandia, Joan, fill del cavaller i habitant de Dénia Bernat d’Esplugues, com a donatari dels seus béns constitueix com a procurador seu Joan Rostoxo, veí de la vila ducal. (AHN, Osuna, llig. I2o6, no. I7, not. Pere Belsa).

54. Doc. 98. El nomenament el farà conjuntament amb Joan de Bluses; els cavallers Ramon Guillem Català, Galceran de Vich i Ausiàs March; i els donzells Galceran de Monpalau i Joan de Monpalau -menor de dies. 
Desconeixem la data i el contingut exacte de les capitulacions matrimonials establides; però el més probable és que la data no n'estiga molt allunyada de la cerimònia eclesiàstica de casament. ${ }^{55}$ Cal situar-ne la cerimònia amb posterioritat al 3 d'abril de $\mathrm{I} 433$, però en una data molt propera a aquesta, car, en aquest dia i a Gandia, se signà un document de reconeixement del lliurament i recepció de dot entre Aldonça de Cabrera - donzella filla de Joan de Cabrera i d'Alamanda-i Ausiàs Roís de Corella, cavaller habitant de Gandia, amb ocasió de la realització del seu matrimoni i on Ausiàs qualifica Aldonça d" "uxori futuri mei" (doc. r29). Aldonça de Cabrera, nascuda abans del I8 de setembre de I4I4 - data de publicació de les darreres voluntats del seu pare-, amb el consentiment de sa mare i dels seus parents es va "col·locar" en matrimoni amb Ausiàs Roís de Corella i, segons s’indica en el document, ara, en el moment d'efectuar-se el matrimoni, Aldonça lliura a Ausiàs, com a dot seu, un total de 27.000 sous: 24 .0oo sous en diners i censals donats pel seu germà Ausiàs de Cabrera, com a hereu de son pare, atés el llegat testamentari fet pel seu pare a Aldonça; i els restants 3.000 sous li són donats per sa mare, Alamanda Cabrera, en ajuda del seu matrimoni. Per la seua banda, Ausiàs Roís de Corella reconeix el lliurament d'aquest dot i, d'acord amb la legislació foral i la virginitat d'Aldonça, li fa a Aldonça “uxori futuri mei” un augment o creix de I3.500 sous. Ausiàs Roís de Corella es compromet, també, a restituir les quantitats de dot i creix en els casos establits per la legislació foral.

El mateix 3 d'abril de I433, Ausiàs de Cabrera, donzell habitant de Gandia, en el seu nom propi i com a hereu universal testamentari de son pare, per tal de lliurar a Ausiàs Roís de Corella el dot de 27.00o sous acordat per la seua germana Aldonça de Cabrera, ven i transporta a Corella diversos censals per valor de $22.4 \mathrm{I} 4$ sous (doc. I3O).

Molts d'aquests censals seran la font de supervivència de la família Corella a partir dels anys 40 i, fins i tot, estaran en la base de moltes de les demandes judicials de la dona i dels fills d'Ausiàs Roís de Corella. És el cas, per exemple, de la demanda que el 27 de novembre de I46o Aldonça Roís de Corella, com a usufructuària dels béns del seu marit Ausiàs Roís de Corella i, també, com a tutora i curadora dels seus fills, posà a diversos musulmans de Gata i de Mecleta reclamant el pagament de Ioo sous per les pensions degudes en raó de 5 O sous censals carregats a Joan de Cabrera, pare d'Aldonça, i transportat en favor d'Ausiàs Roís de Corella per escriptura notarial feta, davant el notari Andreu Puigmicha, el 3 d'abril de $1433 \cdot{ }^{56}$

Com hem dit, la data del matrimoni eclesiàstic entre Ausiàs Roís de Corella i Aldonça de Cabrera ha de ser molt propera al 3 d'abril de I 433 . Ja es trobaven casats el 29 de desembre de I 433 . En aquesta darrera data, Antoni Soler, veí de Gandia, posà la seua filla Margarida, de dotze anys d'edat, al servei d'Ausiàs Roís de Corella i de la seua esposa durant sis anys. Al llarg d'aquest període ell es comprometia a la no fugida de la seua filla i, per la seua banda, els Corella haurien de donar-li 20 lliures al seu termini (doc. I32).

55. El més normal era casar-se poc després d'establides les capitulacions matrimonials però coneixem casos en què el matrimoni eclesiàstic es va retrasar: Ausiàs March (Chiner 1993, 98-IO2), Bertomeu Tallades (Chiner I993, 99), Guillem Ramon de Vila-rasa (Torro 2009, 205) o Berenguer Salelles, oncle del Joan de Mompalau contrincant de Joanot Martorell (Chiner I993, 99).

56. Doc. 233. La constatació que es tractava d'una de les primeres transportacions d'un censal dels Cabrera a Ausiàs Roís de Corella, ens va impulsar a cercar aquesta escriptura notarial en els protocols del dit notari conservats a l'ARV. A aquesta recerca també contribuïren les informacions proporcionades per Mari Cruz Cabeza Sánchez-Albornoz qui, en el curs d'una visita nostra professional vinculada a la seua candidatura al premi Lluís Guarner, ens va comunicar l'existència, en els protocols d'aquest notari, de diversos documents referits a les famílies de Roís de Corella i d'Ausiàs March (un d'ells, per exemple, es refereix a Violant de Vilarig-ARV, protocols, no. 19O2, not. Andreu Puigmicha, 3 d'octubre de I433- i altre a Joan de Próxita -ARV, protocols, no. I9O2, not. Andreu Puigmicha, I6 de juny de I433). Que servisca aquesta menció com a reconeixement pòstum a la il-lustre investigadora i directora de la Biblioteca Històrica de la Universitat de València. 
En aquest sentit, cal recordar que el 22 d'abril de I434, la seua sogra, Alamanda de Cabrera, i el seu cunyat, que encara era donzell, li varen vendre diferents censals per valor de 6r lliures $i$, al seu torn, Ausiàs Roís de Corella va reconéixer a la seua sogra l'abonament de 2.220 sous deguts encara d'aquells 3.00o sous establits en les capitulacions matrimonials de la seua esposa, Aldonça de Cabrera (docs. I37 i I38). Uns mesos després ell, com a cessionari d'Ausiàs i d'Alamanda de Cabrera, va reconéixer a Bertomeu Renart, veí de Dénia, el lliurament de 3I lliures, IO sous degudes per ell als referits Cabrera (doc. I43).

En morir el seu pare en I422, Ausiàs Roís de Corella, cosí prim com ja hem dit d’Ausiàs March, esdevingué senyor de Miraflor. Amb la seua esposa, el ı2 de setembre de I 438 va vendre aquest lloc a Pere Perpinyà, ciutadà de València, juntament amb certes propietats en el terme de "lo cap de la mar" i una terra en l'horta de l'alqueria de Mateu Corella sota cens de i6 sous, 4 diners. La venda s'efectuà per I2.500 sous, dels quals els Corella cobraren aqueix mateix dia I2O0O $\mathrm{i}$, la resta, Perpinyà se'n comprometé a l'abonament en el termini d'un any. ${ }^{57}$

Molt probablement, cal relacionar aquesta transacció comercial amb l’imminent trasllat definitiu de la família a València, donat que, si en aquesta data encara els esposos figuren com a habitants de Gandia, el I4 de desembre de I439 Ausiàs Roís de Corella es qualifica a si mateix de cavaller habitant de València i antic poblador de Gandia, en cobrar de Pere Perpinyà els 5 Oo sous que encara li devia (doc. I6I). Ja en anys anteriors, concretament en documents de I427 i I 430, el pare del futur escriptor apareix com a habitant de València, però cal considerar aquests sojorns com a temporals, atés que en I434, I 436 i I 438 ell es considera habitant de la vila ducal. En aquest sentit, cal assenyalar que serà la seua residència continuada a Gandia, i el seu coneixement de la vida social de la vila ducal, els que justifiquen que, en maig de I432, el pare de l'escriptor siga una de les persones consultades respecte a l'establiment d'un compromís entre Aldonça-donzella, filla i hereua del difunt cavaller de Gandia Joan Eximenes Romeu- i mossén Joan de Cervató - com a curador d'Aldonçad'una part, i mossén Galceran de Vich, habitant de Gandia, en raó del debat existent entre ells per una casa i diferents censals (doc. I26).

En la dècada dels quaranta, sobretot des de València, Ausiàs Roís de Corella continuarà administrant els seus interessos i cobrant els seus censals, gairebé amb tota seguretat la base de l'economia familiar dels Corella, una volta venudes les seues possesions senyorials:

El 2 de desembre de I44O, el notari Cristòfol de Montblanch, ciutadà de València, com a procurador d'Ausiàs Roís de Corella, reconeix a Jaume Martorell, veí d’Alzira, el lliurament de I5O sous corresponents a la paga del mes d'octubre d'un violari de 3 oo sous (doc. I63).

* El I6 de desembre de I440, Ausiàs Roís de Corella vengué, per preu de 20 lliures, a Bernat Perpinyà, ciutadà de València, tots aquells 33 sous, 4 diners censals que a Corella feia Pere Perpinyà, germà de Bernat. Aquest censal va ser venut a Ausiàs Roís de Corella per Bernat d'Esplugues, fill i hereu de Joan d'Esplugues, per escriptura notarial feta davant el notari Joan Ferrer en el mes d'abril de I439 (doc. I64).

El I6 de juny de I442, el veí d’Alzira Andreu Roig, com a procurador de Lluc i de Mateu Martorell i, també, del donzell Jaume Martorell i de la seua dona Úrsula -tots ells habitants d'Alzira- va redimir diversos censals i violaris carregats per diferents persones. Entre aquestes persones figura el cavaller Ausiàs Roís de Corella, habitant de València, qui, davant el notari

57. Docs. I56, I57 i I58. Segons el doc. I56, Miraflor era al terme de Dénia i afrontava amb terres de Setla, del Palmar [sic] i de Verger. 
Cristòfor Monblanch el 27 d'abril de I44O, va comprar 300 sous de violari per preu de 2000 sous. Aqueix mateix dia, el I6 de juny de I442, Ausiàs vengué a Jaume Martorell aquests 300 sous censals anuals de violari (docs. I65 i i66).

* El i6 de febrer de I443, a València, els pares de Joan Roís de Corella vengueren per 35 lliures a Valentí de Barberà, habitant de València, Ioo sous de violari que a ells dos feien Joan Arbúcies, doctor en lleis, i Francina, la seua esposa, i que varen ser carregats per escriptura notarial davant Domènec Barreda l's de juny de I44I (doc. I69).

El 22 d'agost de I 443 el noble Felip Boïl, senyor de Rafadell, carrega a Ausiàs Roís de Corella I6o sous de violari (doc. 203).

* El I7 de setembre de I443, Ausiàs Roís de Corella reconeix al ciutadà Bernat Perpinyà el lliurament de 23 lliures, I sou i 8 diners en raó d'aquelles 23 lliures, I sou i 8 diners censals restants d'aquells I.ooo sous censals anuals que a ell li havia de donar com a senyor de Miraflor. ${ }^{58}$

* El 2 de setembre de I444 Ausiàs Roís de Corella ven a Ausiàs March el censal de Ioo sous adquirit en I 436 per Roís de Corella i que, originalment, Elionor Ripoll -mare d'Ausiàs March- va vendre en I42I a Guillem de Vilarig (doc. I75).

Sabem, també, que, probablement a finals de I 442 o principis de I443, va vendre certes terres amb vinyes a Ondara (doc. I68) i que, el I9 de juny de I444, va vendre una esclava seua "de generum russorum" anomenada Margarida, de 25 anys d'edat, per 67 lliures a Brioland, esposa de Lope Eximènez de Tolossa, donzell habitant de València (doc. I74). Un dies abans de la venda de l'esclava, el veí d’Alcoi Lluís Alçamora prometé conservar indemne Ausiàs Roís de Corella en raó de la caplleuta donada, a pregàries seues, per Ausiàs per tal que Ramon Alçamora, parent de Lluís, no estiguera pres en mans de Joan de Gallach, doctor en lleis i jutge delegat per la reina. ${ }^{59}$

Com a cavaller del regne de València, mossén Ausiàs Roís de Corella formava part del braç militar de les corts regnícoles i tenia dret a assistir a les seues sessions.

Figura entre els assistents l'I de juny de I437 a les corts celebrades a la catedral de València convocades, en nom del monarca Alfons el Magnànim, per Joan, rei de Navarra (doc. I53).

També apareix al costat d’Ausiàs March i de diversos membres de la família Martorell -entre ells Joanot Martorell-, ${ }^{60}$ entre els integrants del braç militar de les corts convocades per carta datada a Traiguera el 23 de febrer de I443. El pare del poeta i mestre en teologia va rebre la convocatòria el 4 de març de I443, segons va declarar Pere Navarro al Batle General de València. ${ }^{61}$ A diferència d’Ausiàs March, el pare de Joan Roís de Corella assistí a gairebé totes les sessions de les corts. El trobem com a assistent a les sessions celebrades, normalment al palau reial de València, el 3 o de març, I3 d'abril i 5 de juny de I443; 27 i 29 de juliol de I443; 8, 26 i 29 d'agost de I443; 4, I2, 26 de setembre de I443; I6 de juny de I444; I8 de gener de I445; I de març de I445; 8 de maig i I d'octubre

58. Doc.I72. El document I77 mostra un nou pagament d'aquestes característiques de Bernat Perpinyà a Ausiàs Roís de Corella.

59. Doc. I73. Ausiàs Roís de Corella va prometre restituir Ramon Alçamora a la justícia en el moment en què així ho demanaren.

6o. Doc. I7r. Hi figuren Pere, Guillem i Galceran Martorell, tots ells cavallers. Entre els convocats apareixen també d'altres coneguts de la història de la nostra literatura com, per exemple, els donzells Joan de Monpalau i Jofre de Blanes (AMV, procesos de corts, yy-I7, f. 7r). Hi trobem, també els cavallers Pere Roís de Corella i Joan Roís de Corella,

6r. Doc. I7. El dia 25 de febrer es lliurà la carta de convocatòria a Jofre de Blanes, Joan Roís de Corella i Pere Roís de Corella i, el 2 de març de I443, a Ausiàs March (AMV, procesos de corts, yy-I7, ff. I2r-I4r). 
de I445 (doc. I7I). Va ser un dels signadors de les cartes sobre la llibertat de Berenguer Saranyana. ${ }^{62}$

Igual que Ausiàs March, la seua esposa i el seu fill Francesc, una bona part dels membres de la família Roís de Corella varen contribuir entre I 446 i I 449 a la fâbrica del monestir de la Trinitat de València, del qual serà abadessa l'escriptora Isabel de Villena. Col-laborar-hi era un signe social significatiu i, al seu torn, comportava un cert prestigi social, donat que la reina Maria impulsava decididament la fundació del referit monestir. Segons Sales (I76I, 237), en les llistes de contribuents dels anys I446, I447, I448 i I 449 hi figuren, amb un donatiu de 55 sous cadascun,

...la honorable na Pera, muller de mossen Alfonso Roís de Corella; Lo honorable en Johan Roís de Corella, Doncell; na Violant Roís de Corella, Donzella... Lo honorable Mossen Auzias Roís de Corella, cavaller; La honorable na Aldonza, Muller sehua. En Johan Roís de Corella, fill seu, Frare Manuel de Corella, fill seu. Lois Roís de Corella, fill seu.

Aldonça, filla d'Ausiàs Roís de Corella i d'Aldonça de Cabrera, apareix amb un donatiu de 55 lliures que cal considerar més com una espècie de "dot conventual” lligat al seu ingrés al monestir de la Trinitat que com un donatiu a la fâbrica del monestir. ${ }^{63}$

El pare de l'autor de la Tragédia de Caldesa morí, molt probablement, a València, ciutat on residí en els seus darrers dies; si bé tenim constància d’alguns sojorns a Gandia en I 443 i I 447 (docs. I68 i I79). Hi testà el 9 de febrer de I 443 davant el notari Joan Sart, i es publicà el testament a la ciutat del Túria el dia I6 de gener de I 450 per mort seua ${ }^{64}$ Desconeixem l'exacte contingut d'aquest testament però, a partir d'altres documents, es poden deduir algunes de les seues clàusules:

* Sepultura a l'església del monestir de la Trinitat de València “construït fora los murs de la dita ciutat, ço és al cap del pont del portal appellat de la Trinitat” (docs. I87 i 207).

* Nomenament del seu fill Joan Roís de Corella com a hereu universal (doc. I87). Li deixa diversos censals i violaris, amb els quals podia fer el que volguera, amb l'única condició de ser major de 25 anys (doc. 207).

Elecció de la seua esposa Aldonça de Cabrera com a tutora i curadora dels seus fills (docs. $192 \mathrm{i}$ 233) i usufructuària dels béns i drets del difunt (docs. I84, I85 i 233).

* Llegat de ioo florins d'or als seus fills Manuel, Aldonça, Lluís i Dalfina, “per tota part e legítima" (docs. 207 i 23I).

Tenint en compte que el testament del pare de Corella es va publicar el i6 de gener de I450, i que l'ı d'octubre de I45 I Aldonça de Cabrera ja es qualifica de vídua en una escriptura notarial referent a un censal de I.ooo sous sobre el lloc de Gata ${ }^{65}$ i en un testament d'aquest mateix any (doc. ${ }^{8} 87$ ), cal atribuir a un altre individu els documents que, posteriors al i6 de gener de I450, figuren a nom d’Ausiàs Roís de Corella, habitant de la vila ducal. ${ }^{66}$ Aquest habitant de Gandia encara vivia l'any

62. Així figura a AMV, procesos de corts, yy-I7, f. I85v. No figurarà ni ell ni Ausiàs March en els documents que sobre el mateix tema trobem a ff. I79v-I82r.

63. Doc. i78. La llista també a Mata 199I, 67; i la referència a sor Aldonça Corella, qui figura esmentada com “sor Aldonceta", a Mata I99I, I44.

64. Doc. 385 . Per error, a l’inventari de béns de Joan Roís de Corella apareix com a data del testament la del 9 de novembre de i 443 (doc. $36 \mathrm{I}$ ).

65. Doc. I86. Aquest document es troba datat a València, on el notari Joan Sart, que figura com a antic veí de Dénia, s'havia aveïnat el ıo d'octubre de I439 per espai de deu anys (Piles I978, 26I).

66. És el cas, per exemple, d'un document del 3 I de maig de I $45^{2}$ on un Ausiàs Corella, que es qualifica a si mateix d'habitant de Gandia, va vendre per 25 lliures a Antoni Frígola, prevere i habitant de Sueca, , 20 sous censals i anuals 
I483 en el carrer major de la vila segons el llibre de la col-lecta de la peita d'aquest any. ${ }^{67}$

El 3 o de setembre de I434, Aldonça de Cabrera, mare de l'escriptor Joan Roís de Corella, va establir a Gandia un testament (doc. I42). Entre d'altres disposicions, nomena com a marmessors el seu marit -a qui declara hereu universal-, el prevere Guillem Pons, i el seu germà Ausiàs de Cabrera; elegeix ser sepultada a la capella de son pare; llega 3.ooo sous a sa mare i 2.500 a Ausiàs de Cabrera. No figura esmentat cap fill, fet que suggereix que, en la data de redacció del testament, el matrimoni Corella-Cabrera no tenia descendència. ${ }^{68}$

Sabem que, el 4 d'octubre de I 447, va redactar ella davant el notari Joan Sart, un altre testament i un codicil on no havia establit tutors ni curadors per al seus fills i filles. En maig de I 450 -una volta mort el seu marit-, va redactar un codicil on, per a esmenar aquest descuit, nomenava el notari Joan Sart com a tutor i curador de tots els seus fills (doc. I82).

Per les dades que s'hi contenen, resulta més interessant el testament que Aldonça de Cabrera, mare de l'escriptor Joan Roís de Corella, va establir a València davant el notari Antoni Barreda l'I d'octubre de I $45{ }^{\mathrm{I}},{ }^{69}$ on revocava, entre d'altres, el redactat en I 434 .

S'hi esmenta expressament la "vespra de la festa de sant Miquel de any Mil CCCC sexanta" com la data en què l'escriptor haurà els vint-i-cinc anys, dada que ens permet fixar el 28 de setembre de I 435 com a data del naixement de Joan Roís de Corella.

Ultra aquesta capital dada biogràfica sobre el prosista i poeta, d'aquest testament d'Aldonça de Cabrera mereixen ser remarcades diverses clàusules:

* Nomena marmessor testamentari Lluís de Calatayud, cavaller i habitant de València.

Elegeix ser sepultada al monestir de la Santìssima Trinitat de València, on era soterrat el seu marit.

* Lliura al donzell Joan Roís de Corella, fill seu, Ioo florins d’or, és a dir, I.Ioo sous “per tota part e legíttima e altre dret que a aquell en mos béns pertangués eo pertany pogués com aquell sia instituït hereu per lo dit quòndam honorable mossén Auziàs Roís de Corella, pare seu e marit meu".

* Als seus fills, Manuel Roís de Corella, "frare e cavaller de l’orde de Sancta Maria de Muntesa", i sor Aldonça, monja del monestir de la Trinitat de València, els fa lliurament d'un timbre d'or.

* Nomena els seus fills Lluís i Dalfina hereus universals de tots els altres béns seus, però amb la condició que si algú d'ells moria abans de complir els 20 anys i sense fills legítims, la seua part passaria en herència al sobrevivent. Si finaren tots dos abans de complir 20 anys i sense fills legítims, institueix hereu universal Joan Roís de Corella.

Nomena tutor i, en el seu cas, curador de Lluís i Dalfina, els seus hereus universal, Lluís de Calatayud fins que el futur escriptor tinga 25 anys. En el cas que Calatayud no acceptara la tutoria i la curadoria, o si moria abans o durant l'exercici d'aquestes, i sempre que Joan Roís no tinguera encara els 25 anys, elegeix com tutor i curador el cavaller Joan Català.

de violari (AHN, Osuna, llig. I206, no. 2O, not. Pere Belsa). El violari havia estat venut a Corella per Bertomeu Colom, Joana -esposa seua-, Antonio Coves i Francesca -la seua muller-, Bertomeu Movató i la seua dona Isabel, tots ells veïns de Cullera.

67. AHG, manuscrits, AB 499, f. 6v. Apareix “tatxat” amb 35 sous per un total de zo lliures, a raó de 6 diners per lliura.

68. En la nostra opinió, la no menció de fills es una prova, gairebé segura, que no havia fills però no ho podem afirmar amb total seguretat perquè no es infreqüent trobar pares -com per exemple, el cavaller i mestre en teologia Joan Roís de Corella- que no fan cap menció dels seus fills en els seus testaments.

69. Doc. I87 publicat en Chiner I994b, 49-62. 
En aquest testament de I45I figuren com a testimonis el rector i preveres de l'església de Sant Andreu de València. La raó, amb tota seguretat, és que la casa on vivia en I45 I era situada en aquesta parròquia. En efecte, encara que ja vivia a València, en morir el seu marit, Aldonça de Cabrera s'aveïna a la ciutat del Túria el 7 de novembre de I $45^{2}$ i declara viure a la parròquia de Sant Andreu de València "al cantó de la plaça de Sent Jordi": ${ }^{70}$

\section{Die martis VII novembris anno $\mathrm{M}^{\circ} \mathrm{CCCC}^{\circ} \mathrm{LII}^{\circ}$}

La honorable dona n'Aldonça, muller de l'honorable mossén Ausiàs Rö̈ç de Corella, cavaller quòndam habitant de la vila de Gandia, de present habitant en la ciutat de València en la parròquia de Sent Andreu al cantó de la plaça de Sent Jordi, precedent voluntat e consentiment dels honorables en Johan de Natera, generós, en Pere Sadrelles, mossén Johan Vives, cavaller, e en Luís Blanch, ciutadans [sic], quatre dels honorables jurats en lo present any de la dita ciutat, jura lo vehïnatge de aquella a temps de deu anys primer vinents. Lo qual jurament féu e prestà en poder de Bernat de Sent Feliu, notari, per comissió a ell feta per l'onorable en MartíScolà, justícia civil en l'any present de la dita ciutat. En axí e en fe de l'honorable en Luís d'Alpicat, ciutadà de la dita ciutat, fill de l'honorable Martí Gil d'Alpicat, present e acceptant, obligaren e renunciaren, etc.

Testes en Berthomeu Chiva, studiant, e en Jacme Jovell, scuder, habitant en València. E de la ferma del dit en Luís d'Alpicat, qui ferma lo dit dia, són testimonis lo discret en Matheu Steve, notari, e en Luís Belluga, cambiador, ciutadans de València.

Com ja comentàrem quan el donàrem a conéixer en I997, aquest document ens permet suposar l'existència d'un tracte personal entre Joanot Martorell i Joan Roís de Corella, car si la mare d'aquest darrer vivia "al cantó de la plaça de Sent Jordi", el domicili a València de Jaume Martorell, germà de Joanot, es trobava "prop de San Jordi". Cal recordar que, durant el conflicte de l'any I450 entre Gonçalbo d'Íxer i l'autor del Tirant, el marit d'Agnés de Portugal va demanar que fos imposat a Joanot callament perdurable i que fos notificat a Barcelona, on era Joanot llavors. Com que a València no el podien trobar, el 4 de maig el Governador General de València va ordenar que col-locassen, en les portes de les cases de Jaume i Damiata Martorell, germans de Joanot, sengles cèdules amb la provisió contra ell, car se sabia que, quan Joanot era a València, sovint s’allotjava a casa d'aquests germans (Chiner 1993, I47).

A més a més, cal recordar diverses dades positivistes que ens permeten afirmar que Joanot Martorell i Joan Roís de Corella es coneixien i varen tenir relacions entre ells i no sols a nivell dels "manlleus" que apareixen al Tirant lo Blanc (Hauf ı993; Chiner 1992; Chiner 1993, I84-85) o de la possible assistència plegats a alguna de les tertúlies literàries de la ciutat:

* Els pares respectius, antics habitants de Gandia, es coneixien molt i, fins i tot, molt possiblement eren amics: no sols Ausiàs Roís de Corella signarà diverses escriptures amb els Abelló -la família de la mare de Joanot Martorell- (AHN, Osuna, llig. I27O, no. 2, not. Pere Pugeriol ), sinó que, a més a més, l’any I 447 el cavaller habitant de València Ausiàs Roís de Corella, pare de Joan Roís, va ser testimoni en dos processos referents a Francesc Martorell, pare de Joanot (Chiner 1993, I85). Quan li van preguntar si sabia que Francesc Martorell havia estat senyor de la Vall de Xaló mentre va viure, el pare de Joan Roís contestà de forma molt semblant en els dos processos: "ell testimoni hac gran notícia ab lo dit mossén Francesc Martorell de mentres vivia, e véu e sabé com posseïa la dita Vall de Xaló, lochs e alqueries de aquella" (ARV, Governació, no. 2275, mà 20, f. 429v).

7o. Doc. I89 publicat en Chiner 1997, 547-48. Resum d'aquest aveïnament a Cabanes 2008, 354. 
* La relació entre els dos escriptors pot estar avalada, així mateix, per la relació familiar que hi havia entre Ausiàs March, que era cunyat de Joanot Martorell, i Joan Roís de Corella.

Com varen fer també Alamanda Cabrera i Saura d'Esplugues anys abans, mort el seu marit Aldonça de Cabrera administrà amb energia els seus béns (docs. 2I6, 227, 234, 238, 239, 242, 244, 248, 262 i 280 ).

En ocasions, persones com Jaume de Bellmont àlies Gil (doc. 204), Pere Garcia (doc. 222), Lluís Goçalbo (doc. 228), Joan Rodrigo (doc. 256) i Nicolau Ferrer (doc. 27I) varen ajudar Aldonça, mare de Joan Roís de Corella, i en foren nomenats procuradors i representants. Però el protagonisme d'aquesta funció el van tenir el notari Antoni Barreda i Bertomeu Chiva.

L'estudiant Bertomeu Chiva va ser nomenat procurador d'Aldonça el I9 de gener de I45I (doc. I84), a l'any escàs de la mort d'Ausiàs Roís de Corella, i la va representar en diverses ocasions reclamant censals, cobrant pensions (doc. 190), acudint als tribunals de justícia, etc. Des d'aquesta data -en què Chiva ja era major de vint anys, car, d'acord amb la legislació foral, un menor de vint anys no pot ser nomenat procurador- fins al I5 de maig de I460 figurarà en la documentació com a estudiant i resident a la casa de la mare de l'escriptor (docs. I83, I84, I89, 206, 2II, 2I4, 225 i 23I). La primera volta que l'hem trobat qualificat de mercader és en un document del I 4 de gener de I463 (doc. 243), i així figurarà sempre en totes les actuacions on va representar els Roís de Corella, des d'aleshores fins a la seua mort (docs. 245, 246, 259, 260, 26I, 28I, 29O, 294, 295, 3O2, 3I5, 33I) I1. $^{71}$. Com es mostra ja en el seu testament de I456, Aldonça, la mare de Joan Roís de Corella, sempre tindrà per a Chiva bones paraules pels seus serveis a la família Roís de Corella-Cabrera, i per la seua bona gestió en els assumptes encarregats. El mateix farà el cavaller i mestre en teologia Joan Roís de Corella en el seu darrer testament de I478 (doc. 299).

Bertomeu Chiva era natural de Llutxent, i contribuí amb 55 lliures a la fâbrica del monestir de la Santíssima Trinitat de València (Mata I99I, 97). Es va desaveïnar-hi el ı6 de maig de I46r per a aveïnarse, el 25 de maig de I462, en el carrer de Rotlons “prop l'ort d'en Pere de Montblanch” a la parròquia de Sant Martí de la ciutat de València, és a dir, i com posteriorment veurem, molt prop de l'anomenat carrer de Mossén Corella on vivien l'escriptor i la seua germana Dalfina (doc. 24I). En el darrer testament d'Aldonça, la mare de l'escriptor, del 24 de novembre de I 466 , aquesta afirma que Chiva residia en eixe moment a la casa d'ella (doc. 250).

El 27 d'agost de I466, Bertomeu Chiva va dictar un testament on figura la primera menció coneguda a Magdalena, la filla del cavaller i mestre en teologia Joan Roís de Corella (doc. 249):

* Nomena Magdalena, "donzella de edat de set anys, la qual stà en la casa de la dita magnífica n’Aldonça de Corella”, com a hereua universal i indica que, en cas de morir menor de quinze anys i sense fills nascuts de legítim matrimoni, tots els seus béns seran d’Aldonça Roís de Corella o de l'hereu d'Aldonça.

* Deixa a voluntat d'Aldonça de Cabrera el lloc on ser soterrat.

* Llega ro lliures a cadascun dels seus germans: Martí i Joan Chiva, veïns de Llutxent, i Francesca, esposa en segones núpcies d'en Bernat Martí.

En abril de I479, Bertomeu Chiva tornà a fer testament (doc. 305) i, el I8 de juliol de I483, fou testimoni de la darrera voluntat de Lluís Figuerola, marit de Dalfina Roís de Corella (doc. 3I9).

7I. En Chiner 1997, 549, identificàvem el mercader Bertomeu Chiva amb el procurador d'Aldonça Cabrera, mentre que consideràvem que era un fill seu homònim l'estudiant Bertomeu Chiva que figura com a testimoni de l'aveïnament al cap i casal de la mare de Joan Roís de Corella. Corregim ací l’errònia dualitat, car es tracta de la mateixa persona. 
Sabem que en una data anterior al 9 de maig de I489, Chiva es va casar amb Úrsula (doc. 334) i que, uns mesos després, Bertomeu redactava un nou testament on deixava diversos llegats testamentaris al cavaller i mestre en teologia Joan Roís de Corella (doc. 336).

El seu darrer testament porta data del I3 de juliol de I490 i va ser publicat en morir el testador, el 2 de març de I 492 per Magdalena Roís de Corella, a qui Chiva havia declarat hereua universal seua (doc. 343). Entre els seus béns -venuts el I2 de març de I 492 per Miquel Pérez, ${ }^{72}$ com a procurador de la seua esposa Magdalena, en públic encant al mercat de València per un total de 6o9 sous i II diners (doc. 344) - figuren un llibre d'hores i "un llibre de mestre Francesc Eximenis apellat De les dones" (doc. 343).

Tornant ara a Aldonça de Cabrera, mare de Joan Roís de Corella, indicarem que, des de la segona meitat de l'any I450, la tenim constatada comprant i rebent censals i violaris des de sa casa a València. Entre d'altres, podem esmentar els següents:

: El I2 d'octubre de I450, Joan Sart, notari i ciutadà de València, com a procurador de Ramon de Riusec àlies Francesc Gilabert de Centelles, comte d'Oliva, ven a Aldonça de Cabrera, vídua d'Ausiàs Roís de Corella, 5 oo sous censals, rendals i anuals per preu de 7.500 sous (doc. I83).

* El 2 de març de I45I, la vídua d’Ausiàs Roís de Corella, com a usufructuària dels béns i drets que foren del seu marit, reconeix al notari Jaume Pérez de Culla, el lliurament de I58 sous, 4 diners per pensions degudes en raó de $5^{8}$ sous i 4 diners censals, anuals i rendals que el notari feia a Aldonça Roís de Corella (doc. I85).

* L’i d'octubre de I45, Aldonça cedeix al notari Pere Banyuls, arrendador del lloc de Gata, les accions que li pogueren pertànyer a ella contra l'aljama de Gata en raó de I.ooo sous censals que, a Aldonça, feia l'aljama. També li reconeix el lliurament a ella de les quantitats corresponents a dues pensions d'eixos I.ooo sous censals carregats sobre el lloc de Gata. ${ }^{73}$

* El 25 de maig de I453, reconeix a Ramon de Riusec àlies Francesc Gilabert de Centelles, conseller reial, la venda de 5 Oo sous censals (doc. 193).

* Prop d'un mes després, el I 4 de juny, va reconéixer a Pere Martorell, cavaller de València, que per mans d'Azmet Banne, sarraí d'Ondara i arrendador de Negrals i Beniomer, li havia lliurat 29I sous, 8 diners d'aquells $5^{8} 3$ sous, 4 diners que Martorell abonava a Aldonça. ${ }^{74}$

El I9 de juliol de I453, Aldonça signa una àpoca a Pere Ribera, veí d’Oliva, per valor dels 3.Ooo sous deguts per Ribera i que ara li lliurava (doc. 195).

* El 7 d'octubre de I458, Aldonça de Cabrera, vídua d'Ausiàs Roís de Corella, reconeix als jurats de Teulada el lliurament, per mans de Joan Livillo, de Io9 sous i io diners en raó d'aquells 2I9 sous, 8 diners censals que els dits jurats li feien anualment (doc. 225).

El 27 de novembre de I460, Aldonça de Cabrera, com a usufructuària dels béns del seu marit i, també, com a tutora i curadora dels seus fills, reclama, a diversos musulmans de Gata i de Mecleta, el pagament de Ioo sous per les pensions degudes en raó de 5 O sous censals carregats a Joan de Cabrera, pare d'Aldonça, i transportat en favor d'Ausiàs Roís de Corella per escriptura notarial feta, davant el notari Andreu Puigmicha, el 3 d'abril de I433 (doc. 233).

72. Actualment, la grafia del cognom d'aquest escriptor sol prendre la forma "Peres". Tanmateix, hem de fer constar que és general a la documentació l’altra grafia, “Pérez”. Per aquest motiu, i per no variar-la en relació a la de la resta de la família (pare, fills), hem respectat la forma Pérez. En la transcripció de documents sempre consta la forma original.

73. Doc. I86. Als docs. 2II, 2I 7 i 2I9 tenim diferents pagaments per part de l’aljama de Gata a Aldonça en raó del censal carregat.

74. Doc. I94. Als docs. 208, 209 i 2IO corresponents a I 456 tenim diferents pagaments per part de Pere Martorell a Aldonça en raó de diferens censals. 
* Aldonça de Cabrera ven, el 8 de juny de I46I, al mercader Bernat Andreu, Ioo sous rendals de violari que a ella li feien Joan Arbúcies, doctor en lleis, Francesca -la seua esposa-, el cavaller Jaume Arbúcies i Guillem Xerta (doc. 237).

: El I3 de juny de I47O, Pere Boïl de Lladró, noble de la ciutat de València, i Isabel, la seua muller, reconeixen deure a Aldonça 35 lliures en raó de ${ }_{5} 5 \mathrm{O}$ sous rendals i anuals de violari. ${ }^{75}$

El i6 de novembre de I $47^{2}$ la mare de Joan Roís de Corella reclama pensions no pagades d'un censal a Andreu de Vallterra, cavaller de la ciutat de València (doc. 279). Prop de quatre anys després, el 27 de maig de I474, Aldonça de Cabrera va reconéixer a Vallterra el lliurament de Io lliures, Io sous com a lluïció i quitament de 3 o sous anuals de pensió en raó de 6o sous rendals $i$ anuals de violari (doc. 282).

Un d'aquests censals, concretament el carregat per Pere Martorell, va provocar diverses reclamacions d'Aldonça davant la cort del Governador del regne.

En efecte, en abril de I 462 i de I 46 \%, Aldonça reclamà, davant la cort del Governador general del regne de València, un deute a Pere Martorell, senyor de Negrals (docs. 240 i 252). Novament el 23 de març de I468, Aldonça Corella es presentà davant el governador, don Pedro d'Urrea, i afirmà que al seu difunt marit li havien estat carregats pel cavaller Pere Martorell i la seua esposa Caterina 200 sous de violari mentre visqueren tant Aldonça com el seu marit. Assabentada de la mort de Pere i Caterina, la vídua d'Ausiàs Roís de Corella sol-licita que els hereus de Pere Martorell foren condenats a "lluir e quitar lo dit violari", fet al qual s'oposa el cavaller Galceran Martorell, com a hereu de Pere Martorell (doc. 255).

Anys després, el Governador General del regne de València sentencià un plet en raó de I75 sous censals, carregats davant el notari Pere Roig el 8 de juliol de I308, sobre les Algoleges, unes cases i diverses heretats (doc. 278). Segons el contingut de la resolució judical, aquestes Algoleges a la vila d'Alzira “dites de Pere Martorell, les quals huy són de mossén Pere Martorell” no podien ésser subhastades ni venudes sense el càrrec del censal esmentat, tal com volia Violant, vídua de Mateu Martorell. Davant aquest intent de venda, Aldonça de Cabrera s'oposà judicialment el I9 de juny de I472. Violant, el I6 d'agost de I473, requerí del Governador que, malgrat la suara esmentada oposició, permetera a la cort del justícia d'Alzira la venda de les Algoleges com a béns de la marmessoria del difunt mossén Pere Martorell (doc. 278). Aconsellat pels seus assessors, el Governador ho consentí i així ho comunicà al justícia d’Alzira el mateix dia.

La mare de l'escriptor no sols reclamarà judicialment el pagament de censals sinó que, també, intervendrà davant la justícia per a evitar que els seus drets es vegen perjudicats per l'acció indirecta d’altres persones sobre censals que no són seus (docs. I97 i I98), sobre propietats com les Algoleges a la vila d'Alzira (doc. 278), sobre cases d'altri: en març de I 453 intervingué per a evitar que es venguera una casa de Pasqual Miró ubicada a la parròquia de Sant Joan del Mercat de València i que havia comprat el pare del seu marit al barber Pere de la Rochella (doc. I92); un altre plet del mes d'agost de I453 la vincula amb una casa al carrer major de Gandia (doc. I96), etc.

A partir de gener de $\mathrm{I} 454$ i fins l'agost de I470, Aldonça de Cabrera realitzarà una intensa activitat comprant violaris, la duració dels quals vincula a les vides dels seus fills Joan, Lluís o Dalfina. Els venedors seran persones com Pere Pelegrí, el noble Joan de Próxita, Pere Roís Escrivà de Corella, Francesc Aguiló, Andreu de Vallterra, Tristany Pardo de la Casta, Miquel Albert, etc (docs. 199, 2OO, 2OI, 2O2, 2O5, 2I2, 2I 4, 2I5, 2I8, 22O, 22I, 229, 23O, 232, 236, 25I i 269). En un

75. Doc. 267. Hi ha una nota marginal on s’afirma que, el 5 de juny de I47 I, Aldonça de Cabrera reconegué haver rebut la totalitat del deute. 
d'aquests violaris datat a l'abril de I474, figurarà esmentada Maria, filla de Joan Roís i neta d'Aldonça de Cabrera (doc. 28I).

La mare de Joan Roís de Corella era usufructuària dels béns d’Ausiàs Roís de Corella en raó del testament del seu marit (docs. I84, I85 i 233). Aquest usdefruit es va veure reforçat quan el seu fill Joan Roís de Corella -hereu universal de son pare- li cedí el 22 de desembre de I 455, en qualitat de donació inter vivos, tots els seus béns i drets menys ıoo florins dels quals ell podria testar lliurement. ${ }^{76}$ Encara que no tenim dades documentals que ho puguen confirmar taxativament, és possible que aquesta donació de l'autor de la Tragèdia de Caldesa servira per a retornar la part corresponent del dot i creix d'Aldonça, sa mare, tal com establien els furs que havia de fer-se pel marit al llarg de la seua vida o pels seus hereus després de la mort d'aquest, i com havien fet l'avi de Roís de Corella amb Saura d’Esplugues (doc. II), i Bertomeu Figuerola amb sa mare Dalfina Roís de Corella (doc. 397). També és possible que, amb aquesta donació, l'escriptor tan sols pretenguera proporcionar uns mitjans de vida a la seua mare.

Dies després d'aquesta donació, el I5 de gener de I 456 (doc. 207), Aldonça Corella establirà un nou testament, actuant-hi com a testimonis preveres de l'església de Sant Andreu de València. Com a modificacions o punts més destacats respecte de l'anterior darrera voluntat, hem d'assenyalar-ne els següents:

* Nomena com a marmessor Joan Roís de Corella, encara donzell.

Elegeix sepultura en "lo monestir de la sanctíssima Trinitat construït fora los murs de la dita ciutat, ço és al cap del pont del portal appellat de la Trinitat, dins la ecclésia del dit monestir en la fossa” on està soterrat el seu marit, Ausiàs Roís de Corella.

* L'escriptor, com hereu universal del seu pare, ha de lliurar a cadascun dels germans -frare Manuel, sor Aldonça, Lluís i Dalfina- Ioo florins d’or “per lo dit quòndam honorable mossén Ausiàs Roïz de Corella a cascú d'aquells legats per tota part e legítima que en los béns e heretat d'aquells los pertangués". Ara bé, tenint en compte que, per la donació que Joan Roís de Corella li acabava de fer, Aldonça succeïa en l'esmentada heretat i béns d'Ausiàs i, per tant, estava obligada a pagar a cadascú d'ells l'esmentada quantitat, ordena en aquest testament que els paguen els ioo florins després de la seua mort, si abans ella no ho haguera fet.

* En compliment de l'establit per Ausiàs Roís de Corella al seu testament, Aldonça deixa al seu fill Joan diversos censals i violaris amb els quals aquest podrà fer el que vulga, amb l'única condició de ser major de 25 anys.

* L'autor del Plant dolorós és nomenat tutor i curador dels seus germans, Lluís i Dalfina Corella. ${ }^{77}$ Aquests serien, com en l'anterior testament de la mare, els seus hereus universals a parts iguals, però amb la condició que si algú d'ells moria menor de 25 anys i sense fills legítims, passaria la seua part a l'altre i, en cas de defunció de tots dos, els béns serien de Joan Roís de Corella.

* Als seus altres fills, frare Manuel i sor Aldonça, els llega un timbre d'or dels seus béns.

* El mobiliari trobat a casa seua en el moment de morir, llevat dels diners en metàl-lic, haurà de ser repartit entre Joan Roís de Corella i el seu germà Lluís.

D’una d'aquestes clàusules es pot deduir que Lluís i Dalfina degueren nàixer amb posterioritat a l'any I44I, ja que, si en I 456 necessitaven un tutor per a les seues persones havia de ser perquè encara no havien complit I5 anys, segons establia la legislació foral. A més, si Ausiàs Roís de Corella, 
el testament del qual va ser fet el 9 de febrer de I 443 i publicat el I6 de gener de I 45 O, va deixar el llegat a què es fa referència per a ells, caldria datar el naixement de Lluís i Dalfina entre I44I i I4433.

El I5 de maig de I46o, Aldonça va establir un nou testament on no esmenta Magdalena, la seua neta filla de Joan Roís de Corella que ja havia nascut, i on actuaren com a testimonis, una volta més, preveres de Sant Andreu (doc. 23I):

* Nomena Joan Roís com a marmessor i hereu universal seu.

* Demana que tots els seus deutes siguen pagats.

* Elegeix ser soterrada “en lo vas dels pobres de aquella ecclésia parroquial de la qual en lo dia de la mia fi fore parroquiana”.

* Absol l'estudiant Bertomeu Chiva "resident de present en ma casa”, procurador seu, de qualsevol deute que tinguera amb ella en raó de les seues gestions com a procurador.

* Deixa al seu fill Lluís i6.85o sous “per tot e qualsevol dret de legíttima eo altre dret que a aquell en mos béns li pertangués eo pertànyer pogués axí per los cent florins per lo dit quòndam honorable mossén Ausiàs Roïz de Corella a aquell ab son testament leixats com alias per qualsevol altre dret”. En cas que morira menor de 20 anys i sense fills legítims, el substituiria en aquest llegat Dalfina, qui, cas de morir també menor de 20 anys i sense fills legítims, seria substituïda per l'escriptor Joan Roís de Corella.

* Deixa a Dalfina altres i6.85o sous per les mateixes raons i amb condicions semblants al llegat fet a Lluís.

* Llega a fra Manuel, cavaller de Montesa, i a sor Aldonça un timbre d'or com a tot dret en els seus béns.

* Nomena Joan Roís de Corella tutor i curador dels seus germans Lluís i Dalfina, "lo qual encarrech en lur consciència que, en la tutela e cura de les persones e béns de aquells, se haja axí com de bon tudor e curador se pertany e yo àmplament fie de aquell”.

Aldonça de Cabrera va establir el seu darrer testament davant el notari Antoni Barreda a València el 24 de novembre de I466 (doc. 250). Ja no actuaren com a testimonis preveres de Sant Andreu, sinó preveres de Santa Caterina i de Sant Martí, la parròquia on vivien els seus fills Joan i Dalfina. Igual que passa en el testament de I460, no esmenta Magdalena, la seua neta.

Es tracta, en comparació amb els anteriors testaments, d'una escriptura notarial molt breu en què revocava les seues anteriors darreres voluntats i establia una sèrie de noves clàusules:

Ordena que siguen pagats tots els seus deutes i demana que se li done eclesiàstica sepultura com a persona pobra, encara que no indica el lloc on vol ser soterrada.

* Deixa a les seues filles i al seu fill Lluís cinc sous “per tota part e legíttima” en els seus béns.

* De tots els altres béns, en nomena hereu universal el seu fill Joan Roìs de Corella.

Després de redactar aquest testament, Aldonça continuà realitzant diversos actes. El més important per al futur de la família Roís de Corella-Cabrera pels lligams que establia, serà el realitzat el 2i de gener de I469. En aquest dia, Aldonça Roís de Corella i els seus fills Joan i Dalfina, en contemplació del matrimoni acordat entre el cavaller Lluís Figuerola i Dalfina Roís de Corella i que prompte se celebraria eclesiàsticament, establiren a Dalfina un dot de io.ooo sous (vid. infra, 2.2.4) .

La mare de Joan Roís de Corella va morir el 20 de juliol de I475, i el testament es va publicar a València quatre dies més tard, a la casa del cavaller Lluís Figuerola -marit de Dalfina-, a instàncies 
de l'escriptor com a hereu universal de la seua mare i en presència d'ell.

Respecte al lloc on descansen les seues despulles mortal, cal assenyalar que no el podem conéixer amb seguretat, ja que, si bé en els primers testaments redactats després de morir el seu marit volia ser soterrada juntament amb ell en una fossa de l'església del monestir de la Trinitat de València, en el testament de I460 indica que "en lo vas dels pobres de aquella ecclésia parroquial de la qual en lo dia de la mia fi fore parroquiana” i, en el de I466, no estableix res sobre el lloc de soterrament.

En la nostra opinió i sense descartar la possibilitat d'estar soterrada a la Trinitat, per les darreres disposicions d'Aldonça lligant la seua sepultura a on estiguera vivint, i per la publicació del testament a casa de la seua filla -aquesta publicació allí és difícil d'explicar si no estiguera residint amb Dalfina-, ens inclinem a pensar que el seu cos pot estar soterrat a l'església de Sant Martí, pertanyent a la parròquia on vivien els seus fills Joan i Dalfina.

Del matrimoni entre Ausiàs Roís de Corella i Aldonça de Cabrera havien nascut cinc fills: Manuel, Joan, Aldonça, Lluís i Dalfina.

\subsection{Fra Manuel, sor Aldonça, Lluís i Dalfina Roís de Corella, els germans}

\subsection{Fra Manuel, cavaller de l'orde de Montesa}

El 23 de març de I446, el Papa Eugeni IV concedí, a instàncies de la reina Maria, certes indulgències per a qui contribuira a la fâbrica del monestir de la Trinitat de València. Aquestes indulgències varen ser prorrogades al llarg de I448 fins al dia de Pentecosta de I449 (Mata I99I, 5-8). Com ja hem comentat, els Corella contribuïren amb un donatiu de 55 sous cadascun (Mata I99I, 67 i I 44; Sales I76I, 237). ${ }^{78}$ Probablement, la seua contribució va tenir lloc en I446, en I 448 o en I 449 , és a dir, inmediatament després i com a conseqüència de l'emissió d'una de les indulgències papals atorgades. ${ }^{79}$

En quina data va nàixer fra Manuel Roís de Corella? És ell el primogènit? Ho és Joan?

Des de Riquer (I964, 255-56), l'ordre en què figuren esmentats els membres de la família Roís de Corella en la llista de contribuents a la fâbrica del monestir de la Trinitat, ha estat utilitzat com a prova que Joan era el fill més gran, fra Manuel el segon, i que Dalfina no havia nascut encara. Pel contrari, el r994 plantejaràrem com a hipòtesi que fra Manuel, "frare e cavaller de l'orde de Sancta Maria de Muntesa”, qualificat així en el testament de I45I de sa mare (doc. I87), era el major, i que Joan Roís, com a segon dels fills, s'hauria vist obligat a escollir la carrera eclesiàstica: "Al meu parer, [Joan Roís de Corella] no era el major. Crec que ho era frare Manuel Roís de Corella, cavaller i mestre de Montesa (...) Joan Roís de Corella potser es va veure obligat a escollir la carrera eclesiàstica per tal com era el segon dels fills" (Chiner I994b, 56-57).

Aquesta hipòtesi nostra, fins i tot el lapsus calami de dir que era mestre de Muntesa quan mai ho va ser, la reiteràrem en la introducció al facsímil del Quart del Cartoixà publicat per l’Ajuntament de València (Chiner 1998, 28). Al nostre vell article (redactat en 1993) mostravem que la menció com a frare de Manuel en el llistat de la Trinitat era deguda al fet "que aquesta classificació [la de frare] s'aplicava als cavallers de l'orde de Montesa" (Chiner I994b, 57). Encara que d'una manera potser poc clara, intentàvem fer veure que, si fra Manuel era "frare e cavaller de l'orde de Sancta Maria de

78. Doc. I78. També hi figura sor Aldonça Roís de Corella, qui apareix amb un donatiu de 55 lliures (sobre aquesta vid. infra 2.2.2).

79. Segons Daniel Benito $\left(1998,5^{2}\right)$, "la perdida bula de concesión de indulgencias de Eugenio IV, fue dada en Roma, [...] en 23 de marzo de I446, Nicolás las concedió en I448 y I449”. 
Muntesa" tal com el qualificava sa mare en I45I -en un moment en què el seu germà havia I6 anys i era donzell-, es podia deduir que Manuel, també ho era quan se li esmenta com a "frare" en el llistat dels contribuents de I446-I449, on també figurava el seu germà Joan Roís, nascut en I435. Fra Manuel, pensàvem, havia de ser més gran que el futur poeta per a estar ja dins de l'orde de Montesa com a cavaller entre I 446 -I $449^{80}$.

Aquesta primogenitura o no de Joan Roís de Corella tenia les seues implicacions literàries, car, si Joan Roís era el segon fill, el més habitual a l'època era és que haguera entrat en l'estament eclesiàstic no per vocació sinó per obligació i, per tant, seria lògica i natural la seua dedicació a la religió i la teologia.

A partir del nostre article, una bona part dels investigadors optaren -i fins i tot opten (Escartí 20I4, I2) - per fer a Joan Roís el segon dels fills del matrimoni Corella-Cabrera, si bé existeixen altres especialistes avui dia que consideren Joan Roís com el primogènit (Domènech et al. 20I4, IO5; Rubio 2OI4, 443-47).

Ara, després d'anys de llegir documentació arxivistica sobre Joan Roís de Corella i d'aproximarnos a la seua obra des de la "imatge" d'ell que, al nostre parer, dóna la documentació, estem convençuts que l'estricta qüestió de la primogenitura no va influir massa en la dicotomia temàtica existent en la seua obra literària; i sí, pel contrari, la seua vocació de dedicar-se a la predicació. Per les raons que veurem en un altre lloc, Joan Roís de Corella no podia deixar d'ésser cavaller, no podia convertir-se en un eclesiàstic ordenat in sacris, però ell volia dedicar-se a la predicació i a ajudar els pobres i malalts.

Si bé nosaltres defensem que Joan Roís de Corella era el segon fill mascle d’Ausiàs Roís de Corella i d'Aldonça de Cabrera, cal dir que, ara per ara, no tenim cap documentació arxivística on s'indique clarament la data del naixement del seu germà Manuel i no existeix, de moment, cap prova documental que ens permeta determinar, sense cap mena de dubte, si fra Manuel és el primogènit del matrimoni Roís de Corella-Cabrera o si ho és Joan, el futur mestre en teologia. Fins que aparega un document indubtable, qualsevol d'aquestes dues possibilitats és, al nostre parer i des del punt de vista de les hipòtesis, vàlida. Dit això, en la nostra opinió Manuel Roís de Corella seria el primogènit tal com, a continuació, intentarem demostrar.

Desconeixem a quina edat i en quina data va entrar Manuel a l'orde de Montesa, però, com hem dit, sabem que ja era frare de l'orde en el moment de contribuir a la fâbrica del monestir de la Trinitat. Respecte a l'edat d'ingrés en l'orde de Montesa, si bé algun autor estableix l'edat per a professar-hi en els I8 anys, ${ }^{81}$ un document fet en I427 per Romeu de Corbera, mestre de Montesa

8o. El fet de ser "frare e cavaller" (eren denominats per H. Samper "freyles cavalleros"), excloïa la possibilitat que Manuel fóra un dels "freyles clérigos” dedicats als assumptes espirituals que esmenta l’il·lustre historiador de l'orde de Montesa en la seua clàssica obra (Samper ı669, 75-79). La no menció com a cavaller en el llistat de la Trinitat és fâcil d'entendre atenent a l'economia de dades d'un llistat; però, sobretot, a què fent a Manuel fill de mossén Corella i germà de Joan Roís de Corella, no podia haver-hi possible confussió amb un hipotètic monjo -un "frare" - que s'anomenàs també Manuel Roís de Corella.

8г. Segons Demurger (2005, Io8-09): “tanto el Temple como las demás órdenes, si no reclutaron, al menos acogieron a niños que sus padres les entregaron. No era fácil rechazar al hijo de una familia de benefactores de la orden [...]. Así pues, no se rechazaba a los niños pero se instituía una edad mínima para profesar: 20 años para los hospitalarios, I8 en las órdenes españolas dependientes del Císter (Citeaux, a diferencia de Cluny, rechazaba a los oblatos), I 5 años para Santiago, I 4 para los teutónicos. Con estos últimos, los menores de I 4 años ofrecidos a la orden por sus padres eran niños de coro. De todos modos, una vez alcanzada la edad de profesar, los niños debían recuperar su libertad de elección. Con el tiempo, esa barrera de edad no siempre fue respetada, como lo muestra esta definicio del abad de Morimond para Calatrava en I468, en que establecía que había que tener al menos diez años para profesar en la orden, y al menos iz para hacerse cargo de una encomienda. Las órdenes fueron más estrictas en cuanto a la edad de los hermanos sacerdotes o de los capellanes. El Hospital sólo los admitía si habían recibido las órdenes menores. 
des de I4IO fins a setembre de I 445 afirma, taxativament, que "per nostra fundació e regla e edicte fet en la dita Religió no hi podem ésser reebuts sinó fills de hòmens generosos de linatge, e de edat de puericia; ço és de catorze fins en dihuit anys" ${ }^{82}$ Atés que Romeu de Corbera, el mestre de Montesa que va regir l'orde des d'abans del matrimoni d'Ausiàs Roís de Corella fins a pràcticament la fâbrica del monestir de la Trinitat, va aplicar eixos límits d'edat per a l'ingrés a l'orde fins i tot davant la petició de monarques segons ell mateix declara-i, lògicament, els Corella no eren més que els reis-, cal suposar que Manuel Roís de Corella entraria en l'orde de Montesa entre els i 4 i els I8 anys d'edat. Com en la llista de contribuents de la Trinitat feta entre I 446 i I449, ja figura com a frare Manuel Roís de Corella, amb unes senzilles operacions matemàtiques veiem que solament contribuint en I 448 o en I 449 podia ell tenir I 4 anys i ser membre de l'orde. ${ }^{83}$

Si triem la data de I449, Manuel naixeria en I435, el mateix any que el seu germà Joan -cosa que sols podria passar sent bessons o amb un part molt prematur del futur poeta, i de cap d'aquestes dues circumstàncies havem el menor indici-, però, si optem per la contribució en I448, ens trobarem amb I434, un moment en què Ausiàs Roís de Corella i Aldonça de Cabrera duien ja molts mesos casats i havien tingut prou de temps per a concebre un descendent. ${ }^{84}$

Altres dades poden apuntalar un poc més aquesta hipòtesi del seu naixement en I 434, i per tant de la seua primogenitura, si les relacionem entre elles.

Sabem que, al testament de la seua mare del 30 de setembre de I434, no és esmentat cap fill, fet que pot indicar que, en eixa data, encara no havia nascut cap d'ells. ${ }^{85}$ Si aquest testament

Tenían que ser mayores y haber pasado por un año de noviciado para recibir las órdenes mayores. Por último, no podían ser sacerdotes antes de los 26 años”. L'orde de Montesa, pels seus lligams amb la de Calatrava, pot englobar-se dins de la categoria depenent del Císter.

82. El text sencer de la carta del mestre de Montesa, i les circumstàncies que expliquen la seua redacció -petició del bisbe de Lleida per a donar l'hàbit de Montesa a un fill del doctor Colom, ciutadà de Barcelona-, es troben en Samper (ı669, 266-69) i en Ferran (ı926, 28-29). El text, segons la versió de Samper, és el següent:

"Senyor Molt Reverent: A vostra letra que he rebuda responch que no me-s possible enseguir vostres prechs e de micer Berenguer Colom sens gran carrech e dany esdevenidor de ma Religió. És la causa que així com vostra Senyoria sap, aquesta Religió es poch ha poblada en aqueste regne de València tan solament e, per diverses voltes, som estat pregat e congoxat per molts ciutadans de aquesta ciutat ab intercessions precedents de reys, de reynes, e de infants, e altres, yo degués rebre de llurs fills en la Religió, ab les quals tots temps, e yo, e ma Religió nos som excusats, que per nostra fundació e regla e edicte fet en la dita Religió no hi podem ésser reebuts sinó fills de hòmens generosos de linatge, e de edat de puericia; ó és de catorze fins en dihuit anys, e en la forma desús, conservant nostros statuts.Yo•m só defés de no reebre frares en la dita Religió si no en la forma desús dita, e si ara començava fer lo contrari de ço que he scusat fins ara, pot considerar vostra senyoria en quin trantill me metria ab los ciutadans de aquesta ciutat ab los quals yo, e ma religió, havem a viure, e a comarcar, perquè, senyor molt reverent, attés lo desús dit, no solaments de vostres prechs e instància vos plàcia haver-me per escusat, mas encara ab lo dit micer Berenguer Colom, al qual sens ducte en lo que.m fos possible me dispondria fer-ly plaers e honors. Evullats sonservar la Sancta Trinitat en la sua amor e gràcia. Feta en la ciutat de València a XXII de giner any MCDXXVII

De la vostra molt reverent senyoria, afectat servidor. Lo Mestre de Muntesa”.

83. Una edat superior als I 4 anys ens portaria més enllà de la data de matrimoni d'Ausiàs Roís de Corella i Aldonça de Cabrera.

84. Per exemple i com veurem en un altre apartat, Elionor Flors de Vallterra i el seu marit firmaren capitulacions matrimonials en agost de I 474 i, en el moment de morir l'espòs en setembre de I475, tenien ja una filla.

85. En la nostra opinió, la no menció de fills es una prova, gairebé segura, que no havien fills; però no ho podem afirmar amb total seguretat, perquè no es infreqüent trobar pares -com per exemple, el cavaller i mestre en teologia Joan Roís de Corella- que no fan cap menció dels seus fills en els seus testaments. 
haguera estat fet per Aldonça davant la por al part, com no era infreqüent a l'època (García I984, 2II) ${ }^{86}$ tindríem un naixement -el de Manuel- en el mes d’octubre de I 434 com a mínim, i encara quedaria temps per a una nova concepció, la de Joan Roís de Corella, a finals de desembre de I 434 o primers dies de gener de I435. A més a més, si Manuel no havia nascut encara el zo de setembre de I434, la seua concepció biològica ens portaria a principis de I434 O a finals de desembre de I433, un moment en què el matrimoni Corella-Cabrera contractà els serveis durant sis anys de Margarida, de dotze anys d'edat, qui sap si en previsió d'un desitjat embaràs i de l'atenció als futurs nouvinguts (doc. $\left.13^{2}\right)$.

És segur que Joan Roís de Corella va nàixer el 28 de setembre de I 435 i que, en els llistats de contribuents del I446-I 449 a la fâbrica del monestir de la Trinitat, "frare Manuel de Corella" figura esmentat darrere del seu germà Joan. Aquest ordre de menció en el llistat ha estat sempre l'argument principal per a suposar que l'escriptor era major que Manuel, però aquest ordre podria ser explicat també perquè, després del testament d'Ausiàs Roís de Corella de febrer de I 443 , Joan era l'hereu de son pare i el visible cap de la família després d'ell. És cert, així mateix, que en alguns altres documents també apareix esmentat Joan davant de Manuel; però, respecte de l'ordre de menció dels fills del matrimoni Roís de Corella, cal assenyalar que, per exemple, en el testament d'Aldonça de Cabrera redactat en I460 (doc. 23I), Lluís i Dalfina apareixen esmentats abans que fra Manuel i sor Aldonça, i que, en el seu darrer de I466, els llegats de sa mare a Lluís són indicats abans que els de les seues dues germanes o que el nomenament de Joan Roís com a hereu universal (doc. 250$)$.

Al costat d'aquest ordre en el llistat de la fâbrica del monestir de la Trinitat, hom podia al.legar, també, a favor de la primogenitura de Joan Roís de Corella, el seu nom de pila -el costum seria que els primogènits portaren el nom dels pares o dels avis i, per això, l'escriptor, en la seua condició de primogènit, s'anomenaria com el difunt avi patern en record i homenatge a ell- però cal dir que aquesta és una pràctica certa però no invariable. Citarem dos casos molt coneguts com a exemple: Joan -primogènit del primer matrimoni del poeta Pere March- no porta ni el nom del seu pare ni el de l'avi; el primogènit de Francesc Martorell -pare de l'autor del Tirant lo Blanc- tampoc el porta. En aquest sentit, fins i tot l'argument de posar al primogènit un nom com a homenatge a un membre de la família pot ser utilitzat a favor de la primogenitura de Manuel: Quan varen nàixer els fills d'Ausiàs Roís de Corella, el membre més important de la família i, per tant, el membre a qui calia honorar -l'avi Joan havia faltat onze anys abans de casar-se els pares de l'escriptor- era fra Manuel Roís de Corella, germà d'Ausiàs i comanador de Culla en el moment del naixement dels fills del matrimoni Corella-Cabrera. I quin més gran homenatge que posar al primogènit el nom de pila del membre més destacat, en eixe moment, de la família? Un homenatge que, a més a més, també justificaria de ser el primogènit de la família qui entrara en l'orde de Muntesa, i no el secundogènit com era freqüent en l'època.

També es podria argumentar a favor de la primogenitura de Joan que son pare el va declarar hereu universal dels seus béns; però cal assenyalar que no sempre els primogènits eren els hereus universals. És el cas, entre d'altres, de Lluís i Dalfina Roís de Corella -declarats hereus universals de sa mare en els testaments de I45I i I 456-, de Joanot Martorell -hereu universal de la majoria dels béns familiars sense ser el primogènit-, de Beatriu Figuerola -filla de Dalfina Roís de Corella (doc. 409)-, d'Antoni Vich, ${ }^{87}$ o de Francesc Miquel, hereu universal del mestre racional i escriptor

86. És cert que ella diu “stant malalta de greu malaltia de la qual tem morir”, però res no lleva que no volguera fer referència directa a l'embaràs i posterior part.

87. En el seu testament Joan de Vich, “tras dejar diferentes cantidades a sus numerosos sobrinos Soler y a Joanot, 
Joan Ram Escrivà sense ser tampoc el primogènit (Parisi 2009a, 7I). En aquests casos, a banda del possible major o menor amor dels pares per un fill determinat, una raó per a no fer hereu universal el primogènit residia en el desig dels pares de proporcionar un patrimoni suficient a un fill menor que no tenia resolta o encarrilada la seua vida: en el cas de Joanot Martorell, el primogènit Galceran ja era senyor de Llíber (Chiner I993, 63) i, en el cas, del fill de Joan Ram Escrivà, el tertulià de Corella havia aconseguit que el càrrec de mestre racional fóra per al seu fill major (Cruselles I989, I52; Parisi 2009a, 7I). Si Manuel fóra el primogènit i son pare considerara que el futur d'aquest fill seu estava ja ben encarrilat en vestir l'hàbit de l'orde de Montesa sota la protecció del germà d'aquell, comanador de Culla, no seria estrany que deixara com a hereu universal un altre fill seu, en aquest cas, Joan Roís de Corella.

Així mateix, el fet d'atorgar a Joan Roís de Corella la tutoria i curadoria dels seus germans menuts, tambe podia ser al-legat com a prova de la primogenitura del futur poeta; però cal recordar que, després de la mort de son pare, ell era l'hereu dels béns de la família i, per tant, el seu cap; i que, en el moment de fer sa mare el codicil testamentari de maig de I45O o el seu testament de I45I, no podia nomenar-lo tutor i curador dels seus germans menors per no tenir l'edat legal per a ser-ho.

Com veiem, a favor de la primogenitura de Joan Roís de Corella tan sols tenim suposicions $\mathrm{i}$ indicis sense prova documental, mentre que, pel contrari, per a la primogenitura de Manuel comptem amb el suport històric del document del mestre de Muntesa Romeu de Corbera i la cronologia relativa de les almoines per a la fâbrica del monestir de la Trinitat.

En conclusió, en la nostra opinió fra Manuel és el primogènit del matrimoni Corella-Cabrera, i naixeria poc després del testament de sa mare del 30 de setembre de I434 (doc. I42), molt probablement en el mes d'octubre de I 434 .

En el testament redactat l'i d'octubre de I45 (doc. I87), Aldonça de Cabrera llega a Manuel Roís de Corella, "frare e cavaller de l'orde de Sancta Maria de Muntesa" un timbre d'or "per tota part e legíttima e altre dret que a aquell en mos béns li pertangués eo pertànyer pogués e aquell dit frare Manuel Roïz de Corella, fill meu, en lo dit timbre de la dita moneda hereu meu propri faç e instituesch per dret de institució". Aquesta donació d'un timbre d'or es repetirà en els seus testaments del I5 de gener de I456 i del I5 de maig de I46o (docs. 207 i 23I).

No tenim constància que Manuel ocupara cap comanda ni càrrec en l'orde de Montesa i, si ho va fer, no han d'ésser d'importància, atés que mai no figura esmentat amb aquests hipotètics càrrecs o comandes. ${ }^{88}$

Desconeixem la data de la seua mort, però cal situar-la després del I5 de maig de I460, quan encara figura esmentat en el testament de sa mare, i abans del 24 de novembre de I466, data d'un altre testament d'Aldonça, on no ho és (doc. 250).

hijo de su hermano Luis, legaba I.ooo sueldos anuales de renta a su hijo Miquel Jerònim, dejando a su primogénito Guillén Ramón tan solo un ducado por legítima y por cualquier derecho que le pudiese corresponder, mandando que se le pagase la dote que su madre le había aportado al tiempo de su matrimonio. Nombraba heredero universal a su segundo hijo Antonio. Fallecería casi tres años después de redactado su testamento, el 5 de febrero de I492" (Gómez-Corbalán $2009,45)$. Aquest Joan de Vich, família del famós ambaixador Vich, residia a la parròquia de San Martí. En la redacció del testament de la seua esposa, Beatriu d'Esplugues, actuà com a testimoni Lluís Figuerola i fou publicat el 3 d'abril de I486 a la casa de l’escriptor Joan Roís de Corella (Gómez - Corbalán 20o9, 44).

88. En Siete Iglesias (I957, I86) figura Manuel de Corella en la llista de cavallers i religiosos de l'orde de Montesa de l'any I450. Com ja hem comentat, en Chiner I994b, 56 i Chiner 1998, 28 per un lapsus calami i un “copia-enganxa” informàtic no gaire curós, afirmàrem que fra Manuel era mestre de Muntesa quan no ho va arribar a ser. 


\subsubsection{Sor Aldonça, monja de la Trinitat de València}

Sor Aldonça Roís de Corella era la filla major del matrimoni format per Aldonça de Cabrera i Ausiàs Roís de Corella.

Respecte d'aquesta germana de l'escriptor Joan Roís de Corella, cal esmentar que la major part de les notícies que en tenim les proporciona el cronista Agustí Sales a la seua Historia del Real Monasterio de la Ssma. Trinidad, religiosas de Santa Clara, de la Regular Observancia, fuera los Muros de la Cüudad de València publicada en I76r. ${ }^{89}$ Segons aquest autor i com ja hem comentat abans, juntament amb els seus pares i els seus germans Joan, fra Manuel i Lluís, figura entre els contribuents a la fâbrica del referit monestir. Sor Aldonça Roís de Corella consta "entre las Religiosas que dieron limosna [per a la fâbrica del dit monestir], con sola mencion de Sor Aldonzeta, i en ultimo lugar; lo que denota que entró alli para educacion”. En concret, al llibre conegut com a Libro de la casa de la reina, figura sor Aldonça amb 55 lliures, que cal considerar més com una espècie de "dot conventual" que com un donatiu a la referida fâbrica (Mata I99I, I44).

Segons Daniel Benito (I998, 42-52),

los trinitarios habitaron el Monasterio [de la Santíssima Trinitat] hasta I 444 cuando esta comunidad entró en decadencia y empezaron a ser mal vistos por el pueblo desde que allí se trasladaron dos religiosos de otra orden que trastornaron la vida conventual, organizando facciones de tal manera que, como consta en el Libro Mayor de Títulos del Monasterio, casi había cesado de celebrarse el culto divino (...) Desde I 436 deseaba fundar [la reina Maria] en Valencia un monasterio de religiosas de Santa Clara de la Observancia, a quienes tenía gran afición pues con ellas se había educado en su convento de Tordesillas (...). Así obtuvo permiso de Eugenio IV en una bula expedida en Siena el 23 de julio de I 443, siempre que el edificio tuviese iglesia, claustro y las demás dependencias, concediéndole además el patronato mientras viviera. (...) La última abadesa de Gandía sor Violante Despuig, es confirmada en el abadiado. Entran nuevas religiosas que se suman a las diecisiete venidas de Gandía el día 22 de enero de I445, siendo la primera de ellas en ingresar Leonor de Villena, que tras tomar el hábito el último día de febrero de I445, se llamará sor Isabel de Villena (...). Como patrimonio propio de la nueva fundación estaban todas las donaciones que reyes, nobles y particulares fueron haciendo a partir de I 445 (...). En este extensísimo libro de bienhechores [el Llibre de la casa de la reina], que se custodia en el archivo del monasterio se recogen 4.623 donantes y aparece retratada toda la sociedad valenciana de mediados del siglo XV, señalados con sus oficios y estatus social; todas las personas que contribuyeron entre I 446 y I 449 para la fábrica y se hicieron acreedores de las indulgencias concedidas para la ocasión por Eugenio IV y Nicolás $V$ a quienes colaborasen en la obra con la limosna al menos de cinco florines o el trabajo o materiales euqivalentes. La perdida bula de concesión de indulgencias de Eugenio IV, fue dada en Roma, según Sales en 23 de marzo de I 446 , Nicolás las concedió en I 448 y I $449 \cdot{ }^{90}$

Segons Sales, sor Aldonça Roís de Corella va prendre l'hàbit el 5 de maig de I 457. Professà l'any següent. Fou nomenada abadessa del convent de Jerusalem de Barcelona el 7 de gener de I 495 “de edad de unos 53 años empleados en servir a Dios, i practicar virtudes en este Monasterio de la SS. Trinidad”. Passà, posteriorment, a reformar el convent de Pedralbes, segons afirma Sales (I76I, I27-

89. La primera pedra d'aquest convent es posà el 2 d'abril de I446 (Sales I76I, 25).

90. Segons Sales (I76I, 25), “contibuyeron muchos a èfeto de ganar las Indulgencias que concediò el Papa Eugenio IV por sus Letras Apostolicas dada en Roma à 23 de Marzo I 446 que prorigò en 2 de Deciembre del mismo; i las que determinò Nicolas V à peticion de la misma Reina, i repitiò en I448 i, I 449 (...) la primera que para ganarlas diò la limosna, que fueron dos mil florines de oro, aunque las Letras Apostolicas solo señalavan cinco, i cada uno eran once sueldos, en que contribuyeron muchos". 
3):

En Barcelona una Matrona de Pisa llamada Antonina, Prelada de la Casa de Santa Maria de Gerusalen en que moravan Terceras de San Francisco, procurò que tomaran todas el Velo de Monjas de Santa Clara. Era Obispo de Barcelona Don Pedro Garcia, natural de Jativa, Dotor Parisiense, Capellan del Cardenal Don Rodrigo de Borja, el qual no ignorava la gran santidad de vida de las que se deseavan por fundadoras. I assi no repugnó à que esta Matrona rogara à este Convento de la S.S. Trinidad, que embiara quatro Religiosas para la fundación de este nuevo Monasterio. I en efecto fueron destinadas la Ven. Sor Aldonza de Corella por Abadessa; la Vener. Sor Leonor de Vilarig; Sor Isabel Alpicat; i Sor Geronima Peñaroja, quatro Valencianas de los linages mas distinguidos, i del mas singular ejemplo: de cuyas calidades se trata en el libro original de Ingressos. El P.M. Fr. Francisco Diago, que escrivio en Barcelona, dà por assentado, que las quatro Religiosas de la Trinidad fueron allà el año I 499, lo mismo el P. Sorribas. Pero es constante, que partieron de aquí, dia 7 de Enero del año I 495 como se lee en el libro original de Ingressos, notado por mano contemporánea, que asimismo asegura, que estas quatro Señoras que pasaron alla, à edificar el Monasterio de Gerusalem, fueron de gran virtud, i ejemplo, i hicieron gran fruto (...).

Fundado ya el insinuado Monasterio de Barcelona, i puestas las cosas en su debido orden, las dos Venerables Sor Corella Abadessa, i Sor Villarig, pasaron por orden de la Religion à reformar el Monasterio de Santa Maria de Pedralvas Orden de Santa Clara, en la Vega de Barcelona (...).

La Ven. Sor Aldonza de Corella, fuè del mismo tronco de los Corellas, Ricos hombres de Navarra; i del que procedieron Don Gimen Perez de Corella Conde de Cosentaina; i descendiente de los que del mismo tronco quedaron heredados en Valencia, en que vivian por esos años Mossen Auzias Roiz de Corella, Cavallero mui principal, marido de la honorable na Aldonza, que creo fueron sus Padres, i están nombrados entre los que dieron limosna para la fabrica del Monasterio quando lo levantava la Reina. En cuyo tiempo contribuyò nuestra Venerable, i està su nombre entre las Religiosas que dieron limosna, con sola insinuación de Sor Aldonzeta, i en ultimo lugar; lo que denota entrò allí para educación. I en efeto tomò el Habito dia 5 de Mayo de I 457 i professò en el siguiente, como se nota por mano coetánea en el libro original de Ingressos. Sus nobles prendas, assistidas de tantos ejemplos como veìa en el Monasterio, i en especial de la divina gracia, la hicieron correr por el camino de la vida Monastica, por el qual llegó à mui elevada perfeccion. Fuè puntualissima en la observancia de su Instituto: i aborreció quanto no sabia à la virtud de la pobreza, de que fuè amantissima. Viviò súbdita todo el tiempo de la Prelacìa de la Vener. Sor Isabel de Villena, i pudo observar todas sus santas acciones: asimismo de otras Preladas. Era virtuosissima; i como los aromas de sus virtudes, aunque ocultas, no podían dissimular su fragancia, fueron por si tan manifiestas, que viéndola tan espiritual los Prelados, i por otra parte tan prudente, i mortificada, la mandaron pasar à Barcelona con caracter de Abadessa, à la fundación del convento de Gerusalen, en 7 de Enero I 495 de edad de unos 53 años, empleados en servir à Dios i practicar virtudes en este Real Monasterio de la S.S. Tinidad. Aunque en Barcelona experimentò muchas contradicciones, supo vencerlas con su constancia i paciencia. Viviò allà entre sus Religiosas tan desprendida de los cuidados temporales, que sentía mucho que llegaran à sus Venerables Claustros, las voces de lo que passava en el Siglo. Fuè celozissima de la disciplina Monastica. Assimismo, piadosa Madre en la Assistencia de las Religiosas sanas, i en el regalo, i discreta condecendencia de las Enfermas mirando siempre à sus Subditas, como hijas amantissimas. Antes del Capitulo de culpas, ò de reprehender alguna Subdita, quando lo pedia la necesidad, se iva al Coro a tener oración, invocando en su asistencia al Divino Espiritu, i cerrava la deprecación con una rigurosa disciplina. Esto afligia, i compungia mucho el corazón de sus Subditas: i lloraban que assi padeciera por el bien espiritual de todas. Hizole sobre el assunto una amorosa queja una familiar Subdita; i diò por respuesta: "Se que mis peccados impiden en mis Subditas, que se les impriman mis documentos, à menos que yo no desenoje à mi Dios: $i$ assi me prevengo con la penitencia antes de enseñar como Maestra, i de reprehender como Prelada”. Despues de aver plantado en su Monasterio de Barcelona tantas virtudes, mandòle la Obediencia reformar el Convento de Pedralvas. 
Passò a dicha Reforma acompañada de la Vener. Sor Leonor de Villarig, Valenciana noble, de la Ilustre Cassa de los Condes de Sirat, Religiosa de grande espíritu, que avia tomado el Habito en la Trinidad de Valencia dia de la Aparicion de San Miguel, à 8 de Mayo de I 474 i professado en I48I como se advierte en el libro original de Ingressos. Fuè esta Religiosa, una de las que ayudaron à la Vener. Villena en las Obras del Monasterio, como ella misma lo notò de su mano en el Libro I de Titulos. Ambas à dos Sor Corella, i Sor Villarig, llenaron à Cataluña de santos ejemplos, i dejaron gran fama de Santidad. El P. Sorribas supone que la Vener. Sor Aldonza, bolvió al Real Monasterio de la S.S. Trinidad donde muriò. Pero es cierto que muriò Abadessa en su convento de Gerusalen de Barcelona, como se nota por mano coetanea en el libro de Ingressos, que nunca viò el Padre Sorribas. Cuyo libro se escrivia quando por muerte de la Vener. Aldonza, era Abadessa de aquel mismo Convento de Gerusalen, la Vener. compañera Sor Leonor de Villarig, como en èl se advierte. I assi ambas Venerables Señoras yacen allà sepultadas. Lo cierto, que la fama de estas dos Religiosas, es mui celebre en los tres insinuados Monasterios, i monumentos de la Orden. I èste en especial de la S.S. Trinidad de Valencia, tendrà el perpetuo honor de aver producido heroìnas de rara santidad, i egemplo, que han podido remediar el menoscabo que amenazava la libertad de otros.

Algunes de les informacions cronològiques proporcionades per Sales sobre l'arribada d'Aldonça a terres catalanes han de ser posades en quarentena, car les monges de la Trinitat arribaren a Barcelona en 4494 (Botinas et al. 2002, 75-76). i sor Aldonça Corella ja figura com a abadessa de Santa Maria de Jerusalem en un document del 22 de desembre de I494 (doc. 353) publicat per Madurell (1948, I57-58). El més lògic és que l'elecció com a abadessa es produïra uns quants mesos abans -fins i tot a poc d'arribar a Barcelona-, i que, per tant, l'arribada de les monges de la Trinitat haja de col-locar-se, molt probablement, en els primers mesos de I494. Si això fóra així, i tenint en compte l'aportació documental de Madurell, és posible suposar amb cert grau d'encert que la data aportada per Sales com a dia de la partida de les monges de la Trinitat a Barcelona -7 de gener de I495- que, segons ell, era una anotació manuscrita, continga un error de lectura, i que calga transformar aquesta data en la de 7 de gener de I494.

D’altra banda, Sales afirma que sor Aldonça Roís de Corella va anar a reformar el convent de Pedralbes després d'estar-se a Santa Maria de Jerusalem, on, posteriorment, tornaria i estaria soterrada. L'afirmació respecte a Pedralbes és errònia: a finals del segle XV i principis del XVI, les abadesses de Pedralbes varen ser Violant de Moncada, Teresa Enríquez, Maria d’Aragó -filla natural del rei Ferran el Catòlic-, Damiata de Mendoza i Teresa de Cardona -cosina del rei Ferran. ${ }^{91}$

La marxa d'Aldonça al monestir de Jerusalem s'insereix dins l'onada de reformes que, en aquests anys, va afectar als monestirs de clarisses de la Corona d'Aragó i, especialment, de Catalunya: entre I 494 i I 496, es reformaren els convents de Santa Maria de Jerusalem de Barcelona, Santa Clara de Villafranca del Penedés, Santa Clara de Tarragona, Montblanc, Girona, Castelló d’Ampúries, Perpinyà, Balaguer, Puigcerdà, Conques, Vic, Tàrrega, Cervera i Tortosa. ${ }^{92}$

Si, com va dir Sales, Aldonça Roís de Corella havia uns 53 anys quan va anar a Barcelona, cal situar la data del seu naixement al voltant de I440, tenint en compte que ja en I 494 figura com a abadessa de Pedralbes. Aquesta cronologia resulta versemblant si recordem que el seu pare ja li deixà certs llegats al seu darrer testament realitzat davant el notari Joan Sart a València el 9 de febrer de I443. La presència, durant la vida de l'escriptor Joan Roís de Corella, d'aquesta germana seua

9I. Per a la successió d'abadesses en Pedralbes i la greu disputa que es produí per ocupar aquest càrrec a finals del s. XV, vid. Castellano (2003), Anzizu (I897) i Sanjust (2009). Isabel March, germana dels poetes Jaume i Pere March, va ser abadessa de Pedralbes -el mateix monestir on, el 7 de desembre de 1360 , va ser adobat cavaller el seu pare Jaume March- on morí el ı2 d'agost de I4II (Chiner I997, 62 i 66).

92. Sobre aquest moviment general de reforma a les clarisses, vid. Soriano (I995). 
entre les monges de la Santíssima Trinitat de València -on també hi havia Violant, filla de l'escriptor Jaume Roig, metge titular de la reina Maria i del mateix monestir (Chiner 1993-94, I77) - ens permet suposar que el nostre prosista i poeta tindria forts contactes amb el cercle teològic i literari format al voltant d'Isabel de Villena, abadessa de la Trinitat des de I463 i autora de la Vita Christi. ${ }^{93}$

$$
\text { 2.2.3. Lluís Roís de Corella }
$$

Lluís és el tercer fill mascle del matrimoni format per Ausiàs Roís de Corella i Aldonça de Cabrera. Igual que la majoria dels seus germans, figura en les llistes de contribuents a l'obra del monestir de la Santíssima Trinitat de València.

De les clàusules dels testaments de la seua mare de I45I i I 456 on es parla de l'establiment de la tutoria i curadoria de Lluís i Dalfina Roís de Corella, es pot deduir que ambdós degueren nàixer amb posterioritat al I5 de gener de I44I, ja que, per a necessitar un tutor el I5 de gener de I456, encara no havien d'haver complit els I5 anys (doc. 207). Aquesta cronologia pot ser acotada un poc més si pensem que Ausiàs Roís de Corella, el seu pare, va testar el 9 de febrer de I 443 i deixava, a ell i a Dalfina, un llegat de ıoo florins. Per tant, cal situar el naixement de Lluís Roís de Corella entre el i5 de gener de I44I i el 9 de febrer de I443.

Els documents que, a partir de l'any I 454, esmenten Lluís Roís de Corella ho fan al costat de la seua mare i del seu germà Joan, donant-li la titulació de donzell. Es tracta de diverses escritures de venda i carregament de censals i violaris realitzats a Aldonça Roís de Corella per diferents persones -entre elles el noble don Joan de Próxita, un dels tertulians esmentats per Corella en el Parlament en casa de Berenguer Mercader-, durant les vides dels seus dos fills en la majoria de les ocasions (docs. I99, 200, 2OI, 202) o durant les vides d'ella i de Lluís (doc. 269).

Com ocorre amb altres membres de la família Roís de Corella i de la societat valenciana de l’època, Lluís també va tenir en els censals i violaris un dels seus mitjans de vida. Uns censals i violaris que el portaren a pledejar judicialment per a reclamar l'abonament de les pensions degudes:

El 20 de març de I50o reclamarà I5o sous a Honorat de Coblliure, Lluís Jeroni d’Alpicat, al cavaller de l'orde de Sant Jaume de l'Espasa mossén Jeroni de Vila-rasa i al donzell Joan Lluís de Vila-rasa -fill de Guillem Ramon de Vila-rasa, tertulià del Parlament en casa de Berenguer Mercader-(doc. 377).

El I5 de setembre d'eixe mateix any, reclamà 27 lliures, I3 sous i I diners a mossén Pere Martorell -antic senyor de Negrals-, a Caterina -la seua esposa-i a Francesc Miró -senyor en eixe moment de Negrals-, en raó de $5^{8} 3$ sous i 4 diners censals que ells havien carregat a mossén Ausiàs Roís de Corella i als seus en I442. El 8 de desembre de I475, i per escriptura rebuda pel notari Antoni Barreda, aquest censal passà a mans de Lluís, probablement donat per Joan Roís de Corella en raó del llegat testamentari de sa mare ja morta. ${ }^{94}$ Un censal que farà que, en setembre de I49O i I49I, Francesc Sard, senyor de Negrals, li lliure diverses quantitats (docs. 340 i 342 ).

El 29 d'abril de I5OI, Lluís reclamarà a Pere Martorell, a Caterina -la seua esposa- i a Francesc Miró 24 lliures, 3 sous i 6 diners de pensions degudes per aquest censal carregat pel senyor de Negrals a Ausiàs Roís de Corella, pare de Lluís (doc. 386 ).

* A finals del mes de desembre de I5OI, demandà els jurats de la Pobla de Vallbona per un total de

93. Sobre aquest cercle literari i les seues implicacions en la vida cultural valenciana, vid. Hauf (I990).

94. Doc. 382. En ARV, Governació, no. 254, mà 8, f. 48 figura un altre procés, datat el 23 d'octubre de I5o8, de Lluís Roís de Corella per un censal, pertanyent a Ausiàs Roís de Corella, carregat sobre Negrals el 2i de febrer de I442. 
I42 sous i Io diners deguts de la paga d'un censal que la seua mare li havia deixat al seu darrer testament (doc. 39I).

Coneixem el contingut de diversos testaments d'aquest germà de l'escriptor.

El primer n'està datat el 25 de juny de 1477 (doc. 289). Lluís nomena hereu universal de tots els seus béns el seu germà Joan, cavaller i mestre en teologia, a qui "recoman la ànima mia e lo càrrech de la mia sepultura, la qual vull sia feta a tota voluntat, beneplàcit e ordinació de aquell”.

El segon, el va realitzar el 22 de setembre de I48I davant el notari Antoni Barreda. Hi revoca expressament el seu testament de I477 i elegeix el cavaller Ramon Torrelles, habitant de València, com a hereu universal. Així mateix, llega roo lliures a la seua germana Dalfina Roís de Corella, esposa del cavaller Lluís Figuerola. No esmenta cap altre dels seus germans (doc. 3I3).

Prop de vuit anys després (doc. 333), en un nou testament nomenarà hereu universal dels seus béns el comte d'Oliva Ramon de Riusec, àlies Serafí de Centelles, germà de l'escriptor i canonge Jordi Centelles..$^{95}$

El darrer testament que coneixem de Lluís Roís de Corella, el va fer el i6 de juny de I5O2. Revoca els seus anteriors testaments i nomena com a marmessors el dominic Pere de Sentandreu i el noble don Rodrigo de Borja, habitant de València, a qui nomena, també, hereu seu universal. Esmenta el seu desig de ser soterrat en el "vas” de les Ànimes del Purgatori que és al cantó del claustre al costat de l'església del monestir de Sant Domènec. Realitza diverses deixalles testamentaries: A la seua germana Dalfina, li llega 50 lliures demanant-li que el perdone si no li deixa més, atés que ell té pocs béns; a Isabel Muntanyesa -esposa de Llàtzer, mestre d'esgrima-, Io lliures per qualsevol tipus d’obligació que tinguera amb ella, i a Jerònima Vives tots els mobles de la casa del testador més 20 lliures pels serveis que, en alguna ocasió, li ha prestat (doc. 392).

Si lliguem la pobresa de Lluís amb la declaració com a hereus del comte d'Oliva en I489 i del noble don Rodrigo de Borja - probable parent d'Alexandre VI - ${ }^{96}$ en I5O2, podria aventurar-se com a hipòtesi que aquestes declaracions d'hereus poden amagar el desig d'aquest germà de l'escriptor de viure protegit, unit d'alguna manera a dues de les grans famílies valencianes de finals del s. XV i principis del XVI.

Per la seua banda, les relacions del fill mascle menor d'Ausiàs i Aldonça Roís de Corella amb el mercader Bertomeu Chiva són, igual que els de la resta de la família, molt estretes, i demostren la màxima confiança en l'antic veí de Llutxent. Així, per exemple, el mateix 25 de juny de I 477 en què Lluís dictava el seu testament, nomenava Chiva com a procurador seu (doc. 290).

Les relacions amb la seua neboda Magdalena -filla del poeta Joan Roís de Corella- semblen haver estat també bones, ja que ella el va constituir en hereu universal, sota certes condicions de successió, en els seus testaments de I480 i I 490. ${ }^{97}$ Una molt bona relació nascuda, segurament, de la convivència d'ells dos en la casa d'Aldonça Roís de Corella, mare de Lluís i àvia de Magdalena.

L’i d'abril de I5I4, el donzell Lluís Roís de Corella -mai no serà adobat cavaller- es farà càrrec de

95. Que Jordi Cetelles i Ramon de Riusec són germans es veu, clarament, en AHN, Osuna, llig. I322, no. 26, not. Antoni Barreda -7 de maig de I489.

96. Aquest don Rodrigo de Borja pot ser identificat, amb moltes probabilitats d'encert, amb Roderic de BorjaLlançol, primogènit de Jofre de Borja-Llançol i de Joana de Montcada, qui exercí a Roma el càrrec de capità de la guardia pontifícia. Mort Alexandre VI, retornà amb els seus a València. Durant la guerra de les Germanies ajudà a Germana de Foix en la sufocació de la revolta. Deixà una nombrosa descendència dels seus dos matrimonis, el primer amb Jerònima de Calatayud i Mercader; el segon amb Maria de Centelles (Batllori i994, 28).

97. Docs. 3II i 339. Vid. també infra 3.2.2. 
quitar un censal de 3500 sous de principal que en aquell moment posseïa. Era un censal per valor de 233 sous i 4 diners que Isabel Martínez de Vera i els seus fills Joan Roís de Corella i Estefania, havien venut, per preu de I75 lliures, al cavaller de València Nicolau Ferrando (doc. 390). Aquesta és la darrera notícia documental que hem trobada de Lluís Roís de Corella.

Desconeixem la data de la seua mort però, lògicament, ha de ser posterior a la del quitament d'aquest antic censal d'Isabel Martínez de Vera.

\subsubsection{Dalfina Roís de Corella}

Dalfina Roís de Corella sembla ser la filla més menuda d'Ausiàs Roís de Corella i Aldonça de Cabrera.

Tal com hem comentat en parlar del seu germà Lluís (supra, 2.2.3), cal situar el naixement de Dalfina Roís de Corella entre el I5 de gener de I44I i el 9 de febrer de I443, data del testament de son pare on va deixar-li un llegat de Ioo florins.

A diferència de la resta de germans, Dalfina no figura en les llistes de contribuents a l'obra del monestir de la Santíssima Trinitat de València quan sabem que, en el període de contribució (I 446 I448) ja havia nascut. Desconeixem la raó exacta d'aquesta absència. Error del copista del Llibre de la casa de la reina? Figurava en el text de les indulgències papals alguna clàusula excloent la contribució de persones menors d'una edat determinada?

En el període I455-I468, trobem Dalfina Roís de Corella, sempre qualificada com a donzella, en diversos violaris i censals al costat de sa mare i del seu germà Joan (docs. 205, 2I2, 2I4, 2I5, 2I8, 22O, 22I, 223, 224, 229, 230, 232, 236, 25 I i 257).

Poc més de dos anys després de dictar Aldonça Roís de Coirella un testament on deixava a Dalfina tan sols cinc sous com a tota herència, el 2I de gener de I469 Aldonça i el seu fill Joan, en contemplació del matrimoni acordat entre el cavaller Lluís Figuerola i Dalfina Roís de Corella que prompte es celebraria eclesiàsticament, establiren per a Dalfina un dot de i8.ooo sous (doc. 258). En eixa època, com veurem, Corella obtindrà el grau de mestre en teologia i ajudarà a la seua amistançada Isabel Martínez de Vera a comprar una casa.

Els Corella acordaren lliurar el dot establit a Lluís Figuerola de la següent manera:

7.5II sous, 5 diners en metàl-lic.

Per valor de 7.203 sous, I diners li transporten tots aquells $5^{83}$ sous, 4 diners censals que el cavaller Pere Martorell i la seua esposa originalment carregaren a Ausiàs Roís de Corella el 2i de febrer de I 442 davant el notari Joan Sart i que ara pertanyen a Aldonça com a donatària del seu fill Joan Roís de Corella, hereu universal del seu pare, segons consta per escriptura feta davant el notari Antoni Barreda el 22 de desembre de I 455 .

Per valor de 3.245 sous, li transporten tots aquells 265 sous censals que Violant de Vilarig-vídua de Joan March-, Ausiàs March i Pere Guillem Lançol -senyor de Vilallonga- vengueren a Ausiàs Roís de Corella el 2I d'octubre de I 444 davant el notari de València Joan Sart. ${ }^{98}$

Per la seua banda, Lluís Figuerola, vidu de Damiata Valleriola des d’octubre de I468, va prometre donar

98. Doc. 258. En el moment de fer aquesta escriptura notarial, el primer d'aquests censals era pagat per Pere Sart, habitant de Dénia, com a senyor de Negrals, mentre que el segon, ho era per Roderic de Borja, nebot del futur Papa Alexandre VI. 
a Dalfina Roís de Corella 9.ooo sous en qualitat de creix. Ell, amb aquest nou matrimoni, cercava ràpidament una nova mare per al fill nascut del matrimoni amb Damiata Valleriola. Dalfina Roís de Corella -amb una edat tardana per al matrimoni ${ }^{99}$ - podia cercar assegurar-se un futur casant-se amb un membre d'una important família de València. Malgrat això, el temps va demostrar que no sols Dalfina va fer un bon matrimoni des del punt de vista econòmic, sinó que va trobar un home que l'estimà sincerament, tal com ens mostren els documents.

Lluís Figuerola era membre d'una important família de juristes de la València dels segles XV i XVI (Graullera 2009, I99-2O0 i 348). Els seus pares foren el cavaller Joan Figuerola i Joana -filla de Lluís d'Exarch-, i els seus germans eren Andreu, Joan i Aldonça. ${ }^{100}$ Joan Figuerola i la seua esposa Joana tenien a València una casa al carrer de Cavallers (RCSCCV, protocols, no. 935, not. Francesc Pelegrí -23 de juny de I45O), i una altra al carrer de la parròquia de Sant Nicolau anomenat del Forn Nou - prop de la casa del metge escriptor Jaume Roig- que va ser venuda per Andreu i Lluís Figuerola al sastre Joan Pujades per 67 lliures i Io sous (doc. 348). En I 456 el cavaller Joan Figuerola va vendre per 250 sous, al batle general de València, "un libre appellat Los test de filosofia d'Aristòtil en un volum scrits en pregamí a dos corondells la plana, per ops de trametre lo dit libre a sa magestat del senyor rey en lo realme de Nàpols" qui l'havia demanat expresament en setembre de I $455 \cdot{ }^{101}$

Andreu Figuerola, el germà del marit de Dalfina Roís de Corella, va establir en I 463 capitulacions matrimonials amb Francesca de Monpalau, filla de Joan de Monpalau -el de les lletres de batalla amb Joanot Martorell- i cunyada de Joan Ram Escrivà. ${ }^{102}$ Andreu fou elegit jurat de València el I3 de maig de I475 per part dels cavallers i generosos (Carreres I930-35, 2, 657) i, en febrer de I488, va vendre al cavaller i teòleg Joan Roís de Corella 9oo sous censals per preu de I35OO sous (doc. 332).

$\mathrm{El}_{25}$ d'octubre de I $_{4} 65$ Lluís Figuerola, el seu germà Andreu i Francí Romeu establiren un compromís entre ells en raó de les taules de la carnisseria de València. ${ }^{103}$

Del primer matrimoni de Lluís Figuerola amb Damiata Valleriola nasqueren Enric Joan Figuerola

99. “Tot i que no disposem encara d'estudis quantitatius sobre l'edat del matrmoni, ben probablement aquesta se situaria entre els vint-i-cinc anys en l’home, (...) i al voltant dels divuit anys en la dona” (Furió, et al. I994, IO4).

IOO. Aquestes dades figuren en un llarg testament de Joan Figuerola fet el 23 de juny de I 450 davant el notari Francesc Pelegrí (RCSCCV, protocols, no. 935, not. Francesc Pelegrí -23 de juny de I45O). Figuerola nomenarà marmessors el seu germà micer Andreu Figuerola, el seu oncle Manuel d’Exarch i el ciutadà Vicent Alegre. Elegirà ser soterrat a la seua capella del Corpus Christi de l'església de Sant Martí, i deixarà diversos llegats, entre d’altres, als seus germans Andreu i Joana.

El darrer testament de Joan Figuerola va ser rebut pel notari Ambrosi Alegret el 26 d'agost de I 457 i publicat per mort del testador pel mateix notari el i6 de novembre de I462 (doc. 348; ARV, protocols, no. 9950, not. García de Artés, -7 de gener de I464). Blanques".

Segons Vicente Graullera (2009, I99) el cavaller Joan Figuerola, pare de Lluís i Andreu, fou “dueño de Tabernes

IOI. "Item, pos en data, los quals per mi liurà lo dit En Pere Garró a l’honorable mossén Johan Figuerola, cavaller habitador de la ciutat de València, CCL sous de reyals per preu dels quals de aquell he comprat un libre appellat Los test de filosofia d'Aristòtil en un volum scrits en pregamí a dos corondells la plana, per ops de trametre lo dit libre a sa magestat del senyor rey en lo realme de Nàpols senyor [sic] per lo dit senyor me és stat manat ab letra sua dada en lo castell de la ciutat de Nàpols a XXII de settembre de l'any proppassat M CCCC LV. E haví àpoca closa pe l'escrivà de la mia cort a XVIII de maig de l'any M CCCC LVI" (ARV, Mestre Racional, no. 67, f. 304rv).

IO2. Així figura en AHN, Osuna, llig. I322, no. 2I, not. Antoni Barreda -6 de juliol de I474.

IO3. RCSCCV, protocols, no. 24136, not. Joan Verdancha -25 d'octubre de I465. El I3 de novembre de I467, trobem el cavaller Andreu Figuerola signant un compromís amb el carnisser Pere de la Pas, de la ciutat de València, per tal de solucionar les disputes que els enfrontaven (RCSCCV, protocols, no. 965, not. Joan de Eroles -I3 de novembre de I467). 
i Jerònima, segons declarà Lluís Figuerola en I483 (doc. 3I9). Damiata aportà al seu matrimoni prop de 5 o.ooo sous de dot (doc. 398). L'instrument nupcial de Lluís Figuerola i de Damiata Valleriola va ser fet davant el notari Ambrosi Alegret el 6 d'abril de I464 (RCSCCV, protocols, no. 13877, not. Pere Andreu -I8 agost I5OI).

Un any després, concretament el I6 de febrer de I465, Damiata dictà el seu darrer testament davant el notari Garcia d'Artés, qui, l'iı d'octubre de I468, el va publicar per mort de la testadora (RCSCGV, protocols, no. I3877, not. Pere Andreu -I8 agost I5OI). Segons el Dietari del capellà d'Alfons el Magnànim (Rodrigo 2OII, 328), Damiata Valleriola moriria per la pesta que, des de setembre fins desembre de I468, estava establida a València i els seus voltants.

D’acord amb la cronologia del matrimoni de Lluís i Damiata Valleriola, i de la mort d’aquesta, cal situar el naixement d'Enric Joan Figuerola -fill de Damiata i del futur cunyat de Joan Roís de Corella- entre el 6 d'abril de I464 i l'iı d'octubre de I468. Enric Joan Figuerola figura com a habitant de València en la documentació, però sabem que, el I8 d'agost de I5OI, residia a Almenara amb Vicenta, esposa seua (RCSCCV, protocols, no. I3877, not. Pere Andreu -I8 agost I5OI).

Per la seua banda, Jerònima nasqué després del i6 de febrer de I465, dia de la redacció del testament de Damiata Valleriola, sa mare, i va morir en "pupil.lar edat" (doc. 3I9).

Lluís Figuerola lliurarà, en juliol de I469, diverses quantitats de diners a Joana -esposa del cavaller Pere d'Odena-, a Beatriu -esposa del donzell Francesc Aguiló-, al ciutadà Joan Capinya, i a Violant -vídua del mercader Joan Amat-, en raó de diversos violaris venuts a aquestes persones pel propi Lluís i per Francesc Martorell, "magister portularium” del regne de Sicília (RCSCCV, protocols, no. 24I26, not. Joan Verdanxa -diverses escriptures del 28 de juliol de I469).

Uns mesos després d'establir les capitulacions matrimonials, i ja casats eclesiàsticament, Lluís Figuerola, cavaller habitant de València, nomenà la seua esposa Dalfina Roís de Corella i el seu cunyat Joan Roís de Corella, cavaller i mestre en sacra teologia, com a procuradors seus per a cobrar diverses quantitats en raó de pensions de censals i violaris (doc. 263). Així mateix, ja des del primer moment, Figuerola va fer servir els drets de la seua nova muller respecte de les pensions degudes d'alguns dels censals aportats per Dalfina al seu matrimoni: és el cas del plet iniciat en gener de I47I pel censal de Pere Martorell i la seua esposa (doc. 270). Per la seua banda, com a procuradora del seu marit, Dalfina realitzarà diferents accions: així, per exemple, en I479 saldarà un deute del seu marit a l'argenter Joan Fontanet, per valor de 447 I sous, Io diners (doc. 3o6).

Del matrimoni format entre Dalfina i Lluís Figuerola nasqueren, almenys, els següents fills, segons es dedueix dels testaments d'ambdós esposos: Bertomeu, Jerònim -nascut ja l'i de març de I483 (doc. 3I7)-, Lluís i Beatriu, aquesta menor de 20 anys en I5O4 (doc. 409). Molt probablement, a Bertomeu cal identificar-lo amb el jurat homònim de València de I5O2 i I5I5 (Carreres I930-35, 2, 72I i 76 I), mentre que el seu germà Lluís Figuerola és posible que siga el valencià homònim que va acompanyar l'emperador Carles V a la seua coronació papal en I5I5 a Bolonya (Carreres I93O-35, 2, 8I7).

L'herència del pare de Lluís i Andreu Figuerola va provocar certes disputes entre els dos germans, cavallers i habitants de València, en raó de diversos censals i violaris i, especialment, en raó de l’administració d'una “companyia de les carns” de mossén Joan Figuerola -pare d'ells- feta per Andreu Figuerola després de la mort del seu pare.

Joan Roís de Corella - "in sacra pagina professorem”-, Salelles de Monpalau -cavaller-, Nicolau Balaguer i Lluís Nadal -mercaders de València-, varen ser elegits pels dos germans com a àrbitres i amigables componedors mitjançant una "carta de compromís" rebuda pel notari Joan Verdanxa el 30 de març de I474 (doc. 283). Dos mesos després, Corella i la resta dels amigables componedors 
dictaren una sentència arbitral d'acord amb la qual els Figuerola es comprometien a anul.lar els plets judicials que havien entre d'ells i a renunciar a iniciar qualsevol nou plet. Lluís Figuerola acceptà el contingut d'aquesta sentència mentre que, el seu germà Andreu, es negà a escoltar la sentència quan varen intentar llegir-li-la en casa de Salelles de Monpalau, a Torrent (doc. 283).

Després d'un cert estira-i-arronsa que va durar dos anys (docs. 284 i 285), Lluís Figuerola, en el seu nom propi i com a hereu, juntament amb el seu germà Andreu, dels béns del seu pare Joan Figuerola, i segons l'estipulat en la sentència arbitral donada, va cedir certs drets al seu germà Andreu (doc. 288).

Aquesta actuació de Joan Roís de Corella mostra que les relacions amb el seu cunyat Lluís eren molt bones. Això també es pot deduir del fet que Lluís actuara de testimoni en escriptures notarials del lletraferit valencià (doc. 3I2), i en la lectura d'una sentència arbitral donada per Corella i Guillem Ramon de Vila-rasa en I49I entre el monestir de Sant Jeroni de Cotalba i el cavaller Pere de Cabrera, senyor de Ròtova, (doc. 34I) però, sobretot, es pot deduir del nomenament de Corella com a marmessor testamentari fet pel seu cunyat en I 483 preferint el mestre en teologia al seu germà Andreu Figuerola (doc. 3r9).

L'economia del matrimoni Figuerola-Roís de Corella era forta i incloïa tant censals -com, entre d'altres, el que en octubre de I 478 vinculava Lluís Figuerola amb Elionor Flors de Vallterra, a qui Joan Roís de Corella dedicà la seua Història de santa Magdalena (docs. 300, 369, 37I) - com botigues (doc. 4OO), horts i cases ${ }^{104}$ que anaven comprant i venent. És el cas, per exemple, d’una casa amb un hort en el carrer de Mossén Corella a la parròquia de Sant Martí venuda, el 2 de juny de I482, per Lluís Figuerola i Dalfina Roís de Corella per i 47 lliures, a Francesc Villes, mercader de València. Aquesta casa, que estava a cens de 48 sous i 9 diners censals, afrontava amb casa de Melcior Miralles -subsagristà de la Seu de València i suposat autor del Dietari del capellà d'Alfons el Magnànim-, amb hort del monestir de Sant Francesc i amb casa d'una persona cognomenada Pinó (docs. 32 i i 322 ).

$\mathrm{El}_{7}$ de febrer de I407 Joan Roís de Corella, en presència del justícia civil de València, donà a la seua germana Dalfina -esposa de Lluís Figuerola- tots els seus béns mobles, immobles, etc. presents i futurs. D’aquesta donació inter vivos que Dalfina acceptà, Corella va exceptuar, per a ell i els seus, certes cases situades a la parròquia de Sant Martí que afrontaven amb un hort i una casa de Lluís Figuerola, amb dues vies públiques i amb una altra casa de Figuerola. ${ }^{105}$ Una d'aquestes cases de Joan Roís de Corella serà, si les nostres deduccions són correctes, finalment venuda a Dalfina per l'escriptor en I488 (doc. 398) i, després, donada per ella a Isabel Martínez de Vera en I 497 (doc. $362)$.

El 23 de novembre de I489, Dalfina, com a donatària dels béns del seu germà Joan Roís de Corella, en presència de Francesc Barceló, cavaller i justícia civil de València, restituí al seu germà tots els béns i drets que, anteriorment, ell li havia donat (doc. 338).

Desconeixem quins són els motius exactes que portaren al mestre en teologia i cavaller a fer aquesta donació a la seua germana entre I487 i I489, però, en l'apartat dedicat al mestre i cavaller Joan Roís de Corella, n’apuntarem un posible motiu.

Després de morir el seu germà, qui l'havia nomenada hereua universal, el 7 d'octubre de I497

IO4. La pròpia Dalfina Roís de Corella esmenta un parell de cases al seu darrer testament.

I05. Doc. 329. Aquestes cases del cavaller i mestre en teologia estaven subjectes al domini directe de la confraria dels forners, abans anomenada de la Santíssima Trinitat, sota cens de 9 sous. Figuren com a testimonis d'aquesta escriptura notarial el donzell Joan Ramon de Caldes i el notari Domingo Garcia. 
Dalfina féu l'inventari dels béns del difunt Joan Roís de Corella (doc. 36I). Tres dies després, davant el notari Jaume Albert, Dalfina, com hereua universal del seu germà, donà tots els béns de la dita herència a Isabel Martínez de Vera, així com una casa a la parròquia de Sant Martí -sota el domini directe de la confraria de la Santíssima Trinitat i de Sant Miquel Arcàngel, anomenada dels peraires, a cens de 9 sous anuals- que limitava amb dues cases de Lluís Figuerola i un carrer (doc. 362). Cal observar que, en el document de donació, Dalfina diferencia perfectament els béns pertanyents a l'herència del seu germà i la casa que donava a Isabel, i això es així perquè aquesta casa no pertanyia en aquell moment a l'herència, ja que era seua. Amb aquesta donació de Dalfina a Isabel, les dues antigues cases del cavaller i mestre en teologia Joan Roís de Corella tornaven a estar juntes. Això es veu, perfectament, si observem que els límits de les cases expressats per Corella en el document de donació a Dalfina són els mateixos que els que tenen les cases del carrer de Mossén Corella en mans d'Isabel, i que seran llogades en I5OI per ella. ${ }^{106}$

En setembre de I499, Dalfina actuà conjuntament amb Isabel Martínez de Vera per tal de complir amb un compromis del seu germà difunt amb la família del mercader Pere Vidal (doc. 373; vid. infra $3 \cdot 2 \cdot 3)$.

En juny de I5O2, Dalfina i Isabel declararen davant el Justícia Civil que el valor de l’herència del poeta, llevats els corresponents càrrecs, era menor de 5.Ooo sous i que, per això, la donació s’havia fet sense el decret legal del Justícia Civil tal com exigien els furs. Aquesta manca de vistiplau legal es va intentar reparar en eixe moment per a evitar que algú poguera dubtar que aquesta donació no excedís de 500 florins. El Justícia Civil féu declarar sota jurament tant a Dalfina com a Isabel que la referida donació s'havia fet sense dol ni en frau dels creditors. ${ }^{107}$

No són molts els documents que hem trobat del matrimoni Figuerola-Corella amb els seus fills. Els més importants són, per un costat, la venda per ells i els seus fills Enric Joan i Bertomeu, en I5OI, a Anna Canoguera, filla del difunt Joan Canoguera -senyor de Catarroja i Patraix-, de I73 sous censals per preu de I33 lliures (doc. 388) i, per un altre costat, les capitulacions matrimonials establides l's de juny de I499 entre Bertomeu Figuerola, els seus pares -Lluís Figuerola i Dalfina Roís de Corella-i Àngela, donzella filla del difunt mercader i ciutadà de València Miquel Ferrer. Àngela aportà al seu matrimoni amb Bertomeu Figuerola un dot de 50.000 sous, i Bertomeu li va reconéixer un creix de 25.0oo sous (doc. 372).

Com hem vist, Lluís Roís de Corella llegà a sa germana, en el seu testament de I5O2, 50 lliures i, com veurem, la seua neboda Magdalena Roís de Corella -la filla primogènita del lletraferit valencià- li llegarà, també, altres 5o en el seu testament de I480, i només ıo lliures en el de I490.

Arribat el I3 d'agost de I5O2, Lluís Figuerola va dictar el seu darrer testament davant el notari Pere Andreu (doc. 394) i, tres dies després, redactà un codicil (doc. 395). Revocava així un testament seu anterior fet, davant el notari i escriptor Joan Verdanxa el I8 de juliol de I483, en un moment en què hi havia hagut una epidèmia de pesta en la ciutat (Chiner I994a). En aquest testament de I $483^{108}$ anomenava marmessor testamentari el "reverent i magnífich mestre” Joan Roís de Corella i, si ell no poguera fer-se càrrec de la marmessoria en el moment de l'òbit, anomenava el seu germà, el cavaller

I06. Docs. 329 i 387 . Dir que les cases afronten amb la séquia dels beguins és igual que dir que afronten amb el carrer de Rotlons, car la referida séquia recorria aquest carrer.

IO7. Doc. 393. Ampliem totes aquestes dades infra, al capítol 3.

IO8. Doc. 3I9. Com a testimonis del testament figuren mossén Francesch Corts, canonge i paborde de la Seu de València, mossén Miquel Alfajarí, prevere beneficiat en l’església de Vilafermosa, i Bertomeu Chiva, mercader ciutadà de València. 
Andreu Figuerola. Entre les clàusules més destacables d'aquest testament de I483 podem esmentar:

* Elegeix ser sepultat en "la sglésia del monestir dels frares de Sant Vicent fora els murs de la dita ciutat construhit als peus del crucifici el qual stà davall el cor de la dita sglésia”. Aquesta elecció es justificada pel fet que, malgrat estar tots els seus parents soterrats en l'església de Sant Martí, "per devoció del dit crucifici com de la dita sglésia com encara per quant la magnífica na Dalfina Roïç de Corella, molt cara muller mia, m’ha dit e notificat que en aquell loch el seu cos, aprés mort sua, bol ésser incinerat e sepellit". ${ }^{109}$

En la seua sepultura, a la qual mana dedicar Io lliures, ha d'intervenir la confraria de sant Jaume de la que ell és confrare. Demana Ioo misses de rèquiem.

* Confessa que la seua difunta primera esposa, Damiata Valleriola -filla del cavaller Joan Valleriola-, li va portar en dot 4I.I97 sous, 7 diners, segons constava per les cartes nupcials rebudes pel notari Ambrosi Alegret, als quals, posteriorment, el pare d'ella va afegir Io.0oo sous, fent un total de 5.197 sous, 7 diners. D’aquest matrimoni havien nascut Enric Joan Figuerola -declarat per la seua mare hereu universal en el seu testament redactat davant el notari Garcia d'Artés en el mes de febrer de l'any I465-i Jerònima, nascuda després de la redacció del testament de Damiata Valleriola i morta "dins pupilllar edat". En raó del dot i herència de Damiata, Lluís Figuerola atorga al seu fill Enric Joan un total de 30.000 sous restants del dit dot i, com a tota part que li poguera correspondre en els béns del testador, una dobla d'or.

* Deixa a Bertomeu, Jerònim, Lluís i a Beatriu Figuerola, fills seus i de Dalfina Roís Corella, i als altres fills que pogueren nàixer d'aquest matrimoni, una dobla d'or, equivalent a 20 sous, com a legítima en els seus béns.

* En tots els altres béns seus, nomena Dalfina Roís de Corella com a hereua universal, amb la condició que no es torne a casar. Si es casara, nomena Enric Joan Figuerola hereu universal amb el manament de donar a Dalfina I8.ooo sous que ella li va portar en dot i 9.ooo de creix. Eixos 9.ooo sous de creix passarien a mans d'Enric Joan Figuerola en cas de mort de Dalfina Roís de Corella.

Assigna la tutoria i curadoria de Bertomeu, Jerònim, Lluís i Beatriu a Dalfina, sa mare.

En el seu darrer testament, el del I3 d'agost de I5O2, el cunyat de Joan Roís de Corella canvia el contingut d'algunes d'aquestes clàusules:

* Com que ja no pot nomenar marmessor el seu cunyat ja difunt, ho fa sobre la persona de fra Miquel Orts, confesor seu i frare del monestir de Sant Agustí, i elegeix ser sepultat en la capella dels Figuerola, existent a la parròquia de Sant Martí, on estan soterrats els seus pares.

Nomena hereu universal el seu fill Bertomeu, nascut del seu matrimoni amb Dalfina Roís de Corella.

* Realitza diferents llegats als altres fills seus: A Beatriu, filla seua i de Dalfina, li deixa 360 florins; a Jerònim i a Lluís, fills seus i de Dalfina, els lliura Io sous com a tota part en els seus

Io9. Cal considerar aquesta renúncia a ser soterrat en la tradicional capella familiar en l'església de Sant Martí, indubtablement, com una mostra d'amor a Dalfina Roís de Corella, però també com una mostra de la devoció de la família del lletraferit valencià al monestir de Sant Vicent de la Roqueta, car Magdalena, la filla de l'escriptor, també, com veurem, establí en el seu testament de I48o que volia ser soterrada en eixe monestir. Una devoció al lloc on, segons la tradició, descansaven les despulles mortals de Sant Vicent Màrtir, que cal fer extensiva a Joan Roís de Corella, si prenem la referència al monestir existent a la Sepultura de mossén Francí Aguilar com alguna cosa més enllà d'un lloc tranquil per on passejar. 
béns; a Enric Joan, fill del difunt i de la seua primera esposa, li deixa els béns que restaven dels aportats per Damiata Valleriola al matrimoni.

Figuerola morí el 20 d'agost de I5O2, i el testament fou publicat, a la casa del difunt, tres dies després (doc. 394). L'almoneda dels seus béns va ser realitzada, el següent 2 de setembre al mercat de València, pel seu fill Bertomeu nascut del matrimoni amb Dalfina Roís de Corella. Els béns venguts alcançaren un total de I32 sous, II diners (doc. 396).

Una volta mort el seu pare, i tal com establia la legislació foral, Bertomeu Figuerola, l'hereu, havia de tornar el dot i creix a sa mare, Dalfina Roís de Corella. Per a fer-ho, Bertomeu va haver de vendre, el 26 de novembre, diversos béns de l'herència del difunt i va donar 5 .028 sous, 7 diners a Dalfina Roís de Corella que restaven per pagar-li del seu dot i creix matrimonial després que Lluís Figuerola donara, el 24 d'octubre de I 485 davant el notari Joan Ramos, diverses quantitats monetàries a la seua dona. Entre els béns venuts per Bertomeu Figuerola consta "un libre appellat Cartoixà per tres sous" (doc. 397).

Després de la mort del seu marit, Dalfina, com havia ja fet la seua mare, no s'estarà de reclamar judicialment les pensions de censals i violaris que diferents persones li devien (doc. 4I9) o de vendre inmobles -com la botiga en el Grau de València que vengué, en abril de I503, a Francesc Bonfill per preu de Io5 sous (doc. 4OO) - o, simplement, de recuperar diners deguts al seu marit (doc. 4II). Un d'aquests censals té, des del punt de vista de les relacions dels Corella amb altres lletraferits valencians de finals del segle XV, una especial importància, perquè vincula el matrimoni FiguerolaCorella amb Bernat Fenollar, i ens informa de la venda d'una casa en I 488 per part del mestre i cavaller Joan Roís de Corella a la seua germana Dalfina.

En efecte, el I8 de març de I5O3, Dalfina, ja vídua, vengué un total de 75 sous censals per preu de 5 o lliures a Bernat Fenollar -domer de la Seu- i a Joan Jerònim Fenollar -ocupant del benefici existent en l'església de Sant Llorenç sots invocació de la Verge Maria de la Salut, establit pel domer Bernat Fenollar mitjançant escriptura del Io de gener de I 497 davant el notari Felip Abella. Entre els censals venuts en figura un per valor de 22 sous i 6 diners carregat sobre una casa existent al carrer de Mossén Corella, sota domini directe de l'ofici de peraires a cens de 9 sous anuals, que afrontava amb casa d’Isabel Martínez de Vera, amb altra casa de Dalfina Roís de Corella,

et cum dicto vico et a posteriori parte cum cequia et vico ex aliis partibus que domus, per reverendum magistrum Joannem Roïz de Corella, vendite michi fuerunt cum instrumento acto in posse discreti Genisii Barrot, notarium, die vicesima quarta mensis aprilis anni MCCCC octuagesimo octavi (doc. 398).

La venda dels 75 sous censals fou realitzada per Dalfina per tal de pagar una part dels io.ooo sous que restaven donar a Enric Joan Figuerola, fill de Lluís Figuerola i de la seua primera esposa, dels prop de 5 o.ooo sous que Damiata Valleriola, mare d'Enric Joan, va portar com a dot al seu marit. ${ }^{110}$

El 8 d’abril de I5O5, el donzell Enric Joan de Figuerola reclamà judicialment a Dalfina Roís de Corella, que complira la seua promesa de "quitació" de 76 sous, 8 diners censals pagadors anualment que Enric Joan i altres carregaren al notari de Morvedre Bernat Vesià (doc. 412).

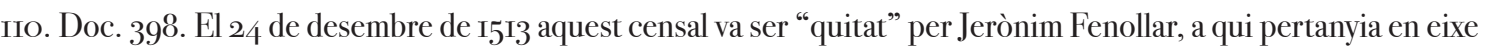
moment. 
El 22 de juliol de I5O4, Dalfina Roís de Corella, germana i hereua universal de l'escriptor Joan Roís de Corella, va establir, a la ciutat de València, el seu darrer testament davant el notari Pere Andreu (doc. 409). Hi nomenava la seua filla Beatriu com a hereua universal dels seus béns, feia diferents llegats a dues serventes, atorgava diverses cases als seus fills Lluís i Bertomeu (a aquest darrer la casa al costat de la de l'escriptor Joan Roís de Corella) i establí que volia ser soterrada a l'església de Sant Martí en la capella del Corpus Christi -la capella familiar dels Figuerola on estava sepultat el seu marit- amb la realització davant la seua sepultura de les "cinch mises de les cinch plagues de nostre Déu e creador Déu Jhesuchrist". ${ }^{111}$

Aquest testament va ser publicat el 6 de desembre de I5o8 en la casa, on viví i morí la testadriu (doc. 409). Molt probablement, atés que no s’indiquen els dies transcorreguts entre la mort de la testadriu i la publicació del testament, ${ }^{112}$ Dalfina moriria aquell mateix 6 de desembre de 5508 en la casa que posseïa al costat de la del seu germà Joan Roís de Corella. ${ }^{113}$ Una casa, la del prosista i poeta, que, com veurem després, hem localitzat i ubicat en el conegut plànol de València del pare Tosca, i en l'actual xarxa de carrers de la capital del Túria.

\section{El cavaller i mestre en teologia Joan Roís de Corella: vida pública, vida privada}

\section{I.Joan Roís de Corella, cavaller i mestre en teologia}

Tal com es dedueix del testament de sa mare de l’i d'octubre de I45I, Joan Roís de Corella va nàixer el 28 de setembre de I435 (doc. I87), molt probablement a Gandia, on residien els seus pares en aquella època. Al nostre parer, és el segon fill baró del matrimoni format per Ausiàs Roís de Corella i Aldonça de Cabrera.

Igual que els seus pares i la majoria dels seus germans, Joan Roís de Corella, qualificat com donzell, figura entre les persones que, entre I 446 a I449, contribuïren a la fâbrica del monestir de la Trinitat amb un donatiu de 55 sous cadascun. També figuren com a contribuents Ausiàs March, Jaume Roig i Bernat Fenollar, tots ells amb 55 sous, mentre que Aldonça Roís de Corella -la germana de l'escriptorapareix amb un donatiu de 55 lliures, una quantitat elevada que cal relacionar amb la seua entrada com a monja en el monestir. Col-laborar-hi era un signe social significatiu i, al seu torn, comportava un cert prestigi social, donat que la reina Maria impulsava decididament la seua fundació.

Indirectament sabem que, el matex dia en què complí els quinze anys, el 28 de setembre de I45O, Joan passà a sa mare, Aldonça de Cabrera, un censal originalment carregat al seu avi Joan de Cabrera per uns veïns de Xàbia en I4OI, i que havia estat comprat per Ausiàs Roís de Corella en I430 (doc. 254). Encara que en el document no figura el nom del futur mestre en teologia, l'única

III. Com farà la seua neboda Magdalena Roís de Corella en els seus testaments de I480 i i490, Dalfina també encarregarà en el seu testament "mises de les plagues". Sobre aquesta devoció molt lligada al franciscanisme medieval i, sobre tot, a Caterina de Sena, vid. Labarga I999.

II2. La legislació foral establia que els testaments s’havien de publicar en el termini de tres dies després de mort el testador (Furs de València, llibre vi, rúbrica IV, fur I9, segons Colón-Garcia, I99O, I59).

II3. Les dades documentals arreplegades sobre els límits de les cases de Corella i la seua germana, ens permeten invalidar la ubicació donada per Mercedes Gómez-Ferrer i Juan Corbalán de Celis (Gómez-Corbalán 20o9, 44) sobre que el matrimoni format per Lluís Figuerola i Dalfina Roís de Corella hauria viscut a la "parroquia de San Martín, en la calle que llamaban de Mossén Corella, esquina a la calle llamada de la virgen María de Gracia, lindante con el convento de San Agustín". 
forma legal existent perquè aquest censal anara a mans d'Aldonça era per via del seu fill com a hereu universal de son pare, ja que, complits els quinze anys, d'acord amb la legislació foral aquest ja podia administrar en certa mesura el seu patrimoni (Furió et al. 1994, 80).

Un parell de mesos després, el 23 de novembre de I450, el matrimoni format per Joan Renard i la seua esposa carregaren 4I sous, 8 diners censals anuals a Joan Roís de Corella (docs. 349 i 35I).

En novembre de I455, el futur poeta demanà al Justícia Civil de València que es confirmara oficialment la seua majoria d'edat legal -els 20 anys-, cosa que es va fer per sentència del 3 de desembre de I455 (doc. 206). Una volta aconseguida aquesta diguem-ne certificació oficial sobre la seua majoria d'edat, Joan Roís de Corella cedí el 22 de desembre de I 455 a la seua mare, en qualitat de donació inter vivos, tots els seus béns i drets menys ioo florins dels quals ell podria testar lliurement. ${ }^{114}$ Atés que aquests béns superaven els 5 Oo florins, Joan Roís de Corella demanà, el 22 de desembre de I455, que el Justícia Civil de València concedira, d'acord amb la legislació foral, el seu vistiplau (doc. 206). Una acció, la del futur cavaller i mestre en teologia, que, cinquanta anys després, repetirien la seua germana Dalfina i Isabel Martínez de Vera respecte a l'herència de l'autor de la Tragèdia de Caldesa (doc. 393).

Com ja hem dit, encara que no tenim dades documentals per a confirmar-ho taxativament, és possible que aquesta donació de l'autor de la Tragèdia de Caldesa servira per a retornar la part corresponent del dot i creix d'Aldonça tal com establien els furs que havia de fer-se pel marit al llarg de la seua vida, o pels seus hereus després de la mort d'aquest; però també és possible que, amb aquesta donació, l'escriptor tan sols pretenguera proporcionar uns mitjans de vida a la seua mare. Amb aquesta donació de la majoria dels béns heretats, Corella facilitava a sa mare una situació econòmica bona, i li assegurava una vellesa tranquil.la des d'aquest punt de vista, mentre ell iniciava o continuava els seus estudis de teologia al mateix temps que galantejava dones i cercava amors que, en I459, varen tenir com a conseqüència el naixement de la seu filla Magdalena Roís de Corella (vid. infra 3.2.2).

Joan Roís de Corella, encara donzell, assistí a la redacció a València del testament de sa mare datat el I 5 de gener de I456, tal com fa constar expressament Aldonça de Cabrera (doc. 207). En una escriptura notarial de venda d'un violari a Aldonça, vídua d'Ausiàs Roís de Corella, feta el 28 de desembre de I457, Joan Roís de Corella ja figura com a cavaller (doc. 2I4). Aquestes dades cronològiques són precisades per Conca i Guia $(2 \mathrm{OI} 2,7)$, que afirmen que "als protocols del notari Antoni Barreda, figura com a donzell l'i de desembre de I 456 i com a miles el 26 d'octubre de I 457". Encara és possible reduir-ne més l'arc cronològic amb la modificació d'aquesta darrera data proposada per J. J. Domènech, J. Ll. Martos i M.P. Domènech, que afirmen que el I 5 de juny del I457, en un censal a favor d'Aldonça de Cabrera i els seus fills Joan i Lluís, aquests apareixen referenciats respectivament com a cavaller i donzell (Domènech et al. 20I4, IO5).

Comptat i debatut, si les aportacions de tots aquests investigadors són correctes, Joan Roís de Corella fou armat cavaller, una volta complits els 2 I anys d'edat $\mathrm{i}$ abans de complir els 22, entre l'I de desembre de I 456 i el 15 de juny de I $_{45} \cdot{ }^{115}$

Després de realitzar-se la donació entre Corella i sa mare, el jove cap de la família va poder

II4. Doc. 206. L'estudiant Bertomeu Chiva figura com a testimoni d’aquesta escriptura de donació inter vivos.

II5. Des del punt de vista de les fonts arxivístiques que sostenen les seues dades, Conca i Guia afirmen que es tracta de documents existents en els protocols del notari Antoni Barreda mentre que els altres autors no esmenten cap font arxivística, probablement pel caràcter divulgatiu de la seua obra. 
dedicar-se, com déiem, a cercar amors i al conreu de la literatura. I li va anar bé perquè, en el moment del seu debat epistolar amb el príncep de Viana-mort el 23 de setembre de I46I-, Roís de Corella ja és un escriptor amb un cert prestigi, com demostren els elogis que li fa el príncep. ${ }^{116}$ No té encara el títol de mestre en teologia, però ja portava temps en aquests estudis, car, al Debat epistolar, Corella s'hi presenta com a "criat en los braços de la sacra teologia".

Martí de Riquer (Riquer I964, 3, 316) data el debat entre el juny de I $45^{8}$ i el 23 de setembre de I46I i, més concretament, entre l'agost de I459 i el 23 de setembre de I46I (Riquer I964, 3, 297300). Aquesta datació és matisada per M. Conca i J. Guia:

En aquesta darrera obra [el Debat epistolar], Corella apareix, de manera molt repetitiva (nou vegades), amb el tractament de mossèn, talment com si fos l'estrena d'un títol acabat de concedir.

Precisament, sobre la data del seu accés al rang de cavaller, podem dir que, als protocols del notari Antoni Barreda, figura com a donzell l's de desembre de ${ }_{4} 456$ i com a miles el 26 d'octubre de I 457. Per tant, en aquest període de temps fou armat cavaller, als 2I anys d'edat $\mathrm{o}$ als 22 acabats de fer. D'altra banda, com que el 22 de desembre de I 455 havia fet donació a sa mare de totes les seves pertinènces i drets com a hereu universal dels béns de son pare (...), talment com si anés a emprendre un viatge, i com que la seva presència a València no la tenim documentada des del I $_{5}$ de gener de I 456 (quan és present al tercer testament de sa mare (...) fins al 26 d'octubre de I $45^{8}$ (quan ell i sa mare venen un censal a Andreu Gassull (...), podem conjecturar que probablement s'hi va absentar durant aquest temps. La conjectura pot continuar amb la hipòtesi que va anar a Nàpols, a la cort del Magnànim, on el príncep de Viana arribava el 20 de març del I 457 i on tingueren ocasió -de fet, l'única ocasió- de trobar-se i conéixer-se tots dos, ja que el príncep, al Debat epistolar, li diu:

Mémbranos haveros dicho que (...). E nós, assí de esta necesitat compelido, a vós, como el más suficiente ante nuestra presencia, con nuestra turbación deliberamos vos la agora comunicar.

Les expressions "haveros dicho", "ante nuestra presencia" i "agora" presuposen una certa temporalitat en la relació mútua. Per això, afinant les dates proposades per Jordi Carbonell (195556), si el Debat epistolar es va fer aleshores, caldria datar-lo a Nàpols, entre el 20 de març de I 457 i el 27 de juny de I $45^{8}$ (data de la mort del Magnànim), o a Sicília, entre el I5 de juliol de I $45^{\circ}$ (data de l'arribada a l'illa de Carles de Viana, on sojornà un any) i l'octubre d'aquell any, en què Corella apareix documentat de nou a València. Aquesta segona opció és més improbable ja que no consta documentalment que Corella formés part de la casa del príncep i, doncs, el més normal era-si es trobava a Nàpols- que tornés a València després de la mort del rei (Conca-Guia 20I2, 7).

Per a d'altres especialistes, en canvi, el Debat es va poder realitzar entre agost de I 459 i juny de I46I (Miranda 2OII, 6I2) o entre el 24 de juny de I46I i el 23 de setembre de I46I (Rodríguez 2OO2, 378) o bé a l'estiu de I46r, tal vegada formant part d'una ambaixada valenciana enviada a Barcelona (Domènech et al. 20I4, IO5-O6) -cal advertir, però, que el nom de l'escriptor no figura entre els ambaixadors (Rubio 2OI3, 596)-, si no és que vaja anar per motius personals lligats a la presència, a la cort del príncep de Viana, de Guillem Ramon de Vila-rasa -amic de Corella i tertulià del Parlament en casa de Berenguer Mercader- qui, segons Miranda (20II, 607), fou cambrer major del príncep en Sicília en I459.

No hem trobat documentació que ens permeta ubicar millor la datació tòpica i cronològica del debat epistolar; però, si existeix la possibilitat que les expressions que suggereixen presència física entre

II6. Sobre el debat i els seus aspectes literaris, vid. entre d'altres Carbonell ı955-56, Cantavella i997 i Rodríguez 2002. 
els dos contendents dialèctics foren un joc literari i el debat s'hagués produït en absència (Rodríguez 2002, 378), ${ }^{117}$ aquest es podria haver donat no sols quan el príncep estigué a Nàpols, a Sicilia o a Barcelona, sinó també estant el príncep de Viana a Mallorca. Al’illa balear, Carles de Viana arribà, des de Sicília, el 20 d'agost de I 459 a l'espera de l'autorització paterna per a entrar en terres catalanes, i hi va romandre fins a finals de març de I46o (arribà a Barcelona el 28 de març de I460). Durant el seu sojorn a Mallorca, el príncep es podria haver cartejat amb l'autor de la Tragèdia de Caldesa, igual que ho va fer amb els valencians Lluís Despuig, mestre de Montesa, i Joan Roís de Corella, comte de Cocentaina, tal com consta documentalment en l'Arxiu de la Corona d'Aragó (Miranda 2005, 43I i 439). ${ }^{118}$

Per a concloure amb el tema de la seua relació amb el príncep de Viana, assenyalem el nostre acord amb Rubio Vela quan aquest fa palés que la posició del patriciat urbà de València fou favorable al príncep, però sense derivar en insurgència, a diferència del cas dels catalans. Dins d'aquesta via, segons Rubio (2OI3, 60I), ha de situar-se Joan Roís de Corella, amb un afecte literari i també polític pel de Viana. Corella rebutjarà, igual que les autoritats municipals de València, l'actitud autoritària de Joan II, però sense insurrecció; aquesta actitud explica tant les frases elogioses de Corella al príncep en el Debat com les referències al monarca en la Tragèdia de Caldesa; una dualitat que també tindrà Melcior Miralles en el Dietari del capellà d'Alfons el Magnànim (Rubio 2013: 594602 ).

En el període I454-I468, trobem Joan Roís de Corella en diferents violaris i censals al costat de sa mare i dels seus germans Lluís (docs. 199, 2OO, 2OI) i Dalfina (docs. 205, 2I2, 2I4, 2I5, 2I8, $22 \mathrm{O}$, 22I, 223, 224, 229, 23O, 232, 236, 25I i 257). En un d'ells, l'escriptor i sa mare reconeixien, el 26 d'octubre de I458, al secretari reial Andreu Gassull, pare de l'escriptor Jaume Gassull, el lliurament de 4 .Ooo sous, preu en què li varen vendre 266 sous i 8 diners censals i anuals (doc. 226).

Com ja hem comentat, com a hereu universal del seu pare i, per tant, com a cap visible de la família Roís de Corella, l'escriptor va establir, juntament amb sa mare, el dot de sa germana Dalfina per al seu matrimoni amb el vidu Lluís Figuerola. En vespres de la celebració eclesiàstica del casament, Aldonça i Joan Roís de Corella establiren, el 2i de gener de I469, el lliurament a Figuerola dels r8.ooo sous de dot en diners en metàl-lic i li transportaren uns censals. ${ }^{119}$ Per la seua banda, Lluís Figuerola prometé donar a Dalfina Roís de Corella 9.ooo sous en qualitat de creix.

Uns mesos després del matrimoni, Lluís Figuerola nomenarà Dalfina i el seu cunyat com a procuradors seus (doc. 263). Aquesta serà la primera d'una serie d'actuacions en les quals el cavaller i mestre en teologia farà serveis al seu cunyat; i algunes en mostren una gran confiança entre ambdues parts, com hem vist ja: serà àrbitre i amigable componedor en el conflicte que enfrontava Lluís Figuerola amb el seu germà Andreu per qüestions lligades a l'herència del seu pare en l'any I474 (docs. 283, 284 i 288); i també serà nomenat marmessor pel seu cunyat en un testament de I483, preferint aquest el poeta al seu germà Andreu Figuerola (doc. 3r9).

II7. “Tot i que l’infant d’Aragó nomena Corella 'el mas suficiente ante nuestra presencia', no entrarem a discutir si ambdós van coincidir en un mateix lloc, perquè és possible que aquesta afirmació no s’hagi d’interpretar al peu de la lletra (...). De moment, però, no podem saber amb seguretat si el cavaller valencià va visitar la cort del princep o si la relació literaria va tenir lloc en absencia” (Rodríguez 2002, 378).

II8. Agraïm a l'amiga i col·lega Rosa Ma Gregori, de l’Arxiu de la Corona d'Aragó, la comprovació de les dades arxivístiques referides a Despuig i Roís de Corella proporcionades per Miranda.

II9. Doc. 258. Sobre Dalfina Roís de Corella i el seu marit vid. supra 2.2.4. 
No sabem amb seguretat documental l'any en què Isabel Martínez de Vera es va convertir en l'amistançada de Joan Roís de Corella, si bé alguns autors parlen d'una relació sentimental estable iniciada entre I462-I464 després que ella arribara a València durant la primavera del I462 (Soler 2OI3, 6I8; Domènech et al. 2OI4, IO5). En la nostra opinió, les relacions amoroses entre ells cal situar-les un poc abans de I469, moment en què el poeta li prestà diners per a comprar una casa (doc. 266); com a molt, uns tres o quatre anys abans, el temps suficient perquè un jove i famós escriptor enamoradís se sentira obligat a ajudar-la en l'adquisició. ${ }^{120}$ Considerem que l'inici d'aquesta relació amorosa no es pot anar molt lluny de la data de consecució del títol de mestre en teologia per part de Corella perquè estem convençuts que són la consecució d'aquest títol, l'existència de la seua filla Magdalena -nascuda en I459- i la voluntat de Roís de Corella de dedicarse a la predicació els motius que fan que no es casara amb Isabel. Com veurem de seguida, hom no podia compatibilitzar el matrimoni amb la predicació. En la nostra opinió, Corella, que ja té una filla, no vol ser un "eclesiàstic" amb una amistançada i fills: si esdevenia capellà hauria pogut ser criticat per aquestes circumstàncies personals, i reprovat pel poble. ${ }^{121}$ Corella no vol ser un predicador amb órdens majors, tenint com té una situació familiar que hauria minvat llavors força moral al seus sermons i actuacions públiques.

Per això, en la nostra opinió, Corella no va voler mai ser capellà, rebre els órdens majors, ser ordenat in sacris. Per això, mai no va renunciar a la seua condició de cavaller, encara que ell preferia que el món el coneguera com a "mestre Corella” fent palés que, als seus ulls, era superior la teologia a la cavalleria. I això és així fins al punt que, no sols era el poble qui el considerava i el considerarà primer com a "mestre" i, després, com a cavaller - ¿quanta gent que l’escoltava predicar sabia que era cavaller?-, sinó que ell mateix, en el seu únic testament es qualificarà en primer lloc de mestre i, sols en segon, de cavaller. Tot açò, cal tenir-ho present en intentar comprendre en la seua totalitat la figura de Corella; car, si ell haguera volgut deixar la seua condició de cavaller i convertir-se en un eclesiàstic ordenat in sacris, en un eclesiàstic de totes totes, el seu prestigi social, literari i intel-lectual guanyat des d'abans de I470, fins i tot les seues relacions amb els Borja en els anys 8o, li hagueren obert totes les portes de l'Església.

Aquesta relació amb Isabel Martínez de Vera, l'existència de Magdalena Roís de Corella, la seua vocació religiosa i aquesta forta voluntat de ser coherent -de "dir-se honest" com diria Cingolani (1998) - amb el seu plantejament interior com a teòleg i predicador serien, al nostre parer, els motius de resistir-se Corella a deixar la seua condició de cavaller i, també, de resistir-se a les pressions del cardenal de València perquè s'ordenara; aquests motius explicarien, també, la “disposició" corellana per a negar-se Corella a rebre els órdens, de què parla Joan II -"e no compelir-lo a pendre órdens fins que sia en altra disposició” - en una missiva al cardenal de què parlarem tot seguit. Per últim, aquests motius també seran, pensem, els que expliquen aspectes claus tant del seu únic testament de l'any I $47^{8} \mathrm{com}$ de la vida del prosista i poeta considerats enigmàtics per la critica corellana: no esmentar Isabel i els seus fills en el testament, nomenar hereua universal la seua germana Dalfina, no casar-se amb Isabel, la donació dels béns de l'escriptor a Isabel Martínez de Vera per part de Dalfina Roís de Corella, etc.

I2O. En aquest sentit, i com veurem en l'apartat d'aquest article dedicat a Isabel Martínez de Vera, en juny de I466 la seua germana Dalfina, beata de vida honesta, ni l'esmenta en el seu testament, i és possible que això poguera estar relacionat amb la seua relació amb Corella.

I2I. Els eclesiàstics amb fills i amistançades són criticats en tot tipus de textos coetanis -legals, religiosos, etc.-, pero la seua existència era normal en una època on trobem tipus com el bel-licós i enamoradís canonge don Jordi Centelles i on, fins i tot, el bisbe de València i posterior papa Alexandre VI no tenia cap problema a mostrar públicament els seus fills. 
De tot açò anirem parlant poc a poc al llarg d'aquest apartat del nostre article, i del dedicat a Isabel Martínez de Vera.

Segons Josep Guia $(1999,46)$, Corella obtingué el grau de mestre en teologia entre novembre de I468 i setembre de I469. Desconeixem el lloc exacte on va obtenir el títol de mestre en teologia i, fins i tot, on va cursar els seus estudis en teologia si bé, en aquest cas, el més lògic és que estudiara en alguna de les dos principals escoles de teologia existents en eixos moments a València: la dels dominics en el convent de predicadors i la de la catedral on impartia clases el bisbe cristopolità Jaume Pérez. Si hem de triar entre alguna de les dues, ens inclinaríem per la de Pérez perquè això podria explicar fâcilment l'origen de la bona amistat i dels lligams existents entre Joan Roís de Corella i el bisbe agustinià que residí al convent de Sant Agustí de València, enfront, com veurem, d’una de les cases propietat d’Isabel Martínez de Vera.

En l'època de Corella, els laics no podien fer prèdiques religioses, no podien sermonar, perquè ho prohibien les disposicions eclesiàstiques. ${ }^{122}$ El fet de tenir el grau de teologia permetia a Roís de Corella predicar, sempre i quan no fóra un laic; és a dir, sempre i quan fóra un clergue encara que sols amb órdens menors. En efecte, en el sínode del bisbe Alfons de Borja -futur Calixt IIIconvocat el 2 de febrer de I $43^{2}$, es varen aprovar unes constitucions sinodals on, entre d'altres coses, s'establí que

como hemos de reconocer con dolor, hay muchos que asumen el oficio de la predicación, de los cuales algunos por impericia, otros por malicia, incluso bajo el hábito simulado de aparente santidad, no siendo sobrios, contra lo que enseña el Apóstol, sino excediendo la medida, tanto se exceden en sus sermones que, dejenado lo que conduce a la útil instrucción y edificación del pueblo, eluden la sencillez sacerdotal, denigran continuamente la fama de los prelados y clérigos, siembran cizaña y novedades en el pueblo, causan, como enseña la experiencia, muchos escándalos en el pueblo y entre los mayores, perturbando el estado de la república y político con perversas ficciones y ardides malvados y dogmas nefandos y no dejan de predicar frecuentemente muchas cosas, que se apartan de las reglas apostólicas y tradiciones de los santos padres, no sin grandes peligros para las almas. Por eso Nos, Alfonso, por la gracia de Dios, obispo de Valencia, deseando, como es nuestro deber, proveer con provecho sobre esto y ahuyentar completamente de la grey a Nós encomendada al lobo bajo la apariencia de cordero, presidiendo este santo sínodo, establecemos y ordenamos y en virtud de santa obediencia preceptuamos y mandamos, que en adelante en la ciudad y en nuestra diócesis valentina, ningún clérigo, cualquiera que sea su estado o condición, se atreva a predicar, ni los curas ni otros, a quienes corresponde agenciar los sermones en sus iglesias o en cualesquiera otros lugares $u$ oratorios, se atrevan a admitir a alguien a predicar, si no es maestro, doctor, licenciado o bachiller en sagrada Teologia o Derecho o al menos que habiendo sido examinado por Nos, por nuestro vicario general u oficial, haya sido hallado idóneo y haya sido admitido al oficio de predicar. ${ }^{123}$

Poc temps després d'accedir al magisteri en teologia, Roís de Corella començarà a dedicar-se a la predicació, activitat que, abans, li havia estat prohibida per Roderic de Borja, cardenal de València, vicari de la Seu i futur papa Alexandre VI. I açò ens indica que Corella ja era un clergue tonsurat amb órdens menors, perquè sinò fos així difícilment haguera pogut predicar.

La raó de la prohibició del Borja sembla raure en el desig del cardenal i bisbe de València que

I22. Abans de ser inclosa en els Decretals aquesta prohibició de predicar, el pontífex Gregori IX s’hi refereix en una carta del ı228 al bisbe de Milà (Le Goff-Schmitt 2003, 658; Longère I983, 90).

I23. Seguim les dades proporcionades en Pérez I994, $35^{8}$ i ss. El text és reproduït a les pàgines $363^{\text {i }} 3_{64}$ (la cursiva és nostra). 
Corella prenguera órdens majors i es convertira en un autèntic sacerdot, en un autèntic eclesiàstic abandonant la seua condició de cavaller -compatible aquesta amb els órdens menors-car, a l'època i des del punt de vista de l'Ésglesia, un cavaller-predicador havia d'ésser una mica estrany. A fi d'anul-lar aquesta prohibició de predicar, el rei Joan II d'Aragó va intervenir, primer, indirectament, fent arribar les seues peticions al cardenal de València a través d'intermediaris, i, després davant la manca de resposta, directament, transmetent-li una missiva datada a Montsó el 27 de juny de I470.

En aquesta lletra, el monarca li sol-licita que permeta les predicacions de "mestre Corella", atés el gran benefici que "se ha seguit, e segueix, a les ànimes dels feels christians de les predicacions e doctrina de mestre Corella, lo qual axí bé e virtuosament ha predicat, que ha provocat a gran devoció al poble". Joan II demana al futur papa Alexandre VI, que, atés que Corella "ja tinga títol de mestre en sacra teologia e li sia lícit fer les dites predicacions", permeta i anime dites predicacions encara que Corella no prenga els órdens majors tal com es pot veure en el text d'aquesta missiva que reproduïm a continuació:

\section{Magistri Corella.}

Reverendíssim Pare en Christ, e senyor amich nostre molt car, per altres havem scrit e significat a la Reverent Paternitat vostra quant beniffici se ha seguit, e segueix, a les ànimes dels feels christians de les predicacions e doctrina de mestre Corella, lo qual axí bé e virtuosament ha predicat, que ha provocat a gran devoció al poble. E havem pregat la vostra reverent Paternitat volgués, de nou, donar licència al dit mestre Corella de fer e continuar les dites predicacions e no compelir-lo a pendre órdens, fins que sia en altra disposició, atés majorment com ja tinga títol de mestre en sacra teologia e li sia lícit fer les dites predicacions. E perquè, fins ací, no havem hagut resposta de vostra Reverent Paternitat e los qui tenen devoció en oyr los sermons del dit mestre Corella stan desijosos de haver la dita licència, vos tornam a fer la present he us pregam, ab quanta affecció e voluntat podem, doneu la dita licència e facultat al dit mestre Corella de poder preÿcar axí com fahia abans de vostra inibició. En lo qual vostra Reverent Paternitat farà servey a nostre Senyor Déu, per lo beneffici que se'n seguirà a les ànimes dels feels christians, e a Nós complaurà singularment axí com lo contrari, ço que de aquella no se spera, donaria grandíssima admiració e entrenyorament al poble. Car dien, que a la Reverent Paternitat vostra, no solament sia convenient donar la dita licència mes, encara com a pastor del dit poble, manar al dit mestre Corella faça e continue les dites predicacions.

Data en Monçó a XXVII dies de juny de l'any mil CCCC LXX. Rex Joan.

Dominus rex mandavit mihi Philippo Clementis.

Rex Aragonum, lo rey d’Aragó, de Sicília, de Navarra, etc.

Al reverendíssimo Pare en Christ e senyor, lo Cardenal de València, vicari de la Seu apostòlica, amich nostre molt car.

Fuit duplicata (doc. 268). ${ }^{124}$

Ni la intitulació de "reverend" que, molt sovint, s'aplica a Corella, ni el títol de mestre en teologia impliquen que fos sacerdot, és a dir, haver estat ordenat in sacris. Aquest títol tan sols li permetia explicar la pagina sacra i predicar. Mai no va ser ordenat sacerdot.

Serà en l'època anterior a l'obtenció del títol de mestre en sacra teologia on cal, en la nostra opinió, situar la major part de l'obra no religiosa de Corella, la denominada obra profana, per tal que la producció literària corellana tinga coherència amb l'experiència vital i anímica del cavaller i

I24. Doc. 268. Aquesta missiva de Joan II va ser donada a conéixer en Chiner 2OI3, treball redactat en abril de 20 I3. 
mestre en teologia Joan Roís de Corella. Ara bé, considerem que no ha de fer-se de la data d'obtenció del títol de mestre en teologia una frontera infranquejable perquè, en la vida de Corella, tampoc no hi ha compartiments estancs -com ja ha estat destacat per Cingolani, Badia o, darrerament, per Martínez Romero (20I3) - i, si ell era capaç de ser cavaller i predicar al mateix temps, també ho era de participar en la redacció de proses mitològiques com Lo johí de Paris, datat després de I468-I469 per Conca i Guia $(2 \mathrm{OI} 2,7) \cdot{ }^{125}$ Fins que la investigació històrica i filològica no avance prou, nosaltres no descartaríem res a priori, perquè, en l'etapa final de la vida de Corella, quan més endinsat estava en la redacció d'obres religioses i en la predicació, ens trobem amb unes poesies amoroses castes que, segons Romeu i Figueras (I992), estarien dedicades a una jove, Lionor Flors de Vallterra, a la qual portava uns trenta anys de diferència (vid. infra aquest mateix apartat), i que serà present a la secció documental.

El Corella autor de la Tragèdia de Caldesa (escrita al voltant de I458-I459), ${ }^{126}$ després d'aconseguir el títol de mestre en teologia entre novembre de I468 i setembre de I469, serà capaç d'escriure poesies, epitafis, peces de circumstàncies, de fer jocs poètics amb el seu amic Bernat Fenollar, de participar en certamen poètics; però, en la majoria d'aquestes participacions o activitats literàries, podem trobar un to moralitzant o moralista, una forta connotació moral cristiana que està molt lluny de la part de la seua obra etiquetada per la crítica com poesia i prosa profana. Les seues participacions de to moral en Lojohí de Paris, en la Sepultura de mossén Francí Aguilar (I482) o en l'epitafi de Perot de Pena-roja -parroquià de Sant Martí, com Roís de Corella i el matrimoni Figuerola-Corella, i mort en el setge de Màlaga en I487 (Revest 1952) - si és que, realmente es tracta d'una obra de Corella (Martínez 2OI3), mostren la xarxa de relacions socials del literat valencià; però també serveixen per a lloar les virtuts dels "màrtirs cristians", dels cavallers i donzells que lluiten i moren no en torneigs cavallerescs sinó defenent el cristianisme davant els infidels musulmans. En aquest sentit, cal recordar també que Corella participarà en certàmens poètics com els de I474 i I487 pel prestigi social i perquè estaven dedicats a la Verge Maria, però que es negarà a ésser jutge en el debat poètic entre Fenollar, Vidal, Verdanxa i Vilaspinosa (Riquer I964, 3, 323; Fuster I991, 352). ${ }^{127}$

Per tot això, també, considerem que han de pertànyer a una època anterior a l’obtenció del títol de mestre en teologia les composicions de l'anomenat Parlament en casa de Berenguer Mercader on figuren, com a amics "en vida e entendre conformes", Berenguer Mercader, Joan Escrivà -esmentat ja en I463 com a Joan Ram Escrivà, adobat cavaller entre el 6 de juny de I477 i el 9 de juny de I478 i casat, en I479, amb Beatriu de Monpalau, germana de l'esposa de Lluís de Castellví i filla del Joan de

I25. Segons aquests autors, l'obra seria posterior d'aconseguir Corella el títol de mestre en teologia (I468-I469) perquè l'escriptor manifesta que, en participar en la redacció, se sentia “content dels sermons girar la ploma”.

I26. Per a la datació de l’obra i del cicle poètic dedicat a Caldesa, vid. Riquer (I964, 292), Romeu (I992, II7-II8) i Martínez (2013).

I27. Joan Fuster, concretament, afirma: "Un pensa que si Corella va excusar-se d'intervenir com a jutge en la Qüestió que debatien els clergues Fenollar i Vidal i els notaris Verdanxa i Vilaspinosa, no seria tant 'per ser ocupat' com per no ficar-se entre estils i temes literaris que no eren els seus" (Fuster I99I, 352). 
Monpalau contrincant de Joanot Martorell-, ${ }^{128}$ el baró Joan de Próxita, ${ }^{129}$ Lluís de Castellví -mort a finals d'abril de I48I, a la muller del qual, Violant de Monpalau ("na Monpalaua de Castellví"), Corella dedicà La vida de la gloriosa santa Anna-, Guillem Ramon de Vila-rasa o el propi Joan Roís de Corella. ${ }^{130}$

En la nostra opinió, ara com ara no existeixen suficients proves documentals per a determinar, sense cap mena de dubte, si l'amfitrió d'aquesta fictícia tertulia literària referida per Corella és el vell Batle General del regne de València Berenguer Mercader ${ }^{131}$ - postura tradicional des d'època de Riquer (I964) - o bé és un dels dos joves Berenguer Mercader assenyalats per Guia (2003).

Si l'amfitrió es poguera identificar amb el Batle General, podria haver actuat com una espècie de pater familias de tots els "hòmens d'estat" reunits en sa casa al carrer de Cavallers de València, ja que seria el més vell de tots, el de més prestigi social i, amb gairebé tots ells, tindria relacions familiars segons Riquer (1964, 3, 3I5). Segons Rubio Vela, en el seu palau del carrer de Cavallers, conegut encara com "la casa de Berenguer Mercader" dues dècades després de faltar el vell Batle General senyor de la baronia de Bunyol,

Corella hi hagué de compartir afinitats estètiques amb el seu habitant, senyor de la baronia de Bunyol i cap de la branca principal de la família, l'home que havia estat en terres itàliques en la seua joventut, les intervencions del qual davant el consell de València meresqueren elevats elogis per les seues belles i elegants paraules (Rubio 2013, 606-607).

En reforçament d'aquesta possibilitat, i després d'assenyalar l'existència d'una sèrie d'indicis que apuntarien en la seua opinió a que el Parlament podria haver-se gestat cap al I458, Antoni Ferrando afirma:

si l'amfitrió hagués estat un dels altres dos [Berenguer Mercader], segurament Corella no ho hauria deixat d'especificar per distingir-lo del batle general. En aquest cas, caldria interpretar el sintagma 'en vida e entendre conformes' en el sentit que tots el contertulians (...) compartien unes mateixes afinitats literàries (...) si la tertúlia corellana hagués tingut una base real, difícilment podria haver reunit els sis contertulians després del I 4 de gener de I459, ja que almenys un, el donzell Guillem

I28. Sobre els Escrivà i Joan Ram Escriva, vid. entre d’altres Caruana (I940), Cruselles (I989), Parisi (2009a i 2009b) i Tomás (20I3). Joan Ram Escrivà, nascut al voltant de I435, ocupà el càrrec de Mestre Racional des de I479, encara que ja havia estat designat per Ferran el Catòlic; ocupà, també, la receptoria de béns del Sant Ofici entre I482 i I487. El 6 de juny de I477, el rei encara el qualifica com a donzell en una carta feta a Medina del Campo, mentre que l'anomena mossén en una altra feta a Sevilla el 9 de juny de I478 (ARV, Mestre Racional, no. 9052, ff. Ir-2v. vid. Cruselles i989, I44 i 22I). Escrivà va establir capitulacions matrimonials amb Beatriu Monpalau el 23 de juliol de I479 davant el notari Antoni Barreda (AHN, Osuna, llig. I322, no 22, not. Antoni Barreda -23 de juliol de I479). Figura com a Joan Ram Escrivà -concretament com a "Joanot Ram àlies Escrivà" - ja en I463 (ARV, Mestre Racional, no. 73, f. I73r.). Joan Ram Escrivà, com a receptor dels béns del Sant Ofici, va quedar "tornador” en els seus comptes de I482-I484, de diversos objectes, entre ells una Bíblia impresa en paper escrita en pla, que havia pertangut a Felip Salvador i que encara en I 487 no havia lliurada al receptor Joan Claver (Tomás 20I3, 262-64).

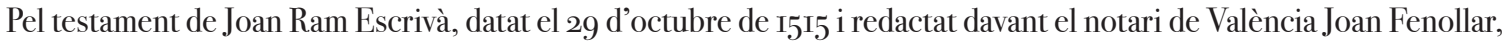
sabem que, del seu matrimoni amb Beatriu de Monpalau, va tenir cinc fills i que nomenà hereu universal a un d'ells Francesc Miquel. A Beatriu de Monpalau, esposa de Joan Ram Escrivà, dedicà Miquel Pérez, gendre de Joan Roís de Corella, en I 494 la seua Història de la Sacratíssima Verge Maria (Riquer I964, 3, 358-359).

I29. Sobre Joan de Próxita, vid. Caruana (I932). És un dels jutges del certamen poètic marià de I 474 i, el seu germà Tomàs estava casat amb Violant Mercader, neta del vell Batle General (Riquer I964, 3, 3I5).

I3o. Per a l'anàlisi de les composicions del Parlament, resulta imprescindible Badia I988, especialment les pàgines I66-7O.

I3I. Sobre Berenguer Mercader i la seua família, vid. entre d’altres obres Tintó (I979), Rubio (20I3, 602-6o7) i Caruana (1940), aquest últim amb amplis arbres genealògics. 
Ramon de Vila-rasa, fou nomenat llavors cambrer del príncep de Viana (...) i no tornà a València fins després de la mort d'aquest, ja convertit en cavaller (...) En tornar a València, el ja cavaller mossén Guillem Ramon de Vila-rasa es casà amb Violant de Monsoriu (I462) i l'any següent comprà la casa d'Ausiàs March (...). Si el Parlament s'hagués produït després de setembre de I46r, Corella difícilment hauria deixat d'atorgar-li el tractament de cavaller (Ferrando 20I3a, 64I-642).

Si, pel contrari, com sosté Guia (2003), la frase "en vida e entendre conformes", que qualifica i engloba els tertulians del Parlament, suggereix que devien ser tots ells d'una edat semblant a la de Corella, l'amfitrió podria no ser el vell Batle General. Això faria, segons Guia, que l'amfitrió poguera ser o bé el cavaller Berenguer Mercader senyor d'Argelita que es relaciona amb Joan Roís de Corella en I 485 en nomenar-lo com a amigable componedor en una disputa familiar juntament amb el reverent Macià Mercader (doc. $3^{26}$ ) i que, probablement, calga identificar amb un dels testimonis del nomenament de Corella com a membre de la comissió de I 482 creada per a l'estudi de l'erecció d'un hospital general (doc. 3I4); o bé és el donzell homònim que, en I467, carregà un violari de 200 sous censals que va quitar en I480 (doc. 3IO). Guia (2003) s'inclina per identificar l'amfitrió amb el cavaller Berenguer Mercader senyor d'Argelita; i d'acord amb això, Ferrando afirma que si la identificació proposada per Guia fóra correcta, el Parlament no se celebraria en la coneguda casa dels Mercader en el carrer de cavallers, sinó

a la casa que el senyor d'Argelita tenia al carrer Vidal, de València, situat darrere el palau dels futurs ducs de Sogorb (actual Hotel Inglés), en la parròquia de Sant Martí, que era també la de Corella. Però per les mateixes raons igualment podria haver estat el donzell, que devia conèixer molt bé l'ambient cultural de Nàpols, ja que el seu pare, el cavaller Galceran Mercader, hi residí sota el regnat del Magnànim i ell s'hi degué formar. Probablement era el més italianitzat dels tres Mercader i el més afí a Corella en edat. Respondria així millor al perfil que se’n dedueix al Parlament. Si fos així, tot faria pensar que, llevat de Corella i Próxita, la resta de contertulians eren, el I458, joves i encara donzells. Potser per això no apareixen amb el tractament de 'mossén' en cap dels manuscrits que en l'ha transmés. En canvi, Joan de Próixita hi és presentat com a ‘lo noble’ i amb el títol de 'don'. I, a Lo joí de Paris, Corella no deixarà d'introduir el seu amic Joan Escrivà com a 'mossèn' (Ferrando 2013a, 639-640).

Pel que fa al cas de la polèmica sobre quan hauria de situar-se cronològicament la suposada tertúlia, no hem localitzat documentació arxivística respecte del tema; però, en la nostra opinió, el Parlament ha de ser datable a finals de la dècada dels anys cinquanta. Per dues raons, principalment: primerament, el nomenament en gener de I459 de Guillem de Vila-rasa com a cambrer del Príncep de Viana, i la seua marxa de la ciutat de València fins a la mort d'aquest; en segon lloc, l'aprofitament del Parlament al Tirant lo Blanc, començat a escriure per Joanot Martorell el 2 de gener de I460. ${ }^{132}$

Sobre quin dels tres Berenguer Mercader és l'amfitrió del Parlament, tampoc podem aportar cap document definitiu que puga inclinar, definitivament, la balança en un sentit o en l'altre. Sí que podem, però, donar a conéixer una sèrie de documents que relacionen, abans de la consecució del títol de mestre en teologia, un jove Joan Roís de Corella amb tertulians del Parlament i amb alguns dels referits tres Mercader -especialment amb el donzell Berenguer Mercader:

\section{Amb.Joan Ram Escrivà:}

I32. Joan Ram Escrivà ja figura amb aquesta denominació en documents de I463, i ens sembla difícil que el seu amic el nomenara tan sols "Joan Escrivà" si el Parlament fóra posterior a aquest any. 
Trobem relacionat Joan Roís de Corella amb el donzell Joan Escrivà ja el 26 de maig de I460, quan ell i el seu germà Eximén Pérez de Romaní Escrivà, menor de dies, veneren a Aldonça, vídua d'Ausiàs Roís de Corella, I5O sous rendals anuals de violari durant les vides de Joan Roís de Corella i de la seua germana Dalfina. ${ }^{133}$

\section{* Amb el donzell Berenguer Mercader:}

Trobem relacionat Joan Roís de Corella amb el donzell Berenguer Mercader, menor de dies, ja el 7 de maig de I465, quan aquest i Eximén Pérez de Romaní àlies Escrivà, donzell habitant de València i germà de Joan Ram Escrivà, vengueren a Aldonça Roís de Corella 400 sous rendals i anuals de violari durant les vides de Joan Roís de Corella, cavaller habitant de València, i de Dalfina Roís de Corella, donzella (doc. 25I). Aquests mateixos membres de les famílies Mercader i Escrivà carregaren un altre violari de 200 sous als Corella davant el notari Antoni Barreda en I467 (doc. 3 IO).

Serà en març de I468 quan veurem relacionar-se novament Joan Roís de Corella amb el donzell Berenguer Mercader. En efecte, el 26 de març de I468 es publicà el darrer testament del prestigiós jurista Pere Joan Belluga ${ }^{134}$ a la casa del donzell Berenguer Mercader, marmessor del finat. Com a testimonis de la publicació figuren "los religiosos frare Andreu Malràs, de l'orde de la Sancta Trinitat; frare Johan Lorenç, de l’orde de la Verge Maria del Carme e los magnífichs micer Andreu Sart, doctor en leys e mossén Johan Rohís de Corella, cavaller, habitadors de la present ciutat de València". ¿Qui va demanar la presència de Corella? No ho sabem amb seguretat però el més probable és que fóra cridat expressament per a l'ocasió per Mercader, o que estiguera allí visitant-lo, per raons d'amistat, car aquest es trobava malalt i no podia eixir de sa casa-segons es diu diverses vegades al llarg de la publicació del testament.

\section{* Amb Joan de Próxita:}

El trobem relacionat amb el nostre escriptor el ig de gener de I454 quan ell, el noble Joan de Próxita (com se’l qualifica en el document), juntament amb Pere Pelegrí -ciutadà de València-i el cavaller de València Joan Canoguera Escrivà vengueren a Aldonça Roís de Corella, vídua d'Ausiàs Roís de Corella, I5O sous censals anuals de violari durant les vides dels seus fills Joan i Lluís Roís de Corella, donzells. El preu de venda va ser de $5^{2}$ lliures i Io sous (doc. I99).

De Lluís de Castellví -cunyat per part de muller de Joan Ram Escrivà i d’Andreu Figuerola,

I33. Doc. 232. Joan Escrivà era fill d’Eximén Pérez Escrivà de Romaní, senyor de la meitat de la baronia de Patraix i de la de Beniparrell, formà part del Consell suprem de Joan II i en fou el primer falconer. Vers I 435 es va casar amb Beatriu Ram; van tenir dos fills: Eximén Pérez Escrivà de Romaní i Joan Ram Escrivà. (Parisi 2ooga, 59).

I34. Doc. 253 publicat en Roca 1973, I43-50. S’esmenta el metge i literat Lluís Alcanyís com un dels metges que atengueren, en la seua malaltia, Belluga. Sobre el jurista Belluga, autor del Speculum principum imprés a París en I53O, vid. l'obra esmentada de Roca Traver i les dades biogràfiques proporcionades per Vicente Graullera Sanz (2009, I3O-32). Segons Graullera (2009, I32), “cuando se confeccionó el inventario de sus bienes, se encontraron con una biblioteca con I72 libros y varios cuadernos, en su mayoría de juristas italianos, entre ellos unos 'Fueros del rey don Jaime’ y 'Fueros de diversos reyes', además de unos ‘Usatges de Catalunya y Furs de Arago’ y algunos inéditos, escritos con letra del propio Belluga". 
cunyat al seu torn de Dalfina Roís de Corella - ${ }^{135}$ i Guillem Ramon de Vila-rasa ${ }^{136}$ no hem trobat documentació que els relacione directament amb Joan Roís de Corella abans de la consecució del títol de mestre en teologia per part de Corella.

També seria anterior a l'obtenció del títol de mestre en teologia el poema dedicat a Bernat del Bosch si identifiquem aquest personatge amb el Bernat del Bosch, cavaller de l'orde de Sant Jaume de l'Espasa, cremat per sodomita en I 466 segons el Dietari del capellà d'Alfons el Magnànim (Rodrigo ed. 2OII, 322). El poema, com ha demostrat Tomás Martínez després d'una anàlisi exhaustiva ( $1998,53^{-62}$ ), va ser concebut i redactat "abans del setembre de I466, és a dir abans que el cavaller del Bosch morís a la foguera” (Martínez 1990, 6I), en no haver-hi referències a la condició sexual que va portar del Bosch a ser condemnat. A aquest Bernat del Bosch -encara que no se'l qualifica de cavaller de l'orde de Sant Jaume de l'Espasa- es refereix un document del 5 de novembre de I 466 on el Mestre Racional posa en data 42 sous i 5 diners per les despeses realitzades en la seua execució:

Ítem, pos en data [Almarge dret del fol. 33rv figura la quantitat de 42 sous, 5 diners] los quals per mi liurà lo dit en Pere Garró a·n Johan Martí, morro de vaques de la ciutat de València, XXXXII sous, $V$ diners de reyals per salari e treballs seus sostenguts de manament e ordinació d'en Bernat Vives, donzell subrogat del spectable don Pedro de Urrea -Governador del regne de València-, per rahó de la execució per aquell d'ordinació del dit subrogat feta en la persona d'en Bernat del Bosch condempnat a ésser cremat per crim de sodomita, axí per lo turmentar, cremar, lenya e altres coses necessàries fetes per causa de la dita execució. E haví àpoca closa per l'escrivà de la mia cort a cinch de noembre de l'any MCCCCLXVI (ARV, Mestre Racional, no. 76, fol. 33Irv).

I35. Sobre la família Castellví, vid. Caruana i940. Lluís de Castellví, fill de Pere de Castellví, es casà amb Violant de Monpalau -la “Monpalaua de Castellvi”” a qui Corella dedicà La vida de santa Anna- d'acord amb les capitulacions matrimonials fetes el 27 de gener de I 462 davant el notari Antoni Barreda. Conservem els darrer testament i codicils de Lluís de Castellví realitzats davant el notari Francesc Pintor el ig d'abril de I48I (RCSCCV, protocols, no. 22522, not. Francesc Pintor -escriptures de I9 abril I48I) i publicat per mort del testador el 27 d'abril de I48I. El llarg i detallat inventari dels béns deixats en morir per Lluís de Castellví va ser realitzat el 7 de maig de I48I i es conserva en RCSCCV, protocols, no. 22522, not. Francesc Pintor -7 maig I 48I.

Violant de Monpalau va dictar diferents testaments al llarg de la seua vida: el 9 de gener de I474 (AHN, Osuna, llig. I322, no. 22, not. Antoni Barreda), el 2I de febrer de I488 (AHN, Osuna, llig. I322, no. 25, not. Antoni Barreda); el r8 de abril de I488 (AHN, Osuna, llig. I322, no. 25, not. Antoni Barreda). Va morir Violant a finals de I5o8, ja que el notari Pere Andreu publicà el día 23 de desembre de I5o8 el seu darrer codicil del 30 de juliol de I5o6 (RCSCCV, protocols, no. II937, not. Pere Andreu -30 juliol I5O6) on se n’esmenta com a darrer testament un fet el 30 de maig de 5505 davant Pere Andreu.

I36. Sobre la família Vila-rasa, vid. Caruana I940 i Torró 2009, I99-2I2. A banda de les dades conegudes sobre la seua biografia -relació amb el Príncep de Viana, compra de casa de Ausiàs March (Chiner 1997, 470), etc.- i dels que apareixen en aquest article vinculats a Corella -acords hospitals, sentència arbitral de Ròtova, etc.- podem assenyalar les següients dades: En setembre de I469 era àrbitre i amigable componedor juntament amb Francesc Sarçola en una disputa que enfrontava el cavaller Berenguer Mercader (justícia civil de València en I469-ARV, Mestre Racional, no. 8I, f. 22Ir) amb Gómez Suaris de Figueroa (RCSCCV, protocols, no. 24I26, not. Joan Verdanxa -diverses escriptures de 28 setembre I469). Els vincles i capítols matrimonials amb Violant de Monsoriu, germana de Gracià de Monsoriu -senyor d’Estivella- i filla de Galceran de Monsoriu, s'establiren davant el notari Antoni López el ig de desembre de I46r i l'acta matrimonial és de 25 de març de ${ }_{4} 62$ (Arxiu Municipal de València, Genealogia de los Marqueses de la Casta, f. 7ov). El testament de Guillem Ramon de Vila-rasa va ser rebut pel notari Bernat Dassió el 25 de setembre de $5_{502}$ i nomenà hereu universal al seu fill el cavaller Joan Lluís de Vila-rasa qui, el 3 de juny de I527 i davant el notari Joan Munyoç, instituí Joan Llorenç Vila-rasa hereu universal (Arxiu de la Catedral de València, Llibre vell de Administracions, no. 508o, f. 255). Violant de Monsoriu, esposa de Guillem Ramon de Vila-rasa, va dictar els seu darrer testament el ı2 de setembre de I5Oo i fou publicat, per mort de la testadora, el 9 de gener de I5Or a la casa de Guillem situada a la parròquia de Sant Joan, en el carrer d’Alcover (RCSCCV, protocols, no. 20386, not. Bernat Dassió). 
No podem afirmar amb total seguretat que aquest Bernat del Bosch siga membre de la important família de juristes d'aquest cognom estudiada per Vicent Graullera (2O09, 56-9I, I4I, I67-68, $25^{8}$, 287, 318-I9) -un dels seus més importants membres, Ausiàs del Bosch, era nebot del Jaume del Bosch cavaller de Montesa i comanador d'Onda a qui Corella va dedicar la traducció del Cartoixà -; si bé pensem que el primer vers del poema de Roís de Corella ("In utroque jure gran doctor, com somies”) sí que permet plantejar aquesta hipòtesi amb un alt grau d'encert. ${ }^{137}$

El ı3 de juny de I470, Isabel Martínez de Vera retornà a Corella les 50 lliures que ell li havia prestat per a fer obres i adquirir certa casa al carrer de Santa Maria de Gràcia (doc. 266).

Ja retirada la prohibició de predicar, Joan Roís de Corella sermonà el 28 de desembre de 1470 en l'Hospital dels Innocents de València, i això ho coneixem gràcies a una anotació en aquest sentit del metge i poeta Jaume Roig, administrador de l'esmentat hospital, on figura l'abonament de Io sous a Corella pel seu sermó (doc. 265).

Aquest tipus de contractació de predicadors en festes litúrgiques importants era habitual en les viles del regne de València. A tall d'exemple, direm que el jurats de Gandia optaren per contractar tant frares dominics com franciscans en les grans solemnitats del calendari litúrgic anual:

* El I5 de març de I42I els jurats de Gandia lliuraren a fra Joan Eimerich O.P., lector del convent de Xàtiva, 5 O sous del total de Ioo que el consell municipal atorgava al convent per la predicació dels seus membres a Gandia (Arxiu Històric de Gandia, manuscrits, $\mathrm{AB}$ 458, f. $3^{8 \mathrm{r}}$ -I5 de març de I42I).

* El 5 d'abril de I 442 hom abonà 54 sous al dominic Miquel Sànchez per 27 dies d'estància i predicació a Gandia durant la Quaresma i la festa de Pasqua. ${ }^{138}$ El I6 d'agost, li paguen 6 sous per la seua predicació de tres dies amb ocasió de la festa de Nostra Senyora Sancta Maria d'agost (Arxiu Històric de Gandia, manuscrits, AB I5, f. 93r).

* L'any següent tenim constància del pagament a Miquel Mestre, frare franciscà de Xàtiva $\mathrm{i}$ mestre en sacra teologia, que sermonà durant 5 dies amb ocasió de la festa de cinquagesma (Arxiu Històric de Gandia, manuscrits, AB I5, f. I2Or -II de juny de I443).

Amb un fort prestigi com a predicador -en març de I47I era considerat "valent e famós sermonador" per membres destacats de la societat valenciana, com veurem-, Corella contemplà l'arribada, el I8 de juny de I472, de Roderic de Borja a la ciutat de València. El cardenal i bisbe de València hi va romandre un parell de mesos, reuní un sínode per a demanar recursos econòmics, $\mathrm{i}$ visità diferents monestirs i hospitals.

Si la devoció i el prestigi literari de l'autor de la Tragèdia de Caldesa en la València de la segona meitat del segle XV ens permet explicar la participació de Corella en certamens literaris como el que, en I474, originà les Trobes en lahors de la Verge Maria, o el convocat per mossén Ferrando Dieç sobre la Inmaculada Concepció en I $487,{ }^{139}$ seran el prestigi social, la conexença personal i l'amistat els motius que trobem darrere d'alguns dels documents que regestem i publiquem en el nostre repertori

I37. Sobre Bernat del Bosch, vid. Rubio 20I4, 447-450.

I38. Arxiu Històric de Gandia, manuscrits, AB I5, f. 33v. En aquesta quantitat s'inclouen les despeses per l'anada i tornada del frare des del seu convent de Xàtiva.

I39. El 28 de juny de I488, l’impressor Lambert Palmart publicarà un rar opuscle que conté el cartell de Ferrando Dieç, una poesia de mossén Dimas, un sermó de mestre Felip de Malla i l'Obra del reverend mestre Corella e vesió que véu a la porta de la senyora nostra de Gràcia (Riquer I964, 3, 280-8I). Sobre aquesta composició literària de Corella, vid. Wittlin I995. 
documental.

És el cas, per exemple, dels llegats de llibres i robes, i de l'encàrrec personal fet, el I8 de febrer de I47I, per Joan de Vallseca frare del monestir de Sant Francesc de València "en lo primer any del meu noviciat e ans de fer proffesió en la dita religió”. En concret, li dóna un llibre

appellat lo Rodí e hun altre appellat lo Ignocent sobre les decretals e una spica sobre lo Ignocent que va per a b c, e una Bíbria e hun briviari e les mies robes de vestir; e com n'Aduart de Vallsequa, pare meu, jo no sàpia si es viu o mort, per ço exort lo dit reverent mestre Johan Corella que si lo dit pare meu serà viu lo vulla socórrer en les sues necessitats en la manera que li serà ben vist al dit reverent mestre Johan lexant-ho tot a llíbera volentat de aquell (doc. 272 ; testament publicat el 27 d'octubre de I472).

Aquest llibres, molt probablement, serien utilitzats per Corella, i es trobarien -qui sap si amb part de la roba- en la seua cambra del convent de Sant Francesc en el moment de morir. Aquest document es mostra també que, ja des dels inicis de la seua vida pública com a predicador, Roís de Corella es troba relacionat amb el convent de Sant Francesc i els seus ocupants. Una relació que, almenys indirectament, podem també constatar el 24 de març de I472 (Rubio 20I3, 6I4-I5), quan el poeta actuà de testimoni de l'acta notarial de la donació realitzada per Guillem Saera, racional de la ciutat de València, de diversos vestiments litúrgics al convent de Sant Francesc de València, per tal que foren utilitzats en la capella de sant Vicent Ferrer, santa Maria Magdalena i sant Miquel que Saera havia en el dit convent (doc. 277).

El prestigi social, la conexença personal i l'amistat expliquen, també, l'elecció de Roís de Corella com a padrí en el bateig, l'I de març de I47 I, d'Isabel Llopis -la darrera filla del notari Antoni Llopis i de la seua esposa Agnés- juntament amb mossén Lluís de Vich -mestre racional del regne-, mossén Honorat Berenguer Mercader -cavaller i batle general del regne- i Isabel de Castellví -esposa del donzell Joanot de Castellví, de Murla. En aquell moment, I47 I, Corella era molt conegut per les seues predicacions en la ciutat, fins al punt que en uns fulls a mena de memorial familiar redactats per Antoni Llopis - un dels notaris més importants i més ben relacionats socialment de la seua època, tal com mostra la nòmina de padrins de la seua filla $-{ }^{140}$ a l'escriptor se'l qualifica de "cavaller e mestre en sacra teología e valent e famós sermonador en lo dit temps". ${ }^{141}$

La conexença personal i una forta amistat són les que portaren el mestre en teologia Joan Rocafort a elegir Corella, juntament amb el seu fill Vicent Rocafort, com a marmessor del seu darrer testament fet l's de març de I47. ${ }^{142}$ Publicat el testament el 6 d'abril, el mateix dia es va fer l'inventari de béns del difunt pels seus marmessors Vicent Rocafort i Joan Roís de Corella, i per Joana, la seua esposa

I40. Doc. 273. Segons Cruselles (I998, 243), encara en una carta del 6 de desembre de I476, Joan Llopis, fill d’Antoni Llopis resident a Roma, esmenta el poeta i teòleg entre els amics i parents de la família juntament amb el canonge i doctor en lleis Joan Marromà; el mestre en teologia Melcior Miralles -suposat autor del Dietari del capellà d'Alfons el Magnànim - i el paborde Joan Boscà: "Moltes comendacions al senyor padrí micer Marromà, al reverent mestre Martí, mestre Melchior, mestre Miquel Aragonés, mestre Corella e al paborde Boscà. Moltes saluts a la senyora mare, germans e germanes, a l'oncle En Menor, al cosí En Sala e a llurs mullers, al cosí En Floris, a Lluís Romero e a tots los de la casa" (ARV, Clero, llibres, no. I777, solt).

I4I. Doc. 273. La llista de persones lligades a la seua confirmació és, també, molt significativa: “fon confermada per lo reverent mestre Jacme Pérez, bisbe de Gràcia, e fon padrí lo honorable mossén Damià Vinyoles, prevere e domer de la Seu, e comare la honrada na Yolant, muller de l'honrat i discret En Johan de Sent Feliu, notari”.

I42. Doc. 274. Al seu darrer testament, Rocafort nomenà hereua universal la seua dona Joana i el seu fill Vicent, deixà diversos llegats a les seues filles Esperança i Justina, i elegí ser sepultat al vas on sa mare era soterrada al convent de Sant Francesc de València. El 2 de març de I47I Joan de Rocafort, mestre en teologia, establí un codicil que es conserva, igual que el testament, en aquest mateix protocol de Berenguer Cardona. 
-nomenada tutora i curadora del seu fill Vicent, hereu testamentari juntament amb ella del mestre Rocafort, en el codicil establert per Joan Rocafort el 2 de març de I477 davant el notari Berenguer Cardona. En l'inventari, els marmessors parlen d'uns llibrets "de gramàtica e de arts, de poqua valor" (doc. 275). Sabem la llista d'aquests llibres perquè, el 9 d'abril de I47I, Joana -com a tutora i curadora testamentària del seu fill Vicent- i Joan Roís de Corella demanaren que es fera pública escriptura dels llibres de Rocafort que ells dos havien fet vendre pel "corredor de coll” Miquel Sanç a la plaça de la Seu de València:

Primo, hun Precià menor, ab la lectura, a·n Luís lo librer, per quatre sous. Ítem, unes Qüestions de philosofia, al dit en Luís, per un sou. Ítem, hun Tractat d'astrologia, a mossén Matheu Jordi, prevere, per un sou, sis [diners]. Ítem, hun Qüestionari sobre universals e predicaments, a.n Rodrigo Sànxez, studiant, per dos sous. Ítem, hun Dotrinal a n Andreu Canemàs, studiant, per quatre sous, sis [diners]. Ítem, hun Qüestionari de teologia, a.n Luís de Sent Jordi per un sous, cinc [diners]. Ítem, hun Alexandre, al dit en Luís, per nou dinés. Ítem, unes Proposicions de Uxonia, al dit en Luís, per huit dinés. Ítem, unes Fal.làcies, al dit en Luís, per un sou. Ítem, unes notes de Catalayú, a·n Pere Eximeno, perayre, per huit dinés. Ítem, unes Qüestions de philosofia, a·n Pere Leal, studiant, per un sou. Ítem, hun Libre de confessions, a mossén Miquel Jornet, prevere, per dos sous. Ítem, la Poetria nova, a·n Navarro, studiant, per dos sous, quatre [diners]. Ítem, dos cartapaços de gramàticha, al dit en Pere Leal, per nou dinés. Ítem, unes Qüestions de philosofia, al dit en Pere Leal, per hun sou e sis dinés. Ítem, hun Cató, ab himnes, a.n Johan Navarro, notari, per tres sous, sis [diners]. Ítem, tres librets de lògiqua, al dit en Pere Leal, per un sou, quatre [diners]. Ítem, un cartapaç de lògiqua, a·n Pere Pèreç, barber, per un sou. Ítem, hun Precià menor, a·n Gargori Navarro, studiant, per dos sous. Ítem, hun Anrich contra Fortuna, e unes Ordinacions de la Sglésia, a·n Miquel Alfagerí, studiant, per dos sous.

Ítem, tres cartapaços de lògiqua e de philosofia, a·n Johan Maló, forner, per dos sous, dos [diners]. Ítem, una lectura sobre lo De causis, a mestre Colom, per tres sous. Ítem, tres cartapaços al dit Luís, lo librer, per un sou, sis [diners]. Ítem, tres cartapaços de gramàticha, a mossén Terrades, prevere, per hun sou. Ítem, uns qüerns squinçats, a·n Miquel Ahiç, tapiner, per un sou, dos [diners]. Ítem, tres qüerns d'arts, a mossén Uguart, prevere, per un sou, quatre [diners]. Ítem, hun qüern d'arts, al dit mestre Colom, per un sou, sis [diners]. Ítem, hun qüern sobre lo Perimènias, al dit mossén Uguart, per dos sous, hun [diners] (doc. 276).

El preu total de venda dels llibres va ser de 2 lliures, 8 sous i to diners. D’acord amb el que figura en aquesta escriptura notarial, els marmessors comissionaren l'estudiant Gabriel Ferrando -que figura com a testimoni del testament i inventari de béns de Rocafort- per a portar el llibres a Miquel Sanç, rebre els diners de la seua venda i donar-los a Joana, esposa de Rocafort.

Martí de Riquer (I964, 3, 256 i 357) identificà fa anys aquest Joan Rocafort amb el mestre Rocafort que, juntament amb Francesc Ferrer, respongué a la demanda "als trobadors de València" feta pel valencià Pere Martines. Per a Antoni Ferrando (2013a, 648) -qui, seguint a Riquer (I964, 3, 256 i 357), parla erròniament de l'existència d'una "Poètica nova" entre els llibres de Rocafort quan, en realitat es tracta de la Poetria nova de Geoffrey de Vinsauf-, Rocafort compartiria amb Corella "la professió teològica i la dedicació a l'oratòria sagrada (...) també l’afició per la poesia”.

Beatriu d'Esplugues, esposa de Joan de Vich des de I460, va fer testament el 3 d'abril de I486. 
Elegí com a marmessor el seu germà Pere d'Esplugues, nomenà son fill Guillem Ramon com a hereu universal i ordenà ser soterrada a l'església de Sant Martí -concretament, a la capella de Sant Pere i Sant Pau- on eren soterrats els seus pares. La redacció d'aquest testament, donat a conéixer per Mercedes Gómez-Ferrer i Juan Corbalán de Celis, va tenir com a testimonis el cavaller Lluís Figuerola i el mestre d'escola Lluís Navarro. Va ser publicat aquell mateix 3 d'abril en la casa del cavaller i mestre en teologia Joan Roís de Corella (Gómez-Corbalán 2009, 44) ${ }^{143}$ Raons de coneixença -i qui sap si també familiars $-{ }^{144}$ han d'estar, amb tota seguretat, també rere aquesta publicació a casa de Corella.

A aquest prestigi social i personal, caldrà afegir el component familiar per a valorar com cal el nomenament de Corella com a marmessor testamentari del seu cunyat Lluís Figuerola en el testament redactat el I8 de juliol de I483 davant el notari i escriptor Joan Verdanxa (doc. 3I9). Un component familiar i un prestigi social que existí, també, en l'elecció de Corella el 30 de març de I474 com a àrbitre i amigable componedor en el conflicte que enfrontava Lluís Figuerola amb el seu germà Andreu Figuerola per questions lligades a l'herència del seu pare. La sentència arbitral es va atorgar el 30 de maig de I474 pels amigables componedors Joan Roís de Corella -mestre en teologia-, Salelles de Monpalau -cavaller-, Nicolau Balaguer i Lluís Nadal (docs. 283, 284 i 288; vid. supra, 2.2.4).

Després de morir sa mare en I475, veurem el cavaller i mestre en teologia Joan Roís de Corella actuant en la càrrega i transportació de censals i, també, en la reclamació judicial de les pensions a ell degudes, com no podia ser d'altra manera atenent la seua gran dependència econòmica d'aquest tipus d'instruments financers en no tenir altra font important d'ingressos:

* En novembre de I 475, el lletraferit valencià reclamarà al noble Pero Maça de Liçana i a la seua esposa, al cavaller mossén Lluís Mascó i al notari Jaume Gisquerol, zoo sous de pensions degudes d'un violari (doc. 286).

* En abril de I 476, reclamarà 62 sous, 6 diners a Miquel Sànchiz i a la seua esposa Guillamona, a Guillem Corts -veí de Pego- i a la seua esposa Miquela, i a Jaume Pérez de Culla i la seua esposa Joana (doc. 287).

*n octubre de I477, la reclamació de Corella serà per 75 sous als veïns de Gandia Antoni Aguiló i a la seua esposa; en novembre d'eixe mateix any, a Gabriel Sànchez àlies Garcia i a Elvira, la seua mare, veïns de Dénia, I33 sous de pensions degudes d'un censal i, també, a Guillem de Canemàs 5 IO sous i 9 diners (docs. 29I, 292 i 293).

* En febrer de I479, l'escriptor reclamà judicialment l'abonament de 6I7 sous i 6 diners a Mateua, vídua de Berenguer Jàfer, al seu fill i al matrimoni format per Francesc Climent i la seua esposa (doc. 302).

* En maig de I478, Joan Canoguera -cavaller, senyor de Catarroja i habitant de València- lliurà Ioo sous deguts a Corella per la paga d'un censal (doc. 295).

* En maig de I48I, Corella rescatà per 35 lliures tots aquells Ioo sous de violari que Joan Canoguera, senyor de Catarroja, feia a Corella i que varen ser carregats davant el notari Antoni Barreda en la dècada del $1460 .{ }^{145}$

En juliol de I482, Bertomeu Chiva-procurador del poeta valencià- reclama judicialment a

I43. Segons Gómez-Ferrer i Corbalán $(2009,44)$, “Joan de Vich era señor de Xeresa y Alcodar y vivia en la parroquia de San Martín de Valencia, junto a la casa de su hermano Luis, que posteriormente se convertiría en la conocida como casa del embajador Vich, cuando Jerónimo de Vich la transforma a su regreso de la embajada de Italia”.

I44. Cal recordar que la besàvia de Roís de Corella era Saura d'Esplugues.

I45. Doc. 3I2. Com a testimonis figuren Bertomeu Segur i Lluís Figuerola, cunyat de l'escriptor i teòleg, habitants tots ells de València. 
Abrahim Ajubet i a la seua esposa, veïns d'Ondara, 4I sous, 8 diners deguts en raó d'un censal pertanyent a Corella (doc. 3I5).

Molts d'aquests censals havien pertangut als progenitors de Corella -fins i tot als seus avis i besavis-, i ara estaven en les seues mans com a hereu universal d'ells. En altres ocasions, els censals són carregats al propi Joan Roís de Corella, com, per exemple, el violari de ioo sous que, l'i d'agost de i476, Galvany de Castellví i Joan de Vallterra, senyor de Torres Torres, carregaren a Joan Roís de Corella i als seus. ${ }^{146}$

Alguns dels plets judicials on es va veure involucrat Joan Roís de Corella ens proporcionen informacions interessants sobre propietats del cavaller i mestre en teologia. És el cas de l'adquisició per part del poeta d'un tros de terra campa anomenat "la Vela" en el terme de Dénia per mitjà de la cúria del Governador de València el I7 d'octubre de I478 (doc. 308). La compra, finalment, va ser feta en novembre de I479 després que Corella adquirira tots els drets sobre aquesta partida de terra que tenien altres persones (doc. 3O7). Molt probablement, mesos després Joan Roís de Corella va vendre la Vela a Joan Coris, mercader i alcaid del castell de Dénia, una possibilitat que explicaria que, el i7 de febrer de I480, Joan Roís de Corella li reconeguera el lliurament de 63 lliures i 3 diners en raó del terreny anomenat "la Vela", i d’altres 23 sous i 3 diners a ell també deguts (doc. 3o9).

És justament en els darrers anys de la dècada dels zo del segle XV, després de la mort d'Aldonça de Cabrera que sempre havia estat pendent de les qüestions lligades al patrimoni familiar, precisament en l'època en què més endinsat, afaenat i atabalat estava per les qüestions més terrenals -censals, reclamacions judicials, etc- quan, en la nostra opinió, Joan Roís de Corella va pensar en el futur dels seus fills, de Magdalena, de Joan i d'Estefania, en el futur d'Isabel Martínez de Vera. Ell, el cavaller i mestre en teologia més famós del cap i casal, mentre va viure sa mare s’havia despreocupat en certa mesura dels temes econòmics -cal recordar que havia fet donatària universal a sa mare, amb qui, no és aventurat pensar, Corella va viure molt de temps-, i s'havia dedicat al conreu de la literatura, a l'estudi de la teologia, a la predicació.

Però, morta sa mare i ben casada la seua germana Dalfina, calia baixar a terra i donar-se un bany de realitat i ocupar-se dels seus fills; sobretot si, com pensem, ja tenia totalment decidit dedicar-se plenament a la teologia i a la predicació amb connotacions franciscanes. Ell, Corella, no volia abandonar l'estudi de la teologia ni la predicació, però tampoc volia despreocupar-se de Magdalena, d'Isabel, de Joan i d'Estefania.

Com hem dit fa unes pàgines, aquest no voler despreocupar-se, aquest mirament pel futur dels seus fills però sense trair la seua vocació per la predicació, explica plausiblement, al nostre entendre, no sols la coincidència cronològica del dot de Magdalena i la redacció del seu darrer testament, sinó també el fet curiós que, al seu testament, Joan Roís de Corella no esmente Isabel Martínez de Vera ni els seus fills Joan i Estefania; i també el fet, més estrany encara, que tenint una constant relació amb Isabel i els seus fills -encara que fóra per la proximitat de les cases on vivien- no variara mai el seu testament després de redactar-lo en I478; i, encara més, que fera hereua universal la seua germana Dalfina i que aquesta, uns dies després de morir el prosista i poeta, fera donació dels béns del difunt a la seua amistançada com si estiguera complint amb un desig expressat per Corella a la seua germana.

Encara que donarem amb més detall els arguments més avall, avancem que el motiu de la declaració de Dalfina com a hereua universal del seu germà rau en el fet que així els futurs béns de l'escriptor arribaren lliures de deutes a Isabel Martínez de Vera i als seus fills. Aquesta béns, en I $47^{8}$ el literat ja imaginava que serien escassos, atesa la seua voluntària i glatida pobresa franciscana; atés

I46. Coneixem aquest violari per la reclamació judicial de ıoo sous de pensions degudes feta per Corella (doc. 294). 
el seu voluntari allunyament del que feien altres membres de la societat valenciana que tenien com a objectiu de vida la consecució de diners, les disputes cavalleresques, o cercar el benestar futur dels seus fills.

Magdalena Roís de Corella, la filla del cavaller i mestre en teologia, nascuda de mare desconeguda el I459, i el ciutadà i escriptor Miquel Pérez, establiren les seues cartes nupcials davant el notari Antoni Barreda el I8 d'octubre de I477 (Chiner 2013). ${ }^{147}$ El matrimoni eclesiàstic se celebraria poc després.

Magdalena aportà un dot de IO.OOO sous, si bé, en un primer moment, tan sols lliurà a Pérez 4.500 sous, atés que, el 3I d’agost de I 478 i juntament amb el seu pare, Magdalena, per a complir amb la promesa feta de donar-li els $5 \cdot 5$ oo sous restants, li lliurà dos censals de què diferents persones responien a Joan Roís de Corella com a hereu d'Ausiàs Roís de Corella i d’Aldonça de Cabrera (docs. 297 i 298$)$.

Es tractava d'un bon matrimoni per a la primogènita de Joan Roís de Corella -com tornarem a veure infra a 3.2.2 -; igualment, per a l'autor de la Tragèdia de Caldesa representava no haver-se ja de preocupar pel futur econòmic de la seua filla. Una jove que, cal recordar, no tenia una família materna que li donara suport, sinó, tan sols, els seus oncles Lluís i Dalfina Roís de Corella -amb els quals va viure en la casa de l'àvia Aldonça de Cabrera-i Bertomeu Chiva, qui la nomenarà hereua universal dels seus béns en el seu darrer testament de I 490. Per la seua banda, Miquel Pérez podia estar ben content i no pel dot -poc més de la meitat del de Dalfina Roís de Corella en I469-, sinó per l'establiment d’un fort lligam familiar amb el seu admirat Joan Roís de Corella.

Amb una situació de pesta en la ciutat de València, ${ }^{148}$ finalitzat l'establiment de les referides capitulacions matrimonials amb Miquel Pérez, aquell 3i d'agost de I 478 i davant el mateix notari, Joan Roís de Corella feia el seu darrer testament:

En nom de nostre Senyor Déu e de la gloriosíssima Verge Maria, mare sua, advocada de tota crestiandat molt piadossa, yo, Joan Roïz de Corella, en sacra theologia mestre e cavaller, habitador de la ciutat de València, sa, per gràcia de nostre Senyor Déu, de cos e de pensa ab memòria e loqüela íntregues, convocats e preguats los testimonis e notari dejús scrit, fas e ordén mon derrer testament e derrera voluntat, en e per la forma seguent:

Primerament, vull e ordén que quant a nostre Déu, Senyor e Redemptor, serà plaent appellar-me a la sua sancta glòria de paradís en la qual, per mèrits de la sua sacratíssima sanch, mort e passió, preu infinit de nostra redemptió, me vulla col-locar, lo meu cors sia liurat a ecclesiàstica sepultura dins lo vas o fossa que la magnífica germana, e hereua mia dejús scrita, volrà e elegirà, a la qual la ànima mia carament acoman. La qual sepultura ab son anniversari e cap d'any, vull e ordén sien fets segons aquella volrà e ordenarà.

Ítem, com lo honrat en Berthomeu Chiva, mercader, habitador de la dita ciutat, procurador meu en lo dit nom reba e acostume rebre les ànnues pensions dels censals, recensos, violaris e altres reponsions e altres quantitats e béns meus e a mi pertanyents, e de les quals a mi fa delliurament e dóna e restitueix e, per semblant de aquelles, fa los paguaments per mi li són manats fer sens per mi no li és feta cautela alguna. E com yo fie d'aquell, vull, man e ordén que, aprés òbit meu, lo dit honorable en Berthomeu Chiva per la hereua mia dejús scrita, sia absolt e disfinit pleníssimament. E vull e ordén lo dit honorable en Berthomeu Chiva, per sa sola simple loqüela, sens prova alguna e sens jurament, sia cregut del que dirà, en nom de procurador meu, ha rebut e donat e liurat a mi, e

I47. Doc. 297. Per a una ampliació de les dades sobre Magdalena i Miquel Pérez, remetem infra a 3.2.2.

I48. Que la pesta assolava la ciutat de València en aquell moment, ho sabem per la menció expressa a aquesta situació i a la por de morir-hi, existent al testament de Castellana March, vídua del donzell Joan March, fill del poeta Ausiàs March (RCSCCV, protocols, no. I9O3I, not. Jaume Gisquerol, -I2 juny I478). 
per manament meu ha donat. E, açò, sens cautela, jurament, o prova alguna més tan solament per sa simple loqüela, segons he dit, e a mi plau. E, si per subtilitat de dret o en altra manera, per la hereua mia dejús scrita o per altra qualsevol persona, serà demanat compte a aquell e, per la dita rahó, serà condemnat en pagar cosa alguna o restituir més del que aquell per sa sola loqüela afermarà ésser tornador, sia del dit honorable en Berthomeu Chiva com de aquella dita quantitat ara, de present, per al dit cas, temps e loch, li faç legat de la dita quantitat en la qual serà condemnat. E a cautela ara per al dit cas, temps e loch absolch, defenesch e delliure lo dit honorable en Berthomeu Chiva de tota acció, pensió, questió e demanda que per la dita rahó li sia feta, faent-li, de present, per al dit temps, cas e loch, pleníssima absolució, remissió e general fi, e solemne e perpetual pacte, axí real com personal, d'aquí avant no demane aquell en juhí e fora juhí. E sobre les dites coses e sengles de aquelles, a mi e als meus imposse callament perdurable com axí a mi plàcia e sia aquesta ma incommutable voluntat.

En tots los altres béns meu [sic] mobles, semovents e inmobles, deutes, drets e actions a mi pertanyents e pertànyer devents, de lluny o de prop, per qualsevol títol, causa, manament o rahó, la magnífica na Dalfina, germana mia, muller del magnífich mossén Loís Figuerola, cavaller, habitador de la dita ciutat, hereua mia pròpria e universal, faç e instituesch a fer dels dits béns a totes ses planes voluntats.

Aquest és lo meu derrer testament e derrera voluntat mia, lo qual e la qual vull valer e tenir, e que valgua e tingua per dret de derrer testament meu e derrera voluntat mia. E, si per dret de derrer testament valer e tenir no porà, vull e ordén aquell valgua e tingua per dret de codicils e altra qualsevol derrera voluntat per tots aquells furs, privilegits e drets que mils valer e tenir porà.

Foren fetes les dites coses en la ciutat de València a trenta-hu del mes de agost any de la nativitat de nostre Senyor mil quatre-cents setanta-huyt. Se + nyal de mi, dit Joan Roïz de Corella, testador dessús dit, qui les dites coses faç e ordene, e vull e ordén sien fetes e enseguides segons per mi son dispostes e ordenades.

Presents foren per testimonis a les dites coses convocats, e per lo dit testador preguats, en Pere Steve olim barber, en Joan Meyans, fuster, e en Pere Vidal, scuder, habitadors de la ciutat de València, qui coneixien lo dit testador. E, per semblant yo, Antoni Barreda, notari rebedor del dit testament, coneixia aquell. ${ }^{149}$

Com podem veure, les clàusules són escasses: l'escriptor estableix una disposició referent al mercader Bertomeu Chiva semblant a unes altres contigudes als testaments d’Aldonça de Cabrera sobre la mateixa persona en atorgar-li l'exempció dels possibles deutes contrets amb ell en raó de l'administració i el cobrament dels censals de l'escriptor; fa hereua universal dels seus béns la seua germana Dalfina, mentre que no deixa cap tipus de llegat als altres germans, per bé que sabem que dos d'ells -Lluís i sor Aldonça-, encara vivien quan va redactar el testament.

Tampoc no hi fa cap mena de referència a cap dels seus fills ni a Isabel Martínez de Vera -amb qui mai es va casar-, per bé que, segons el que ha posat de manifest Riquer (I964, 3, 259), Joan Roís de Corella -el fill de l'escriptor i d'Isabel- degué nàixer si més no el I474, el mateix any en què el nostre literat participà en el certamen que originà Les Trobes en lahors de la Verge Maria. Únicament podria ser entesa com una vaga referència a ells el "als meus" que figura a la frase "e sobre les dites coses e sengles de aquelles a mi e als meus imposse callament perdurable" de l'esmentat testament. Cal dir, però, que es tracta d'una frase molt corrent als testaments de l'època i que no sols es pot referir als fills de Corella sinó, també i amb més probabilitat, a la seua germana Dalfina i als altres germans seus.

El testament és senzill però, des de la seua primera frase, Corella fa, al nostre parer, una

I49. Doc. 299. Esmentat per Riquer I964, 3, 257, assenyalant-ne com a data la del 30 d'agost. Publicat a Chiner I994b, 49-6I. 
important declaració existèncial: ell és "Joan Roïz de Corella, en Sacra Theologia mestre e cavaller", ell se sent, fins i tot en el document més important i transcendent de la seua vida, primer mestre en teologia i, després, cavaller. Roís de Corella així vol ser conegut pels seus conciutadans i així el coneixeran. Per a la majoria, primer serà mestre i després cavaller o, fins i tot, únicament mestre: serà qualificat només com a mestre per Jaume Roig i pel rei Joan II (docs. 265 i 268), pels jurats de València (docs. 3I6, 32O, $325^{\mathrm{i}}$ 350), per la Seu de València i per la confraria de les òrfenes a maridar (docs. 335, 345, 346, 35I, 359 i 360) i ho serà fins i tot per a membres de la seua família directa com són el seu germà Lluís -que primer el qualifica de mestre i després de cavaller en I477 (doc. 289)- i la seua filla Magdalena que, en els seus testaments de I480 i I490, sempre li dirà mestre en teologia i mai cavaller (docs. 3II i 339).

Des de Riquer (I964, 3, 259), en la ment dels investigadors ha rondat una sèrie de qüestions lligades al no casament de Corella amb Isabel Martínez de Vera i a la no menció d'ella en el testament de l'escriptor: ¿Estava ordenat in sacris i per això no es casà ni esmentà Isabel al seu testament? Si no estava ordenat in sacris ¿̨per què no va esmentar o fer qualsevol llegat a Isabel i als seus dos fills quan, a València, la família de Corella i tots els parroquians, almenys de Sant Martí, coneixien la seua relació amb ella i la paternitat dels seus fills? ¿Per què des de I $_{47} 8$ no va fer un nou testament on esmentara Isabel i els seus fills? ¿Per què nomenà hereua universal Dalfina i ella pocs dies després donà els béns del lletraferit a Isabel? ¿Per què es va utilitzar aquesta via indirecta per a fer arribar els béns de Corella a la seua amistançada i no la dreta via del testament?

Com hem apuntat abans, i després tornarem a veure, el motiu de no deixar-li cap llegat, de no fer Isabel o els seus fills hereus universals seus, naix d'un estratagema legal: la declaració com a hereua de Dalfina com a mitjà de què arribaren els béns del poeta a Isabel Martínez de Vera i els seus fills lliures de deutes. Si Corella nomenava hereus testamentaris seus Isabel o els seus fills, d'acord amb la legislació foral, aquestos havien de fer-se càrrec dels seus deutes; i el mateix passava si rebien llegats i, per tant, els hipotètics escassos béns corellans que arribarien a Isabel i els seus fills es veurien minvats. És el que diu el fur VI-VII-3 fet per Jaume I:

Lo hereu del defunt és obligat a tots los creedors del defunct que pach tots los deutes, los quals lo defunct los devie.

Mas lo legatari a qui el defunct lexà alcun camp o alcuna altra cosa singular no és obligat a pagar los deutes del defunct. Mas si la heretat no bastara a pagar los deutes, los creedors del defunct poden demanar als legataris aquel camp o aquela cosa que.l defunct los haurà lexada entrò que a ell sia satisfeit dels deutes que a ells aquell defunct devie. Car e.ls béns que foren del defunct mellor rahó han e mellor dret los creedors, que·s treballen per lur dan a esquivar, que no han los legataris, que·treballen per lur prou a fer (Colón-Garcia 1990, 230).

El I4 de gener de I479, el lletraferit valencià donà i transportà a Isabel Martínez de Vera dos censals un de 2 r9 sous i 8 diners, $i$, altre, de 66 sous i 8 diners- que havien pertangut a la família de Corella per valor de 3.65 o sous (doc. 3oI). Deixant a banda la mostra d'amor que es podria veure en aquest acte notarial, pensem que és en el context del que hem parlat de "deixar les coses clares" on adquireix tot el seu sentit la referida venda dels dos censals que adquireixen un cert caràcter de compensació a Isabel Martínez de Vera en no figurar al testament.

El i6 de febrer de I479, el cavaller i mestre en teologia Joan Roís de Corella figura com a testimoni d'un acte que cal posar en relació amb un conjunt d'actuacions del monarca Ferran el Catòlic en el marc d'una reforma de l'administració reial i dels càrrecs municipals en el regne de València, destinada a la reafirmació del seu poder només arribar al tron d'Aragó, front dels representants 
administratius del seu pare Joan II, i que ha estat estudiada per Belenguer Cebrià entre d'altres. Aquell dia, el conseller reial i batle general Pere Garró lliurà al comte d'Oliva Francesc Gilabert Riusec àlies Centelles, Governador del regne de València, una carta del monarca signada a Trujillo el 8 de febrer de I479, on el rei comunicava al comte d'Oliva el seu cessament en el càrrec de Governador i, a Eximén Pérez Escrivà de Romaní, la seua inhibició com a nou governador (doc. 303). La missiva va ser lliurada per Garró en la casa del comte d'Oliva i Corella era allí, juntament amb el cavaller Pere Ramon de Monsoriu i Pere Capdevila, habitants de València. Del contingut d'aquest document no es pot deduir amb seguretat per què estava Corella en casa del comte d'Oliva, si va acudir-hi acompanyant Garró o no. Malgrat aquesta manca d'informació documental, en la nostra opinió el més probable és que estaria en la casa o bé circumstancialment, o bé cridat pel comte d’Oliva, amb qui Aldonça Roís de Corella -i per tant, el seu fill Joan- havia tingut relació per raó d'uns censals en octubre de I45O, maig de I453 i l'agost de I47O (docs. I83, I93 i 269).

Després d'un temps de certa convulsió política i administrativa en el regne de València per l'arribada al poder de Ferran el Catòlic -un altre episode molt conegut és la substitució del mestre racional nomenat per Joan II, Jaume Garcia d'Aguilar, el pare del corellà Francí d'Aguilar, per Joan Ram Escrivà en I479 (Cruselles I989, IO7-I2)-, els jurats de València contractaren Corella per encarregarse de "la lectura de la sancta theologia" a la sala de la ciutat des de l'i de novembre de I 482 a l'I de novembre de I484. ${ }^{150}$ Es va establir un salari de I.ooo sous a l'any, i entre els representants municipals que ho acordaren i les persones que assistiren com a testimonis de l'acte en I482, podem trobar gent relacionada amb Corella com són els juristes Miquel Albert -relacionat amb la família de Corella des de setembre de I $45^{8}$ (doc. 224), va contractar el 30 de maig de I 495 amb l'impressor Lope de Roca la realització de la segona edició del Quart del Cartoixà (Serrano I898-99, 498503)-, Jaume Garcia d'Aguilar -pare, com hem dit, del Francí d’Aguilar lloat literàriament com a màrtir cristià per Corella a la Sepultura de mossén Francí Aguilar (novembre de I482) - ${ }^{151}$ i el mestre racional Joan Ram Escrivà -tertulià del Parlament en casa de Berenguer Mercader, autor amb Corella de Lojohí de Paris i, com hem dit, substitut de Jaume Garcia d'Aguilar en el càrrec de mestre racional en I479.

En els acords municipals de I482 i I483, s'especifica que Corella farà "la lectura dels sagrats Evangelis" i de "los Actes dels Apòstols, e acabat aquells liga lo Psaltiri". En la nostra opinió, són aquestes lliçons teològiques, especialment les dels salms, les que es troben darrere de la traducció corellana i posterior impressió del Psalteri a Venècia en I49O. ${ }^{152}$ El darrer pagament a Roís de Corella que hem localitzat "per legir cascun jorn una liçó de la Sacra Scriptura en les cases de la sala de la dita ciutat” és per valor de I6 lliures, I3 sous i 4 diners, i està datat el 25 d'agost de I484 (doc. 323 ).

Considerem que és el prestigi, el reconeixement social i intel-lectual que tenia Corella en uns moments en què els jurats li havien encarregat donar clase de teologia a la sala de la ciutat, els que expliquen fàcilment que fóra consultat, juntament amb un altre teòleg prestigiós, el bisbe Jaume Pérez -autor del Commentum in librum Psalmorum (València, I484) i de l'Expositio in cantica canticorum (València, I486)-, per les persones que estaven traduïnt la Bíblia sobre certs dubtes en la traducció

I50. Docs. 316 i 320 publicats en Torre I924-25, IO8-o9 i en Guia I999, 42-43. Jaume Garcia d'Aguilar no es trobà present en la sessió, però no va fer cap esmena a aquest acord.

I5I. Erròniament, Antoni Ferrando (20I3a, 647) afirma que el pare de Francí era Francesc Jeroni d’Aguilar. Sobre Francí d'Aguilar, el seu pare, i la família Aguilar, senyors d’Alaquàs, vid. Graullera (ı998, 9-22), Cuñat (2005), Graullera (2009, II-28), Perea (2OO7, I9-26), Rubio (2OI3, 6IO-I5) i Rubio (2OI4, 45O-62).

I52. La impressió, com demostra Josep Lluís Martos amb arguments amb què estem plenament d'acord, es va fer a Venècia el 30 d'abril de I490 en les premses de l'alemany Johan Hertczog (Martos 2OI3). 
d'algunes expressions dels salms. Així, pensem, ho deixen veure clarament els interrogatoris que, en abril i juny de I483, la Inquisició féu a Daniel Vives, al bisbe Jaume Pérez, a l’impressor Lambert Palmart, a fra Jaume Borrell i a fra Bernat Comes sobre llurs participacions en la correcció i edició de la Bíblia impresa a València en I478 atribuïda, tradicionalment, a Bonifaci Ferrer, germà de Sant Vicent. ${ }^{153}$ El bisbe Jaume Pérez apareixerà també al costat de Corella, segons les declaracions fetes el I 4 de febrer de I 490 davant la Inquisició pel diaca Jeroni Fuster, en la consulta que se'ls va fer a ambdós sobre l'ortodòxia teològica de les opinions del convers Lluís Roís, recollides en

certes cobles en llaors de sant Nicolau de Tolentí, en les quals havia posada una conclusió errònea, dient que nostre senyor Déu l’havia transplantat el paraís en terra al dit sant. La qual conclusió per los reverents senyós bisbe cristopolità e mossén Joan Roís de Corella li fonc dita conclusió ésser herètica talmotista (Ventura 1978, 47).

Serà, també, en I483 quan s’imprimirà per Lambert Palmart el primer volum del Crestià de Francesc Eiximenis, "lo qual dit primer libre a suasió, consell e instància del molt reverend mestre mosén Johan Ruys de Corella, mestre en sancta theologia, zelant la salut de les ànimes és stat tret o empremptat del dit libre appellat Crestià, lo qual és en la librería del monestir de frares menors de la insigne ciutat de València" 154 . La participació de Corella en aquesta edició no sols el vincula amb un dels primers impressors de la València del s. XV sinó, també, novament amb el convent de Sant Francesc on finirà sos dies i on, probablement, ja sojornava en ocasions.

En la nostra opinió, Corella també es troba rere l'edició del Dotzé del Crestià o Regiment de prínceps e de comunitats (València, I484), ${ }^{155}$ perquè ambdós formen part d'un mateix projecte editorial eixit de les premses de Lambert Palmart en dos anys successius; un projecte editorial que s’entén perfectament si, darrere d'ell, està el "franciscanisme" de Roís de Corella qui, en eixos moments de forta relevància seua social i de lligam amb el poder municipal, potser se "sentia" en el seu interior com un nou fra Francesc Eiximenis, com un nou predicador i conseller àulic cristià de les autoritats municipals. Un nou "conseller àulic" que, molt probablement, va ser capaç d'influir en la política assistencial i hospitalària de la ciutat de València i dotar-la d'un fort caràcter cristià, com veurem a continuació.

Segons consta en els manuals de Consells conservats a l'Arxiu Municipal de València, el 24 d'abril de I402, els jurats del cap i casal -el cavaller Lluís Mascó, menor de dies; i els ciutadans Berenguer Martí, Joan Alegre i Miquel Camarena- es plantejaren la necessitat de construir un hospital general en la ciutat i nomenaren una comissió que es reuniria dos vegades per setmana per tal d'estudiar la viabilitat i les despeses que suposaria la construcció d'aquest hospital. Els membres d'aquesta comissió -Lluís Mascó, menor de dies, com a jurat en cap pels cavallers i generosos; Berenguer Martí de Torres, com a jurat en cap pels ciutadans; el racional Bernat Català, mossén Joan Roís de Corella, cavaller i mestre en teologia i els advocats de la ciutat Jaume Garcia d'Aguilar i Miquel Dalmau-, havien de comunicar els resultats de les seues deliberacions als jurats de València. ${ }^{156}$ Com

I53. Doc. 3I8 publicat en Ventura 1993, I5-67.

I54. Fol. I9rv de l'incunable (http://tinyurl.com/o26gc46).

155. Així opinen també Ferrando i Escartí (1998, I65).

I56. Doc. 3I4. Dóna notícia d'aquesta deliberació Teixidor (1895, 2, 325-30), si bé s’equivoca en esmentar com a font el volum 44 i no el 42 dels Manuals de Consells. El document ha estat transcrit per Gallent 1980, Gómez-Ferrer 1998, $37^{2}$ i per Guia 2002, ${ }^{2} 75^{-7} 6$.

Segons s’afirma en el document, Lluís Mascó i Berenguer Martí formarien part de la comissió "durant emperò los temps de llur juraderia e, en los anys subsegüents, sien ordenats, ensemps ab los davall scrits, los jurats en cap, ço és, lo hu per los cavallers e generosos, l'altre per los ciutadans, quisvulla que sien axí graduats". 
a testimonis d'aquesta provisió municipal figuren el cavaller Berenguer Mercader i els ciutadans de València Galeàs Joan i Pere Lor.

A finals de I484, Joan Roís de Corella figura com a testimoni en la rendició de comptes de l'administrador de l'hospital de Sant Llàtzer, Berenguer Martí de Torres, germà de misser Jaume Garcia d'Aguilar i oncle del Francí d'Aguilar lloat per Corella (Rubio 20I3, 6IO-I3). ${ }^{157}$

El 29 de març de I485, els jurats de València reiteraren la necessitat de construir un hospital general en la ciutat que unificara els altres hospitals hi existents així, "que los pobres sien millor albergats e receptats e subvenguts a llur necessitats" i nomenaren una comissió per tal d'estudiar la viabilitat i les despeses que això suposaria. Els membres d'aquesta comissió serien Macià Mercader, artiaca de la Seu de València; els cavallers Jofre de Thous àlies de Mompalau i Guillem Ramon de Vila-rasa -tertulià del Parlament en casa de Berenguer Mercader-; els ciutadans Berenguer Martí de Torres, Bernat de Pena-roja, Lluís d’Alpicat, Lluís Pellicer, Ramon Berenguer i Bernat Català i el canonge de la Seu Francesc Corts. Com a testimonis d'aquesta provisió municipal figuren el cavaller i mestre en teologia Joan Roís de Corella i Berenguer Mercader, "conseller del senyor rey e lochtinent de batle general de regne de València”. ${ }^{158}$

Anys després, l'ı de maig de I494, la preocupació de Joan Roís de Corella per l'assistència hospitalària als pobres serà recordada en l'acte de fundació del nou hospital dels Innocents anomenat "spital del Sant Sperit de la Verge Maria dels dits sants Innocents". En aquesta acta s'afirma que els diputats de l’Hospital dels Innocents volien fundar un nou hospital

recordant-se aquells moltes e diverses vegades ésser estat pricat e amonestat per alguns mestres en sacra theologia en les trones de les sglésies parrochials de la dita ciutat, e senyaladament al reverent mestre Johan Roïz de Corella, mestre en sacra theologia, la gran fretura e necessitat que en la dita ciutat és de hun spital per obs de acollir en aquell los pobres, malalts e mendicants, sancts de entendiment, com aquells fossen freturossos de habitació e subvenció per les necessitats e misèries que nostre Senyor Déu los dóna per sos demèrits e culpes. ${ }^{159}$

En el document de l'acte de fundació no figura Joan Roís de Corella, però no es pot excloure la possibilitat que hi assistira; una possibilitat que donaria més caràcter de reconeixement públic a la seua menció en el document.

Per tal d'emmarcar des del punt de vista històric tant la deliberació de I482 com la de I485 o la de I494, es necessari reproduir in extenso les paraules sobre la creació de l'Hospital General de la professora Gómez-Ferrer en la seua tesi doctoral. Aquestes ens permetran situar en el seu exacte context no sols les determinacions i actuacions dels jurats de València per a la creació de l’Hospital General sinó, també, les predicacions de Corella referides a l'ajuda als pobres en la València de finals del segle XV assolada per la fam, la pesta i la crisi econòmica:

Los primeros datos sobre la intención de realizar un Hospital General en la ciudad de Valencia aparecen en las deliberaciones del Consell Municipal en la temprana fecha de I482. El 24 de abril de I482 se propuso por vez primera que fuera construido y edificado "en la present ciutat un

I57. Doc. 324, document esmentat en Rubio 20I3, 6I2. Segons Rubio Vela (2OI3, 6I3) a Berenguer Martí de Torres es refereix Joan Roís de Corella en la Sepultura de mossén Francí Aguilar quan diu que, en morir, Francí "ha deixat noble senyor e pare [Jaume Garcia d'Aguilar], ensems ab un estimat oncle [Berenguer Martí de Torres], lo qual, sens fill, ab sobreabundant heretat, adoptant-lo en fill, largament l'heretava".

I58. Doc. 325. Transcrit prèviament en Gómez-Ferrer I998, 372.

I59. Doc. 350. Publicat prèviament per Gómez-Ferrer 1998, 373-74, i per Guia 2002, I76-78. 
devot e solempne Espital General", dotado de toda suerte de gracias, indulgencias, privilegios y prerrogativas, tanto por parte del santo Padre, como por parte de su majestad el Rey. Para ello, los jurados debían basarse en los ejemplos proporcionados por capítulos y ordenaciones de otros Hospitales Generales, para que de esta forma, se les pudiera imitar, e incluso mejorar. Con ello se pretendía servir tanto a Dios como a los pobres de la ciudad. Se proponía el nombramiento de unos diputados que se reunirían dos veces por semana para estudiar la viabilidad y los costos de este proyecto, y que debían comunicar a los jurados de la ciudad los resultados de sus deliberaciones.

No se vuelve a tener noticias sobre este proyecto hasta el 29 de marzo de I485, en el que hay una nueva deliberación del Consell de la Ciudad, en la que se insiste en lo provechoso que sería para la ciudad la construcción de un Hospital General. Este Hospital permitiría albergar a los pobres de la ciudad para atenderles en sus necesidades y facilitaría la gestión de las atenciones sanitarias, pues todos los hospitales existentes en la ciudad de Valencia, se unificarían en uno. En esta segunda proposición, se elegía a una serie de personas para que fueran administradores y regidores de este Hospital General y se concretaba un poco más el proyecto, proponiendo la idea de agregarle los hospitales que ya estaban sometidos a la autoridad municipal, es decir, el den Clapers, el de la Reina, el dels Beguins y el de San Lázaro. El principal problema era de índole económica, ya que no se había dispuesto una forma concreta de subvención, sino que la construcción del Hospital General se pretendía financiar en base a donativos.

A pesar de estas firmes proposiciones, la propuesta de unificación de los hospitales medievales de la ciudad, con la consiguiente creación de un Hospital General, no se materializaría hasta el año I5 ${ }^{\mathrm{I} 2 .}$

(...)

Mercedes Gallent, que ha estudiado el proceso de unificación, señalaba varias causas que contribuyeron al retraso de la creación del Hospital General. Por un lado, la difícil coyuntura política que atravesaban los estados de la Corona de Aragón, entre ellos Valencia, que estaba cada vez más presionada por el poder real. Por otro, (...) situación económica [de València] empeoró notablemente hacia finales del siglo XV, años en que la ciudad hace numerosos empréstitos a los Reyes Católicos. (...) Estos años coinciden además con una gran crisis triguera, iniciada en I479I480, que culminó con las grandes hambrunas de los años I480-I483, y finalmente con incidencias epidemiológicas a partir de los años I 480 , entre las que destacan las epidemias de I483, I 485 y I487. A esto, se unían problemas de índole interhospitalario, pues la ciudad regía un gran número de hospitales que, al igual que ella, estaban atravesando graves dificultades económicas. Por el contrario, el Hospital de Inocentes poseía una economía más fuerte y la unificación no sería de su agrado ya que significaría ceder la totalidad de los beneficios políticos y económicos de los que disfrutaba.

(...)

En realidad, hasta que el Hospital General no se funda en el año I5I2, no se produce la unión de todos lo hospitales existentes en la ciudad, pues el nuevo Hospital auspiciado por los diputados del de Inocentes, en el año I494, sólo tenía la intención de ser un Hospital General, en cuanto a las atenciones hospitalarias dispensadas, pero no era el único de toda la ciudad, sino uno más. Se denominaba "Spital del Sant Sperit de la Verge Maria dels Sants Ignoscents", para diferenciarlo del de Ignocents, Folls e Orats, a la vez que para manifestar la relación entre ambos. Ya en la petición formulada al rey don Fernando el Católico, se indicaba que este nuevo hospital contemplaba en su programa la acogida a otros enfermos que no fueran únicamente dementes. Esta noticia se repite en otros documentos, como el que recoge el acto fundacional, de puesta de la primera piedra, que se refiere a un hospital para pobres dementes y "otros", de la ciudad de Valencia e incluso del extranjero. Vemos como se añadía también la acogida de niños huérfanos que eran abandonados en las iglesias, plazas y rincones de la ciudad. Este problema de los niños huérfanos era un mal persistente, que había llevado a la toma de un acuerdo por parte del Consell de la Ciudad, que se materializa precisamente en una provisión de 27 de junio de I 494 , en la que se realizó "Una crida sobre lo lansar de les criaturas als spitals, esglesies y altres llochs", que recogía las mismas palabras del acto fundacional del nuevo hospital y la preocupación ante esta situación. Aun así, el problema 
no parecía resuelto pues, el I6 de julio de I 499 se publica un nuevo pregón por parte del justicia y de los jurados de la ciudad de Valencia, que comenzaba afirmando que el hecho de abandonar las criaturas en las puertas de los templos y de las casas de algunas personas principales constituía una nota de gran infamia para la ciudad y quienes la regían.

En el acto de colocación de la primera piedra del Hospital del Santo Espíritu de la Virgen Maria de los Inocentes, se recogían palabras parecidas y se indicaba que el nuevo Hospital era de gran necesidad para la ciudad para poder acoger en él, a mendigos, a pobres enfermos y a gentes sin entendimiento que carecían de habitación, lo que causaba que algunos de estos enfermos se murieran en las calles, en los bancos y mesas de la ciudad. Del mismo modo, recogería a los niños abandonados en las calles. Los diputados, según manifestaban, habían sido instados por las palabras del "mestre en Sacra Theologia Joan Roig de Corella", quien también había participado en las reuniones del Consell Municipal donde se deliberó sobre la conveniencia de la construcción de un Hospital General, en I 482 como jurado y en I 485 como testigo.

(...)

Sin embargo muchos de los motivos que impulsaron a la construcción del hospital son esencialmente de carácter cristiano y hacen referencia a las obras de misericordia e incluso a determinados pasajes de la escritura. Esta ideas se encontraban en la provisión de I482, en la que se indicaba que los jurados de la ciudad de Valencia estaban movidos por buenas y santas consideraciones como era la de ejercitar las obras de misericordia de las cuales la hospitalidad era la primera. Este ideal cristiano se reitera en el acto de fundación del nuevo Hospital de Inocentes en I494, donde se practicaban las siete obras de misericordia en honor de Dios y de la Virgen, y se apelaba a la Carta de San Pablo a los Hebreos, capítulo XIII: "caritats fraternitatis maneat in vobis e hospitalite nolite oblimei (...)" y se indicaba que si los pobres no eran recogidos en un Hospital, no podrían recibir los santos sacramentos lo que sería en gran detrimento para la santa fe católica. Se recordaba también el Sermón de la Montaña y las Bienaventuranzas, sobre todo la que hacía referencia a los misericordiosos y se invocaba a la Virgen de la Misericordia, en la cual los diputados depositaban todas sus esperanzas. Estas manifestaciones expresan una dualidad, ya que junto a ideas novedosas como pueden ser el recoger a los enfermos y niños de las calles y el de aceptar a todo tipo de enfermos y necesitados, aparecen los tradicionales motivos de práctica de la misericordia y de permitir una muerte cristiana para todos los enfermos, es decir, de celo cristiano, "zell de caritat". (...)

El Hospital de Sant Esperit de la Verge Maria dels Sants Ignoscents fue la primera de las nuevas fundaciones hospitalarias de fines del siglo XV, que aún sin asumir completamente el carácter de Hospital General, contó con el apoyo directo de los monarcas quienes no sólo autorizaron su creación sino que se empeñaron en apoyarlo con la consecución de privilegios y prerrogativas. Contó también con las sanciones regias y papales desde un punto de vista institucional y el impulso para su construcción definitiva, vino del acuerdo entre los dos grandes sectores que controlaban los hospitales, los diputados del Hospital de Inocentes de un lado, y el Consell de la Ciudad, de otro (Gómez-Ferrer 1995, 35-47). ${ }^{160}$

Respecte de l'esment de Joan Roís de Corella en els actes de I482, I485 i I494, cal dir que estem d'acord amb Josep Guia quan afirma:

Cal subratllar la importància de la inclusió en la comissió [de I482] de Joan Roís de Corella, l'únic que hi és sense càrrec municipal, al costat de la més alta representació ciutadana: els dos jurats en cap, el mestre racional i dos dels advocats de la ciutat. Era el mateix any que els jurats contractaven Corella per dictar lliçons de teologia a la sala de la ciutat (...) El document [de I494] (...) ens innova que Joan Roís

I6o. Per error, Gómez-Ferrer parla de l'escriptor Joan Roís de Corella com a jurat de València. Unes ordenances amb actuacions per a prevenir el contagi de la pesta de I483, es poden consultar en Chiner I994a, 25-34. 
de Corella predicava públicament en favor de la resolució del problema assistencial hospitalari i que la seva no era una prèdica qualsevol, ja que els diputats de l'Hospital dels Sants Innocents en fan una menció destacada (Guia 2002, I76-79).

$\mathrm{Si}$, a aquestes consideracions de Guia, afegim la situació dels pobres a la ciutat de València i l'esperit d'actuació cristiana que aflora en els actes de I 482 però, sobretot, en el de I 494 segons l'opinió de Gómez-Ferrer, i que, en el període I482-I494, Corella no va deixar de predicar, no és descaminat pensar en Joan Roís de Corella com un dels més importants artífexs intel-lectuals de l'erecció del futur Hospital General de I5I2.

Coneixem en aquesta dècada dels anys 80 , un acte una mica estrany respecte a la trajectòria vital en eixos moments d'un Joan Roís de Corella que, malgrat ésser cavaller, s'havia bolcat en la teologia i en la predicació: es tracta de la presa de possessió feudal del lloc de Bellreguard en nom de Pere Lluís de Borja, nou duc de Gandia. Un acte com diem estrany, però que, amb tota seguretat, es pot entendre si tenim en compte els estrets lligams familiars del nou duc amb el cardenal Roderic de Borja, futur papa Alexandre VI, en aquell moment bisbe de València. El rei Ferran el Catòlic va concedir el I $_{485}$ el títol de duc de Gandia a Pere Lluís de Borja, primogènit de Roderic de Borja i, per la seua actuació a la campanya de Granada, ell i els seus germans reberen del monarca el títol d'egregis. Així culminava

una operació que havia començat amb l'adquisició de terres de l'antic ducat de Gandia, creat al segle XIV per Jaume II de Catalunya-Aragó per al seu fill, l'infant Pere. Després d'un període d'esplendor sota el govern del segon duc, Alfons el Vell (mort el I4I2) i la breu successió del seu fill Alfons, el ducat havia tornat a la dinastia reial el I425; posteriorment, el I470, Joan II havia hipotecat la ciutat de Gandia a València per tal d'aconseguir recursos econòmics per a la guerra civil catalana. El territori de l'antic ducat, fragmentat en petites jurisdiccions senyorials, estava immers en un procés de despoblació i endeutament que la creació del nou ducat borgià de Gandia venia a redreçar.

Roderic es proposava fundar un patrimoni peninsular per als seus fills, que havia d'igualar els Borja amb l'alta noblesa del país. El I 479 s'havia comprat la baronia de Llombai; el I484, la de Xella; el I485, Gandia. Tot i que el nou ducat requeia en la persona de Pere Lluís, era la fortuna del pare, un dels cardenals més rics de l'Església, la que s'havia fet càrrec de les enormes despeses de les operacions. ${ }^{161}$

És en aquest context històric on cal situar el nomenament, el Io de març de I486, per part de Pere Lluís de Borja, nou duc de Gandia i fill primogènit del cardenal Roderic de Borja, del mestre i cavaller Joan Roís de Corella com a procurador seu. ${ }^{162}$ Com a representant legal ducal, Corella va prendre possessió, eixe mateix dia, del lloc de Bellreguard que Pere Lluís de Borja, havia adquirit del cavaller Joan Roca per 200.00O sous. ${ }^{163}$

Pensem que aquest document té una gran importància, en lligar la figura de l'escriptor als Borja, i en fer palés que les relacions de Corella amb la més important família valenciana del moment eren bones i de confiança.

No sabem, però, si, en acceptar la procuració i fer l'acte de possessió, Corella pensava servir el nou duc, abandonar la predicació - cosa que ens sembla molt difícil de creure-i unir el seu destí -i, probablement, el del seu fill- a un nou senyor que, malauradament va faltar en I 480 , i que probablement s'havia proposat portar el vell ducat al seu antic esplendor.

I6I. IIEB 2006. Sobre l'adquisició del senyoriu i posterior ducat borgià, vid. La Parra 2006.

I62. Doc. 327. Aquesta procuració és coneguda per Guia 1999, 52. També se’n parla, amb esment de la presa de possessió de Corella, a Bellreguard 20I4.

I63. Doc. 328. Sobre les preses de possessió i les seues formes jurídiques, vid. Chiner I99I. 
Tampoc sabem si acceptar la procuració del jove Pere Lluís va ser una decisió personal de Corella presa sense cap tipus de pressió o si, pel contrari, va intervenir algun manament en aquest sentit del cardenal Roderic de Borja, a qui, segurament, Corella havia conegut en el viatge a terres valencianes en I472 del cardenal, qui ocupava nominalment el bisbat de València des de feia anys, i a qui, per tant, Corella devia certa obediència per la seua condició de clergue amb órdens menors.

Però el que sí que és clar és que aquesta procuració mostra el respecte i el prestigi social i intel-lectual assolit per l'escriptor Joan Roís de Corella en els anys 7o i 80 del s. XV, ja que, lògicament, un qualsevol no podia representar al nou duc, el primogènit del bisbe de València, un dels hereus del cardenal Borja.

En I487, Pere Lluís de Borja tornarà a Roma, on morirà en I488. Mentrestant, i com hem comentat en l'apartat dedicat a Dalfina Roís de Corella (2.2.4), el 7 de febrer de I487 Joan Roís de Corella, en presència del justícia civil de València, donà a la seua germana Dalfina -esposa de Lluís Figuerolatots els seus béns mobles, immobles, etc. presents i futurs. D’aquesta donació inter vivos que Dalfina acceptà, Corella va exceptuar, per a ell i els seus, certes cases seues situades a la parròquia de Sant Martí que afrontaven amb un hort i una casa de Lluís Figuerola, amb dues vies públiques i amb una altra casa de Figuerola. Aquestes cases de Joan Roís de Corella estaven subjectes al domini directe de la confraria dels forners abans anomenada de la Santíssima Trinitat sota cens de 9 sous. ${ }^{164}$ Són les mateixes cases que, després de la seua mort, arribaran a Isabel Martínez de Vera per mitjà de la donació de Dalfina Roís de Corella.

Eixe mateix dia i davant el mateix notari, i no creiem que siga una mera coincidència cronològica, el cavaller i mestre en sacra teologia reconeix deure a Miquel Honorat Pérez, ciutadà de València i gendre seu, I3o lliures que aquest graciosament li prestà amb la condició de tornar-li-les quan desitjara Pérez (doc. 330). Així mateix, el 9 de febrer de I488, Corella reconegué al mercader Bertomeu Chiva el lliurament de 80 lliures, preu total de venda de Ioo sous censals (doc. 33I) i, dies deprés, Andreu Figuerola, el germà del seu cunyat Lluís, vengué i carregà al poeta 9oo sous censals per preu de I3.5OO sous (doc. $33^{2}$ ). El 27 de març de I 488 Corella ja havia retornat els diners prestats pel seu gendre Miquel Pérez (doc. 330).

En aquests anys finals del segle, Corella continuarà amb la seua tasca de predicador fins i tot en la Seu de València, on era domer el seu amic Bernat Fenollar, qui li dedicà la coneguda poesia sobre les seues predicacions que "llegint-la tota diu mal e llegint-la per mitat diu bé" ("Un altre sant Pau - no sou vós, mossényer”). El 4 de juliol de I 489 el mestre en teologia Joan Roís de Corella publica a la Seu de València la indulgència papal extraordinària atorgada als fidels que contribuïssen a refer el retaule d'argent de la Seu de València cremat el 2i de maig de I469. A continuació de la publicació, sabem que Corella sermonà:

...E axí a quatre dies del mes de juliol del dit any [I489], per los dits senyors de capítol fonch provehït e manat ésser publicada dita indulgència en Aragó, Cathalunya, València e per tot lo present regne. E de la dita bulla fossen fets transumpts en forma de vidimus, los qual foren provehïts e decretats per lo reverent micer Jaume Honorat Roig ${ }^{165}$, doctor en decrets, canonge de la Seu de València e vicari general del dit reverendíssim senyor cardenal e bisbe de València, a instància del reverent mestre Jaume Serra, mestre en sacra theologia, canonge e síndich dels dits senyors de capítol de la Seu de València,

I64. Doc. 329. Figuren, com a testimonis d'aquesta escriptura notarial, el donzell Joan Ramon de Caldes i el notari Domingo Garcia.

165. Era fill del metge i poeta Jaume Roig (Chiner I993-94). 
e tramesos per les dites parts d'Aragó, Cathalunya e València ab persones eletes per los dits senyors de capítol. E, en la present ciutat de València, fonch publicada dita indulgència en la Seu [En blanc] per lo reverent mestre Johan Roïç de Corella, mestre en sacra theologia, qui lo dit dia en la Seu sermonà.

E essent ja prop la festa de la Assumptió de la Verge Maria, tres jorns ans de aquella los dits reverents senyors de capítol del-liberaren que los magnífichs senyors jurats de la dita ciutat de València fossen pregats de part de lurs senyories que ells, o persones eligidores per ells, fossen presents e assistissen continuament en les caxes on se posarien los diners de la indulgència per aquelles persones que volrien guanyar e penre aquella... (doc. 335).

Gran part de la societat valenciana contribuí monetàriament a la recuperació de l'altar. Entre d'altres persones, en les llistes de contribuents figuren els lletraferits Miquel Pérez -amb 2 lliures, 5 sous-, Lluís Alcanyís -amb 2i sous-, Bernat Fenollar -amb I lliura, II sous i 6 diners-i Jaume Roig -amb I lliura, 2 sous. ${ }^{166}$

Uns dies després del seu sermó a la Seu de València, el feel servidor Bertomeu Chiva, mercader de València, dictà, el Io de juliol de I489, un testament on deixava diversos llegats testamentaris a Joan Roís de Corella (doc. 336).

Un mes després de la publicació de la indulgència i del sermó de Corella, aquest lliurà una àpoca per valor de io lliures i ro sous cobrats del canonge Francesc Cots, vicari general, i del canonge Joan Pelegrí, administradors de les pecúnies de la indulgència de la Seu de València per a fer l'altar d'argent que s'havia cremat (doc. 337).

Dos anys i nou mesos després d’haver donat els seus béns a la seua germana Dalfina, aquesta, el 23 de novembre de I489 i en presència del cavaller i justícia civil de València Francesc Barceló, va restituir al poeta tots els béns i drets dels quals, anteriorment, ell li havia fet donació (doc. 338).

Com ja hem dit en un altre apartat d'aquest article, desconeixem amb seguretat els motius que varen portar a Joan Roís de Corella a fer aquesta donació entre I487 i I489 a sa germana, i que hagué, com a conseqüència immediata, no sols la petició de diners als seus familiars i amics (Miquel Pérez, Andreu Figuerola, etc.) sinó, també, la venda, en I488, a Dalfina d’una de les dues cases que posseia l'escriptor en el carrer de Mossén Corella. ${ }^{167}$ Dalfina era, des de I478, la seua hereua universal, i no calia aquesta donació des del punt de vista de l'economia del matrimoni CorellaFiguerola. S’ha suggerit que la donació seria per evitar que la Inquisició es fera amb els seus béns i que la tornada dels béns en I489 estaria relacionada amb una disposició de març de I489 en virtut de la qual, abonant una sanció econòmica, els condemnats i els seus hereus podrien conservar l'amenaçat patrimoni (Soler 20I3, 632). Això significaria que Corella se sentiria amenaçat i que hauria estat "sancionat" per la Inquisició acollint-se a una disposició negociada per la comunitat de neòfits amb clares connotacions comercials i econòmiques. ${ }^{168}$

I66. Les referències a les almoines de Miquel Pérez, Lluís Alcanyís, Bernat Fenollar i Jaume Roig es troben a ACV, Llibre d'obres del retaule de la Seu, no. I5o6, ff. Ir, Iv, 5 r i 6r, respectivament. Per a tot el tema de l'altar d'argent de la Seu de València, resulta imprescindible l'estudi de Roc Chabàs (ı896), que n’arreplega diversa documentació, publica el text íntegre de la indulgència extraordinària, i la participació de Corella a les pàgines 6-9 del seu estudi. Sobre l'incendi i la seua data, vid. Sanchis I909, I67-68, i Rodrigo 20II, I35-36.

I67. Doc. 398. D’aquesta venda parla també Soler 20I3, 63I.

I68. "No sólo eran confiscados los bienes de los vivos, sino también los de aquellos que, acusados después de muertos, resultaban condenados por delito de herejía, de forma que los herederos se veían privados de sus propiedades. Esto aumentaba el desasosiego de los judeoconversos, conscientes de que en cualquier momento podían quedar desposeídos de su medio de vida e inhabilitados para ejercer actividades profesionales -entre ellas, la mercadería- por estar emparentados con un reo inquisitorial. (...) Las necesidades económicas obligaron a buscar soluciones. En I489, la comunidad de neófitos llegaba a un acuerdo con la Corona que supondría, sin duda, un alivio en su difícil situación y 
Però com afirma Antoni Ferrando, "Corella no fou víctima física de la Inquisició (...) El van poder protegir la fama, la gratitud per les seues implicacions cíviques i els seus contactes socials privilegiats, que el van convertir en un veritable líder literari i religiós a la València de l'època" (2013a, 657). Per altra banda, cal dir que el període I487-I489 és un dels que més poder hi té la Inquisició i, per tant, pensem que si la Inquisició haguera volgut prendre Roís de Corella o els seus béns no s’hauria aturat en una mera sanció econòmica. A més a més, si bé és cert que la Inquisició cremarà la seua edició del Psalteri (I49O) després de la mort de Corella, també ho és que si la seua màquinaria repressiva haguera volgut que Corella "callara perdurablement" era més fâcil, més directe i més efectiu per als objectius inquisitorials prohibir-li predicar -i, com veurem, va continuar predicant fins a la seua mort- que no prohibir-li escriure o publicar els seus escrits religiosos; i aquesta prohibició de publicar no es va donar: els volums del Cartoixà es publicaren en I $4955^{\mathrm{i}}$ I 496 i es vengueren molt bé (del Quart es feren dues impressions el mateix any), la publicació del Psalteri no es féu amagadament a València amb lloc d'impressió canviat per por a la Inquisició sinó a Venècia, com ha demostrat Josep Lluís Martos, per estrictes, i rendibles, motius tipobibliogràfics de l’impressor (Martos 20I3, I3-29).

Una altra cosa és que, des de I485, més o menys, Corella estiguera centrat, des del punt de vista literari, en la redacció de les seues traduccions dels salms i del monumental Cartoixà i que, això, ens semble a nosaltres actualment un "silenci" o, també, que el propi Corella tinguera molta cura de no provocar gratuïtament a la Inquisició, fins i tot fent la mena de confessió general, sobre tots els seus escrits, obres i paraules, que conté el pròleg aparegut en el volum del Primer del Cartoixà imprés en I496:

Hi no m'oblide que, de cor, voluntat y pensa proteste, com a cristià cathòlich, ab tot que gran pecador indigne, que tots los meus scrits, obres hi paraules, humilment sotsmet hi presente a correcció, decret y smena de la sacrosanta romana Sgleya, hi de tots los reverents mestres qui en la sua unitat y obediència viuen (Guia 1999, 85).

Com a resum de l'evolució i força de la Inquisició a València, reproduïm un aclaridor text de Belenguer Cebrià:

entre I 460 y I467, es decir, cuando el tribunal era autóctono, sólo hubo quince procesos. De ellos, trece fueron penitenciados, uno condenado a muerte y otro absuelto, lo que equivale a una media de dos condenas por año (...) entre I 484 y I530, cuando ya la dureza de la nueva Inquisición estaba en marcha, hubo 754 relajados, o sea quemados, I55 relajados en estatua porque los inquisidores no consiguieron hacerse con ellos, IO 6 penitenciados y sólo I2 absueltos. A todos ellos hay que añadir 357 cuyas penas impuestas no se conocen. Por tanto, en esos 46 años el total de procesos alcanzó la cifra de 2354 y una media de víctimas de $5^{\text {I }}$ por año (...) el primer paso [en la implantació de la Inquisició] lo dio [Ferran el Catòlic] en I482, cuando, presionando al poder eclesiástico, nombró personalmente a Juan Orts y Cristóbal de Gualbes como inquisidores de Valencia, los cuales fueron confirmados por el papa en diciembre de I482 (...) en I 482 y hasta I483 la actuación de Gualbes sobre todo empezó a hacer mella en el país y comenzaron algunas huidas de conversos. Pero todavía no se podía decir que esta Inquisición era verdaderamente la del modelo real que se originó en Castilla. Los inquisidores Orts y Gualbes se situaban muy cercanos a la propia tierra. Con ellos colaboraba también el silencio de los patricios urbanos que hablaba

también una esperanza para la reactivación de la maltrecha economía urbana: a cambio de pagar al rey unas sumas muy elevadas, aquellos 'podrían conservar los bienes heredados de sus difuntos, condenados por judaizantes, y quedaban librados de las penas o inhabilitaciones inherentes a su situación personal'. Aunque leve, era una señal inequívoca de distensión tras unos años de gran rigor represivo, que tuvo de inmediato efectos positivos” (Rubio I989, IO3-O4). 
por sí mismo, solo roto por el jurado Lluís Mascó en I482 (...) a Gualbes le sucedió en octubre de I 483 el nombramiento de fray Tomás de Torquemada. Éste sería el inquisidor general de toda la Monarquía -Corona de Castilla y Corona de Aragón- con el permiso de Sixto IV que había renunciado a cualquier batalla. A Torquemada, por lo demás, se le concedían plenos poderes para delegar funciones en sus representantes (...) Torquemada ya nombraba inquisidores para Zaragoza y Valencia. En consecuencia, Pedro de Épila y Martín Íñigo se desplazaron a la ciudad del Turia (...) [y] se presentaron a las puertas de la ciudad, que ya no comulgaba con los sectores contrarios a los conversos de tiempo atrás. (...) los estamentos del reino -muy poco después, el 7 de agosto [de I484]- prohibían al inquisidor general, maestre Épila, que iniciase sus actividades en Valencia (...) el 3I de agosto el rey tranquilizó en primer lugar a los inquisidores, asegurándoles que no encontrarían más obstáculos en su gestión (...) [El rei] exigía -el 24 de diciembre de I484- pleno acatamiento a las directrices de Pedro de Épila. La Inquisición parecía ya haber triunfado en toda regla. (...) la Inquisición descargó toda su ira sobre el mundo judeo-converso. Además, pocos paliativos encontró éste en las instituciones de la ciudad y reino. A fin de cuentas el vicario general Mercader había sido destituido y ya no hubo contrabalanceo eclesiástico frente al aparato inquisitorial. Torquemada, como inquisidor general, amplió poderes gracias al nuevo papa Inocencio VIII en I486, y su estela la siguió aquel que tenía más jurisdicción en Valencia: Épila (...) hacia I488-I489 los ediles valencianos parecían haber aceptado ya la nueva Inquisición del rey Fernando, al menos formalmente hablando. Además, en I488 la Inquisición, a nivel de toda la Monarquía, amplió aún más sus jurisdicciones al conseguir la creación del Consejo de la Suprema (Belenguer 20I2, I75-83).

Per acabar aquest punt sobre la donació entre els germans Corella en I487-I489, cal plantejar-se si la Inquisició haguera permés a un sospitòs i sancionat Corella publicar la indulgència papal de I489 a la Seu de València i sermonar-hi. Pensem que no.

Per la nostra part, plantegem com a hipòtesi que la donació de I487 por indicar l'inici d'un trasllat momentani al monestir de Sant Francesc; mentre que, els prèstecs de diners de Miquel Pérez i la venda d'una casa a Dalfina en I480, podien haver-se produït per la necessitat d'obtenir ràpidament diners, bé per a poder viure un cert temps amb certa tranquil-litat, o bé per a fer Corella algun tipus de despesa important; però no en podem aportar proves.

Com havia ocorregut anys enrere, el prestigi social i intel-lectual de Corella -i, probablement, també raons de parentiu, atés que una de les parts involucrades són els Cabrera de Ròtova-, farà que siga elegit el 30 de març de I49I, juntament amb el seu amic i literat Guillem Ramon de Vila-rasa -un dels tertulians del Parlament en casa de Berenguer Mercader-, com a amigable componedor per a sentenciar les diferències existents entre el monestir de Sant Jeroni de Cotalba i el cavaller Pere de Cabrera, senyor de Ròtova, en raó del bovalar del monestir, de les aigües de reg i de les fites dels térmens del monestir i de Ròtova. ${ }^{169}$ La sentència arbitral va ser llegida a les parts, el 2 d'abril de I49I, "en la casa e habitació” de Corella, actuant com a testimonis el seu cunyat Lluís Figuerola i Joan de Gallach, ciutadà de València. Aquesta referència a "la casa e habitació" de Corella pot suggerir que, en eixe moment, no s'havia traslladat, definitivament, al convent de Sant Francesc.

Segons alguns autors, Joan Roís de Corella hauria tingut una relació amorosa amb Elionor Flors de Vallterra, vídua de Francesc de Vallterra, a qui dedicà la seua Història de santa Magdalena. Per a Romeu i Figueras (1992), existiria un cicle de poesies dedicades a aquesta dama sota el senyal "Flor d'honestat" - que apareix també al final de la Història de santa Magdalena-, i que estaria format pels poemes Plant d'amor, per l'esparsa “Des que perdí a vós, déu de ma vida” i per La sepultura on,

I69. Doc. 341. Sobre aquest plet i sentència vid. infra 3.2.2. 
segons Romeu, Corella manifesta la seua tristesa per un amor fidel no correspost on la dama és casta i honesta. A partir de l'excel-lent anàlisi dels tres poemes, segons l’il·lustre crític, a Corella

el degué unir [amb Elionor Flors de Vallterra] la mena d'amor que veiem, virtuós i espiritualitzat, però no correspost, si per cas no en la mesura que Corella entenia l'amor total, en tant que conjunció i complementació de voluntat i unió física (...) Ell aconseguí d’aquesta dama, a causa de la seva voluntat de castedat, només comunió espiritual (...) per això ha pregat sempre per la puresa i la santedat de l’ànima d'ella (...) de manera que (...) ha respectat profundament la seva "onestat" (Romeu I992, I30-37).

Des d'almenys octubre de I478, Elionor Flors de Vallterra tenia vinculacions en raó de censals amb Lluís Figuerola (docs. 300, 369, 37I), i membres de la família del seu marit vengueren violaris en I458 a la mare del poeta (doc. 22I). Però, a més, hem localitzat un document de març de I 494 on trobem Joan Roís de Corella -que està prop de complir 59 anys- actuant de testimoni en una escriptura notarial feta per Elionor Flors de Vallterra.

Aquest document, podria recolzar les paraules de Romeu i Figueras, atés que Elionor era més jove que ell. Si bé desconeixem quina edat tenia aquella en casar-se amb Francesc de Vallterra en I474, l'edat més usual per al casament, a l'època, era al voltant dels divuit anys (Furió, et al. I994, IO4), i ella ja havia nascut en novembre de I460, moment en què morí el seu pare, el cavaller Joan de Flors. ${ }^{170}$ Si aquest amor existí, hauria estat un darrer amor, sense unió física, cast i espiritualitzat entre una jove i un home prop de trenta anys major que ella.

Elionor Flors, filla del cavaller Joan de Flors i d'Elionor Cetrilla, aportà 3o.ooo sous com a dot al seu matrimoni amb Francesc de Vallterra, d'acord amb les capitulacions matrimonials establides, davant el notari Bernat Dassió, el Ig d'agost de I $474 .{ }^{171}$ Francesc de Vallterra era fill del matrimoni format per Jofre de Vallterra y Joana, ${ }^{172}$ els quals, juntament amb el seu fill i d'altres membres de la família Vallterra, vengueren, mitjançant escriptura notarial feta pel notari Bertomeu Carries el I2 de gener de I474, el lloc de Sot, al terme de Sogorb, al donzell Tomàs Sorell per preu de Ioo.ooo sous. Un mesos després, el 30 de setembre de I474, Francesc de Vallterra comprà Sot a Sorell per preu de 6o.ooo sous, dels quals pagà inmediatament 30.0oo gràcies al dot aportat per Elionor Flors (ARV, Procesos de Madrid, letra L, exp. 82).

Francesc de Vallterra testà al lloc de Sot el 5 de setembre de I 475 davant el notari sogorbí Jaume Maçana. Hi feia diferents llegats a la seua dona i a la seua filla Flors de Vallterra, nascuda del seu

I7o. RCSCCV, protocols, no. 502, not. Miquel Pérez -22 de novembre de I492-, document esmentat en Riquer I964, 3, 266. D'acord amb el contingut d'aquest document, Diòmedes de Flors, germà d'Elionor Flors de Vallterra, va ser declarat hereu universal del seus pares d'acord amb el codicil del seu pare fet davant el notari Llorenç Garcia el I5 de novembre de I46o - publicat per mort seua el 2I de dit mes i any- i amb el testament d'Elionor Cetrilla de Flors rebut pel notari Bernat Dassió el 22 d'abril de I474 i publicat, per mort de la testadriu, el 2 de maig d'eixe mateix any.

En l’Arxiu Municipal de Gandia es conserva una àpoca del 2 de març de I 467 segons la qual Pere Llopis, notari procurador d'Elionor de Flors, reconeix haver rebut de la vila de Gandia, de mans de Joan de Montalbà, clavari de l'any I466, 466 sous i 8 diners deguts de la paga de novembre per raó d’un censal del doble pagador en dues meitats (Olaso I987, I56). Molt possiblement, aquesta Elionor de Flors és Elionor Cetrilla de Flors.

I7I. Així figura en ARV, Procesos de Madrid, letra L, exp. 82. Aquesta dada i una bona part de les que esmentarem sobre la biografia d'Elionor Flors de Vallterra ens varen ser proporcionades l'any 2oor per l'investigador Juan Corbalán de Celis Durán, a qui ho agraïm molt sincerament.

Segons J. Guia (I999, I29), qui esmenta com a font informacions del propi Corbalán de Celis, les capitulacions matrimonials es feren el 9 d'agost de I 474 .

I72. Francesc de Vallterra havia lligams familiars amb els Vallterra senyors de Torres Torres, i amb els Blanes, parents d’Ausiàs March i del seu hereu Jofre de Blanes. 
matrimoni amb Elionor. El testament va ser publicat, per mort del testador, el 7 de setembre de I475. ${ }^{173}$ Per tant, atés que Corella dedica la Història de santa Magdalena a la "molt magnífica, virtuosa, honestíssima senyora, la senyora viuda Flors de Vallterra”, aquesta obra ha de ser posterior al 7 de setembre de I475, data en què es va publicar el testament del marit d'Elionor Flors de Vallterra.

En raó de l'herència del seu difunt marit i de la cura i tutela de la seua filla, Elionor actuà en I477 com a patrona del benefici instituït en la Seu de València per Gil Sànchez Muñoz, canonge de la referida Seu, sota l'advocació de Santa Anna (RCSCCV, protocols, no. 2I5I4, not. Joan Gamiça -I8 d'agost de I 478 ).

El 29 de novembre de I476, Elionor Flors de Vallterra va vendre a Lluís Ferrer el lloc de Sot, juntament amb una heretat anomenada "Albayda" al terme de Sogorb, i una casa anomedada "les barraques" situada al camí reial. El preu de venda va ser de 85.0oo sous, i aquell mateix dia Lluís Ferrer prengué possessió de Sot. ${ }^{174}$ Des d'aquell moment, Elionor cobrà de Lluís Ferrer, lloctinent del General Governador de València, diferents pagues de censals en raó d'aquesta venda ${ }^{175}$.

Precisament, l'escriptor Joan Roís de Corella figura com a testimoni d'un document notarial datat el 8 de març de I 494 on Elionor Flors de Vallterra reconeix a Lluís Ferrer el lliurament de 33 lliures, 6 sous i 4 diners degudes per pagues d'un censal (doc. 349). Si la hipòtesi de Romeu respecte d'un amor entre Corella i Elionor fos correcta, és al voltant dels inicis d'aquesta dècada dels noranta on nosaltres situaríem les poesies del cicle "Flor d'honestat".

El 6 d'octubre de $5_{525}$ encara figura Elionor Flors de Vallterra com a viva, en un document on Julián Piniel, el seu escuder i procurador, cobra en el seu nom una quantitat deguda per la pensió d'un censal. ${ }^{176}$

Com ja hem comentat, si seguim Romeu i Figueras, el del vell mestre en teologia per Elionor hauria estat un amor no correspost, tardà, un amor no físic; en un moment de la seua vida on, tal com pensem que es pot deduir dels documents i del seu obstinat desig de dedicar-se al món espiritual i a la predicació, les relacions amb Isabel Martínez de Vera haurien estat més com a mare dels seus fills que no com a dona. Estava pendent de les seues necessitats, es preocupava pel futur d'ella i dels seus descendents quan ell ja no estiguera viu, però no trobem en els documents

I73. ARV, Governació, no. 2347, mà I4 a , f. 35r i mà I5 a , f. 23r. Segons J. Guia (I999, I29) esmentant novament com a font informacions de Corbalán de Celis, la data de publicació del testament de Vallterra seria el ıз de setembre de I475. La data del I3 de setembre es arreplegada en ARV, Procesos de Madrid, letra L, exp. 82 però preferim les dades cronològiques que figuren en l'expedient de Governació referit i en RCSCCV, protocols, no. 2I5I4, not. Joan Gamiça (i8 d'agost de I478), donada la proximitat d'aquestes fonts arxivístiques a la mort de Vallterra.

I74. ARV, Procesos de Madrid, letra L, exp. 82. La presa de possessió a RCSCCV, protocols, no. 2038o, not. Bernat Dassió.

I75. Tenim constància del següents pagaments: 20 de novembre de I489, 50O sous deguts per la paga del mes de juny de I.ooo sous censals, rendals i anuals (RCSCCV, protocols, no. 26398, not. Guillem Ramon Tovia -2o de novembre de I489); en I49I, un total de 66 lliures, I2 sous i I2 diners de pagues d'un censal (RCSCCV, protocols, no. 26399, not. Guillem Ramon Tovia -I3 de gener, I9 de març i 24 de desembre de I49I -; 26 d'agost de I493, 33 lliures, 6 sous i 4 diners degudes per pagues d'un censal (RCSCCV, protocols, no. 20I6o, not. Lluís Tovia-26 d'agost de I 493); 7 d'abril de i 495, 25 lliures degudes de pagues d'un censal (RCSCCV, protocols, no. 26402, not. Guillem Ramon Tovia -7 d'abril de I495); 5 de març de I496, 33 lliures, 6 sous i 4 diners degudes per pagues d'un censal (RCSCCV, protocols, no. 264OI, not. Guillem Ramon Tovia -5 de març de I496).

I76. RCSCCV, protocols, no. 24495, not. Jeroni Durà -6 d'octubre de I525. Altres actuacions de Julián de Piniel com a procurador d'Elionor referides al cobrament de pensions degudes per censals en RCSCCV, protocols, no. 24492, not. Jeroni Durà -I5 de maig de I52I -; RCSCCV, protocols, no. 24496, not. Jeroni Durà -I6 de març i 23 d'agost de I522 -; RCSCCV, protocols, no. 24493, not. Jeroni Durà -24 de setembre de I524 -; RCSCCV, protocols, no. 24492, not. Jeroni Durà -4 de febrer i ig de maig de 1525 . 
d'aquesta època el ressò d’una vinculació física, passional, per Isabel.

L'activitat predicadora de mestre Corella no havia acabat amb el sermó de la indulgència de I489, tal com deixa clar el document fundacional de l'Hospital "del Sant Sperit de la Verge Maria dels dits sants Innocents" en I494. Fins i tot podem donar notícia que predicà anualment en l'església de Sant Martí, de la que ell i la seua família eren parroquians, fins un mesos abans de la seua mort. En efecte, tenim constància documental que, almenys, hi va sermonar amb ocasió de la festa de Santa Anna (26 de juliol) dels anys I492, I493, I 494, I 496 i I 497 a càrrec de la confraria de les òrfenes a maridar, que tenia en aquesta església un benefici (docs. 345, 346, 35 I, 359 i 36o). Aquesta confraria va estar regida, en els anys finals de la vida de l'escriptor Joan Roís de Corella, per majordoms com Berenguer Martí de Torres - germà de misser Jaume Garcia d'Aguilar i oncle del Francí d'Aguilar lloat per Corella en la Sepultura de mossén Francí d'Aguilar-, Lluís Granullés, Nofre Caera, etc (docs. 345, 346, 35I, 359 i 360). Fins que Berenguer Martí de Torres -membre de les comissions municipals creades en I484 i I485 per al tema de l'erecció d'un hospital general en les quals participà o es troba present Joan Roís de Corella i administrador de l'hospital de Sant Llàtzer que, a finals de I484, rendirà comptes actuant com a testimoni Joan Roís de Corella- prenga la majordomia en I492, no figurarà en els llibres de comptes de la confraria cap referència ni a sermons lligats al benefici de Sant Martí, ni al predicador que els realitzava. ${ }^{177}$ Això ens pot suggerir d'una banda l'alt grau d'amistat entre Martí - qui sembla ser qui va encarregar-li les predicacions- i Roís de Corella; i de l'altra ens parla, també, de la relevància social de Corella, car la seua "entitat" i fama com a predicador era tal que es féu constar explícitament el seu nom als llibres de comptes de la confraria, igual que, també, va fer en I470 Jaume Roig com a majordom de l'Hospital dels Innocents de València (doc. 265). Igualment, atesa la continuïtat dels seus sermons a l'església de Sant Martí des de I492, no és gens arriscat suposar que en els anys I $495^{\text {i } ~} 49^{8}$ també hi hauria sermonat Roís de Corella, malgrat que, en la documentació, el nom per al predicador figure en blanc. ${ }^{178}$

Pel que fa a l'esfera de la seua vida privada, direm que, en juliol de i 495, Corella féu dues reclamacions judicials en raó de les pensions degudes per censals carregats a ell i als seus: en la primera, a Joan Renard i a la seua esposa demanà el pagament d'un total de 4I sous i 8 diners; en la segona, seran Nofre Cafâbregues i Andreu Garcia a qui reclamarà 75 sous (docs. 354 i 355); en agost de I495, reclamà 4I sous, 8 diners novament a Joan Renard i a la seua esposa, habitants de Dénia (doc. $356)$.

Un document molt important, opinem, de la darrera etapa vital de Joan Roís de Corella és el publicat per Guia (2003) que mostra al mestre en teologia i cavaller actuant conjuntament amb el seu fill. Es tracta de la venda realitzada per ells dos, el 27 d'octubre de I 495, per preu de 35 lliures a Caterina de Riusec, esposa del mercader Jofre de Riusec, de Ioo sous de violari que, originalment, els donzells Galvany de Castellví i Joan de Vallterra-senyor de Torres Torres-carregaren al mestre en

I77. Per exemple, no consta en els volums corresponents als anys I488-I489, I489-I490 i I490-I49I (Arxiu General i Fotogràfic de la Diputació Provincial de València -AGFDV, Fons Hospital, Confraria òrfenes a maridar, II-8/46; AGFDV, Fons Hospital, Confraria òrfenes a maridar, II-8/47; AGFDV, Fons Hospital, Confraria òrfenes a maridar, II-8/48).

I78. En AGFDV, Fons Hospital, Confraria òrfenes a maridar, II-8/52, f. 7v corresponent a l'any I 495 figura “E per lo sermó al reverent [En blanc] VI sous"; en AGFDV, Fons Hospital, Confraria òrfenes a maridar, II-8/55, f. 7V corresponent a l'any I 498 figura "E al sermó lo reverent [En blanc] VI sous". La presència del qualificatiu "reverent" tan lligat al mestre Corella reforça la nostra hipòtesi si ve, en els volums datats a partir de la mort de Corella i fins al corresponent als anys I5OO-I5OI (II-8/57), encara figuren frases semblant a aquestes -“E per lo sermó lo reverent [en blanc], VI sous". 
teologia per instrument notarial fet a València l'i d'agost de I 476 davant el notari Antoni Barreda. ${ }^{179}$ No coneixem altre document en què es produïsca aquesta actuació conjunta de pare i fill $i$, al nostre parer, és una prova documental que el cavaller i teòleg no deixà de preocupar-se pels seus fills i per Isabel Martínez de Vera.

El 23 de març de I496, en la ciutat de València, el prestigi social i literari de Joan Roís de Corella era evident però és gairebé segur que, en determinats cercles, aquest prestigi hagué d'augmentar en saber-se que el mateix monarca Ferran el Catòlic havia escrit, des de Tortosa, a Diego de Torres, Batle General de València, ordenant-li la compra i tramesa d'un exemplar del Cartoixà fet per Corella:

Letra del Senyor Rey al batle general manant-li que li trametés hun libre del Cartoxà de mestre Corella

Al noble, magnífico, amado consejero y camarero nuestro don Diego de Torres, Bayle General en el el nuestro reyno de Valencia.

El rey.

Camarero y Bayle General, sabido havemos que maestre Corella ha fecho una translación del Cartuxano que es muy buena obra la qual Nós queremos haver en todo caso. E, por tanto, vos encargamos e mandamos que lueguo merquedes una d'ellas e la faguades ligar e poner a punto e nos la embiedes que mucho servicio nos faredes en ello. De Tortosa, a XXIII de março del anyo mil CCCC LXXXXVI.

Luis Gonçales, secretarius. ${ }^{180}$

Amb un prestigi, amb un reconeixement social i literari guanyat al llarg del temps, Joan Roís de Corella morí als seixanta-dos anys, el 6 d'octubre de I497, dia de la publicació del seu vell testament de I478:

En aprés, divendres qui·s comptava sis dies del mes de octubre de l'any de la nativitat de nostre Senyor Jhesuchrist mil quatre-cents noranta-set, a instància e requesta de la magnífica na Dalfina Roïç de Corella, muller del magnífich mossén Luís Figuerola, cavaller, jermana y hereua scrita en lo desús dit testament, e en presència dels magnífichs mossén Luís Roïz de Corella, donzell, jermà del dit testador, e del dit mossén Luís Figuerola e en la casa de aquell, lo preinsert testament per mi, Pere Andreu, notari públich de la ciutat de València, regent les notes e libres del venerable e discret en Antoni Barreda, quòndam, notari, fonch lest e publicat. E, lest e publicat aquell, en continent la dita magnífica na Dalfina de Corella dix que ella se retenia acord sobre la acceptació de la dita herència o repudació de aquella, e que lo ínterim temps algú no li precóregue ans li reste salvu e il.lés, requirint de premisis carta pública.

Presents foren per testimonis a la publicació del dit testament, lo magnífich mossén Luís Mascó, cavaller, menor de dies, y lo honorable en Joan Caldes, studiant en arts de la ciutat de València.

De post vero die septima mensis octobris dicti anni millesimi CCCC nonagesimi septimi, la dita magnífica na Dalfina Roïç de Corella, muller del dit magnífich mossén Luís Figuerola, cavaller,

I79. Doc. 357. Document esmenta en Guia 2003. Figuren com a testimonis d'aquesta venda fra Antoni Cevilla i fra Francesc Maça, frares del convent dels franciscans de València.

I80. Doc. 358. Document esmentat en Riquer I964, 3, 257. En Domènech et al. 2014, Io8, es data el document en el dia 24 de març i, segons els autors, l'interés de Ferran el Catòlic “va donar lloc a la traducció castellana que els Reis Catòlics van encarregar a Ambrosio de Morales i que es va publicar entre el I5O2 i el I5O3”. 
convocats mi, Pere Andreu, notari, e los testimonis dejús scrits, declarant lo acord per ella retengut sobre la acceptació o repudiació de la dita herència, dix que acceptava la dita herència ab benefici de inventari, protestant que, en fer aquell, temps algú no li precórregue ans li reste salvu e il.lés, requerint carta publica.

Presents foren per testimonis a les dites coses, en Bernad Ferreres, studiant en arts del loch de la Gana ${ }^{181}$, e en Ramon del Scrivà, scuder de Beru de Ay, habitadors en la dita ciutat. ${ }^{182}$

L'endemà, dia 7 d'octubre de I497, acceptada l'herència per la seua germana Dalfina -qui, en un primer moment, manifestà "que ella se retenia acord sobre la acceptació de la dita herència o repudació de aquella” - es realitzà l'inventari de béns a la casa que tenia Joan Roís de Corella al carrer del seu nom -la part de dalt de la casa estava, en eixe moment, llogada a una persona. Es feren portar els béns que el mestre en teologia tenia en la cambra del convent de Sant Francesc, però no tots, perquè hi "restaren molts libres de Theologia y altres, y aquells lo dit defunct en sa vida donà als frares de Sanct Francesch”. Transcrivim a continuació l'inventari de béns de l'escriptor, que també figura a la secció documental:

\section{Die septima octobris anno $\mathrm{M}^{\circ} \mathrm{CCCC}^{\circ} \mathrm{LXXXXVII^{ \circ }}$}

Iesu Christi nomine invocato. Com per squivar dol, frau y engan e tota manera de sospita de aquells, quascuns hereus, marmesors, tudors y altres administradors de béns de la lur heretat degen e sien tenguts fer memorial reportori e capbreu dels béns e drets atrobats e rechaents en lurs marmessories y herències perquè, quant mester sia, de aquells se puixa donar bon compte $\mathrm{e}$ rahó, hoc encara per ço com per legíttimes sanctions e disposicions de fur y privilegi del present regne per la confectió de l'inventari als hereus no solament són conservats encara són preservats de dan per quant no són obligats ultra los béns hereditaris, per tal yo, na Dalfina Rö̈ç de Corella e de Figuerola, muller del magnífich mossén Luís Figuerola cavaller habitador de la ciutat de València, hereua universal del magnífich y reverent mossén Johan Roïç de Corella, quòndam, cavaller, mestre en sacra theologia, consta de la mia herència ab testament rebut per lo discret en Anthoni Barreda notari, quòndam, a trenta de agost de l'any mil quatre-cents setanta-huyt e publicat en poder de Pere Andreu notari a VI de octubre de l'any mil quatre-cents noranta-set. En lo dit nom, precedint lo senyal de la vera $\mathrm{Cre}^{+} \mathrm{u}$, faç inventari, memorial e capbreu dels béns atrobats en la herència del dit mossén Johan Roïç de Corella, quòndam, cavaller, en e per la forma següent:

E, primerament, confés haver trobat en béns de la dita herència una casa eo ort situats en la parròchia de Sanct Martí en lo carrer appellat de Mossén Corella e antigament nomenat d'en Monblanch, tengut sots directa senyoria de la confraria dels perayres de la dita ciutat a cens de nou sous fadigua e loisme e a recens de cent cinquanta sous pagadors quascuns anys en certs terminis al noble don Gisbert Pardo, qui-s poden quitar per preu de cent lliures. La qual affronta ab cases e ort

I8I. Aquest estudiant apareix també com a testimoni en l'acte de transferència a Dalfina de diversos censals fet en febrer de I 498 per Isabel Martínez de Vera (doc. 363). També figurarà com a testimoni del testament de Lluís Figuerola en agost de I5O2 (doc. 394) i com a procurador de Bertomeu Figuerola en l’almoneda dels béns de son pare (doc. 396), però, en ambdós casos, apareix qualificat de prevere de la diòcesi de Tortosa. Aquesta incardinació a la diòcesi de Tortosa és lògica si tenim en compte que "La Gana” és la forma medieval que, en ocasions, pren en la documentació el topònim de la població castellonenca de La Jana, tal i com es pot veure en Sánchez I976, 83. En el darrer testament de Dalfina Roís de Corella redactat el 22 de juliol de $5_{5} \mathrm{O}$ figura com a testimoni, però qualificat de "prevere beneficiat en Sanct Andreu" (doc. 409).

I82. Doc. 299. Tenint en compte que aquests notaris -Antoni Barreda i Pere Andreu-tenen una especial cura a assenyalar els dies transcorreguts entre el de l'òbit i el de la publicació del testament, i atès que en el cas de la darrera voluntat legal de Joan Roís de Corella no figura aquest lapse, cal concloure que l’escriptor va finar el mateix dia de l'obertura del testament, és a dir, el 6 d'octubre de ı497, com ja havia indicat Martí de Riquer (ı964, 3, 257). Com a testimoni de lectura d'aquest testament hi figura Joan Caldes, estudiant. 
del magnífich mossén Luís Figuerola, ab altra casa de mi dita hereua e ab carreró e ab lo dit carrer; en la entrada de la qual fonch atrobats los béns mobles següents, los quals foren portats de la cambra que lo dit defunct tenia en lo monestir de Sanct Francesch:

Primo, hun lit de posts e sos peus de fu[s]ts de pi nou e tres matalafs blanchs plens de llana castellana e hun coixí de fluxell, e dos parells de llançolls de li, de dos teles y miga quascú, mig usats. Ítem, una flaçada cardada e una vanoveta prima e hun cubertor prim enbastat. Ítem, hun papalló ab son pom, sens manteta, de drap vinté blanch. Ítem, hun altre lit de posts ab cinch posts e sos peus, nou, e dos matalaffs plens de lana de Cerdenya, blanchs. Ítem, hun coixí de ploma e dos parells de lançols de mascó, quasi nous, e una flaçada cardada e una vànova bona mig usada. Ítem, dos artibanchs de dos caixons quascú, nous, tot buyt en los quals havia molts papers de pocha vàlua.

Ítem, una caixa plana ab pay [sic] sense clau dins la qual fonch atrobada la roba següent: Primo, una clocha de rohà molt usada. Ítem, hun sayó de rohà sotil. Ítem, hun gipó lo hu de cos de fustant e les mànegues de drap negre stamet. Ítem, altre gipó lo cors e les mànegues de drap rohà.

Ítem, deu cadires entre grans y chiques. Ítem, dos canalobros de llautó migancers. Ítem, dos cànters de terra e una làntia. Ítem, una taula de megar [sic] ab sos peus. Ítem, hun sobrepelliç y la muça e hun barret doble e altre barret senar. Ítem, tres camises de Olanda e dos tovalloles mig usades.

E, en la dita cambra, restaren molts libres de Theologia y altres, y aquells lo dit defunct en sa vida donà als frares de Sanct Francesch.

Ítem, set-cents huytanta volums que són lo Quarty lo Primer del Cartoixà.

E per ço com en la dita casa havia statger dalt, no fonch atrobat més en aquella com lo restant que en la casa era fos del dit statger.

E, aprés, fonch atrobat hun libret del dit defunct en lo qual són continuats los censals y interessos següents:

Primo, tots aquells quaranta-hun sous, huyt diners censals que fa e fer és tengut a la dita herència en Berthomeu Renart, vehí de la vila de Dénia, e na Johana, sa muller, e per aquells foren venuts a la magnífica na Alamanda de Cabrera per preu de vint-i-cinch lliures, ab carta rebuda per lo discret en Joan Sart, notari, a cinch de janer de l'any mil quatre-cents trenta-quatre. En aprés, lo dit censal foch venut al magnífich mossén Ausiàs de Corella, cavaller, ab carta rebuda per lo dit en Johan Sart, notari, a trenta de janés any mil quatre-cents trenta-quatre. E mossén Ausiàs de Corella féu testament en poder del dit en Johan Sart, notari, a nou de noembre any mil quatre-cents quarantatres e publicat, en poder del mateix notari, a setze de janer any mil quatre-cents cinquanta.

Ítem, en aprés fonch trobat en béns de la dita herència tots aquells quaranta-quatre sous censals los quals fa en Johan Rovira, de la vila de Pego, pagadors a vint-y-set de abril; los quals foren carregats per en Anthoni Rovira y na Francescha, sa muller, per preu de trenta-tres lliures al discret en Ramon Egualada, notari, ab carta rebuda per en Pere Pugeriol, notari, a vint-i-set de abril any mil quatre-cents dehuyt. En aprés, ab carta rebuda per Pere Puig, notari, a tres de abril l'any mil quatrecents trenta-tres pertanygué al magnífich mossén Ausiàs Roïç de Corella. E en aprés, són stats reduhits ab carta rebuda per en Guillem Olzina, notari, a onze de juny any mil quatre-cents norantatres.

Ítem, tots aquells quaranta-hun sous, huyt diners censals que fan $\mathrm{Ab}[\mathrm{r}] \mathrm{ahim}$ Ajubet e sa muller d'Ondara e huy los fa Cahat Ajubet de aquells huytanta-tres sous, quatre diners censals pagadors a XXIII de noembre en una paga, e per aquells foren carregats a.n Johan Pelegrí per preu de cinquanta lliures ab carta rebuda per en Pere Andreu Sart, notari de Dénia, a XXIII de noembre any mil quatrecents setze. En aprés, han pertangut a na Aldonça de Corella quaranta-hun sous, huyt diners censals del dit ab carta rebuda per en Johan Sart, notari, a XXI de febrer any MCCCC cinquanta.

Ítem, tots aquells sexanta-sis sous, huyt diners censals que fa en Sabastià Xulbet los quals foren venuts per na Elvira, muller d'en Garcia Garcia, quòndam, e en Gabriel Sànxiz Garcia, fill seu, vehins de Dénia, a·n Miquel Pérez, de Ondara, per preu de quaranta lliures ab carta rebuda per en Berthomeu Jornet, notari, a VIIII de noembre any MCCCC vint-i-sis. En aprés, ab carta rebuda per en Anthoni Barreda, notari, a XXII de dehembre any MCCCCL cinch ha pertangut a na Aldonça de Corella. 
Ítem, totes aquelles setze lliures que en Pere Stheve àlies lo Serrà, de Pego, confessa deure al dit defunct de preu de hun troç de terra pagadores [sic] dins quinze anys e, en lo entretant, ab responsió de interés de vint-y-sis sous, y huyt diners pagadors lo primer de janer ab carta rebuda per en Johan Sanç, notari, a vint-i-quatre de janer any MCCCC huytanta.

Ítem, totes aquelles nou lliures de deute que en Guillem Tamarit, de la vila de Pego, ha confessat deure al dit defunct de preu de una vinya, e les quals prometté pagar dins temps de tres anys e, en lo entrant, prometté respondre quatorze sous, tres diners de interés pagadors en la festa de Sanct Miquel, ab carta rebuda per lo discret en Bernad Sanç, notari, a VIIII de noembre any MCCCLXXX set.

E com, a present, no sàpia altres béns de la dita herència més dels que són continuats y expresats en lo present inventari, aquells confesse tenir com a béns de la herència del dit mestre Johan Roïç de Corella protestant que, per la present acaptació, no·n sia fet perjuhí per enmiscrire aquells ab los que són propris meus, ni fer ni causar prejuhí, dan, ni confusió de actions degunes a mi pertanyents en qualsevol manera ans me resten salves, íntegres e sanes in omnibus et per omnia. E ara e per tots los temps, loch e cars si per creedors o alias yo fos tenguda y obligada dels dits béns, axí per via de creedors eo alias de aquells, hagués a donar compte e rahó no sia tenguda ni obligada ultra ni en més que.s són los dits béns e forces de la dita heretat.

E encara proteste que, si per havant a notícia mia en lo dit nom pervendran altres béns dels que dessús són inventariats pertànyer e recaure en la dita heretat, que aquells puga en lo present eo en altre inventari continuar e, generalment, proteste que en fer totes les dites coses e sengles de aquelles per als loch, temps e cars se poran seguir, $\mathrm{o} \cdot \mathrm{s}$ seguiran, temps algú no·n precórrega ans aquells tots e qualsevol drets meus me resten salvos e il-lesos in omnibus et per omnia.

Requerint de premissis carta pública.

Foren fetes les dites coses en la ciutat de València a set dies del mes de octubre de l'any de la nativitat de nostre Senyor mil quatre-cents noranta-set.

Se+nyal de mi, Dalfina de Corella y de Figuerola, desús dita, que en lo dit nom lo preinsert inventari, memorial e capbreu, faç y atorgue.

Presents foren per testimonis a les dites coses, en Bernad Ferreres, studiant en arts del loch de la Gana, e en Ramon del Scrivà, scuder de Berní de Ay, habitants en la dita ciutat. ${ }^{183}$

Com podem veure, al final de la seua vida Roís de Corella tenia escassos béns: uns pocs mobles, una poca roba i els 78o volums del Quart i el Primer del Cartoixà, una quantitat molt elevada que suggereix que va participar econòmicament en la seua edició i impressió, i que, si els guardava, probablement els considerava també una font d'ingressos futurs per a ell o per a Isabel Martínez de Vera i els seus descendents. A més a més, hi havia un llibret on constava que Corella havia, en eixe moment, tan sols quatre censals -per valor de 48 sous, 8 diners; de 44 sous; de 48 sous, 8 diners $i$ de 66 sous, 8 diners- i, també, on s'indicava que Corella havia de rebre i6 lliures -pagadores en un termini de quinze anys- i 9 lliures - pagadores en un termini de tres anys- que li devien per la venda de dos trossos de terra.

Els mobles semblen formar part dels d'una casa; ${ }^{184}$ la roba és escassa $i$, front als vint-i-un censals

183. Doc. 36r. Document esmentat en Riquer 1964, 3, 258.

184. Si es tractara de mobles d'una casa -n'hi han dos llits, cinc matalafs, quatre parells de llançols, una taula de menjar, deu cadires entre grans i menudes, etc.- no seria molt aventurat pensar que poden ser part dels de la seua pròpia casa del carrer de Mossén Corella i que, probablement, els portara a la cambra de Sant Francesc després de llogar-ne part.

Abel Soler, si hem entés bé, sembla afirmar què l'existència de deu cadires “entre grans i chiques” i una sola taula, ens indica que Corella impartia lliçons de teologia en la seua cambra de Sant Francesc -“a la recòndita 'cambra' del monestir de Sant Francesc, on escrivia i impartia lliçons (hi havia una sola taula, però deu cadires), i on 
que afirma tenir sa mare en el seu testament de I456 (doc. 207), Corella en té tan sols quatre, i per un valor molt, molt inferior. A més a més, pels terminis establits per a cobrar els deutes, no semblava tenir gaire pressa a cobrar-los.

Així doncs, el cavaller, mestre en teologia i escriptor Joan Roís de Corella morí amb un patrimoni econòmic pràcticament nul; però la seua pobresa era, en la nostra opinió, voluntariament volguda i cercada per ell i estava dins de l'esperit franciscanista que alimentava molts actes de la seua vida des de feia anys.

Tres dies després de l'acceptació de l'herència, i davant el notari Jaume Albert, Dalfina Roís de Corella, esposa de Lluís Figuerola, com hereua universal de Joan Roís de Corella, va fer, el dia Io d'octubre, donació inter vivos de tots els béns de l'herència del seu germà a Isabel Martínez de Vera, així com d'una casa a la parròquia de Sant Martí sota el domini directe de la confraria de la Santíssima Trinitat i de Sant Miquel Arcàngel, anomenada dels peraires, a cens de 9 sous anuals. ${ }^{185}$ Aquesta casa feia marge amb dues cases de Lluís Figuerola i una via pública i, com ja hem dit en l'apartat dedicat a Dalfina Roís de Corella, es tracta, gairebé amb total seguretat, de la casa que el poeta li va vendre en I488.

D’aquesta manera, nomenant Dalfina com a hereua seua, els escassos béns de Joan Roís de Corella podien passar a Isabel Martínez de Vera i als seus fills lliures de càrregues; perquè, com estableix la legislació foral, els deutes del testador són assumits per l’hereu que accepta l'herència, ${ }^{186}$ és a dir, en el nostre cas, Dalfina, que tenia un bon patrimoni amb Lluís Figuerola. Per la mateixa legislació foral, en el testament no podien figurar llegats a Isabel Martínez de Vera si l'escriptor preveia que els deutes serien majors que els béns de l'herència. Com ja hem afirmat més amunt, en la nostra opinió aquesta és la raó de no fer, directament en el seu testament, hereus seus Isabel ni els seus fills, i de fer-ne en canvi Dalfina -casada des de I 469 amb el benestant Lluís Figuerola-, de no esmentar-los en el seu testament de I 478 i no fer-ne un altre de nou.

Des de que va pendre, probablement a finals de la dècada dels 6o o principis de la dels 7o, la decisió de dedicar-se a la predicació de tipus franciscà acostada als pobres, als infants i als seus problemes, Roís de Corella sabia que no es faria ric ni deixaria als seus hereus un potent patrimoni. L'autor de la Tragèdia de Caldesa seria, per la seua pròpia voluntat, un cavaller i mestre en teologia pobre, amb prestigi però amb un futur en què, segurament, els diners serien escassos, i els deutes potser alts.

L’única manera de protegir, dels possibles deutes i creditors, no a Magdalena (que tampoc és esmentada en el testament, però a qui havia casat bé en un moment en què encara li quedaven rendes familiars), sinó als seus fills Joan i Estefania i a la seua mare, era deixant la seua herència a la seua germana Dalfina, qui, arribat el cas, podia fer-se càrrec de possibles deutes; i que aquesta donara la

moriria el I497", diu literalment Soler (2OI3,632). Mancant cap document que avale aquesta impartició de lliçons en la cambra de Sant Francesc més enllà de la referència a les deu cadires i a la taula de menjar, opinem que la proposta de Soler és imaginativa, però agafada pels pèls i no pels documents (¿Els adults seurien en les cadires grans i els xiquets en les cadires menudes? ¿Els dos llits i els cinc matalafs de l’inventari serien utilitzats tots per Corella o serien per al descans dels alumnes?). No coneixent més documentació provatòria d'aquesta espècie d'acadèmia d'ensenyament teològic corellà, opinem que tan sols de la taula de menjar i de les cadires de l'inventari de l'escriptor, no es pot deduir directament l'existència d'aquestes lliçons. Malgrat tot, és possible que existisca documentació que desconeixem i que sí que conega Antoni Ferrando, qui també pareix referir-se, si no ens equivoquem, a aquesta mena d’acadèmia d'ensenyament en la cambra de Corella en Sant Francesc quan afirma: "Corella, reclòs en una cambra del convent de Sant Francesc, on es dedicà a l'elaboració de textos cristològics (Lo Cartoixà, Lo Passi amb la glosa en romans) i a l'ensenyament de la teologia" (Ferrando 20I3a, 655).

I85. Doc. 362. Document esmentat en Riquer I964, 3, 258.

I86. És el Fur VI-VII-3 (Colón-García I99O, 230) que hem reproduït anteriorment. 
casa i els béns de Corella ja lliures de càrregues a Isabel, Joan i Estefania.

En la nostra opinió, trobem proves que aquesta suposició és correcta en: primer, el temps d'un dia que tardà Dalfina Roís de Corella a acceptar l'herència del seu germà a benefici d'inventari ${ }^{187}$ -segurament per a calcular la suma de tots els deutes del prosista i poeta- quan, el més habitual era acceptar l'herència en el mateix moment de publicar-se el testament del difunt. Així ho havien fet Joan Roís de Corella respecte als béns de sa mare (doc. 250), Vicent Rocafort i sa mare respecte als béns del mestre Joan Rocafort (doc. 274), l’hereu de Lluís de Castellví -tertulià del Parlament en casa de Berenguer Mercader - ${ }^{188}$ o Beatriu Figuerola respecte als béns de Dalfina Roís de Corella (doc. 409); en segon lloc, l’interés que, en el moment de fer l'inventari dels béns deixats pel seu difunt germà, mostra Dalfina en remarcar dues vegades que els hereus, davant els creditors, "no són obligats ultra los béns hereditaris". ${ }^{189}$

On eren les cases de l'escriptor Joan Roís de Corella a la ciutat de València, eixes cases que permetien que el carrer on estaven ubicades fóra conegut com carrer de Mossén Corella? A poc a poc, i posant en relació tots els documents on són esmentades cases de Corella, de la seua germana Dalfina i de la seua amistançada Isabel Martínez de Vera, n’hem pogut localitzar la ubicació tant en el conegut plànol del pare Tosca com en la xarxa de carrers actuals de València.

El poeta tenia dues cases a la parròquia de Sant Martí, en el referit carrer de Mossén Corella, que va reservar per a si en l'acte de donació a la seua germana Dalfina fet en I487. Aquestes cases feien marge amb una casa i hort de Lluís Figuerola, altra casa de Lluís Figuerola, i dos carrers (doc. 329). En I488, una en va ser venuda a Dalfina (doc. 398), qui la va donar, juntament amb l'altra de l'herència de l'escriptor, a Isabel Martínez de Vera, fet que fa que, en I 497 (doc. 362), les dues cases de Corella estiguen juntes en una sola mà un altra volta, i que els seus límits siguen els mateixos que els esmentats per l'escriptor en I487. Que són els mateixos límits es pot comprovar en l'escriptura

I87. Doc. 299. En repetim els passatges, remarcant-los: "En aprés, divendres qui.s comptava sis dies del mes de octubre de l'any de la nativitat de nostre Senyor Jhesuchrist mil quatre-cents noranta-set a instància e requesta de la magnífica na Dalfina Roïç de Corella, muller del magnífich mossén Luís Figuerola, cavaller, jermana y hereua scrita en lo desús dit testament, e en presència dels magnífichs mossén Luís Roïz de Corella, donzell, jermà del dit testador, e del dit mossén Luís Figuerola e en la casa de aquell, lo preinsert testament per mi, Pere Andreu, notari públich de la ciutat de València, regent les notes e libres del venerable e discret En Antoni Barreda, quòndam, notari, fonch lest $\mathrm{e}$ publicat. E lest e publicat aquell, en continent la dita magnífica na Dalfina de Corella dix que ella se retenia acord sobre la acceptació de la dita herència o repudació de aquella, e que lo ínterim temps algú no li precóregue ans li reste salvu e il.lés, requirint de premisis carta pública. (...)

De post vero die septima mensis octobris dicti anni millesimi CCCC nonagesimi septimi, la dita magnífica na Dalfina Roïç de Corella, muller del dit magnífich mossén Luís Figuerola, cavaller, convocats mi, Pere Andreu, notari, e los testimonis dejús scrits, declarant lo acord per ella retengut sobre la acceptació o repudiació de la dita herència, dix que acceptava la dita herència ab benefici de inventari, protestant que en fer aquell temps algú no li precórregue ans li reste salvu e il-lés, requerint carta publica".

I88. Conservem els darrer testament i codicils de Lluís de Castellví realitzats davant el notari Francesc Pintor el ig d'abril de I48I (RCSCCV, protocols, no. 22522, not. Francesc Pintor -escriptures de i9 abril I48I) publicats per mort del testador el 27 d’abril de I48I. El llarg i detallat inventari dels béns deixats en morir per Lluís de Castellví va ser realitzat el 7 de maig de I48I i es conserva en RCSCCV, protocols, no. 22522, not. Francesc Pintor -7 maig I481.

I89. Doc. 36r. En remarquem el passatge: "Com per squivar dol, frau y engan e tota manera de sospita de aquells, quascuns hereus, marmesors, tudors y altres administradors de béns de la lur heretat degen e sien tenguts fer memorial reportori e capbreu dels béns e drets atrobats e rechaents en lurs marmessories y herències perquè, quant mester sia, de aquells se puixa donar bon compte e rahó, hoc encara per ço com per legíttimes sanctions e disposicions de fur y privilegi del present regne per la confectió de l'inventari als hereus no solament són conservats encara són preservats de dan per quant no són obligats ultra los béns hereditaris, per tal yo, na Dalfina Roïç de Corella [...] E ara e per tots los temps, loch e cars si per creedors o alias yo fos tenguda y obligada dels dits béns, axí per via de creedors eo alias de aquells, hagués a donar compte e rahó no sia tenguda ni obligada ultra ni en més que.s són los dits béns e forces de la dita heretat". 
del lloguer d'aquestes cases fet en I5OI a Gaspar Joan de Monsoriu (doc. 387 ).

Si les cases de Corella feien marge amb el carrer de "Mossén Corella" i amb un carrer-séquia dels beguins -que sense cap mena de dubte cal identificar amb el carrer de Rotlons, ${ }^{190}$ on es va aveïnar Bertomeu Chiva-, és que les cases feien cantonada. Aquest carrer de Rotlons-Reglons, com es pot veure al plànol del pare Tosca de I7O4 (publicat per l'Ajuntament de València en 2003, Gavara 2003, 2O7), correspon a l'actual carrer de l'Arquebisbe Mayoral, i era molt a prop del convent de Sant Francesc. Aquesta situació en cantonada és confirmada pels límits establits a una casa de Dalfina

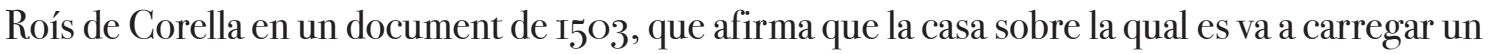
censal feia marge amb casa d'Isabel Martínez de Vera, amb altra casa de Dalfina Roís de Corella, i amb el carrer de Corella "et a posteriori parte cum cequia et vico". Però quin de tots els possibles carrers que creuen el referit de Rotlons és l'anomenat de "Mossén Corella”? En la nostra opinió es tracta del carrer que al plànol de Tosca apareix anomenat "carrer dels Figueroles" -corresponent a l'actual carrer Periodista Azzati-, ${ }^{191}$ i optem per aquest, preferint-lo als que apareixen en el referit plànol com a "carrer de les Velles" i "carrer de la Figuerera" -unificats actualment amb el nom de carrer de les Ànimes-, perquè, segons la documentació, en primer lloc les cases de Corella deixen al seu darrere la séquia-carrer de Rotlons, i en segon lloc perquè, segons es diu en el darrer testament de Dalfina Roís de Corella els porxes de la seua casa que feia marge amb l'antiga del seu germà Joan Roís de Corella, miren al carrer de Sant Vicent cosa que és posible si el carrer de Mossén Corella és l'anomenat dels Figueroles i no el “de les Velles”; ja que, si fóra així, els porxes mirarien al carrer de Rotlons i no al de Sant Vicent (doc. 409).

A més a més, creiem que hi ha un argument difícil de refutar, i és el manteniment, encara en I704, del nom de Figueroles per al carrer, fet que ens indica que la família Figueroles havia tingut cases allí, i que els descendents del matrimoni de Dalfina Roís de Corella i Lluís de Figuerola foren prou importants com perquè, després de la mort de l'autor del Parlament en casa de Berenguer Mercader, pervisquera el cognom en la denominació del carrer. Per tant, al nostre parer, el carrer de Mossén Corella on vivien l'escriptor i el matrimoni format per Dalfina Roís de Corella i Lluís Figuerola és, sense cap mena de dubte, el posteriorment anomenat carrer dels Figueroles i actual carrer de Periodista Azzati que, quan s’anomenava "carrer de Mossén Corella” arribava fins als horts del monestir del convent de Sant Francesc (doc. 32I).

Comptat i debatut, després de revisar els límits que figuren en la documentació arxivística referits a les cases de Mossén Corella -abans del seu traspàs i quan ja eren d'Isabel Martínez de Vera- i a les del matrimoni format per la seua germana Dalfina i Lluís Figuerola, podem afirmar que les cases on va viure el cavaller i mestre en teologia Joan Roís de Corella són les que formen la cantonada entre els carrers Arquebisbe Mayoral i Periodista Azzati, concretament estarien ubicades en els actuals

I90. "L’últim canal, així mateix derivat de Favara, és el de l’Hospital (...) i que a la plaça devora el convent de Sant Agustí es bifurca en dos braços. Un va pel Mur de Sant Pau (actual carrer de Xàtiva), vers el portal de Russafa, vora el qual ix cap a extramurs. L'altre baixa pel carrer de Sant Vicent, torça pel del Porxi de Sant Pau (ara de Sant Pau) i passa al de Renglons o Rotlons (Arzobispo Mayoral). Aquesta és la séquia anomenada dels beguins, a causa de l’Hospital del mateix nom, situat prop del Portal de Sant Vicent. Aquesta dada és confirmada per un document de la regesta (I436) referit al pagament de jornals per a adobar un pont sobre la Séquia dels Beguins que travessa el carrer dels Rotlons (...). Desde l'esmentat carrer arriba fins al de la Sang on vessa a la Séquia de Rovella. També és possible que hi hagués una derivació de Favara que tot recorrent el carrer de Sant Vicent, des del portal del mateix nom, s’aboqués a Rovella a l'altura del carrer dels Adressadors" (Teixidor-Domingo, I989, 297).

I9I. Quan el carrer s'anomenava de Mossén Corella arribava fins als horts del monestir de Sant Francesc (doc. 32I) i, per tant, estaria integrat pels carrers que al plànol de Tosca de I7O4 figuren anomenats com "carrer de Culla" i "carrer dels Figueroles”. Cal assenyalar que, en època de Corella, l'ermita de la confraria dels genovesos que apareix en el plànol, no hi era, ja que es va començar a construir a partir de I487, moment en què el convent de Sant Francesc en cedí uns terrenys (Igual 2000). 
números 8, $9^{192}$ i Io del carrer de Periodista Azzati, i número I4 del d’Arquebisbe Mayoral.

Per la seua banda, les cases de Dalfina i el seu marit estarien ubicades en els actuals números II, I2 i I3 del carrer Periodista Azzati.

Totes aquestes cases, les de Mossén Corella i les de Dalfina, eren molt a prop de les cases que tenia Isabel Martínez de Vera, tant la del carrer de Sant Vicent (la casa d'Isabel estaria a la cantonada de l'actual carrer de Xàtiva amb la plaça de Sant Agustí) com les del carrer de la Verge Maria de Gràcia (estarien a l'actual illa d'edificis formada per l'avinguda del Baró de Càrcer, carrer músic Peydró - continuació del vell carrer de Santa Maria de Gràcia- i el carrer En Sans). Són tan pròximes que, encara actualment, un vianant no tarda més de quatre minuts a arribar d'unes a les altres.

Com es veu, Joan Roís de Corella tenia molt a prop tot el que volia: el convent de Sant Francesc, Dalfina Roís de Corella, Isabel Martínez de Vera i els seus fills.

Ubiquem a continuació les cases de tots ells en Google Maps, i en una imatge basada en el plànol de Tosca de I7O4: el gravat de Josep Fortea imprés al voltant de I738. ${ }^{193}$ Cal tenir present que, en aquest darrer, l'orientació és contrària a la moderna (el nord baix i el sud dalt).

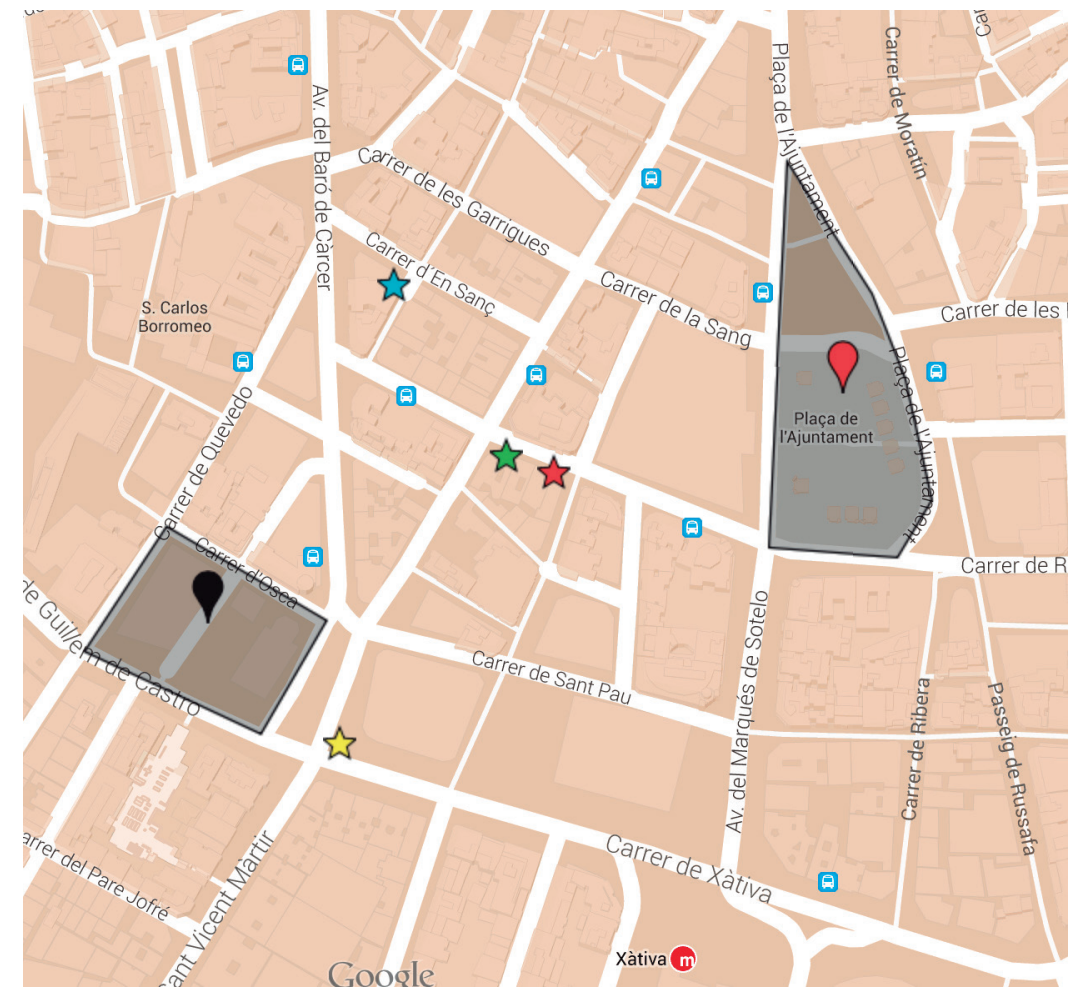

Estrela blava: Cases d’Isabel Martínez de Vera al carrer de Santa Maria de Gràcia. Estrela groga: Casa d'Isabel Martinez de Vera en carrer de Sant Vicent. Estrela verda: Cases de Dalfina Roís de Corella i Lluís Figuerola Estrela roja: Cases de Joan Roís de Corella

Pin roig: Convent de Sant Francesc (actual plaça de l'Ajuntament). Pin negre: Convent de Sant Agustí.

I92. Aquest correspon a la popular tenda de teixits Julián López, del carrer Periodista Azzati. I93. El lector en pot aplicar aquesta ubicació també sobre el de I7O4 publicat a Gavara 2003, I93 i 207. 


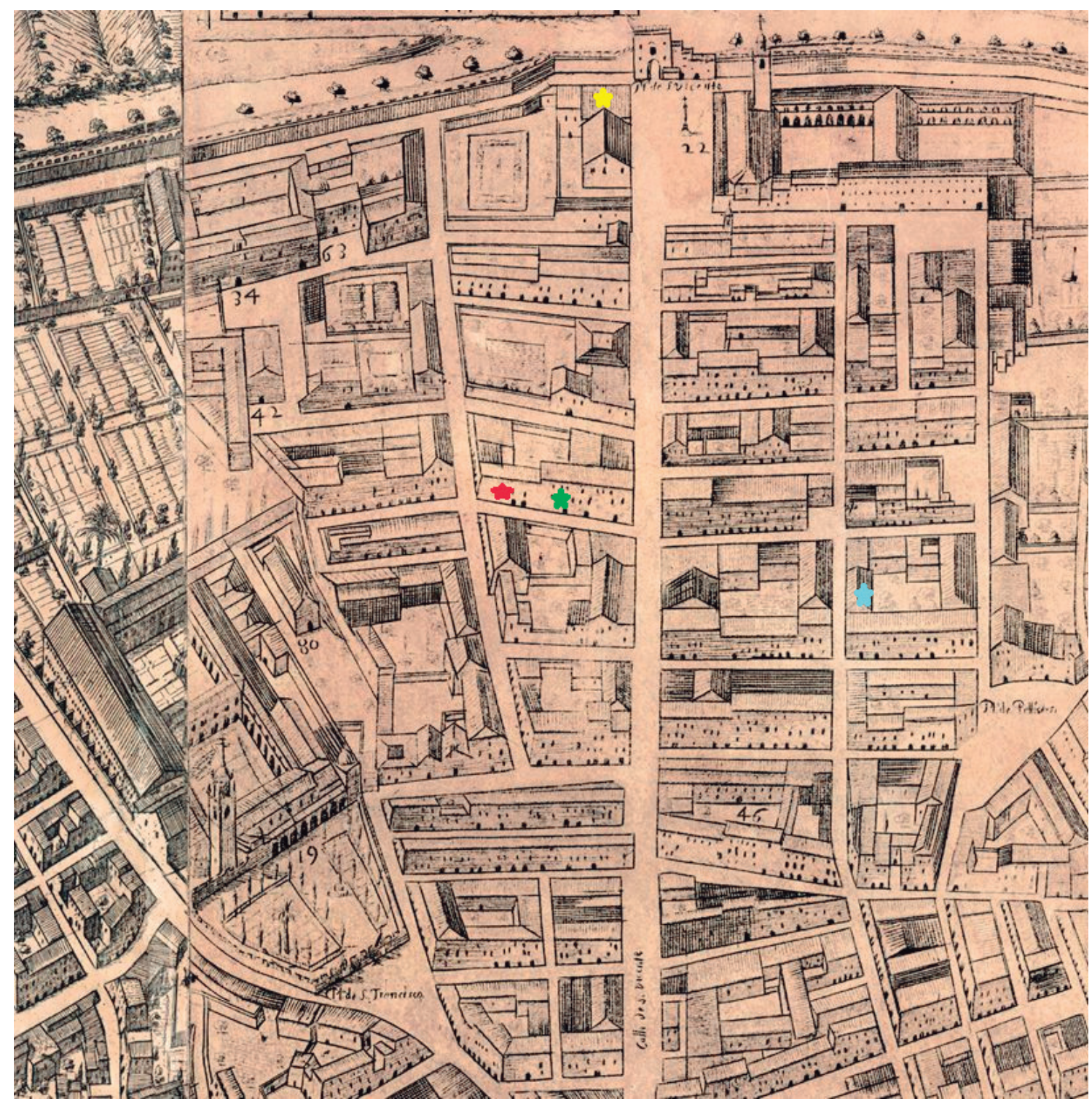

(C) Arxiu del Regne de València.

Estrela blava: Cases d'Isabel Martínez de Vera al carrer de Santa Maria de Gràcia. Estrela groga: Casa d'Isabel Martinez de Vera en carrer de Sant Vicent. Estrela verda: Cases de Dalfina Roís de Corella i Lluís Figuerola Estrela roja: Cases de Joan Roís de Corella I9: Convent de Sant Francesc (actual plaça de l'Ajuntament). 22: Convent de Sant Agustí.

Sabem que el 25 de maig de I5OI, Isabel Martínez de Vera llogà a Gaspar Joan de Monsoriu, donzell habitant de València, certes cases ubicades a la parròquia de Sant Martí, concretament al carrer anomenat de Mossén Corella, per temps de quatre anys -a partir de I5O2- a raó de I2 lliures anuals (doc. 387). Aquestes cases afrontaven amb casa de Lluís Figuerola, séquia dels beguins i amb l'esmentat carrer de Corella. 
En juny de I5O2, Dalfina i Isabel declararen davant el Justícia Civil que el valor de l’herència del poeta, llevats els corresponents càrrecs, era menor de 5.0oo sous i que, per això, la donació s'havia fet sense el decret legal del Justícia Civil tal com exigien els furs. Aquesta mancança de vistiplau legal es va intentar subsanar en eixe moment per a evitar que algú poguera dubtar que aquesta donació no excedia de 500 florins. El Justícia Civil féu declarar sota jurament tant a Dalfina com a Isabel que la referida donació s'havia fet sense dol o en frau dels creditors (doc. 393). Remarquem que la declaració d'haver-se fet la donació sense dol i frau es fa quatre anys després de morir l'escriptor -i no immedatament com va passar en el cas de la donació de I 455 entre l'escriptor i sa mare Aldonça de Cabrera-, quan és possible que algú ja s'havia adonat de la jugada legal ideada, molt probablement pel propi Corella o per algun jurista acostat; i pensem, sense dades documentals ni a favor ni en contra, en algú de la família dels juristes Figuerola. Perquè si el matrimoni CorellaFiguerola no hagués estat asabentat de la jugada, no hagueren acceptat l'herència i el posterior traspàs de béns a Isabel Martínez de Vera.

Com ja hem dit, Joan Roís de Corella, un dels escriptors més precoços i més importants de la nostra cultura, tenia en morir seixanta-dos anys. Era un lletraferit que ocupà un lloc preeminent en el seu temps: el príncep Carles de Viana, abans de i46r, li dedica grans elogis; en el Johí de Paris, Joan Escrivà confessa imitar les poesies de Corella; en la Qüestió entre Fenollar, Vidal, Verdanxa i Vilaspinosa, els elogis a la seua figura són hiperbòlics; en el Somni de Joan Joan, Jaume Gassull no s'està de situar Corella al costat de la Bíblia i del Tirant, etc.

Probablement les seues obres mitològiques, com les seues poesies, circulaven manuscrites fins i tot abans de ser portades a la impremta -perquè si no, no s'explica el reconeixement literari dels seus coetanis valencians-, tal com va passar amb el Tirant lo Blanc de Joanot Martorell.

Amb aquestes obres, Isabel Martínez de Vera va intentar comerciar (com veurem a 3.2.3). Unes obres per alguna de les quals el seu fill aconseguí en I5O6 (i no en I5O2 com es pensava) un permís d’impressió en exclusiva per part dels jurats de València.

\subsection{De Maria a Estefania: La descendència de l'escriptor}

\subsection{Maria Roís de Corella}

La primera -i única- ocasió en què hem trobat citada Maria és en un document del 27 d'abril de I474 fet a València. Mitjançant aquest, Pere Maça de Liçana àlies Lluís Cornell, en el seu nom propi i com a procurador de la seua esposa Beatriu, el cavaller Lluís Mascó -menor de dies- i el notari Jaume Gisquerol, tots ells habitants de València, venen per Io5 lliures a Aldonça de Cabrera, vídua del cavaller Ausiàs Roís de Corella, 3 oo sous rendals anuals de violari durant les vides de Joan Roís de Corella, cavaller i mestre en teologia, i de Maria, donzella, filla de l'esmentat Joan Roís de Corella (doc. 28I).

Amb aquest violari del 27 d'abril de I474, està relacionada la demanda interposada pel literat en el mes de novembre de l'any següent reclamant l'abonament de 3 oo sous de pensions degudes (doc. 286).

El I7 de febrer de I480 Joan Roís de Corella, com a fill i hereu d’Aldonça Corella, confesa haver rebut les pensions d'aquest violari segons instrument de quitament en mans del notari Pere Soler datat el dia d'abans. Hi apareixen com a testimonis el mercader Bertomeu Chiva i l'escuder Pere Vidal (doc. 28I). 
Atés que tan solament hem localitzat un document on figura Maria, es podria suposar que és un error del notari i que, realment, es tractaria de Magdalena, la filla de Joan Roís de Corella que es va casar amb el lletraferit Miquel Pérez. Però pensem que, a no ser que apareguen nous documents en aquest sentit, cal rebutjar aquesta hipòtesi identificativa per les següents raons:

* El nom de Maria figura clarament escrit al document notarial de 1474 ("ad vitas magnifici Joannis Roiz de Corella, militis ac magistri in sacra theologia, filii vestri [d'Aldonça], et Marie, domicelle filie dicti magnifici Joannis Roiz de Corella").

* Cap de les persones que figuren al document no s'adonaren d'aquest hipotètic error notarial. I no parle sols d'Aldonça o de l'escriptor, sinó dels altres esmentats, malgrat els seus estrets lligams, almenys de coneixença, amb els Corella: Bertomeu Chiva -el sempre fidel procurador i que, com veurem, nomenarà Magdalena Roís de Corella hereua universal seua en el seu darrer testament- i Lluís Mascó -menor de dies-, la família del qual figura lligada per censals amb la mare de l’escriptor en I $45^{8}$ i I 464 (docs. 2I8 i 247). A més a més, el referit Lluís Mascó no sols formarà part, amb Joan Roís de Corella, de la comissió creada en I482 per a estudiar la viabilitat de construir un hospital general a València, ${ }^{194}$ sinó que, també, és un dels testimonis de la publicació del testament del cavaller i mestre en teologia (doc. 299).

* Si Magdalena fóra "Maria”, pensem que hauria d'haver signat al costat de son pare en el document del I7 de febrer de I480, car, en eixe moment, Magdalena vivia, i el violari escripturat en I474 estava vinculat, originàriament, a la duració de les vides de Roís de Corella i d'eixa filla seua.

El fet de no ser esmentada Maria en la demanda de I475 o en el document de I480 a què ens hem referit, pot significar que, en aquestes dates, ja havia mort; o bé que no calia la seua participació, en actuar son pare com a hereu d'Aldonça Roís de Corella.

\subsubsection{Magdalena Roís de Corella, esposa de Miquel Pérez}

Com ja hem comentat, el 27 d'agost de I466, el mercader Bertomeu Chiva, l'home de confiança dels Roís de Corella que va estar sempre al costat de la família, feia un testament. Hi nomenà hereua universal seua Magdalena, "donzella de edat de set anys, la qual stà en la casa de la dita magnífica n’Aldonça de Corella”. En cas de morir Magdalena menor de quinze anys i sense fills nascuts de legítim matrimoni, tots els béns de Chiva serien d’Aldonça Roís de Corella, o del seu hereu en cas d'haver mort ja la mare del prosista i poeta:

En tots los altres béns meus, mobles e inmoble e privilegiats, drets e accions a mi pertanyents, eo pertànyer podents o devents, per qualsevol títol, causa, manera o rahó, Magdalena, donzella de edat de set anys la qual stà en la casa de la dita magnífica n'Aldonça de Corella, en los dits béns e drets hereua mia universal faç e instituesch per dret de institució. Sots tal vincle e condició que, si la dita Magdalena, hereua mia, morrà menor de quinze anys e sens fills legíttims e naturals de carnal matrimoni nats e procreats a aquella sobrevivents, que, en tal cars, tots los dits béns de la mia herència, éntregament sens disminució e detracció alguna de trebel-leyànica o altre qualsevol dret, sien de la dita magnífica n’Aldonça de Corella a fer dels dits béns a ses voluntats. E, si advenint lo dit cars, la dita magnífica n’Aldonça de Corella viva no serà, vull e man la dita mia heretat éntregament, segons dit és, sia de l'hereu o hereus o successor o successors, ab testament o ab intestat de la dita magnífica n’Aldonça de Corella, a fer dels dits béns a ses voluntats.

I94. Doc. 3I4. Cal recordar que Lluís Mascó, menor de dies, era el jurat en cap de la ciutat en eixe moment. 
E vull e man que, la dita magnífica n’Aldonça de Corella, e premorint aquella eo aprés mort de aquella, los hereus o hereu o successors de aquella, axí ab testament com sens testament, tinguen, procuren, regeixquen, administren, reben, prenguen e venen los béns de la mia heretat, e ho recahents en aquella, fins la dita Magdalena, hereua mia, haja atesa edat de vint anys o fins que, aquella dita Magdalena, haja afermat matrimoni. E, per los dits béns, responguen e entrevinguen en juhí e facen tots aquells actes que yo, personalment, constituhit fer poguera; e, açò, facen e puixen fer sens auctoritat o decret de jutge o oficial algú e sens solemnitat de dret alguna, sols a lur beneplàcit, com aquesta sia ma voluntat. ${ }^{195}$

Aquest testament ens permet deduir que Magdalena nasqué en I459 ${ }^{196}$ quan Joan Roís de Corella, son pare, tenia 24 anys. Desconeixem el nom de la seua mare però, en la nostra opinió, no és filla d'Isabel Martínez de Vera, com afirmen alguns investigadors, ${ }^{197}$ atesa, d'una banda, la seua criança a la casa de l'àvia i no amb Isabel -a diferència de què ocorre amb els seus fills Joan i Estefania- i, per altra, atés que no es coneix, fins ara, cap document tant primerenc que lligue Joan Roís de Corella amb Isabel -que desconeixem si residia a València en eixe moment. A més a més, si fóra filla d’Isabel, és il-lògic que Magdalena no l'esmente a ella o a Estefania i Joan en els seus testaments de I480 i I49O, on sí esmenta son pare i els seus oncles Lluís i Dalfina Roís de Corella.

Magdalena Roís de Corella i Miquel Pérez establiren les seues cartes nupcials davant el notari Antoni Barreda el I8 d'octubre de I477 (doc. 297). El matrimoni eclesiàstic se celebraria poc després i és aquesta forta relació familiar la que explica, perfectament, l'estreta relació literària entre els dos escriptors Joan Roís de Corella i Miquel Pérez. ${ }^{198}$

Com hem vist abans (en parlar a 3.I de les circumstàncies del testament del seu pare), Magdalena aportà un dot de Io.ooo sous, si bé, en un primer moment, tan sols lliurà a Pérez 4.500 sous, atés que, el 3 I d'agost de I 478 i juntament amb el seu pare, Magdalena, per a complir amb la promesa feta de donar-li els $5 \cdot 5$ Oo sous restants, li lliurà dos censals de què diferents persones responien a Joan Roís de Corella com a hereu de son pare i de sa mare (docs. 297 i 298).

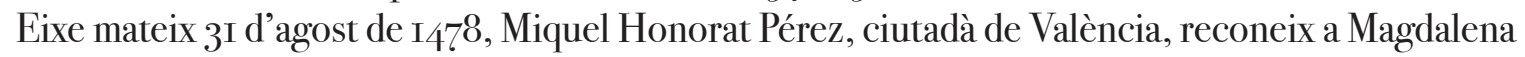
Roís de Corella, la seua esposa, el lliurament dels 5·5oo sous (doc. 298). Com ja havíem dit, era un bon matrimoni per a Magdalena i per al mestre en teologia i, si bé el dot era escàs -un poc més de la mitad de l'establit a Dalfina Roís de Corella en I469-, Miquel Pérez podia estar ben content de lligar-se familiarment de per vida amb el seu admirat Joan Roís de Corella.

Finalitzada aquesta transacció (i, com ja hem opinat, no per casualitat), aquell mateix dia i davant el mateix notari, el cavaller, mestre en teologia i escriptor dictà el seu darrer testament, després d'haver assegurat el futur de la seua primogènita.

Miquel Honorat Pérez era ciutadà de València i fill del notari valencià Pero Pérez (doc. 296). En tots els documents que, sense cap mena de dubte l'identifiquen -documents amb Corella, la seua filla, amb

I95. Doc. 249. Aquest document permet corregir l'esmentat en Domènech et al. (2OI4, IO5): “Esta [Isabel Martínez de Vera] va arribar a València durant la primavera del I462 i, pocs anys després, va concebre de Joan Roís de Corella la seua primogènita Magdalena (...) Poc després, vingueren al món Joan i Estefania, els dos fills menors de la parella”. I96. Les dates de naixement de Magdalena Roís de Corella i de les seues capitulacions matrimonials amb Miquel Pérez varen ser anunciades en Chiner 20I3, document redactat en abril de $20{ }_{3}$.

I97. Magdalena seria “la filla primogènita (...) del nostre escriptor i d’Isabel Martínez de Vera” en Ferrando 2OI3a, $65^{2}$ mentre que, per al mateix professor (Ferrando 2OI3b, III), seria "filla natural primogènita de Corella, nascuda el I459, de mare desconeguda”. Per a Domènech et al. 2OI4, IO5, també seria la primogènita de la parella Joan Roís de Corella i Isabel Martínez de Vera.

I98. Sobre l'abast exacte d'aquesta relació literària en els escrits de Miquel Pérez, vid. Martínez Romero 2 OI2. 
Isabel Martínez de Vera, etc- sempre se'l qualifica de ciutadà, i mai no apareix com a notari, fet que ens porta a afirmar que no va exercir aquesta professió i que alguns dels documents i càrrecs que se li han atribuït corresponen a altres persones homònimes.

Un poc abans del seu casament, el 9 de juny de I478, el seu cunyat, el mercader de València Ferran Eximenis, com a tutor i curador de l'hereu del difunt notari Pero Pérez -sogre de Ferran i pare de Miquel-, va lliurar-li una sèrie de llibres que havien pertangut al difunt. L'autor de La vida de santa Caterina de Sena es comprometia a tornar-li'ls en el moment que aquest li ho demanara. El llistat, amb més de 75 llibres, és molt interessant, atesa la importància literària de Miquel Pérez i del seu sogre, qui, igual que el gendre, segurament consultaria més d'una vegada d'aquests volums, molts d'ells d'impremta. Hi trobem obres d'Ovidi, Cèsar, Homer, Plini, Demòstenes, Aristòtil, Juvenal, Boeci, Valeri Màxim, Sant Agustí, Heròdot, Dant, Beccadelli, Facio, Tucídides; llibres de dret, d’història, de filosofia... Fins i tot una gramàtica italiana (doc. 296).

Cal assenyalar, com ha fet Josep Guia (2003), que existiren relacions entre el matrimoni format per Magdalena i Miquel Pérez i Isabel Martínez de Vera, atés que, en els primers dies de març de I479, Isabel nomenà Miquel com a procurador seu (doc. 304), i que, el I9 de març de I486, davant el notari Pere Joan Çabrugada, Miquel Pérez, Isabel Martínez de Vera i els germans Joan, Lluís i Dalfina Roís de Corella, carregaren I5O sous censals al noble Gisbert Pardo, habitant de València. ${ }^{199}$

La possessió de nombrosos censals, d'una alqueria a les Tendetes de Campanar -residència, juntament amb València, de Miquel Pérez i de la seua dona ja en I478 (doc. 297)-, els diners aportats per l'arrendament de l'alqueria i de certes terres ${ }^{200}$ els possibles càrrecs administratius ocupats, etc., mostren clarament que l'economia i hisenda de Miquel Pérez era molt major que la del seu sogre. Aquesta economia li va permetre deixar a aquest izo lliures el 7 de febrer de I487, que el cavaller i teòleg li retornà un any després (doc. 33o).

Coneixem dos testaments de Magdalena Roís de Corella, redactats a l'alqueria que el seu marit tenia a les Tendetes de Campanar: un fet el I8 d'octubre de I480 (doc. 3II), i l'altre, el 7 de gener de I490 (doc. 339), originat, probablement, en la por a la pesta que, en aquell moment, hi havia a la capital del Túria. ${ }^{201}$

En el primer testament, Magdalena nomena marmessors el seu marit i el seu pare Joan Roís de Corella -a qui qualifica de "pare meu molt amat". Elegeix ser sepultada al monestir de Sant Vicent fora els murs de València (Sant Vicent de la Roqueta) "en lo lloch on los dits marmessors meus plaurà e poran ab los dits frares del dit monestir", i demana que en dit monestir "los dits marmesors me facen dir les cinch mises de les cinch plagues del gloriós redemptor meu Jhesuchrist de les quals tinch gran devoció”. Llega a sa tia Dalfina Roís de Corella-qui, com hem vist a 2.2.4, també tenia gran devoció pel monestir de San Vicent de la Roqueta i per les misses de les cinc plagues ${ }^{202}-5$ o lliures, i nomena hereu universal Miquel Pérez, establint el seu pare, els seus oncles Lluís i Dalfina o els fills d'ells com a hereus succesius en determinades circumstàncies:

I99. Doc. 366 . Aquest censal va ser quitat l'iı d'octubre de I498.

200. Docs. 430 i 432. L'existència d'aquests arrendaments en I5 $5^{\text {I2 }}$ i I5 $5^{\mathrm{I}} 6$ ens fa pensar que, molt probablement, en anys anteriors també s’arrendaren les terres de Miquel Pérez.

20ı. Cal recordar que en I490, i molt probablement per la pesta, morien escriptors com el bisbe Jaume Pérez i sor Isabel de Villena.

202. Sobre aquesta devoció, molt lligada al franciscanisme medieval i, sobretot, a Caterina de Sena, vid. Labarga I999. És oportú recordar, en aquest context, que el seu marit Miquel Pérez és l'autor de La vida de santa Caterina de Sena. 
E, aprés mort de aquell [Miquel Pérez], los fills e filles mies que de aquell hauré e tendré, si vius seran e estaran en la casa sua e mia vius, per eguals parts entre aquells dits fills e filles mies e del dit marit meu fahedores a fer aquells a ses planes volentats. E si fills ne filles meus e del dit marit meu en lo dia de la mia mort no y havia, ço que a Déu no plàcia, en tal cars dits béns meus e accions e drets lo dit en Miquel Pérez, marit meu e marmesor, tinga e posseixqua aquells, segons dit he dessús, de vida sua e, aprés mort de aquell, sens nenguna diminució, difalcació de dret, de legítima trebeliànica o altre qualsevol dret éntregament los dits béns, drets e accions tornen e vinguen al dit reverent mestre Johan Roïç de Corella si béns de la Sglésia no tendrà e puxa fer de aquells a ses plenes volentats. E si béns de la dita Sglésia tendrà, tinga en los dits béns, drets e accions la vida e, en los dits casos, hereu faç e institueix aquell de vida de aquell e, aprés mort de aquell, lo magnífich en Luís de Corella, donzell, jermà de aquell e oncle meu, sots tal emperò vincle e condició que, si aquell dit magnífich en Luís de Corella morrà quantquequant sens fills legíttims o de legíttim matrimoni procreats e nats, que en tal cars los dits béns meus, drets e accions, éntregament sens nenguna diminució e difalcació, vinguen a la dita magnífica na Dalfina, tia mia, e als fills e filles de aquella; e aquella e aquells puxen testar dels dits béns meus, drets e accions a ses plenes volentats e fer de aquells tot ço e quant volran fer. E, si lo dit magnífich en Luís de Corella, en lo dia de la sua mort, tenia fills e filles legíttims e de legíttim matrimoni procreats e nats, en tal cars aquell puxa dispondre e testar de aquells dits béns meus, drets e accions en los dits fills e files sues. E, advenint lo dit cars, hereus meus propris faç los dits fills e files a fer de aquells a ses planes volentats, sens vincle e condició alguna, no obstant la dita na Dalfina, tia mia, fos viva e tingés fills e filles legíttimes e naturals, com ma intenció sia que hon fills e filles del dit en Luís de Corella legíttims e naturals hi hagués, vulla aquells sien hereus meus e dels dits béns meus e $\cdot n$ la forma dessús dita facen a ses planes volentats

(doc. 3II).

Aquest testament ens mostra, per un costat que, en octubre de I480, encara no havia nascut cap fill del matrimoni de Magdalena i Miquel Pérez i, per altre, que, malgrat els anys passats des de que havia viscut amb la seua àvia i els seus oncles, tenia presents a Dalfina i a Lluís Roís de Corella, mentre que ignorava Isabel Martínez de Vera i els seus fills. Així mateix, la referència a una hipotètica concessió o adquisició de rendes eclesiàstiques per part de Joan Roís de Corella ens mostra que, almenys per a la seua filla, aquesta era una possibilitat real.

El segon testament, redactat el 7 de gener de I 490, és molt paregut a l'anterior -nomena com a marmessors el seu marit i Joan Roís de Corella a qui torna a qualificar de "pare meu molt amat", misses de les cinc plagues de Jesucrist, son pare no ha de tenir béns d'Església per a ser hereu d'ella, etc- si bé presenta unes importants diferències:

Deixa a elecció del seu marit on ser soterrada.

* Llega a Dalfina Roís de Corella deu lliures.

* Llega una dobla, com a legítima en els seus béns, a Joan, Aldonça, Beatriu i Jerònim Pérez, fills nascuts del seu matrimoni amb Miquel entre la data de l'anterior testament i la d'aquest de I490.

* Nomena hereu universal Miquel Pérez però amb un vincle de successió on incorporarà als seus fills i on també figuren l'autor de la Tragèdia de Caldesa i els seus germans Dalfina i Lluís Roís de Corella.

Dos anys després d'aquest testament, concretament el 7 de març de I492, Magdalena feia l'inventari de béns del difunt mercader Bertomeu Chiva -casat amb Úrsula en una data anterior al 9 de maig de I489 (doc. 334) - qui, com ja havia fet en I466 i malgrat haver-se casat, l'havia declarada hereua universal al seu darrer testament fet el I3 de juliol de I490 i publicat, per mort del testador, el 2 de 
març de I 492 (doc. 343). Entre els seus béns -venuts el I2 de març de I 492 per Miquel Pérez, com a procurador de la seua esposa, en públic encant al mercat de València per un total de 6og sous i II diners (doc. 344) - figuraven, com ja hem indicat al parlar d'aquest servidor d'Aldonça de Cabrera, un llibre de hores i "un llibre de mestre Francesc Eximenis apellat De les dones"(doc. 343).

No sabem amb seguretat quan va morir Magdalena Roís de Corella, però encara era viva el 4 de juny de I498, moment en què el seu marit, el ciutadà Miquel Pérez, va dictar testament a les Tendetes de Campanar (doc. 365). Pérez hi nomena, com a marmessors, Francesc Cabrera i la seua esposa Magdalena Roís de Corella, a qui elegeix com a hereua universal, i demana ser sepultat en la fossa que ell tenia al monestir de la Verge del Carme de València. Si lliguem aquesta darrera dada amb la decisió de Magdalena, al seu testament de I49o, de ser soterrada on el seu marit volguera, ens trobarem amb un fet com és que desconeixem si, finalment, Magdalena Roís de Corella està soterrada al monestir de Sant Vicent de la Roqueta, com va demanar en I480, si al del Carme de València, o si en altre lloc.

Poques dades tenim dels fills de Magdalena i Miquel Pérez. Tan sols podem esmentar una dada segura i un altra de probable, però de certa importància en cas de confirmar-se, tant pel seu contingut literari com perquè implicaria una continuació en les relacions dels Pérez amb Isabel Martínez de Vera més enllà de 5505 .

Comencem amb la dada probable. Com veurem en parlar més detingudament d'Isabel Martínez de Vera, al principi de I 498 Isabel va vendre 780 llibres "in lingua materna" del Cartoixxà, al llibreter Joan Caulet; i encara l'ı de març de I5Oo Caulet devia diners a Isabel (docs. 374 i 375). Però el que hem documentat és una nova transacció comercial entre ells, en I506, amb una sèrie de llibres -entre d'altres, 6o Cartoixans i un Tirant- propietat d'Isabel, de Bertomeu de Cars i de Jerònim Pérez (doc. 420).

Fins ara, no tenim cap dada documental més sobre aquest assumpte, i ens movem en el marc de les hipòtesis; però, des del punt de vista cronològic, és possible -i seria molt suggeridor- que aquest Jerònim Pérez fóra el fill homònim de Magdalena Roís de Corella i Miquel Pérez.

Pel que fa a la dada segura, sense cap mena de dubte cal identificar amb Miquel Pérez, gendre de Corella, amb el seu fill Joan i amb Dalfina Roís de Corella, alguns dels diferents personatges que figuren en un procés successori seguit, entre I5OI i el I5I3, per la senyoria de Ròtova:

Pere Cabrera [senyor de Ròtova] aconseguí casar la seua filla i hereua, Damiata, amb un jurista de prestigi de la capital, Ximén Peris de Figuerola (València, c. I47O-Mallorca, I538), que aconseguia així emparentar amb la petita noblesa. La cosa fou una miqueta complicada, no tant pels diners, atesos els estipendis que del rei cobrava pel seu ofici de regent de la Cancelleria del Consell d'Aragó (I5O9-I5I4), com pel conflicte que causà a cals Cabrera l'afer de la successió. Tanmateix, a la fi, la muller vengué la senyoria al marit i donà origen a la nissaga dels Figuerola senyors de Ròtova (I5I3). El procés successori seguit entre el I5OI i el I5I3 fou summament complicat, segons el que comenta Juan Francisco Pardo:

En efecto, las aspiraciones sociales de Figuerola se plasmaron en el ventajoso matrimonio que contrajo en fecha aún desconocida con Damiata Cabrera, hija de Pere Cabrera, señor de Rótova (lugar próximo a la Gandía de los Borja) y de Margarita Gallach, pariente del citado jurista y de Isabel Gallach, esposa de Lluís de Cabanilles jr. Damiata murió joven, en 1501, y dejó a Figuerola una hïa, Isabel Joan, y un extraño pleito. Al parecer, años atrás, probablemente cuando aún era soltera, 
Damiata, en complicidad con el notario de Gandia Pero Pérez de Culla, falsificó el testamento de su hermano, Perot Cabrera, incluyéndose a sí misma como heredera universal. Almenos estos hechos denunció la madre, Margarita Gallach, lo que costó el encarcelamiento del notario en la torre de Valencia y el confinamiento de la joven en casa de la viuda de un tal mosén Lluís Figuerola, cuya relación con nuestro jurista no hemos podido establecer.

El caso es que al cabo de seis meses, Damiata, desamparada de sus familiares y amigos, tuvo que abandonar su asilo y fue acogida por un ciudadano llamado Miquel Pérez. Sin que sus motivos estén claros, Pérez se hizo cargo de los pleitos de la joven, que lo nombró su procurador. No sabemos si Damiata se reconcilió con su madre antes de casarse con Figuerola, pero las relaciones con el resto de la familia debían ser buenas, pues en su testamento nombró a su padre albacea y a su hermano heredero, en caso de que sobreviviese a su hija Isabel, instituida heredera universal; asimismo dio instrucciones para ser enterrada en el panteón familiar, en el monasterio de San Jerónimo de Cotalba.

Pero, aun muerta y enterrada Damiata, Miquel Pérez y su hijo Joan prosiguieron la causa. Sobre todo a raíz de la muerte de Pere Cabrera y de su hijo Perot, que no sobrevivieron muchos años a Damiata. La sucesión al señorío de Rótova quedó entonces oscura, y más al encontrase muy cargado de censales, pues los censalistas pidieron que se ejecutara aquel, a fin de garantizarse el cobro de sus pensiones. Entonces Figuerola, aliado con su suegra, Margarita Gallach, presentó una opción de compra. Los Pérez, que tenían diversos instrumentos de procura y cesión tanto de Damiata como de Perot Cabrera, pleitearon contra de esa posibilidad, de modo que se acumularon dos procesos paralelos, uno en la corte de la Bailía General, yotro en la Audiencia valenciana.

Els Pérez volgueren evitar la previsible parcialitat dels jutges valencians, ben relacionats amb Gallach, i buscaren elevar la causa a instàncies superiors. El I508 passà el cas al Consell d'Aragó. Tanmateix, l'II de febrer del I5I2 arribà la sentència de la Reial Audiència de València, favorable a Ximén i Margarida. S’admeté la compra per part de Figuerola de la senyoria de Ròtova per preu de 50.000 sous. I així el jurista esdevingué senyor dels vassalls de la seua difunta dona. Pérez presentà recurs de suplicació davant el Consell d'Aragó, que demanà la comparecència de Figuerola. Tanmateix, la sentència definitiva, dada a 8 de juliol de 15 I3, confirmà la venda de Ròtova i ordenà la part contrària a pagar les costes judicials. ${ }^{203}$

Segons Abel Soler,

...en el transcurs d'aquella prolongada controvèrsia familiar, consta que Miquel havia enviat el seu fill Joanot, amb dos mules i un criat, a la cort del rei: primerament, a Sevilla i, després, a Valladolid. Allí tenia contactes el pare, en qualitat de receptor del Sant Ofici de València, però aquests foren insuficients per a guanyar el plet. En la dedicatòria a na Cirera, Miquel manifesta que aquesta li havia pregat traduir la vida de sant Vicent “pochs dies ans que partís per a la real cort” (Pérez I5IO: 2r). Aquest viatge de Miquel Pérez deu estar relacionat, com el del fill, amb les successives apel-lacions d'un litigi que acabà dirimint-se en presència del rei Ferran i dels seus assessors. ${ }^{204}$

La cronologia d'aquest afer de Damiata de Cabrera i el seu refugi a casa de la "vídua de mossén Figuerola" i de Miquel Pérez és un poquet fosca, ja que, quan hom situa el refugi de Damiata en casa de Dalfina Roís de Corella, la germana de l'escriptor encara no era vídua. Fins i tot, quan Damiata

203. Soler-Jordà 2005, IO6-IO7. Com a font s'esmenta Pardo Molero, J. F. De jurista a virrey: aproximación a la vida política y administrativa de Eximén Pérez de Figuerola (Valencia, c. 1470-Mallorca, 1538), treball de recerca per a la Universitat de València, 2006 (en premsa).

204. Soler 2OI4, I4O. Com a font s'hi indica ARV, Reial Audiència, processos, part. $3^{\text {a }}$, apèndix 783; i la mateixa obra inèdita de Pardo Molero De jurista a virrey. Per a Antoni Ferrando (2OI3b, IO9) i Tomàs Martínez (2OI2, I97), la partida a la cort referida en la dedicatòria a na Cirera seria d'ella, i no del traductor de La vida de sant Vicent Ferrer. 
morí a finals d'agost de I5OI deixant com a hereua la seua única filla Isabel ${ }^{205}$ Lluís Figuerola encara vivia.

De tota manera, la mínima variació cronològica que es pot donar en la datació d'aquest plet no és gaire transcendent. El realment important, al nostre parer, és que confirma que les relacions entre els Cabrera i els Corella continuaven a finals del segle XV i principis del segle XVI, després de la mort de Joan Roís de Corella i de la sentència arbitral de I49I dictada entre el monestir de Sant Jeroni de Cotalba i Pere de Cabrera, senyor de Ròtova i pare de Damiata Cabrera.

Respecte al grau exacte de parentesc existent entre Pere de Cabrera i l'escriptor Joan Roís de Corella, no el podem fixar amb total seguretat car, si bé podien ser cosins germans, al testament realitzat per Ausiàs de Cabrera en agost de I 436 no figura esmentat Pere com a fill seu; un fet tampoc concloent, perquè Pere podria haver nascut després d'aquesta data i abans de la mort d'Ausiàs de Cabrera ocorreguda entre l'agost de I448 i el mes de desembre de I45. Cal recordar, en aquest sentit, que Joan Roís de Corella fou nomenat amigable componedor en i 49 I per a sentenciar les diferències existents entre el monestir de Sant Jeroni de Cotalba i el cavaller Pere de Cabrera, i que la setència arbitral va ser llegida a les parts, el 2 d'abril de I49I, "en la casa e habitació" de Corella, actuant com a testimonis Lluís Figuerola, cunyat de l'escriptor, i Joan de Gallach. Així mateix, recordem que Miquel Pérez, en el seu testament de I498, nomenarà marmessor a Francesc Cabrera.

Respecte a l'Eiximén Pérez de Figuerola que pledejà amb Miquel Pérez, gendre de Joan Roís de Corella, cal dir que era fill d'Isabel Almenara i de Joan Figuerola ${ }^{206}$-a qui, molt probablement, cal identificar amb el germà homònim de Lluís Figuerola, cunyat de l'escriptor. Fou un dels prohoms més importants de la València del segle XVI segons Pardo Molero, qui resumeix així la seua trajectòria:

Nacido en València, en una familia del patriciado, se doctoró en derecho en Pisa en I494. Inició su carrera judicial en las asesorías del Justiciazgo de la capital y trabajando ocasionalmente para la Gobernación y la Audiencia real. En I509 sentó plaza como oidor de la renovada Real Audiencia y cinco años después pasó al Consejo de Aragón. En I520, vísperas de la guerra de las Germanías, volvió al reino como principal consejero del virrey, Diego Hurtado de Mendoza, y cabeza de una Audiencia que debía refundarse. Concluidas las Germanías, en las que luchó junto al virrey y la nobleza, dirigió la represión judicial y fiscal de los rebeldes con cargo de vicecanciller, el oficio más alto para un jurista en la Corona de Aragón. Mandó parte del ejército real en la guerra contra los musulmanes alzados en la sierra de Espadán en ${ }_{52} 6$ e intervino en los proyectos de defensa del litoral valenciano. Gracias a su experiencia y posición tuvo un protagonismo indiscutible en las Cortes de I528, después de las cuales reasumió sus funciones judiciales en Valencia, hasta que en I534, y esto es lo excepcional para un jurista, fue nombrado virrey de Mallorca, donde murió cuatro años más tarde (Pardo 2OI2, 77-78). ${ }^{207}$

Per a concloure amb aquest apartat, i havent assenyalat l'existència de confusions ja tradicionals -notariat, claveria de censals municipals sota el control del mestre racional, etc.- fruit de la

205. ARV, protocols, no. 345, not. Damià Burgal -27 d'agost de I5OI. Al seu testament va nomenar el seu marit i son pare Pere de Cabrera com a marmessors, i ordenà ser soterrada al monestir de Sant Jeroni de Cotalba. Eixe mateix dia, Damiata va fer un codicil nomenant Eiximén Pérez de Figuerola com a usufructuari dels seus béns fins que Isabel haguera 20 anys. El testament es publicà el 29 d'agost de I5Or. (Agraïsc al professor i amic Vicente Graullera la tramesa de totes aquestes dades del testament de Damiata Cabrera.)

206. Dada proporcionada pel professor Vicente Graullera.

207. Segons aquest mateix autor, en I 499 Eiximén Pérez de Figuerola va dibuixar un mapa de la Vall d’Albaida que constitueix la representació cartogràfica més antiga conservada d'una porció del territori valencià (Pardo 20I2, 79-80). 
coincidència onomàstica i cronològica de diversos personatges homònims, citarem un passatge de la tesi doctoral de Carme Arronis sobre l'escriptor Miquel Pérez, un continuador de la "valenciana prosa" corellana:

Poques són les dades que coneixem de la vida d'aquest autor valencià; i una de les dificultats principals, com ja Ferrando (1983: 196) féu notar, és que a la València de l’època hi hagué diferents personatges homònims, que, a més, exercien la professió de notari, com el nostre autor. (...) Alguns d’aquests càrrecs els exercí [Miquel Pérez] per designació directa del rei, cosa que duu a pensar que fou un personatge ben relacionat socialment i políticament.

La primera notícia que tenim sobre l'autor ens parla d'un jove Miquel Pérez participant en el certamen de I474, celebrat en lahors de la sacratíssima verge Maria. (...) Aquesta dada ens permet situar-lo per primera vegada en contacte amb el cercle de lletraferits que constituïa la quintaessència de la intel-lectualitat valenciana del segle xv: Roís de Corella, Bernat Fenollar, Jaume Gassull, Jaume Roig, Joan Moreno, Joan Verdanxa o Narcís Vinyoles, són només alguns dels noms dels participants en el certamen.

(...)

També altres de les seues produccions ens permeten conèixer els vincles socials, culturals i literaris que degué mantenir amb personatges de relleu en la València de l'època: la primera de les seues obres impreses, la Imitació de Jesucrist, publicada en I482, li la dedica a l'abadessa del convent de la Trinitat, sor Isabel de Villena, probablement un dels personatges erudits més destacats de la societat valenciana quatrecentista. El I 494 endreçà la Vida de la sacratíssima verge Maria a la muller de Joan Escrivà, mestre racional del regne de València i poeta de renom en els cercles valencians. Uns anys després, el I 499, s'edità la versió que realitzà de La vida de sancta Catherina de Sena, traducció que enllestí, segons declara en el pròleg, per precs de mossèn Fenollar, i que dedicà a les monges del monestir dominic de santa Caterina, edició que s'acompanya d'unes Cobles de Narcís Vinyoles, un altre dels personatges importants del poder municipal i del món cultural valencià. En I5IO, s'estampà la Vida de sant Vicent Ferrer, obra que dedicà a na Cirera d'Alpont, "muller del magnífic micer Pere d'Alpont, regent de la cancelleria y del consell del rey, nostre senyor", és a dir, tresorer reial.

Més enllà de les relacions que hi pogué establir amb personatges lletraferits de la València quatrecentista, cal esmentar també la participació en certàmens poètics i tertúlies literàries, és a dir, en la vida erudita i intel-lectual de la ciutat. Ja hem esmentat més amunt la intervenció en el certamen en Lahors de la verge Maria de l'any I474. Escrigué, probablement, una peça per un altre certamen en "prosa llatina" en honor de la Immaculada Concepció celebrat a la Seu de València en I488, i la composició poètica de Pérez que arreplega l'edició del I5I4 del Cancionero General d’Hernando del Castillo és una "Demanda", és a dir, una composició resultant del joc literari -pregunta/respostamantingut amb un altre autor, en aquest cas, Joan Verdanxa: "Demanda feta per Miquel Pérez a Joan Verdancha”. La fama del poeta i traductor devia ésser, llavors, coneguda entre el cercle erudit de la ciutat, cosa que justificaria la seua inclusió en la compilació.

Les dades documentades sobre l'autor ens presenten una figura ben relacionada políticament, exercint càrrecs de relleu en el govern de la ciutat. El I488 trobem Miquel Pérez elegit "clavari de censals", és a dir, administrador del deute públic de la ciutat, càrrec que el situava com a subordinat del mestre racional -aleshores Joan Escrivà-, i pel qual regia l'economia de les estructures municipals i actuava com a delegat del monarca a la ciutat (Ferrando I983: 196). El I49o Ferran el Catòlic el va nomenar, per manament directe, escrivà extraordinari de la cúria reial amb caràcter vitalici, en un moment en què hi eren vigents pragmàtiques que prohibien ampliar el nombre d'escrivans en aquell càrrec. El I5OI li és encarregada, de nou per exprés manament reial, la receptoria inquisitorial, també sota la jurisdicció de Joan Escrivà (Ventura 1978: I 42, I 46). Sembla confirmar-se, doncs, que gaudia de cert tracte preferencial per part del monarca, no sabem si afavorit per la bona relació que es dedueix amb Joan Escrivà, ja que els càrrecs solien estar sota la seua supervisió. El I5O2 va estar proposat, sense èxit, per al càrrec de justícia criminal, però, en canvi, el mateix any és elegit 
“administrador de l'obreria de Murs i Valls”, càrrec que tenia com a funció principal el manteniment de les ínfraestructures públiques de la ciutat, especialment de les muralles i els ponts (Ferrando I983: I96). L'any següent el trobem, a més, com a delegat dels jurats de València, participant en la resolució d'un conflicte ciutadà provocat per la carestia del blat, pel qual se l'havia enviat a Castella per comprar forment, juntament amb Jeroni Alegre, per tal d'alleugerir la situació (Belenguer Cebrià I976: 336-337). L'any I5I3 figura al llibre de la "Tacha Real” d'aquell any com a veí de la parròquia de ia Santa Creu i, un any després, el I5I 4 resulta elegit conseller de la ciutat per la classe de jurats vells, el que pressuposa que ja havia sigut conseller de la ciutat amb anterioritat. El I5I8 va exercir el càrrec de lloctinent del mostassaf de la ciutat, el tercer càrrec en la jerarquia municipal de l'etapa foral, després dels justícies i dels jurats, pel qual s'encarregava del desenvolupament econòmic (control de pesos i mesures, transaccions comercials, abastiment del mercat local amb queviures de bona qualitat...) i de la gestió urbanística (alineació de carrers, noves construccions, higiene i salubritat pública, etc). En darrer lloc, el I52O -última notícia que tenim de l'escriptor- fou elegit jurat de la classe de ciutadans per la parròquia de Sant Martí (Ferrando 1983: 196).

(...)

Tot plegat sembla apuntar que estava ben relacionat amb personalitats de l'àmbit polític i literari del moment, cosa que indica que gaudia d'un cert prestigi i renom com a integrant del sector de l'alta burgesia regnícola.

Sobta, però, que de les dades aplegades no hi ha cap evidència a hores d'ara que ens aporte llum sobre la formació de l'autor més enllà de la necessària per a exercir el càrrec de notari, especialment si tingué algun tipus de formació teològica específica, o, si més no, quina biblioteca devia posseir o a quines obres podia tenir accés. La majoria de les obres conservades, com hem vist, són eminentment de tarannà religiós, a diferència de la majoria dels autors contemporanis amb què es relaciona, com Fenollar o Vinyoles, entre d'altres, que alternaven la creació religiosa amb la profana. Tanmateix, Miquel Pérez sembla fer-se un ressò especial del clima espiritual de la tardor medieval, i es dedica al conreu d'obres de caire edificant, especialment hagiogràfiques, que es veuen especialment influïdes pel sentiment espiritual renovador de l'època, i pel gust estètic imperant (Arronis 20I2, 23-28).

\subsubsection{Isabel Martínez de Vera i els seus fills, Joan i Estefania}

El cavaller i mestre en teologia Joan Roís de Corella mai es va casar amb Isabel Martínez de Vera, filla del donzell de Cocentaina Diego Martínez de Vera. ${ }^{208}$ De la seua relació sentimental amb l'escriptor, constatada per Josep Guia almenys des de I469, ${ }^{209}$ varen nàixer dos fills, Joan i Estefania.

Desconeixem si Isabel Martinez de Vera era parenta de l'escuder Joan Martínez de Vera que, en el seu darrer testament rebut a Beniarjó el 25 d'octubre de I404 pel notari Francesc Fiscal, nomenà el poeta Pere March i Elionor de Ripoll com a hereus universals seus. Posseïa una casa a la parròquia de Sant Martí, per a la venda de la qual el matrimoni March va nomenar procurador seu Gerard Traver el I7 de febrer de I405 (AHN, Osuna, llig. II36, no. IO, not. Francesc Fiscal -I7 de febrer de I4O5).

Tampoc sabem amb seguretat, tot i que és molt possible, si era també parenta del cavaller i alcaid del castell de Guadalest Joan Martínez de Vera que, el I2 de novembre de I4I9, va reconéixer el lliurament, pel despenser del duc de Gandia, de I.Ioo sous per la "retinença" del castell de Guadalest (ARV, Mestre Racional, no. 9592, f. 6or) i que, el 8 d'octubre de I 422 al palau reial de València, lliurà 9Io sous procedents dels sarraïns de Guadalest a Guillem de Vilarig, despenser i col·lector general del duc de Gandia (AHN, Osuna, llig. I323 no. 7, not. Joan Lorca). Encara vivia 
aquest oficial ducal el 20 d'octubre de I43O, atés que en aquesta data Mahomat Bençuleyman, veí de Guadalest, aconseguí del batle general de València una lletra dirigida a Joan Martínez de Vera per tal que aquest no el detinguera quan hi anara a liquidar els seus deutes amb la finalitat d'aveïnar-se en terres de reialenc (ARV, Batlía, llibres, no. II47, f. 235 r).

Probablement fill d'aquest siga l'homònim escuder habitant de Xàtiva que, a València el i9 de juny de I448, en el seu nom propi i com a tutor i curador dels seus germans Nicolau i Úrsula, nomenà Jaume Ivars, ciutadà de València, com a procurador seu per a cobrar les pensions d'un censal carregat sobre certes terres de Finestrat. Aquest censal havia estat propietat de Francesca, difunta esposa de Joan Martínez de Vera, i aquell l'havia deixat als seus fills en el seu darrer testament (RCSCCV, protocols, no. I6704, not. Joan d'Aragó).

Segons Josep Guia,

És sabut que Joan Roís de Corella, cavaller i mestre en teologia, no estava casat amb Isabel Martínez de Vera, tot i que va tenir amb ella un fill i una filla, de noms Joan i Estefania, i va deixar a tots tres els seus béns, mitjançant la intervenció de la seva germana, Dalfina, que rebé el llegat i els en féu donació. Respecte a l'antiguitat de la relació entre Joan i Isabel, avui podem aportar uns documents que ens permeten atestar-la des de l'any I469, quan Isabel va comprar i arreglar una casa amb l'ajut dinerari de Corella. En efecte, el 3 de novembre de I469, Cristià Cardona, estanyer, marmessor dels béns d'Úrsula Canader, va vendre en pública subhasta a "Ysabel Martinez de Vera, filia magnifici Didaci Martinez de Vera, q ${ }^{\circ}$ domicelli”, per setanta lliures, un "hospicium [...] situm et positum in parrochia sancti Martini prenarrate civitatis, in vico vulgariter nuncupato de la verge Maria de Gratia [...] confrontatum cum hospicio venerabili Francisci Godall, prebiteri habitator dicte civitatis, et cum hospicio Francisce Rovira, uxoris Jacobi Rovira, q ${ }^{\circ}$ traginerii, et cum via publica”. Poc temps després, el I3 de juny de I470, Joan Roís de Corella, "miles et magister in sacra theologia", signava una àpoca a Isabel per les cinquanta lliures que li havia prestat de franc: "quas vobis graciose mutuavi ad opus emendi quoddam hospicium quod nunch vos possidetis, situm in vico de la verge Maria de Gratia”. No és estrany, doncs, que mestre Corella servés una especial afecció pel carrer de Gràcia, com ell mateix ens ho diu, canviant el motiu: "Havia la sol-licitud combatent així assetjat la mia sol-lícita pensa que no comportava (...) pensant com (...) poguésen alguna mínima part descriure la celsitud inestimable de la humil tostemps e verge intemerada, de Déu mare. Ab pensament de pensa tan alta endrecí los meus passos a la sua devota casa que de Gràcia se nomena, estimant que la influència de les sues gràcies en aquesta devota capella pus fâcilment sobre mi rosaria". Un altre document referent a transaccions econòmiques entre Joan i Isabel és la venda de 2.85o sous censals que fa el primer a la segona, la qual operació podria ser una manera discreta de cedir-li unes rendes.

En la documentació consultada, apareix que Isabel Martínez de Vera tenia quatre germanes: Dalfina, Úrsula, Joana i Violant. Dalfina consta com a beata, és la primera que apareix documentada i fa un primer testament en I466, amb un codicil posterior, on fa hereua sa mare, Caterina Campos, i on esmenta ses germanes Úrsula i Violant, però d’Úrsula ja no n’hem trobat cap més rastre. Dalfina i Joana figuren com a germanes, filles de Dídac, " $q^{\circ}$ domicelli ville Cocentayne", en un acte de venda de la primera a la segona. En un darrer codicil de Dalfina, posterior a un nou testament de data desconeguda, aquesta introdueix com a marmessora sa germana Joana. D'altra banda, Violant i Joana figuren com a germanes i reconeixen conjuntament un deute al notari Francesc Pintor; Violant, filla de Dídac, signa una àpoca a Joana, germana seva, ven 45 sous censals a Isabel, germana seva, i compra una casa al carrer de Carnissers. Quant al document de l'any I 494 comentat per Riquer, on apareixen les tres germanes Joana, Isabel i Violant amb l’àlias Dalfina, aquest àlias comú no vol dir que la mare es deia Dalfina (hem vist que es deia Catalina) sinó que les tres germanes possiblement actuaven com a legatàries d'algun bé que havia estat de llur germana Dalfina, morta el I48I; segons el document, venen 6o sous de violari a Pere Mascarell, assaonador, en presència de 
Pere Mascarell, estudiant, "filii vestri dicti emptoris et mei dicte Yolantis de Vera vendituris" i en presència, també, de "Johannis Roiz de Corella, filii magnifici magistri Johannis Roiz de Corella, magistri in sacra theologia”. Així, doncs, dues de les germanes, Isabel i Violant, es feren acompanyar dels seus fills a cal notari.

La saga femenina del llinatge Martínez de Vera compta amb una altra representant: Eliseu Martínez de Vera, monja, filla de Joan, cavaller de Cocentaina, i germana de Joan, donzell habitant d'Alzira, i d'Alfons, donzell habitant d'Elda, després batlle d'Alacant. Si el cavaller Joan Martínez de Vera i el donzell Dídac Martínez de Vera, tots dos de Cocentaina, ja morts l'any I462, fossin germans, aleshores Eliseu, Joan i Alfons serien cosins germans de Dalfina, Úrsula, Joana, Isabel i Violant. No és estrany, doncs, que la cosina Eliseu, monja, i la germana Dalfina, beata i virtuosa, no veieren amb bons ulls la relació d'Isabel amb Corella, per molt mestre en teologia que fos aquest, però que "no és casat ni per casar", per usar una expressió del Col-loqui de dames, que ve molt al cas.

L’any I479, Isabel Martínez de Vera nomena procurador seu Miquel Pérez, ciutadà de València, present de testimoni Francesc Despí, notari; anys a venir, el I498, trobem Miquel Pérez actuant amb els germans i el fill de Corella, absent Isabel, en la liquidació d'un censal que Corella havia venut al noble Gisbert Pardo: "Sit omnibus notum quod ego Gisbertus Pardo, nobilis habitatoris civitatis Valencie, instante e requirente vobis magnifico Joanne Roiç de Corella, domicello [...] recognosco vobis magnificis Joanni Roiç de Corella, militi et in sacra theologia magistro $q^{\circ}$, et Ludovico Roiz de Corella, Dalfine Figuerola, uxori magnifici Ludovici Figuerola, militis, Miquaeli Perez, civi, et Ysabeli Martinez de Vera, absentibus, et vobis jamdicto Joanni Roiz de Corella, domicello, presenti... (Guia 2003). ${ }^{210}$

Algunes dades més podem afegir per a completar la informació referida per Guia sobre la família

2IO. Els documents esmentats per Guia en el seu article corresponen als següents documents de la secció documental: $266,268,303,306,347,35^{2}$ i 359 .

Altres documents referits a Dalfina, Violant i Joana Martínez de Vera en què es basa Josep Guia són:

; Nomenament de procurador fet per Dalfina Martínez de Vera el 23 de juny de I462 (RCSCCV, protocols, no. 2255O, not. Francesc Pintor -23 juny I 462).

* Testament de Dalfina Martínez de Vera, filla del difunt donzell de Cocentaina Diego Martínez de Vera, fet el r8 de juny de I466 (ARV, protocols, no. I84I, not. Francesc Pintor -I8 juny I466).

* Codicil testamentari de Dalfina Martínez de Vera fet el 27 de desembre de I468 (RCSCCV, protocols, no. 22547, not. Francesc Pintor -27 desembre I468).

* Venda de Dalfina Martínez de Vera a la seua germana Joana de 3 o sous censals de violari realitzada el 24 de gener de I474 (RCSCCV, protocols, no. 22549, not. Francesc Pintor -24 gener I474).

* Reconeixement de deute al notari Francesc Pintor per part de les germanes Violant i Joana Martínez de Vera fet el 2 de desembre de I476 (AHG, protocols, not. Lluís Collar, microfilm rotlle 29, -2 desembre I476).

* Pagament de 3 o lliures, part d'aquelles 35 lliures amb què Dalfina Martínez de Vera, qualificada de beata, va comprar una casa a la parròquia de Sant Martí (AHG, protocols, not. Lluís Collar, microfilm rotlle 29, -I8 juliol I477).

: El prevere Joan Martínez, beneficiat a la Seu de València, dóna una paga de 200 sous anuals a Dalfina Martínez de Vera, beata, mentre visca ell, pels serveis prestats a ell i per la vida casta i honesta portada per Dalfina (AHG, protocols, not. Lluís Collar, microfilm rotlle 29, -I5 setembre I477).

* Àpoca de Violant a Joana Martínez de Vera, la seua germana, per 23 lliures, 4 sous, 6 diners, que Violant havia despés en obres per ella fetes a la casa de Joana on Violant vivia (RCSCCV, protocols, no. 22556, not. Francesc Pintor -I6 desembre $147^{8}$ ).

* Violant, filla del donzell Diego Martínez de Vera, ven a la seua germana Isabel 45 sous censals carregats sobre dues cases de Violant a la parròquia de Sant Martí: una al carrer de Gràcia -sota domini directe de Bertomeu de Cruilles- i, l'altra, al carrer dels Archs (AHG, protocols, not. Lluís Collar, microfilm rotlle 3O, -I 4 gener I479).

* Venda realitzada, el 3 de febrer de I479, per Francesc Aguiló, menor de dies, a Violant Martínez de Vera d'una casa al carrer de carnissers de València, a la parròquia de Sant Joan del Mercat, per preu de 3 olliures (ARV, protocols, no. I845, not. Francesc Pintor -3 febrer I479).

* Codicil testamentari de Dalfina Martínez de Vera fet el iz de març de i48ı. Fou publicat el 20 de març d'eixe any per mort de la testadora (RCSCCV, protocols, no. 22552, not. Francesc Pintor -I7 març I48I). 
Martínez de Vera:

* El i9 de gener de I463 Úrsula, esposa del donzell Guillem Celma, lloga a Eliseu Martínez de Vera, filla de Joan Martínez de Vera -difunt cavaller habitant de Cocentaina-, una casa seua situada a la parròquia de Sant Esteve per espai de dos anys a raó de 7 lliures anuals (RCSCCV, protocols, no. 22546, not. Francesc Pintor -I9 gener I463).

* El 3 o d'octubre de I466, a Alzira, Joan Martínez de Vera, senyor de Rafalet -al terme d'Alzirai Francesca, la seua esposa, tots dos habitants d'Alzira, venen a Joan de Vilanova, també veí de la població, una heretat situada part al terme d'Alzira i part al terme de Corbera -prop del lloc anomenat Montcada- per preu de $5 \cdot 5$ Oo sous. ${ }^{211}$

* El I3 de gener de I475 Joana Martínez de Vera vengué a Maria -vídua de Domènec de Decho i ara esposa de Joan de Castellví, "panipator" - una casa al carrer de Santa Maria de Gràcia, per preu de 15 lliures (RCSCCV, protocols, no. 22554, not. Francesc Pintor). Joana és qualificada de beata en $5_{503}$ (doc. 399), i ens consta que en I5O9 vivia una filla seua anomenada Elena (doc. 427).

El 8 de juliol de I483 Joana Martínez de Vera signa una àpoca a Francesc Aguiló, de l'ofici del Mestre Racional de València, en raó d'uns censals (RCSCCV, protocols, no. 22557, not. Francesc Pintor -8 juliol I483).

En quin moment arribaren els Martínez de Vera a València des de Cocentaina? Per a alguns, seria en I462, i la relació d'Isabel amb Corella s’iniciaria entre I462 i I464 (Soler 2013, 6I8; Domènech et al. 2OI4, IO5) i, tot i que Guia diu que el pare d'Isabel ja seia mort en I462 (fet que podria ser una data de referència per a l'arribada dels Martínez de Vera a València des de Cocentaina), també és cert que alguns aspectes del testament de Dalfina Martínez de Vera realitzat en I 466 suggereixen una presència anterior a València de la família Martínez de Vera. Passem a veure’ls:

Sabem que el I8 de juny de I466 (és a dir, quatre anys després de I462) Dalfina Martínez, filla del difunt donzell de Cocentaina Diego Martínez i germana d'Isabel, establí un testament on nomenava com a marmessors la seua mare Caterina Campos i el religiós Francesc Cassió. ${ }^{212}$ Elegí ser sepultada en "lo vas o ciminteri" del convent de Sant Francesc on eren soterrats "tots los meus antecessors". Deixava diferents quantitats a repartir entre els pobres, i llegava a la seua germana Violant zo lliures per a entrar en un convent o perquè es casara, mentre que, a la seua germana Úrsula, li donava II lliures. En la resta dels seus béns nomenava hereua unversal la seua mare Caterina Campos. No esmenta ni deixa cap llegat a Isabel Martínez de Vera.

$\mathrm{El}_{27}$ de desembre de I468, Dalfina redacta un codicil (RCSCCV, protocols, no. 22547, not. Francesc Pintor -27 desembre I468) on elegeix com a marmessors Caterina Campos i els notaris Joan Adzuara i Lluís Collar. Llega 80 reals a sa germana Úrsula i, respecte a on desitja ser soterrada, afirma que ja no vol ser soterrada en lo vas del seus antecessors en Sant Francesc, sinó "en lo vas o ciminteri que novament los frares del dit monestir, concordantment en capítol, me han donat e atorgat; lo qual vas està en la sglésia major, prop lo altar de monssènyer Sent Bernardí”.

El I7 de març de I48I, Dalfina torna a establir un codicil, que es va publicar el 20 de març següent, per mort de la testadriu (RCSCCV, protocols, no. 22552, not. Francesc Pintor -I7 març I48I). Hi ordena que els seus marmessors no venguen res sense el consentiment de la seua germana Joana

2II. AHN, Clero Secular Regular, carpeta 3i67, no. I5. Aquest document de venda es realitzà davant el notari Narcís Martí, d'Alzira.

2I2. El document es localitza en ARV, protocols, no. I84I, not. Francesc Pintor -I8 juny I466-, i no en RCSCCV, protocols, no. I84I, not. Francesc Pintor-I8 juliol I466- indicat en Guia 2003. 
Martínez de Vera. Deixa a la seua cosina Francina Mir 200 sous i, al monestir de Sant Francesc, un altar i un retaule per a la capella que Dalfina havia al dit monestir, on havia de mostrar-se un "davantal [...] e una tovallola [...] quant se farà festa o solempnitat en la dita capella".

Si ens fixem, en I466 i I 468 Dalfina parla d'un vas on estan soterrats "tots los meus antecessors", i d'una capella al convent de Sant Francesc i, fins i tot, d'un acord del franciscans per a donar-li un nou vas dins l'església major, dades que suggereixen una relació estreta amb el convent de Sant Francesc, i una presència o sojorn estable i de llarg temps dels Martínez de Vera en el cap i casal; i no d'una presència en la ciutat com a nouvinguts des de Cocentaina al voltant de I462, data en què ja figura com a mort el pare d'Isabel i Dalfina Martínez de Vera. A més a més, cal dir que, en alguns documents, Diego Martínez de Vera figura com a habitant de València ${ }^{213}$.

Respecte a Eliseu, la filla del cavaller de Cocentaina Joan Martínez de Vera de qui també parla el text de Josep Guia, tan sols podem dir que el document que s'hi esmenta sobre ella datat el 22 de desembre de I462, i el que nosaltres hem referit de I 463 , ens permeten afirmar que, en I462-I463, ja tenia més de 20 anys, que és l'edat legal segons els Furs per a la capacitat individual jurídica plena de contractar i realitzar accions comercials.

Amb una ciutat atacada per la pesta, el 3I d'agost de I478, el mateix dia en què Joan Roís de Corella lliurà a Miquel Pérez 55 oo sous "deguts” del dot de Magdalena, la seua filla major, el cavaller i mestre en teologia va dictar el seu darrer testament, i ja hem comentat a bastament que no hi esmentava Isabel ni els fills tinguts amb ella. Com ja hem comentat, cinc mesos després, el I 4 de gener de I479, probablement en "compensació" per no ser esmentada en el testament i com un pas més en la seua estratègia de preparar el futur d'Isabel Martínez de Vera i els seus fills, Corella donà i transportà a Isabel diferents censals per valor de 3.65 o sous. ${ }^{214}$ Eixe mateix dia, la seua germana Violant Martínez de Vera també lliurà a Isabel 45 sous censals, carregats sobre dues cases de Violant a la parròquia de Sant Martí: una al carrer de Gràcia -sota domini directe de Bertomeu de Cruilllesi, l'altra, al carrer dels Arcs (AHG, protocols, not. Lluís Collar, microfilm, rotlle 3O, -I4 gener I479).

Recordem que el cavaller i mestre en teologia Joan Roís de Corella morí el 6 d'octubre de I497; i que dies després, el Io d'octubre, Dalfina Roís de Corella, com a hereua universal del seu germà, va fer donació inter vivos de tots els béns de l’herència a Isabel Martínez de Vera, així com d'una casa a la parròquia de Sant Martí sota el domini directe de la confraria de la Santíssima Trinitat i de Sant Miquel Arcàngel, anomenada dels peraires, a cens de 9 sous anuals. Aquesta casa feia marge amb dues cases de Lluís Figuerola i una via pública (doc. 362). Com acabem de comentar en l’apartat d'aquest article dedicat a Joan Roís de Corella (per això no repetirem ací els motius i l'estratègia jurídica que expliquen la donació de Dalfina Roís de Corella), encara en juny de I5O2, Dalfina i Isabel hagueren de declarar davant el Justícia Civil que el valor de l'herència del poeta, llevats els corresponents càrrecs, era menor de 5.Ooo sous. El Justícia Civil féu declarar sota jurament tant a Dalfina com a Isabel que la referida donació s'havia fet sense dol o en frau dels creditors (doc. 393).

Ja el 23 i 24 de febrer de 1498 trobem Isabel Martínez de Vera exercint com a donatària dels béns de l'escriptor, i lliurant a Dalfina, la germana del poeta i hereua seua universal, diferents censals en raó de certs deutes contrets amb la germana de Joan Roís de Corella (docs. 369 i 363 ).

En els dies següents, Isabel es dedicà a la venda de censals com a manera de millorar la seua

2I3. Així figura en els següents documents esmentats en Guia 2003: AHG, protocols, not. Lluís Collar, microfilm, rotlle 29, -I5 setembre I477 -; AHG, protocols, not. Lluís Collar, microfilm, rotlle 30, -I 4 gener I479.

2I4. Doc. 3 OI. Guia parla de 2.85 O sous. 
economia després del traspàs de l'escriptor. Així, el 7 d'abril de I498, Isabel, juntament amb Joan Roís de Corella i Estefania, el seus fills nascuts de la relació amb el lletraferit, vengué 90 sous censals i rendals per 6o lliures a Beatriu Albiol, com a hereua de Joan Albiol i d'Agnés, els seus pares difunts (doc. 364). Aquesta venda de censals es realitzà amb el permís de Bertomeu de Cruïlles, ciutadà de València, atés que era el senyor directe d'una casa d'Isabel Martínez de Vera situada a la parròquia de Sant Martí, en el carrer de la Verge Santa Maria de Gràcia, donada com a garantia hipotecària del referit censal. L'establiment realitzat per Bertomeu a Isabel va ser rebut pel notari Joan Beneyto el ro de gener de I484, sota cens de 4 sous i 6 diners al referit Bertomeu. La casa afrontava amb l'esmentat carrer de Santa Maria de Gràcia, amb una altra casa d'Isabel i amb la séquia del monestir de Sant Agustí i "vico medii" (doc. 364). Era la casa que el 3 de novembre de I469, l'estanyer Cristià Cardona, ciutadà de València, com a marmessor del darrer testament d’Úrsula Canader, li havia venut per preu de zo lliures, i que l'escriptor Joan Roís de Corella li havia ajudat a comprar i reformar (docs. 264 i 266 ).

El I3 de setembre de I5O4, Isabel Martínez de Vera i els seus fills vengueren al notari Martí de Roda, per escriptura rebuda pel notari Beromeu Iviça, aquesta casa i hort en el carrer de Santa Maria de Gràcia sota directa senyoria del difunt Bertomeu de Cruilles. En I5O2, sabem que afrontava amb la casa de "na Johana Martines de Vera, beata, e huy, del noble don Baltazar de Castellví, de una part, e de l'altra part, ab casa del rector de Sant Thomàs, ab carrera pública de la Verge Maria de Gràcia, e l'ort, ab les matexes afrontacions, e a les spal-les, ab carrer dels Sans" (doc. 43I). Aquesta informació ens permet saber que, probablement, Isabel va vendre o cedir a sa germana Joana l'altra casa que posseïa al carrer de la Verge de Gràcia, i que feia marge amb la casa sota senyoria directa de Cruïlles.

Segons el testament del ciutadà Miquel Ferrer fet el 2I de juliol de I487, aquest havia una casa al carrer de Santa Maria de Gràcia que afrontava amb casa d'Isabel Martínez de Vera, amb dos carrers i amb casa de Violant Martínez de Vera (RCSCCV, protocols, no. 24995, not. Jeroni Tovia). Aquest Miquel Ferrer és el pare d'Àngela qui, mort el seu progenitor, va establir l's de juny de I 499 unes capitulacions matrimonials amb Bertomeu Figuerola i els seus pares, Lluís Figuerola i Dalfina Roís de Corella.

Els límits donats a aquesta casa i a l'altra contigua d'Isabel Martínez de Vera fan que puguem ubicarles, respecte al plànol de Tosca (Gavara, 2OO3, 2O7), en l'illa d'edificis que formen el carrer de la Verge Maria de Gràcia amb el carrer en Sans i carrer de la Torre de les Pelades, i que correspon, actualment, a l'espai situat entre l'avinguda Baró de Càrcer, el carrer músic Peydró -que és la continuació del vell carrer de Santa Maria de Gràcia-i el carrer en Sans.

Aquestes cases del carrer de la Verge Santa Maria de Gràcia no són les úniques propietats inmobiliàries d'Isabel Martínez de Vera a la parròquia de Sant Martí.

Sabem que el I5 d'octubre de I498, Isabel adquirí de l'artesà Miquel Nicolau i de la seua esposa Isabel Desplà, veïns de València, una casa situada també a la parròquia de Sant Martí però en el carrer de Sant Vicent, al costat de la porta de la muralla del mateix nom i davant l'església del monestir de Sant Agustí, sota la senyoria directa del monestir de Montaragó a cens de I 4 sous anuals. ${ }^{215}$ El preu de venda de la casa -que afrontava amb casa de Margarita de Monsoriu, vídua del cavaller Baltasar Bou, "cum muro dicte civitatis vico medio et cum dicto vico dicto de Sanct Vicent et a posteriori parte cum vico del mur dicte civitatis ex alteris partibus" - va ser de I 281 liures. ${ }^{216}$ Isabel va lliurar en un primer moment 43 lliures, Io sous (doc. 370) a Nicolau, i es comprometé a pagar-li

2I5. Doc. 378. Isabel va prometre quitar el referit cens en el termini de quatre anys (doc. 379).

2I6. Doc. 367. Aquests límits també figuren als documents 37I, 374 i 418 de la secció documental. 
la resta el I5 de novembre següent; però sembla ser que tardà més que no esperava, car Isabel i els dos fills seus abonaren 28 lliures que quedaven a pagar el 3I d'agost de I5OO (doc. 380). Uns dies després, Miquel Jordà va donar permís a Isabel per a fer obres en l'estructura arquitectònica d'aquesta casa (doc. 38I). El 3I d'agost de I5Oo i el I6 de desembre de I5OI, Isabel i els seus fills vengueren a Miquel Nicolau i la seua esposa diversos censals com a mitjà d'abonar el deute que encara tenien per la casa del carrer de Sant Vicent comprada en octubre de i 498 (docs. 380 i 389 ). També vengueren un censal de 233 sous i 4 diners sobre aquesta casa al cavaller Nicolau Ferrando (doc. 390). Tan sols serà el 20 de desembre de I5OI quan Nicolau signe una àpoca reconeixent el total pagament del deute. ${ }^{217}$

L'endarreriment en el pagament ens pot indicar l'existència de problemes econòmics en la vida d'Isabel Martínez de Vera; sobretot si els lliguem amb el retard de més d'un any que també va patir el pagament del censal de 90 sous venut a Beatriu Albiol i abans esmentat. ${ }^{218}$ No degué ser fâcil per a Isabel viure a la València del segle XV sense ingressos regulars i amb dos fills nascuts fora d'un matrimoni eclesiàstic.

El límits assenyalats en la documentació medieval per a aquesta casa del carrer de Sant Vicent ens permet identificar, amb total seguretat, la seua ubicació en els actuals carrers de la ciutat de València: estaria en l'encreuament del carrer Xàtiva amb la plaça de Sant Agustí, dins de l'espai ocupat ara per l'anomenada pels valencians "finca de ferro", concretament en la cantonada que fan el número I del carrer de Xàtiva i el número 3 de la referida plaça. ${ }^{219}$

Al mateix temps que Isabel carregava censals sobre la casa del carrer de Sant Vicent, cercava ingressos monetaris mitjançant el lloguer de les cases del carrer de Mossén Corella, igual que ja havia fet el cavaller i mestre en teologia anys enrere, probablement en el moment de traslladar-se definitivament al convent de Sant Francesc. ${ }^{220}$ En aquest sentit podem dir que consta documentalment que, el 25 de maig de I50I, Isabel Martínez de Vera llogà a Gaspar Joan de Monsoriu, donzell habitant de València, certes cases ubicades a la parròquia de Sant Martí, concretament al carrer anomenat de Mossén Corella, per temps de quatre anys a partir de I502, a raó de I2 lliures anuals (doc. 387). Aquestes cases afrontaven amb casa de Lluís Figuerola, séquia dels beguins i amb l'esmentat carrer de Corella; i cal identificar-les, per tant, amb les cases en què va viure Corella, atés que els seus límits coincideixen amb els de les cases que l'escriptor reservà per a si en el document de donació en I487 a Dalfina Roís de Corella. ${ }^{221}$

Les demandes judicials per l'impagament de pensions de censals entre Isabel Martínez de Vera, els seus dos fills i diferents persones seran una constant, entre $5_{500}$ i I509, en els organismes judicials del regne, tant en la cort de la Governació com en la cort del Justícia Civil de la ciutat de València. Aquest fet ens mostra que, a mesura que s'avançava en el s. XVI, la seua situació econòmica empitjorava.

Així, coneixem plets amb Joan Martorell -senyor de Beniarbeig- en I5Oo (doc. 376); amb Beatriu Aguilona, Baltasar de Castellví, Nicolau Ferrando i Guillem Exernit en I5O3 (docs. 4OI, 4O2, 403 i 405); amb Gabriel Andreu àlies Rosell, Antoni Ciscar -veí de Pego-, mossén Pere March -senyor de Beniarjó- i Maria Magdalena de Cruilles -filla i hereua del ciutadà Bertomeu de Cruïlles- en I5O4

2I7. Doc. 368 . Aquest censal finalment va ser quitat en I5I4 pel donzell Lluís Roís de Corella, germà del poeta Joan Roís de Corella, qui, en eixe moment, el posseïa (doc. 390).

2I8. El 8 de juny de I499 Beatriu Albiol confessarà haver rebut les 6o lliures (doc. 364).

2I9. Vid. la seua ubicació a la reproducció del plànol de Tosca que figura supra, a finals de l’apartat 3.I.

220. Cal recordar que, quan Dalfina fa l’inventari de béns del seu germà difunt, en la casa de Corella hi havia un llogater.

22I. Doc. 329. Com ja hem advertit prèviament, fer marge amb la séquia dels beguins és igual que fer marge amb el carrer de Rotlons, per on aquella passava. 
(docs. 406, 407, 408 i 4IO); Baltasar de Castellví, Miquel Joan Monyino, Nicolau Ferrando i Lluís Lladró en $\mathrm{I}_{5} \mathrm{O} 5$ (docs. 4I3, 4I4, 4I5, 4I6 i 4I7); Brianda de Vilaragut i de Centelles -muller de Joan de Sentlir Centelles- en I5o6 (doc. 423); Lluís Lladró i Nicolau Ferrando, en I5O7 (docs. 424 i 425); Isabel de Castellví en I5o8 (doc. 426); Lluís Lladró, Anna Isabel de Castellví i Nicolau Ferrando en I5O9 (docs. 427, 428 i 429).

En ocasions, alguns d'aquests plets judicials ens donen informació sobre els béns -i la situació económica, en general- d'Isabel Martínez de Vera i dels seus fills, ja que els demandants, en no ésser pagats, sol-licitaven la venda en pública subhasta de llurs béns. El més freqüent era, per part dels creditors, demanar la subhasta de la casa d'Isabel situada al carrer de Sant Vicent de la ciutat de València, "davant la porta de Sent Agostí” i que estava sota el domini directe de l'abat de Montaragó. Així es demana en juliol de I5O $_{5}$ i el 20 d'agost de I5O $_{7}$ pel procurador del cavaller Nicolau Ferrando (docs. 4I5 i 425).

És el cas també, per exemple, d'un plet de juny de I5O5 (doc. 413), on el notari Jaume Pellicer - procurador de Baltasar de Castellví- esmenta, com a béns d'Isabel i els seus fills, el lloguer o propietat d'algunes terres i cases -sota directa senyoria de Berenguer Amalric, a cens de 7 soussituades totes elles en Meliana, i la propietat o lloguer d'una casa a la parròquia de Sant Martí “en lo carrer apellat de Sent Vicent confrontada ab lo portal de Sent Vicent, ab lo mur carrera pública en mig, e ab lo portal de la sglésia de Sent Agostí carrera pública en mig e ab casa de na Margarita Bou”. El ıo de setembre de I5O5, el porter Pasqual Bernabeu anà a la casa del carrer de Sant Vicent on, a preguntes seues, una dona -probablement Estefania Roís de Corella- contestà "que la alqueria no és sua ni sap si la casa és sua". ${ }^{222}$ De la resposta donada per un membre de la família CorellaMartínez de Vera es pot deduir que, almenys les propietats de Meliana, no eren seues -el senyor directe era Berenguer Amalrich, parent de Jaume Garcia d'Aguilar i del seu fill Francí d'Aguilar (Cuñat 2005)-, tot i que és posible que sojornara en alguna ocasió a Meliana, com pot deduir-se d'un document de Isabel datat en I5O3 on figuren com a testimonis dos habitants d'aquest lloc (Guia 2002, 187 ).

Per a cobrar els deutes menors, la cort de la Governació venia béns mobles que hi havia a casa d’Isabel. Això va passar en I509, quan el noble Lluís Lladró els va reclamar un deute de 55 sous i la cort va vendre per aquest preu "hun mig coffre pintat, huna stora d'espart de peus e hun mattalafet chich de llana, hun pagès de fust e huna altra estora d'espart e dos cadires de costelles" (doc. 427). Joana, la germana d'Isabel, qui estava present en la inscripció judicial d'aquests béns va intentar aturar-la, al.legant que els béns eren de sa filla Elena, però no ho va aconseguir. Aquest document ens mostra que, en gener de I509, Isabel Martínez de Vera no volia o no podia assumir el pagament ni de I5 sous.

Respecte a l'altra casa d'Isabel en el carrer de Gràcia, tenim una notícia on aquesta casa participà, com veurem, en la solució d'una obligació i compromís del difunt poeta Joan Roís de Corella.

Dalfina Roís de Corella i Isabel Martínez de Vera feren donació el i6 de setembre de I 499 a Úrsula, vídua de Miquel Vendrell, de totes les quantitats pecuniàries procedents del lloguer que havia

222. Malgrat que, en un moment determinat, en el document s'anomena "Margarida Corella” a Isabel Martínez de Vera, pensem que la dona que al document figura, el dia Io de setembre, com "magnífica [en blanc] Corella” i que va respondre al porter Bernabeu és Estefania, atenent tant al cognom, com a la vaguetat d’una part de la seua resposta i al fet que ella vivia amb la seua mare en aquesta casa del carrer de Sant Vicent. 
de pagar d'una casa de la dita Isabel, situada al carrer de la Verge Maria de Gràcia i que afrontava amb altra casa d'Isabel Martínez de Vera i amb la casa de Jerònim Fenollar. Aquesta donació duraria fins que morira Pere Joan Vidal, fill del mercader Pere Vidal, i, en cas de morir, cessaria la donació; però la vídua Vendrell hauria de percebre 8o lliures que, a Pere Joan Vidal, li donava Joan Roís de Corella segons constava en un memorial escrit de pròpia mà pel mestre en teologia (doc. 373).

Desconeixem quins són els motius exactes d'aquest lliurament monetari de Corella a Pere Joan Vidal però, si identificàrem el mercader Pere Vidal amb l'escuder Pere Vidal, es podria tractar del reconeixement corellà als serveis prestats per un escuder que sembla haver format part del cercle de confiança del lletraferit, juntament amb Bertomeu Chiva. Aquest escuder és testimoni, en I475, de la publicació per Corella del darrer testament de sa mare (doc. 250); és testimoni, també, en la redacció del darrer testament de mestre Corella en I478 (doc. 299); i, per últim, figura com a testimoni al costat de Chiva en actes notarials del literat fets en I480 (doc. 28I). Tenia el cavaller Roís de Corella un escuder al seu servei, o era simplement un amic? No ho sabem amb seguretat.

En I503, Pere Joan Vidal, el nét d’Úrsula Vendrell, havia mort, i la família Martínez de Vera-Corella va haver de fer front a la clàusula establida per Joan Roís de Corella. El ı2 d'abril, Isabel, la seua germana Joana -beata- i els fills d'Isabel, Joan Roís de Corella -cavaller de l'orde de Sant Jaume de l'Espasa- i Estefania -donzella-, en nom seu propi i com a posseïdors dels béns de Joan Roís de Corella, cavaller i mestre en teologia, s'obliguen a Úrsula Vendrell, vídua de Miquel Vendrell, a donar-li, al llarg de set anys, 83 lliures, I5 sous i 4 diners a raó de I2 lliures anuals, excepte l’últim any en què li donaran el que restara. Aquesta quantitat, es comprometien a donar-li-la per la bona memòria de Joan Roís de Corella, qui, en el moment de la seua mort, va prometre lliurar a Pere Joan Vidal, nét de la dita Úrsula (si viu era), o a Úrsula (si aquest moria), aquestes quantitats de diners per certes causes contingudes en un memorial escrit pel propi Corella. ${ }^{223}$

En total, Isabel Martínez de Vera va arribar a posseir cinc cases, totes a la parròquia de Sant Martí, de València: la del carrer de Sant Vicent en front de la porta del convent de Sant Agustí; les dues de l'escriptor al carrer de Mossén Corella, i les dues al carrer de la Verge Santa Maria de Gràcia -un carrer que, com dirà Corella en La visió a la porta de la Senyora Nostra de Gràcia, del I487 (Wittlin I995), acaba en la porta de la capella existent al mateix convent agustinià, dedicada a la Verge de Gràcia, una de les devocions més importants en la València de l'època.

Com és sabut, entre els béns del difunt prosista i poeta inventariats per la seua germana Dalfina Roís de Corella figuraven uns pocs mobles i censals i els 78o volums del Cartoixà que tenia Corella, a la cambra del monestir de Sant Francesc, en morir.

Sabem que alguns d'aquests censals havien pertangut a Saura d'Esplugues, la besàvia de Joan Roís de Corella. En efecte, a finals de l’any I5oo, Isabel Martínez de Vera figura al costat dels seus fills, el donzell Joan Roís de Corella i Estefania, en la venda a Melcior Demont, doctor en lleis i habitant com ells de València, de 250 sous anuals de violari durant les vides d'ell i d'Àngels Perpinyà, la seua esposa. El preu d'aquest violari va ser de 87 lliures i io sous (doc. 383) i, en raó de les pensions d'aquests 25 o sous anuals de violari, Isabel i els seus dos fills li transferiren tots els drets d'Isabel contra Garcia Gomis, pel lloguer d'una casa d'ella situada al carrer de la Verge Maria de Gràcia, pel qual aquell havia de donar a Isabel 4 lliures, II sous i 8 diners en març i setembre de I5OI. Així mateix, també li cediren tots els seus drets i accions contra Joan Martorell, donzell senyor de Çot, "ad exactione" de 66 sous i 8 diners, que havia de donar a Isabel en abril de I5O i en

223. Doc. 399. Per desgràcia, deconeixem el contingut d'aquest memorial i els motius de l'ajuda de Corella: pagament de serveis prestats, ajuda a uns familiars d'un servidor o amic en situació de pobresa.... 


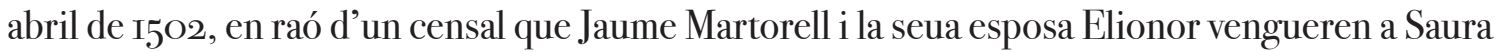
d’Esplugues -besàvia del cavaller i mestre en teologia Joan Roís de Corella- per 4o lliures, i que va ser carregat davant el notari de Gandia Pere Belsa el 2I d'abril de I 435 (doc. 384).

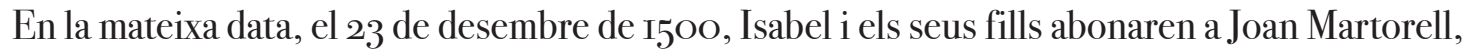
donzell i senyor del lloc de Cot en l'horta de Gandia, 66 sous i 8 diners censals. Aquest censal havia pertangut a Saura d'Esplugues, esposa de Pere Roís de Corella, qui el va llegar al seu darrer testament al seu fill Ausiàs. Posteriorment, d'acord amb el testament d'aquest, passà a mans de Joan Roís de Corella, cavaller, mestre en teologia i pare dels fills d’Isabel Martínez de Vera (doc. 385).

Com ja hem dit, a la cambra del monestir de sant Francesc Corella tenia 780 volums del Primer i del Quart del Cartoixà. La quantitat de volums era gran, però la demanda popular d'eixa obra era prou important com per a fer-la apetitosa als llibreters. Per tant, no és estrany que Isabel considerara el treball intel-lectual de Joan Roís de Corella com una font d'ingressos afegida als censals i a les dues cases que havien pertangut a l'escriptor, i que ara eren seues via donació inter vivos. Tampoc és estrany, com ja hem apuntat abans, que també el propi Corella els considerara una font d'ingressos per als seus descendents.

Escassament als tres mesos de la mort de l'escriptor, concretament el 23 de gener de I498, Isabel va vendre 78o llibres "in lingua materna" del Cartoixà, és a dir de la traducció feta per Joan Roís de Corella, al llibreter de València Joan Caulet ${ }^{224}$ per 237 lliures i r9 sous. Caulet li lliuraria 5 o lliures en la propera festa de Tots Sants, i la resta en el termini de 3 anys. ${ }^{225}$ Encara l'i de març de I5OO, l'esmentat llibreter devia a Isabel Martínez de Vera les quantitats acordades, i aquesta va cedir, en raó d'aquest deute, tots els seus drets contra el llibreter a Solera de Ferrer, esposa del cavaller Lluís Ferrer -lloctinent del Governador General del regne de València i comprador del lloc de Sot a Elionor Flors de Vallterra, a qui l'escriptor dedicà la seua Història de santa Magdalena- (doc. 375). Segons Josep Guia,

el 3I d'agost de I5oo, Isabel Martínez de Vera i altres dos creditors de Joan Caulet pacten amb aquest una concòrdia per tal que aquest vengui a la seva botiga els llibres que té en dipòsit d'aquells i que, així, vagi pagant els deutes. A la fi del document, figuren les corresponents anotacions de cancel-lació, la darrera de les quals, de data 27 de febrer de I503, diu així: 'la dicta na Ysabel Martínez de Vera, tenint-se per contenta de les dites cent cinquanta huit lliures, en lo tercer capítol confessades deure per lo dit mestre Johan Caulet, cancella lo notari, tenint en presents per testimonis moro Guillem Tammar, negre, e Pere Sancho, scuder, habitadors de Meliana' (2002, I87). ${ }^{226}$

Si al poc temps de morir Corella, Isabel Martínez de Vera va mantenir relacions comercials amb el llibreter Caulet en relació amb uns volums del Cartoixà, en I5o6, en un moment econòmic encara més difícil per a Isabel i els seus fills, la veurem novament tractant amb Caulet, amb qui, probablement, no

224. De Caulet cal recordar aquesta altra dada: segons Sanchis Sivera (I93I-32, 4, IO7), Joan Caulet “y los mercaderes Jaime Salvat, Antonio Robinet i Franch Febrer, nombran árbitro en 23 de Febrero de I 495 por cierta cuestión originada con motivo de certis libris stampe florum sanctorum que éstos vendieron al primero. Sigue la sentencia de los árbitros. Caulet compró 2 I6 ejemplares de flos sanctorum que resultaron viciosos". Com a font documental, Sanchis Sivera esmenta un protocol de Joan Casanova conservat al Reial Col-legi Seminari de Corpus Christi de València.

225. Doc. 374. Entre els testimonis d'aquesta escriptura figura el llibreter Ramon Escrivà; aquest també actuarà com a testimoni al doc. 375 .

226. Com a font arxivística, Guia esmenta el protocol I3632 de Pere Cerveró custodiat al Reial Col-legi Seminari de Corpus Christi de València. 
deixà de mantenir relacions comercials.

El 28 de gener de I506, Isabel, a qui el notari qualifica de "vídua”, vengué al llibreter Joan Caulet per 4 lliures, 5 diners “tota la part dels libres que ella té en una ceda feta de mà del dit Caulet". Entre els llibres esmentats en dita ceda figuren seixanta Cartoixans, tres Flors de virtuts, un Vita Christi, quatre salteris en grec, una Summa angelica, un Ysopet, un Compendio theologia, dos Bernardos ad sororem, dotze llibres d'hores francesos i un Tirant lo Blanc. Aquests llibres eren d'Isabel Martínez de Vera, de Bertomeu de Cars i de Jerònim Pérez, a qui, probablement, es puga identificar amb el fill homònim de Magdalena Roís de Corella i de l'escriptor Miquel Pérez. Isabel va vendre a Caulet la seua part,

ab XXXV Cartoxans propris de la dita senyora los quals stan ab los dessús dits libres en una caxa que-s tanca en manera que no-s veu on se ha de posar la clau si no·n saben. E si los dits XXXV Cartoxans no són en la dita caxa que, en tal cars, los dits Cartoxans no sien venuts sinó que sien de la dita senyora a on se vulla que sien e, si n’i ha més dels dits XXXV Cartoxans en la dita caxa, que sien de la dita senyora (doc. 420$)$.

Per un document del mes de maig del mateix I5o6 sabem que, entre els llibres propietat d'Isabel, hi havia exemplars del Segon del Cartoixà -imprés en l'any I5OO-, i que Caulet els va portar a Nàpols, segurament per a la seua venda (doc. 42I).

Com ja hem exposat a l'apartat 3.I, no tenim documentació arxivística que ens concrete l'any en què Isabel es va convertir en l'amistançada de Joan Roís de Corella; però, en la nostra opinió, cal situar l’inici de les relacions amoroses entre ells als voltants de I469. ${ }^{227}$

No sabem, tampoc, amb seguretat quan varen nàixer els seus fills Joan i Estefania. Per a alguns investigadors, "esta [Isabel Martínez de Vera] va arribar a València durant la primavera del I 462 i, pocs anys després, va concebre de Joan Roís de Corella la seua primogènita Magdalena, (...) Poc després, vingueren al món Joan i Estefania, els dos fills menors de la parella" (Domènech et al. 2OI4, IO5). Com hem vist, Magdalena, nascuda en I459, no és filla d’Isabel Martínez de Vera.

Riquer afirma (i ara com ara i fins que no es trobe nova documentació, estem d'acord amb ell) que el naixement de Joan -el fill del literat- hagué de produir-se al voltant de I $473-\mathrm{I} 474,{ }^{228}$ o un poc abans (Riquer I964, 3, 259) si cal datar l’inici de la relació amorosa en una data propera a I469 (Guia 2003). El primer document on l'hem trobat esmentat és el document del mes d'agost de I 494 de què parla Riquer, i on figuren les germanes Joana, Isabel i Violant Martínez de Vera amb l'àlies comú de "Dalfina", àlies que per a Guia -amb qui estem d'acord- es deuria a què les tres germanes possiblement actuaven com a legatàries d'algun bé que havia estat de llur germana Dalfina (doc. 352). Com també afirma aquest autor, el violari venut hauria la duració de les vides de l'estudiant Pere Mascarell -fill de Violant Martínez de Vera- i de Joan Roís de Corella, fill d’Isabel Martínez de Vera i del mestre en teologia Joan Roís de Corella.

A partir de desembre de I5OI, Joan Roís de Corella, el fill de l'escriptor, apareix com a cavaller de

227. Cal recordar en aquest sentit que, en juny de I466, la seua germana Dalfina, la beata de vida honesta, ni l'esmenta en el seu testament, i és possible que això poguera estar relacionat amb la seua relació amb Corella.

228. Com bé pareix advertir Josep Guia (2003), en el doc. 366 de la secció documental datat en I 498 consta el fill de l'escriptor instant el quitament del censal fet en I486, però aquest no figura entre els signants en I486. De tota manera, encara que haguera participat en el seu establiment, això no voldria dir que, en eixe moment, tinguera almenys 20 anys -i que, per tant, hagués nascut, com a mínim, en I466- perquè cal recordar que la participació en l’administració del propi patrimoni -i l'establiment d'un censal ho era-, es podia donar una volta complits els i5 anys; fet que, com a molt, ens situaria en I47 (Furió et al. I994, 80). Com hem dit, en I 498 el fill de Corella tan sols figura instant el quitament. 
l'orde de Sant Jaume de l'Espasa. No sabem des quina data concreta ho era. ${ }^{229}$ No tenim constància que es casara, i encara vivia el I8 de juliol de I5o9. ${ }^{230}$

Són escassos els documents on Joan, el fill d'Isabel i del lletraferit valencià, no figure esmentat al costat de sa mare i la seua germana Estefania. Dos n'estan relacionats amb les reclamacions judicials fetes en $\mathrm{I}_{5} \mathrm{O} 3$ i I5O5 per pensions degudes, en raó de 6o sous de violari carregats pel jove comanador de Sant Jaume de l’Espasa -juntament amb el cavaller Lluís Carbonell-a Àngels Perpinyà, esposa del noble Bernat de Riusec (docs. 404 i $4 \mathrm{I} 8$ ).

En la nostra opinió, entre els documents on figura el fill de Corella sense la seua mare ni la seua germana, cal destacar-ne dos.

El primer és el document, datat el 27 d'octubre de I495, on el mestre en teologia vengué juntament amb el seu fill un violari a Caterina de Riusec, esposa del mercader Jofre de Riusec. ${ }^{231}$ Com ja hem dit abans, no coneixem altre document en què es produïsca aquesta actuació conjunta de pare i fill i, al nostre parer, és una prova documental que el cavaller i teòleg no deixà de preocupar-se pels seus fills i per Isabel Martínez de Vera.

El segon és, des del punt de vista literari, molt més important i està datat el I5 de maig de I5O6 -i no el I3 de maig de I5O2, com sempre s'havia afirmat des que Carreres Calatayud (I949, 625-626) va donar notícia d'aquest document amb una data equivocada i una localització arxivística també errònia. Es tracta de la llicència atorgada a Joan, el fill del mestre en teologia i d’Isabel Martínez de Vera, pels jurats de València per a poder imprimir una obra del seu pare sobre "los Passis":

Dicto die [divendres 15 de maig de 1506]

Los magnífichs jurats et síndic [... $]^{232}$ en Johan Alegre, attenent que lo reverent mossén Johan Corella, quòndam, féu e ordenà una bella obra sobre los Passis la qual lo fill de aquell vol fer estampar per ço proveexen que nengú altre sinó aquell stampar e fer stampar aquella dita obra dins terme de dos anys, sots pena de X lliures e perdre la dita obra.

Testimonis, Agostí Mo(n)yós e Johan Noguera. ${ }^{233}$

El moment cronològic en què el fill de Corella demana i obté aquest privilegi d'edició en exclusiva coincideix en el temps amb els contactes documentats de sa mare amb el llibreter Joan Caulet, i amb moments de precarietat econòmica d'Isabel i els seus fills. Segons Antoni Ferrando (20I3a, 648), Joana Martínez de Vera, germana d'Isabel, contribuí -entre d’altres persones, segons Ferrando- a publicar aquesta "obreta inèdita del pare, Lo Passis ab la glosa en romans, de set fulls".

229. Doc. 389. Segons les aportacions d’Antonio Sánchez Gijón en la seua biografia de Pere Lluís Escrivà, sembla que l'edat límit per a ingressar a l'orde de Sant Joan estava fixada en els iz anys, si bé molts fills “segundons” de famílies importants aconseguien ordenar-se, amb algunes prerogatives, als I2 anys (Sánchez I995, I72-73, apud Parisi 20ogb, I47).

23o. Doc. 429. La lectura directa de l'inventari de béns d'un Joan Roís de Corella, cavaller de Sant Jaume de l’Espasa, fet l'i de maig de I520 (RCSCCV, protocols, no. I5792, not. Joan Munyoz) i esmentat per Guia (I999, 6I), m’ha fet rebutjar la identificació, plantejada per Guia i que en algun moment jo mateix he defensat, del fill de Corella amb aquest Joan - germà bastard de Roderic, comte de Cocentaina- casat en I5I8 amb Beatriu de Vilanova. De tota manera, agraïsc sincerament el treball de l'amic que fa anys, quan no vaig poder veure personalment el document, me'l va resumir.

23I. Doc. 357. Document esmentat en Guia 2003. Figuren com a testimonis d'aquesta venda fra Antoni Cevilla i fra Francesc Maça, frares del convent dels franciscans de València.

232. Paraula abreujada de lectura dificultosa.

233. Doc. 422. Com hem dit, la notícia d'aquesta llicència d'impressió va ser donada per Francesc Carreres Calatayud (I949, 625-26). La datà, erròniament, en el dia I3 de maig de I5O2, i la localitzà en un manual de consell de l’Arxiu Municipal de València on mai no ha estat. 
Probablement, cal identificar aquesta obra amb el "libret de emprempta ab cubertes de pregamí, lo qual és los Passis aromançats" que figura en l’inventari de béns, fet entre maig i juny de 1520 , de Joan, germà bastard de Roderic Roís de Corella, comte de Cocentaina (Guia I999, 6I). ${ }^{234}$

Respecte a Estefania, la filla del mestre en teologia i d'Isabel Martínez de Vera, apareix sempre a la documentació com a donzella i al costat de la seua mare, amb qui vivia, i del seu germà (docs. 364, 380, 383, 384, 385, 389, 39O, 4OI, 4O2, 4O3, 4O5, 4IO, 4I3, 4I5, 4I6, 4I 7, 423, 425, 426, 427, 428 i 429).

No sabem quan va nàixer, però pareix ser menor que el seu germà. Encara era viva el juliol de 5509 (doc. 429) i no tenim notícia que es casara.

\section{Secció documental}

I373. Gandia.

Pere Roís de Corella, besavi patern de l'escriptor Joan Roís de Corella, rep, com a membre de la casa del marqués de Villena, 74 sous pel seu servei amb dues bèsties.

Arxiu del Regne de València (ARV), Batllia, llibres, no. II592, f. I5r.

2

I379, juliol, 20. -I379, desembre, 7. Gandia.

Berenguer Torres, receptor general de les rendes i drets de les moreries del comtat de Dénia, paga a Pere Roís de Corella, alcaid del castell de Gallinera, 1500 sous "los quals deu haver per retinença del dit castell segons los ha acostumat haver en tres terces. E ha-y àpoques fetes per en Ramó Dalmau, notari, la una a XX dies de juliol, l'altra a VII dies de deembre de l'any MCCCLXXIX".

ARV, Mestre Racional, no. 9824 , f. 26 r. ${ }^{235}$

3

I379, setembre, 20. Gandia.

Berenguer Torres, receptor general de les rendes i drets de les moreries del comtat de Dénia, paga a Joan de Cabrera perordre del marqués de Villena 12240 sous "per preu d'aquells MXX sous que.l senyor marqués lifahia de cens mort cascun any, e d'aquells IIII mília sous que mossén Xemén Pèreç [...] haví censals sobre Palma, los quals pagarà en Pere Carbonell dels drets de sa cullita cascun any, e són carregats a rahó de XII sous per M, segons per carta de revenda e àpoqua feta per en Ramon Dalmau, notari de Gandia, a XX dies de setembre, any MCCC setanta-nou".

234. La font de les afirmacions de Guia es RCSCCV, protocols, no. I5792, not. Joan Munyoz -I maig I52O - 2I juny I52O.

235. Document publicat en Argente 1987, 304. 
ARV, Mestre Racional, no. 9824, f. 3 Ov. ${ }^{236}$

4

I379, octubre, 8. Gandia.

Berenguer Torres, receptor general de les rendes i drets de les moreries del comtat de Dénia, paga a Pere Roús de Corella per ordre del marqués de Villena 1000 sous "los quals lo senyor marqués lifa cascun any rendals, los quals són carregats sobre l'alqueria del Patró de la vall de Gallinera".

ARV, Mestre Racional, no. 9824, f. 2 IV. $^{237}$

5

I379, desembre, I2. Gandia.

Berenguer Torres, receptor general de les rendes i drets de les moreries del comtat de Dénia, paga a Joan de Cabrera per ordre del marqués de Villena 200 sous com a salari anual del seu ofici de procurador de Pere March, procurador general del marqués.

ARV, Mestre Racional, no. 9824 , f. $28 \mathrm{v} .{ }^{238}$

6

I38I. Gandia.

Els oficials de la cort del marqués de Villena abonen a Joan Roís de Corella, de casa del marqués, diverses quantitats de diners per quitació d'una bèstia amb la qual Roís de Corella havia servit al marqués en maig, juny, agost $i$ setembre.

ARV, Mestre Racional, no. 96oI, ff. I33V, I5Ir, I55r, I7Or i I92r.

7

I383, febrer, 5. Gandia.

Els oficials de la cort del marqués de Villena abonen a Joan Roís de Corella 18 sous i 9 diners "per messió [...] feta al senyor comte a Cullera anant a Gandia".

ARV, Mestre Racional, no. 9590 , f. $64 \mathrm{v}$.

8

I386, octubre, 26. Gandia.

Joan March, fill de Pere March, reconeix als jurats de Gandia el lliurament de tots aquells 250 sous censals que a ell lifeia la vila. Com a testimonis figuren.Joan Roís de Corella i Bernat Garrigas, de casa del marqués.

Arxiu Històric Nacional (AHN), Osuna, llig. I324, no. 2, not. Guillem Ferrer.

236. Document publicat en Argente 1987, 3 IO

237. Document publicat en Argente 1987, 307.

238. Document publicat en Argente 1987, 309 .

Magnificat CLM I, 2OI4, III-377. ISSN 2386-8295 
9

I386, novembre, 3. Gandia.

Joan de Cabrera, com a procurador de Joan March - de casa del marqués de Villena-, reconeix haver rebut de Francesc Cerola, despenser de la vila de Gandia, 250 sous deguts de la paga de Tots Sants per raó d'un censal de 500 sous pagador en dues meitats. L'escriptura de procuració va ser signada, davant el notari Guerau Utal, a Biar el зo d'octubre de 1386.

Arxiu Històric de Gandia (AHG), pergamins, no. 78. ${ }^{239}$

IO

I387, octubre, IO. Gandia.

Mossén Pere March, cavaller i senyor de Beniarjó, reconeix haver rebut de Francesc Cerola, despenser de la vila de Gandia, 250 sous anticipats de la paga de Tots Sants d'un censal de 500 sous pagador en dues meitats. Figura com a testimoni Joan de Cabrera.

AHG, pergamins, no. 8I. ${ }^{240}$

II

I388, juny, 20. Gandia.

Joan Roús de Corella, membre de la casa del marqués de Villena, com a fill i hereu del seu difunt pare Pere Roís de Corella i, així mateix, com a tutor i curador testamentari dels seus germans Pere, Alfons, Manuel i Joana segons consta pel testament de Pere fet a Gandia l'n de febrer de 1384 davant de Jaume Vilavella -notari de la vila ducal-, lliura a sa mare, Saura d'Esplugues, 1400 sous censals i anuals que a Pere Roís de Corella i a ell feien diverses persones. Aquest lliurament es va fer en pagament $i$ solució de 16.000 sous, part d'un dot total de zo.ooo sous que Saura va portar al matrimoni, i de 15.00o sous de creix que Pere Roís de Corella va confessar i reconéixer a la seua dona.

AHN, Osuna, llig. II36, no. $5^{\mathrm{I}-4}$, not. Francesc Fiscal.

$\mathrm{I} 2$

I388, juny, 23. Gandia.

Saura d'Esplugues reconeix al seu fill Joan Roís de Corella el lliurament de 1400 sous censals anuals com a paga i solució del seu dot.

AHN, Osuna, llig. II36, no. $5^{\mathrm{I}-4}$, not. Francesc Fiscal.

I3

239. Document publicat en Olaso 1987,36 .

240. Document publicat en Olaso 1987, 36 .

Magnificat CLM I, 2OI4, III-377. ISSN 2386-8295 
I388, octubre, I9. Gandia.

Joan Roís de Corella, habitant de Gandia, nomena procurador seu Pere Matern àlies Çavila. Matern habitava en l'alqueria de Benieto, propietat de Roís de Corella.

AHN, Osuna, llig. I323, no. 4, not. Miquel Burgal.

I4

I388, octubre, 30. Gandia.

Esteve Amat i Flor, la seua esposa, veïns de Gandia, venen a Saura d'Esplugues, vídua de Pere Roís de Corella -habitant de Gandia-, 5 o sous anuals de violari durant la seua vida i la de Joan Roís de Corella, el seu fill, per preu de 350 sous. ${ }^{241}$

AHN, Osuna, llig. I323, no. 4, not. Miquel Burgal.

I5

I388, desembre, I. Gandia.

Castili Garberà, pescador, i Nicolasa, la seua esposa, veïns de Gandia, reconeixen a Saura d'Esplugues, vídua de Pere Roís de Corella, el lliurament de 350 sous en raó de la venda de 50 sous censals i rendals de violari durant la vida de Saura i el seu fill.Joan Roís de Corella. ${ }^{242}$

AHN, Osuna, llig. I323, no. 4, not. Miquel Burgal

I6

I390, juny, II. Gandia.

Saura d'Esplugues, vídua de Pere Roís de Corella, i Joan Roís de Corella, el seu fill, reconeixen deure a Pere de la Rochella, barber del marqués de Villena, i a la seua esposa Celestina, 2.20o sous pels quals Pere de la Rochella i la seua esposa van vendre a Joan Roís una casa a Gandia.

AHN, Osuna, llig. Iı 36 , no. $6^{\mathrm{I}}$, not. Francesc Fiscal.

I7

I390, setembre, 7. Gandia.

Saura d'Esplugues, vídua de Pere Roís de Corella habitant de Gandia, i Joan Roís de Corella el seu fill, col-loquen en matrimoni a Joana, filla de Pere i Saura i germana de Joan Roís, amb Bernat Domènech, fill de Guerau Domènech, habitant d'Alcoi, establint com a dot 2000 florins comuns d'Aragó equivalents a 2200 o sous reials de València. En preu d'ells, li donen aquells 1000 sous censals que a Saura feia Bernat Escorna ${ }^{243}$ sobre el lloc de Pedreguer-situat en terme de Dénia. Per la seua

241. El mateix dia, en dues escriptures notarials diferents, per un costat Esteve Amat i Flor, esposa seua, reconeixen a Saura d'Esplugues el lliurament de 35 o sous; i, per l'altre, aquesta reconeix a l'esmentat matrimoni el lliurament del violari i obliga els seus béns (AHN, Osuna, llig. I323, no. 4, not. Miquel Burgal).

242. Eixe mateix dia, Saura d'Esplugues reconeixia el lliurament del violari obligant els seus béns per a pagar les pensions anuals (AHN, Osuna, llig. I323, no. 4, not. Miquel Burgal).

243. Bernat Escorna és el pare de Joana Escorna, segona esposa del poeta Ausiàs March. Sobre aquest senyor de 
banda, Bernat Domènech dóna a Joana 10oo florins comuns d'Aragó equivalents a 11000 sous.

AHN, Osuna, llig. Iı36, no. 4, not. Joan Lorca.

I8

I39I, desembre, s.d. Gandia. ${ }^{244}$

En els llibres comptables de la cort del marqués de Villena figuren, entre d'altres, les següents rebudes pecuniàries fetes al mes de desembre: "Ítem, d'en Pere Martorell, per la carta de la sua col.lecta, XX sous";" "Item, de mossén Andreu Castellà, per mudar la carta de l'acostament de sa muller, III sous, IIII [diners]"; "Item, d'en Johan Rö̈z de Corella, per mudar la carta de la alcaydia, III sous, IIII [diners]".

ARV, Mestre Racional, no. 9600, f. I24v.

I9

I39I, desembre, 25. Gandia.

Bernat Domènech, fill de Guerau Domènech, habitant d'Alcoi, reconeix a Saura d'Esplugues, vídua de Pere Roís de Corella, habitant de Gandia, i al seu fill Joan Roís de Corella, que d'aquells 22.0oo sous que a ell van constituir en dot de Joana, filla d'ella i germana de Joan Roís, tan sols queda donar-li 2.0oo sous d'aquells 4.000 sous que el marqués de Villena donà graciosament a Joana pel seu matrimoni. Així mateix, Bernat reconeix a Saura i a Joan Roís de Corella el lliurament, com a part del referit dot, 1.ooo sous censals que Bernat Escorna feia a Saura d'Esplugues sobre el lloc de Pedreguer.

AHN, Osuna, llig. II36, no. $6^{5}$, not. Francesc Fiscal.

$2 \mathrm{O}$

I392, gener, 23. Gandia.

Pere Martorell, col.lector dels drets del marqués de Villena, abona el seu salari a Joan de Cabrera, lloctinent de Pere March-procurador general del marqués de Villena. ${ }^{245}$

ARV Mestre Racional, pergamí de l’any I392.

$2 \mathrm{I}$

I394, març, I9. Gandia.

Joan Roís de Corella, de casa del marqués de Villena, reconeix a Margarida, vídua de Francesc Seguí - de casa del marqués de Villena-, el lliurament de з.ooo sous, preu pel qual es van vendre a Joan Roís

Pedreguer i la seua filla, vid. Chiner $1997,353-82$.

244. Molt probablement, totes les rebudes que figuren en aquesta regesta es realitzaren a partir del "digmentje a III dies de deembre del dit any ·XC hu. [quan] lo senyor marqués fou tornat en Gandia” (ARV, Mestre Racional, no. 96oo, f. I34V).

245. Document publicat en Villalmanzo I995, 253. 
de Corella 250 sous censals.

AHN, Osuna, llig. I323, no. 5, not. Joan Lorca.

22

I394, abril, I5. Gandia.

Saura d'Esplugues, vídua de Pere Roís de Corella, reconeix a Ramon Castellà, fill de Ramon Castellà id'Aldonça, el lliurament de 2.400 sous, preu pel qual es va vendre a Saura 200 sous censals.

AHN, Osuna, llig. I323, no. 5, not. Joan Lorca.

23

I394, octubre, 27. Castell d'Aiora.

Als llibres comptables de Guillem Martorell, despenser del marqués de Villena i avi del novel-lista Joanot Martorell, s'assenta un pagament a Joan Roís de Corella "de casa del dit senyor" pel seu servei durant zo dies.

ARV, Mestre Racional, no. 9592, f. I 45 v.

24

I396, gener, I3. Gandia.

Testament de Joan March, fill del poeta Pere March. Nomena com a marmessors.Joan Roís de Corella-alcaid del castell de Gallinera-iJoan de Cabrera, habitants de Gandia, avis de l'escriptor Joan Roís de Corella. Es va publicar el 23 de febrer de 1398, sis mesos després de la mort del testador, davant de Pere March i dels marmessors del difunt, entre d'altres persones. ${ }^{246}$

AHN, Osuna, llig. II37, no. 5, not. Esteve Corts.

25

I396, abril, 8. Gandia.

Joan de Cabrera, avi de l'escriptor Joan Roís de Corella, figura com a testimoni en un document on Violant March, com a procuradora del seu marit Joan March segons constava en escriptura davant el notari Gonçalbo Çaplana feta a Gandia el 17 de gener de 1387, reconeix a Roseta, vídua del cavaller Pere de Thous, el lliurament de 484 sous d'aquells 968 sous censals anuals que feien al seu espòs, Joan March.

Arxiu de la Catedral de València (ACV), pergamins, no. $199^{8}$.

26

I396, agost, 28. Gandia.

246. Document publicat en Villalmanzo 1999, 212.

Magnificat CLM I, 2OI4, III-377. ISSN 2386-8295 
Joan Roís de Corella, habitant de Gandia i alcaid del castell de Gallinera, reconeix a Pere Martorell, col-lector del marqués de Villena per als sarraïns del comtat de Dénia, el lliurament de 750 sous part d'aquells 1.50o sous que li havia de donar anualment de les pecúnies del castell en dos pagues.

AHN, Osuna, llig. II36, no. 7, not. Francesc Fiscal

27

I397, desembre, 20. Gandia.

Pere Martorell, col-lector dels drets del marqués de Villena, abona el seu salari a Joan Roís de Corella com a alcaid del castell de Gallinera. ${ }^{247}$

ARV Mestre Racional, pergamí de l'any I397.

28

I398, març, 22. Gandia.

L'escuder Domènec Ferrandis, Caterina -vídua de Pere Vidal- i Violant-vídua de Guillem Corona-, tots ells sevidors del difunt Joan March, fill de Pere March, reconeixen a Joan Roís de Corella i a Joan de Cabrera, habitants de Gandia i marmessors testamentaris del difunt, el lliurament dels salaris deguts -571 sous. ${ }^{248}$

29

I398, març, 22. Gandia.

L'escuder Domènec Ferrandis, Caterina -vídua de Pere Vidal-i Violant-vídua de Guillem Corona-, tots ells sevidors del difunt Joan March, fill de Pere March, reconeixen a Joan Roís de Corella i a Joan de Cabrera, habitants de Gandia, com a marmessors testamentaris del difunt, el lliurament de 25 alnes de pany negre perquè ells i Alena, esclava del difunt, es vestiren de dol. ${ }^{249}$

I398, abril, 20. Gandia.

Fra Arnau Cortal, prior del monestir de Sant Jeroni de Cotalba, reconeix a Joan Roís de Corella i a Joan de Cabrera, habitants de Gandia, com a marmessors testamentaris del difunt Joan March, el lliurament de 200 sous, part d'un total de 1.000 sous en què es tasaven les 1.000 misses de rèquiem que el difunt havia establit al seu testament. ${ }^{250}$

247. Document publicat en Villalmanzo I995, 262.

248. Document publicat en Fullana 1936 , I5 $5^{\mathrm{I}} 5^{2}$. Com a font documental, Fullana dona “Arch. Hist. Nac. OsunaGandia, II72".

249. Document publicat en Fullana 1936, I52. Com a font documental, Fullana dona "Arch. Hist. Nac. Osuna-Gandia, II 72 ".

250. Document publicat en Fullana I936, I52. Com a font documental, Fullana dona “Arch. Hist. Nac. Osuna-Gandia, $\mathrm{II} 72$ ".

Magnificat CLM I, 2OI4, III-377. ISSN 2386-8295 
I398, maig, 2. Gandia.

Vicent Sorio, prevere de l'església de Gandia, reconeix a Joan Roís de Corella i a Joan de Cabrera, habitants de Gandia, com a marmessors testamentaris del difunt.Joan March, el lliurament de 40 sous, part d'un total de 1.000 sous en què es tasaven les 1.000 misses de rèquiem que el difunt havia establit al seu testament. La quantitat abonada era per un total de 40 misses celebrades. ${ }^{251}$

32

I398, juliol, 6. Gandia.

Pere Martorell, col-lector dels drets del marqués de Villena, abona el seu salari a Joan de Cabrera, lloctinent de Pere March-procurador general del marqués de Villena.

ARV, Mestre Racional, pergamí de l'any I398. ${ }^{252}$

I399, juliol, I2. Gandia

Joan de Cabrera, habitant de Gandia, acorda amb Bertomeu Rufes, piquer de Xàtiva, la realització per preu de 120 florins d'Aragó d'una capella en l'església de Xàtiva.

AHN, Osuna, llig. II36, no. 9, not. Francesc Fiscal.

34

I4OI, desembre, I3. Gandia.

Joan de Cabrera -habitant de Gandia-, com a procurador d'Aldonça, vídua de Ramon Castellàmenor de dies-i en qualitat d'hereua universal de la seua mare Violant March-vídua de Bonafonat de Vallebrera-, reconeix haver rebut de Bertomeu Martí, despenser i clavari de la vila de Gandia, 200 sous censals deguts de la paga de novembre. L'acte de procuració de Joan de Cabrera va ser signat davant el notari Bertomeu Bonet en València el 10 de desembre de 1397.

AHG, pergamins, no. IO4. ${ }^{253}$

35

I403, maig, I7. València.

Capítols de l'arrendament de terres en Moncada i Massarrojos entre Berenguer March, mestre de Montesa, i els "prohòmens" de Moncada i Massarrojos. Entre els signants de l'escriptura d'arrendament figura fra Manuel Roís de Corella, majordom del mestre de Montesa.

25. Document publicat en Fullana 1936, I53. Com a font documental, Fullana dona “Arch. Hist. Nac. Osuna-Gandia, $\mathrm{II} 72$ ".

252. Document publicat en Villalmanzo 1995, 264.

253. Document publicat en Olaso 1987, 39. 
AHN, Ordes Militars Montesa, manuscrits, no. 542-C, ff. $1944^{\mathrm{r}-\mathrm{I} 98 \mathrm{v} .}{ }^{254}$

36

I404, març, I8. Gandia.

El marqués de Villena dicta una sentència relativa als diferents debats i qüestions sobre el camí del barranc anomenat de Benirrugat i sobre les terres "heremes" del dit barranc en presència de Joan de Cabrera, lloctinent de mossén Pere March-procurador general ducal-, i els jurats de Gandia. Tant Pere March com els jurats havien estat comissionats pel duc de Gandia per a entendre i reconéixer personalment el camí i terres subjectes al plet. ${ }^{255}$

ARV, Mestre Racional, no. 9568, ff. IOIr-IO2r.

37

I404, setembre, I6. Gandia.

Sentència atorgada pel marqués de Villena en un plet entre Garcia Sànchez, veí de Dénia -com a tutor i curador dels fills de Joan Sànchez, tambéveí de Dénia-, i Mateu d'Iviça, veí de Gandia, en raó de l'hostal i alfondec d'Ondara. Joan de Cabrera figura com a testimoni.

ARV, Mestre Racional, no. 9568, ff. I34V-I43v.

$3^{8}$

I4O4, setembre, 22. Gandia.

Joan Roís de Corella, habitant de Gandia, reconeix a Francesc Verderes, veí de Gandia, el lliurament de 100 sous com a paga d'un censal.

AHN, Osuna, llig. Ir36, no. Io, not. Francesc Fiscal

39

I4O4, octubre, 2. Gandia.

Alfons, marqués de Villena i duc de Gandia, ordena a Joan de Cabrera, lloctinent de mossén Pere March -procurador general ducal en el regne de València- que done sentència en les diferències existents entre Pere Celler, habitant de Polop, i el notari de Callosa Jaume Ivarç, major de dies, en raó d'un compromís incomplit, segons Celler, per Jaume Ivars.

ARV, Mestre Racional, no. 9568, ff. I48rv.

40

I4O5, març, 2. Gandia.

254. Document publicat en Díaz 1987, 443-49.

255. Document publicat en Camarena I959-6I, 75-76.

Magnificat CLM I, 2OI4, III-377. ISSN 2386-8295 
Saura d'Esplugues, vídua del venerable Pere Roís de Corella, habitant de Gandia, i Joan Roís de Corella, el seu fill, habitant també de Gandia, reconeixen deure a Jacmeta de Poblet, vídua de Pere Guillem Català-cavaller i habitant de València-, 1.000 sous en raó de certa casa situada en la vila de Gandia.

AHN, Osuna, llig. II36, no. Io, not. Francesc Fiscal.

$4 \mathrm{I}$

I4O5, octubre, 6 . València.

Berenguer d'Ortoneda, justícia de Gandia, es dirigeix al Justícia de València per a informar-lo que Berenguer Francesc de Pertusa, habitant de Gandia, li ha mostrat una carta pública signada el 9 de setembre de 1404 i rebuda pel notari Ramon Agualada, on apareix que Berenguer Francesc de Pertusa, en nom de Lluís de Pertusa -antic habitant de Gandia i ara de València-, va vendre a Joan Roís de Corella 100 sous censals per preu de 6o lliures amb el compromís que Lluís de Pertusa quitaria dit censal en el termini d'un any. Atés que ha passat l'any i s'ha incumplit el referit compromís, Berenguer Francesc de Pertusa ha requerit al justícia de Gandia perquè sol.licite al Justícia de València l'establiment d'un manament executori contra Lluís de Pertusa.

ARV, Justícia Civil, no. 2333, mà 5, sense foliar.

42

I407, gener, 27. València.

El duc de Gandia afirma que lliurarà al comte de Dénia -fill seu amb qui estava enfrontat-, a mossén Pere March, a en Joan de Cabrera, a en Ramon Vidal, a Jaume Oliver, a Jofre Gilabert, a Domingo Corts, a Bernat d'Armanyac o a aquella persona designada pel comte de Dénia, les quantitats degudes a la vila de Gandia. Promet, aixímateix, lliurar-li $50.0 o o$ sous per al manteniment d'ell, de la seua esposa i de la seua casa, i, també, permetre-li creuar o circular per les terres ducals.

ARV, Governació, no. 4375, mà $3^{\text {a }}$,f. $3^{2 \text { rv. }}$

I4O7, juny, IO. València.

Berenguer Manresa, correu de la vila de Gandia, compareix davant mossén Lluís de Castellví, justícia civil de València, i li lliura una carta de mossén Pere March-procurador general del duc de Gandia-datada a Gandia el 7 de juny de 1407 on aquest li sol.licita que faça arribar a Bernat d'Ortoneda, que en aquell moment es troba a València, un manament executori en raó de 586 sous, 8 diners que Ortoneda i la seua esposa devien a Joan Roís de Corella, habitant de Gandia, per pagues no satisfetes d'un censal establit entre Ortoneda i Roís de Corella el 19 de març de 1399 davant el notari Ramon Agualada.

ARV, Justícia Civil, no. 2335, mà 2a ${ }^{\text {a }}$ f. $23^{\text {rv. }}$ 
I409, gener, 8. Gandia.

Escriptura d'emancipació d'Ausiàs March feta davant el justícia de Gandia Bertomeu Martí. Pere March i Elionor de Ripoll hi declaren que el seu fill era major de vuit anys però menor de nou. Com a testimonis d'aquesta emancipació figuren misser Jaume de Guimerà i el notari Francesc Dalmau actuant, com a notari rebedor de l'acte, Guillem Ferrer. El justícia de Gandia nomenà Joan de Cabrera com a tutor i curador del futur poeta, estant present Ausiàs "maioris octo annorum minorisque novem annorum".

ADM, Secció Moncada, llig. I74, document 2, rotlle 8IO, fotogrames 2I8-220. ${ }^{256}$

I409, gener, 8. Gandia.

Pere March renovà la donació feta, el dia 7 de gener de 1409, a Ausiàs March de Beniarjó, Pardines i Vernissa, d'una casa franca a Gandia i de diferents censals que li corresponien a Beniarjó i l'alqueria de Benieto. Entre d'altres, aquesta escriptura de renovació va ser signada a Gandia pel mateix Pere March, per.Joan de Cabrera com a tutor d'Ausiàs March i pel duc de Gandia com a testimoni.

$\mathrm{ADM}$, Secció Moncada, llig. I74, document 2, rotlle 8Io, fotogrames 2I8-223. ${ }^{257}$

46

I4IO, desembre, 9. Gandia.

Darrer testament del poeta i cavaller Pere March, pare d'Ausiàs March, davant el notari Francesc Dalmau. Elegí com a marmessors als seus cosins Joan Roís de Corella-habitant d'Aiora-iJoan de Cabrera -habitant de Gandia-, avis de l'escriptor Joan Roís de Corella, i també als preveres de Gandia Guillem Pons i Francesc Puig. Aquest testament es publicà el 16 de juny de 1413.

ADM, Secció Moncada, llig. I7 I, document I, rotlle 807, fotogrames $556-573 \cdot{ }^{258}$

47

I4II, agost, I9. Sant Mateu.

Acte d'incorporació i agregació del lloc del Molinell al terme de Culla realitzat per fra Romeu de Corbera. Hifigura la confirmació i loació d'aquest acte d'incorporació per diversos frares de l'orde de Montesa, entre d'ells fra Manuel Roís de Corella, comanador de Borriana.

ARV, Clergat, caixa 2355-56, lligall 895, Llibre de concessions del mestre Romeu de Corbera, p. 546 o. $^{259}$

256. Document publicat en Chiner r997, I70-7I.

257. Document publicat en Chiner 1997, I69-70.

258. El testament i el codicil de Pere March -datat el 8 de maig de I4I3- es troben a ADM, Secció Moncada, llig. I7I, document I, rotlle 8o7, fotogrames 539-584 i es poden llegir a Chiner 1997, I44-54.

259. Document publicat en Rabassa-Selma 1994, 568-72. Segons aquests autors, "el Molinell, masada situada a la vora del riu homònim, en la confluència del terme de Culla amb els de Benassal, Vilar de Canes i la Torre d'en Besora, constituí fins l'any I 4 II una entitat de poblament, dins el districte de la Tinença de Culla, amb plena autonomia 
I4I2, abril, 8. Gandia.

Als llibres de comptes de Pere Martorell, col-lector de les rendes ducals, figura un assentament comptable segons el qual hom abonà a Joan Roís de Corella 688 sous, 1 diner a ell deguts en raó de "l'offici de procuració de la vila e vall d'Ayora. E, d'altra part, li era degut per retinença del castell de Gallinera qui certs dies lo havia tengut".

ARV, Mestre Racional, no. 9615, f. $4^{2 \mathrm{v}}$.

49

I4I3, juny, 26. Gandia.

Inventari de béns del poeta Pere March, pare d'Ausiàs, realitzat pel donzell Joan Roís de Corella, per Francesc Puig i per Guillem Pons, marmessors del finat.

ADM, Secció Moncada, llig. I83 document 5, rotlle 82I, fotogrames 245-275. ${ }^{260}$

$5^{\mathrm{O}}$

I4I3, juliol, 2I. València.

Fra Joan de Mena, prior del monestir dels predicadors de la ciutat de València, reconeix al donzell Joan Roís de Corella i als preveres Guillem Pons i Francesc Puig, com a marmessors del darrer testament del difunt cavaller Pere March, el lliurament de 100 sous per tal de celebrar 100 misses de rèquiem per l'ànima del finat.

ARV, protocols, no. 2720, not. Vicent Zaera.

$5^{\mathrm{I}}$

I4I4, agost, 25. Gandia.

Joan de Cabrera, cavaller de Gandia, reconeix haver rebut de la vila de Gandia de mans de Joan Mallol, despenser, 230 sous ig diners censals que li devien.

AHG, pergamins, no. I29. ${ }^{261}$

$5^{2}$

I4I4, octubre, 20. València.

Pere Balaguer-mestre de les obres de la catedral de València-reconeix a Guillem Pons, Francesc Puig - prevere- i al donzell Joan Roís de Corella, com a marmessors del difunt Pere March, el

municipal, amb un terme i una organització comunal propis, els seus càrrecs municipals, ple exercici de la jurisdicció civil i criminal, etc" (Rabassa-Selma I994, 537).

26o. Document transcrit en Chiner 1997, I54-64. L'ordre dels fotogrames a seguir, per a una lectura correcta de l'inventari, és 273-275, 245-248.

26r. Document publicat en Olaso I987, 42. 
lliurament de 212 sous per la realització d'una tomba de pedra dins de la capella dels March a la Seu de València.

ARV, protocols, no. 26o8, not. Andreu Julià.

53

I4I4, octubre, 20. València.

El prevere i beneficiat de la Seu Pere d'Orcal reconeix a Joan Roís de Corella i Joan de Cabrera, marmessors del poeta Pere March, el lliurament d'n lliures, g sous i 10 diners en raó de diferents aniversaris per Bertomeua March, germana del difunt, i per zo misses cantades per la memòria de l'esmentada difunta amb ocasió del trasllat de les despulles mortals de la germana de Pere March a una tomba feta dins la capella dels March a la Seu de València.

ARV, protocols, no. 2608, not. Andreu Julià.

54

I4I5, març, I2. Gandia.

Joan Roís de Corella -avi del futur escriptor homònim, cosí germà i marmessor del poeta $i$ procurador ducal Pere March-figura com a testimoni del contracte matrimonial establit entre el duc de Gandia Alfons el Jove i Aldonça March, filla de Violant de Vilarig i del difunt Joan March -fill del poeta Pere March i germanastre d'Ausiàs March.

AHN, Osuna, llig. II2I, no. 3, not. Joan Llorca.

55

I4I6, gener, 7. Gandia.

Mateu Roís de Corella, prevere, reconeix a Guillem Pons, prevere, i al notari Ramon Agualada com a marmessors del darrer testament del difunt Joan de Cabrera, cavaller i avi del poeta Joan Roís de Corella, el lliurament de 20 florins d'or d'Aragó, "unum missalem et unun vestamentum ad opus" de la capella del dit difunt.

AHN, Osuna, llig. I280, no. 4, not. Pere Pugeriol.

$5^{6}$

I4I6, gener, 7. Gandia.

Mateu Roís de Corella, prevere i beneficiat del benefici institü̈t per Joan de Cabrera, reconeix al notari Ramon Agualada com a marmessor del darrer testament del difunt Joan de Cabrera, el lliurament, "ad opus" de la capella del dit difunt, d'un calze d'argent, un missal, una patena i un "vestimentum album et rubeis".

AHN, Osuna, llig. I280, no. 4, not. Pere Pugeriol. 
I4I6, gener, 23. Gandia.

Violant March, vídua de Joan March -fill del poeta Pere March-, ven a Ramon Agualada, com a tutor $i$ curador dels fills del difunt cavaller Joan de Cabrera, 100 sous censals anuals.

AHN, Osuna, llig. I28o, no. 4, not. Pere Pugeriol.

$5^{8}$

I4I6, gener, 23. Gandia.

Violant March, vídua de Joan March, ven a Ramon Agualada, com a tutor i curador dels fills del difunt cavaller Joan de Cabrera, 183 sous i 4 diners censals anuals.

AHN, Osuna, llig. I280, no. 4, not. Pere Pugeriol.

59

I4I6, juny, I7. Gandia.

Antoni Pérez, pintor i ciutadà de València, reconeix a Ramon Agualada, com a tutor dels fills del difunt Joan de Cabrera, el lliurament de tots aquells 1.000 sous que aquell li va prometre donar per fer un retaule per a la capella del difunt, segons constava en el contracte establit davant el notari Pere Pugeriol el 3 d'abril de 1415. Així mateix, Pérez reconeix també el lliurament, per un costat, de a florins d'or "quibus emi els polseres" del dit retaule i, per un altre costat, de 5 sous, 6 diners que va costar adaptar "staginum dicti retabli".

AHN, Osuna, llig. I280, no. 4, not. Pere Pugeriol.

60

I4I6, juliol, 3I. Gandia.

Ramon Agualada, notari, com a curador dels fills de Joan de Cabrera segons constava al codicil del dit difunt establit a Gandia davant el notari Pere Pugeriol el 18 de juliol de 1414, reconeix a Domingo Belsa, síndic, i a Bernat Mascarell, jurat del lloc de Palma, el lliurament de 3749 sous, 11 diners per censals deguts.

AHN, Osuna, llig. I280, no. 4, not. Pere Pugeriol.

6I

I416, agost, I8. Gandia.

Ramon Agualada, notari, ven a Joan Roís de Corella, senyor de Miraflor i habitant de Gandia, 125 sous restants d'aquells 625 sous censals i anuals que van ser venuts al difunt cavaller Guillem Martorell, avi del novel.lista Joanot Martorell.

AHN, Osuna, llig. I28o, no. 4, not. Pere Pugeriol. 
62

I4I7, agost, I. Gandia.

Ramon Agualada, notari, com a tutor i curador dels fills de Joan de Cabrera, ven a Joan Sànchez Muñoz, cavaller de casa del duc de Gandia i habitant d'eixa vila, 5 o sous censals per preu de 30 lliures.

AHN, Osuna, llig. I28o, no. 5, not. Pere Pugeriol.

63

I4I7, setembre, I2. Gandia.

Ramon Agualada, notari, com a curador dels fills de Joan de Cabrera, reconeix a l'alamí ijurats del lloc de Gata el lliurament de 500 sous d'aquells 1.000 sous que l'aljama feia a la dita tutela.

AHN, Osuna, llig. I280, no. 5, not. Pere Pugeriol.

64

I4I7, novembre, 2. Gandia.

Ramon Agualada, notari, com a curador dels fills de Joan de Cabrera, reconeix a l'alamí ijurats del lloc de Gata el lliurament de tots aquells 291 sous i 8 diners que l'aljama feia a la tutela i cura dels fills de Joan de Cabrera.

AHN, Osuna, llig. I280, no. 5, not. Pere Pugeriol.

65

I4I8, juny, 28. Gandia.

Joan Roís de Corella, habitant de Gandia, ven a Joan Mateu 50 sous censals i anuals carregats sobre un camp anomenat de "domina Argilona".

AHN, Osuna, llig. I28o, no. 6, not. Pere Pugeriol.

66

I4I8, agost, I7. Gandia

Guillem Pons, prevere de l'església de Gandia, com a procurador d'Alamanda, vídua de Joan de Cabrera, cavaller habitant de Gandia, reconeix a Ramon Agualada, notari, que, d'aquells 4.0oo sous que cada any havia de donar als seus fills en quatre pagues, li ha anticipat 1.ooo sous.

AHN, Osuna, llig. I28o, no. 6, not. Pere Pugeriol.

67

I4I8, setembre, 26. Gandia.

Joan de Flovià, senyor de Ròtova i ciutadà de València, promet al notari Ramon Agualada, tutor 
i curador del fill i hereu de mossén Joan de Cabrera-senyor d'Almiserà-, que la font anomenada Baclamala que Flovià vol portar a Ròtova "no cubrirà ans la portarà descuberta per ço que el senyory moros de Almicerà, hayan servitut en aquella per seu obs y necesitad, abrevar bèsties, etc".

AHN, Osuna, llig. I28o, no. 6, not. Pere Pugeriol.

68

I4I8, octubre, I2. Gandia.

Alamanda, vídua de Joan de Cabrera, reconeix al notari Ramon Agualada, com a tutor i curador dels fills d'ella, el lliurament de 115 sous, 5 diners per a fer diverses coses al lloc d'Almiserà.

AHN, Osuna, llig. I28o, no. 6, not. Pere Pugeriol.

69

I4I9, febrer, 24. Gandia.

Alamanda, vídua de Joan de Cabrera, cavaller i habitant de Gandia, reconeix a Ramon Agualada, notari, com a tutor i curador dels fills d'ella, el lliurament de 45 florins d'or d'Aragó.

AHN, Osuna, llig. I324, no. 7, not. Guillem Ferrer.

$7 \mathrm{O}$

I4I9, març, 8. Gandia.

Joan Roís de Corella assisteix a un consell general de la vila de Gandia.

AHG, Manuscrits, AB 458, f. I8v.

$7^{\mathrm{I}}$

I4I9, juny, 6. Gandia.

Joan Roís de Corella assisteix a un consell general de la vila de Gandia.

AHG, manuscrits, AB 458, f. $27 \mathrm{r}$

$7^{2}$

I420. Gandia.

Joan Roís de Corella i Roderic Roís de Corella figuren entre els consellers de la vila de Gandia de l'any 1420.

AHG, manuscrits, $\mathrm{AB} 45^{8}$, f. $34^{\mathrm{V}}$

73

I420, octubre, IO. Almiserà. 
Alamanda, vídua de Joan de Cabrera, cavaller habitant de Gandia, com a hereua dels béns de Pere de Monsant, son pare, mercader de la ciutat de València, dóna a Joan de Bondia, fill de Mateu de Bondia, mercader de la dita ciutat, nét d'ella, tots aquelles quantitats que al pare d'Alamanda devien Pere Bas i Joan Bas, mercaders.

AHN, Osuna, llig. I280, no. 7, not. Pere Pugeriol.

74

I420, octubre, II. Gandia.

Guillem Pons, prevere de l'església de Gandia, nou tutor i curador dels fills de Joan de Cabrera després de la mort de Ramon Agualada, reconeix a Lluís d'Abella, cavaller i senyor de Gata, i a l'alamí i jurats del dit lloc, que li han lliurat 500 sous que l'aljama feia a la tutoria i curadoria dels fills del difunt Joan de Cabrera.

AHN, Osuna, llig. I280, no. 7, not. Pere Pugeriol.

75

I42I, setembre, I4. Gandia.

Ausiàs Roís de Corella, cavaller i habitant de València, ven a Aldonça, esposa del notari Jaume Pérez de Culla-veí de Gandia-, 200 sous de violariper preu de 95 llliures.

AHN, Osuna, llig. I3O5, no. I3, not. Guillem Francés.

76

I422, juliol, 27. Palau reial de València.

En nom de la seua filla Aldonşa March-duquessa de Gandia-, Violant de Vilarig, vídua del cavaller i habitant de Gandia Joan March, ven per preu de 5.065 sous i 7 diners a Guillem de Vilarig, cavaller igermà seu, tots aquells 390 sous censals que el poeta Pere March, avi de la duquessa, en el seu darrer testament llegà a les seues netes Violant i Aldonça, filles de Violant de Vilarig i de Joan March. Els marmessors de Pere March -el donzell Joan Roís de Corella i els preveres Guillem Pons $i$ Francesc Puig-lliuraren aquest censal a les nétes del difunt escriptor-mitjançant document notarial fet a Gandia el 22 de desembre de 1413 davant el notari Francesc Dalmau-per a la seua "col-locació" en matrimoni.

AHN, Osuna, llig. I323 no. 7, not. Joan Lorca.

77

I422, setembre, I8. Gandia.

Els jurats de Gandia abonen a Alamanda de Cabrera, vídua del cavaller mossén Joan de Cabrera, 25 sous a ella deguts en raó de la pensió -corresponent al 1o de març-d'un censal de 1.50o sous carregat per Bernat de Garrigas sobre els seus béns a "obs de la obra de la ecclésia de la dita vila".

$\mathrm{AHG}$, manuscrits, $\mathrm{AB}$ 458, f. 69v. 
I423. Gandia.

Mossén Ausiàs March i mossén Ausiàs Roís de Corella, pare de l'escriptor Joan Roís de Corella, figuren com a consellers de la vila de Gandia en aquest any.

AHG, Manuscrits, AB 458, f. $73^{\mathrm{v}}$.

79

I423, juliol, 29. Gandia

Ausiàs Roís de Corella, cavaller de Gandia, ven al notari.Joan Lorca 50 sous censals.

AHN, Osuna, llig. I280, no. 8, not. Pere Pugeriol.

80

I423, desembre, 4. Gandia

Ausiàs Roís de Corella, cavaller de Gandia, ven al cavaller Guillem de Vilarig 100 sous censals.

AHN, Osuna, llig. I28o, no. 8, not. Pere Pugeriol

8I

I425, gener, I. Gandia.

Testament de Saura d'Esplugues, besàvia de l'escriptor Joan Roís de Corella. Nomena com a marmessors fra Manuel Roís de Corella - de l'orde de Montesa i comanador d'Onda- i mossén Mateu Roís de Corella. Elegeix com a hereu universal fra Manuel Roís de Corella i, en cas de mort d'aquest, Ausiàs Roís de Corella, nét seu i fill del difunt Joan Roís de Corella ${ }^{262}$

AHN, Osuna, llig. I206, no. 3, not. Pere Belsa.

\section{Die lune prima mensis jannuarï anno predicto $\mathrm{M}^{\circ} C C C C^{\circ} X X V^{\circ}$}

Com totes les coses mundanals sien trespasadores e nengú en carns posat scapar a la mort corporal no puxa, emperamor d'açò yo, na Saura d'Esplugues, muller de l’honorable mossén Pere Roïç de Corella, quòndam, de la dita vila de Gandia, stant malalta de greu malaltia de la qual tem morir, emperò en mon seny, éntregra loqüela e paraula maniffesta e sancera, faç e ordén aquest meu darrer testament e aquesta mia darrera voluntat ab lo qual eo la qual revoque tots e qualsevol altres testaments, codicils etc.

E elegesch marmessors e de aquest meu darrer testament execudors, çó és los honorables frare Manuel Roïç de Corella, frare de l'horde de Muntesa e comanador del castell e vila de Onda, e mossén Matheu de Corella, prevere de la ecclésia de la dita vila de Gandia, absents ací com si fossen presents als quals don licència, facultat e plen poder, abduy ensemps e a cascú per sí, tants de mos béns vendre e alienar, etc.

262. En AHN, Osuna, llig. ı2o6, no. I, not. Pere Belsa es va iniciar la còpia d'aquest testament però no es va concloure 
Ítem, vull e man que sia feyta la mia sepultura a coneguda dels dits meus marmessors.

Ítem, que per los dits meus marmessors sia donat de mos béns a cascú bací de aquells que ban per la ecclésia de la dita vila de Gandia, hun sous.

Ítem, leix e man ésser donats al dit mossén Matheu de Corella cent sous de la dita moneda per sos treballs.

Ítem, lex e man ésser donats a la dona na Martha, que a present stà en ma casa, hun çot, gonella, gramalló e mantell dels que seran atrobats ésser meus en ma casa e aquella puxa triar les dites robes a sa voluntat sens constrast algú que no li puxa ésser fet per mos hereus ni per altre.

Ítem, lex [i] a Isabeleta, serventa mia, que a present stà en ma casa, ultra la soldada tres florins comuns d'or d'Aragó.

En tots los altres béns e drets meus, etc., faç hereu meu propri e universal lo dit honorable frare Manuel sots forma e manera que tota ora e quantquequant los dies de la sua fi seran fenits, en tal cars substituesch e aquell hereu meu propri e universal faç, en los dits béns meus lo honorable mossén Auziàs Roïç de Corella, cavaller, nét meu e fill de l'honorable en Johan Roïç de Corella, fill meu quòndam de la dita vila de Gandia. E, si per ventura, lo dit fill meu, ço és lo dit frare Manuel, sobrevivira al dit mossén Auziàs eo a fills de aquell legítims e naturals, en aquest cars vull e man que.l dit frare Manuel ordene de mos béns, vullga's en article de mort, vullga’s en sanitat, axí com a ell serà ben vist dels dits béns meus a ses voluntats. E, per ço, com a mi és duptós que lo dit frare Manuel puxa fer testament, per ço com és religiós, vull que la ordenació que ell faça sia haüda en aquell compte axí com si yo ara, de present, la feya en ma derrera voluntat axí, emperò, que com ne haurà feta huna e moltes aquella eo aquelles puxa mudar a sa voluntat axí com yo poria fer si viva fos. Emperò, vull que, en neguna manera, no puxa ordenar que.ls dits béns meus sien lexats a nengú orde mas que sia tengut lexar-ho a aquells parent eo parents meus al qual eo als quals a ell serà ben visst [sic].

Aquest és lo meu darrer testament, etc.

Present testimonis foren a les dites coses apellats e pregats per la dita testadriu, en Ferrer Galiana -major de dies-, en Martí Vilarnau e en Miquel Feltrer, vehins de la vila de Gandia.

I425, gener, 3 . Gandia.

Codicil de Saura d'Esplugues, besàvia de l'escriptor Joan Roús de Corella ivídua del cavaller Pere Roís de Corella-habitant de Gandia. ${ }^{263}$

AHN, Osuna, llig. I206, no. 3, not. Pere Belsa

Dicta die [3 de gener de I425]

Cum quilibet sic licitur, etc. igitur ego Saura d'Esplugues, muller de l'honorable mossén Pere Roïç de Corella, actenent mi haver fet testament en poder del notari davall scrit lo primer dia del present mes e any, ratifficant e confermant tot ço e quant en lo dit testament és contengut, enadesch a aquell que vull e man ésser mesa en la confraria del benaventurat mossén Sent

263. En AHN, Osuna, llig. I2o6, no. I, not. Pere Belsa, es va iniciar la còpia d’aquest codicil, però no es va concloure. 
Nicholau pregant als majorals de aquella que mi vullen rebre. E, vull e man, que.ls sia donat tot ço e quant sia son dret com yo no sàpia certament que·n deien haver.

Ítem, vull e man que, per los dits meus hereus en lo dit meu testament mencionats, no puxa ésser demanat als meus censals a aquell que tenen los censals carregats a rahó de dos dous sinó a rahó de vint diners per liura, etc.

Presents testimonis foren a les dites coses apellats e pregats en Ferrer Galiana, major de dies, en Martí Vilarnau e en Miquell Feltrer, vehins de la vila de Gandia.

83

I425, gener, I3. Gandia.

Saura d'Esplugues, vídua de Pere Roís de Corella, reconeix a Pere Espinós, veí d'Alcoi, el lliurament de totes aquelles 8 lliures, 6 sous i 8 diners censals, rendals i anuals que a ella lifeia en la festa de Sent Miquel.

AHN, Osuna, llig. I2o6, no. I, not. Pere Belsa

84

I425, gener, 23. Gandia.

Testament de Saura d'Esplugues, vídua del cavaller Pere Roís de Corella, habitant de Gandia. Nomena com a marmessors fra Manuel Roís de Corella-de l'orde de Montesa i comanador d'Ondai mossén Mateu Roís de Corella. Elegeix com a hereu universal Ausiàs Roís de Corella, nét seu i fill del difunt Joan Roís de Corella, i com a usufructuari dels seus béns fra Manuel Roís de Corella. ${ }^{264}$

AHN, Osuna, llig. I2o6, no. 3, not. Pere Belsa

\section{Die martis XXIII januarï anno predicto $\mathrm{M}^{\circ} \mathrm{CCC} \mathrm{C}^{\circ} \mathrm{XXV} \mathrm{V}^{\circ}$}

Com totes les coses mundanals sien trespasadores e nengun en carn posat scapar a la mort corporal no puxa, emperamor d'açò yo, na Saura d'Esplugues, stant sana per gràcia de Déu, etc. faç e ordén aquest meu darer testament e aquesta mia darrera voluntat ab lo qual o la qual primerament e abans de totes coses revoque, case e anul-le tots e qualsevol altres testaments, codicils e darreres voluntats, etc.

Elegesch marmessors meus, e d'aquest meu darrer testament execudors, a los honorables frare Manuel Roíç de Corella, frare de l'orde de Muntesa e comanador dels castells e vila de Onda, e a mossén Matheu de Corella, prevere de la ecclésia de la dita vila de Gandia, absents axí com si fossen presents als quals don licència, facultat e plen poder tants de mos béns, etc. e que la hu sens l'altre, etc.

Ítem, vull e man que sia feyta la mia sepultura a coneguda dels dits meus marmessors, etc.

Ítem, vull per los dits meus marmessors ésser mesa en la confraria del benaventurat mossén Sent Nicholau pregant als majorals qui ladonchs seran que mi accepten donant a aquells son dret, etc.

Ítem, vull e man que per los dits meus marmessors sia donat a cascun bací, de aquells que van per la ecclésia de la dita vila, hun sous.

264. En AHN, Osuna, llig. I2o6, no. I, not. Pere Belsa es va iniciar la còpia d'aquest testament però no es va concloure 
Ítem, leix al dit mossén Matheu de Corella cent sous de moneda reals de València per los treballs sostenidors per la dita marmessoria.

Ítem, leix a la dona na Marta, la qual me ha servit gran temps, hun çot, gonella, garmalló e mantell dels millós que seran atrobats en ma casa dels que ella sabrà triar sens que no li sia feyt embarch algú, etc. los quals vull e man que li sia donats tan tost aprés òbit meu.

Ítem, leix a Isabeleta, serventa mia que a present stà en mia casa, ultra sa soldada tres florins d'or d'Aragó.

Ítem, vull e man que, per lo dit hereu meu ni per altra persona, no puxa ésser demanat als meus censals ço és aquells lo cens a rahó de dos sous per liura més de vuit diners per liura com yo en ma vida no·n haja pres més.

Ítem, lex al dit honorable frare Manuel Roïç de Corella, ultra lo usufruyt de tots mos béns segons davall appar, tots los béns meus mobles e hostillars de l'alberch de la mia habitació detrets los los [sic] legats specialment e specífficament de alguns béns meus mobles desús fets haüts e havedors onsevol que sien. Do e leix a l’honorable mossén Auziàs Roïç de Corella, cavaller habitador de la dita vila de Gandia, nét meu e aquell faç e instituesch hereu meu propri e universal sots emperò vincle e condició que si.l dit mossén Auziàs, hereu meu instituït, morrà quantquequant sens fills de son legítim matrimoni que, en tal cars, tots los béns e drets de la dita mia herència tornen e pervingen als meus pus proïsmes de nom de Splugues qui ladonchs sobreviuran. E sots condició encara, que·l dit mossén Auziàs hereu meu no faça ni fer puxa questió alguna ne inpediment a l'usufructuari meu dejús scrit, ne al poder que li atribuesch, ne ay tanpoch li puxa demanar caució alguna de ben usar e conservar la proprietat dels béns hereditaris en los quals leix lo dit usufruyt.

Ítem, leix usufructuari universal de tots mos béns e drets lo dit honorable mossén frare Manuel Rö̈ç de Corella, fill meu, de e per tota sa vida e, ultra lo legat damunt dit de l'usufruyt universal que li faç, li do plen poder, facultat e auctoritat bastant que, dementres viurà, puxa fermar fer e atorgar qualsevol luïcions, emfranquiments dels censals meus e reebre los preus de aquells e fer e atorgar e fermar qualsevol cartes de les dites luïcions e emfranquiments e àpoques dels preus de aquells en axí, emperò, que·ls dits preus se esmerce en altres censals sobre aquelles possesions eo lochs que li serà ésser vist fahedor migançants cartes de gràcies de poder quitar aquelles, etc.

Aquest és, etc.

Presents testimonis foren apellats e pregats etc en Ferrer Galiana -major de dies-, en Pere Vilarnau e en Miquel Feltrer, perayre, vehins de la vila de Gandia, los quals dixeren ensemps ab mi notari conéxer la dita testadora e ella a nosaltres, etc.

I425, febrer, 28. Gandia.

Lluc Pous, notari veí de Gandia, i Guerarda, La seua esposa, venen a Guillem Ponç, prevere de l'església de Gandia, tutor i curador dels fills i hereus del difunt cavaller Joan de Cabrera, 500 sous censals per preu de 5 oo lliures.

AHN, Osuna, llig. I206, no. I, not. Pere Belsa. 
I425, abril, I7. Gandia.

Alamanda de Cabrera, vídua de Joan de Cabrera, cavaller de Gandia, reconeix a Guerarda, esposa del notari Lucas Pous, i a Joan Martí, com a successors en els béns del difunt Bernat Garrigues, el lliurament a ella de 125 sous que a Alamanda Cabrera feien de cens.

AHN, Osuna, llig. I2O6, no. I, not. Pere Belsa.

87

I425, maig, 26. Gandia.

Mossén Ausiàs Roís de Corella és elegit conseller de la vila de Gandia.

$\mathrm{AHG}$, manuscrits, $\mathrm{AB} 45^{8}$, f. $97 \mathrm{v}$.

88

I426, febrer, I9. Gandia.

Lluc Pous, notari, ven a Alamanda Cabrera, vídua de Joan de Cabrera, cavaller de la dita vila, un censal de 68 sous it diners per preu de 41 lliures.

AHN, Osuna, llig. I206, no. I, not. Pere Belsa.

89

I426, febrer, I9. Gandia.

Lluc Pous, notari, i la seua esposa Guerarda, veïns de Gandia, reconeixen a Alamanda Cabrera, vídua de Joan de Cabrera, el lliurament de 41 lliures com a import d'un censal de 68 sous i 4 diners.

AHN, Osuna, llig. I206, no. I, not. Pere Belsa.

90

I426, març, I2. Gandia.

Ausiàs Roís de Corella, cavaller de Gandia, reconeix a Bernat d'Esplugues, cavaller, ciutadà de València, el lliurament de 1.0oo sous que a ell feia de cens el 7 d'octubre de cada any.

AHN, Osuna, llig. I206, no. 4, not. Pere Belsa.

9I

I426, març, I9. Gandia.

Alamanda de Cabrera, vídua de Joan de Cabrera, reconeix als hereus del difunt notari Bernat de Garrigues, el lliurament de 125 sous censals i anuals per mans de Guillem Balaguer, de la dita vila.

AHN, Osuna, llig. I206, no. 4, not. Pere Belsa. 
92

I426, març, 2I. Gandia.

Alamanda de Cabrera, vídua de Joan de Cabrera, i Guillem Pons, prevere de l'església de Gandia, com a tutor i curador dels fills i béns de Joan de Cabrera, arrenden el lloc d'Almiserà, situat en el terme de la vila de Gandia, a Domingo Belsa, Bernat Bono, Antoni Matamala i Miquel Ros, veïns d'Ador. Els arrendadors hauran de pagar zoo florins d'or d'Aragó per cada any d'arrendament.

AHN, Osuna, llig. I206, no. 4, not. Pere Belsa.

93

I426, juliol, II. Gandia.

Alamanda de Cabrera aprova la venda feta per Guillem Jordà, de la ciutat de València, d'un serf seu anomenat Pere de Saraus, negre de gènere sarraí, al mercader Joan Alegre, de València, per no sous.

AHN, Osuna, llig. I206, no. 4, not. Pere Belsa.

94

I427, març, 3I. Gandia.

Francesc Dalmau, notari ciutadà de València, reconeix a Francesc Cornet, també ciutadà de València, la restitució a ell de 1.30o sous censals. Aquesta quantitat, Guillem Bertomeu, veí de Benissa, com a síndic d'aquest lloc, va vendre-la a Joan Roís de Corella, tutor i curador dels seus germans, segons constava per escriptura notarial davant el notari Francesc Dalmau feta a Gandia el 31 de gener de 1413. Posteriorment, el censal va passar a mans de Roderic Corella qui el va vendre al notari Francesc Dalmau a Gandia.

Reial Col-legi Seminari de Corpus Christi de València (RCSCCV), protocols, no. 2720I, not. Pere Belsa.

95

I427, abril, I6. Ròtova.

Ausiàs de Cabrera reconeix a Domènec Belsa, veí de Palma, el lliurament de 15 lliures censals i anuals.

AHN, Osuna, llig. ı280, no. ı2, not. Pere Pugeriol.

96

I427, maig, I5. Gandia.

Galceran de Vich, cavaller de Gandia, reconeix a Guillem Pons, prevere de l'església de Gandia, com a tutor i curador dels fills del cavaller Joan de Cabrera, el lliurament de 18 lliures, 8 sous que a Galceran devien dos moros del lloc de Xeresa.

RCSCGV, protocols, no. 2720I, not. Pere Belsa. 
I427, maig, I9. Gandia.

Ausiàs Roís de Corella, cavaller habitant de Gandia, reconeix a Bernat d'Esplugues, cavaller habitant de Dénia, el lliurament de 1000 sous que anualment li fa de cens. Van actuar de testimonis el prevere de l'església de Gandia Guillem Pons i Joan de Monpalau, menor de dies, habitant de Gandia.

AHN, Osuna, llig. I280, no. Io, not. Pere Pugeriol.

98

I427, juny, 6. Gandia.

Ramon Guillem Català-cavaller-, Joan de Bluses, Galceran de Vich-cavaller-, Ausiàs Roís de Corella -cavaller-, Galceran de Monpalau-donzell-, Ausiàs March-cavaller-, i el donzell Joan de Monpalau -menor de dies-, nomenen als habitants de Gandia Joan de Monpalau-major de dies-i Joan Cifre-cavaller-com llurs procuradors.

RCSCCV, protocols, no. 2720I, not. Pere Belsa. ${ }^{265}$

99

I427, juliol, 28. Gandia.

Jaume Escuder, com a procurador d'Alamanda de Cabrera -vídua de Joan de Cabrera, cavaller de Gandia-ven una casa, a la parròquia de Sant Andreu, a l'almoina dels assaonadors.

ACV, pergamins, no. 5793 .

IOO

I427, agost, I7. Gandia.

Ausiàs Roís de Corella, cavaller i habitant de València, reconeix a Bernat Martí, de Dénia, el lliurament dels 293 sous, 4 diners que Martí $i$ altres lifeien a ell. Figura com a testimoni.Joan de Monpalau, donzell.

RCSCCV, protocols, no. 272OI, not. Pere Belsa.

IOI

I427, setembre, I2. Gandia.

Saura d'Esplugues, vídua de Pere Roís de Corella, reconeix a Joan de Torragrosa, veí d'Alcoi, el lliurament de 8 lliures, 6 sous, 8 diners que a ella feia de cens.

RCSCCV, protocols, no. 2720I, not. Pere Belsa.

265. Document esmentat en Riquer I964, 3, 255. 
$\mathrm{IO} 2$

I427, octubre, 3. Gandia.

Ausiàs Roís de Corella figura com a testimoni en una escriptura notarial on Fernando de Burgos promet servir a Joan de Monpalau -menor de dies-com a escuder per un salari de 25 florins d'or comuns d'Aragó.

RCSCCV, protocols, no. $272 \mathrm{OI}$, not. Pere Belsa. ${ }^{266}$

IO3

I428, setembre, I8. València.

Alfons el Magnànim reitera el mandat realitzat al seu alguatzir, el cavaller Pere Pardo de la Casta, perquè detinga Ausiàs March, Ausiàs de Cabrera i les altres persones que van participar en la brega iferides causades al cavaller Joan de Flovià a Gandia. Insisteix en el fet que l'alguatzir realitze eixes detencions i ordena que qualsevol autoritat li ajude sil'alguatzir demana ajuda.

ARV, Reial Cancelleria, no. 230, f. $12 \mathrm{Ir}^{267}$

$\mathrm{IO} 4$

I428, octubre, 2O. Beniarjó.

Ausiàs March - en el seu nom propi i tambécom a procurador d'Ausiàs de Cabrera segons constava en escriptura notarial feta davant el notari de Gandia Bertomeu Torrella el 5 d'octubre de 1428-, mossén Guillem Pons -prevere i curador d'Ausiàs de Cabrera-, Alamanda i Ausiàs de Cabrera, d'una part, i, de l'altra, Joan de Flovià -senyor de Ròtova-i Joan de Flovià -cavaller i fill d'aquell-acorden nomenar Francesc del Bosch, de Xàtiva, i el cavaller habitant de Gandia mossén Joan Ciffre, com a arbitres $i$ amigables componedors per a l'establiment d'un compromís sobre "la venda del loch de Ròtova e territori de aquell e drets de aquell, cubs, gerres, deutes de moros e altres aparellaments axí de fer oli com vi, etc fahedora per los dits honorables en Johan de Flovià e na Úrsula, muller de aquell, e mossén Johan de Flovià, son fill, als honorables mossén Ausiàs March, a madona Alamanda de Cabrera e a mossén Guillem Ponz, curador del dit honorable n'Ausiàs de Cabrera, e per quin preu e en quina manera lo dit preu serà pagat e altres coses tocants a la dita venda, etc. E encara sobre la pau e treua fahedora entre les dites parts, e encara sobre [...] de clams e qualsevol questions o debats civils e criminals que entre nos dites parts sien o ×s speren ésser entre nos dites parts de tot lo temps passat en tro en lo present dia de huy, etc". Aquest acord es respectaria sota pena de 3.000 florins i duraria fins al següent dimarts. ${ }^{268}$

AHN, Osuna, llig. I280, no. II, not. Pere Pugeriol.

$\mathrm{IO} 5$

I428, octubre, 22. Gandia.

266. Document esmentat en Riquer I964, 3, 255 .

267. Document publicat en Villalmanzo I999, 280.

268. Com a testimonis figuren entre d'altres, el metge de València Gabriel Garcia, Miquel Valls, Gabriel Martí i fra Joan Puig, del monestir de San Jeroni de Cotalba. 
Ausiàs March - en el seu nom propi i tambécom a procurador d'Ausiàs de Cabrera segons constava en escriptura notarial feta davant el notari de Gandia Bertomeu Torrella el 5 d'octubre de 1428-, mossén Guillem Pons -prevere i curador d'Ausiàs de Cabrera-, Alamanda i Ausiàs de Cabrera, d'una part, i, de l'altra, Joan de Flovià -senyor de Ròtova-iJoan de Flovià -cavaller ifill d'aquell-acorden nomenar el cavaller habitant de Gandia mossén.Joan Cifre i el rector de Gandia Joan Gascó com a amigables componedors per a l'establiment d'un compromís sobre la venda del lloc de Ròtova. Ausiàs March signà aquest document a Vilallonga.

AHN, Osuna, llig. I280, no. II, not. Pere Pugeriol.

Io6

I428, octubre, 26. A l'alqueria del comanador de Montalbà situada al terme de Gandia.

Joan Cifre, cavaller habitant de Gandia, iJoan Gascó, rector de l'església de Gandia, en qualitat d'amigables componedors elegits per Joan de Flovià i el seu fill Joan de Flovià -cavaller-, d'una part, i, per l'altra part, Ausiàs March, Alamanda de Cabrera, Ausiàs de Cabrera i Guillem Pons-curador d'Ausiàs de Cabrera-, dicten una sentència sobre la venda del lloc de Ròtova. ${ }^{269}$

AHN, Osuna, llig. I280, no. II, not. Pere Pugeriol.

$\mathrm{IO} 7$

I428, octubre, 28. Gandia.

Alamanda de Cabrera imossén Guillem Pons, com a curador d'Ausiàs de Cabrera, accepten la sentència atorgada per Joan Cifre, cavaller habitant de Gandia, i Joan Gascó, rector de l'església de Gandia, sobre la venda del lloc de Ròtova.

AHN, Osuna, llig. I28o, no. II, not. Pere Pugeriol.

IO8

I428, octubre, 29. "In vico quo tendit de Beniarjó a Vilallonga, termini ville Olive".

Mossén Ausiàs March i Ausiàs de Cabrera accepten la sentència atorgada per Joan Ciffre, cavaller habitant de Gandia, iJoan Gascó, rector de l'església de Gandia, sobre la venda del lloc de Ròtova. Com a testimonis figuren mossén Antoni Garcia - prevere d'Oliva-i Miquel Valls -veí de Gandia.

AHN, Osuna, llig. I280, no. II, not. Pere Pugeriol.

IO9

I428, octubre, 29. Ròtova.

Joan de Flovià, cavaller senyor de Ròtova, nomena Benet de Vilahur, notari, com a procurador seu per a la defensa de tots els seus béns i drets en el compromís signat, entre d'altres, per Ausiàs March, Alamanda de Cabrera i Ausiàs de Cabrera.

AHN, Osuna, llig. I280, no. II, not. Pere Pugeriol.

269. No hi figura el text de la sentència. 
IIO

I428, octubre, 3 O. Palma. ${ }^{270}$

S'estableix una pau i treva per espai de 100 anys entre dos grups de persones d'acord amb la sentència arbitral donada per Joan Gascó, llicenciat en decrets i rector de Gandia, i.Joan Cifre, cavaller de Gandia. Els dos grups enfrontats eren, d'una part, Ausiàs March -cavaller i senyor de Beniarjó-, Ausiàs de Cabrera-donzell-, Joan de Monpalau-donzell-, Galceran Cirera, el notari Bertomeu Torrella, el prevere Bertomeu Vila, Ausiàs Ferrer, Miquel Ferrer, Nicolau Carbonell, Ramon Closes, Pere Caldes, Miquel Valls -menor de dies-, Joan de Montalbo, Alfons Mateu, Alfons Diez, Jaume Gascó, Pasqual Roca, Bernat Melià, Francesc Munyoz-com a procurador de Bernat Trach-, Joan Marrades, Ferran Burgos, Guillem Busquet, Francesc Garcia, Vicent Oller, Pere Ubach, Francesc Fuster, Lluís Garcia àlies Adeno, tots ells veïns de Gandia, Joan de Cifuentes - de la ciutat de València-, Joan Garcia, Francesc Tristhuyll, Antoni Font, Pere Soreda, Andreu Folcrà, Francesc Garcia, Pere Alfonso-carnisser-, tots ells veïns d'Oliva, i, de l'altra part, Joan de Flovià-cavaller i habitant de València-i Joan de Sent Martíescuder seu. ${ }^{271}$

AHN, Osuna, llig. I280, no. II, not. Pere Pugeriol.

III

I428, octubre, 30. Ròtova.

Úrsula-vídua de Joan Flovià, senyor de Ròtova-i el seu fill Joan, en el seu nom propi i com a curador donat pel justícia de Palma a la persona de la seua germana Isabel, renuncien, en raó del compromís i sentència establit sobre la venda de Ròtova, a continuar amb els plets que contra Ausiàs March i els seus partidaris -entre d'ells, el donzell Ausiàs de Cabrera- havien posat davant les cúries del procurador general del rei de Navarra i duc de Gandia, del justícia de Palma, del rei d'Aragó i de diversos oficials seus, etc. ${ }^{272}$

AHN, Osuna, llig. I280, no. II, not. Pere Pugeriol.

II2

I428, desembre, 20. Ròtova.

Alamanda, vídua de Joan de Cabrera-cavaller i habitant de Gandia-, Ausiàs de Cabrera-el seu fill, com a hereu universal dels béns i drets del seu pare Joan de Cabrera, segons constava pel testament d'aquest fet a Gandia davant el notari Ramon Agualada el 18 d'abril 1414-, Guillem Pons - prevere de l'església de Gandia com a tutor i curador d'Ausiàs de Cabrera segons constava pel codicil de Joan de Cabrera fet el 18 de julliol de 1414 i publicat tant el testament com el codicil a Gandia 18 de setembre de

270. Concretament, l'escriptura notarial localitza l'establiment d'aquest compromís al terme de Palma, en el lloc on estava el molló que dividia el seu terme del de Vilallonga.

27I. Com a testimonis figuren el notari Lluc Pous, Miquel Valls, Joan Belsa, i Simó Mascarell -menor de dies. Joan de Sent Martí procedia de Daroca, segons un testament seu que trobem en aquest mateix protocol amb data del 20 d'octubre (AHN, Osuna, llig. I280, no. II, not. Pere Pugeriol).

272. Segons uns documents datats el 20 de desembre de I 428 conservats en aquest mateix protocol, el testament del pare de Joan Flovià va ser rebut pel notari Dionís Cervera el 5 de març de I 422 i es publicà el 22 de novembre de I428. El 20 desembre I428, Úrsula acceptà notarialment la tutoria i curadoria de la seua filla Isabel (AHN, Osuna, llig. I28o, no. II, not. Pere Pugeriol -20 desembre I428). 
1414-, i Galceran Cirera -habitant de Gandia-, d'acord amb les clàusules del compromís establit per Joan Gascó i Joan Cifre compren a Joan de Flovià i a la seua mare el lloc de Ròtova per preu de 80.0oo sous. Per això, en aquesta data, venen i estableixen a Flovià per preu de 18000 sous, un total de 1.384 sous, 8 diners i òbol censals i anuals carregats sobre el lloc d'Almiserà, propietat d'Ausiàs de Cabrera, situat en el terme de Palma i que afrontava amb el terme de Llutxent i amb terres de Castellonet, d'Alfauir ide Ròtova.

Segons una nota marginal, el 22 de desembre de 1429 a Gandia Ausiàs de Cabrera, en complir la majoria d'edat-els 20 anys-, acceptà totes les clàusules i condicions d'aquesta venda.

AHN, Osuna, llig. I280, no. II, not. Pere Pugeriol.

II3

I428, desembre, 2O. Ròtova.

Alamanda de Cabrera, Guillem Pons i Galceran Cirera, en compliment del compromís arbitral establit per Joan Gascó i Joan Ciffre per a l'adquisició del lloc de Ròtova, venen a Joan de Flovià diferents censals que, a la tutela i cura d'Ausiàs de Cabrera i a la seua mare, feien diverses persones i entitats de Gata, Callosa, Dénia, Valldigna, Oliva, València, Pego i Gandia. En total, varen ser 1821 sous i 8 diners censals i anuals venuts a Flovià per preu de 21.860 sous. ${ }^{273}$

AHN, Osuna, llig. I280, no. II, not. Pere Pugeriol.

II4

I428, desembre, 20. Ròtova.

Joan de Flovià, cavaller, i Úrsula, vídua del cavaller habitant de Gandia Joan de Flovià, en el seu nom propi i també com a tutora i curadora d'Isabel-la seua filla-nomenen el cirurgià Jaume Lorenz, veí de Gandia, com a llur procurador per a la presa de possessió de Ròtova que havien de fer Alamanda de Cabrera, Ausiàs de Cabrera i Guillem Pons-curador i tutor d'Ausiàs de Cabrera-i Galceran Cirera, habitant de Gandia.

AHN, Osuna, llig. I280, no. II, not. Pere Pugeriol.

II5

I428, desembre, 2O. Ròtova.

Alamanda de Cabrera, Ausiàs de Cabrera i Guillem Pons-curador i tutor d'Ausiàs de Cabrera- $i$ Galceran Cirera, habitant de Gandia, com a compradors del lloc de Ròtova, es comprometen, d'acord amb el text del compromís arbitral atorgat per Joan Gascó i Joan Cifre, a quitar, en l'espai de quatre anys $i$ sota pena de 100 lliures, els censals que sobre aquest lloc els Flovià havien carregat.

273. En una altra escriptura -AHN, Osuna, llig. I280, no. II, not. Pere Pugeriol, document del 23 de desembre de I428figura, en lloc d'aquesta xifra, la de ı.86o sous.

El més antic dels censals venuts a Flovià correspon als 50 sous, redimibles per preu de 30 lliures, que restaven d'aquells 83 sous i 4 diners venuts per l'hebreu Usua Cabelmale a Joan de Cabrera segons constava en escriptura feta a Gandia davant el notari Esteve Corts el 3i de març de г39г. Des del punt de vista de la biografia d’Ausiàs March i de Joan Roís de Corella, el més interesants d'ells són el de ıoo sous censals venuts per Violant de Vilarig a la tutela i curatela d’Ausiàs de Cabrera el 23 de gener de I4I6 i, també, el de ıoo sous censals venuts per Elionor Ripoll a Joan de Cabrera el I9 d'octubre de I_II2. 
AHN, Osuna, llig. I28o, no. II, not. Pere Pugeriol.

пі6

I428, desembre, 20. Ròtova.

Joan de Flovià, cavaller, i Úrsula, la seua mare, d'una part, i de l'altra part Alamanda de Cabrera, Ausiàs de Cabrera i Guillem Pons-curador i tutor d'Ausiàs de Cabrera-i Galceran Cirera nomenen misser Joan Gascó com a àrbitre i amigable componedor, i es comprometen a acceptar les seues decisions "sobre qualsevol duptes, debats e questions que sien o s'esperen ésser o sortir entre les dites parts axíper via del compromés fermat entre les dites parts a XXII de octubre del present any com de la sentència donada per los dits àrbitres a XXV [sic] dies del dit mes e declaració de aquella, etc, com encara de la compra e venda del dit loch de Ròtova e pagaments del dit loch e altres totes e sengles coses tocants o devallants de les dites coses, incidens, dependents e emergents de aquelles, etc. E en totes altres e qualsevol questions e debats civils e criminals que entre nos dites parts dien o $\times_{5}$ speren ésser de tot lo temps passat tro en lo present dia de huy entre nos dites parts". Aquest compromís tindrà una duració d'un any a partir del dia de Nadal de 1428 i la seua ruptura estarà penada amb 300 florins d'or.

AHN, Osuna, llig. I280, no. II, not. Pere Pugeriol.

II7

I428, desembre, 2O. Ròtova.

Joan de Flovià, cavaller habitant de Gandia, promet a Alamanda de Cabrera, Ausiàs de Cabrera $i$ a Galceran Cirera eixir del lloc de Ròtova i no romandre-hi després de la presa de possessió dels nous senyors territorials.

AHN, Osuna, llig. I280, no. II, not. Pere Pugeriol.

II8

I428, desembre, 2O. Ròtova.

Joan de Flovià, cavaller habitant de Gandia, dóna a Úrsula, la seua mare, tots aquells 1384 sous is diners censals que a ell havien venut Alamanda de Cabrera, Ausiàs de Cabrera i Galceran Cirera pel lloc de Ròtova. Aquesta donació l'efectuava Flovià com a pagament dels 18.ooo sous que Úrsula havia aportat al seu marit com a dot i que aquest havia reconegut en el seu darrer testament. ${ }^{274}$

AHN, Osuna, llig. I28o, no. II, not. Pere Pugeriol.

II9

I428, desembre, 23. Gandia.

Atés que Ausiàs de Cabrera era menor de 20 anys i restava obligat en totes aquestes vendes $i$

274. Úrsula acceptà aquell mateix dia aquesta donació, però cedí les pagues del primer any d'aquests I.384 sous i 8 diners censals al seu fill, Joan de Flovià (AHN, Osuna, llig. I28o, no. II, not. Pere Pugeriol-2O de desembre de I428). 
compromisos per l'actuació dels seus representants, Ausiàs de Cabrera i el cavaller habitant de Gandia Ausiàs March, senyor de Beniarjó i procurador d'Ausiàs de Cabrera, prometen a Joan de Flovià que, en el moment que Ausiàs de Cabrera complira la majoria d'edat-els vint anys-, acceptaria explícitament $i$ signaria tot allò que en el seu nom s'havia fet en raó de la compra del lloc de Ròtova .

AHN, Osuna, llig. I280, no. II, not. Pere Pugeriol.

$\mathrm{I} 2 \mathrm{O}$

I429, gener, I2. Gandia.

Alamanda de Cabrera, vídua del cavaller de Gandia Joan de Cabrera, ven a Pere Verdeguermenor-, veíde Gandia, cinquanta sous censals anuals per preu de trenta lliures. Aquest censalva ser venut a ella davant el notari Lluc Pous el 13 de juliol de 1424.

AHG, pergamins, no. 261. ${ }^{275}$

I2I

I43O, abril, 5. Gandia.

Joan Mateu, veí de Gandia, i Teresa, la seua esposa, reconeixen a Jaume Català, veí d'Aiora, el lliurament de diversos censals entre els quals se'n troba un per 66 sous i 8 diners que Elionor Ripoll, vídua de Pere March, i Ausiàs March, el seu fill, van vendre a Alamanda de Cabrera segons constava per instrument públic fet a Gandia el 14 de setembre de 1425 davant el notari Lluc Pous. Alamanda va traspassar aquest censal a Mateu per acte de venda fet a Gandia el 28 de setembre de 1428 davant el notari Pere Belsa.

AHN, Osuna, llig. I206, no. 5, not. Pere Belsa.

I22

I430, juny, I3. Gandia.

Codicil de Saura d'Esplugues, vídua del cavaller Pere Roís de Corella. Hi estableix que "Marta, serventa e sclava mia, sia de l'honorable frare Manuel Rö̈ç de Corella a fer de aquella a ses plenes voluntats".

AHN, Osuna, llig. I206, no. 5, not. Pere Belsa.

$\mathrm{I} 23$

I430, juliol, 24. Gandia.

Ausiàs Roís de Corella, cavaller habitant de València, reconeix als jurats de Dénia el lliurament de 291 sous, 8 diners que a ell fan anualment de cens.

AHN, Osuna, llig. I280, no. I3, not. Pere Pugeriol.

275. Document publicat en Olaso I987, 57 . 
124

I430, desembre, 4. Gandia.

Ausiàs de Cabrera, donzell habitant de València, i la seua esposa Damiata de Celma venen a Joan Sànchez Muñoz, cavaller de Gandia, 6o sous censals.

AHN, Osuna, llig. I35O, no. 3, not. Jaume Pérez de Culla.

I25

I43I, desembre, 29. Gandia.

Fra Manuel Roís de Corella, comanador de Culla, constitueix en procurador seu Antoni Sfano, mercader de Gandia, per a rebre 4.680 sous a ell deguts.

AHN, Osuna, llig. I206, no. 6, not. Pere Belsa

126

I432, maig, 3. València. ${ }^{276}$

Declaracions d'Ausiàs Roús de Corella, cavaller habitant de Gandia, en un procés judicial entre Aldonça-donzella, filla i hereua del difunt cavaller de Gandia Joan Eximenes Romeu-i mossén Joan de Cervató -com a curador d'Aldonça-d'una part, i mossén Galceran de Vich, habitant de Gandia, en raó del debat existent entre ells per una casa i diferents censals. Segons Ausiàs Roús de Corella era més profitós per a Aldonça signar el compromís establit amb Vich que continuar pledejant.

Els de juny de 1432 el justícia, d'acord amb els testimoniatges arreplegats, autoritza el curador d'Aldonça a signar el compromís amb Galceran de Vich redactat per Pere Andreu i Lluís Despuig, ciutadans de València.

ARV, Justícia Civil, no. 886, mà 8a , f. $5^{\text {r. }}$

127

I432, juliol, 2. València.

Reclamació de censals als representants del lloc de Gata feta, davant el lloctinent general Pere Bou, pel notari Pere Rubiols, procurador d'Ausiàs de Cabrera.

ARV, Governació, no. 2246, mà 7, f. I7rv.

128

I432, setembre, i6. València.

Elclavaride la Generalitat posa en data, en els llibres de la claveria, la quantitat de 12 lliures, 10 sous que abonà a Ausiàs de Cabrera, donzell de Gandia, i que li eren deguts de la pensió del 29 d'agost passat en raó de 500 sous censals que Cabrera rep anualment sobre els béns del "dit General, pagadors a XXVIIII de agost e de febrer".

${ }_{27} 6$. Encara que hi figura el mes de juny, de la resta del plet es dedueix que la declaració del pare d’Ausiàs es va fer en el mes de maig. 
ARV, Generalitat, claveria, no. 696, f. I47r.

129

I433, abril, 3. Gandia.

Document de reconeixement del lliurament i recepció de dot entre Aldonça de Cabrera-donzella filla de Joan de Cabrera i d'Alamanda-i Ausiàs Roís de Corella, cavaller habitant de Gandia, amb ocasió de la realització del seu matrimoni.

Aldonça de Cabrera amb el consentiment de sa mare i dels seus parents es va col-locar en matrimoni amb Ausiàs Roís de Corella. Ara, en el moment d'efectuar-se el matrimoni, Aldonça lliura a Ausiàs, com a dot seu, un total de 27.0oo sous: 24.0oo sous en diners i censals donats pel seu germà Ausiàs de Cabrera, com a hereu de son pare, atés el llegat testamentari fet pel seu pare a Aldonça; els restants 3.000 sous li són donats per sa mare, Alamanda Cabrera, en ajuda del seu matrimoni.

Per la seua banda, Ausiàs Roís de Corella reconeix el lliurament d'aquest dot i, d'acord amb la legislació foral i la virginitat d'Aldonça, ell fa a Aldonça "uxori futuri mei" un augment o creix de 13.500 sous. Ausiàs Roís de Corella es compromet a restituir les quantitats de dot i creix en els casos establits per la legislació foral.

Com a testimonis figuren els preveres Guillem Ponç i Mateu de Corella i el donzell Pere Trullàs, tots ells habitants de Gandia.

ARV, protocols, no. 1902, not. Andrés Puigmicha.

I3O

I433, abril, 3. Gandia.

Ausiàs de Cabrera, donzell habitant de Gandia, en el seu nom propi i com a hereu universal de son pare, el cavaller de Gandia Joan de Cabrera-segons consta pel seu testament fet a Gandia, davant el notari Ramon Agualada, el 18 d'abril de 1414 i publicat pel mateix notari el 18 de setembre d'eixe mateix any-, per tal de lliurar a Ausiàs Roís de Corella el dot de 27.ooo sous acordat per la seua germana Aldonça de Cabrera-24.ooo sous pel llegat testamentarifet pel seu pare a Aldonça i els restants 3.000 sous donats per Alamanda Cabrera-,ven i transporta a Corella diversos censals per valor de 22.414 sous:

* 1.000 sous censals que Saurina Nebot, esposa de Ramon d'Abella, habitants de València, en el seu nom propi i del seu marit $i$ els representants de l'aljama de Gata carregaren al cavaller Joan de Cabrera per escriptura notarial davant el notari Ramon Agualada feta el 23 d'abril de 1395.

* 166 sous i 8 diners censals que Bernat Gavilà, la seua esposa Guillemona i Miquel Banyuls, de Dénia, carregaren, sobre un troç de terra en el terme de Dénia, al cavaller Joan de Cabrera per escriptura notarial davant el notari Ramon Agualada feta el 5 d'abril de 1406.

* 100 sous censals que Bernat Gavilà, el seu fill Bernat Gavilà-menor de dies-i la seua esposa Joana carregaren al cavaller Joan de Cabrera sobre una casa de Bernat Gavilà-menor de dies-al raval de Dénia per escriptura notarial davant el notari Ramon Agualada feta el 4 de maig de 1409.

* 104 sous, 6 diners censals que Pere Trullàs, donzell de Gandia, carregà al notari Ramon Agualada, com a tutor i curador d'Ausiàs de Cabrera, per escriptura notarial davant el notari Lluc Pous feta el 24 de febrer de $141 \%$.

* 91 sous, 8 diners censals que Jaume Martí, veí de Xàbia, com a procurador de Guillem Secca- 
major de dies- i la seua esposa Ponceta carregaren al cavaller Joan de Cabrera.

* 83 sous, 4 diners censals que Mateua-vídua de Domènec Coves-, el seu fill Antoni Coves,

Bernat Coves i la seua esposa Francesca, tots ells veïns de Benissa, carregaren al notari Ramon Agualada, com a tutor i curador d'Ausiàs de Cabrera, per escriptura notarial davant el notari Pere Pugeriol feta el 22 de desembre de $141 \%$.

* 5 o sous censals que el notari Lluc Pous carregà al prevere Guillem Pons, com a tutor i curador d'Ausiàs de Cabrera, per escriptura notarial davant el notari Jaume Soler feta el 2 de octubre de 1423.

55 sous censals que Antoni Rovira i la seua esposa Francesca, habitants de Pego, carregaren al notari Ramon Agualada, com a tutor i curador d'Ausiàs de Cabrera, per escriptura notarial davant el notari Pere Pugeriol feta el 27 d'abril de 1418.

* 5o sous censals que uns musulmans d'Algar "in montaneis citra collum de Rates" carregaren al cavaller Joan de Cabrera per escriptura notarial davant el notari Bertomeu d'Aragó feta el 18 de febrer de 1418 .

* 83 sous i 4 diners censals que Bertomeu Miró i Elionor, habitants de Pego, carregaren al cavaller Joan de Cabrera per escriptura notarial davant el notari Francesc Dalmau feta l'n de març de 1409.

Com a testimonis figuren els preveres Guillem Ponç i Mateu de Corella i el donzell Pere Trullàs, tots ells habitants de Gandia.

ARV, protocols, no. 1902, not. Andrés Puigmicha.

I3I

I433, abril, 3. Gandia.

Alamanda de Cabrera, el seu fill Ausiàs de Cabrera i Galceran Cirera, tots ells habitants de Gandia, nomenen procurador seu el notari Bernat Sans perquè els represente en qualsevol tipus de juís i demandes.

ARV, protocols, no. 1902, not. Andrés Puigmicha.

I32

I433, desembre, 29. Gandia.

Antoni Soler, veí de Gandia, posa Margarida, filla seua de 12 anys d'edat, al servei d'Ausiàs Roís de Corella, cavaller, i de la seua esposa per sis anys consecutius durant els qual es compromet a què la dita Margarida no fugirà. En finalitzar els sis anys, hauran de donar-li 20 lliures.

AHN, Osuna, llig. I206, no. 7, not. Pere Belsa.

I33

I434, gener, I4. Gandia.

Ausiàs March dicta una sentència arbitral en el debat que enfrontava diversos veïns de la vila per la mort de Ramon Perelló. Com a testimonis figuren els cavallers habitants de Gandia Ramon Soler, Ausiàs Roís de Corella i Bernat d'Esplugues. March sentencià l'establiment d'una treva entre les parts en conflicte per espai de tres anys, que començaria el primer de març vinent $i$, durant aquest temps, ell 
convocaria les parts i les escoltaria per tal de donar una sentència definitiva.

AHN, Osuna, llig. I206, no. 7, not. Pere Belsa.

I34

I434, febrer, IO. Gandia.

Ausiàs Roís de Corella, cavaller i habitant de Gandia, com a procurador de Saura d'Esplugues substitueix Bernat Julià, del lloc de Xàbia.

AHN, Osuna, llig. I206, no. 7, not. Pere Belsa.

I35

I434, abril, 4. Gandia.

Per tal de satisfer el deute que Ausiàs de Cabrera, donzell habitant de Gandia, havia amb Pere de Saraus li fa cessió de 166 sous que devia a Cabrera el cavaller Joan Cifre.

AHN, Osuna, llig. I2o6, no. 7, not. Pere Belsa.

I36

I434, abril, I2. Gandia.

Alamanda de Cabrera, vídua de Joan de Cabrera, i Ausiàs de Cabrera, el seu fill, venen a Damiata de Mota, de la ciutat de València, diferents censals per preu de 6r lliures.

AHN, Osuna, llig. I206, no. 7 , not. Pere Belsa.

I37

I434, abril, 22. Gandia.

Alamanda de Cabrera, vídua de Joan de Cabrera, i el donzell Ausiàs de Cabrera, fill seu, venen a Ausiàs Roís de Corella, cavaller de la dita vila, diversos censals per preu de 61 lliures. S'adjunta àpoca.

AHN, Osuna, llig. I206, no. 7, not. Pere Belsa.

I38

I434, abril, 22. Gandia.

Ausiàs Roís de Corella, cavaller i habitant de Gandia, reconeix a Alamanda de Cabrera, vídua de Joan de Cabrera, cavaller, el lliurament de 2.220 sous restants d'aquells z.ooo sous de la constitució del matrimoni amb Aldonça, filla seua i esposa d'Ausiàs Roís de Corella.

AHN, Osuna, llig. I2o6, no. 7, not. Pere Belsa. 
I434, abril, 27. Gandia.

Ausiàs Roís de Corella, cavaller i habitant de Gandia, reconeix a Bernat d'Esplugues, cavaller $i$

habitant de Dénia, el lliurament de 1.000 sous que a ell feia el de Dénia.

AHN, Osuna, llig. I206, no. 7, not. Pere Belsa.

$\mathrm{I} 4 \mathrm{O}$

I434, maig, I. Gandia.

Ausiàs Roís de Corella, cavaller i habitant de Gandia, i Aldonça, la seua esposa, venen a Miquel Ros, veíd'Ador, diversos censals per preu de 2.000 sous.

AHN, Osuna, llig. I206, no. 7, not. Pere Belsa.

I4I

I434, juliol, I5. Gandia

Ausiàs Roís de Corella, cavaller habitant de Gandia, com a procurador de la seua àvia Saura d'Esplugues - esposa de Pere Roís de Corella, habitant de Gandia-segons constava per acte notarial de procuració fet a Gandia el 28 de gener de 1433 davant el notari Joan Sart, sustitueix Joan Bas, veí de Xàbia, com a procurador.

AHN, Osuna, llig. I206, no. 7, not. Pere Belsa.

142

I434, setembre, 30. Gandia.

Testament d'Aldonça, esposa d'Ausiàs Roís de Corella i mare de l'escriptor Joan Roís de Corella. AHN, Osuna, llig. I206, no. 7, not. Pere Belsa.

Diejovis $X X X$ septembris [I434].

Com totes les coses mundanals sien trespasables e allenegables, etc, emperamor d'açò yo, na Aldonça, muller de l'honorable mossén Auziàs de Corella, stant malalta de greu malaltia de la qual tem morir, emperò en mon bon seny, íntegra loqüela, paraula manifesta e sancera, faç e ordén aquest [sic] aquest meu darrer testament e aquesta mia darrera voluntat. En lo qual, elegesch marmessor meu e d'aquest meu darrer testament execudors, ço és lo dit honorable mossén Auziàs de Corella, present, e la dita marmessoria abcetant, e los honorables mossén Guillem Ponç, prevere, e n’Auziàs de Cabrera, germà meu, absents axí com si fossen presents, als quals don licència, ço és a tots tres o als dos de aquells, que puxen vendre tants de mos béns que basten a conplir aquest meu darrer testament.

Elegesch la mia sepultura e del meu cos fahedora, en la capella de l'honorable en Johan de Cabrera, pare meu. La qual sepultura, ensemps ab lo aniversari e cap d'any, vull e man que sien fets bé e complidament a coneguda dels dits meus marmessors.

Ítem, vull e man que sia messa en les loables confraries, ço és de nostra Dona Sancta Maria e 
del benaventurat mossenyer Sant Nicholau. A les quals lex e man ésser donats de mos béns per los dits meus marmessors ço és, a la confraria de nostra Dona, cent sous, e de Sant Nicholau, cinquanta sous, pregant als senyors de priors e majorals de aquelles que.ls plàcia aceptar mi.

Ítem, vull e man que sia messa en la confraria de Sant Xristòfol, pregant als senyors de [sic] prior e majorals que plàcia acceptar mi. E lex a la dita confraria, tot ço que li pertanga per la entrada.

Ítem, lex a la honorable na Alamanda de Cabrera, mare mia e muller quòndam de l'honorable en Johan de Cabrera, pare meu, present, tres mília sous de reals de València. Los quals vull e man que li sien donats, per lo hereu meu davall scrit, tant tost aprés meu òbit, en diners o en censals en aquella manera que al dit mossén Auziàs de Corella, marit meu, plaurà.

Ítem, lex a l'honorable n’Auziàs de Cabrera, germà meu desús dit, aquells dos míllia cinchcents sous de reals de València per e servir ${ }^{277}$ dels quals me respon cert cens. Los li lex, ab lo cens degut e prorata, lo jorn de la mia fi.

Ítem, lex a na Francesca, muller d'en Anthoni Tortó, la qual a present stà en casa, cinquanta sous. Los quals vull e man que li sien donats tant tost aprés meu òbit.

En tots los altres béns e drets meus, faç hereu meu propri e universal per dret de institució, a fer de aquells dits béns e drets meus a ses planes voluntats, lo dit honorable mossén Auziàs de Corrella, etc.

Aquest és, etc.

Presents testimonis foren a la confecció del present meu testament per la dita testadriu appellats e pregats, lo honorable mossén Vicent Sorio, prevere, en Francesch Cabater e a·n Jacme Torres, sartre, vehins de Gandia. Los quals, ensemps ab mi notari, dixeren sí conéxer la dita testadriu.

I 43

I434, octubre, 29. Gandia.

Ausiàs Roís de Corella, cavaller habitant de Gandia, com a cessionari d'Ausiàs de Cabrera i

d'Alamanda, mare seua, reconeix a Bertomeu Renart, veí de Dénia, el lliurament de 31 lliures, 10 sous que Renart devia a Alamanda i Ausiàs de Cabrera.

AHN, Osuna, llig. I206, no. 7, not. Pere Belsa.

I 44

I435, febrer, I5. Gandia.

Alamanda, vídua de Joan de Cabrera-cavaller de Gandia-, el donzell Ausiàs de Cabrera-fill

d'ella-i Damiata, la seua esposa, tots ells habitants de Gandia, venen a Joan Gascó-prevere, canonge de la Seu de València i rector de Gandia-diversos censals.

AHN, Osuna, llig. I323, no. I4, not. Joan Lorca.

277. Paraula de lectura dubtosa.

Magnificat CLM I, 20I4, III-377. ISSN 2386-8295 
I 45

I436, abril, I9. Gandia.

Ausiàs Roís de Corella, cavaller i habitant de Gandia, confesa a Pere Martí, habitant de la dita vila, el lliurament de 500 sous que a ell feia de violari.

AHN, Osuna, llig. I206, no. 8, not. Pere Belsa.

146

I436, maig, 5. Gandia.

Ausiàs de Cabrera, donzell i habitant de Gandia, nomena com a procurador seu Antoni Ferrer, veí d'Oliva, per a l'execució que Cabrera realitza contra els béns de Joan Ferrando, de la vila d'Oliva.

AHN, Osuna, llig. I206, no. 8, not. Pere Belsa.

147

I436, maig, 7. Gandia.

Damiata, esposa d'Ausiàs de Cabrera -donzell habitant de Gandia-i hereua universal de l'esposa de l'honorable Joan Roca, cavaller habitant de València, nomena Joan Caposa, notari de València, com a procurador.

AHN, Osuna, llig. I206, no. 8, not. Pere Belsa.

I 48

I436, maig, I2. Gandia.

Testament de Damiata, esposa d'Ausiàs de Cabrera. Nomena com a hereus els seus fills Joan $i$ Jaume.

AHN, Osuna, llig. I27O, no. I3, not. Pere Pugeriol.

I 49

I436, agost, I. Gandia.

Saura d'Esplugues, vídua de l'habitant de Gandia Pere Roís de Corella, declara davant de Guillem Balaguer, justícia de Gandia, com a testimoni en un procés de Joan de Monpalau, donzell, contra misser Gabriel de Santa Cília, doctor en lleis, com a curador dels béns deixats per mossén Berenguer Salelles -cavaller i oncle de Monpalau. El procés es feia per tal d'ésser declarat Monpalau successor ab intestato dels béns de Berenguer Salelles. Segons Saura, els pares del demandant-Joan de Monpalau i la seua esposa Francesca-, acudiren a missa per tal de celebrar llur noces "e véu axí mateix ella testimoni com lo senyor duch de Gandia menava a missa la dita na Francesca lo dit dia de les noces, los quals a cavall anaren a missa. E lo dit senyor duch tenia-la en la mà la una part de les regnes de la mula on la dita na Francesca cavalcav. a e axí a cavall véu anar aquells a missa ab molta altra gent que × ls acompanyava. Efon ella testimoni dins la ecclésia de Gandia lo dia que aquels hö̈ren missa en la dita ecclésia". 
ARV, Justícia Civil, no. 3726, mà IO ${ }^{\mathrm{a}}$, f. 8rv.

I5O

I436, agost, I9. Gandia.

Testament d'Ausiàs de Cabrera, donzell, fill d'Almanda de Cabrera i oncle de l'escriptor Joan Roís de Corella. Elegeix com a marmessors mossén Mateu de Corella, prevere de Gandia, Alamanda de Cabrera, la seua mare, i Damiata, la seua esposa. Ordena que sien destinats 2.000 sous dels seus béns per a fer la seua sepultura i aniversaris i, a més, que sien lliurats zoo sous als frares de Sant Jeroni de Cotalba en raó de zoo misses de rèquiem que haurien de fer. Si sobrava cap quantitat d'aquests 2.000 sous, calia lliurar-la per a casar òrfenes i per als pobres vergonyants. Deixa diferents Ilegats testamentaris als seus fills: a Jaume, 1.ooo florins que haurà de cobrar el dia que complisca 20 anys; a Elionor, 500 florins que hom li lliurarà en casar-se. Nomena usufructuària dels seus béns a Damiata, la seua esposa, sempre i quant no es casàs, designant-la aixímateix com a tutora $i$ curadora de llurs fills amb dos condicions: La primera, no poder vendre cap bé de l'herència sense el consell dels altres marmessors testamentaris; la segona, en cas de morir o de casar-se ella abans que Ilurs fills siguen majors d'edat, la tutoria i curadoria passaria a mans d'Alamanda de Cabrera ide Mateu de Corella. Nomena el seu fill Joan com a hereu universal amb el vincle i condició de què, en cas de morir sense fills de legítim matrimoni nascuts, l'hereu en seria Jaume i, si aquest també moria sense fills legítims, ho seria Elionor.

AHN, Osuna, llig. I206, no. 8, not. Pere Belsa.

I5I

I436, novembre, 2I. Gandia.

Testament de Saura d'Esplugues, besàvia del prosista i poeta Joan Roís de Corella.

AHN, Osuna, llig. I206, no. 8, not. Pere Belsa.

\section{Die mercuri XXI novembris anno predicto $M^{\circ} C C C C^{\circ} X X X V I^{\circ}$.}

Com totes les coses mundanals sien trespasables e allenegables e algú en carn posat scapar a la mort corporal no puxa, emperamor d'açò yo, na Saura d'Esplugues, muller quòndam de l’honorable mossén Pere Roïç de Corella quòndam [sic] de la vila de Gandia, stant sana, per gràcia de Déu, de cos e de pensa, etc.

E, primerament, revoque etc, faç e ordén aquest meu darrer testament e aquesta mia darrera voluntat, en lo qual o la qual elegesch marmessors, e d'aquest meu derrer testament execudors, ço és, a saber, los honorables frare Manuel Roïç de Corella -frare de l'orde de Muntesa e comanador de Culla- absent e mossén Matheu de Corella, prevere de la ecclésia de la vila de Gandia, present, als quals don licència, facultat e plen poder tants de mos béns vendre e alienar que basten a.nseguir e complir aquest meu darrer testament, etc.

Ítem, vull e man que sia feta la mia sepultura a coneguda dels dits meus marmessors.

Ítem, vull e man que, [per] los dits meus marmessors, sia mesa en la loable confraria del benaventurat mossenyer Sent Nicholau, pregant als prior e majorals de la dita confraria que.ls plàcia acceptar mi. E que per los dits meus marmessors sia pagat e satisffet, als dits prior e majorals, de mos béns tot ço e quant de dret e de justícia los pertanya e acostumen pendre en 
semblants casos.

Ítem, vull e man que, per los dits meus marmessors, sia donat de mos béns a cascun bací, de aquells que van per la ecclésia de la vila de Gandia, hun sous.

Ítem, vull e man que, per los dits meus marmessors, sien donades e pagades de mos béns, als honorables preveres de la ecclésia de la dita vila, vint lliures de moneda reals de València. Les quals vull e man que les sien donades ço és, déu lliures per un aniversari per la honorable dona na Johana, filla mia e muller de l'honorable mossén Bernat Domènech, cavaller, per ànima sua lexat e instituït en la ecclésia de la dita vila; e, com yo sia certa que aquell dit aniversari no s'és cantat ni celebrat per ço com los dits preveres no són stats pagats del dit aniversari, e per ço, per descàrrech de la ànima de la dita filla mia, vull e man que hajen les dites X lliures e que, de aquí avant, sia celebrat cascuns anys lo dit aniversari e pertualment. E, les altres deu lliures, vull e man que.ls sien donades e pagades per un aniversari lo qual, perpetualment, faç e instituesch en la ecclésia de la dita vila en axí que, cascuns anys, sia celebrat per ànima mia, de mos pare e mare e de tots altres ànimes fels defunts.

Ítem, lex e man ésser donades de mos béns al dit mossén Matheu de Corella, per los treballs per aquell per la dita marmessoria sostenidors, deu florins valents cent deu sous de reals de València.

Ítem, lex a na Marta, la qual me ha servit gran temps, si viva serà lo jorn de la mia mort, un çot, una gonella e mantell dels millors que seran atrobats en casa mia aprés mon òbit. Los quals, vull e man que li sien donats tant tost aprés la mia sepultura.

Ítem, vull e man que, per lo hereu meu davall scrit ni altri per aquell, no sia donada alguna cosa de mos béns a l'honorable en Guerau Domènech, nét meu, com sia ma voluntat que aquell haja res de mos béns, etc.

Ítem, vull e man que, per lo hereu meu davall scrit ni altri d’aquells, no deman ni puxa demanar d'aquells qui fan cens sinó a rahó de vint diners per liura com yo possehesca alguns censals carregats a rahó de dos sous per liura.

Ítem, lex al dit honorable frare Manuel Roïç de Corella, ultra lo usufruyt de tots mos béns segons davall appar, tots los béns meus mobles e postilles de l'alberch de la mia habitació, detrets los legats specialment de alguns béns meus dessús specifficats.

Tots los altres béns e drets meus haüts e per haver on que sien, do e lex e man ésser donats a l'honorable mossén Auziàs Roïç de Corella, nét meu, cavaller habitant de la vila de Gandia, nét meu [sic]. E, aquell, faç e instituesch hereu meu propri e universal per dret de institució a fer de aquels dits béns e drets meus a ses plenes voluntats sots tal pacte, emperò, e condictió que.l dit honorable mossén Auziàs de Corella, hereu meu, no faça ni fer puxa questió alguna ni inpediment a l'usufructuari meu dejús scrit.

Ítem, lex usufructuari universal de tots mos béns e drets, lo dit honorable frare Manuel Roíç de Corella, fill meu, de e per tota sa vida a fer de aquells dits usufruyts a ses plenes voluntats. E, si durant lo temps del dit usufruyt, se farà quitament algú dels dits meus censals, que en tal cas [... $]^{278}$ lo dit frare Manuel Roïç de Corella les dites quantitats emperò que haja e sia tengut $[\ldots]^{279}$ aquells en loch $[\ldots]^{280} \mathrm{e}[\ldots]^{281}$ del dit mossén Auziàs de Corella, hereu meu desús dit.

Aquest és lo meu darrer darrer testament, etc.

Foren fetes les dites coses en la vila de Gandia, etc. 
Presents testimonis foren a la confectió del present testament, apellats e pregats per la dita testadriu, ço és los honorables e discrets mossén Domingo Ramos, mossén Berthomeu Tamarit e mossén Berthomeu Vila, prevere de la ecclésia de la vila de Gandia. Los quals, ensemps ab mi notari, dixeren sí conexien la dita testadriu

$15^{2}$

I437, març, 22. València.

Eximén Pérez de Corella, Governador General del regne de València, es dirigeix a Alamanda de Cabrera, vídua de mossén Joan de Cabrera -cavaller de Gandia-i al donzell Ausiàs de Cabrera, son fill, i a la seua esposa Damiata, i els informa que Mateu Cardona, mercader i ciutadà de València, li ha mostrat una "carta pública executòria ab submissió e renunciació de for" feta a 21 de gener de 1435 rebuda pel notari Andreu de Puigmicha segons la qual tots ells vengueren al dit Cardona 500 sous censals. El mercader reclama als Cabrera 500 sous deguts d'una paga d'aquest censal i altres 200 sous com a pena.

ARV, Governació, no. I, f. I2Irv.

I53

I437, juny, I. València.

Mossén Ausiàs Roís de Corella figura entre els assistents a les corts celebrades a la catedral de València i convocades, en nom del monarca Alfons el Magnànim, per Joan, rei de Navarra.

Arxiu Municipal de València (AMV), processos de corts, yy-I5, f. I44V.

I54

I438, abril, 4. València,

Ausiàs de Cabrera, donzell habitant de Gandia, nomena el notari Pere Robiols com a procurador seu en la qüestió $i$ controvèrsia existent entre ell $i$ Galceran de Vilanova.

RCSCCV, protocols, no. 24335, not. Joan Tamarit.

I55

I438, juliol, I. Gandia Ausiàs March, cavaller habitant de Gandia, nomena com a procurador seu a Berenguer [...], veí de Gandia. Com a testimonifiguren el cavaller Ausiàs Roís de Corella i Joan Felip, habitants de Gandia. AHN, Osuna, llig. I206, no. 9, not. Pere Belsa 
I56

I438, setembre, I2. Gandia.

Ausiàs Roís de Corella, cavalleri habitant de Gandia, i Aldonça, la seua esposa, venen a Pere Perpinyà, ciutadà de València, certa "alcaream meam vullgariter nuncupatam Miraflor", al terme de Dénia, la qual afronta amb terres de la Cella, amb terres del Palmar i amb terres de Verger. Així mateix, livengueren un camp, situat dins el terme de l'alqueria, anomenat "lo camp de la mar" ique afrontava amb "arenis" [sic] de la mar, amb un camí públic i amb terres del Palmar. Tambéli venen un troç de terra, dins l'horta de l'alqueria de Mateu Corella i sota el domini del mateix Mateu Corella, amb un cens de 16 sous, 4 diners. El preu de venda de totes aquestes propietats fou de 12.500 sous.

Entre d'altres testimonis, figura el cavaller Bernat d'Esplugues.

AHN, Osuna, llig. I206, no. 9, not. Pere Belsa

$\mathrm{I} 57$

I438, setembre, I2. Gandia

Pere Perpinyà i Saurina, la seua esposa, reconeixen deure a Ausiàs Roís de Corella 12.0oo sous d'un total de 12.50o en què li varen comprar certes terres.

AHN, Osuna, llig. I206, no. 9, not. Pere Belsa

$15^{8}$

I438, setembre, I2. Gandia.

Pere Perpinyà i Saurina, la seua esposa, prometen lliurar a Ausiàs Roís de Corella 500 sous, part d'aquells 12.500 en què li varen comprar certes terres, en el termini d'un any a comptar des de la propera festa de sant Miquel.

AHN, Osuna, llig. I206, no. 9, not. Pere Belsa.

I59

I438, setembre, 20. Gandia.

Segons una nota marginal que figura en un llistat dels confrares que l'any 1440 integraven la confraria de Nostra Senyora de Sancta Maria de la vila de Gandia, Ausiàs de Cabrera morí el 20 de setembre de 1438 .

$\mathrm{AHG}$, manuscrits, $\mathrm{AB}$ I866, f. $3 \mathrm{~V}$

I6o

I438, setembre, 30. Gandia.

Bononata, vídua del notari de Gandia Guillem Ferrer, reconeix a Pere Demur, veí de Gandia, i a Joana, la seua esposa, la restitució de totes aquelles 20 lliures en què varen ser venuts a Alamanda de Cabrera, vidua del cavaller Joan de Cabrera, 33 sous i 4 diners censals per instrument notarial rebut a Gandia pel notari Pere Pugeriol el dia 13 de febrer de 1416. 
AHN, Osuna, llig. I2o6, no. 9, not. Pere Belsa

I6I

I439, desembre, I4. València.

Ausiàs Roís de Corella, cavaller, habitant de València i antic habitant de Gandia, reconeix a Pere Perpinyà el lliurament de 500 sous part dels 12.500 sous preu del lloc de Miraflor.

RCSCGV, protocols, no. 6433, not. Domènec Barreda.

I62

I440. Gandia.

Alamanda Cabrera figura en un llistat dels confrares de la confraria de Nostra Senyora de Sancta Maria de la vila de Gandia.

AHG, manuscrits, AB I866, f. $5 \mathrm{v}$

I63

I44O, desembre, 2. València.

Elnotari Cristòfol de Montblanch, ciutadà de València, com a procurador d'Ausiàs Roús de Corella - cavaller habitant de València-, segons consta per escriptura davant el notari Domènec Barreda, reconeix a Jaume Martorell, veí d'Alzira, el lliurament de 15 o sous corresponents a la paga del mes d'octubre d'un violari de zoo sous.

RCSCCV, protocols, no. 2736o, not. Joan del Mas.

I64

I440, desembre, I6. València.

Ausiàs Roís de Corella-cavaller habitant de València-, ven, per preu de zo lliures, a Bernat Perpinyà, ciutadà de València, tots aquells 33 sous, 4 diners censals que a Corella feia Pere Perpinyà, germà de Bernat. Aquest censal va servenut a Ausiàs Roís de Corella per Bernat d'Esplugues, fill i hereu de Joan d'Esplugues, per escriptura notarial feta davant el notari Joan Ferrer en el mes d'abril de 1439.

ARV, protocols, no. 254I, not. Berenguer Cardona.

165

I442, juny, I6. València.

Andreu Roig, veí d'Alzira, com a procurador de Lluc i de Mateu Martorell i, també, del donzell Jaume Martorell ide la seua dona Úrsula -tots ells habitants d'Alzira- quita diversos censals i violaris carregats per diferents persones. Entre aquestes persones figura el cavaller Ausiàs Roís de Corella, habitant de València, qui, davant el notari Cristòfor Monblanch el 27 d'abril de 1440, els va comprar zoo sous de violariper preu de 2.0oo sous. 
RCSCCV, protocols, no. 657I, not. Francesc Pelegrí.

I66

I442, juny, I6. València.

Ausiàs Roís de Corella, habitant de València, ven a Jaume Martorell, habitant d'Alzira, tots aquells зoo sous censals i anuals de violari que Martorell li havia carregat, durant la vida d'Ausiàs i de la seua dona Aldonça, per preu de 2.0oo sous davant el notari Cristófor Monblanch .

RCSCCV, protocols, no. 657I, not. Francesc Pelegrí.

I67

I442, octubre, I7. València.

Davant Pere Bou, lloctinent general de Governador de València. compareix mossén Lluís d'Abella, cavaller i senyor de Gata i Gorgos, i li comunica que s'oposa a la subhasta i venda dels béns de les aljames de Gata i Gorgos promogudes per diferents creditors - entre ells Ausiàs de Cabrera, habitant de Gandia-en raó de diverses quantitats degudes per alguns censals carregats pel síndic de dites aljames.

ARV, Governació, no. 2247, mà I2, f. I6rv

I68

I443, gener, 27. Gandia.

Ausiàs Roís de Corella, habitant de Gandia, reconeix a Bonanat Bordils, veí d'Ondara, el lliurament de 12 lliures restants d'aquelles 19, preu de venda d'un tros de terra de vinyes a Ondara. AHN, Osuna, llig. I206, no. I2, not. Pere Belsa.

I69

I443, febrer, I6. València.

Ausiàs Roís de Corella, habitant de València, i Aldonça, la seua esposa, venen per 35 lliures a Valentí de Barberà, habitant de València, 100 sous de violari rendals i anuals que a ells dos feien Joan Arbúcies, doctor en lleis, Francesca, la seua esposa, i altres persones i que varen ser carregats per escriptura notarial davant Domènec Barreda l'1 de juny de 1441.

RCSCCV, protocols, no. 2736r, not. Joan del Mas.

I70

I443, febrer, 26. Pedreguer.

Ausiàs Roís de Corella figura com a testimoni de les capitulacions matrimonials entre el poeta Ausiàs March, senyor de Beniarjó, i Constança Castellà, vídua de Bernat Escorna-senyor de Pedreguer-, sobre el matrimoni del poeta amb Joana Escorna, filla de Constança i de Bernat 
Escorna. ${ }^{282}$

AHN, Osuna, llig. I206, no. I2, not. Pere Belsa.

I $7 \mathrm{I}$

I443, març, 30. València-I445, octubre, I. València.

Mossén Ausiàs Roís de Corella figura, juntament amb Ausiàs de Cabrera, Ausiàs March i Joanot Martorell, entre els assistents a les corts celebrades a la ciutat de València i convocades per carta reial datada a Traiguera el 23 de febrer de 1443. La carta de convocatòria va ser lliurada a Roís de Corella el 4 de marc i assistí a les sessions celebrades el 30 de marş, 13 d'abril $i_{5}$ de juny de 1443; 27 i 29 de juliol de 1443; 8, 26 i 29 d'agost de 1443; 4, 12 i 26 de setembre de 1443; 16 de juny de 1444; 18 de gener de 1445; 1 de març de 1445; 8 de maig i d'octubre de 1445.

AMV, processos de corts, yy-I7, ff. I4r, 42r, 53r, 68v, 72r, 85r, 89v, 94r, IO4V, IO7r, II3V, I24V, I39v, I85v, 209r, 2I2r, 25Ir, 258v, 274r, 298r.

$17^{2}$

I443, setembre, I7. València.

Ausiàs Roís de Corella, cavaller de València, reconeix al ciutadà Bernat Perpinyà el lliurament de 23 lliures, 1 sou i 8 diners en raó d'aquelles 23 lliures, 1 sou i 8 diners censals restants d'aquells 1.000 sous censals anuals que a ell li havia de donar com a senyor de Miraflor.

ARV, protocols, no. 482, not. Berenguer Cardona.

I73

I444, juny, IO, València.

Lluís Alçamora, veí d'Alcoi, promet conservar indemne Ausiàs Roís de Corella en raó de la caplleuta donada, a pregàries seues, per Ausiàs per tal que Ramon Alçamora, parent de Lluís, no estiguera pres en mans de Joan de Gallach, doctor en lleis i jutge delegat per la reina. Ausiàs Roís de Corella va prometre restituir Ramon Alçamora a la justícia en el moment en què així ho demanaren.

RCSCCV, protocols, no. 934, not. Francesc Pelegrí.

174

I444, juny, I9, València.

Ausiàs Roís de Corella ven una esclava seua "de generum russorum" anomenada Margarida de 25 anys d'edat per 67 lliures a Briolanga, esposa de Lope Eximènez de Tolossa-donzell habitant de València.

RCSCCV, protocols, no. 934, not. Francesc Pelegrí. ${ }^{283}$

282. Document publicat en Fullana I935-36, 298-300.

283. Existeix, en aquest mateix protocol i dia, una escriptura en què Lope Eximènez de Tolossa i la seua esposa Briolanga reconeixen deure a Ausiàs Roís de Corella les 6 ? lliures de la venda de Margarida. 
$\mathrm{I} 75$

I444, setembre, 2. València.

Ausiàs Roís de Corella, cavaller habitant de València, ven, per preu de 6o lliures, a Ausiàs March 100 sous censals, rendals i anuals. Aquest censal originalment va ser carregat a Guillem de Vilarig per Elionor Ripoll, mare d'Ausiàs March, davant el notari Pere Pugeriol l'n d'abril de 1421. Aquest censal va ser comprat l'any 1436 per Ausiàs Roís de Corella.

Com a testimonis d'aquesta escriptura figuren Gonçalbo d'Íxer, comanador de Montabà, i el cavaller Joan Fabra, habitants de València.

RCSCCV, protocols, no. 934, not. Francesc Pelegrí.

I76

I444, octubre, 30. Gandia.

Ausiàs de Cabrera, donzell habitant de Gandia, i Damiata, la seua esposa, venen a Francesca, esposa del veí de Cullera Joan Agostí, una esclava anomenada Lícia, de 25 anys, per 66 lliures.

AHN, Osuna, llig. I206, no. I3, not. Pere Belsa.

I77

I444, novembre, 4. València.

Ausiàs Roís de Corella, cavaller de València, reconeix al ciutadà Bernat Perpinyà, com a posseüdor de l'alqueria de Miraflor, el lliurament de 228 sous, 4 diners censals en raó de 228 sous, 4 diners censals que Perpinyà havia de fer anualment a Corella.

ARV, protocols, no. 483, not. Berenguer Cardona.

I 78

I446-I449. València. ${ }^{284}$

Entre els contribuents durant eixos anys a la fàbrica del monestir de la Trinitat figuren, amb un donatiu de 55 sous cadascun, "lo honorable mossén Rö̈ç de Corella, cavaller; la honorable Na Aldonça, muller sua; En Johan Roüç de Corella, fill seu; frare Manuel de Corella, fill seu; Luis Roüç de Corella, fill seu". També hifiguren com a contribuents Ausiàs March, Jaume Roig i Bernat Fenollar, tots ells amb 55 sous, mentre que sor Aldonça Roís de Corella apareix amb un donatiu de 55 lliures.

I79

I447, març, 8. Gandia.

Ausiàs Roís de Corella, cavaller i habitant de València, d'acord amb el pacte establit davant el notari Jaume Pérez de Culla, cedeix a Joan Rostoxo certs drets en raó de 100 sous de violari deguts a Corella.

284. Document publicat en Mata 199I. 
AHN, Osuna, llig. I2o6, no. I6, not. Pere Belsa.

I80

I447, setembre, I6. Gandia.

Ausiàs de Cabrera, donzell i habitant de Gandia, en raó d'aquells 100 sous que Alamanda de Cabrera, la seua difunta mare, va deixar en el seu últim testament a Bernat de Sabrera, escuder d'Ausiàs de Cabrera, fa cessió al seu escuder de 11 lliures is sous.

AHN, Osuna, llig. I206, no. I6, not. Pere Belsa.

I8I

I448, agost, 23. Gandia.

Ausiàs de Cabrera, donzell i senyor de Ròtova, reconeix a Jaume Roca, cavaller i batle general de la vila d'Oriola, que, d'aquells 22 lliures i 10 sous que a ell li feia, li ha lliurat nI lliures, 5 sous.

AHN, Osuna, llig. I206, no. I7, not. Pere Belsa.

$\mathrm{I} 82$

I45O, maig, I8. València.

Codicils d'Aldonça Roís de Corella, vídua d'Ausiàs Roís de Corella i mare de l'escriptor Joan Roís de Corella.

AHN, Osuna, llig. I322, no. I, not. Antoni Barreda.

Com a cascú sia lícit e permés, ans e aprés confectió de son testament, fer e ordenar sos codicils, per tal yo, Aldonça, muller de l’honorable mossén Auziàs Roïz de Corella, cavaller, quòndam, habitant de la ciutat de València, stant sana de cors e de pensa ab paraula íntrega e manifesta, considerat mi haver fets e ordenats testament e codicils en poder del discret en Johan Sart, notari de la ciutat dessús dita, ço és lo testament a IIII del mes d'octubre de l'any M CCCC quaranta-set et los codicils los davalls scrits dia e any, e ab aquells no haver provehït de tudors, curador e administradors qui los meus fills e filles e béns detinguem [sic], regesquen e administren, per ço, ab los presents meus codicils, ajustant e affigint als dits meus testament e codicils, do e assigne en tudor e curador, en son cars e loch, e regidor e administrador als fills e filles mies en los dits meus testament e codicils nomenats e expressats, lo discret en Johan Sart, notari ciutadà de la dita ciutat de València, present. Al qual, molt carament, prech e afectuosa que, en les dites tutela e cura, regiment e administració, se haja bé axí com yo fie de aquell e de sa bona consciència.

Totes les altres coses en los dits meus testament e codicils contengudes, vull que resten en sa força e valor.

Aquest és mon codicil, lo qual vull que valgua per dret de codicils etc. Foren fetes etc, en València etc.

Testimonis foren presents a les dites coses demanats e preguats per la dita honorable codicillant, en Johan Biota, en Johan de Canyete, scuders, e en Johan Riquer, manyà, comorants en la ciutat de València qui coneixien la dita codicillant. E lo notari, axí mateix, 
conexia aquella e, ella, a ells.

183

I45O, octubre, I2. València.

Joan Sart, notari i ciutadà de València, com a procurador de Ramon de Riusec àlies Francesc Gilabert de Centelles, comte d'Oliva, segons constava per escriptura feta a Nàpols el 27 d'abril de 1450, ven a Aldonça Corella, vídua d'Ausiàs Roís de Corella, 500 sous censals, rendals i anuals per preu de 7500 sous.

N'hi ha una nota posterior segons la qual, el dia 25 de maig de 1453, Aldonça Roís de Corella va quitar aquest censal actuant com a testimoni d'aquesta cancel-lació Bertomeu Chiva, estudiant.

AHN, Osuna, llig. I322 no. I, not. Antoni Barreda

184

I45I, gener, I9. València.

Aldonça, en el seu nom propi i com a usufructuària dels béns del seu difunt marit Ausiàs Roís de Corella així com també com a tutora i curadora dels seus fills segons constava en el testament del seu difunt marit fet a València el 9 de febrer de 1443 davant el notari Joan Sart i publicat el 16 de gener de 145o, nomena l'estudiant Bertomeu Chiva, resident a la ciutat de València, com a procurador seu per a rebre qualssevol rendes, censals, etc. a ella pertanyents.

AHN, Osuna, llig. I322, no. 2, not. Antoni Barreda.

185

I45I, març, 2. València.

Aldonça, vídua d'Ausiàs Roís de Corella, com a usufructuària dels béns i drets que foren del seu marit, reconeix al notari Jaume Pérez de Culla, de Gandia, que per mans del mercader de la ciutat de València Bernat Paoner li ha lliurat 158 sous, 4 diners per pensions degudes en raó de 158 sous i 4 diners censals, anuals i rendals que el notarifeia a Aldonça Roís de Corella.

AHN, Osuna, llig. I322 no. 2, not. Antoni Barreda.

I86

I45, octubre, I. València.

Aldonça, vídua d'Ausiàs Roís de Corella, cedeix al notari Pere Banyuls, arrendador del lloc de Gata, Les accions que li pogueren pertànyer a ella contra l'aljama de Gata en raó de 1000 sous censals que, a Aldonça, feia l'aljama. També li reconeix el lliurament a ella de les quantitats corresponents a dos pensions d'eixos 1000 sous censals carregats sobre el lloc de Gata.

RCSCCV, protocols, no. 21312, not. Joan Sart. 
I87

I45 I, octubre, I. València.

Testament d'Aldonça, vídua del cavaller habitant de València Ausiàs Roís de Corella i mare de l'escriptor Joan Roís de Corella. Entre d'altres disposicions, nomena els seus fills Lluís i Dalfina hereus universals, llega a Joan Roís de Corella, fill seu, cent florins d'or i nomena, com a tutor i curador testamentari dels seus hereus universals, el cavaller Lluís de Calatayud fins que el futur escriptor tinga 25 anys "la qual edat attenyerà e complirà la vespra de la festa de Sant Miquel de l'any mil CCCC sexanta". ${ }^{285}$

AHN, Osuna, llig. I322 no. 2, not. Antoni Barreda.

Divendres, primer dia del mes d'octubre de l'any de la nativitat de nostre Senyor M CCCC ${ }^{\circ}$ cinquanta-hu

En nom de nostre Senyor Déus e de la humil e gloriosa Verge madona Sancta Maria, mare sua, advocada de tota crestiandat molt piadosa, e del benaventurat mossényer Sant Miquel. Considerat que mils e pus aptament e discreta, e ab més ,etc., per tal yo n’Aldonça, muller de l'honorable mossén Auziàs Roïz de Corella, cavaller, quòndam, habitador de la ciutat de València, considerades les dites coses, volent de mi e de mos béns en temps de sanitat ordenar e als meus cors e ànima provehir, per disposició testamentària stant sana de cors e de pensa e memòria e paraula íntregues, convocats e preguats los notari e testimonis dejús scrits, faç e ordén lo present meu testament e derrera voluntat.

En lo qual, e en la qual, elegesch, ordén e pose marmessor e exequdor meu e del dit meu present testament e voluntat, lo noble mossén Loís de Calatayhú, cavaller, habitador de la dita ciutat de València, jatsia absent, al qual do, atorgue e tribuesch ple e bastant poder, auctoritat e potestat e licència amplíssima sobre tots mos béns per exequir e complir lo present meu testament e coses en aquell per mi ordenades e davall scrites e que aquelles, per sa pròpria auctoritat, puixa pendre, demanar, haver, exhigir e recobrar, venre e alienar aquells, e los preus rebre e destribuir en complir lo present meu testament e coses en aquell contengudes e ordenades. Donant e atorgant-li, sobre les dites coses e sengles d'aquelles, general manament ab líbera administració volent que les dites coses e sengles d'aquelles faça sens dan llur e de sos béns e sens que no sia tengut donar compte ne rahó alguna de la dita distribució, administració e marmessoria a jutge o offical algú o a altra qualsevol persona, axí ecclesiàstica com seglar, ans vull que de la dita administració, distribució e marmessoria, lla hon request ne puxa ésser, vull aquell dit noble marmessor meu ne sia cregut de lur sola e simple paraula. tot linatge de prova apart posat.

E venint a la ordinació de present meu testament, vull, man e ordén que tots mos torts, deutes e injúries sien paguats e satisfets aquells, emperò que mostraran mi ésser tenguda e obligada ab cartes, albarans e altres legíttimes proves for de ànima, en açò, benignament observat.

En aprés, elegesch sepultura al meu cors en lo monestir de la Sanctíssima Trinitat de la dita ciutat, ço és dins la ecclésia de aquell, en la fossa hon és soterrat lo dit honorable mossén Auziàs Roïz de Corella, quòndam cavaller e marit meu. La qual sepultura vull, man e ordén me sia feta molt simplament e molt tènua, axí com de persona pobre, e sens solemnitat alguna, com aquesta sia ma voluntat inconmutable.

285. Document publicat en Chiner I994b, 49-62. 
Ítem, a l'honorable en Johan Roïz, donzell, fill meu e del dit quòndam honorable marit meu, do e leix cent florins de moneda de València, valent cascun florí onze sous de la dita moneda, per tota part e legíttima e altre dret que a aquell en mos béns pertangués eo pertany pogués, com aquell sia instituït hereu per lo dit quòndam honorable mossén Auziàs Roís de Corella, pare seu e marit meu. E aquell dit honorable en Johan Roïz de Corella, fill meu, en los dits cent florins de la dita moneda, hereu meu faç e instituesch per dret de institució.

Ítem, a frare Manuel Roïz de Corella, frare e cavaller de l'orde de Sancta Maria de Muntesa, fill meu e del dit quòndam honorable marit meu, do e leix hun timbre d'or de moneda de València per tota part e legíttima e altre dret que a aquell en mos béns li pertangués eo pertànyer pogués. E aquell dit frare Manuel Roïz de Corella, fill meu, en lo dit timbre de la dita moneda, hereu meu propri faç e instituesch per dret de institució.

Ítem, a sor Aldonça Roïz de Corella, monga del monestir de la Sanctíssima Trinitat de la dita ciutat de València, filla mia e del dit quòndam honorable marit meu, do e leix hun altre timbre de la dita moneda per tota part e legíttima, e per tot altre dret que a aquella en mos béns li pertangués eo pertànyer pogués. E aquella dita sor Aldonça Roïz de Corella, filla mia, en lo dit timbre hereua mia pròpria faç e instituesch per dret de institució.

Tots los altres béns e drets e accions mies, haüts e per haver, hon que sien e a mi pertanguen eo pertànyer puxen per qualsevol causa, títol, manera e rahó, do e leix a Luís Roïz de Corella e a Dalfina Roïz de Corella, fills meus e del dit quòndam honorable marit meu. E aquells dits Luís Roïz de Corella e Dalfina, fills meus, en los dits béns e drets meus, hereus meus propris faç e instituesch per dret de institució; sots tal emperò vincle e condició que, qualsevol de aquells morint menor de vint anys e sens fill o fills legítims e de legíttim matrimoni nats e procreats a aquells sobrevivents, que, en tal cas, la part de aquell axí morint, sens diminució e defalcació alguna de legíttima trabel-liànica e altre dret, vingua e torne éntreguament a l'altre hereu meu a aquell sobrevivent, e aquell dit hereu meu sobrevivint a l'altre hereu a ell premorint en la manera e forma damunt dita hereu substituesch per dret de substitució e a mi, en lo dit cars, hereu faç e instituesch. E si per ventura serà cars, ço que a Déu no plàcia, que abduy los dits Loís e Dalfina, hereus meus, morram [sic] menors de vint anys e sens fill o fills legíttims e de legíttim matrimoni nats e procreats sobrevivents a aquells, en tal cars substituesch a aquells axí morints lo dit honorable en Johan Roïz de Corella, fill meu, e aquell dit honorable en Johan Roïz de Corella, fill meu, en lo dit cars hereu meu faç e instituesch per dret de institució en los dits béns sens diminució, defalcació e retenció de legíttima trabel-leyànica e altre qualsevol dret, a fer d'aquells a ses voluntats.

En tudor e en son loch e cars curador, do, leix e assigne als dits fills e hereus meus lo dit noble mossén Loís de Calatayhú, marmessor meu damunt dit, pregant-lo, en nostre Senyor Déus e llur bona caritat e amor, que, fins lo dit honorable en Johan Roïz de Corella, fill meu, éntregua edat de vint-e-cinch anys haja attesa la qual edat attenyerà e complirà la vespra de la festa de Sant Miquel de l'any mil CCCC sexanta, la dita tutela e cura dels dits fills e hereus meus vulla pendre, regir e administrar, encarregant-lo y en Déu e sa consciència. E, si per ventura, lo dit noble mossén Loís de Calatayhú morrà ans de pendre la dita tutela e cura, 0 aprés presa aquella e ans que lo dit honorable en Johan Roïz de Corella haja atesa la dita edat de vint-e-cinch, o, si per ventura, aquell dit noble mossén Loís de Calatayhú tudor e curador ésser no volrà o no porà, en tal cars e fins que lo dit honorable en Johan Roïz haja attesa la dita éntregua edat de vint-e-cinch anys, do, leix e assigne en tudor en son loch, e cars en curador, dels dits fills e hereus meus, lo molt honorable mossén Johan Català, cavaller, habitador de la dita ciutat de València; pregant-lo en Déus e sa bona conciència que, en son loch e cars, la dita 
tutela e cura dels dits fills e hereus meus prengua e administre, e los dits fills e hereus meus hajen molt carament en lur comanda com yo axí.u fie molt amplíssimament d'aquells.

Derrerament revoque, casse e anul-le e irrite e per revocats, cassats, anul-lats e irritats vull haver e he, qualsevol testament, codicils e altres qualsevol derreres voluntats per mi ça enrere fetes e ordenades en poder de qualsevol notari e sots expressió de qualsevol paraules axí com si en lo present meu derrer testament e derrera voluntat, de mot a mot aposades e scrites fossen, com d'aquells e aquelles me penida haver fets e ordenats, fetes e ordenades. E vulla lo present meu testament e derrera voluntat a aquells e aquelles prevaler e a aquells e a aquelles derogar, xi [sic] com segons dit és, aquells e aquelles ab lo present meu derrer testament casse, revoque, irrite e anul·le.

Aquest és lo meu derrer testament e derrera voluntat, lo qual e la qual vull valer e tenir per dret de testament e derrera voluntat. E, si per dret de testament e derrera voluntat aquell valer ne tenir porà, vull aquell valer e tenir per de dret de codicils e altra qualsevol derrera voluntat per aquells furs, drets e privilegis que mils valer e tenir porà, valrà.

Foren fetes les dites coses etc en València etc.

Testimonis foren presents a les dites coses, specialment convocats e preguats, los discrets mossén Johan Sànchez, rector de Sant Andreu, mossén Johan Steve e mossén Johan Serra, preveres de la dita ecclésia de Sant Andreu de la ciutat de València, qui, ensemps ab lo notari dejús scrit, dixeren que coneixien molt bé la dita honorable testadriu e aquella, axí mateix, dix que coneixea aquells.

I452, maig, 20. Gandia.

Damiata, vídua d'Ausiàs de Cabrera, ven a Pere Minyana, veí del castell de Palma, 4 o sous censals i anuals.

AHN, Osuna, llig. I206, no. 2O, not. Pere Belsa.

I89

I452, noviembre, 7. València

Aldonça de Cabrera, vídua del cavaller Ausiàs Roís de Corella, que habita en la parròquia de Sant Andreu de la ciutat de València "al cantó de la plaça de Sent Jordi" s'aveïna en la dita ciutat. ${ }^{286}$ AMV, Avehinaments, b ${ }^{3} 5$, f. ${ }^{\circ} 5^{r}$.

Die martis VII novembris anno Mo CCCCo LII ${ }^{\circ}$

La honorable dona n’Aldonça, muller de l'honorable mossén Ausiàs Roïç de Corella, cavaller quòndam habitant de la vila de Gandia, de present habitant en la ciutat de València en la parròquia de Sent Andreu al cantó de la plaça de Sent Jordi, precedent voluntat e consentiment dels honorables en Johan de Natera, generós, en Pere Sadrelles, mossén Johan Vives, cavaller, e en Luís Blanch, ciutadans [sic], quatre dels honorables jurats en lo present any de la dita ciutat, jura lo vehïnatge de aquella a temps de deu anys primer vinents. Lo qual jurament féu

286. Document publicat en Chiner 1997, 547-48. 
e prestà en poder de Bernat de Sent Feliu, notari, per comissió a ell feta per l'onorable en Martí Scolà, justícia civil en l'any present de la dita ciutat. En axí e en fe de l'honorable en Luís d’Alpicat, ciutadà de la dita ciutat, fill de l'honorable Martí Gil d'Alpicat, present e acceptant, obligaren e renunciaren, etc.

Testes en Berthomeu Chiva, studiant, e en Jacme Jovell, scuder, habitant en València. E de la ferma del dit en Luís d'Alpicat, qui ferma lo dit dia, són testimonis lo discret en Matheu Steve, notari, e en Luís Belluga, cambiador, ciutadans de València.

190

I453, gener, 9. València.

Bertomeu Chiva, procurador d'Aldonça Roís de Corella, reconeix haver rebut del notari gandià Jaume Pérez de Culla, a través del mercader Guillem Çafàbregues, 158 sous, 4 diners censals.

AHN, Osuna, llig. I322, no. 4, not. Antoni Barreda

I9I

I 453, febrer, 22. València

Aldonça Roís de Corella, com a cessionària de Joan Sart, reconeix haver rebut de Berenguer Vilarnau, 37 lliures, 6 sous, 9 diners que devia al dit Sart.

AHN, Osuna, llig. I322, no. 4, not. Antoni Barreda

192

I453, març, 20. València. ${ }^{287}$

Antoni Barreda, procurador d'Aldonşa Roís de Corella-tutora i curadora dels fills del difunt mossén Ausiàs Roús de Corella-, exposa davant el Justícia Civil de València que Aldonça havia certs drets d'hipoteca i d'obligació en els béns que foren de mestre Pere de la Rochella, barber de la cuutat de València, "lo qual dit dret devalla d'una compra de alberch que $\times$ l dit mestre Pere venéal pare del dit mossén Ausiàs". La referida vivenda, situada a la parròquia de Sant Joan del Mercat de València, ara la posseeix Pasqual Miró, barber. Barreda, com a representant d'Aldonça, demana al.Justícia Civil que "manets al dit en Pasqual Miró qui huy deté e poseex lo dit alberch ab lo càrrech dels dits dos censals que aquell dit alberch no al × liene ni la propietat dels dits censals pague ho quite ans la tinga per emparada e que si los dits censals ho algú de aquells volrà enfranquir, loyr ho quitar que per tuyció o seguretat dels drets de I la dita tudriu e curadriu meta la propietat de aquell en poder vostre o de vostra cort entimantho a la dita tudriu e curadriu e notificant-ho a aquella com axí sia per justicia faedor".

ARV, Justícia Civil, no. 917, f. ${ }_{7}{ }^{288}$ 
193

I453, maig, 25. València.

Aldonça, vídua d'Ausiàs Roís de Corella, cavaller de València, reconeix a Ramon de Riusec àlies Francesc Gilabert de Centelles, conseller reial, el lliurament a ella, per mans de Joan Sart, de 500 sous censals.

AHN, Osuna, llig. I322, no. 4, not. Antoni Barreda.

I94

I453, juny, I4. València

Aldonça, vídua d'Ausiàs Roís de Corella, cavaller de València, reconeix a Pere Martorell, cavaller de la dita ciutat, que per mans d'Azmet Banne, sarraí d'Ondara, arrendador de Negrals i Beniomer, li ha lliurat 291 sous, 8 diners d'aquells 583 sous, 4 diners que a ella li donava Pere Martorell.

AHN, Osuna, llig. I322, no. 4, not. Antoni Barreda

I95

I453, juliol, I9. València.

Aldonça, vídua d'Ausiàs Roís de Corella, cavaller de València, reconeix a Pere Ribera, veí d'Oliva, haver rebut 3.ooo sous que aquest li devia.

AHN, Osuna, llig. I322, no. 4, not. Antonio Barreda.

I96

I453, agost, 2. València.

El rei Joan II comunica als oficials de la vila de Gandia que Aldonça, vídua d'Ausiàs Roís de Corella, com a tutora i curadora dels seus fills, li ha comunicat que hi havia certa causa hipotecària davant del Justícia de Gandia entre Jaume Gomir i Guillem Olzina -com a possë̈dor d'una casaque va ser sentenciada en contra del dit Olzina. Aquesta sentència va ser recorreguda per Aldonça Roís de Corella i l'esmentat Olzina i, ara, Aldonça havia suplicat al rei l'evocació d'aquest plet a la cúria del Governador General del regne.

ARV, Reial Cancelleria, no. 273 , ff. $5^{\mathrm{v}-6 \mathrm{r} .^{289}}$

197

I453, octubre, I7. València.

Joan Avarca, porter, declara que de manament del Governador del regne i a instàncies d'Antoni Barreda, notari procurador d'Aldonça-vídua d'Ausiàs Roís de Corella, cavaller habitant de

289. Document esmentat en Riquer I964, 3, 255 -tot i que erròniament, amb la data 20 d'agost. Sobre aquest plet davant la cort del Governador General del regne referit a una casa al carrer major de Gandia, tenim nombrosos testimoniatges en ARV, Governació, núm 229I, mà I ${ }^{\mathrm{a}}$, f. $6 \mathrm{r}$ i mà $9^{\mathrm{a}}$, ff. Ir-I6v. 
València-com a tutora i curadora dels seus fills així com a usufructuària del béns del seu difunt marit, empara, en poder del donzell. Joan d'Esplugues, tots aquells 270 sous que anualment feia Lluís Calbet, ciutadà de València. El donzell restava obligat sota pena de 6o sous i restitució del bé emparat.

ARV, Governació, no. 2825, mà $3^{\text {a }}$, f. $46 \mathrm{r}$.

198

I453, novembre, 22. València.

Joan de Múrcia, porter, declara que de manament del Governador del regne i a instàncies d'Antoni Barreda, notari procurador d'Aldonça-vídua d'Ausiàs Roús de Corella, cavaller habitant de València-com a tutora i curadora dels seus fills així com a usufructuària del béns del seu difunt marit, empara en poder del mercader Francesc Tornet, com a comprador i posseïdor de l'alqueria de Beniala, totes les pensions degudes d'aquells 270 sous que anualment feia Lluís Calbet, ciutadà de València. Tornet afirma que feia dos dies que havia abonat a Calbet les referides pensions censals.

ARV, Governació, no. 2825, mà 4a , f. I6v.

I99

I454, gener, I9. València.

Pere Pelegrí-ciutadà de València-, el noble Joan de Próxita i Joan Canoguera Escrivà, cavaller de València, venen conjuntament a Aldonça Roís de Corella, vídua d'Ausiàs Roís de Corella, 150 sous censals anuals de violari durant les vides dels seus fills. Joan i Lluís Roís de Corella, donzells. El preu de venda és de $5^{2}$ lliures i 10 sous.

N'hi ha una nota posterior on figura que el 3o de gener de 1455, per voluntat d'Aldonça, es va cancel.lar aquesta escriptura de violari.

AHN, Osuna, llig. I322, no. 5, not. Antoni Barreda.

$2 \mathrm{OO}$

I454, abril, 29. València.

Pere Roís Escrivà de Corella, noble i cavaller de la ciutat de València, Pere d'Olesa, tintorer i ciutadà de la mateixa localitat, i Isabel, la seua esposa, venen a Aldonça, vídua d'Ausiàs Roís de Corella, 150 sous censals i anuals de violari durant les vides dels seus fills Joan i Lluís Roís de Corella, donzells. El preu de venda va ser de $5_{2}$ lliures i 1 o sous.

AHN, Osuna, llig. I322, no. 5, not. Antoni Barreda.

$2 \mathrm{OI}$

I454, abril, 3O. València.

Francesc Aguiló i Andreu Miquel Corts, donzells de València, venen a Aldonça, vídua d'Ausiàs Roús de Corella, 150 sous censals i anuals de violari durant les vides dels seus fills Joan i Lluís Roís de Corella, donzells. Elpreu devenda va ser de $5^{2}$ lliures i 10 sous. 
AHN, Osuna, llig. I322, no. 5, not. Antoni Barreda.

$2 \mathrm{O} 2$

I454, juliol, 30. València.

Jaume Dartés, cavaller de la ciutat de València, i Damiata, la seua muller, venen a Aldonça, vídua d'Ausiàs Roís de Corella, 171 sous i 6 diners rendals $i$ anuals de violari durant les vides dels seus fills Joan i Lluís Roís de Corella, donzells. El preu de venda va ser de 6o lliures.

N'hi ha una nota posterior on figura que el 30 de gener de 1464, per voluntat d'Aldonça, es va cancel-lar aquesta escriptura de violari actuant com a testimonis d'aquesta cancel-lació el donzell Joan Fabra i el notari Joan Toda.

AHN, Osuna, llig. I322, no. 5, not. Antoni Barreda.

203

I454, desembre, I7. Massamagrell.

Felip Boïl, noble habitant de València, ven a la seua esposa Aldonça el lloc de Rafadell, amb les seues cases i terres, per un total de 6o lliures. Aquesta venda s'efectuà en raó de les pensions degudes d'un violari de 160 sous rendals que Bö̈l feia anualment a la seua dona i que, originalment, va vendre i carregar a Ausiàs Roís de Corella, habitant de València, per escriptura notarial feta davant el notari Bernat Gali el 22 d'agost de 1443.

Arxiu General i Fotogràfic de la Diputació Provincial de València (AGFDV), Fons Duquessa d'Almodòvar, pergamins, no. 22.

204

I455, maig, IO. València.

Aldonça, vídua d'Ausiàs Roís de Corella-cavaller habitant de València-nomena Jaume de Bellmont àlies Gil, sastre de Dénia, com a procurador seu.

AHN, Osuna, llig. I322, no. 6, not. Antoni Barreda.

205

I 455, novembre, 3 . València.

El donzell Eximén Pérez Escrivà de Romaní, menor de dies, -fill d'Eximén Pérez Escrivà de Romaní, donzell habitant de València-, iJaume Síscar-donzell ifill de Pere Síscar, cavaller i habitant de València-venen a Aldonça Corella, vídua d'Ausiàs Roís de Corella, 100 sous rendals i anuals de violari durant les vides dels seus fills, el donzell Joan Roís de Corella i Dalfina Roís de Corella-donzella-, per preu de 35 lliures.

AHN, Osuna, llig. I322, no. 6, not. Antoni Barreda. 
I455, desembre, 22. València.

Joan Roís de Corella, donzell i habitant de València, fill d'Ausiàs Roís de Corella-difunt cavaller i habitant de València-i d'Aldonça, després d'afirmar ésser major de 20 anys, segons constava per sentència atorgada per Francesc de Soler-justícia civil de València-el dia 3 d'aquest mateix mes $i$ any en resposta a una requesta feta el 27 de novembre de 1455, cedeix a la seua mare en qualitat de donació inter vivos tots els seus béns i drets menys 10o florins dels quals ell podrà testar lliurement. Atés que aquests béns superen els 5 oo florins Joan Roís de Corella demana que el Justícia Civil de València concedisca, d'acord amb la legislació foral, el seu vistiplau.

Figura com a testimoni d'aquesta escriptura Bertomeu Chiva, estudiant.

AHN, Osuna, llig. I322, no. 6, not. Antoni Barreda.

207

I456, gener, I5. València.

Testament d'Aldonça Roís de Corella, mare de l'escriptor Joan Roís de Corella.

AHN, Osuna, llig. I322, no. 7, not. Antoni Barreda.

Die jovis intitulatorum XV januarï anno predicto $\mathrm{M}^{\circ} C C C C^{\circ} \mathrm{L}$ sexto.

En nom de nostre senyor Déu e de la humil Verge Maria, mare sua advocada de tota crestiandat molt piadosa, yo, na Aldonça, muller de l'honorable mossén Ausiàs Roïz de Corella, cavaller, quòndam, habitant de la ciutat de València, sana de cors ab pensa, memòria e loqüela íntregues convocats e pregats los notari e testimonis dejú -scrits faç e ordén lo present meu derrer testament e derrera voluntat.

En lo qual e en la qual elegesch, posse e ordén marmessor, e del present meu derrer testament exequdor, lo honorable en Johan Roïz de Corella, donzell, fill meu e del dit quòndam honorable marit meu, ací present; al qual done, atorgue, conferesch e tribuesch plen e bastant poder, auctoritat e potestat amplíssima sobre tots mos béns per exequir e complir lo present derrer meu testament e derrera voluntat, e coses en aquell contengudes e per mi ordenades. En axí que, per sa pròpria auctoritat e sens auctoritat de jutge o oficial algú, axí ecclesiàstich com seglar, puxa pendre, demanar, haver, exhigir, rebre et recobrar, vendre e alienar mos béns, e, los preus de aquells, rebre e distribuir en complir les coses en lo present meu derrer testament contengudes e per mi ordenades donant e atorgant-li, sobre les dites coses e sengles de aquelles, general manament ab líbera administració volent que, les dites coses e sengles de aquelles, lo dit fill e marmessor meu faça sens dan lur e de sos béns.

E, primerament, venint a la ordinació del present meu darrer testament vull, man e ordén que tots mos torts, deutes e injúries sien pagats e satisfets; aquells, emperò, que mostraran mi ésser tenguda e obligada ab cartes, albarans e altres legítimes proves, for de ànima benignament observat.

En aprés, elegesch sepultura al meu cors ésser feta en lo monestir de la sanctíssima Trinitat, construït fora los murs de la dita ciutat, ço és al cap del pont del portal appellat de la Trinitat, dins la ecclésia del dit monestir, en la fossa dins la qual fon soterrat lo dit quòndam honorable mossén Ausiàs Roïz de Corella, marit meu. La qual sepultura vull, man e ordén me sia feta molt simplament e molt tènua, axí com de persona pobre, e sens solemnitat alguna, com aquesta sia 
ma voluntat incommutable.

Ítem, com yo sia donatària universal dels béns e drets del dit honorable en Johan Roïz de Corella, fill meu e marmessor damunt dit, hereu universal qui fonch del dit quòndam honorable mossén Ausiàs Roïz de Corella, marit meu -appar de la donació ab carta rebuda per lo notari davall scrit a [en blanc] del mes de dehembre ara proppassat- lo qual dit honorable en Johan Roïz, en lo dit nom de ereu, era tengut pagar a frare Manuel de Corella, a Loís de Corella e a sor Aldonça de Corella, monga del monestir de la sanctíssima Trinitat, e a Dalfina, fills del dit quòndam honorable mossén Ausiàs Roïz de Corella e meus; ço és, a cascuns de aquells cent florins per lo dit quòndam honorable mossén Ausiàs Roïz de Corella a cascú de aquells legats per tota part e legíttima que en los béns e heretat de aquell los pertangués. E, per la dita donació, yo succehesqua en la dita heretat e béns del dit quòndam honorable mossén Ausiàs Roïz de Corella e sia obligada pagar a cascú de aquells los dits cent florins, per tal, ab lo present meu testament, vull e man que los dits cent florins sien pagats a cascú de aquells aprés òbit meu, si ja en ma vida per mi no.ls seran pagats, volent expressament lo present legat ésser revocat e haüt per revocat si per mi, en vida mia o per altre per mi, los dits cent florins a cascú de aquells, eo en sguart de aquells, als quals los dits cent florins seran stats pagats.

Ítem, leixe al dit honorable en Johan Roïz de Corella, fill e marmessor meu damunt dit, los censals, recens e violaris infrasegüents:

Primo, aquells quaranta-hun sous, huyt diners censals que en Bernat Renart, vehí de la vila de Dénia, e na Johana, sa muller, fan cascuns anys a la heretat del dit quòndam honorable mossén Auziàs Roïz de Corella, cavaller marit meu, pagadors a XXI de giner, sots pena de XXV sous, segons per les cartes de l'original carregament appar.

Ítem, aquells quaranta-hun sous, VIII diners censals que, a la dita herència del dit quòndam honorable mossén Ausiàs Roïz de Corella, son tenguts fer na Matheua, muller d'en Berenguer Jàfer, quòndam, e en Berenguer Jàfer, son fill; Francesch Climent e na Matheua, sa muller, vehins de Gandia, pagadors cascuns anys a VI de jener, sots pena de XX sous.

Ítem, aquells dohents dènou sous, huyt diners censals que la universitat de Teulada cascún any fa a la dita heretat, a XX de jener e juliol migerament, sots pena de cinquanta sous.

Ítem, aquells huytanta-tres sous, quatre diners censals que a la dita heretat fan en Bernat Sartre e na Sança, sa muller, vehins de [en blanc] pagadors en la festa de Nadal, sots pena de trenta sous.

Ítem, aquells dohents cinquanta sous censals que a la dita heretat fan los honorables en Tristany Johan e en Galeàs Johan, ciutadans de València, pagadors a XIII de octubre e de abril, sots pena de cinquanta sous.

Ítem, aquells cinquanta-cinch sous censals que a la dita heretat cascuns anys fan n’Anthoni Rovira e na Francescha, sa muller, vehins de Pego, pagadors a XXVII de abril, sots pena de XX sous.

Ítem, aquells sexanta-sis sous, huyt diners censals que a la dita heretat fan los honorables en Jaume Martorell e na Elionor, sa muller, vehins de Gandia, pagadors a XXI de abril, sots pena de XXX sous.

Ítem, aquells trenta-set sous, sis diners censals que n’Antoni Aguiló e sa muller, vehins de Gandia, fan a la dita heretat pagadors a XXVI de setembre, sots pena de XX sous.

Ítem, aquells cent cinquanta-huyt sous, quatre diners censals que a la dita heretat fan en Jaume Pérez de Culla, notari, e na [en blanc], muller sua, vehins de la vila de Gandia, pagadors a XIII de setembre, sots pena de [en blanc].

Ítem, aquells dohents vint-e-huyt sous censals que a la dita heretat fan en Pere Perpinyà e na Saurina, sa muller, vehins de Dénia, pagadors cascuns anys en la festa de Sant Miquel, sots 
pena de [en blanc] sous.

Ítem, aquells dohents sexanta-cinch sous censals que a la dita heretat fan los honorables mossén Ausiàs March e madona Yolant March e mossén Pere Guillem Lançol, cavallers, cascuns anys pagadors a XXII de octubre, sots pena de huytanta sous.

Ítem, aquells mil sous censals los quals a la dita heretat fa lo honorable mossén Bernat Splugues, cavaller, habitant de la vila de Dénia pagadors a VII de octubre, sots pena de CCCC sous.

Ítem, aquells quaranta-hun sous, huyt diners censals que a la dita heretat fan Abrafim Ajubet e [en blanc], sa muller, e en Johan Pelegrí, de Ondara, pagadors a XXIII de nohembre, sots pena de XX sous.

Ítem, aquells sexanta-sis, sous huyt diners censals que a la dita heretat fan n’Aldonça, muller d'en [en blanc] Garcia e en Gabriel Sànchiz alias Garcia, fill seu, vehins de Dénia, pagadors a VIIII de nohembre, sots pena de XXX sous.

Ítem, aquells cinch-cents sous censals que a la dita heretat fan la universitat de la ciutat de València pagadors cascun any a XXVII de noembre, sots pena de [en blanc] sous.

Ítem, aquells cent cinquanta sous de violari que a mi fan e fer són tenguts los honorables en Francesch Aguiló e n’Andreu Miquel Corts, donzells habitants de la ciutat de València, pagadors cascun any a XXX de abril.

Ítem, aquells cent cinquanta sous de violari que a mi fan los nobles mossén Pere Roïz Scrivà de Corella e lo honorable en Pere d'Olesa, tintorer, e na Ysabel, muller sua, pagadors cascun any a XXVIIII de abril.

Ítem, aquelles cent cinquanta sous de violari que a mi fan los honorable mossén Johan Canoguera Scrivà, cavaller, don Johan de Próxita e en Pere Pelegrí, ciutadà, cascuns anys pagadors a III de joliol.

Ítem, aquells cent setanta-hun sous, sis diners e mealla rendals de violari los quals a mi fan e són tenguts fer los honorables mossén Jacme Dartés, cavaller, e na Damiata, muller sua, pagadors a XXX de joliol e de jener.

Ittem, aquells cent sous de violari los quals a mi fan cascuns anys los honorables n'Eximén Pérez Scrivà, fill de l’honorable n’Eximén Pérez Scrivà de Romaní e en Jacme Síscar, fill de l’honorable mossén Pere Síscar, cascuns anys pagadors a III de nohembre.

Ítem, aquells dohent cinquanta sous de violari que a mi fan cascuns anys lo noble don Jayme d’Aragó e en Pere Jornet, ciutadà, cascuns anys pagadors a [en blanc].

Los quals dits censals, recensos e violaris ab les pensions e prorates degudes fins al dia de la mia fi, íntregament vull, man e ordén ésser del dit honorable en Johan Roïz de Corella, fill e marmessor meu damunt dit, volent que aquell, per sa pròpria auctoritat e sens solemnitat alguna, puxa rebre aquelles, demanar e exhigir axí com a cosa sua pròpria. Volent encara que lo dit legat de censals, recensos e violaris, ab les pensions e prorates degudes, sia decontinent aprés mort mia del dit honorable en Johan Roïz de Corella, fill e marmessor meu damunt dit, e aquell puxa fer de aquelles a ses pròpries voluntats sens contradicció alguna essent emperò aquell major de vint-e-cinch anys, segons per lo testament del dit quòndam honorable mossén Ausiàs Roïz de Corella és ordenat. En lo qual testament, lo dit honorable en Johan Roïz de Corella, fill e marmessor meu damunt dit, és hereu instituït e scrit e sots les condicions aposades a la heretat del dit honorable mossén Ausiàs Roïz de Corella, en lo testament per aquell fet en poder de l'honorable e discret en Johan Sart.

Faç lo present legat al dit honorable en Johan Roïz de Corella, fill meu, e no en altra manera, volent encara e disponent que si en ma vida me seran quitats alguns dels censals o violaris 
damunt conmemorats e per mi legats al dit honorable en Johan Roïz de Corella, fill e marmessor meu damunt [dit], e los preus de aquells per mi no seran stats smerçats e aquells $o$ altres censals o violaris fins en concorrent quantitat dels censals e violaris quitats, no seran consignats expressament en lurs carregaments o en altra manera en ma darrera voluntat leixats al dit honorable en Johan Roïz de Corella, fill e marmessor meu damunt dit, en tal cars vull, man e ordén e lexe al dit honorable en Johan Roïz de Corella, fill e marmessor meu damunt dit, tots los preus dels dit censals e violaris que dels damunt dits a mi seran stats quitats e les pensions e prorates per mi rebudes; e açò, sens contradictió alguna que no li’n puxa ésser feta. Donant facultat expressa al dit honorable en Johan Roïz de Corella, fill e marmessor meu damunt dit, que aquell com a marmessor meu e encara en nom de tudor e curador dels hereus meus dejús scrits, puxa assí pagar axí dels legats dels dits censals com encara de les pensions e prorates degudes com encara dels preus, pensions e prorates que apparrà per mi ésser stats rebuts per quitaments d'alguns dels censals eo violaris damunt dits, e per mi a aquell legats. E en los dits censals, recensos e violaris, pensions, preus e prorates damunt dits lo dit honorable en Johan Roïz de Corella, fill e marmessor meu damunt dit, hereu meu propri faç e instituesch.

Ítem, leixe al dit honorable en Johan Roïz de Corella, fill e marmessor meu damunt dit, tots e qualsevol béns, drets e accions que a mi pertanguen eo puxen pertànyer en virtut de la dita donació per lo dit honorable en Johan Roïz de Corella a mi feta. Volent expressament e de certa sciència, ab lo preset meu testament, que aquells sien adquesits [sic] al dit honorable en Johan Roïz de Corella, fill e marmessor meu damunt dit, axí pròpriament com si per aquell la dita donació a mi no fos stada feta.

Ítem, vull, man e ordén que tot lo moble de la mia casa, exceptats diners e pecúnia comptant, sia egualment partit entre los dits honorables en Johan Roïz de Corella e Loís Roïz de Corella, fills meus damunt dits.

Ítem, leixe a frare Manuel Roïz de Corella, cavaller de l’orde de Muntesa, e a sor Aldonça, monga de la sanctíssima Trinitat, fills meus damunt dits e del dit quòndam honorable mossén Ausiàs Roïz de Corella, marit meu, ço és a cascun de aquells hun timbre d'or de moneda de València per tota part legítima e altre dret que a aquells en mos béns los pertangués eo pertànyer pogués. E cascun de aquells en la dita quantitat, hereu meu propri e universal faç e instituesch per dret de institució.

Ítem, com en Berthomeu Chiva, resident en casa e servir meu, de present com a procurador e en nom de procurador meu, reba les ànnues pensions de tots los censals, recensos e violaris meus e altres quantitats e béns meus e a mi pertanyents, de les quals fa delliurament a mi sens que del dit delliurament per mi no li es feta cautela alguna. E com yo fie molt amplament de aquell e lur consciència, vull e man que, aprés òbit meu, lo dit en Berthomeu Chiva per lo dit honorable en Johan Roïz de Corella, fill marmessor e tudós e curador damunt e dejús scrit, e ho per los hereus meus dejús scrits, sia absolt e difinit largament e amplíssima volent que lo dit en Berthomeu Chiva, per sa nua e simple paraula sens prova alguna sia cregut de tot ço que aquell dirà per mi e en nom de procurador meu per mi haver rebut e haver liurat a mi. E açò, segons dit és, sens prova alguna e per sola aserció de aquell e, si per subtilitat de dret o en altra manera per los hereus meus dejús scrits eo per lo tudor e curador de aquells eo per altra qualsevol persona a qui incumbís, serà demanat compte al dit en Berthomeu Chiva de la dita procura eo de les quantitats que aquell en nom de procurador meu haurà rebut, e aquell serà condemnat en restituhir més quantitat que aquell, per sa sola aserció afermarà ésser a mi e a la mia heretat tornador, en tal cars vull, man e ordén que tot ço e quant serà declarat e ajutgat lo dit en Berthomeu Chiva ésser tornador a la mia heretat més de ço que aquell per sa sola paraula afermarà ésser tornador, sia del dit en Berthomeu Chiva. E, al dit en Berthomeu Chiva, la dita 
quantitat en la qual serà condemnat en més de ço que aquell afermarà ésser deutor a mi, ab lo present meu e darrer testament leixe e mane ésser donada per dret de legat absolent a cautela lo dit en Berthomeu Chiva, ara per lavors e lavors per ara, de tota actió, questió, petició e demanda que li pogués ésser feta en més de ço que atorgarà ésser deutor e tornador a la mia heretat, fahent-li pacte axí real com personal d'aquí avant no demanar la dita quantitat.

En tots los altres béns e drets meus e actions a mi pertanyents eo pertànyer podents e on que sien e a mi pertanguen per qualsevol títol, causa, manera e rahó, do e leix a Loís Roïz de Corella e a Dalfina, germans, fills de dit quòndam honorable mossén Ausiàs Roïz de Corella e meus, egualment entre aquells partidors. E aquells dits Loís Roïz de Corella e Dalfina, en los dits béns e drets, egualment, hereus meus propris e universals faç e instituesch per dret de institució. Sots tal emperò vincle e condició, que qualsevol dels dits Loís Roïz de Corella e Dalfina, hereus meus damunt dits, morints menor de vint-e-cinch anys e sens fills legíttimes eo de legíttim matrimoni nats e procreats a aquell sobrevivints, que, en tal cars, la part de aquell dels damunt dits hereus meus axí morint sens diminució e difalcació [sic] alguna de legíttima o treballiança eo de qualsevol altre dret, éntregament torne a l'altre dels hereus meus sobrevivint e, en lo dit cars, aquell dels damunt dits hereus meus sobrevivint a l'altre en la damunt dita forma e manera, hereu substituesch per dret de substitució e a mi en lo dit cars hereu meu propri e universal faç e instituesch per dret de institució. E si cars serà, ço que a Déu no plàcia, que los dits Loís Roïz de Corella e Dalfina, hereus meus damunt scrits, morran menors de vint-e-cinch anys e sens fills legíttims e de legíttim matrimoni nats e procreats a aquells sobrevivints, en tal cars la dita heretat, sens diminució e difalcació e retenció alguna de legíttima falcida e trabel-liànica e de qualsevol altre dret, éntregament torne al dit honorable al dit honorable [sic] en Johan Roïz de Corella, fill e marmessor meu damunt dit. E aquell dit honorable en Johan Roïz de Corella, fill e marmessor meu damunt dit, en lo dit cars a aquells substituesch per dret de substitució e, a mi, hereu propri e universal faç e instituesch per dret de institució a fer dels dits béns e heretat a ses pròpries voluntats.

E com yo sia certa o informada e sàpia lo meu patrimoni, béns e heretat e drets de aquella e la valor e substància de aquells e a mi plàcia e la voluntat inconmutable sia que los legats e altres coses per mi dessús en lo present e derrer meu testament contengudes e per mi ordenades sien éntregament pagats e complits si e segons per mi és stat ordenat, per tal, ab lo present meu e darrer testament, prohibixch que los hereus meus damunt dits no puxen levar ne detraure dels dits béns e drets, dret de falcídia alguna ne trebel-leyànica ne de qualsevol altre dret a aquells pertanyents. Volent, expressament e de certa sciència, los hereus meus damunt dits ésser hereus en tot ço que restarà pagats primerament e éntrega los dits legats e coses per mi en lo dit meu darrer testament apposades e ordenades.

En tudor e en son loch e cars curador do, leix e assigne als dits Loís Roïz de Corella e Dalfina, hereus meus damunt dits, lo honorable en Johan Roïz de Corella, fill e marmessor meu damunt dit. Lo qual encarrech a lur consciència que en la tutela e cura de aquells eo dels béns de aquells, se haja axí, com yo d’aquell molt carament fie.

Darrerament, casse, revoque, irrite e anul.le, ab lo present meu derrer testament e darrera voluntat, processos vans, tolpis e nul-les he e vull haver, ab lo present meu testament e derrera voluntat qualsevol testament, codicils e altres derreres voluntats per mi fets e fetes ça enrere; en poder de qualsevol notari e sots qualsevol expressió de paraules, axí com si ací, en lo present meu e derrer testament scrites e aposades fossen, com me penida aquells e aquelles haver fets e fetes e vulla aquest meu derrer testament e derrera voluntat a aquells e aquelles prevaler.

Aquest és lo meu derrer testament e derrera voluntat, lo qual vull valer e tenir per dret de testament e derrera voluntat. E si aquell, per dret de testament e derrera voluntat valer e 
tenir no porà, vulla aquell e aquella valer e tenir per dret de codicills e altra qualsevol derrera voluntat, per aquells furs, privilegis, leys e constitucions que mils valer e tenir porà.

Foren fetes les dites coses en València, dijous comptat quinze del mes de jener any de la nativitat de nostre Senyor mil quatre-cents cinquanta-sis. Se+nyal de mi, n’Aldonça, testadriu damunt dita, qui les dites coses atorch, loe e ferme.

Presents foren per testimonis al present testament convocats e demanats, los discrets mossén Pere Simó, prevere ; mossén Bernat Johan, prevere beneficiat en la ecclésia parrochial de Sant Andreu, e mossén Francesch Centonge, prevere de la dita ecclésia de Sant Andreu. Los quals, interrogats per lo notari dejús scrits si coneixien la dita honorable testadriu, e digueren que sí e, lo dit notari, per semblant, coneixia la dita honorable testadriu, e aquella a ells.

208

I456, gener, 23. València.

Aldonça, vídua d'Ausiàs Roís de Corella, com a usufructuària dels béns del dit difunt segons constava en el seu testament fet davant el notari Joan Sart el 9 de febrer de 1443 i publicat per mort dels testador el 16 de gener de 1450, reconeix a Pere Martorell, cavaller habitant d'Alzira, que per mans d'Azmet Banne, sarraí d'Ondara i arrendador dels llocs seus de Beniomer i Negrals, ha lliurat en diferents terminis un total de 58 lliures, 6 sous i 8 diners a ella deguts en raó de 29 lliures, 3 sous i4 diners censals, rendals $i$ anuals que havien de fer a l'herència d'Ausiàs Roís de Corella. Com a testimonis d'aquesta escriptura figuren el mercader Bertomeu Chiva il'escuder Francesc de Vilarig, habitants de València.

AHN, Osuna, llig. I322, no. 7, not. Antoni Barreda

I 456, gener, 23. València.

Aldonça, vídua d'Ausiàs Roís de Corella, com a usufructuària dels béns del dit difunt segons constava en el seu testament fet davant el notari Joan Sart el 9 de febrer de 1443 i publicat per mort dels testador el 16 de gener de 1450, reconeix a Pere Martorell, cavaller habitant d'Alzira, que per mans d'Azmet Banne, sarraí d'Ondara i arrendador dels llocs seus de Beniomer i Negrals, ha lliurat a Aldonça d'un total de 20 lliures degudes, 6 sous i 8 diners a ella deguts en raó de 10 lliures i 10 sous rendals i anuals de violari que tots els anys havien de fer a l'herència d'Ausiàs Roís de Corella.

AHN, Osuna, llig. I322, no. 7, not. Antoni Barreda

$2 \mathrm{IO}$

I456, abril, 6 , València.

Aldonça, vídua d'Ausiàs Roís de Corella, cavaller de València, reconeix a Pere Martorell, cavaller de la dita ciutat, que per mans d'Azmet Banne, sarraí arrendador de Beniomer, li ha lliurat 291 sous $i$ 8 diners d'aquells 583 sous i 4 diners que a ella li donava l'esmentat Martorell.

RCSCGV, protocols, no. 952I, not. Jaume Vinader. 
I457, maig, I4. València.

Bertomeu Chiva, estudiant resident a València, com a procurador d'Aldonça Roís de Corella usufructuària dels béns del seu difunt marit Ausiàs Roís de Corella-reconeix a Ramon de Vilanova i a l'aljama de Gata que, per mans de Miquel Dalmau i Jaume Ferri-arrendadors de Gata-, li han lliurat 5 oo sous deguts de la paga d'un censal.

AHN, Osuna, llig. I322, no. 8, not. Antoni Barreda.

$2 \mathrm{I} 2$

I457, setembre, 7. València.

El noble Francesc Romeu, Francesc Aguiló i Andreu Miquel Corts -donzells-venen a Aldonça Roís de Corella 150 sous rendals i anuals de violari durant les vides dels seus fills.Joan Roís de Corella i Dalfina, donzella.

AHN, Osuna, llig. I322, no. 8, not. Antoni Barreda.

$2 \mathrm{I} 3$

I457, setembre, I4. València.

Aldonça, vídua d'Ausiàs Roís de Corella, reconeix a Bernat Çapena, veí de Xàbia, el lliurament de 45 lliures d'aquelles 61 que ell i Guillamona, vídua de Guillem Figueres, lifeien a ella.

AHN, Osuna, llig. I322, no. 8, not. Antoni Barreda.

$2 \mathrm{I} 4$

I457, desembre, 28. València.

Pere Pelegrí, ciutadà, Francesc Aguiló i Andreu Miquel Corts, donzells de València, venen a Aldonça, vídua d'Ausiàs Roís de Corella, tots aquells 100 sous rendals i anuals de violari durant les vides dels seus fills Joan Roís de Corella, cavaller, i Dalfina, donzella. El preu de venda va ser de 35 lliures.

Bertomeu Chiva, estudiant, figura com a testimoni d'aquesta escriptura notarial. Hi ha una nota posterior on figura que el 25 de febrer de 1461, per voluntat d'Aldonça, es va cancel-lar aquesta escriptura de violari.

AHN, Osuna, llig. I322, no. 8, not. Antoni Barreda.

$2 \mathrm{I} 5$

I458, gener, 9. València.

Gaspar Fabra, donzell, iFrancesc Romeu, habitants de València, venen a Aldonça, vídua d'Ausiàs Roís de Corella, 100 sous de violari durant les vides dels seus fills Joan Roís de Corella i Dalfina, donzella.

AHN, Osuna, llig. I322, no. 9, not. Antoni Barreda. 
$2 \mathrm{I} 6$

I458, gener, 25. València.

Joan Jerònim de Vilaragut, habitant de València, reconeix deure 150 sous a Aldonça Roís de Corella.

AHN, Osuna, llig. I322, no. 9, not. Antoni Barreda.

$2 \mathrm{I} 7$

I458, abril, I2. València.

Aldonça Roís de Corella, vídua d'Ausiàs Roís de Corella, reconeix a l'aljama de Gata el lliurament de 500 sous per mans d'Amet Valentí en nom de l'arrendador del lloc de Gata.

RCSCGV, protocols, no. 9542, not. Jaume Vinader.

$2 \mathrm{I} 8$

I458, maig, I8. València.

Lluís Mascó i Eximén Pérez de Romaní Escrivà, menor de dies, venen a Aldonça, vídua d'Ausiàs

Roís de Corella, la quantitat de 5 o sous de violari durant les vides dels seus fills Joan Roís de Corella $i$ Dalfina, donzella.

AHN, Osuna, llig. I322, no. 9, not. Antoni Barreda.

219

I458, agost, I. València.

Aldonça Roís de Corella reconeix a l'aljama de Gata el lliurament de 500 sous per mans de Jaume Ferri, veí de Gandia i arrendador del lloc de Gata.

AHN, Osuna, llig. I322, no. 9, not. Antoni Barreda.

$22 \mathrm{O}$

I458, setembre, I. València.

Francesc de Menaguera, cavaller i habitant de València, iSibil.la, La seua esposa, venen a Aldonça, vídua d'Ausiàs Roís de Corella, 50 sous rendals de violari durant les vides dels seus fills Joan Roís de Corella i Dalfina, donzella.

AHN, Osuna, llig. I322, no. 9, not. Antoni Barreda.

$22 \mathrm{I}$

I458, setembre, II. València.

Andreu de Vallterra, cavaller i habitant de València, i Damiata, la seua esposa, venen a Aldonça, vídua d'Ausiàs Roís de Corella, 6o sous rendals de violari durant les vides dels seus fills Joan Roís de Corella i Dalfina, donzella. 
AHN, Osuna, llig. I322, no. 9, not. Antoni Barreda.

222

I458, setembre, I4. València.

Aldonça Roís de Corella, vídua d'Ausiàs Roís de Corella, nomena procurador seu Pere Garcia, veí de Dénia.

RCSCCV, protocols, no. 9542, not. Jaume Vinader.

223

I458, setembre, I6. València.

Tristany Pardo de la Casta, cavaller i habitant de València, i Damiata, la seua esposa, venen a Aldonça, vídua d'Ausiàs Roís de Corella, zoo sous rendals anuals de violari durant les vides dels seus fills.Joan Roís de Corella i Dalfina, donzella.

AHN, Osuna, llig. I322, no. 9, not. Antoni Barreda.

224

I458, setembre, 26. València.

Miquel Albert, doctor en lleis i cüutadà de València, ven a Aldonça, vídua d'Ausiàs Roús de Corella, 200 sous rendals anuals de violari durant les vides dels seus fills Joan Roís de Corella i Dalfina, donzella.

AHN, Osuna, llig. I322, no. 9, not. Antoni Barreda.

I 458, octubre, 7 . València.

Aldonça Roís de Corella, vídua d'Ausiàs Roís de Corella, reconeix als jurats de Teulada el lliurament, per mans de Joan Livillo, de 109 sous i 1 o diners en raó d'aquells 219 sous i 8 diners censals que els dits jurats lifan anualment. El notari Antoni Barreda i Bertomeu Chiva, estudiant, habitants de València, figuren com a testimonis d'aquesta escriptura notarial.

RCSCCV, protocols, no. 9542, not. Jaume Vinader.

226

I458, octubre, 26. València.

Aldonça Roís de Corella, vídua d'Ausiàs Roís de Corella, i el cavaller Joan Roís de Corella, fill seu, reconeixen a Andreu Gassull, secretari reial i habitant de València, el lliurament a ells de 4.000 sous preu en què li varen vendre 266 sous $i 8$ diners censals, anuals i rendals.

RCSCCV, protocols, no. 26275, not. Jordi del Royo. 
I459, febrer, I3. València.

Aldonça, vídua d'Ausiàs Roís de Corella, com a usufructuària dels béns i drets de Joan Roís de Corella, fill i hereu d'Ausiàs, segons constava per la donació feta per Joan Roís el 22 de desembre de 1455 davant el notari Antoni Barreda, reconeix a Pere Galceran de la Serra, donzell i habitant de València, i al notari Joan de Monreal que, per via de lluïció i quitament de 6o sous rendals i anuals de violari-originalment carregats al difunt Ausiàs Roís de Corella per Pere Galceran de la Serra, Joan de Monreal i el cavaller Berenguer Saranyana davant el notari Cristòfol de Monblanch el dia 1 d'agost de 1440 a València-, li han lliurat a ella la quantitat de 15 lliures, per una banda, id'altres 140 sous i 8 diners en raó de pensions degudes del dit violari.

Figuren com a testimonis el pintor Lleonard Crespí, de la ciutat de València, i el veí de Sueca Francesc Coll.

AHN, Osuna, llig. I322, no. IO, not. Antoni Barreda.

228

I459, octubre, 3 . València.

Aldonça Roís de Corella, vídua d'Ausiàs Roís de Corella, nomena procurador seu el porter Lluís Goçalbo.

RCSCCV, protocols, no. 9543, not. Jaume Vinader.

229

I460, gener, I8. València.

Baltasar Lladró i Lluís de Vilanova, nobles i habitants de València, venen a Aldonça, vídua d'Ausiàs Roís de Corella, 150 sous rendals anuals de violari durant les vides de Joan Roús de Corella i Dalfina, donzella.

AHN, Osuna, llig. I322, no. II, not. Antoni Barreda.

230

I460, abril, 3. València.

Tomàs de Piera, cavaller i habitant de València, ven a Aldonça, vídua d'Ausiàs Roís de Corella, 60 sous rendals anuals de violari durant les vides de Joan Roís de Corella i Dalfina, donzella.

AHN, Osuna, llig. I322, no. II, not. Antoni Barreda.

$23 \mathrm{I}$

I460, maig, I5. València.

Testament d'Aldonça, mare de l'escriptor Joan Roís de Corella.

AHN, Osuna, llig. I322, no. II, not. Antoni Barreda 


\section{Die intitulatarum XV madii anno predicto $\mathrm{M}^{\circ} \mathrm{CCCC}$ o sexagesimo.}

En nom de nostre senyor Déu e de la humil Verge madona sancta Maria, mare sua advocada de tota crestiandat molt piadosa, yo na Aldonça, muller de l’honorable mossén Ausiàs Roïz de Corella, quòndam cavaller habitant de la ciutat de València, sana de cors ab pensa, memòria e loqüela íntregres, convocats e pregats los testimonis e notari dejús scrits, faç e ordén lo present meu darrer testament e darrera voluntat.

En lo qual elegesch, posse e ordén marmessor, e del dit present meu darrer testament exequdor, lo honorable mossén Johan Roïz de Corella, cavaller, fill meu e del dit quòndam marit meu, al qual done, atorgue e conferesch plen e bastant poder, auctoritat e potestat amplíssima sobre tots mos béns per exequir e complir lo present meu darrer testament e coses en aquell contengudes e per mi ordenades. En axí que, per sa pròpria auctoritat e sens auctoritat de jutge o oficial algú axí ecclesiàstich com secular e sens solemnitat alguna, puixa pendre, demanar, haver, exhigir, rebre, recobrar, vendre e alienar mos béns e, los preus de aquelles, rebre e destribuir en complir les coses en lo present meu darrer testament contengudes, e per mi ordenades, cartes de les dites vendes e alienacions fer e fermar ab aquelles per actes, clàusules, suplicacions, provissions, obligacions, renunciacions e ben vist li serà, fahent-ne com, de cosa sua pròpria. Donant e atorgant-li sobre les dites coses e sengles de aquelles, general manament, ab líbera e general administració, volent que la dita marmessoria e destribució de aquella no sia tengut donar compte ne rahó a jutge o oficial algú, axí ecclesiàstich com secular; e, on per alguna subtilitat de dret hi fos tengut e pogués ésser astret donar lo dit compte, vull que aquell sia cregut de lur simple paraula sens prova alguna de ço que dirà haver distribuït e administrat, volent que, les dites coses e sengles de aquelles, lo dit fill e marmessor meu damunt dit faça sens dan lur e de sos béns.

E, primerament, venint a la ordenació del present meu darrer testament, vull, man e ordén que tots mos deutes, torts e injúries sien pagats e satisfets aquells, emperò, que mostraran mi ésser tenguda e obligada ab cartes, albarans o altres legíttimes proves, for de ànima benignament observat.

En aprés, elegesch sepultura al meu cors ésser feta en lo vas dels pobres de aquella ecclésia parroquial de la qual en lo dia de la mia fi fore parroquiana. La qual sepultura, ab son aniversari e cap d'any, vull e man me sia feta molt simplement, axí com de persona pobre e sens solemnitat alguna, com aquesta sia ma voluntat incomutable.

Ítem, com en Berthomeu Chiva, studiant resident de present en ma casa e servir, com a procurador meu reba les ànnues pensions de tots los censals, recensos e violaris e altres quantitats e béns meus e a mi pertanyents de les quals aquell dit en Berthomeu Chiva ne fa delliurament a mi, sens que no $\cdot n$ rebrà cautela alguna, e, com yo molt àmplament fie de aquell e de mi a provada e experimentada consciència, vull e man que, aprés òbit meu, lo hereu meu dejús scrit, lo dit en Berthomeu Chiva sia absolt e difinit largament e amplíssima de la dita procuració e de les quantitats per aquell com a procurador meu rebudes; volent que, lo dit en Berthomeu Chiva, per sa nua e simple paraula e sens prova alguna, sia cregut de tot ço que aquell dirà, per mi e en nom meu e com a procurador meu, haver rebut e haver liurat a mi e per manament meu a altri per mi. E, si per subtilitat de dret o en altra manera, per lo hereu meu dejús scrit, e per altre havent causa de aquell, serà demanat compte e rahó al dit en Berthomeu Chiva de les quantitats per aquell com a procurador meu rebudes e, aquell dit en Berthomeu Chiva, serà condemnat en restituhir més quantitat que aquell per sa sola asser [sic] asserció afermarà ésser a mi e a la mia heretat tornador, en tal cars vull, man e ordén que tot ço e quant serà declarat lo dit en Berthomeu Chiva de la dita procuració e per causa de aquella ésser 
deutor e tornador a la mia heretat, ab lo present meu testament leixe e man ésser donada ab lo dit en Berthomeu Chiva per dret de legat. E, a cautela, ara per lavors e lavors per ara, absolch e difinesch lo dit en Berthomeu Chiva de tota questió, pensió e demanda que li pogués ésser feta en lo més de ço que aquell atorgarà per sa simple paraula ésser tornador e deutor a mi e a la mia heretat per rahó de la dita procuració, fahent-li pacte axí, real com personal, de aquí avant no demanar la dita quantitat.

Ítem, leixe a Loís Roïz de Corella, donzell, fill meu e del dit quòndam honorable marit meu, setze mília huyt-cents cinquanta sous moneda reals de València per tot e qualsevol dret de legíttima o altre dret que a aquell en mos béns li pertangués o pertànyer pogués, axí per los cent florins per lo dit quòndam honorable mossén Ausiàs Roïz de Corella a aquell ab son testament leixats com alias per qualsevol altre dret. Sots tal vincle e condició que, si lo dit Loís de Corella, fill e legatari meu damunt dit, morrà menor de vint anys e sens fills legíttims e naturals de legíttim matrimoni nats e procreats a aquell sobrevivents que, en tal cars, lo dit legat, éntregament, sens diminució e defalcació alguna de legítima o trebel-leyànica o de qualsevol altre dret, torne éntregament, e sia, de Dalfina, donzella filla mia e de dit quòndam honorable marit meu; e, advenint lo dit cars, la dita Dalfina al dit Loís Roïz de Corella en lo dit legat substituesch e, a mi, legatària instituesch. E, si advenint lo dit vincle, la dita Dalfina viva no serà, o viurà e en aprés morrà menor de vint anys e sens fills legíttims e de legíttim matrimoni nats e procreats aquella sobrevivint, en qualsevol dels dits cassos substituesch, en lo dit legat, lo dit honorable mossén Johan Roïz de Corella, cavaller, fill e marmessor meu damunt dit e hereu meu universal dejús scrit, e, a mi, legatari instituesch a fer del dit legat a ses plenes voluntats.

E, per semblant, leixe a la dita Dalfina, donzella filla mia e del dit quòndam honorable marit meu, altres setze mília huyt-cents cinquanta sous de la dita moneda per tota part e dret de legíttima aquella en mos béns pertanyent e per lo dret de cent florins per lo dit quòndam marit meu ab son testament aquella en mos béns li pertangués. Sots tal emperò vincle e condició que, si la dita Dalfina morrà menor de vint anys e sens fills legíttims e naturals de legíttim matrimoni nats e procreats a aquella sobrevivint que, en tal cars, lo dit legat éntregrament torne, e sia, de Loís Roïz de Corella, fill meu damunt dit; e, advenint lo dit cars, lo dit Loís Roïz de Corella en lo dit legat a la dita Dalfina substituesch e a mi legatari instituesch. E, si advenint lo dit cars, lo dit Loís Roïz de Corella viu no serà, o viurà e en aprés morrà menor de vint anys e sens fills legíttims e naturals de legíttim matrimoni nats e procreats a aquell sobrevivents, en qualsevol dels dits cassos substituesch en lo dit legat lo dit honorable mossén Johan Roïz de Corella, cavaller, fill e marmessor meu damunt dit e hereu meu universal dejús scrit e, a mi, legatari instituesch a fer del dit legat a ses planes voluntats.

Ítem, vull, man e ordén que lo dit honorable mossén Johan Roïz de Corella, cavaller, hereu universal meu dejús scrit, dins lo temps de sis mesos començant a córrer del dia avant que aquell haurà acceptada la mia heretat universal contínuament conptadors e no abans, per aquell sia tengut pagar als dits Loís Roïz de Corella e Dalfina, fills meus legataris damunt dits, lo dit legat de setze mília huyt-cents cinquanta sous a cascuns de aquells per mi dessús fet e leixat. Los quals dits legats sien pagats en pecúnia de comptants o en censals de la mia heretat ço és, en los censals que lo dit honorable mossén Johan Roïz de Corella, hereu meu dejús scrit, volrà e elegirà; lexant totalment la electió de pagar los dits legats en pecúnia de comptant o en censals e en quins censals, al dit honorable mossén Johan Roïz de Corella, cavaller, fill e hereu meu dejús scrit. En lo pagament e alienació dels quals censals en paga solució dels dits legats donadors, vull que lo dit honorable mossén Johan Roïz de Corella, hereu meu dejús scrit, tan solament sia tengut d'evictió, perfets negocis e contractes propris de aquell e no en altra 
manera, com aquesta sia ma voluntat.

Ítem, leix a frare Manuel Roïz de Corella, cavaller de l'orde de Muntesa, e a sor Aldonça de Corella, monga del monestir de la Sanctíssima Trinitat de la ciutat de València, fills meus e del dit quòndam honorable marit meu, ço és, a cascun de aquells, hun timbre d'or de moneda de València per tot dret, part e legíttima e altre dret que a aquells e cascun de aquells en mos béns los pertangués o pertanguer-los pogués.

En tots los altres béns, drets e actions meus e a mi pertanyents o pertànyer podents e devents per qualsevol títol, causa, manera e rahó, faç e instituesch hereu meu universal, per dret de institució, lo dit honorable mossén Johan Roïz de Corella, cavaller, fill e marmessor meu damunt dit, a fer de aquells a ses planes voluntats. En tudors en son loch e cars curador do, leixe, assigne als dits Loís Roïz de Corella e Dalfina, fills meus legataris damunt dits, lo dit honorable mossén Johan Roïz de Corella, cavaller, fill, marmessor e hereu meu universal damunt dit, lo qual encarrech en lur consciència que, en la tutela e cura de les persones e béns de aquells, se haja axí com de bon tudor e curador se pertany e yo àmplament fie de aquell.

Darrerament, casse, revoque, irrite e anul-le e, ab lo present meu darrer testament, per cassos, irrits, revocats e anul-lats he, e vull haver, qualsevol testaments, codicils e altres darreres voluntats axí en poder del discret en Johan Sart, notari, com del notari dejús scrit, com encara en poder de qualsevol altres notaris e, per mi, ça enrere fets e fermats e sots qualsevol expressió de paraules en aquelles aposades axí com si en lo present meu testament apossades fossen scrites e continuades com me penida aquells e aquelles haver fets e fetes e vulla, aquest meu darrer testament e derrera voluntat, a aquells e aquells prevaler e ésser lo meu darrer testament e última voluntat.

Aquest és lo meu darrer testament e darrera voluntat, lo qual vull valer e tenir per dret de testament e darrera voluntat e, si aquell per dret de testament e darrera voluntat valer e tenir no porà, vull aquell e aquella valer per dret de codicils e altra qualsevol darrera voluntat per aquells furs, privilegis, leys e constitucions que mils valer e tenir porà.

Foren fetes les dites coses en València a quinze del mes de maig any de la nativitat de nostre Senyor mil quatre-cents sexanta. Se+nyal de mi, n’Aldonça, testadriu damunt dita, que les dites coses ferme, lohe e atorgue.

Presents foren per testimonis al present testament convocats los discrets mossén Johan Sànchiz, prevere rector de la ecclésia parrochial de Sant Andreu, e mossén Pere Simó, prevere beneficiat en la dita ecclésia de Sant Andreu, e mossén Francesch Centonges, prevere, habitants de la dita ciutat de València. Los quals, interrogats per lo notari dejús scrit si coneixien la dita testadriu, e digueren que aquella coneixien molt bé e, per semblant, lo notari dejús scrit coneixia aquella dita honorable testadriu.

232

I460, maig, 26. València.

Els habitants de València Eximén Pérez de Romaní Escrivà, menor de dies, i el donzell Joan Escrivà, germà seu, venen a Aldonça, vídua d'Ausiàs Roís de Corella, 150 sous rendals anuals de violari durant les vides de Joan Roís de Corella iDalfina, donzella.

AHN, Osuna, llig. I322, no. II, not. Antoni Barreda. 
I460, novembre 27. València.

Macià Cardona, doctor en lleis i lloctinent de l'assessor ordinari subrogat de mossén Lluís de Cavanyelles, lloctinent del Governador General del regne de València, es dirigeix a diversos musulmans de Gata i de Mecleta i els comunica que Aldonça Roís de Corella, com a usufructuària dels béns del seu marit Ausiàs Roís de Corella i, també, com a tutora i curadora dels seus fills, els reclama el pagament de 100 sous per les pensions degudes en raó de 5 o sous censals carregats a Joan de Cabrera, pare d'Aldonça, i transportat en favor d'Ausiàs Roís de Corella per escriptura notarial feta, davant el notari Andreu Puigmicha, el 3 d'abril de 1433.

ARV, Governació, no. 33, mà I22, f. 84rv. ${ }^{290}$

234

I460, novembre 27. València.

Macià Cardona, doctor en lleis i lloctinent de l'assessor ordinari subrogat de mossén Lluís de Cavanyelles, lloctinent del Governador General del regne de València, es dirigeix a Miquel Sànchez $i$ a Guillamona -la seua esposa-i, també, alveí de Pego Joan Corts i els comunica que el notari Antoni Barreda, com a procurador d'Aldonça-usufructuària dels béns del seu difunt marit el cavaller Ausiàs Roís de Corella (hereu del difunt donzell.Joan Roís de Corella) itutora i curadora dels seus fills-, els reclama el pagament de 41 sous $i 8$ diners per les pensions degudes en raó d'un censal anual de 41 sous is diners adquirit pel referit donzell Joan Roís de Corella, per escriptura davant el notari Pere Pugeriol, el 18 de maig de 1419 .

ARV, Governació, no. 33, mà I22, f. $85^{\text {rv. }}{ }^{291}$

I46I, gener, 2I. València.

El subrogat de Lluís de Cavanyelles, lloctinent del Governador General del regne de València, es dirigeix a Violant March, mossén Ausiàs March ${ }^{292}$ i mossén Pere Guillem Lançol-cavaller-i els comunica que el notari Antoni Barreda, com a procurador d'Aldonça Roís de Corella-hereua d'Ausiàs Roís de Corella, difunt marit seu-, li ha mostrada una "carta pública executòria ab submissió e renunciació de for" feta el 22 d'octubre de 1444 davant el notariJoan Sart, segons la qual aquells varen carregar a Ausiàs Roís de Corella i als seus 265 sous censals. Barreda reclama l'abonament de 265 sous de la paga deguda del mes d'octubre.

ARV, Governació, no. 34, mà 6, f. $36 \mathrm{r}^{293}$

290. Document esmentat en Almiñana 1984-85, 392.

29I. Document esmentat en Almiñana r984-85, 392.

292. Ausiàs March havia faltat en I459. Des del punt de vista judicial, la demanda s'ha d'entendre dirigida als hereus del poeta.

293. Document publicat en Villalmanzo I999, 433 . 
236

I46I, febrer, 25. València.

Aldonça, vídua del cavaller Ausiàs Roís de Corella, reconeix al noble cavaller Baltasar Lladró el liurament de 52 lliures i 1 o sous, mitjançant Lluís Munyós, per a quita 150 sous de violari durant les vides de dos del seus fills -un d'ells Dalfina. ${ }^{294}$

RCSCCV, protocols, no. II362, not. Manuel d'Esparça.

237

I46I, juny, 8. València.

Aldonça Roís de Corella ven a Bernat Andreu, mercader, 100 sous rendals de violari que a ella lifeien Joan Arbúcies, doctor en Ileis, Francesca-la seua esposa-, el cavaller Jaume Arbúcies i Guillem Xerta.

AHN, Osuna, llig. I322, no. I2, not. Antoni Barreda.

$23^{8}$

I46I, juliol, I4. València.

Pedro d'Urrea, conseller i Governador del regne de València, comunica a mossén Tomàs de Piera, cavaller, que el notari Antoni Barreda -procurador d'Aldonça Roís de Corella-li ha mostrada una "carta pública executòria ab submissió e renunciació de for" feta el 3 d'abril de 1460 davant el mateix Antoni Barreda, segons la qual Piera carregà a Aldonça i als seus 6o sous de violari. El procurador d'Aldonça Roís de Corella reclama un total de 6o sous deguts en raó d'una paga d'aquest violari.

ARV, Governació, no. 36 , mà $53^{\text {a }}$, f. 2 Ir. $^{295}$

I46I, juliol, 2I. València.

Pedro d'Urrea, conseller i Governador del regne de València, comunica a mossén Tristany Pardo de la Casta, cavaller, i a la seua esposa, que el notari Antoni Barreda -procurador d'Aldonça Roís de Corella- li ha mostrada una "carta pública executòria ab submissió e renunciació de for" feta el 16 de setembre de 1458 davant el mateix Antoni Barreda, segons la qual el matrimoni Pardo de la Casta carregà a Aldonça i als seus zoo sous de violari. Barreda els reclama un total de 25 sous deguts en raó d'una paga d'aquest violari.

ARV, Governació, no. 36 , mà $55^{\text {a }}$, f. 4 orv. ${ }^{296}$

294. Document esmentat en Almiñana I984-85, 392. Encara que el nom del germà de Dalfina que figura en aquesta escriptura està mal escrit, suposem que es tracta de Joan Roís de Corella perquè existeix un altre document del i8 de gener de I460 referit a un violari de I50 sous amb el mateixos protagonistes.

295. Document esmentat en Almiñana I984-85, 392. Correspon al f. II 7 r en numeració moderna.

296. Document esmentat en Almiñana I984-85, 392. Correspon al f. 23Irv en numeració moderna. 
240

I462, abril I4. València.

Davant la cort del Governador General del regne de València, Aldonça Roís de Corella reclama al cavaller Pere Martorell-senyor de Negrals-i a la seua esposa el pagament d'una pensió de 583 sous i 4 diners censals. ${ }^{297}$

ARV, Governació, no. 57, mà 28, f. 26r.

$24 \mathrm{I}$

I462, maig, 25. València

Bertomeu Chiva, natural de Lutxent, d'on s'ha desaveïnat el 16 de maig de 1461, s'aveïna en el carrer de Rotlons "prop l'ort d'en Pere de Montblanch" a la parròquia de Sant Martí de la ciutat de València. ${ }^{298}$

AMV, Avehinaments, b33-5, I8r.

242

I462, novembre, I7. València.

Pedro d'Urrea, conseller i Governador del regne de València, comunica al donzell Joan d'Esplugues que el notari Antoni Barreda -procurador d'Aldonça Roís de Corella, com a usufructuària dels béns del seu difunt marit- li ha mostrada una "carta pública executòria ab submissió e renunciació de for" feta el 23 d'abril de 1459 segons la qual Esplugues carregà a Aldonça $i$ als seus 81 lliures censals. Barreda reclama un total de 31 lliures degudes en raó d'aquest violari.

ARV, Governació, no. 42, mà 73 , f. $5^{\text {rv. }}$

243

I463, gener, I4. València.

Bertomeu Chiva, mercader habitant de València, com a procurador d'Aldonça, vídua d'Ausiàs Roís de Corella, reconeix que el notari de Gandia Pere de Culla-hereu de Jaume Pérez de Culla-, li havia lliurat, per mans de Guillem Cardona, 158 sous i 4 diners.

AHN, Osuna, llig. I322, no. I3, not. Antoni Barreda.

244

I463, febrer 26. València.

Davant la cort de la Governació General del regne de València, Aldonça Roís de Corella reclama el pagament de les pensions degudes d'un censal posseït per ella i que, originalment, va ser carregat a

297. Document esmentat en Almiñana I984-85, 392.

298. Encara que aquest document està en el recte d'un foli numerat com a “I8”, la realitat és que es l'últim foli d'un gruixot volum d'aveïnaments i, per tant, aquesta numeració es equívoca. Un resum d'aquest aveïnament ha estat publicat en Cabanes 2008, 368 . 
Alfons Roís de Corella per Miquel Dalmau, Joan Todó i les esposes d'aquests. ${ }^{299}$

ARV, Governació, no. 36, f. 23Ir.

245

I463, març, 22. València.

Bertomeu Chiva, mercader habitant de València, com a procurador d'Aldonça, vídua d'Ausiàs Roís de Corella, reconeix que Ramon de Riusec, comte d'Oliva, li havia lliurat, per mans de Miquel Dymra, 12 lliures i 10 sous deguts a la referida, en raó d'un violari per valor de 12 lliures i 10 sous.

AHN, Osuna, llig. I322, no. I3, not. Antoni Barreda.

246

I464, maig, 28. València.

Bertomeu Chiva, mercader habitant de València, com a procurador d'Aldonça, vídua d'Ausiàs Roís de Corella, reconeix que Ramon de Rüsec, comte d'Oliva, li havia lliurat, per mans de Joan Solanes, 12 lliures i 1 o sous deguts a la referida dona en raó d'un violari per valor de 12 lliures i 10 sous.

AHN, Osuna, llig. I322, no. I4, not. Antoni Barreda.

247

I464, maig, 29. València.

Aldonça, vídua d'Ausiàs Roís de Corella, ven a Castellana, esposa d'Eximén Pérez de Romaní Escrivà - donzell de València-, tots aquells 150 sous anuals de violari que, originalment, Lluís Mascó lifeia a ella. AHN, Osuna, llig. I322, no. I4, not. Antoni Barreda.

248

I464, maig, 29. València.

Aldonça, vídua d'Ausiàs Roís de Corella, ven a Castellana, esposa d'Eximén Pérez de Romaní Escrivà -donzell de València-, tots aquells 100 sous anuals de violari que, originalment, Eximén i Jaume Súscar li feien a ella.

AHN, Osuna, llig. I322, no. I4, not. Antoni Barreda.

249

I466, agost, 27. València.

Testament de Bertomeu Chiva, mercader de la ciutat de València. Nomena Magdalena, "donzella de edat de set anys, la qual stà en la casa de la dita magnífica n'Aldonça de Corella", com hereua universal i, en cas de morir menor de quinze anys i sense fills nascuts de legítim matrimoni, tots els

299. Document esmentat en Almiñana I984-85, 392. 
seus béns seran d'Aldonça Roís de Corella. ${ }^{300}$

AHN, Osuna, llig. I322, no. I5, not. Antoni Barreda.

\section{Die XXVII augusti anno predicto $M^{\circ}$ CCCCLX' sexto.}

En lo nom de nostre senyor Déu e de la gloriosa Verge Maria, mare sua advocada de tota crestiandat molt piadosa, yo, en Berthomeu Chiva, habitant en la ciutat de València, en ma sanitat, seny e memòria stant, volent e entenent provehir a ordinació de mos béns, convocats e pregats los testimonis e notari dejús scrits, faç e ordén lo present darrer testament meu e derrera voluntat mia.

E, primerament, vull, man e ordén que tots mos deutes, torts e injúries sien pagats e satisffets a aquells, enperò, qui mostraram [sic] mi ésser tenguts e obligats ab cartes, albarans, testimonis o altres legíttimes proves, for de ànima benignament observat.

En aprés, elegesch sepultura al meu cors sia feta en lo vas o fossa en la qual la magnífica n’Aldonça de Corella, muller del magnífich mossén Ausiàs Roïz de Corella, quòndam, cavaller habitador de la dita ciutat, volrà e elegirà. La qual sepultura vull, man sia feta a lur coneguda e axí com aquella volrà e ordenarà.

Ítem, leix a·n Martí Chiva, Joan Chiva, germans meus, vehins de Luxén, e a na Francesca, germana, muller en segones núbcies d'en Bernat Martí ço és, a cascun dels dits germans e germana, deu lliures moneda de València. E, si cars serà que los dits germans e germana a mi premorran, que les dites deu lliures hajen lurs hereus o successors o los hereus e sucessors de aquells dels dits germans o germana que a mi premorís o premorta serà.

En tots los altres béns meus, mobles e inmoble e privilegiats, drets e accions a mi pertanyents, eo pertànyer podents o devents, per qualsevol títol, causa, manera o rahó, Magdalena, donzella de edat de set anys, la qual stà en la casa de la dita magnífica n’Aldonça de Corella, en los dits béns e drets hereua mia universal faç e instituesch per dret de institució. Sots tal vincle e condició que, si la dita Magdalena, hereua mia, morrà menor de quinze anys e sens fills legíttims e naturals de carnal matrimoni nats e procreats a aquella sobrevivents, que, en tal cars, tots los dits béns de la mia herència, éntregament sens disminució e detracció alguna de trebel-leyànica o altre qualsevol dret, sien de la dita magnífica n’Aldonça de Corella a fer dels dits béns a ses voluntats. E, si advenint lo dit cars, la dita magnífica n’Aldonça de Corella viva no serà, vull e man la dita mia heretat éntregament, segons dit és, sia de l'hereu o hereus o successor o successors, ab testament o ab intestat de la dita magnífica n'Aldonça de Corella, a fer dels dits béns a ses voluntats.

E vull e man que, la dita magnífica n’Aldonça de Corella, e premorint aquella eo aprés mort de aquella, los hereus o hereu o successors de aquella, axí ab testament com sens testament, tinguen, procuren, regeixquen, administren, reben, prenguen e venen los béns de la mia heretat, e ho recahents en aquella, fins la dita Magdalena, hereua mia, haja atesa edat de vint anys o fins que, aquella dita Magdalena, haja afermat matrimoni. E, per los dits béns, responguen e entrevinguen en juhí e facen tots aquells actes que yo, personalment, constituhit fer poguera; e, açò, facen e puixen fer sens auctoritat o decret de jutge o oficial algú e sens solemnitat de dret alguna, sols a lur beneplàcit, com aquesta sia ma voluntat.

Aquest és lo meu derrer testament e la mia derrera voluntat, lo qual e la qual vull valer e tenir per dret de testament e derrera voluntat. E, si per dret de testament e derrera voluntat, valer e tenir no porà, vull aquell e aquella valer e tenir per dret de codicils o altra qualsevol derrera

30o. Com es pot comprovar per d'altres documents, Magdalena era filla del poeta Joan Roís de Corella. 
voluntat per aquells fur, privilegis, leys e drets que mils valer e tenir porà.

Foren fetes les dites coses en València a vint-e-set dies del mes de agost any de la nativitat de nostre Senyor mil CCCC sexanta-sis. Se+nyal de mi dit Berthomeu Chiva, testador, qui dessús qui $[s i c]$ les dites coses lohe e atorgue e mane ésser fetes e complides, segons per mi és dispost e ordenats.

Presents foren per testimonis al present testament convocats e demanats, los honorables e discrets mossén Bernat Garcia, prevere beneficiat en Sanct Martí; mossén Leonart Pérez, prevere beneficiat en Sancta Caterina, e en Jaume Martí, perayre, habitants de la dita ciutat. Los qual, interrogats per lo notari dejús scrit si coneixien lo dit testador, dixeren que aquell coneixen molt bé; aquell dit testador, a ells e, per semblant, lo notari dejús scrit coneixia lo dit testador.

I466, novembre, 24. València.

Darrer testament d'Aldonça Roís de Corella, mare de l'escriptor Joan Roís de Corella. Nomena l'escriptor hereu universal, deixa a la resta de sos fills 5 sous "per tota part e legíttima que en mos béns los pertangua o puixa pertànyer" i estableix que no se li reclame res a Bertomeu Chiva, procurador de la testadriu, en raó de l'administració dels seus béns.

AHN, Osuna, llig. I322, no. I5, not. Antoni Barreda. ${ }^{301}$

\section{Die XXIIII novembris anno predicto $M^{\circ} C C C C L X^{\circ}$ sexto.}

En lo nom de Jesús e de la gloriosa Verge Maria, mare sua, yo, Aldonça, muller del magnífich mossén Ausiàs Roïz de Corella, quòndam, cavaller habitador de la ciutat de València, en mon bon seny e memòria stant. Revocant tots los altres testaments per mi fets ans del present e volent ordenar de mos béns, faç e ordén lo present meu derrer testament e derrera voluntat mia en e per la qual vull e man ésser fetes e enseguides les coses dejús scrites.

E, primerament, vull, man e ordén que tots mos torts, deutes e injúries sien pagades e satisfetes a aquells qui mostraran mi ésser tenguda e obligada ab cartes, albarans e altres legíttimes proves, for de ànima benignament observat.

E encara vull, man e ordén que lo meu cors sia liurat a eclesiàstica sepultura, la qual sepultura vull e man sia feta axí com a cos de persona pobre.

En aprés, do e leix a mon fill Loís Roïz de Corella cinch sous per tota part e legíttima que en mos béns li pertangua o pertànyer puixa.

E, a cascuna de mes filles, do e leix cinch sous per tota part e legíttima que en mos béns los pertangua o puixa pertànyer.

Tots los altres béns meus mobles e inmobles, drets e accions hon que sien e a mi pertanguen, pertanyeran o puixen pertànyer, do e leix a mossén Joan Roïz de Corella, cavaller, fill meu; e aquell hereu meu universal faç e instituesc per dret de institució.

Ítem, com en Berthomeu Chiva, de present en casa mia resident, en nom de procurador e com a procurador meu, reba e acostuma rebe les ànnues pensions de tots los censals, recensos e violaris meus, e altres quantitats e béns meus e a mi pertanyents dels quals aquell

30I. Document esmentat per Riquer I964, 3, 257 . 
fa delliurament a mi e a altres persones, de manament meu, sens que del dit delliurament no li és feta cautela alguna. E com yo amplament fie de aquell, vull, man e ordén que, aprés òbit meu, lo dit en Berthomeu Chiva per lo dit mossén Joan Roïz de Corella, fill e hereu meu dessús scrit, sia absolt e diffinit largament e pleníssima, volent que lo dit en Berthomeu Chiva per sa sola simple paraula, sens prova alguna e altra natura de cautela sia cregut de tot ço que dirà en nom de procurador meu e per mi haver rebut, donat e liurat a mi o per manament meu, a altres persones. E açò, segons és dit, sens prova e altra natura de cautela, mas tan solament per sola aserció de aquell e de sa sola e simple paraula. E si, per subtilitat alguna de dret o en altra manera, per lo fill e hereu meu dessús scrit, eo per altra qualsevol persona, per aquell serà demanat compte al dit en Berthomeu Chiva de la dita procuració eo, per rahó de aquella eo de les quantitats que aquell en nom de procurador meu haurà rebut, e aquell dit en Berthomeu Chiva serà condemnat en restituhir més quantitat que, aquell, per la sola sua simple aserció afermarà ésser tornador, en tal cas vull, man e ordén que tot ço e quant serà declarat e jutgat lo dit en Berthomeu Chiva ésser tornador a la heretat mia més de ço que aquell per sa simple e sola aserció afermarà ésser tornador, sia del dit en Berthomeu Chiva e al dit en Berthomeu Chiva la dita quantitat en què aquell serà condemnat en més de ço que aquell afermarà ésser deutor a la heretat mia, ab lo present meu testament leixe, e·n faç legat e mane ésser donada per dret de legat al dit en Berthomeu Chiva.

E, a cautela, ara per lavors e lavors per ara, absolch e defeneixch aquell, dit en Berthomeu Chiva, de tota acció, questió, petició e demanda que per la dita rahó li pogués ésser feta en més de ço que aquell afermarà ésser deutor a la mia heretat. E li faç pacte, axí real com personal, de aquí avant no demanar la dita quantitat. E vull e declare que lo dit fill e hereu meu solament haja dret e acció en demanar aquella quantitat que lo dit en Berthomeu Chiva, per sa sola simple paraula e aserció, afermarà deure, ésser tornador a la heretat mia.

Aquest és lo meu derrer testament e derrera voluntat, lo qual vull valer e tenir per dret de testament e derrera voluntat. E, si per dret de testament e derrera voluntat valer e tenir no porà, vull aquell e aquella valer e tenir per dret de codicils o de altra qualsevol derrera voluntat per aquells drets, leys, furs e privilegis que mils valer e tenir porà.

Foren fetes les dites coses en València a vint-e-quatre dies del mes de noembre any de la nativitat de nostre Senyor mil quatre-cents sexanta-sis. Se+nyal de mi, Aldonça, testadriu dessús dita, qui les dites coses lohe, atorgue e mane e ordén sien fetes, enseguides e complides.

Presents foren per testimonis al present testament convocats e demanats los honorables e discrets mossén Bernat Garcia, prevere beneficiat en la ecclésia parrochial de Sanct Martí, de la ciutat de València; mossén Leonart Pérez, prevere beneficiat en la esgléya parroquial de Sancta Caterina de la dita ciutat, e en Jacme Martí, perayre, habitants de la dita ciutat, qui, interrogats per lo notari dejús scrit si coneixien la dita testadriu, e dixeren que aquella coneixen e aquella als dits testimonis e, per semblant, lo notari dejús scrit coneixia la dita testadriu.

En aprés, en lo dia de dilluns que-s conptava vint-e-quatre del mes de juliol any de la nativitat de nostre Senyor Mil CCCC setanta-cinch, que era lo quart dia aprés òbit de la dita testadriu, a instància e requisició del dit reverent e magnífich mossén Joan Roïz de Corella, fill e hereu de la dita testadriu, dins la casa e ort del magnífich mossén Loís Figuerola, cavaller habitant de la dita ciutat, situats dins la dita ciutat, lo dit testament per lo notari dejús scrit 
fonch lest e publicat, de la primera línea fins a la darrera inclusivament. E lest e publicat lo dit testament, lo dit reverent e magnífich mossén Joan Roïz de Corella dix que acceptava la dita herència ab benifici de inventari, requirent-ne carta pública.

Foren fetes les dites coses en la ciutat de València los propdits scrits dia e any. Presents foren per testimonis a les dites coses convocats e demanats, n’Antoni Pérez, mercader, e en Pere Vidal, scuder, habitants de la dita ciutat de València.

I467, febrer, I9. València.

Eximén Pérez de Romaní àlies Escrivà, donzell habitant de València, en el seu nom propi i com a procurador de la seua esposa Castellana-segons consta per escriptura del 24 de maig de 1464 davant el notari Joan Rull-i Berenguer Mercader, menor de dies, -donzell i habitant tambéde València-tenint en compte que ells el 7 de maig de 1465 davant el notari Jaume de Bellmont vengueren i carregaren a Aldonça Roís de Corella 400 sous rendals i anuals de violari durant les vides de Joan Roís de Corella, cavaller habitant de València, i de Dalfina Roís de Corella, donzella, i que els protocols de Jaume Bellmont no es troben, ells confirmen, a petició d'Aldonça Roís de Corella, la venda d'aquests 400 sous de violariamb totes les clàusules de la venda original. Aquesta venda es va fer per preu de 140 lliures.

Segons una nota marginal, aquest instrument notarial va ser cancel.lat el dia g de gener de 1483 per Joan Roís de Corella, cavaller i mestre en Teologia, com a hereu de la seua mare d'acord amb el testament rebut per Antoni Barreda el 24 de novembre de 1466.

AHN, Osuna, llig. I322, no. I6, not. Antoni Barreda.

$25^{2}$

I467, abril, I6. València.

Lluís de Cavanyelles, lloctinent del Governador General del regne de València, es dirigeix a mossén Pere Martorell i a Caterina, la seua esposa, o a qualsevol dels seus marmessors i els comunica que el notari Antoni Barreda -com a procurador d'Aldonça Roís de Corella, esposa i usufructuària dels béns del seu difunt marit- li ha mostrat un document notarial rebut en 1441 segons el qual Pere Martorell $i$ Caterina carregaren 200 sous censals de violari a mossén Ausiàs Roís de Corella i als seus. Barreda reclama l'abonament de diverses quantitats degudes en raó d'aquest violari.

ARV, Governació, no. 57, mà 29, f. 23 r.

I468, març I5-I468, març, I6. València.

Testament i codicils de Pere Joan Belluga, doctor en dret i jurista de la ciutat de València. Elegeix ser soterrat a la seua capella del convent de Sant Francesc de València, fa diferents llegats a parents $i$ servidors i nomena marmessors el donzell Berenguer Mercader, parent seu, i el carmelità Lorenç Garcia, mestre en sacra teologia.

Va ser publicat, per mort del testador, el 26 de març de 1468 "huytén dia aprés mort" de Pere Joan Belluga a la casa de Berenguer Mercader, marmessor del finat. Com a testimonis de la publicació figuren "los religiosos frare Andreu Malràs, de l'orde de la Sancta Trinitat; frare Johan Lorenç, de l'orde de la 
Verge Maria del Carme e los magnífichs micer Andreu Sart, doctor en leys e mossén Johan Rohís de Corella, cavaller, habitadors de la present ciutat de València". 302

ARV, protocols, no. I9IO, not. Miquel Puigmicha, junior.

254

I468, març, I7. València.

Aldonşa, vídua del cavaller habitant de València Ausiàs Roís de Corella, restitueix per via de llüció i quitament als veïns de Xàbia Antoni Blasco i Jaume Bas, tots aquells 41 sous i 8 diners censals anuals que Jaume Bas, La seua esposa Gràcia, Guillem Morató i la seua esposa Sibil.la, tots ells de Xàbia, varen vendre a Joan de Cabrera, habitant de Dénia, el 21 d'octubre de 1401 davant el notari de Xàbia Pau Morató. Posteriorment, Ausiàs Roús de Corella comprà aquest censal el dia zo de gener de 143 o davant el notariJoan Sarti, el 28 de setembre de 1450 davant el mateix notari, el referit censal passà a mans d'Aldonça. Aquesta restitució es féu per preu de 22 lliures que Blasco i Bas pagaren a Aldonça Roís de Corella.

AHN, Osuna, llig. I322, no. I7, not. Antoni Barreda.

255

I468, març, 23--I468, abril, 6. València.

Aldonça Roís de Corella, vídua d'Ausiàs Roís de Corella, declara davant Pedro d'Urrea, Governador General del regne de València, que el cavaller Pere Martorell i la seua esposa Caterina carregaren a Ausiàs Roís de Corella 200 sous de violari durant la seua vida i la d'Aldonça Roís de Corella. Atés que Pere i Caterina han mort, Aldonça sol.licita que els seus hereus -entre d'ells el cavaller Galceran Martorell-, siguen condemnats a "lluir e quitar lo dit violari". 303

ARV, Governació, no. 2324, mà 3, f. 48 r.

$\mathrm{ARV}$, Governació, no. 2326 , mà 23 , f. 2 rv.

256

I468, octubre, II. València.

Aldonça Roís de Corella, vídua d'Ausiàs Roís de Corella, nomena el porter Joan Rodrigo, habitant de València, com a procurador seu.

RCSCCV, protocols, no. I5948, not. Bernat Julià, menor de dies.

302. Document publicat en Roca I973, I43-50. S’esmenta el metge i literat Lluís Alcanyís com un dels metges que atengueren, en la seua malaltia, Belluga.

303. Amb data també del 23 de març de I468, conservem l’inici d’un altre procés “De la magníficha n’Aldonça Corella contra lo magnífich mossén Galceran Martorell” (ARV, Governació, no. 2324, mà 2, f. 4Or). Malauradament tan sols en conservem 5 línies del contingut, però la data i els involucrats en aquesta causa judicial ens fa relacionar-la, sense cap mena de dubte, amb la que hem regestat. 
257

I468, novembre, I8. València.

Aldonça Roís de Corella i els seus fills Joan, cavaller, i Dalfina, donzella, venen 333 sous i 4 diners censals a Beatriu Bö̈l-anomenada Andreua de Castellet antigament-, vídua del cavaller Pere Centelles, per preu de 5.0oo sous. Aquest censal orginalment va servenut a Ausiàs Roís de Corella conjuntament pel doctor en lleis Miquel Dalmau i la seua esposa Isabel i pel notari Joan Todó i la seua esposa Tecla per escriptura feta el 7 de desembre de 1448 davant el notari Cristòfol de Montalbà.

RCSCCV, protocols, no. 25216, not. Joan Argent. ${ }^{304}$

$25^{8}$

I469, gener, 2I. València.

Aldonça Roús de Corella i els seus fills Joan, cavaller, i Dalfina, donzella, en contemplació del matrimoni acordat entre el cavaller Lluís Figuerola i Dalfina Roís de Corella ique prompte se celebrarà eclesiàsticament, estableixen a Dalfina un dot de 18.ooo sous. Aquest dot, el lliuraran a Lluís Figuerola de la següent manera: 7.511 sous, 5 diners en metàl-lic; pervalor de 7.203 sous, 1 diner li transporten tots aquells 583 sous, 4 diners censals que el cavaller Pere Martorell i la seua esposa originalment carregaren a Ausiàs Roís de Corella el 21 de febrer de 1442 davant el notari.Joan Sart i que ara pertanyen a Aldonça com a donatària del seu fill Joan Roís de Corella, hereu universal del seu pare, segons consta per escriptura feta davant el notari Antoni Barreda el 22 de desembre de 1455; per valor de 3.245 sous li transporten tots aquells 265 sous censals que Violant de Vilarig-vidua de Joan March-, Ausiàs March i Pere Guillem Lançol-senyor de Vilallonga-vengueren a Ausiàs Roís de Corella el 21 d'octubre de 1444 davant el notari de València Joan Sart. ${ }^{305}$

Per la seua banda, Lluís Figuerola promet donar a Dalfina Roís de Corella g.ooo sous en qualitat de "creix".

AHN, Osuna, llig. I322, no. I8, not. Antoni Barreda.

I469, gener, 27. València.

Bernat Dassió, notari de la ciutat de València, com a propietari dels protocols del difunt notari Leonard Vilar, cedeix a Aldonça, vídua d'Ausiàs Roís de Corella, tots els drets i accions legals possibles contra Violant, vídua del cavaller i habitant de València Ramon Soler, per a cobrar 100 sous a Dassió deguts en raó del pagament de diverses escriptures fetes per ella davant el notari Leonard Vilar el 22 de març de 1451. A canvi d'aquesta cessió, Bernat Dassió reconeix a Aldonça Corella el lliurament de 100 sous per mans del mercader de València Bertomeu Chiva.

AHN, Osuna, llig. I322, no. I8, not. Antoni Barreda.

304. Document esmentat en Riquer I964, 3, 256 amb data, però, del 20 de novembre.

305. En el moment de fer aquesta escriptura notarial, el primer d'aquests censals era pagat per Pere Sart, habitant de Dénia, com a senyor de Negrals, mentre que, el segon, ho era per Roderic de Borja, nebot del futur Papa Alexandre VI. 
260

I469, abril, I5. València.

Bertomeu Chiva, mercader habitant de València, com a procurador d'Aldonça, vídua d'Ausiàs Roís de Corella, reconeix que Ramon de Rüsec, comte d'Oliva, li havia lliurat 12 lliures, 10 sous deguts a la referida dona en raó d'un violari per valor de 12 lliures, 10 sous.

AHN, Osuna, llig. I322, no. I8, not. Antoni Barreda.

$26 \mathrm{I}$

I469, juliol, 24. València.

Bertomeu Chiva, mercader habitant de València, com a procurador d'Aldonça, vídua d'Ausiàs Roís de Corella, reconeix que Ramon de Rüsec, comte d'Oliva, Li havia lliurat 15 lliures degudes a la referida dona en raó d’un violari per valor de 15 lliures.

AHN, Osuna, llig. I322, no. I8, not. Antoni Barreda.

262

I469, setembre, 6 . València.

Violant, vídua del cavaller Ramon Soler-habitant de València-, atorga a Aldonça Roís de Corella la propietat de 500 sous censals que lifan els jurats de València. Aquesta donació serà efectiva una volta morta Violant.

AHN, Osuna, llig. I322, no. I8, not. Antoni Barreda.

263

I469, setembre, I6. València.

Lluís Figuerola, cavaller habitant de València, nomena la seua esposa Dalfina Roís de Corella $i$ el seu cunyat Joan Roís de Corella, cavaller i mestre en sacra teologia, com a procuradors seus per a cobrar diverses quantitats en raó de pensions de censals i violaris. ${ }^{306}$

RCSCCV, protocols, no. 24I26, not. Joan Verdanxa.

264

I469, novembre, 3 . València.

L'estanyer Cristià Cardona, ciutadà de València, com a marmessor del darrer testament d'Úrsula Canader, ven per preu de zo lliures a Isabel Martínez de Vera, filla del difunt donzell Diego Martínez de Vera, una casa al carrer de la verge Maria de Gràcia, sota la directa senyoria de Bertomeu de Crü̈lles, que afrontava "cum hospicio venerabili Francisci Godall, presbiteri habitator dicte civitatis, et cum hospicio Francisce Rovira, uxoris Jacobi Rovira, quondam, traginerï, et cum via publica".

3o6. Document esmentat en Almiñana I984-85, 398 . 
AHG, protocols, not. Lluís Collar, microfilm rotlle $26 .{ }^{307}$

265

I470. València.

Elmetge Jaume Roig, com a majordom de l'Hospital dels Innocents de València, anota en el "Llibre major de la majordomia de la casa sancta eo spital dels ygnocents" de l'any 1470 un pagament de 10 sous almestre en teologia Joan Roís de Corella per predicar "solepnement lo dia de la festa dels ygnocents". 308

AGFDV, Llibres de majordomia de l'Hospital dels Ignocents, $\mathrm{V}-\mathrm{I} / 5^{2}$, f. 57 r.

Dates

Sermons

Paguí al venerable mossén Pere Navarro per les caritats per ell distribuïdes als venerables sermonadors qui han preÿcat en la capella de la casa XXXV dies per cascun dia III sous. [Al marge dret $]$ V lliures, V sous.

Paguí al susdit Pere les caritats per ell donades per los sermons de quaresma, II lliures, XII sous, VI diners. [Almarge dret] II lliures, XII sous, VI diners.

Paguí al venerable mestre Johan Roïç de Corella qui preÿcà solepnement lo dia de la festa dels ygnocents, $\mathrm{X}$ sous. [Almarge dret $] \mathrm{X}$ sous

266

I47O, juny, I3. València.

Joan Roís de Corella, cavaller i mestre en teologia, reconeix a Isabel Martínez de Vera, donzella ifilla de Diego Martínez de Vera, el lliurament de 5 o lliures que ell li havia prestat per a fer obres i adquirir certa casa al carrer de Santa Maria de Gràcia.

AHG, protocols, not. Lluís Collar, microfilm rotlle 26. 309

267

I470, juny, I3. València.

Pere Bö̈l de Lladró, noble de la ciutat de València, i Isabel, la seua esposa, reconeixen deure a Aldonça, esposa d'Ausiàs Roís de Corella, 35 lliures en raó de 150 sous rendals i anuals de violari. Hi ha una nota marginal on figura que el 5 de juny de 1471 de voluntat d'Aldonça es cancel-là aquest instrument en haver-li pagat les dites 35 lliures.

AHN, Osuna, llig. I322, no. 19, not. Antoni Barreda.

307. Document esmentat en Guia 2003. Mitjançant escriptura del I 4 de novembre de I 469 conservada en aquest mateix protocol, Cardona va reconeixer el pagament d'Isabel.

308. Document publicat en Guia 2008, 63I.

309. Document esmentat en Guia 2003. 
I470, juny, 27. Montsó.

El rei Joan II escriu al cardenal de València-vicari de la Seu apostòlica-sol-licitant-li que permeta les predicacions de "mestre Corella" atés el gran benefici que "se ha seguit e segueix a les ànimes dels feels christians de les predicacions e doctrina de mestre Corella, lo qual axí bé e virtuosament ha predicat, que ha provocat a gran devoció al poble". El cardenal havia prohibit que Corella predicara, i volia obligar-lo a prendre els ordes religiosos; però el rei demana que, atés que Corella ja té el títol de mestre en teologia, el cardenal i vicari de València permeta i anime dites predicacions encara que Corella no prenga el ordes religiosos.

ARV, Reial Cancelleria, no. 29I, f. 223rv.

\section{Magistri Corella.}

Reverendíssim Pare en Christ, e senyor amich nostre molt car, per altres havem scrit e significat a la Reverent Paternitat vostra quant beniffici se ha seguit, e segueix, a les ànimes dels feels christians de les predicacions e doctrina de mestre Corella, lo qual axí bé e virtuosament ha predicat, que ha provocat a gran devoció al poble. E havem pregat la vostra reverent Paternitat volgués, de nou, donar licència al dit mestre Corella de fer e continuar les dites predicacions e no compelir-lo a pendre órdens, fins que sia en altra disposició, atés majorment com ja tinga títol de mestre en sacra teologia e li sia lícit fer les dites predicacions. E perquè, fins ací, no havem hagut resposta de vostra Reverent Paternitat e los qui tenen devoció en oyr los sermons del dit mestre Corella stan desijosos de haver la dita licència, vos tornam a fer la present he us pregam, ab quanta affecció e voluntat podem, doneu la dita licència e facultat al dit mestre Corella de poder preÿcar axí com fahia abans de vostra inibició. En lo qual vostra Reverent Paternitat farà servey a nostre Senyor Déu, per lo beneffici que se’n seguirà a les ànimes dels feels christians, e a Nós complaurà singularment axí com lo contrari, ço que de aquella no se spera, donaria grandíssima admiració e entrenyorament al poble. Car dien, que a la Reverent Paternitat vostra, no solament sia convenient donar la dita licència mes, encara com a pastor del dit poble, manar al dit mestre Corella faça e continue les dites predicacions.

Data en Monçó a XXVII dies de juny de l'any mil CCCC LXX. Rex Joan.

Dominus rex mandavit mihi Philippo Clementis.

Rex Aragonum, lo rey d’Aragó, de Sicília, de Navarra, etc.

$\mathrm{Al}$ reverendíssimo Pare en Christ e senyor, lo Cardenal de València, vicari de la Seu apostòlica, amich nostre molt car.

Fuit duplicata.

I47O, agost, 8. València.

Ramon de Riusec, àlies Francesc Gilabert de Centelles, comte d'Oliva, ven a Aldonça Roís de Corella 1.000 sous rendals i anuals de violari durant la seua vida i la del seu fill Lluís Roís de Corella. El preu de venda fou 7.ooo sous. 
Hi ha una nota marginal segons la qual el 24 d'octubre de 1471 es cancel.là aquest instrument notarial de voluntat de la referida Aldonça Roís Corella.

AHN, Osuna, llig. I322, no. I9, not. Antoni Barreda.

270

I47I, gener, 2. València.

Joan Roís de Corella, comte de Cocentaina i Governador General del regne de València, comunica a Pere Martorell i a Caterina, la seua esposa, que Nicolau Ferrer-notari procurador del cavaller Lluís Figuerola - li ha mostrada una escriptura pública rebuda el 21 de febrer de 1442 pel notari Joan Sart segons la qual Pere Martorell i Caterina carregaren 583 sous i 4 diners censals anuals a mossén Ausiàs Roís de Corella -pare de Dalfina Roís de Corella, esposa del referit Figuerola-ials seus. Així mateix, el procurador de Lluís Figuerola li ha mostrat un document fet davant el notari Antoni Barreda el 22 de gener de 469 segons el qual aquest censal de Pere Martorell va passar, en contemplació de matrimoni, a Dalfina Roís de Corella.

Antoni Barreda, com a procurador de Lluís Figuerola, reclama, davant la cort del Governador, 62 lliures, 18 sous i 4 diners en raó de diferents pensions degudes d'aquest censal.

ARV, Governació, no. 66, f. 23 rv.

$27 \mathrm{I}$

I47 I, gener, 4. València.

Joan Roís de Corella, comte de Cocentaina i Governador General del regne de València, comunica al notari Jaume Pérez de Culla, habitant de Gandia, i a la seua esposa Aldonça, que Nicolau Ferrer - notari procurador d'Aldonça, vídua d'Ausiàs Roís de Corella i ususfructuària dels seus béns- li ha mostrada una escriptura pública rebuda el 14 de setembre de 1440 pel notari Pere Belsa segons la qual el matrimoni Pérez de Culla carregaren 158 sous i 4 diners censals anuals a mossén Ausiàs Roís de Corella $i$ als seus.

Nicolau Ferrer reclama, davant la cort del Governador, 158 sous i 4 diners en raó de pensions degudes d'aquest censal.

ARV, Governació, no. 66, f. $77^{\mathrm{rv}}$.

272

I47I, febrer, I8. València.

Testament de Joan de Vallseca, frare del monestir de Sant Francesc de València "en lo primer any del meu noviciat e ans de fer proffesió en la dita religió". Llega al cavaller i mestre en teologia Joan Roús de Corella un llibre "appellat lo Rodí e hun altre appellat lo Ignocent sobre les decretals e una spica sobre lo Ignocent que va per a bc, e una Bíbria e hun briviari e les mies robes de vestir; e com n'Aduart de Vallsequa, pare meu, jo no sàpia si es viu o mort, per ço exort lo dit reverent mestre.Johan Corella que si lo dì pare meu serà viu lo vulla socórrer en les sues necessitats en la manera que li serà ben vist al dit reverent mestre Johan lexant-ho tot a llibera volentat de aquell". Aquest testament va ser publicat el 27 d'octubre de $147^{2}$.

ARV, protocols, no. 5O2, not. Berenguer Cardona. 
I47I, març, I. València.

Joan Roís de Corella, cavaller i mestre en teologia, és padrí en el bateig d'Isabel Llopis -filla del notari Antoni Llopis i de la seua esposa Agnés- juntament amb mossén Lluís de Vich -mestre racional del regne-, mossén Honorat Berenguer Mercader -cavaller i batle general del regne- i Isabel de Castellví - esposa del donzell Joanot de Castellví, de Murla. Es qualifica l'escriptor de "cavaller e mestre en sacra teología e valent e famós sermonador en lo dit temps".

ARV, Clero, llibres, I777, f. 77 v.

\section{[Almarge esquerre] Nativitat de Ysabel}

Dimarts, comptat XXVI del mes de febrer any Mo CCCCo LXX hú, a les cinch hores de matí, en lo qual dia se fehien carnestoltes, la dita n’Agnés, muller mia, parí una filla. La qual, en aprés divendres primer dia de març, fon batejada en la Seu per l'onrat mossén Jacme Bisbal, prevere sotsvicari de Sent Pere, e fon-li imposat nom de madona Sancta Ysabel, e foren padrins los molt honorables mossén Luís de Vich, mestre racional del senyor rey en lo present regne de València, mossén Onorat Mercader, cavaller e batlle general del dit regne, e mossén Johan de Corella, cavaller e mestre en sacra teologia e valent e famós sermonador en lo dit temps, e la honorable na Ysabel de Castellví, muller de l’honorable en Johanot de Castellví de Murla, donzell.

\section{[Almarge esquerre] Confirmació.}

En aprés, digmenge comptat XXVIIII de deembre any M CCCC LXX dos, fon confermada per lo reverent mestre Jacme Pérez, bisbe de Gràcia, e fon padrí lo honorable mossén Damià Vinyoles, prevere e domer de la Seu, e comare la honrada na Yolant, muller de l'honrat i discret en Johan de Sent Feliu, notari.

274

I47I, març, I. València.

Testament de Joan de Rocafort, mestre en sacra teologia. Nomenà com a marmessors el cavalleri mestre en teologia Joan Roús de Corella i al seu fill Vicent Rocafort. Nomenà hereus universals la seua dona Joana i el seu fill Vicent Rocafort, i elegí ser sepultat al vas on sa mare era soterrada al convent de Sant Francesc de València. Aquest testament va ser publicat el 6 d'abril per mort del testador.

ARV, protocols, no. 5O2, not. Berenguer Cardona. ${ }^{310}$

I47I, abril, 6. València.

3IO. Document esmentat en Riquer I964, 3, 256. El 2 de març de I47I, Joan de Rocafort establí un codicil que es conserva en aquest mateix protocol de Berenguer Cardona. 
Inventari de béns del difunt Joan de Rocafort, mestre en sacra teologia, realitzat pels seus marmessors Vicent Rocafort i Joan Roís de Corella, cavaller i mestre en teologia, i per Joana -la seua esposa nomenada tutora i curadora del seu fill Vicent, hereu testamentari juntament amb ella del mestre Rocafort, en el codicil establert per Joan Rocafort el 2 de març de 1471 davant el notari Berenguer Cardona. Els marmessors esmenten uns llibrets "de gramàtica e de arts, de poqua valor" (vid. doc. següent).

ARV, protocols, no. 5O2, not. Berenguer Cardona.

276

I47I, abril, 9. València.

Joana, esposa del difunt Joan de Rocafort-mestre en teologia-, iJoan Roís de Corella-cavaller, mestre en teologia i marmessor testamentari del difunt-, demanen que es faça pública escriptura dels llibres de Rocafort que ells dos han fet vendre pel "corredor de coll" Miquel Sanç a la plaça de la Seu de València. El preu total de venda dels llibres va ser de 2 lliures, 8 sous i 1 o diners que varen ser lliurats a l'estudiant Gabriel Ferrando -que figura com a testimoni del testament i inventari de béns de Rocafort-qui estava comissionat pels marmessors per a portar el llibres a Miquel Sanç, rebre els diners de la seua venda i donar-los a Joana, esposa de Rocafort. Figuren esmentats els següents llibres:

ARV, protocols, no. 502, not. Berenguer Cardona. ${ }^{311}$

Primo, hun Precià menor, ab la lectura, a·n Luís lo librer, per quatre sous.

Ítem, unes qüestions de philosofia, al dit en Luís, per un sou.

Ítem, hun tractat d'astrologia, a mossén Matheu Jordi, prevere, per un sou, sis [diners].

Ítem, hun qüestionari sobre universals e predicaments, a·n Rodrigo Sànxez, studiant, per dos sous.

Ítem, hun dotrinal a n Andreu Canemàs, studiant, per quatre sous, sis [diners].

Ítem, hun qüestionari de teologia, a·n Luís de Sent Jordi per un sous, cinc [diners].

Ítem, hun Alexandre, al dit en Luís, per nou dinés.

Ítem, unes proposicions de Uxonia, al dit en Luís, per huit dinés.

Ítem, unes fal-làcies, al dit en Luís, per un sou.

Ítem, unes notes de Catalayú, a·n Pere Eximeno, perayre, per huit dinés.

Ítem, unes qüestions de philosofia, a·n Pere Leal, studiant, per un sou.

Ítem, hun libre de confessions, a mossén Miquel Jornet, prevere, per dos sous.

Ítem, la Poetria nova, a·n Navarro, studiant, per dos sous, quatre [diners].

Ítem, dos cartapaços de gramàticha, al dit en Pere Leal, per nou dinés.

Ítem, unes qüestions de philosofia, al dit en Pere Leal, per hun sou e sis dinés.

Ítem, hun Cató, ab himnes, a·n Johan Navarro, notari, per tres sous, sis [diners].

Ítem, tres librets de lògiqua, al dit en Pere Leal, per un sou, quatre [diners].

Ítem, un cartapaç de lògiqua, a·n Pere Pèreç, barber, per un sou.

Ítem, hun Precià menor, a·n Gargori Navarro, studiant, per dos sous.

Ítem, hun Anrich contra Fortuna, e unes ordinacions de la Sglésia, a·n Miquel Alfagerí, studiant, per dos sous.

Ítem, tres cartapaços de lògiqua e de philosofia, a·n Johan Maló, forner, per dos sous, dos

3II. Document esmentat en Riquer I964, 3, 256. Riquer parla d'una "Poètica nova" i, realment, es tracta de la "Poetria nova" de Geoffrey de Vinsauf. 
[diners].

Ítem, una lectura sobre lo De causis, a mestre Colom, per tres sous.

Ítem, tres cartapaços al dit Luís, lo librer, per un sou, sis [diners].

Ítem, tres cartapaços de gramàticha, a mossén Terrades, prevere, per hun sou.

Ítem, uns qüerns squinçats, a·n Miquel Ahiç, tapiner, per un sou, dos [diners].

Ítem, tres qüerns d'arts, a mossén Uguart, prevere, per un sou, quatre [diners].

Ítem, hun qüern d'arts, al dit mestre Colom, per un sou, sis [diners].

Ítem, hun qüern sobre lo Perimènias, al dit mossén Uguart, per dos sous, hun [diners].

277

I472, març, 24. València.

Acta notarial de la donació realitzada per Guillem Saera, racional de la cüutat de València, de diversos vestiments litúrgics al convent de Sant Francesc de València, per tal que siguen utilitzats en la capella de sant Vicent Ferrer, santa Maria Magdalena i Sant Miquel que Saera havia en el dit convent. En concret, Saera dóna "uns vestiments beneÿts e consecrats, de domàs blanch, ço és, una casulla ab la fresadura de brocat d'argent picholada, de vellut vert, dos dalmàtiques per a diacha et sotsdiaca, dos stoles, tres maniples, dos collars, e una tovallola ab flocadures blanques e verdes, e ab les armes mies [...] Los quals vestiments [...] servexquen en los divinals oficis en les festes següents, ço és, en la festa que.s fa de nostra dona sancta Maria a II de febrer e a XXV de març e a XV d'agost e a VIII de setembre, e encara en les festes de la Concepció e d'Esperança de nostra dona sancta Maria. Eencara vull que servexquen los dits vestiments en la mia capella en les festes de sanct Vicent Ferrer, de sancta Maria Magdalena e de sent Miquel, sots invocació dels quals sancts és construÿda. E encara vull que, si per lo administrador del spital de la Reyna de la present ciutat requests sereu que per al dia de sancta Lúcia, de la qual se fa festa e commemoració en lo dit spital, los presteu, siau tenguts e obligats, sens intermissió de temps e sens contradicció alguna, prestar los dits vestiments al dit administrador, com aquesta sia la mia voluntat incommutable".

Figuren com a testimonis d'aquesta escritptura notarial el plater Llorenç Malloli Joan Roís de Corella, mestre en teologia. ${ }^{312}$

AMV, protocols, 8/4, not. Jaume Eiximeno, ff. $53^{\mathrm{r}-5} 4^{\mathrm{V}}$.

278

I472, juny, I9. València.

Aldonça, vídua d'Ausiàs Roís de Corella, s'oposa judicialment, davant el Governador General del regne de València, a qualsevol intent de subhasta o de venda de les Algoleges "dites de Pere Martorell, les quals huy són de mossén Pere Martorell", a la vila d'Alzira, sense el càrrec dels 175 sous censals carregats davant el notari Pere Roig el 8 de juliol de 1388 sobre les dites Algoleges, unes cases i diverses heretats, tal com volia Violant, vídua de Mateu Martorell. Violant, el 16 d'agost de 1473, requerí del Governador que, malgrat l'esmentada oposició, permetera a la cort del justícia d'Alzira la venda de les Algoleges com a béns de la marmessoria del difunt mossén Pere Martorell. Aconsellat pels seus assessors, el Governador ho consentí, iaixí ho comunicà al justícia d'Alzira el mateix dia .

3I2. Document publicat en Rubio 2OI3, 6I4-I5. 
ARV, Governació, no. 2337, ff. 29r-3or.

279

I472, novembre, I6. València.

Davant el Justícia Civil de València, compareix el notari Antoni Barreda com a procurador d'Aldonça, esposa del difunt mossén Ausiàs Roís de Corella, i exposa que, davant el mateix notari Antoni Barreda, mossén Andreu de Vallterra i Damiata, la seua muller, carregaren al dit Ausiàs 6o sous de violari. Antoni Barreda reclama un total de 6 lliures de pensions degudes. ${ }^{313}$

ARV, Justícia Civil, no. 2586, mà, 3I, f. 9r.

280

I473, febrer, 26. València.

Gracià de Monsoriu, Justícia Civil de València, comunica, a micer Miquel Dalmau, Isabel-la sea esposa-, el notari Joan Roca i Tecla-la sea esposa-com a propietaris d'un censal per valor de 333 sous i4 diners venut per Alfons Roís de Corella, que el notari Antoni Barreda, com a procurador de Aldonça Roís de Corella, ha interposat davant d'ell una reclamació en raó de 166 sous, 8 diners deguts de la paga de novembre del referit censal.

ARV, Justícia Civil, no. 2507, mà, 6, f. 6v.

28I

I474, abril. 27. València.

Pere Maça de Liçana, àlies Lluís Cornell -en el seu nom propi i com a procurador de la seua esposa Beatriu-, el cavaller Lluís Mascó - menor de dies-iel notari Jaume Gisquerol, tots ells habitants de València, venen per 105 lliures a Aldonça Corella, vídua del cavaller Ausiàs Roís de Corella, 300 sous rendals anuals de violari durant les vides de Joan Roís de Corella, cavaller $i$ mestre en teologia, i de Maria, donzella, filla de l'esmentat Joan Roús de Corella ("ad vitas magnifici Joannis Roiz de Corella, militis ac magistri in sacra theologia, filii vestri, et Marie, domicelle filie dicti magnifici Joannis Roiz de Corella").

El 17 de febrer de 1480 Joan Roís de Corella, fill i hereu d'Aldonça Corella, confesa haver rebut les pensions d'aquest violari segons instrument de quitament en mans del notari Pere Soler datat el dia d'abans. Figuren com a testimonis el mercader Bertomeu Chiva i l'escuder Pere Vidal.

AHN, Osuna, llig. I322, no. 2I, not. Antoni Barreda.

282

I474, maig, 27. València.

Aldonça Corella reconeix a Andreu Vallterra, cavaller de la ciutat de València, el lliurament de 10 lliures, 10 sous com a llü̈ció i quitament de zo sous anuals de pensió d'aquells 60 sous rendals i anuals de

3³. Document esmentat en Almiñana I984-85, 392. 
violari que livaren vendre ell i la seua esposa Damiata davant el notari Antoni Barreda l'n de setembre de 1458 .

AHN, Osuna, llig. I322, no. 2I, not. Antoni Barreda

283

I474, maig, 30. "In loco de Torrent, in domo magnifici Joannis Ram alias Scrivà, domicelli".

Sentència arbitral donada per Joan Roís de Corella -mestre en teologia-, Salelles de Monpalau - cavaller-, Nicolau Balaguer i Lluís Nadal-mercaders de València-, com a àrbitres i amigables componedors elegits pels germans i cavallers Lluís i Andreu Figuerola ${ }^{314}$ en raó de diversos censals i violaris i, especialment, en raó de l'administració d'una "companyia de les carns" de mossén Joan Figuerola -pare d'ells-feta per Andreu Figuerola després de la mort del seu pare. D'acord amb aquesta sentència, els Figuerola es comprometien a anul-lar els plets judicials que havien entre d'ells $i$ a renunciar a iniciar qualsevol nou plet.

Lluís Figuerola acceptà el contingut d'aquesta sentència, mentre que el seu germà Andreu es negà a escoltar la sentència quan varen intentar llegir-li-la en casa de Salelles de Monpalau, a Torrent.

RCSCCV, protocols, no. 24I4I, not. Joan Verdanxa. ${ }^{315}$

284

I474, juny, 23. València.

Lluís Figuerola, a la casa del seu germà Andreu Figuerola i davant la seua presència, fa llegir al notari Joan Verdanxa una escriptura d'intimació perquè, d'acord amb la sentència arbitral donada el зo de maig de 1474 pels amigables componedors Joan Roís de Corella-mestre en teologia-, Salelles de Monpalau -cavaller-, Nicolau Balaguer i Lluís Nadal, Andreu Figuerola cancel-lara qualsevol denúncia interposada per ell contra Lluís Figuerola i els seus béns.

RCSCCV, protocols, no. 24I II, not. Joan Verdanxa.

285

I474, juny, 28. València.

Andreu Figuerola protesta contra l'escriptura d'intimació feta contra ell pel seu germà Lluís Figuerola i afirma que no està obligat a fer cas d'aquesta intimació en allò referit a les accions efectuades per ell en raó del vincle testamentari establit pel seu difunt pare Joan Figuerola. Segons Andreu Figuerola, a aquestes accions seues no els afectava la sentència arbitral donada perquè els compromisaris Joan Roís de Corella -mestre en teologia-, Salelles de Monpalau-cavaller-, Nicolau Balaguer i Lluís Nadal no tenien poder per a tractar sobre elles.

RCSCCV, protocols, no. 24I II, not. Joan Verdanxa.

3I4. Segons la sentència, l’elecció del compromisaris es va fer mitjançant una “carta de compromés” rebuda pel notari Joan Verdanxa el 30 de març de I 474 .

355. Document esmentat en Riquer I964, 3, 257. 
I475, novembre, 6 . València.

Joan de Gallach, doctor en lleis, en nom de Lluís de Cavanyelles, lloctinent del Governador General del regne de València, es dirigeix al noble Pero Maça de Liçana -i a la seua esposa-, al cavaller mossén Lluís Mascó i al notari Jaume Gisquerol i els comunica que el notari Antoni Barreda, com a procurador del mestre en teologia i cavaller Joan Roís de Corella -hereu d'Aldonça, mare seua-, li ha mostrada una "carta pública executòria ab submissió e renunciació de for" feta el 27 d'abril de 1474 davant el mateix Antoni Barreda, segons la qual ells varen carregar a la referida Aldonça ials seus zoo sous de violari. Barreda, en nom del seu representat, reclama l'abonament de zoo sous de pensions degudes de dues pagues d'aquest violari.

ARV, Governació, no. 9I, mà 52, f. 28 rv.

287

I476, abril, I8. València.

Lluís de Cavanyelles, lloctinent del Governador General del regne de València, es dirigeix a Miquel Sànchiz i a la seua esposa Guillamona, a Guillem Corts -veí de Pego- i a la seua esposa Miquela, $i$ a Jaume Pérez de Culla i la seua esposa Joana, i els comunica que el notari Antoni Barreda-com a procurador del mestre en teologia Joan Roís de Corella- li ha mostrat diversos documents notarials segons els quals ells varen carregar un censal als membres de la família Roís de Corella ique ara, per dret d'herència, pertany al mestre en teologia Joan Roís de Corella. Barreda reclama l'abonament de 62 sous, 6 diners deguts en raó d'aquests censals. ${ }^{316}$

ARV, Governació, no. 94, mà 29, f. 3rv.

288

I476, agost, I7. València.

Lluís Figuerola, cavaller, en el seu nom propi i com a hereu juntament amb el seu germà Andreu dels béns del seu pare Joan Figuerola, cedeix a Andreu Figuerola, cavaller i germà seu, certs drets segons l'estipulat en una sentència arbitral donada, davant el notari.Joan Verdanxa, el dia 30 de maig de 1474 per Joan Roís de Corella, "in sacra pagina professorem”, Salelles de Monpalau -cavaller-, Nicolau Balaguer i Lluís Nadal-mercaders de València-com a àrbitres i amigables

componedors elegits per Lluís $i$ Andreu,.

RCSCCV, protocols, no. 24I43, not. Joan Verdanxa.

289

I477, juny, 25. València.

Testament del donzell Lluís Roís de Corella, germà de l'escriptor Joan Roís de Corella. Nomena hereu universal de tots els seus béns al seu germà Joan, cavaller i mestre en sacara teologia, a

36. Document esmentat en Almiñana I984-85, 399 . 
qui "recoman la ànima mia e lo càrrech de la mia sepultura, la qual vull sia feta a tota voluntat, beneplàcit e ordinació de aquell".

AHN, Osuna, llig. I273, no. I, not. Antoni Barreda.

\section{Die XXV junï anno predicto $M^{\circ}$ CCCC LXX septimo}

En lo nom de nostre senyor Déu e de la gloriosíssima Verge Maria, mare sua, advocada de tota crestiandat molt piadosa, yo, Loís Roïz de Corella, donzell, habitant de la ciutat de València, fill del magnífich mossén Ausiàs Roïz de Corella, quòndam, cavaller habitant de la dita ciutat, sa per gràcia de nostre senyor Déu de cos e pensa, ab memòria e loqüela íntregues, convocats e preguats los testimonis e notari dejús scrits, faç e ordén lo present meu derrer testament en e per la forma següent. Ço és, que en tots los béns meus mobles e inmobles, drets e accions a mi pertanyents e pertànyer devents de lluny o de prop per qualsevol títol causa, manera o rahó, lo reverent e magnífich mestre Joan Roïz de Corella, mestre en sacra teologia, cavaller, germà meu, hereu meu propri e universal faç e instituesch per dret de institució a fer dels dits béns e drets a totes ses planes voluntats. Al qual recoman la ànima mia e lo càrrech de la mia sepultura, la qual vull sia feta a tota voluntat, beneplàcit e ordinació de aquell.

Aquest és lo meu derrer testament e derrera voluntat mia lo qual e la qual vull valer e tenir e que valgua e tingua per dret de mon derrer testament e derrera voluntat mia. E, si per dret de derrer testament e derrera voluntat mia, valer e tenir no porà, vull aquell valgua e tingua per dret de codicils e altra qualsevol derrera voluntat per tots aquells drets, furs e privilegis que mils valer e tenir porà.

Foren fetes les dites coses en la ciutat de València a vint-e-cinch dies del mes de juny any de la nativitat de nostre Senyor mil quatre-cents setanta-set. Se+nyal de mi, Loís Roïz de Corella, testador dessús dit qui les dites coses faç e ordene e vulle man sien fetes e enseguides segons per mi són dispostes e ordenades.

Presents foren per testimonis a les dites coses convocats e per lo dit testador preguats, en Nicholau de la Vall, perayre; en Joan Cavalleri, scuder, e-n Miquel Aparici, carnicer, habitants de la ciutat de València, los quals coneixien lo dit testador e, per semblant yo, Antoni Barreda, notari, coneixia lo dit testador.

290

I477, juny, 25. València.

Lluís Roís de Corella, germà de l'escriptor Joan Roís de Corella, nomena el mercader Bertomeu Chiva, habitant de la ciutat de València, com a procurador seu.

AHN, Osuna, llig. I273, no. I, not. Antoni Barreda.

29I

I477, octubre, 6 . València.

Joan Roús de Corella, comte de Cocentaina i Governador General del regne de València, comunica a Antoni Aguiló i a la seua esposa, veïns de Gandia, que el notari Antoni Barreda-com a procurador del mestre en teologia Joan Roís de Corella - li ha mostrada una escriptura pública rebuda el 26 de 
setembre de 1440 pel notari Pere Belsa segons la qual l'esmentat matrimoni carregà 37 sous i 6 diners censals anuals a mossén Ausiäs Roís de Corella i als seus. Antoni Barreda reclama, davant la cort del Governador, 75 sous en raó de pensions degudes d'aquest censal.

ARV, Governació, no. IOI, mà 56 , f. IIr.

292

I477, novembre, I5. València.

Joan Roís de Corella, comte de Cocentaina i Governador General del regne de València, comunica a Gabriel Sànchez àlies Garcia i a Elvira, la seua mare, veïns de Dénia, que el notari Antoni Barredacom a procurador del mestre en teologia Joan Roís de Corella-, els reclama 133 sous de pensions degudes d'un censal que havia pertangut a Aldonça, mare del mestre en teologia, i que ara pertanyia a Joan Roís de Corella com a hereu de sa mare.

ARV, Governació, no. IO2, f. $226 \mathrm{rv}$.

293

I477, novembre, 2O. València.

Joan Roís de Corella, comte de Cocentaina i Governador General del regne de València, comunica a Guillem de Canemàs que el notari Antoni Barreda-com a procurador del mestre en teologia Joan Roís de Corella-, li reclama 510 sous ig diners de pensions d'un censal que havia pertangut a Aldonça, mare del mestre en teologia, i que ara pertanyia a Joan Roís de Corella com a hereu de sa mare.

ARV, Governació, no. IO2, f. $228 \mathrm{r}$.

294

I478, març, 2. València.

Joan Roís de Corella, comte de Cocentaina i Governador General del regne de València, comunica a Galvany de Castellví i a Joan de Vallterra, senyor de Torres Torres, que Bertomeu Chiva-com a procurador del cavaller imestre en teologia Joan Roís de Corella- li ha mostrada una escriptura pública rebuda l's d'agost de 1466 pel notari Antoni Barreda segons la qual Castellví $i$ Vallterra carregaren 100 sous de violari a Joan Roís de Corella i als seus. Bertomeu Chiva, com a procurador del mestre en teologia, reclama 100 sous en raó de pensions degudes d'aquest violari.

ARV, Governació, no. IO5, f. I6Irv.

295

I478, maig, 22. València.

Bertomeu Chiva -habitant de València-com a procurador de Joan Roís de Corella segons acte de procuració fet davant el notari Antoni d'Aranda el 31 de juliol de 1475, reconeix a Joan Canogueracavaller, senyor de Catarroja i habitant de València- que, per mans d'Ausiàs Pintor, li ha lliurat 1oo sous deguts a Corella per la paga d'un censal.

RCSCCV, protocols, no. 22556, not. Francesc Pintor 
I478, juny, 9. València.

Miquel Honorat Pérez, ciutadà de València, reconeix a Ferran Eximenis-mercader de València $i$ cunyat seu-com a tutor i curador de l'hereu del venerable i discret notari Pero Pérez-sogre de Ferran i pare de Miquel Honorat Pérez-, el lliurament d'una sèrie de llibres que el mercader li havia donat $i$ que perteneixien al difunt notari. Miquel Honorat asegura que els tornarà en qualsevol moment que se lidemanen.

AHN, Osuna, llig. I273, no. 2, not. Antoni Barreda.

Primo, los Comentaris de Cèsar, scrits en paper e perguamí, cubertes de fust a la ytaliana ab aluda vermella de forma de full.

Ítem, hun Coment de Juvenal, en paper, ab cubertes de post a la ytaliana ab cuyro vermell de forma de full.

Ítem, hun libre de les Faules de Ovidi e [...] a la moralitat, scrit en paper, de forma de quatre cartes lo full qüernat en post ab cuyro vermell e les Faules de Ysop et De vita et moribus philosophorum en hun volum.

Ítem, hun Vessori Sobre les Èthiques, de quatre cartes lo full, qüernat en post ab cuyro vermell.

Ítem, Bartholomeus Facius De vite felicitate, en perguamí, ab cubertes vermelles foguegades.

Ítem, unes Epístoles de Ovidi, en pergamí, ab cubertes de post tenat.

Ítem, Mafeus Vegins De felicitate et misseria e altres obres, en pergamí, ab cubertes de post vermelles.

Ítem, Manipulus poetarum, en paper e pergamí, ab cubertes engrutades ab aluda vert.

Ítem, hun formulari romà, qüernat sens post.

Ítem, unes Epístoles de Sant Dionís, en perguamí, ab cubertes de post tenades, bollades e Epístoles de Plini, en un volum tot.

Ítem, les Philípiques de Demostenes, en perguamí, quernades en post ab cubertes negres.

Lo Juvenal, en perguamí, qüernat en post a la ytaliana ab cuyro burell.

Vessori Sobre los test de Aristòtil, de forma de full, en paper, qüernat en posts ab cuyro vermel a la ytaliana.

Ítem, Epístoles de Oraci e altres obres, en pergamí, de posts ab cubertes vermelles.

Ítem, Boeci De consolacio, en paper y en pergamí, ab cubertes de fusts sens cuyro.

Ítem, hun libret de Sant Agostí Hencheridion, en pergamí, ab cubertes vermelles.

Emilius Probus, en paper, qüernat ab cubertes engrutades de vermell.

Epístoles de Fallaris, en paper, ab cubertes de post a la ytaliana ab cuyro vermell.

Hun troç del Comprehensori novament traduhit per A B C començant de la M fins a la V, en post, ab cuyro groch a la ytaliana.

Ítem, una gramàtica ytaliana, en perguamí, ab cubertes de post vermelles.

Ítem, hun libre, en pergamí, ab cubertes de post sens cuyro appellat Testimoni Veteris et Novi Testamenti.

Ítem, hun libre, en paper e perguamí, ab cubertes vermelles engrutat que comença "Senium est tedium".

Ítem, lo Valeri Maximo, en pergamí, ab cubertes de post vermelles.

Ítem, lo Tucicides e Herodoto, en paper e pergamí, en post ab cubertes vermelles.

Ítem, hun saltiri, en perguamí, ab cubertes vermelles. 
Ítem, speculum Beati Bernardi, en pergamí, ab cubertes de aluda en post.

Ítem, lo Homero traduït per micer Leonardo, en paper, ab cubertes de post vermelles. Ítem, de exemples de sacra scriptura, en pergamí, qüernat ab post sens cuyro.

Ítem, les paradoxes de Tuli e algunes declamacions de Quintilià, en paper e pergamí.

Ítem, hun Salusti, en paper, ab cubertes de post burelles a la ytaliana.

Ítem, Lactanci De ira Dei, en pergamí, en post ab cubertes tenat foguejades bollat.

Ítem, les Abstractions de Plini, en paper, ab cubertes vermelles engrutades.

Ítem, De bello punico, en paper, ab cubertes de post grogues.

Illebertii de tedio huius vite ab altres tractats de Sen[e]ca De clemencia, en pergamí, ab cubertes de post sens cuyro.

Ítem, Confessio beati Bernardi ad [...], en paper, ab cubertes engrutades blanques.

Ítem, hun libre en tosquà que comença: "Por que terra", en paper, ab cubertes de post tenat.

Ítem, hun libre sobre les Decretals, en paper, ab cubertes de post e la una cuberta trenquada ab aluda grogua e vermella que comença "Prissimi Jesus".

Ítem, Compendiosa istoria Yspanie, en paper, de emprempta, ab cubertes de post tenades.

Ítem, los Furs del rey en Jacme, en pergamí, ab cubertes de post groch e vermell bollades.

Ítem, Terenci, en pergamí, de cubertes engrutades ab aluda vermella.

Epístoles de Leonardo Aretino, en paper, ab cubertes de post vermelles a la ytaliana.

Ítem, Tuli De officis, en pergamí, ab cubertes vermelles de post.

Ítem, un libre de mestre Quintà dreçat a.n Caera racional, en paper, ab cubertes de post vermelles.

Ítem, Qüestions tosculanes, en pergamí, ab cubertes de post negres, hi De natura deorum et de Dedunnacipe ${ }^{317}$ et de fato et de legibus, en un volum bollat.

Ítem, Macobrius super sommium Scipionis, en pergamí, ab cubertes de post vermelles.

Ítem, Ovidi De arte amandi, en pergamí, ab cubertes de post vermelles.

Ítem, Apotechmata Plutarchi, de emprempta, ab cubertes de posts vermelles a la ytaliana.

Ítem, los Topichs de Tuli, en paper, ab cubertes vermelles engrutades, ab una altra obreta de Comodis romane curie.

Ítem, Rethorica de Aristòtil a Alexandre, en paper ,ab cubertes de post verts.

Ítem, Apianus De bello civili, de emprempta, ab cubertes de posts vermelles.

Ítem, lo Lucà, en pergamí e paper, ab cubertes de post vermelles.

Ítem, lo Precià menor, en pergamí, ab cubertes de fust ab cubertes de aluda blanques.

Ítem, Laertius Diogenes Devitis philosophorum, en pergamí, ab cubertes de post blaves.

Ítem, Hieronimus Super Matheum, en pergamí, ab cubertes post [sic] negres.

Ítem, De profecto oratorum, en paper, ab cubertes de post ab aluda burella an [sic] una post trenquada.

Ítem, les Oracions de Tuli, en pergamí, ab cubertes de post vermelles ab cantoneres de lautó.

Ítem, Epístoles de Oraci, en pergamí, de post ab aluda blanqua.

Ítem, Ugo de Sancto Victore De sacramentorum fidei, cubertes de post verts.

Ítem Pogius De infelicitate, en pergamí e molt paper après, ab cubertes de post foguerades.

Ítem, les Qüestions tosqulanes, en paper, ab cubertes de post vermelles.

Ítem, Tabula super Valerium, en paper, ab cubertes de post vermelles e, una cuberta de aluda blanqua, dessús.

Ítem, De dictis et factis regis Alfonsi, en pergamí, ab cubertes vermelles foguejades.

3I7. Paraule de lectura dubtosa: De dum accipe?

Magnificat CLM I, 2OI4, III-377. ISSN 2386-8295 
Ítem, Calderma De concordia decreti cum Biblia, en paper, ab cubertes engrutades vermelles.

Ítem, una epístola De amore, en pergamí, ab les armes de Centelles ab cubertes engrutades vermelles.

Ítem, Epistole Sancti Hieronimi, en paper, ab cubertes de post verts.

Ítem, un Dant, en pergamí, ab cubertes de post vermelles.

Libres de emprempta, desqüernats.

Ítem, lo Juvenal ab la glosa, de emprempta, desqüernat.

Ítem, Rethorica de trepesima, en paper, desqüernat de emprempta.

Ítem, Bartholomeus Facius, en paper, desqüernat.

Ítem, Cornelius Tantus, de emprempta, desqüernat.

Ítem, Ansomus, de emprempta, desqüernat.

Ítem, lo Colomella, de emprempta, desqüernat.

Ítem, lo Calderino sobre les obres del Marcial, desareglat, de emprempta.

Ítem, part de les Facècies de Pogi, de emprempta.

Ítem, part del Plutarcho, d'emprempta.

Ítem, lo Quintilià, de emprempta.

297

I478, agost, 3I. València.

Joan Roís de Corella, cavaller i mestre en sacra teologia habitant de València, i la seua filla Magdalena, esposa de Miquel Honorat Pérez, ciutadà de València, per tal de lliurar conjuntament a Miquel Honorat Pérez aquells 5.500 sous que Magdalena va prometre donar al seu marit com a complement i paga íntegra d'aquells 10.000 sous que es van constituir com a dot seu, segons constava en els cartes nupcials rebudes pel notari Antoni Barreda el dia 18 d'octubre de 1477 , venen $i$ transporten a Miquel Honorat Pérez diferents censals:

* Per preu i estimació de 3.0oo sous livenen aquells 250 sous que a Joan Roís de Corella responia Joan Canemàs, habitant de Dénia, en nom seu propi i com a hereu de Joan Canemàs son pare, mercaders de Dénia, així com a procuradors de Jaumeta, la seua esposa, i Tomàs Perelló, habitant de Dénia, i Francesca, la seua esposa, tots els quals "in solidum" van vendre aquests 250 sous censals originàriament al cavaller Ausiàs Roís de Corella amb instrument de carregament fet davant el notari Joan Sart l'i de març de 1446. Aquests 250 sous van pertànyer a Joan Roís com a hereu universal de son pare segons constava en el testament en poder de Joan Sart el 9 de febrer de 1443 i per mort d'aquell publicat pel dit notari el 16 de gener de 1450. Per escriptura notarial feta davant el notari Antoni Barreda el dia 22 de desembre de 1455, els referits 250 sous van pertànyer a Aldonça Corella i, posteriorment, a Joan Roís de Corella, hereu universal d'Aldonça d'acord amb el seu darrer testament fet el 24 de novembre de 1466 davant Antoni Barreda i publicat el 24 de juliol de 1475.

* Per preu de 2.ooo sous venen aquells 133 sous, 4 diners censals que restaven d'aquells 233 sous, 4 diners part d'aquells 800 sous censals que per Ramon Tolsà, cavaller i senyor de Quesa, originalment foren venuts a Joan Galceran de la Serra, donzell habitant de València, davant el notari Joan de Monreal el dia g de novembre de 1447. Per escriptura del 13 de gener de 1463 davant el notari Antoni Barreda, els esmentats 233 sous, 4 diners varen servenuts a Aldonça Roís de Corella i, posteriorment, passaren a mans de Joan Roís de Corella com a hereu 
universal de la seua mare.

Com a testimonis de la signatura d'aquesta escriptura per part de Joan Roís de Corella figuren Pere Esteve -antic barber-i Joan Mayans -fuster-, habitants de València, mentre que Miquel Honorat Pérez ho fou de la de Magdalena, qui va signar a l'alqueria del seu marit a la partida de Campanar de l'horta de València.

AHN, Osuna, llig. I273 no. 2, not. Antoni Barreda.

298

I478, agost, 3I. València.

Miquel Honorat Pérez, ciutadà de València, reconeix a Magdalena Roís de Corella, la seua esposa, el lliurament de 5.50o sous que ella li va prometre donar al seu marit com a complement i paga íntegra d'aquells 10.000 sous que Magdalena va constituir com a dot seu, segons constava en les cartes nupcials rebudes pel notari Antoni Barreda el dia 18 d'octubre de $147 \%$.

AHN, Osuna, llig. I273 no. 2, not. Antoni Barreda.

I478, agost, 3I. València.

Testament de l'escriptor Joan Roís de Corella, cavaller i mestre en Teologia. ${ }^{318}$

AHN, Osuna, llig. I273 no. 2, not. Antoni Barreda

\section{Iam dicte die XXXI augusti anno predicto $\mathrm{M}^{\circ} \mathrm{CCCC} \mathrm{C}^{\circ} \mathrm{LXX}$ octavo.}

En nom de nostre Senyor Déu e de la gloriosíssima Verge Maria, mare sua, advocada de tota crestiandat molt piadossa, yo, Joan Roïz de Corella, en sacra theologia mestre e cavaller, habitador de la ciutat de València, sa, per gràcia de nostre Senyor Déu, de cos e de pensa ab memòria e loqüela íntregues, convocats e preguats los testimonis e notari dejús scrit, fas e ordén mon derrer testament e derrera voluntat, en e per la forma seguent:

Primerament, vull e ordén que quant a nostre Déu, Senyor e Redemptor, serà plaent appellar-me a la sua sancta glòria de paradís en la qual, per mèrits de la sua sacratíssima sanch, mort e passió, preu infinit de nostra redemptió, me vulla col·locar, lo meu cors sia liurat a ecclesiàstica sepultura dins lo vas o fossa que la magnífica germana, e hereua mia dejús scrita, volrà e elegirà, a la qual la ànima mia carament acoman. La qual sepultura ab son anniversari e cap d'any, vull e ordén sien fets segons aquella volrà e ordenarà.

Ítem, com lo honrat en Berthomeu Chiva, mercader, habitador de la dita ciutat, procurador meu en lo dit nom reba e acostume rebre les ànnues pensions dels censals, recensos, violaris e altres reponsions e altres quantitats e béns meus e a mi pertanyents, e de les quals a mi fa delliurament e dóna e restitueix e, per semblant de aquelles, fa los paguaments per mi li són manats fer sens per mi no li és feta cautela alguna. E com yo fie d'aquell, vull, man e ordén que, aprés òbit meu, lo dit honorable en Berthomeu Chiva per la hereua mia dejús scrita, sia

318. Document esmentat en Riquer I964, 3, 257 -assenyalant com a data la del 3o d'agost-i publicat en Chiner I994b, 49-6I. 
absolt e disfinit pleníssimament. E vull e ordén lo dit honorable en Berthomeu Chiva, per sa sola simple loqüela, sens prova alguna e sens jurament, sia cregut del que dirà, en nom de procurador meu, ha rebut e donat e liurat a mi, e per manament meu ha donat. E, açò, sens cautela, jurament, o prova alguna més tan solament per sa simple loqüela, segons he dit, e a mi plau. E, si per subtilitat de dret o en altra manera, per la hereua mia dejús scrita o per altra qualsevol persona, serà demanat compte a aquell e, per la dita rahó, serà condemnat en pagar cosa alguna o restituir més del que aquell per sa sola loqüela afermarà ésser tornador, sia del dit honorable en Berthomeu Chiva com de aquella dita quantitat ara, de present, per al dit cas, temps e loch, li faç legat de la dita quantitat en la qual serà condemnat. E a cautela ara per al dit cas, temps e loch absolch, defenesch e delliure lo dit honorable en Berthomeu Chiva de tota acció, pensió, questió e demanda que per la dita rahó li sia feta, faent-li, de present, per al dit temps, cas e loch, pleníssima absolució, remissió e general fi, e solemne e perpetual pacte, axí real com personal, d'aquí avant no demane aquell en juhí e fora juhí. E sobre les dites coses e sengles de aquelles, a mi e als meus imposse callament perdurable com axí a mi plàcia e sia aquesta ma incommutable voluntat.

En tots los altres béns meu [sic] mobles, semovents e inmobles, deutes, drets e actions a mi pertanyents e pertànyer devents, de lluny o de prop, per qualsevol títol, causa, manament o rahó, la magnífica na Dalfina, germana mia, muller del magnífich mossén Loís Figuerola, cavaller, habitador de la dita ciutat, hereua mia pròpria e universal, faç e instituesch a fer dels dits béns a totes ses planes voluntats.

Aquest és lo meu derrer testament e derrera voluntat mia, lo qual e la qual vull valer e tenir, e que valgua e tingua per dret de derrer testament meu e derrera voluntat mia. E, si per dret de derrer testament valer e tenir no porà, vull e ordén aquell valgua e tingua per dret de codicils e altra qualsevol derrera voluntat per tots aquells furs, privilegits e drets que mils valer e tenir porà.

Foren fetes les dites coses en la ciutat de València a trenta-hu del mes de agost any de la nativitat de nostre Senyor mil quatre-cents setanta-huyt. Se + nyal de mi, dit Joan Roïz de Corella, testador dessús dit, qui les dites coses faç e ordene, e vull e ordén sien fetes e enseguides segons per mi son dispostes e ordenades.

Presents foren per testimonis a les dites coses convocats, e per lo dit testador preguats, en Pere Steve olim barber, en Joan Meyans, fuster, e en Pere Vidal, scuder, habitadors de la ciutat de València, qui coneixien lo dit testador. E, per semblant yo, Antoni Barreda, notari rebedor del dit testament, coneixia aquell.

En aprés, divendres qui-s comptava sis dies del mes de octubre de l'any de la nativitat de nostre Senyor Jhesuchrist mil quatre-cents noranta-set, a instància e requesta de la magnífica na Dalfina Roïç de Corella, muller del magnífich mossén Luís Figuerola, cavaller, jermana y hereua scrita en lo desús dit testament, e en presència dels magnífichs mossén Luís Roïz de Corella, donzell, jermà del dit testador, e del dit mossén Luís Figuerola e en la casa de aquell, lo preinsert testament per mi, Pere Andreu, notari públich de la ciutat de València, regent les notes e libres del venerable e discret en Antoni Barreda, quòndam, notari, fonch lest e publicat. E, lest e publicat aquell, en continent la dita magnífica na Dalfina de Corella dix que ella se retenia acord sobre la acceptació de la dita herència o repudació de aquella, e que lo ínterim temps algú no li precóregue ans li reste salvu e il-lés, requirint de premisis carta pública. Presents foren per testimonis a la publicació del dit testament, lo magnífich mossén Luís Mascó, cavaller, menor de dies, y lo honorable en Joan Caldes, studiant en arts de la ciutat de València. 
De post vero die septima mensis octobris dicti anni millesimi CCCC nonagesimi septimi, la dita magnífica na Dalfina Roïç de Corella, muller del dit magnífich mossén Luís Figuerola, cavaller, convocats mi, Pere Andreu, notari, e los testimonis dejús scrits, declarant lo acord per ella retengut sobre la acceptació o repudiació de la dita herència, dix que acceptava la dita herència ab benefici de inventari, protestant que, en fer aquell, temps algú no li precórregue ans li reste salvu e il.lés, requerint carta publica.

Presents foren per testimonis a les dites coses, en Bernad Ferreres, studiant en arts del loch de la Gana, e en Ramon del Scrivà, scuder de Beru de Ay, habitadors en la dita ciutat.

300

I478, octubre, I3. València.

Elionor Flors de Vallterra, vídua del donzell i habitant de València Francesc de Vallterra, ven go sous censals al cavaller Lluís Figuerola, cunyat del poeta Joan Roís de Corella, per preu de 6o lliures.

RCSCCV, protocols, no. 24I44, not. Joan Verdancha.

3OI

I479, gener, I4. València.

Joan Roís de Corella, cavaller i mestre en teologia, dóna i transporta a Isabel Martínez de Vera dos censals -un de 219 sous $i 8$ diners, $i$, un altre, de 66 sous $i 8$ diners- que havien pertangut a la família de l'escriptor per valor de 3650 sous.

AHG, protocols, not. Lluís Collar, microfilm rotlle $30 .{ }^{319}$

$3 \mathrm{O} 2$

I479, febrer, I. València.

Francesc Gilabert de Centelles, comte d'Oliva, conseller reial i Governador del regne de València, es dirigeix a Mateua, vídua de Berenguer Jàfer, al seu fill, i al matrimoni format per Francesc Climent i la seua esposa, i els exposa que Bertomeu Chiva, procurador del mestre en teologia i cavaller Joan Roís de Corella -hereu d'Aldonça Corella, sa mare-li ha mostrat diversos documents notarials. El primer d'ells és una escriptura del 6 de gener de 1410 davant el notari Ramon Agualada segons la qual els damunt dits vengueren i carregaren a Saura d'Esplugues, vídua de Pere Roís de Corella, i als seus 41 sous, 8 diners censals; el segon document, rebut pel notari Antoni Barreda el 22 de desembre de 1455, mostra que el dit censal va passar a mans d'Aldonça Corella. Bertomeu Chiva reclama un deute de $6 r$ sous i 6 diners en raó d'aquest censal.

ARV, Governació, no. Io9, mà $7^{\mathrm{a}}$, f. 39 rv. $^{320}$ 
I479, febrer, I6. València.

El conseller reial i batle general Pere Garró lliura al comte d'Oliva Francesc Gilabert Riusec àlies Centelles, Governador del regne de València, una carta del monarca signada a Trujillo el 8 de febrer de 1479, on el rei comunicava: al comte d'Oliva, el seu cessament en el càrrec de Governador; i a Eximén Pérez Escrivà de Romaní, la seua inhibició com a nou governador.

La missiva va ser lliurada per Garró en la casa del comte d'Oliva davant el cavaller i mestre en teologia Joan Roís de Corella, el cavaller Pere Ramon de Monsoriu i Pere Capdevila, habitants de València.

ARV, Batlia, llibres, no. II $_{5} 6$, ff. $375^{\mathrm{r}-376 \mathrm{v}^{321}}$

304

I479, març, 4. València.

Isabel Martínez de Vera, filla del difunt donzell Diego Martínez de Vera, nomena Miquel Pérez com a procurador seu.

ARV, protocols, no. 1845 , not. Francesc Pintor. ${ }^{322}$

305

I479, abril, I5. València.

Bertomeu Chiva, mercader, revoca els testaments i codicils redactats, fins a eixe moment, davant el notari Antoni Barreda.

AHN, Osuna, llig. I322, no. 22, not. Antoni Barreda

306

I479, juny, 28. València.

Dalfina Corella, esposa de Lluís Figuerola, cavaller i habitant de València, en el seu nom propi $i$ com a procuradora del seu marit segons consta en escriptura datada el 16 de setembre de 1469 davant el notari Joan Verdanxa, atorga a Joan Fontanet, argenter, 392 sous censals "pro solucion" feta a Fontanet d'aquells 4.471 sous i 1 o diners que Lluís Figuerola li devia en raó del preu de 280 sous censals venuts a Lluís Figuerola.

AHN, Osuna, llig. I322, no. 22, not. Antoni Barreda.

307

I479, octubre, I. València.

Bernat Blavi, prevere i habitant de Gandia, reconeix un deute de 8 lliures, 14 sous i 7 diners a Joan

32I. Document esmentat en Almiñana 1984-85, 399.

322. Document esmentat en Guia 2003 i publicat per Soler 20I4, I47.

Magnificat CLM I, 2OI4, III-377. ISSN 2386-8295 
Roís de Corella, cavaller habitant de València i mestre en sacra teologia. D'aquesta quantitat total, 6 lliures, 10 sous eren degudes pel preu d'una terra campa que, a instància dels procuradors de Corella, la cort del justícia de Gandia el dia 27 d'agost passat -per manament del lloctinent del Governador del regne i a instància de Corella interposada davant la cúria del Governador el 23 d'octubre de 1478va vendre com a béns de la difunta Bonaventura, vídua de Berenguer Jàfer, habitant de Gandia $i$ adquirida per Bernat Blavi mitjançant 420 sous i 8 diners censals que havien preu de 6 lliures i 10 sous. La resta del deute -2 lliures, 4 sous i 7 diners - eren pensions degudes del referit censal. Corella sol-licita a Blavi que, en raó del referit deute, li cedisca tots els seus drets sobre una terra anomenada "la Vela".

Figuren com a testimonis d'aquesta escriptura Bertomeu Chiva, mercader, i Ferran de Guevara, antic sastre i habitant de València.

AHN, Osuna, llig. I322, no. 22, not. Antoni Barreda.

308

I479, novembre, 3 . València.

Andreu Sart, doctor en lleis i habitant de València, reconeix a Joan Roís de Corella, cavaller $i$ mestre en sacra teologia, la venda per zo lliures d'una terra campa anomenada "la Vela" situada en el terme de Dénia feta per la cúria del Governador de València el 17 d'octubre de 1478 a favor de Joan Roís de Corella. Aquesta venda va ser feta per la cúria a instàncies de Corella com a béns de Guillem Canemàs, veí de Dénia.

AHN, Osuna, llig. I322, no. 22, not. Antoni Barreda.

309

I480, febrer, I7. València.

Joan Roís de Corella, cavaller de la ciutat de València i mestre en sacra teologia, reconeix a Joan Coris, mercader i alcaid del castell de Dénia, el lliurament de 63 lliures iz diners en raó del terreny anomenat "la Vela", situat al terme de Dénia, i d'altres 23 sous iz diners a ell també deguts.

AHN, Osuna, llig. I322, no. 23, not. Antoni Barreda.

$3^{\mathrm{IO}}$

I480, abril, I. València.

Joan Roís de Corella, cavaller i mestre en teologia, reconeix a Berenguer Mercader, donzell habitant de València, que per mans de Bertomeu Çapena, estudiant, i utilizant diners de Joana Garró - esposa de Mercader-, li ha restituït 1.400 sous en raó de quitament d'un violari de 200 sous carregat, davant el notari Antoni Barreda en 1467, conjuntament pels donzells Berenguer Mercader i Eximén Pérez Escrivà .

AHG, protocols, not. Lluís Collar, microfilm rotlle $3 \mathrm{O} .{ }^{323}$

323. Document esmentat en Guia 2003. 
I480, octubre, I8. "In alquerea Michaellis Perex extra menia" (Tendetes de Campanar). Testament de Magdalena Roís de Corella, filla del cavaller, teòleg i escriptor Joan Roís de Corella i esposa de Miquel Pérez.

RCSCGV, protocols, no. 19072, not. Pere Guisquerol. ${ }^{324}$

\section{Die intitulata XVIIII [sic] mensis octobris anno $M^{\circ}$ CCCC LXXX' in alquerea Michaellis} Perex extra menia.

En nom de Déu sia, etc., com totes les coses mundanals, etc., enperamor de acò, yo, Magdalena Corella, muller del magnífich en Miquel Pérez, ciutadà de la ciutat de València, stant sana de cors e pensa, emperò en mon bon seny, paraula íntegra e manifesta stant per la gràcia de Déu, considerat que res al món no és tant cert com la mort e tant incert com la ora de aquella, desigant venir al sobiran gog de paradís, revocant, cassant e annul-lant tots e qualsevol testaments, donacions e altres derreres últimes volentats per mi ça enrere feyts e feytes en poder de qualsevol notari sots qualsevol solemnitats de paraules, ara, de nou, faç e ordén aquest meu derrer testament e la mia derrera volentat. En la qual faç e elegeix marmessors e de aquest meu derrer testament execudors ço és lo reverent mestre Johan Roïç de Corella, mestre en taulogia, pare meu molt amat, e lo dit en Miquel Pérez, marit meu, e a cascun de aquells et insolidum als quals done licència, facultat e plen poder tots los meus béns vendre, alienar, dividir e departir que basten a complir totes les coses que per mi en lo present testament són lexades e jaquides segons que en aquells largament ho trobaran scrit e ordenat per llur pròpria auctoritat, licència ne decret de cort e de altre qualsevol jutge o persona axí eclesiàstica com seglar sobre les dites coses no sperada ni demanada ans ço que per la hu de aquells serà començat, per l'altre puxa ésser fenit e acabat.

E, primerament, ans de totes coses vull e man tots mos deutes, torts e injúries sien satisfeyts e restituyts e pagats aquells emperò que apparran mi ésser tengut e obligat per justícia, cartes, albarans, testimonis dignes de fe e altres legittimes proves for de ànima en açò benignament observat.

E comanant la mia ànima al seu creador, vull e man que la mia sepoltura, aniversari e cap d'any al meu cors fahedora sia feta bé e onradament segons que de mi-s pertany a coneguda dels dits meus marmessors. La qual sepoltura elegeix ésser feta en la sglésia e monestir del gloriós mossén Sent Vicent de la ciutat de València en lo lloch on los dits marmessors meus plaurà e poran ab los dits frares del dit monestir. Lloch pagant de mos béns tot ço e quant ab aquells se poran concordar per la dita sepoltura. E, ans que lo dit cors meu sia liurat a ecclesiàstica sepoltura, sia quantat damunt aquella la lletania bé e onradament segons que de mi.s pertany per aquells preveres que als dits marmessors meus plaurà e ben vist serà.

Ítem, vull e man que aprés obte meu me sien dites e de fet me facen dir les trenta-tres mises appellades de sent Amador ab ses canelles e offerta en aquella sglésia o monestir que als dits marmesors meus plaurà e ben vist serà.

E més, vull e man que en lo dit monestir los dits marmesors me facen dir les cinch mises de les cinch plages del gloriós redemptor meu Jhesuchrist de les quals tinch gran devoció.

Ítem, leix e lege als dits marmesors meus que sien vestits de dol ço és cascú de aquells de gramalla e capiró de dol, de mos béns.

324. Document publicat en Soler 20I4, I48-5 amb errors de transcripció i absència d'alguna ratlla del document. 
Ítem, leix e lege a la magnífica na Dalfina Figuerola, tia mia, muller del magnífich mossén Luís Figuerola, cavaller, de mos béns cinquanta lliures, les quals vull que, aprés mort mia, de continent li sien donades.

De tots los altres béns meus, drets e accions a mi pertanyents o pertànyer podents o devents, luny o prop, per qualsevol títol, causa, manera e rahó hereu meu propri universal per dret de institució faç e jaquex al dit honrat en Miquel Pérez, marit meu e marmesor, de vida tant solament de aquell, de aquells dits béns, drets e accions meus. E, aprés mort de aquell, los fills e filles mies que de aquell hauré e tendré, si vius seran e estaran en la casa sua e mia vius, per eguals parts entre aquells dits fills e filles mies e del dit marit meu fahedores a fer aquells a ses planes volentats. E si fills ne filles meus e del dit marit meu en lo dia de la mia mort no y havia, ço que a Déu no plàcia, en tal cars dits béns meus e accions e drets lo dit en Miquel Pérez, marit meu e marmesor, tinga e posseixqua aquells, segons dit he dessús, de vida sua e, aprés mort de aquell, sens nenguna diminució, difalcació de dret, de legítima trebeliànica o altre qualsevol dret éntregament los dits béns, drets e accions tornen e vinguen al dit reverent mestre Johan Roïç de Corella si béns de la Sglésia no tendrà e puxa fer de aquells a ses plenes volentats. E si béns de la dita Sglésia tendrà, tinga en los dits béns, drets e accions la vida e, en los dits casos, hereu faç e institueix aquell de vida de aquell e, aprés mort de aquell, lo magnífich en Luís de Corella, donzell, jermà de aquell e oncle meu, sots tal emperò vincle e condició que, si aquell dit magnífich en Luís de Corella morrà quantquequant sens fills legíttims o de legíttim matrimoni procreats e nats, que en tal cars los dits béns meus, drets e accions, éntregament sens nenguna diminució e difalcació, vinguen a la dita magnífica na Dalfina, tia mia, e als fills e filles de aquella; e aquella e aquells puxen testar dels dits béns meus, drets e accions a ses plenes volentats e fer de aquells tot ço e quant volran fer. E, si lo dit magnífich en Luís de Corella, en lo dia de la sua mort, tenia fills e filles legíttims e de legíttim matrimoni procreats e nats, en tal cars aquell puxa dispondre e testar de aquells dits béns meus, drets e accions en los dits fills e files sues. E, advenint lo dit cars, hereus meus propris faç los dits fills e files a fer de aquells a ses planes volentats, sens vincle e condició alguna, no obstant la dita na Dalfina, tia mia, fos viva e tingés fills e filles legíttimes e naturals, com ma intenció sia que hon fills e filles del dit en Luís de Corella legíttims e naturals hi hagués, vulla aquells sien hereus meus e dels dits béns meus e·n la forma dessús dita facen a ses planes volentats.

Aquest és lo meu derrer testament, etc lo qual és fet fora los murs de la present ciutat de València en la dita alqueria del dit en Miquel Pérez, marit e marmessor e hereu meu, la qual stà a les Tendetes a XVIII del mes de octubre de l'any de la nativitat de nostre Senyor Déu M CCCC LXXX.

Se+nyal de mi dita Magdalena, testadriu que dessús qui lo present meu testament e la mia derrera volentat loe e aprove, ratiffique e conferme de la primera línea fins a la derrera inclusive.

Presents foren per testimonis a la confecció del present meu testament appellats e per la dita testadriu pregats qui aquells conexia e los dits testimonis a ella. E yo, dit notari rebedor del present testament, conech a tots ells, ço és en Matheu Ferrer e en Johan Canero, tapiners de la ciutat de València, e en Francesch Ballester, laurador, qui stà en la servitut del dit marit meu.

I481, maig, I8. València.

Joan Roís de Corella, mestre en teologia i habitant de València, rescata per 35 lliures tots aquells 100 
sous de violari que Joan Çanoguera, senyor de Catarroja, feia a Corella i que varen ser carregats davant el notari Antoni Barreda en la dècada dels 1460.

Com a testimonis figuren Bertomeu Segur i Lluís Figuerola, cunyat de Corella, habitants tots ells de València.

RCSCCV, protocols, no. 22552, not. Francesc Pintor. ${ }^{325}$

I48I, setembre, 22. València.

Testament del donzell Lluís Roís de Corella, germà de l'escriptor Joan Roís de Corella. Revoca expressament el seu testament de 1477 on el seu germà Joan figura com a hereu universal seu, i ara elegeix el cavaller Ramon Torrelles, habitant de València, com a hereu universal. Així mateix, Ilega 100 lliures a la seua germana Dalfina Roís de Corella, esposa del cavaller Lluís Figuerola.

AHN, Osuna, llig. I273, no. 3, not. Antoni Barreda.

Die XXII septembris anno predicto $M^{\circ}$ CCCC LXXX primo.

En lo nom de nostre senyor Déu e de la gloriosíssima verge Maria, mare sua advocada de tota crestiandat, molt piadosa yo Loís Roïz de Corella, donzell habitant de la ciutat de València, fill del magnífich mossén Ausiàs Roïz de Corella, quòndam, cavaller habitant de la dita ciutat, sa per gràcia de nostre senyor Déu de cos e pensa ab memòria e loqüela íntregues, convocats e preguats los testimonis e notari dejús scrits, faç e ordén lo present derrer testament meu en e per la forma següent:

E primerament do e leixe a la magnífica na Dalfina de Corella, germana mia e muller del magnífich mossén Loís Figuerola, cavaller habitant de la dita ciutat, cent liures moneda reals de València.

En tots los altres béns meus mobles, semovents e inmobles, deutes e drets e accions a mi pertanyents e pertànyer devents e podents per qualsevol títol, causa, manera ho rahó, lo magnífich mossén Ramon Torrelles, cavaller, habitant de la dita ciutat, hereu meu propri e universal, faç e instituesch a fer dels dits béns a totes ses plenes voluntats al qual recoman la ànima mia e lo càrrech de la mia sepultura, la qual vull e ordén sia feta a tota voluntat, beneplàcit e ordinació de aquell.

Derrerament revoque he per revocats qualsevol testaments e altres qualsevol derreres voluntats per mi ça enrere fetes en poder de qualsevol notari e en qualsevol altra manera per mi fets e fetes e, senyaladament, revoque e he per revocat lo testament per mi fet en poder de Antoni Barreda, notari dejús scrit, a XXV del mes de juny de l'any de la nativitat de nostre Senyor mil CCCC setanta-set e tots altres testaments e derreres voluntats per mi ça enrere fets, ordenats e fermats en qualsevol manera com me penida haver fets aquells e aquelles. E aquells e aquelles vull prevaler e prevalgua lo present meu derrer testament.

Aquest és lo meu derrer testament e derrera voluntat mia lo qual e la qual vull valer e tenir e que valgua e tingua per dret de derrer testament e derrera voluntat e, si per dret de derrer testament meu valer e tenir no porà, vull aquell e aquella valer e tenir e que valgua e tingua per dret de codicils e altra qualsevol derrera voluntat per tots aquells furs, privilegis e drets que mils valer e tenir porà.

325. Document esmentat en Almiñana 1984-85, 400. 
Foren fetes les dites coses en la ciutat de València a vint-e-dos dies del mes de setembre de l'any de la nativitat de nostre Senyor Déu mil quatre-cents huytanta-hu. Se+nyal de mi Loís Roïz de Corella, testador dessús dit qui les dites coses faç e ordén e vull e mane sien fetes e enseguides segons per mi són dispostes e ordenades.

Presents foren per testimonis a les dites coses convocats e pregats per lo dit testador en Nicholau de la Vall, perayre, en Bernat Olesa, sartre, e Francesch Joan de Casanova, scrivent, habitants de la ciutat de València, los quals coneixien lo dit testador e per semblant yo, Antoni Barreda, notari, conexia bé lo dit testador.

$3 \mathrm{I} 4$

I482, abril, 24. València.

Els jurats de València -el cavaller Lluís Mascó, menor de dies, i els ciutadans Berenguer Martí, Joan Alegre i Miquel Camarena- es plantegen la necessitat de construir un hospital general en la ciutat de València i nomenen una comissió que es reunirà dues vegades per setmana per tal d'estudiar la viabilitat i les despeses que suposaria la construcció d'aquest hospital. Els membres d'aquesta comissió -Lluís Mascó, menor de dies, com a jurat en cap pels cavallers i generosos; Berenguer Martí de Torres, com a jurat en cap pels ciutadans; el racional Bernat Català; mossén Joan Roís de Corella, cavaller i mestre en teologia; els advocats de la ciutat Jaume Garcia d'Aguilar i Miquel Dalmau-, havien de comunicar els resultats de les seues deliberacions als jurats de València.

Lluís Mascó i Berenguer Martíformarien part de la comissió "durant emperò los temps de llur juraderia e, en los anys subsegüents, sien ordenats, ensemps ab los davall scrits, los jurats en cap, ço és, lo hu per los cavallers e generosos, l'altre per los ciutadans, qui.s vulla que sien axí graduats".

Com a testimonis d'aquesta provisió municipal figuren el cavaller Berenguer Mercader i els ciutadans de València Galè̀s Joan i Pere Lor.

AMV, Manuals de Consells, A-42, ff. $246 \mathrm{v}-247 \mathrm{r}^{326}$

35

I482, juliol, 8. València.

Joan de Castellsent de Vila-rasa, cavaller, subrogat de mossén Lluís Ferrer lloctinent general del Governador General del regne de València, comunica a Abrahim Ajubet i a la seua esposa, veïns d'Ondara, que Bertomeu Chiva-com a procurador del mestre en teologia Joan Roís de Corella-els reclama 41 sous $i 8$ diners deguts en raó d'un censal que pertany al seu representat.

ARV, Governació, no. II6, f. 34 $\mathrm{Ir}^{327}$

$3^{\mathrm{I} 6}$

I482, novembre, 2I. València.

Els jurats de València ordenen el pagament a Joan Roís de Corella, mestre en teologia, de 1.000 sous "en tres terces per temps de hun any, lo qual començà a Tots Sants propassat, per alguns bons

326. El document ha estat transcrit en Gallent I980, Gómez-Ferrer I998, 372 i en Guia 2002, I75-76.

327 . Document esmentat en Almiñana I984-85, 400 . 
respectes e, principalment, per la lectura que fa dels sagrats Evangelis en la sala de la present ciutat, provehint que, de continent, li sia fet albarà de la primera terça".

AMV, Manuals de Consells, A-43, ff. $65^{\mathrm{v}-66 \mathrm{r} .}{ }^{328}$

Die jovis XXI mensis novembris anno $\mathrm{M}^{\circ} \mathrm{CCCC}^{\circ} \mathrm{LXXXII}^{\circ}$, los magnífichs en Joan de Castellví, generós, en Galeàs Joan, mossén Nicholau Torres, cavaller, en Joan de Gallach, en Felip de Vesach e en Leonard Ferrer, ciutadans, jurats de la insigne ciutat de València, presents lo magnífich en Bernat Català, racional, en Berthomeu Abat, notari síndich de la ciutat, micer Miquel Dalmau, micer Andreu Sart e micer Miquel Albert, doctors advocats de la dita ciutat, ensemps ab lo magnífich micer Jacme Garcia d'Aguilar, absent, proveheixen que, de les peccúnies comunes de la dita ciutat de València, sien pagats al reverent e venerable mestre Joan Corella, mestre en sacra theologia, mil sous, en tres terces, per temps de hun any; lo qual començà a Tots Sants propassat, per alguns bons respectes e, principalment, per la lectura que fa dels sagrats Evangelis en la sala de la present ciutat, provehint que, decontinent, li sia fet albarà de la primera terça.

Testimonis foren presents a les dites coses los magnífichs en Joan Ram Scrivà, mestre racional de la cort del senyor rey, e mossén Andreu Català, cavaller, mestre de la secca.

I483, març, II. València.

Jaume Salvat, cütadà de València, i Beneta, la seua esposa, venen a Dalfina Roís de Corella 6o sous de violari, durant les vides de Dalfina i del seu fill Jerònim Figuerola, per preu de 21 lliures.

RCSCCV, protocols, no. 2I689, not. Joan Ramos.

$3 \mathrm{I} 8$

I483, abril, I2-I483, juny, I7. València.

Interrogatoris de la Inquisició a Daniel Vives, el bisbe Jaume Pérez, l'impressor Lambert Palmart, fra Jaume Borrell i fra Bernat Comes sobre llurs participacions en la correcció i edició de la Bíblia impresa a València. Segons aquestes declaracions, en certs dubtes sobre la traducció d'algunes expressions dels salms va ser consultat Joan Roís de Corella, juntament amb el bisbe Jaume Pérez. ${ }^{329}$

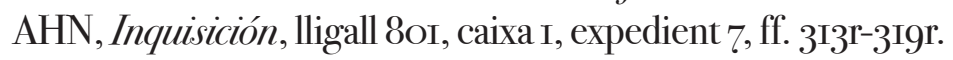

I483, juliol, I8. València.

Testament del cavaller i habitant de València Lluís Figuerola, cunyat de l'escriptor Joan Roís de Corella i espòs de Dalfina Roís de Corella.

Anomena marmessor testamentari el "reverent i magnífich mestre" Joan Roís de Corella, cavaller

328. Document publicat en Torre I924-25, Io8 i en Guia, I999, $4^{2}$.

329. Document publicat en Ventura I993, I5-67. Es tracta de la Bíblia impresa a València en I478 que s'atribuïa tradicionalment a Bonifaci Ferrer, germà de Sant Vicent. 
i mestre en Teologia, i, si ell no poguera fer-se càrrec de la marmessoria en el moment de l'òbit, anomena el seu germà, el cavaller Andreu Figuerola. Elegeix la seua sepultura en "la sglésia del monestir dels frares de Sant Vicent fora els murs de la dita ciutat construhit als peus del crucifici el qual stà davall el cor de la dita sglésia". Aquesta elecció es justificada pel fet que, malgrat estar tots els seus parents soterrats en l'església de Sant Martí, "per devoció del dit crucifici com de la dita sglésia, com encara per quant la magnífica na Dalfina Rö̈ç de Corella, molt cara muller mia, m'ha dit e notificat que en aquell loch el seu cos, aprés mort sua, bol ésser incinerat e sepellit". En la seua sepultura, a la qual mana dedicar 1 lliures, ha d'intervenir la confraria de sant Jaume de la que ell és confrare. Demana 100 misses de rèquiem.

Confessa que la seua difunta primera esposa, Damiata Valleriola -filla del cavaller Joan Valleriola-, li va portar en dot 41.197 sous, 7 diners, segons constava per les cartes nupcials rebudes pel notari Ambrosi Alegret, als quals, posteriorment, el pare d'ella va afegir 10ooo sous fent un total de 51.197 sous, 7 diners. D'aquest matrimoni havien nascut Enric Joan Figuerola - declarat per la seua mare hereu universal en el seu testament redactat davant el notari Garcia d'Artés en el mes de febrer de l'any 1465-i Jerònima, nascuda després de la redacció del testament de Damiata Valleriola i morta "dins pupil.lar edat". En raó del dot i herència de Damiata, Lluís Figuerola atorga al seu fill un total de zo.ooo sous restants del dit dot i, com a tota part que li poguera correspondre en els béns del testador, una dobla d'or.

Deixa a Bertomeu, Jerònim, Lluís i a Beatrü Figuerola, fills seus i de Dalfina Roís Corella i als altres fills que pogueren nàixer d'aquest matrimoni, una dobla d'or, equivalent a 20 sous, com a legítima en els seus béns.

En tots els altres béns seus, nomena Dalfina Roís de Corella com a hereua universal amb la condició que no es torne a casar. Si es casara, nomena Enric Joan Figuerola hereu universal amb el manament de donar a Dalfina 18000 sous que ella li va portar en dot i g.ooo de creix. Aquests 9.0oo sous de creix passarien a mans d'Enric Joan Figuerola en cas de mort de Dalfina Roús de Corella.

Assigna la tutoria i curadoria de Bertomeu, Jerònim, Lluís i Beatriu a Dalfina, sa mare.

Com a testimonis del testament figuren mossén Francesch Corts, canonge i paborde de la Seu de València, mossén Miquel Alfajarí, prevere beneficiat en l'església de Vilafermosa, i Bertomeu Chiva, mercader ciutadà de València.

RCSCCV, protocols, no. 24I49, not. Joan Verdancha

$32 \mathrm{O}$

I483, novembre, 7. València.

Els jurats de València ordenen el pagament a Joan Roís de Corella, mestre en teologia, de 1.0oo sous "en tres terces per temps de hun any, lo qual començà a Tots Sants propassat, per alguns bons respectes e, principalment, per la lectura que fa dels sagrats Evangelis en la sala de la present ciutat, provehint que, de continent, li sia fet albarà de la primera terşa".

AMV, Manuals de Consells, A-43, ff. I78v-I79r. ${ }^{330}$

Die veneris septimo mensis novembris anno predicto a nativitate Domini $\mathrm{M}^{\circ} \mathrm{CCCC}^{\circ}$ $L X X X I I I^{\circ}$, los magnífichs en Matheu Scrivà, generós, en Joan Figuerola, ciutadà, mossén Jacme Pelegrí, cavaller, en Pere Caposa, en Francesc Gil e en Miquel Polo, ciutadans, jurats de la insigne ciutat de València en lo any present, presents lo magnífich en Bernat Català, racional

330. Document publicat en Torre I924-25, Io8-o9 i en Guia I999, 42-43. 
de la dita ciutat, e en Bernat Bayona, notari subsíndich de la mateixa ciutat, jurats de la insigne ciutat de València, proveexen que lo reverent mestre Joan Corella, continue la lectura de la sancta theologia e, principalment, los Actes dels Apòstols e, acabats aquells, liga lo Psaltiri. E per temps de altre any, li constituexen salari de cinquanta lliures les quals sien pagades per lo clavari comú de la dita ciutat, de terça en terça, segons en altra provisió, a XXI de novembre de l'any $\mathrm{M}^{\circ} \mathrm{CCCC}^{\circ} \mathrm{LXXXII}^{\circ}$, fonch provehït e ordenat. Lo qual any comence de la festa de Tots Sancts ara proppassada, e finirà lo dia de Tots Sancts de l'any següent M CCCC LXXXIIII.

Testimonis foren presents a les dites coses en Joan Tristany e en Berthomeu Monçó, verguers dels dits magnífichs jurats.

$3^{2 \mathrm{I}}$

I484, juny, 2. València.

Lluís Figuerola i Dalfina Roís de Corella venen, per 147 lliures, a Francesc Villes, mercader de València, una casa amb un hort en el carrer de Mossén Corella a la parròquia de Sant Martí. Aquesta casa, que estava a cens de 48 sous ig diners censals, afrontava amb casa de Melcior Miralles subsacrista de la Seu de València-, amb hort del monestir de Sant Francesc i amb casa de [...] Pinó.

RCSCCV, protocols, no. 25Io6, not. Francesc Pérez.

322

I484, juny, 2. València.

Elmercader Francesc Villes i la seua esposa reconeixen deure 140 lliures a Lluís Figuerola i Dalfina Roís de Corella del total de 147 lliures en què el matrimoni Figuerola els veneren una casa amb un hort en el carrer de Mossén Corella.

RCSCCV, protocols, no. 25Io6, not. Francesc Pérez.

323

I484, agost, 25. València.

Els jurats de València paguen a Joan Roís de Corella, mestre en Sacra Teologia, 16 lliures, 13 sous it diners "per la darrera terça e paga de hun any per legir cascun jorn una liçó de la Sacra Scriptura en les cases de la sala de la dita ciutat".

AMV, Claveria Comuna, J-72, f. 7 r

I484, novembre, 6 . València.

Rendició de comptes de l'administrador de l'hospital de Sant Llàtzer, Berenguer Martí de Torres -germà de misser Jaume Garcia d'Aguilar i oncle de Francí d'Aguilar. Figuren com a testimonis el notari Bernat Santfeliu i Joan Roís de Corella, mestre en sacra teologia. 
AMV, protocols, not. Jaume Ximeno, 8-I6, ff. I65V-I66r. ${ }^{331}$

I485, març, 29. València.

Els jurats de València reiteren la necessitat de construir un hospital general en la ciutat de València que unifique els altres hospitals ja existents en la ciutat i, així, "que los pobres sien millor albergats e receptats e subvenguts a llur necessitats", inomenen una comissió per tal d'estudiar la viabilitat $i$ les despeses que suposaria la construcció d'aquest hospital. Els membres d'aquesta comissió serien Macià Mercader, artiaca de la Seu de València; els cavallers Jofre de Thous àlies Mompalau i Guillem Ramon de Vila-rasa; els ciutadans Berenguer Martí de Torres, Bernat de Pena-roja, Lluís d'Alpicat, Lluís Pellicer, Ramon Berenguer i Bernat Català i el canonge de la Seu Francesc Corts.

Com a testimonis d'aquesta provisió municipal figuren el cavaller i mestre en teologia Joan Roís de Corella i Berenguer Mercader, "conseller del senyor rey e lochtinent de batle general de regne de València".

AMV, Manuals de Consells, A-44, ff. II4V-II5v. ${ }^{332}$

En nom de Jesús e de la gloriosísima Verge Maria, mare sua, sia a tots en memòria quants legir ho volran que, en lo any de la nativitat de nostre Senyor mil CCCC LXXXV, dimarts a XXVIIII de març, tercer dia de la Setmana Sancta, los magnífics mossén Ot de Borja, cavaller; en Bernat Lorenç, en Guillem Mir, en Pere Vicent e en Loís Coll, ciutadans, jurats de la insigne ciutat de València; ensemps ab lo magnífic mossén Francesc Robert, cavaller, qui és absent de aquest acte; en Bernat Català, racional; micer Miquel Dalmau, micer Andreu Sart, micer Miquel Albert, micer Joan Valero, doctors en leys, advocats; en Bertomeu Abat, notari, síndich, e en Bertran Bayona, notari, subsíndich de la dita ciutat, ajustats e congregats en la cambra del consell secret.

Considerant lo grandíssim benefici que·n pot resultar, que hun Spital General se faça en aquesta insigne ciutat, per forma que los pobres sien millor albergats e receptats, e subvenguts a llurs necessitats, e tots los altres hospitals fâcilment se puixen unir. E perquè pus prompta expedició en aquest negoci se puixa fer maturament e digesta, e en unitat e concòrdia confiant que lo magnífic Consell loarà e aprovarà hun tant sanct e bon pensament com és aquest que de present se vol ordenar, ço és, de elegir persones tals per la administració de una tant sancta e caritativa e virtuosa obra. E, per ço, los dits magnífics jurats e los altres dessús dits, per a fer totes quantes coses sien necesàries, còmodes e oportunes en aquest negoci, elegeixen les persones dejús scrites, ço és, lo reverent e magnífic micer Macià Mercader, artiacha de la Seu de València; mossén Jofre de Thous àlies Mompalau, cavaller; en Berenguer Martí de Torres, ciutadà; mossén Francesc Corts, canonge de la dita Seu; mossén Guillem Ramon de Vila-rasa, cavaller; en Bernat de Penarroja, en Loís Alpicat, en Loís Pellicer, en Ramon Berenguer, en Bernat Català, ciutadans, en administradors, regidors e protectors de aquest Spital General fahedor.

En la administració del qual volen que de present recayguen e sien enclosos los hospitals d'en Clapers, de la Reyna, dels Beguins e de Sent Làtzer, los quals, ja per una particular administració, són sots la administració de la dita ciutat, no obstant les particulars 
administracions dels dits hospitals que, de present, són acomanades a diverses persones. Emperò, volen que la dita electió de les dites persones sia feta en aquesta forma: que, durant la vida de aquelles no·s puixa mudar [el que] la dita electió administrar volrà, e, si era cas que alguna de les dites persones en algun temps vendrà a defallir, que la dita ciutat, en loch de aquella persona de les dites deu persones axí morint o defallint o no volen ésser en la dita congregació, elegeixcha altra persona de la condició de aquella persona que y mancarà, en la forma dessús dita o en altra qualsevol manera.

E, feta la dita electió de persones e publicada aquella, per donar forma a la expedició de aquesta tant sancta obra, se contarà entre totes les dessús dites persones eletes per executar totes quantes coses sien necessàries, axí en generalitat com en particularitat, per a fer e exercir tot lo que en aquest negoci sia mester per augmentar, endreçar e governar aquesta tant sancta obra; per forma que los que veuran la virtut e concòrdia de aquesta tant sancta administració, pus fâcilment sien inclinats a fer-hi legats e altres almoynes e caritats.

Testimonis foren presentes a les dites coses, los reverents e magnífichs mestre Johan Corella, en sacra Theologia professor, e en Berenguer Mercader, conseller del senyor rey e lochtinent de batle general de regne de València.

$3^{26}$

I485, juliol, I. València.

Berenguer Mercader, cavaller, i el seu fill Pere Capata àlies Mercader nomenen com a amigables componedors al reverent Macià Mercader, de la Seu de València, a Jaume Rosell, doctor en dret, i a Joan Roís de Corella, mestre en teologia, per tal de resoldre certes qüestions existents entre ells.

ARV, protocols, no. I846, not. Francesc Pintor. ${ }^{333}$

327

I486, març, IO. Gandia.

Pere Lluís de Borja, duc de Gandia, nomena procurador seu el cavaller i mestre en teologia Joan Roís de Corella.

AHN, Osuna, llig. II23, no. 3, not. Lluís Erau.

328

I486, març, Io. Bellreguard.

El cavaller i mestre en teologia Joan Roís de Corella, com a procurador del duc de Gandia Pere Lluís de Borja, pren possessió del lloc de Bellreguard de mans del seu antic senyor feudal, el cavaller Joan Roca, qui havia venut el lloc a Pere Lluís de Borja per 20o.ooo sous.

AHN, Osuna, llig. II23, no. 3, not. Lluís Erau.

333. Document esmentat en Guia 2003.

Magnificat CLM I, 2OI4, III-377. ISSN 2386-8295 
329

I487, febrer, 7. València.

Joan Roís de Corella, en presència del Justícia Civil de València, dóna a la seua germana Dalfina - esposa de Lluís Figuerola- tots els seus béns mobles, immobles, etc. presents ifuturs. D'aquesta donació inter vivos que Dalfina accepta, Corella va exceptuar, per a ell i els seus, certes cases seues situades a la parròquia de Sant Martí que afrontaven amb un hort i una casa de Lluís Figuerola, amb dues vies públiques i amb una altra casa de Figuerola. Aquestes cases estaven subjectes al domini directe de la confraria dels forners, abans anomenada de la Santíssima Trinitat, sota cens de g sous.

Figuren com a testimonis d'aquesta escriptura notarial el donzell Joan Ramon de Caldes i el notari Domingo Garcia

AHN, Osuna, llig. I322, no. 24, not. Antoni Barreda.

330

I487, febrer, 7. València.

Joan Roís de Corella, cavaller i mestre en sacra teologia, reconeix deure a Miquel Honorat Pérez, ciutadà de València, 130 lliures que aquest graciosament li ha prestat, amb la condició de tornar-li-les quan desitge Pérez. N'hi ha una anotació posterior que indica que Miquel Honorat Pérez va cancel.lar el 27 de marş de 1488 aquesta escriptura de deute en abonar-li Corella l'esmentada quantitat.

AHN, Osuna, llig. I322, no. 24, not. Antoni Barreda.

$33^{\mathrm{I}}$

I488, febrer, 9. València.

Joan Roís de Corella reconeix a Bertomeu Chiva, mercader de València, el lliurament de 8o lliures, preu total de venda de 100 sous censals.

AHN, Osuna, llig. I322, no. 25, not. Antoni Barreda.

332

I489, gener, I2. València.

Andreu Figuerola, cavaller i habitant de València, reconeix haver venut icarregat, per escriptura feta el 29 de febrer de 1488 davant el notari Joan Verdancha, a Joan Roís de Corella, cavaller i mestre en sacra teologia, goo sous censals per preu de 13.500 sous.

RCSCCV, protocols, no. 28836 , not. Joan Verdancha.

333

I489, maig, 2. València.

Testament de Lluís Roís de Corella, fill d'Ausiàs Roús de Corella i germà de l'escriptor Joan Roús de Corella. Deixa hereu universal dels seus béns al comte d'Oliva don Ramon de Rüusec àlies Serafí de 
Centelles: ${ }^{334}$

AHN, Osuna, llig. I322, no. 26, not. Antoni Barreda.

I489, maig, 9. València.

Bertomeu Chiva, mercader de València, i la seua esposa Úrsula, venen i cedeixen diversos censals, per un valor total de 53 lliures, a Lluís Roís de Corella.

AHN, Osuna, llig. I322, no. 26, not. Antoni Barreda.

I489, juliol, 4. València.

El mestre en teologia Joan Roís de Corella publica a la Seu de València la indulgència papal extraordinària atorgada als fidels que contribuïsquen a refer el retaule d'argent de la Seu de València cremat el 21 de maig de 1469. Hi contribuïren, entre d'altres, Miquel Pérez-amb 2 lliures, 5 sous-, el metge Lluís Alcanyís - amb 21 sous-, Bernat Fenollar -amb 1 lliura, 11 sous i 6 diners - i el metge Jaume Roig-amb 1 lliura, 2 sous. 335

ACV, Llibre d'obres del retaule de la Seu, no. I5o6, ff. 3Ir-33v.

... E axí a quatre dies del mes de juliol del dit any [I489], per los dits senyors de capítol fonch provehït e manat ésser publicada dita indulgència en Aragó, Cathalunya, València e per tot lo present regne. E de la dita bulla fossen fets transumpts en forma de vidimus, los qual foren provehïts e decretats per lo reverent micer Jaume Honorat Roig, ${ }^{336}$ doctor en decrets, canonge de la Seu de València e vicari general del dit reverendíssim senyor cardenal e bisbe de València, a instància del reverent mestre Jaume Serra, mestre en sacra theologia, canonge e síndich dels dits senyors de capítol de la Seu de València, e tramesos per les dites parts d’Aragó, Cathalunya e València ab persones eletes per los dits senyors de capítol. E, en la present ciutat de València, fonch publicada dita indulgència en la Seu [en blanc] per lo reverent mestre Johan Roïç de Corella, mestre en sacra theologia, qui lo dit dia en la Seu sermonà.

E essent ja prop la festa de la Assumptió de la Verge Maria, tres jorns ans de aquella los dits reverents senyors de capítol del-liberaren que los magnífichs senyors jurats de la dita ciutat de València fossen pregats de part de lurs senyories que ells, o persones eligidores per ells, fossen presents e assistissen continuament en les caxes on se posarien los diners de la indulgència per aquelles persones que volrien guanyar e penre aquella...

334. Aquest Serafí de Centelles era germà del literat i canonge Jordi Centelles (AHN, Osuna, llig. I322, no. 26, not. Antoni Barreda -7 de maig de I489).

335. Les referències a les almoines de Miquel Pérez, Lluís Alcanyís, Bernat Fenollar i Jaume Roig es troben a ACV, Llibre d'obres del retaule de la Seu, no. I506, ff. Ir, Iv, 5 r i 6r, respectivament.

336. Era fill del metge i poeta Jaume Roig (Chiner 1993-94). 
336

I489, juliol, IO. València.

Testament de Bertomeu Chiva, mercader de València. Realitza diversos llegats testamentaris a Joan Roís de Corella.

AHN, Osuna, llig. I322, no. 26, not. Antoni Barreda

337

I489, agost 28. València.

El cavaller i mestre en sacra teologia Joan Roís de Corella signa una àpoca per valor de 10 lliures i 1 o sous cobrats del canonge Francesc Cots, vicari general, i del canonge Joan Pelegrí, administradors de les pecúnies de la indulgència de la Seu de València per a fer l'altar d'argent que s'havia cremat.

ACV, protocols, lligall 3685, not. Jaume Esteve.

338

I489, novembre, 23. València.

Dalfina Corella, esposa del cavaller Lluís Figuerola, com a donatària dels béns del seu germà Joan Roís de Corella -segons consta per instrument de donació fet el 7 de febrer de 1487-, en presència de Francesc Barceló, cavaller i justícia civil de València, restitueix al seu germà tots els béns i drets de què, anteriorment, ell li havia fet donació.

AHN, Osuna, llig. I322, no. 26, not. Antoni Barreda.

339

I490, gener, 7. "In alquerea de Micell Perez" (Tendetes de Campanar).

Testament de Magdalena Roís de Corella, filla del cavaller, teòleg i escriptor Joan Roís de Corella i esposa de Miquel Pérez. Nomena, com a marmessors, el seu marit i el seu pare Joan Roís de Corella. Elegeix el seu marit com a hereu universal ifa diferents deixalles testamentàries als seus fills -Joanot, Aldonça, Beatrü i Jerònim Pérez-i a Dalfina i Lluís Roís de Corella-germans de son pare.

RCSCCV, protocols, no. 16883 , not. Pere Guisquerol. 337

Die intitulata VII mensis januarï anno $M^{\circ} C C C C L X X X X^{\circ}$ in alquerea Micell Perez.

En nom de Déu sia, etc., com totes les coses mundanals de aquest món sien transpasants e allenegables e allgú en carn posad a la mort corporal scapar no puxa, la ora de la qual a tots és incerta e, per ço, se pertanga de cascuna persona sàvia sovint pensar e cogitar en aquella e, en tal manera dispondre e ordenar de sos béns mentres que ha spay de vida per tal manera que quant Jhesuchrist salvador e Senyor nostre lo volrà al seu regne apellar, bon compte li puxa retre de ço que acomanat-li haurà, enperamor de acò, yo, na Magdalena Corella, muller del magnífich en Miquel Pérez, ciutadà de la ciutat de València, stant sana de cors e pensa, e en mon bon seny e ferma memòria e paraula manifestat, considerant que res al món no és pus cert

337. Document publicat en Soler 20I4, I5I-55 amb errors de transcripció i absència d'alguna paraula del document. 
que la mort e tant incert com la ora de aquella, cassant, irritant e annul-lant e revocant tots e qualsevol testaments, donacions, codecills e altres derreres últimes voluntats per mi ça enrere feyts e feytes e senyaladament un testament en poder del notari dejús scrit sots calendari de XVIII del mes de octubre de l'any M CCCC LXXX fet en la dita alqueria, ara, de nou, faç e ordén aquest meu derrer testament e la mia derrera voluntat dels béns meus per nostre Senyor Déu a mi acomanats en lo qual elegex marmessors e de aquest meu derrer testament execudors ço és lo reverent mestre Johan Roïç de Corella, mestre en sacra taulogia, pare meu molt amat, absent, e lo dit magnífich en Miquel Pérez, marit meu, present e a cascun de aquells et insolidum als quals done licència e facultat e plen poder tots los béns meus vendre, alienar, dividir e departir que basten a conplir totes les coses que per mi en lo present meu testament són lexades e jaquides segons que en aquell largament ho trobaran scrit e annotat per llur pròpria auctoritat, licència ne decret de cort o de altre qualsevol persona en açò no demanada ans ço que per la hu de aquells serà començat, per l'altre puxa ésser fenit e acabat.

E, primerament, ans de totes [coses], vull e man que tots mos torts, deutes e injúries sien pagats, satisfeyts e restituhits aquells emperò que apparran mi ésser tenguda e obligada per cartes, testimonis dignes de fe e altres legíttimes proves e açò sens pleyt algú mas tan solament atesa la veritat del feyt e for de ànima en açò benignament observat.

E comanant la mia ànima al seu creador, vull e man que, aprés mort mia, sia cantada sobre los dit cors meu la lletania bé e onradament segons és acostumat cantar per aquells preveres que als dits marmessors meus plaurà e ben vist serà.

E encontinent feta e cantada lla letania sobre lo dit cors meu, en aprés aquell sia liurat a ecclesiàstica sepoltura, la qual elegeix ésser feta llà on lo dit magnífich en Miquel Pérez, marit meu, volrà e eligirà com tot açò lexe a voluntat sua jatsia en lo altre testament volia ésser soterrada en lo monestir de Sent Vicent e ara, segons he dit, entena e vulla lo dit cors meu haja la sepoltura hon lo dit marit meu volrà e eligirà segons és dit dessús.

Ítem, vull e man que aprés obte meu me sien dites e de fet me facen dir les trenta-tres mises appellades de sent Amador ab ses canelles e offerta en aquella sglésia o monestir que als dits marmesors meus plaurà e ben vist serà.

E més, vull e man que, per lo semblant, me facen dir los dits marmessors meus les cinch mises de les cinch plagues del gloriós redemptor meu Jhesuchrist de les quals tinch gran devoció. Ítem, leix e legue als dits marmesors meus aquells ésser vestits de gramalla e capiró de dol, de mos béns.

Ítem, leix e legue a la magnífica na Dalfina Figuerola, tia mia e muller del magnífich mossén Luís Figuerola, cavaller, de mos béns deu lliures, jatsia en lo testament li lexàs cinquanta lliures com ma intenció és que pus no haja sinó tantum les dites deu lliures de mos béns. Ítem, lex e legue a Johanot Pérez, Aldonça, Beatriu e Gerònim Pérez, fills meus e del dit en Miquel Pérez, marit meu, per part e per legíttima, a cascú de aquells una dobla.

E per quant no entenga pendre quantitat alguna ne designar de mos béns per a la mia ànima ne per aquella fer ne destribuir circa la sepoltura, aniversari ne cap d'any e altres necessitats sinó lo que los dits marmessors volran e a aquells plaurà, per ço vull e man que tot lo que aquells circa les dites coses despendran sia fet, com la elecció de les dites coses e conexença lexe a aquells.

En tots los altres béns meus, drets e accions a mi pertanyents o pertànyer podents o devents, luny o prop, per qualsevol títol, causa, manera e rahó hereu meu propri e universal per dret de institució faç e institueix al dit magnífich en Miquel Pérez, marit e marmessor meu, de vida de aquell tant solament. E, aprés mort de aquell, tots los dits béns meus éntregament vinguen e tornen als dits Johanot Pérez e Aldonça Pérez, fills meus legíttims e naturals e de 
legíttim matrimoni procreats e nats per eguals parts entre aquells fahedores, sots tal emperò vincle e condició: que si algú de aquells dits Johanot e Aldonça morran menors de vint anys o quantquequant sens fills legíttims o de legíttim matrimoni procreats la part de aquell axí morint torne e éntregament e vinga a l'altre sobrevevint e axí.s seguixca de l'un a l'altre e de l'altre a l'altre. E, si abduys morien menors de vint anys o quantquequant sens fills legíttims e naturals o de legíttim matrimoni procreats e nats, en tal cars vull la dita heretat e béns tornen éntregament a Beatriu [e] Gerònim Pérez, fills meus e del dit marit meu, o als altres fills meus si vius n'i haurà e extaran e, si vius no seran, als fills e filles de aquells o de l'altre de aquells que extaran e vius seran per eguals parts entre aquells fahedores. Vull emperò e man que si aquells dits Beatriu e Gerònim morien majors de vint anys que, en tal cars, aquells, no obstant lo dessús dit en son testament, puxen dispondre dels dits béns entre sos fills e filles a ses planes volentats. E si-s seguia cars, ço que a Déu no plàcia, que aquells dits Beatriu e Gerònim e los fills e filles de aquells morien menors de vint anys o quantquequant sens fills legíttims segons dit és, en tal cars, tots los dits béns per mi lexats éntregament tornen e vinguen al reverent mestre Johan Roïç de Corella, pare meu molt amat si aquell, emperò, no tendrà ne possehirà rendes o benefficis alguns de la Sglésia car, en lo dit cars, tenint aquell béns de Sglésia, no vull haja los dits béns meus sinó en lo cars, segons dit és, aquell no tendrà ne possehirà béns alguns ni rendes de Sglésia, e, tenint aquell béns de Sglésia, vull e man que los dits béns tornen decontinent e vinguen al magnífich en Luís de Corella, donzell oncle meu e jermà del dit reverent mestre Johan Roïç de Corella pare meu, e, advenint lo dit cars, aquell dit magnífich en Luís de Corella hereu meu faç e substitueix de la vida de aquell e, aprés mort de aquell, als fills e filles que Déus li donarà legíttims e naturals e de legíttim matrimoni procreats e nats. E si fills ne filles legíttims e naturals e de legíttim matrimoni procreats e nats de aquell e de muller sua no y haurà, en tal cars vull e man que los fills e filles de la magnífica senyora na Dalfina, tia mia, aquells dits béns éntregament hajen e tinguen e tornen a aquells e, advenint lo dit cars, a aquells faç hereus e institueix a fer de aquells a ses planes voluntats.

Aquest és lo meu derrer testament e la mia derrera voluntat lo qual vull aquell valga per dret de derrer testament e derrera voluntat e, si per dret derrer testament etc, lo qual és fet en la alqueria del dit magnífich en Miquel Pérez, marit meu e marmessor, la qual stà en les tendetes de Campanar, prop lo molí del magnífich en Perot Palomar, fora los murs de la dita ciutat de València a deu $[s i c]$ del mes de jener de l'any de la nativitat de nostre Senyor Déu M CCCC LXXXX.

$\mathrm{Se}^{+}$nyal de mi dita na Magdalena Pérez, testadriu que dessús qui lo present meu testament e la mia derrera volentat de la primera línea fins a la derrera inclusive, loe, ratiffique e conferme. Presents foren per testimonis a la confecció del present meu testament appellats e per la dita testadriu pregats, qui aquells conexia e los dits testimonis a ella. E yo, dit notari rebedor del present testament, conech a tots ells, ço és en Pere Franch, en Johan March, lauradors de la orta de Campanar, e en Jacme Irles, obrer de villa, ciutadans de la ciutat de València.

I490, setembre, I. València.

Lluís Roís de Corella, donzell habitant de València, reconeix a Francesc Sard, senyor del lloc de Negrals - en el marquesat de Dénia-, el lliurament de g lliures.

AHN, Osuna, llig. I327, no. 25, not. Antoni Barreda. 
$34 \mathrm{I}$

I49I, abril, 2. València.

Sentència arbitral atorgada pels àrbitres Joan Roús de Corella-cavaller imestre en teologia- $i$ el cavaller Guillem Ramon de Vila-rasa en les disputes existents entre el monestir de Sant Jeroni de Cotalba i el cavaller Pere de Cabrera, senyor de Ròtova, en raó del bovalar del monestir, de les aigües de reg $i$ de les fites dels térmens del monestir i de Ròtova. L'escriptura d'elecció dels amigables àrbitres va ser realitzada el 30 de març de 1491 davant el notari Lluís Collar.

La sentència arbitral va ser llegida a les parts "en la casa e habitació" de Corella actuant, com a testimonis el seu cunyat Lluís Figuerola iJoan de Gallach, ciutadà de València. ${ }^{338}$

ARV, Manaments i empares, any I7oo, llibre 3, mà 25, ff. 2r-9r.

$34^{2}$

I49I, setembre, 24. València.

Lluís Roís de Corella reconeix a Francesc Sard, senyor del lloc de Negrals -en el marquesat de Dénia-, el lliurament de 35 lliures mitjançant Andreu Sart.

AHN, Osuna, llig. I322, no. 28, not. Antoni Barreda

343

I492, març, 7. València.

Magdalena Roís de Corella, esposa del cüutadà de València Miquel Pérez, com a hereua universal dels béns del difunt mercader Bertomeu Chiva segons consta pel seu testament fet el 13 de juliol de 1490 i publicat el 2 de març de 1492, realizz l'inventari de béns del referit difunt. Hifiguren un llibre d'hores $i$ "un llibre de mestre Francesc Eximenis apellat De les dones".

AHN, Osuna, llig. I322, no. 29, not. Antoni Barreda.

344

I492, març, I2. València.

Miquel Pérez, ciutadà de València, com a procurador de la seua esposa Magdalena Roís de Corella, hereua universal dels béns del difunt mercader Bertomeu Chiva segons consta pel seu testament fet el i3 de juliol de 1490 i publicat el 2 de març de 1492, fa pública almoneda en el mercat de València dels béns del referit difunt. En total, es varen obtenir 6og sous in diners.

AHN, Osuna, llig. I322, no. 29, not. Antoni Barreda.

338. Document publicat en Soler-Jordà 2005, IO4-05. En aquesta sentència arbitral actuà el cavaller Gracià de Monsoriu, com a síndic procurador del monestir de Cotalba. 
345

I492, juliol, 26. València.

En el llibre de comptes de "la loable almoyna de les òrfenes maridadores" que comença l’’ d'abril de 1492 i acaba el 31 de març de 1493, Berenguer Martí de Torres, majordom de la confraria, anota una despesa de 6 sous pagats al mestre en teologia Joan Roís de Corella per sermonar el dia de Santa Anna en l'església de Sant Martí de la cütat de València.

AGFDV, Fons Hospital, Confraria òrfenes a maridar, II-8/49, f. Iov.

Dates en lo benifet de Sant Martí

$[\ldots]$

Item, al sermó ha mestre Corella, sis sous. [Al marge dret $]$ VI sous.

346

I493, juliol, 26. València.

En el llibre de comptes de la confraria de les òrfenes a maridar que comença l'i d'abril de 1493 iacaba el 31 de marc de 1494, Nofre Caera, majordom de la confraria, anota una despesa de 6 sous pagats al mestre en teologia Joan Roís de Corella per sermonar el dia de Santa Anna en l'església de Sant Martí de la ciutat de València.

AGFDV, Fons Hospital, Confraria òrfenes a maridar, II-8/5o, f. 8v.

Dates en lo benifet de Sant Martí

[...]

E al reverent mestre Corella per lo sermó........ [Almarge dret $]$ VI sous

347

I493, setembre, 6. València.

Joan Roís de Corella, cavaller i mestre en teologia, en el seu nom propi i com a hereu de sa mare Aldonça Roís de Corella d'acord amb el seu testament fet en 1466 i publicat en 1475, ven a Jaumeta, esposa del mercader de Pego Pere d'Ochoa, 83 sous i 4 diners censals. Aquest censal fou venut per Bertomeu Xulbet i la seua esposa a Joan Roís de Corella, avi patern del poeta, per escriptura notarial feta davant el notari Pere Pugeriol el 18 de maig de 1419 i, passà a mans d'Ausiàs Roís de Corella, pare de l'escriptor, d'acord amb el testament de l'aviJoan Roís de Corella fet davant el notari Lluc Pous el 7 de maig de 1422 i publicat pel mateix notari el 4 de juliol de 1422. Posteriorment, els 83 sous censals i 4 diners passaren a mans d'Aldonça Roís de Corella d'acord amb el testament del seu marit publicat, per mort d'ell, en $1450^{339}$

RCSCCV, protocols, no. I3866, not. Pere Andreu.

339. Document esmentat en Riquer I964, 3, 254 i en Almiñana r984-85, 390. 
I493, setembre, IO. València.

Els cavallers i germans Andreu i Lluís Figuerola, habitants de València, com a hereus universals dels béns del seu pare, el cavaller Joan Figuerola, segons consta en el testament d'aquest fet a València el 26 d'agost de 1457 davant el notari Ambrosi Alegret i publicat el 16 de novembre de 1462 per mort del testador, reconeixen a Joan Pujades, sastre, el lliurament de 33 lliures i 15 sous restants d'aquelles 67 lliures, 10 sous, preu en què ells a Joan Pujades vengueren una casa de l'esmentada herència situada a la parròquia de Sant Nicolau en el carrer anomenat del Forn Nou.

RCSCGV, protocols, no. 20I6o, not. Lluís Tovia.

I494, març, 8. València.

Elionor Flors de Vallterra reconeix a Lluís Ferrer que, per mans d'Antoni Fenollar, ha rebut un total de 33 lliures, 6 sous i4 diners degudes per pagues d'un censal.

Figuren com a testimonis Joan Roís de Corella, mestre en sacra teologia, i Llorenç Pertusa, escuder de València.

RCSCCV, protocols, no. 20I57, not. Lluís Tovia.

I494, maig, I. València.

Acte de fundació del nou hospital dels Innocents anomenat "spital del Sant Sperit de la Verge Maria dels dits sants Innocents". En aquesta acta s'afirma que els diputats de l'Hospital dels Innocents volien fundar un nou hospital "recordant-se aquells moltes e diverses vegades ésser estat pricat e amonestat per alguns mestres en sacra theologia en les trones de les sglésies parrochials de la dita ciutat, e senyaladament al reverent mestre Johan Roï de Corella, mestre en sacra theologia, la gran fretura e necessitat que en la dita ciutat és de hun spital per obs de acollir en aquell los pobres, malalts e mendicants, sancts de entendiment, com aquells fossen freturossos de habitació e subvenció per les necessitats e misèries que nostre Senyor Déu los dóna per sos demèrits e culpes" ${ }^{340}$

RCSCGV, protocols, no. 2500o, not. Jaume Blasco.

\section{[Die jovis primo mensis madii anno a nativitate Domini $\mathrm{M}^{\circ} \mathrm{CCCC}^{\circ} \mathrm{LXXXXIII]}$}

Sàpien tots quants la present carta veuran e legiran com, a laor, onor e glòria de la Sanctíssima e individita Trinitat e de la Sacratíssima Verge Maria, mare del Verb etern, com los magnífics senyors diputats de la Verge Maria del Sants Ignoscents, qui són per orde nomenats segons per antiquitat són elets, ço és a saber en Bernat de Pena-roga, en Ramon Berenguer, en Loís Berenguer, en Pere Capossa, en Jaume Bou, en Bernat Vidal, en Berenguer Martí de Torres, en Loís Stellés, en Pere Solanes, e en Guillem Navarro, deu qui són deputats en lo govern e regiment de la cassa e Spital de la Verge Maria dels Sancts Ignocents en la present ciutat de València, hon les set obres de misericòrdia de continu, a laor de Déu e de la sua

340. Aquest document ha estat publicat en Gómez-Ferrer 1998, 373-74 i Guia 2002, I76-78. 
glorisíssima Mare segons la humana fragilitat pot fer amplament en la dita cassa e spital exercitar no cessen, ab haugment de major caritat per servey de la Divina Majestat e subvenció dels miserables pobres e persones en necessitats constituhïdes e en remisió dels pecats e culpes que cascun jorn cascun de aquells cometen contra la Divina Majestat, tenint recort de aquell parlar de gloriós Sanct Pau ad ebreos, capitulo XIII ${ }^{\circ}$, caritats fraternitatis maneat in vobis e hospitalitatem nolite oblivisci, e recordant-se aquells moltes e diverses vegades ésser estat pricat e amonestat per alguns mestres en sacra theologia en les trones de les sglésies parrochials de la dita ciutat, e senyaladament al reverent mestre Johan Roïz de Corella, mestre en sacra theologia, la gran fretura e necessitat que en la dita ciutat és de hun spital per obs de acollir en aquell los pobres, malalts e mendicants, sancts de entendiment, com aquells fossen freturossos de habitació e subvenció per les necessitats e misèries que nostre Senyor Déu los dóna per sos demèrits e culpes. E no res menys, se vés per la speriència que alguns dels dits malalts, de cascun dia morien e moren per les carreres, sobre les taules e banchs de la dita ciutat, e encara era estat vist aquells malalts en les dites carreres ésser-los estats lliurats los sagraments de sancta mare sglésia, lo que és en gran detriment de la sancta fe chatòlica.

Moguts per ço los dessús dits deputats de zell de caritat e misericòrdia, tenint scolpides dins les consciències de aquells aquelles paraules del Senyor Redemptor dient "Benaventurats són los misericordes, que ells atenyeran misericòrdia”, e humilment invocada per aquells aquella Verge, senyora reyna de Paradís, Mare de Déu, humil Verge Maria, reyna de misericòrdia, en la clemència e pietat de la qual los sobredits diputats tenent totes les sues sperances, per tant és estat entre aquells, plaent a la Divina Magestat, deliberat e concordat, ultra la pau, concòrdia, amor e germandat que entre aquells tot temps és estada e és en lo regiment e pròsper estar de la dita cassa dels Sancts Ignoscents, inspirats per divinal inspiració, tots hunànimes e concordes, han propossat e obrar effecte, singularment deliberat e més en obra que's fes hun spital per als pobres vergonyants, estants sans de enteniment, e de altres tenints necessitats, de aquesta ciutat insigne de València e de altres parts estranyes, a conexença e beneplàcit dels dits diputats, hon aquells, per lo servey de Déu, sien sustentats, acceptats e socorreguts e ajudats de les necessitats humanes, e aquells poguessen tan digna obra e tant caritativa executar e fer en lahor, haugment e glòria de la divina esència e exercitar de bones e sanctes voluntats, ab consell de spertes e singulars persones en aquest negoci molt ampliament sabudes e sperimentades, han fet tractar e metre en mostra com ni en quina manera lo dit spital comodament se porà fer e acabar. E feta la dita trassa, an fet cavar los fonaments en lo loch hon se ha de fer lo dit spital fins a la cara d'aygua e tenints ja tots los preparatoris e cosses necesàries per la dita obra, ço és de reble, colre arena e altres cosses que de la dita obra són molt necessàries.

E axí, segons que era comptat lo primer dia del mes de maig de l'any de la nativitat de nostre Senyor $\mathrm{M}^{\circ}$ CCCC ${ }^{\circ}$ LXXXX quatre, convocat primerament e ans de totes cosses lo divinal Spirit e lo reverent senyor mestre Matheu Pérez, ${ }^{341}$ bisbe cristopolità qui administra los episcopals actes per lo reverendíssim senyor cardenal e bisbe de la dita ciutat de València, lo clero de sant Martí ab molts preveres e capellans de la sglésia e altres solempnes eclesiàstichs de altres parròquies qui ab ses creus vingueren al benehir e lansar de la primera pedra, asistents allí molts hòmens d'estat e honor e altres singulars persones en moltitut copiosa, fetes les acostumades benediccions e oracions, convocat e appellat a mi Jacme Blasco, notari públich de la dita ciutat de València e per tota la terra e senyoria del molt alt senyor Rey de Aragó e síndich del dit spital, e los testimonis dejús escrits, lo dit reverent senyor bisbe, presents, 
justats, asistents e requirents los magnífichs en Bernat de Pena-roga, en Ramon Berenguer, en Jacme Bou, en Bernat Vidal, en Berenguer Martí de Torres, e en Pere Sonales, majordom en l'any present de la dita cassa e spital dels dits Sancts Ignoscents e del dit spital novament començador e principiador, ab humil supplicació supplicaren de dit senyor bisbe que, en nom de Déu e de la sanctíssima Verge Maria, lansàs e possàs la primera pedra en los fonaments principiadós en la edifficació del dit spital nou, la qual era huna ymatge de la Senyora nostra ab son fill al bras, en pedra blancha escolpida, lo qual obtemperant e aderint a les dites supplicacions e aquelles benignament admesses, e amant e donant laors de la Divina Majestat ab sos devots ymnes e oracions, en presència dels dessús dits e de moltes altres notables persones que alí heren, met e possà la dita ymatge per fonament e primera pedra del dit nou spital principiador, appellat del Sant Sperit de la Verge Maria dels Sants Ignoscents.

De totes les qualls cosses e sengles de aquelles, los dessús dits diputats requeriren a mi, dit Jacme Blasco, notari qui dessús, que de totes les dites cosses, en presència e asistència mia fetes, los fes, rebés e redigís carta pública per conservació de sos drets e per haver de les dites coses memòria en esdevenidor. La qual, per mi, dit notari, los fonch rebuda, los dessús dits dia, mes e any, en la forma dessús dita. Les quals cosses, totes e sengles de aquelles, foren fetes en la ciutat de València, en los orts o patits del dit spital del Sant Sperit de la Verge Maria del dits Sants Ignoscents, los dessús dits dia e any.

Testimonis foren presents a totes les dites cosses e sengles de aquelles, ço és a saber, los magníffichs mossén Loís Masquó, menor de dies, mossén Francesc Almenara, cavallers, e en Miquel Solanes, ciutadà, habitadors de la dita ciutat de València.

I494, juliol, 26. València.

En el llibre de comptes de la confraria de les òrfenes a maridar que comença l'i d'abril de 1494 iacaba el 31 de març de 1495, Lluís Granullés, majordom de la confraria, anota una despesa de 6 sous pagats al mestre en teologia Joan Roís de Corella per sermonar el dia de Santa Anna en l'església de Sant Martí de la cuitat de València.

AGFDV, Fons Hospital, Confraria òrfenes a maridar, II-8/5, f. 7v.

Dates en lo benifet de Sant Marti ${ }^{342}$

$[\ldots]$

E al reverent mestre Corella per lo sermó........ [Almarge dret] VI sous.

$35^{2}$

I494, agost, I8. València.

Joana Martínez de Vera àlies Dalfina, Isabel Martínez de Vera àlies Dalfina i Violant Martínez de Vera àlies Dalfina, germanes habitants de València, venen, per preu de 21 lliures, a Pere Mascarell, sastre de la ciutat del Túria, la quantitat de 6o sous de violari durant les vides de l'estudiant Pere Mascarell-fill de Pere Mascarell i de Violant Martínez de Vera-i de Joan Roís de Corella, fill del

342. El beneficiat era mossén Jaume Serra. 
mestre en teologia Joan Roús de Corella.

RCSCCV, protocols, no. 22562, not. Francesc Pintor. ${ }^{343}$

353

I494, desembre, 22. Barcelona.

Acta de definició de comptes signada, el 22 de desembre de 1494, entre sor Aldonça Roís de Corella, abadessa del monestir de Santa Maria de Jerusalem, i el mestre Bertomeu Mas, relativa a les obres realitzades en el convent per Mas. ${ }^{344}$

Arxiu Històric de Protocols de Barcelona, Pere Pascual, llig. 8, man. 3, anys I494-I 495.

I495, juliol, 3I. València.

Lluis de Cavanyelles, Governador General del regne de València, comunica a Joan Renard i a la seua esposa que el notari Nicolau Ferrer -com a procurador del mestre en teologia Joan Roís de Corellali ha mostrada una escriptura pública rebuda el 23 de novembre de 1450 pel notari Antoni Barreda segons la qual el matrimoni Renard carregaren 41 sous, 8 diners censals anuals a Joan Roís de Corella $i$ als seus.

Nicolau Ferrer reclama, davant la cort del Governador, 41 sous i 8 diners en raó de pensions degudes d'aquest censal. ${ }^{345}$

ARV, Governació, no. I63, mà 58, f. 7 r.

355

I495, juliol, 3I. València.

Lluís de Cavanyelles, Governador General del regne de València, comunica a Nofre Çafàbregues i a Andreu Garcia que el notari Nicolau Ferrer-com a procurador del mestre en teologia Joan Roís de Corella- li ha mostrada una escriptura pública rebuda el 4 de desembre de 1479 pel notari Andreu Sard, segons la qual Çafàbregues i Garcia carregaren 75 sous censals anuals a Joan Roís de Corella ials seus.

Nicolau Ferrer reclama, davant la cort del Governador, 75 sous en raó de pensions degudes d'aquest censal.

ARV, Governació, no. I63, mà 58, f. 8r.

356

I495, agost, 4. València.

Lluís de Cavanyelles, Governador General del regne de València, comunica a Joan Renardi a la seua esposa, habitants de Dénia, que el notari Miquel Vives -com a procurador del mestre en teologia

343. Document esmentat en Riquer I964, 3, 258-59.

344. Document esmenta en Madurell I948, $157^{-} 5^{8}$.

345. Document esmentat en Almiñana I984-85, 400 . 
Joan Roís de Corella - li ha mostrada una escriptura pública rebuda el 23 de novembre de 1450 pel notari Antoni Barreda segons la qual el matrimoni Renard carregaren 41 sous i 8 diners censals anuals a Joan Roís de Corella ials seus.

Miquel Vives reclama, davant la cort del Governador, 41 sous i 8 diners deguts de la paga de novembre d'aquest censal.

ARV, Governació, no. I63, mà 59 , f. I 7 . $^{346}$

357

I495, octubre, 27. València.

Joan Roís de Corella, cavaller i mestre en teologia, i el seu fill Joan Roís de Corella, habitants de València, venen, per preu de 35 lliures, a Caterina de Rüsec, esposa del mercader Jofre de Rüusec, 100 sous de violari que, originalment, els donzells Galvany de Castellví i Joan de Vallterra-senyor de Torres Torres-carregaren al mestre en teologia per instrument notarial fet a València l'i d'agost de 1476 davant el notari Antoni Barreda. ${ }^{347}$

RCSCCV, protocols, no. I3629, not. Pere Cerveró.

$35^{8}$

I496, març, 23. Tortosa.

El rei Ferran el Catòlic escriu a Diego de Torres, Batle General de València, i li ordena la compra $i$ tramesa d'un exemplar del Cartoixà fet per Joan Roís de Corella. ${ }^{348}$

ARV, Reial Cancelleria, no. 596, f. 2 oor.

Letra del Senyor Rey al batle general manant-li que li trametés hun libre del Cartoxà de mestre Corella

Al noble, magnífico, amado consejero y camarero nuestro don Diego de Torres, Bayle General en el el nuestro reyno de Valencia.

El rey.

Camarero y Bayle General, sabido havemos que maestre Corella ha fecho una translación del Cartuxano que es muy buena obra la qual Nós queremos haver en todo caso. E, por tanto, vos encargamos e mandamos que lueguo merquedes una d'ellas e la faguades ligar e poner a punto e nos la embiedes que mucho servicio nos faredes en ello. De Tortosa, a XXIII de março del anyo mil CCCC LXXXXVI.

Luis Gonçales, secretarius.

346. Document esmentat en Almiñana I984-85, 40I.

347. Document esmentat en Guia 2003. Figuren com a testimonis d'aquesta venda fra Antoni Cevilla i fra Francesc

Maça, frares del convent dels franciscans de València.

348. Document esmentat en Riquer $1964,3,257$.

Magnificat CLM I, 20I4, III-377. ISSN 2386-8295 
I496, juliol, 26. València.

En el llibre de comptes de la confraria de les òrfenes a maridar que comença l'1 d'abril de 1496 iacaba el 31 de març de 1497, Francí Granullés, majordom de la confraria, anota una despesa de 6 sous pagats al mestre en teologia Joan Roís de Corella per sermonar el dia de Santa Anna en l'església de Sant Martí de la ciutat de València.

AGFDV, Fons Hospital, Confraria òrfenes a maridar, II-8/53, f. 7v.

Dates en lo benifet de Sant Martí

[...]

E per lo sermó al reverent mestre Corella....... [Almarge dret $]$ VI sous.

360

I497, juliol, 26. València.

En el llibre de comptes de la confraria de les òrfenes a maridar que comença l'i d'abril de 1497 i acaba el 31 de març de 1498, Bernat Català, majordom de la confraria, anota una despesa de 6 sous pagats al mestre en teologia Joan Roís de Corella per sermonar el dia de Santa Anna en l'església de Sant Martí de la ciutat de València.

AGFDV, Fons Hospital, Confraria òrfenes a maridar, II-8/5o, f. 8v.

Dates en lo benifet de Sant Martí

$[\ldots]$

E per lo sermó al reverent mestre Corella........ [Almarge dret $]$ VI sous.

$3^{6 I}$

I497, octubre, 7. València.

Inventari de béns de Joan Roís de Corella, cavaller i mestre en teologia, fet per la seua germana $i$ hereua universal Dalfina Roís de Corella. ${ }^{349}$

RCSCCV, protocols, no. I3872, not. Pere Andreu.

\section{Die septima octobris anno $\mathrm{M}^{\circ} \mathrm{CCCC} \mathrm{C}^{\circ} \mathrm{LXXXXVII^{ \circ }}$}

Iesuchristi nomine invocato. Com per squivar dol, frau y engan e tota manera de sospita de aquells, quascuns hereus, marmesors, tudors y altres administradors de béns de la lur heretat degen e sien tenguts fer memorial, reportori e capbreu dels béns e drets atrobats e rechaents en lurs marmessories y herències perquè, quant mester sia, de aquells se puixa donar bon compte e rahó; hoc encara per ço com, per legíttimes sanctions e disposicions de fur y privilegi del present regne, per la confectió de l'inventari als hereus no solament són conservats, encara són preservats de dan per quant no són obligats ultra los béns hereditaris. Per tal yo, na Dalfina Roïç de Corella e de Figuerola, muller del magnífich mossén Luís Figuerola, cavaller habitador

349. Document esmentat en Riquer I964, 3, $25^{8 .}$ 
de la ciutat de València, hereua universal del magnífich y reverent mossén Johan Roïç de Corella, quòndam, cavaller, mestre en sacra theologia, -consta de la mia herència ab testament rebut per lo discret en Anthoni Barreda, notari, quòndam, a trenta de agost de l'any mil quatrecents setanta-huyt, e publicat en poder de Pere Andreu notari a VI de octubre de l'any mil quatre-cents noranta-set-, en lo dit nom, precedint lo senyal de la vera Cre+u, faç inventari, memorial e capbreu dels béns atrobats en la herència del dit mossén Johan Roïç de Corella, quòndam, cavaller, en e per la forma següent:

E, primerament, confés haver trobat en béns de la dita herència una casa o ort situats en la parròchia de Sanct Martí en lo carrer appellat de mossén Corella e antigament nomenat d'en Monblanch, tengut sots directa senyoria de la confraria dels perayres de la dita ciutat, a cens de nou sous, fadigua e loisme, e a recens de cent cinquanta sous pagadors quascuns anys en certs terminis al noble don Gisbert Pardo, qui-s poden quitar per preu de cent lliures. La qual affronta ab cases e ort del magnífich mossén Luís Figuerola, ab altra casa de mi dita hereua e ab carreró e ab lo dit carrer. En la entrada de la qual fonch atrobats los béns mobles següents, los quals foren portats de la cambra que lo dit defunct tenia en lo monestir de Sanct Francesch:

Primo, hun lit de posts e sos peus de fu[s]ts de pi nou e tres matalafs blanchs plens de llana castellana e hun coixí de fluxell, e dos parells de llançolls de li, de dos teles y miga quascú, mig usats. Ítem, una flaçada cardada e una vanoveta prima e hun cubertor prim enbastat. Ítem, hun papalló ab son pom, sens manteta, de drap vinté blanch. Ítem, hun altre lit de posts ab cinch posts e sos peus, nou, e dos matalaffs plens de lana de Cerdenya, blanchs. Ítem, hun coixí de ploma e dos parells de lançols de mascó, quasi nous, e una flaçada cardada e una vànova bona mig usada. Ítem, dos artibanchs de dos caixons quascú, nous, tot buyt en los quals havia molts papers de pocha vàlua.

Ítem, una caixa plana ab pay [sic] sense clau dins la qual fonch atrobada la roba següent: primo, una clocha de rohà molt usada. Ítem, hun sayó de rohà sotil. Ítem, hun gipó lo hu de cos de fustany e les mànegues de drap negre stamet. Ítem, altre gipó, lo cors e les mànegues de drap rohà.

Ítem, deu cadires entre grans y chiques. Ítem, dos canalobros de llautó migancers. Ítem, dos cànters de terra e una làntia. Ítem, una taula de megar [sic] ab sos peus. Ítem, hun sobrepelliç y la muça, e hun barret doble e altre barret senar. Ítem, tres camises de Olanda e dos tovalloles mig usades.

E, en la dita cambra, restaren molts libres de Theologia y altres, y aquells lo dit defunct en sa vida donà als frares de Sanct Francesch.

Ítem, set-cents huytanta volums que són lo Quarty lo Primer del Cartoixà.

E per ço com en la dita casa havia statger dalt, no fonch atrobat més en aquella com lo restant que en la casa era fos del dit statger.

E, aprés, fonch atrobat hun libret del dit defunct en lo qual són continuats los censals y interessos següents:

Primo, tots aquells quaranta-hun sous, huyt diners censals que fa e fer és tengut a la dita herència en Berthomeu Renart, vehí de la vila de Dénia, e na Johana, sa muller, e per aquells foren venuts a la magnífica na Alamanda de Cabrera per preu de vint-i-cinch lliures, ab carta rebuda per lo discret en Joan Sart, notari, a cinch de janer de l'any mil quatre-cents trentaquatre. En aprés, lo dit censal fonch venut al magnífich mossén Ausiàs de Corella, cavaller, ab carta rebuda per lo dit en Johan Sart, notari, a trenta de janés [sic] any mil quatre-cents trentaquatre. E mossén Ausiàs de Corella féu testament en poder del dit en Johan Sart, notari, a nou de noembre any mil quatre-cents quaranta-tres e publicat, en poder del mateix notari, a setze de janer any mil quatre-cents cinquanta. 
Ítem, en aprés fonch trobat en béns de la dita herència tots aquells quaranta-quatre sous censals los quals fa en Johan Rovira, de la vila de Pego, pagadors a vint-y-set de abril; los quals foren carregats per en Anthoni Rovira y na Francescha, sa muller, per preu de trenta-tres lliures al discret en Ramon Egualada, notari, ab carta rebuda per en Pere Pugeriol, notari, a vint-i-set de abril any mil quatre-cents dehuyt. En aprés, ab carta rebuda per Pere Puig, notari, a tres de abril l'any mil quatre-cents trenta-tres, pertanygué al magnífich mossén Ausiàs Roïç de Corella. E en aprés, són stats reduhits ab carta rebuda per en Guillem Olzina, notari, a onze de juny any mil quatre-cents noranta-tres.

Item, tots aquells quaranta-hun sous, huyt diners censals que fan $\mathrm{Ab}[\mathrm{r}] \mathrm{ahim}$ Ajubet e sa muller d'Ondara e huy los fa Cahat Ajubet de aquells huytanta-tres sous, quatre diners censals pagadors a XXIII de noembre en una paga, e per aquells foren carregats a·n Johan Pelegrí per preu de cinquanta lliures ab carta rebuda per en Pere Andreu Sart, notari de Dénia, a XXIII de noembre any mil quatre-cents setze. En aprés, han pertangut a na Aldonça de Corella quaranta-hun sous, huyt diners censals del dit ab carta rebuda per en Johan Sart, notari, a XXI de febrer any MCCCC cinquanta.

Ítem, tots aquells sexanta-sis sous, huyt diners censals que fa en Sabastià Xulbet los quals foren venuts, per na Elvira, muller d'en Garcia Garcia, quòndam, e en Gabriel Sànxiz Garcia, fill seu, vehins de Dénia, a·n Miquel Pérez, de Ondara, per preu de quaranta lliures ab carta rebuda per en Berthomeu Jornet, notari, a VIIII de noembre any MCCCC vint-i-sis. En aprés, ab carta rebuda per en Anthoni Barreda, notari, a XXII de dehembre any MCCCCL cinch ha pertangut a na Aldonça de Corella.

Ítem, totes aquelles setze lliures que en Pere Stheve àlies lo Serrà, de Pego, confessà deure al dit defunct, de preu de hun troç de terra, pagadores dins quinze anys. E, en lo entretant, ab responsió de interés de vint-y-sis sous, y huyt diners pagadors lo primer de janer, ab carta rebuda per en Johan Sanç, notari, a vint-i-quatre de janer any MCCCC huytanta.

Ítem, totes aquelles nou lliures de deute que en Guillem Tamarit, de la vila de Pego, ha confessat deure al dit defunct de preu de una vinya, e les quals prometté pagar dins temps de tres anys. E, en lo entrant, prometté respondre quatorze sous, tres diners de interés pagadors en la festa de Sanct Miquel, ab carta rebuda per lo discret en Bernad Sanç, notari, a VIIII de noembre any MCCCLXXX set.

E com, a present, no sàpia altres béns de la dita herència més dels que són continuats y expresats en lo present inventari, aquells confesse tenir com a béns de la herència del dit mestre Johan Roïç de Corella. Protestant que, per la present acaptació, no·n sia fet perjuhí per enmiscrire aquells ab los que són propris meus, ni fer ni causar prejuhí, dan, ni confusió de actions degunes a mi pertanyents en qualsevol manera ans me resten salves, íntegres e sanes in omnibus et per omnia. E ara e per tots los temps, loch e cars si per creedors o alias yo fos tenguda y obligada dels dits béns, axí per via de creedors o alias de aquells, hagués a donar compte e rahó no sia tenguda ni obligada ultra ni en més que·s són los dits béns e forces de la dita heretat.

E encara proteste que, si per havant a notícia mia en lo dit nom pervendran altres béns dels que dessús són inventariats pertànyer e recaure en la dita heretat, que aquells puga en lo present eo en altre inventari continuar. E, generalment, proteste que en fer totes les dites coses e sengles de aquelles per als loch, temps e cars se poran seguir, o·s seguiran, temps algú no·n precórrega ans aquells tots e qualsevol drets meus me resten salvos e il.lesos in omnibus et per omnia.

Requerint de premissis carta pública. Foren fetes les dites coses en la ciutat de València a set dies del mes de octubre de l'any de la nativitat de nostre Senyor mil quatre-cents noranta-set. 
$\mathrm{Se}^{+}$nyal de mi, Dalfina de Corella y de Figuerola, desús dita, que en lo dit nom lo preinsert inventari, memorial e capbreu faç y atorgue.

Presents foren per testimonis a les dites coses en Bernad Ferreres, studiant en arts del loch de la Gana, e en Ramon del Scrivà, scuder de Berní de Ay, habitants en la dita ciutat.

362

I497, octubre, Io. València.

Dalfina Roís de Corella, esposa de Lluís Figuerola, com hereua universal del seu germà Joan Roís de Corella, fa donació inter vivos de tots els béns de l'herència del seu germà a Isabel Martínez de Vera, així com d'una casa a la parròquia de Sant Martí sota el domini directe de la confraria de la Santíssima Trinitat i de Sant Miquel Arcàngel, anomenada dels peraires, a cens de g sous anuals. Aquesta casa feia marge amb dues cases de Lluís Figuerola i una via pública.

RCSCCV, protocols, no. II265, not. Jaume Albert. ${ }^{350}$

363

I498, febrero, 23. València

Isabel Martínez de Vera, habitant de València, donatària de tots els béns de l'herència del magnífic i reverend Joan Roís de Corella -mestre en sacra teologia i cavaller-d'acord amb un instrument de donació en poder del notari Jaume Albert del 1o d'octubre de 1497, transfereix a Dalfina Roís de Corella diversos censals -per preu de 33 lliures, 10 sous - en raó de 66 lliures i 1 o sous degudes a Dalfina, germana de Joan Roís de Corella.

Figuren com a testimonis d'aquest document Mateu Dondorí, velluter, i Bernat Ferreres, del lloc de La Jana.

RCSCCV, protocols, no. 13873 , not. Pere Andreu. ${ }^{351}$

364

I 498, abril, 7. València.

Isabel Martínez de Vera, habitant de València, Joan Roís de Corella i Estefania, fills d'ella, venen go sous censals per preu de 6o lliures a Beatriu Albiol, com a hereua del difunt.Joan Albiol, son pare, i d'Agnés Albiol, la seua difunta mare. Aquests go sous censals varen ser carregats sobre una casa de dita Isabel Martínez de Vera localitzada en la parròquia de Sant Martí, en el carrer de la Mare de Déu de Gràcia i que afrontava amb el dit carrer de la Mare de Déu de Gràcia, amb una altra casa de dita Isabel i amb séquia del monestir de Sant Agustí i "vico medii", amb llicència de Bertomeu de Cruïlles, ciutadà de la dita ciutat de València, senyor directe de la referida casa. ${ }^{352}$

El8 de juny de 1499 Beatriu Albiol confessà haver rebut 6o lliures, preu del dit censal.

350. Document esmentat en Riquer I964, 3, $25^{8}$.

35. Document esmentat en Riquer $1964,3,25^{8}$.

352. Segons aquesta escriptura, Bertomeu de Cruilles, ciutadà de València, era senyor directe de la referida casa sota cens de 4 sous 6 diners establit davant el notari Joan Beneyto el ro de gener de I484. 
RCSCCV, protocols, no. ${ }^{38} 873$, not. Pere Andreu. ${ }^{353}$

365

I498, juny, 4. Tendetes de Campanar (València).

Testament de Miquel Pérez, cuutadà de València i gendre de l'escriptor Joan Roús de Corella.

Nomena marmessors Francesc Cabrera i la seua esposa Magdalena Roís de Corella, a qui elegeix com a hereua universal. Demana ser sepultat en la fossa que ell havia al monestir de la Verge del Carme de València.

RCSCGV, protocols, no. II264, not. Jaume Albert.

366

I498, octubre, II. València

Elnoble Gisbert Pardo, habitant de València, a instàncies del donzell Joan Roís de Corella - fill de l'escriptor i d'Isabel Martínez de Vera-fa una escriptura de quitament de 150 sous censals que a Pardo van vendre, per preu de 100 lliures, els germans Joan, Lluís i Dalfina Roís de Corella, el ciutadà Miquel Pérez i Isabel Martínez de Vera mitjançant escriptura notarial del 19 de març de 1486 davant el notari Pere Joan Çabrugada. ${ }^{354}$

RCSCGV, protocols, no. I3873, not. Pere Andreu.

367

I498, octubre, I5. València

Miquel Nicolau, veí de València, i la seua esposa Isabel Desplà venen a Isabel Martínez de Vera, habitant de València, certa casa seua ${ }^{355}$ en la parròquia de Sant Martí, sota directe senyoriu del monestir de Montaragó a cens de 14 sous anuals, per preu de 128 lliures. La casa afrontava d'una part amb casa Margarita de Monsoriu -vídua del cavaller Baltasar Bou-, "cum muro dicte civitatis vico medio et cum dicto vico dicto de Sanct Vicent et a posteriori parte cum vico del mur dicte civitatis ex alteris partibus".

Hi ha àpoca de Miquel Jordà, procurador del monestir de Montaragó, per 6 lliures i 8 sous per llüsme ifadiga de la dita venda a Isabel Martínez de Vera.

RCSCCV, protocols, no. I3873, not. Pere Andreu.

368

I498, octubre, I5. València.

353. Document esmentat en Riquer $1964,3,25^{8}$.

354. Document esmentar en Guia 2003.

355. Per error del notari, com mostren escriptures notarials posteriors, el document parla de la venda de vàries cases (“quasdam domos mei, dicti Michaelis, sitis et positis in parochia Sancti Martini, in vico lingua materna appellato de Sanct Vicent iuxta jannam dicte civitatis dicti vici coramque ecclesia monasterii beati Agustini”). 
Isabel Martínez de Vera afirma haver lliurat a Miquel Nicolau 6 lliures i 8 sous per a pagar el llüsme d'una casa venuda a ella per Miquel Nicolau i la seua esposa i, per tant, reconeix deure-li 121 lliures i 1 o sous. D'aquesta quantitat deguda, Isabel es compromet a lliurar-li 43 lliures i 10 sous el 15 de novembre de 1498 i la resta posteriorment.

Hi ha nota marginal del 20 desembre de 1501 segons la qual Miquel Nicolau confessà haver rebut les referides 78 lliures en dues pagues: el 30 d'agost de 1500 i el 20 de desembre de 1501.

RCSCCV, protocols, no. I3873, not. Pere Andreu.

369

I498, octubre, I5. València.

Lluís Figuerola, cavaller habitant de València, i Dalfina, la seua esposa, venen per preu de 24 lliures a Jaume Puig, ciutadà de València, tots aquells 37 sous, 6 diners censals que Antoni Aguiló, agricultor de Gandia, i Isabel-la seua esposa-van vendre i carregar a Ausiàs Roís de Corella, davant el notari Pere Belsa a Gandia el 26 de setembre de 1440.

Aquest censal havia passat a mans del poeta Joan Roís de Corella com a hereu universal del seu pare-testament en poder del notari Joan Sart del g de febrer de 1443 i publicat pel dit notari el 16 de gener de 1450- i de la seua mare-testament en poder del notari Antoni Barreda a 24 novembre 1466, publicat el 24 de juliol de 1475. Posteriorment, el censal va passar a mans de Dalfina Roís de Corella-com a hereua universal seua d'acord amb el testament de l'escriptor fet el 31 d'agost de 1478 , publicat pel notari Pere Andreu el 6 d'octubre de 1497- id'ella a mans d'Isabel Martínez de Vera amb la donació dels béns de Joan Roís de Corella feta a Isabel per Dalfina amb instrument de donació rebut pel notari Jaume Albert el 10 d'octubre de 1497. Isabel va vendre, el 24 de febrer de 1498 i davant el notari Pere Andreu, a Dalfina Roís de Corella els referits 37 sous, 6 diners censals en raó d'un deute contret amb la germana de Joan Roís de Corella.

Hi ha àpoca per import d'aquestes 24 lliures preu dels 37 sous i 6 diners censals.

RCSCCV, protocols, no. I3873, not. Pere Andreu

$37 \mathrm{O}$

I498, desembre, 7. València.

Els veïns de València Miquel Nicolau i Isabel, la seua esposa, reconeixen a Isabel Martínez de Vera el lliurament de 43 lliures i 10 sous, part d'aquelles 121 lliures i 10 sous restants d'un total de 128 lliures en què ells li vengueren una casa al carrer de Sant Vicent, pertanyent a la parròquia de Sant Martí. La venda va ser efectuada el 15 d'octubre de 1498 per escriptura notarial davant el notari Pere Andreu. RCSCGV, protocols, no. 13873 , not. Pere Andreu.

$37^{\mathrm{I}}$

I499, maig, 22. València.

Berenguer Mercader, donzell i Justícia Civil de València, es dirigeix a mossén Lluís Figuerola, cavaller, Dalfina Roís de Corella -la seua esposa-, i al matrimoni format per Joan Guardiola -espaser-i Isabel, i els comunica que el notari Joan Pere Gilabert li ha mostrada una carta pública amb sumissió de for feta el 13 de setembre de 1497 rebuda pel notari Jaume Prats, segons la qual Figuerola i els altres vengueren $i$ 
carregaren a Joan Pere Gilabert i als seus zo sous censals cascun any pagadors a 4 de maig sota pena de 5 sous. Gilabert reclama un total de zo sous deguts de la paga del mes de maig.

ARV, Justícia Civil, no. 2598, f. 3 r.

$37^{2}$

I499, juny, I. València.

Capitulacions matrimonials establides entre Bertomeu Figuerola, els seus pares -Lluís Figuerola $i$ Dalfina Roús de Corella-i Àngela, donzella filla del difunt mercader i ciutadà de València Miquel Ferrer, per al matrimoni de Bertomeu i Àngela. Angela aportà al matrimoni un dot de 50.000 sous, i Bertomeu li va reconéixer un creix de 25.00o sous.

RCSCGV, protocols, no. 13878, not. Pere Andreu.

373

I499, setembre I6. València.

Dalfina Roís de Corella, com a hereua universal testamentària del cavaller i mestre en teologia Joan Roís de Corella, i Isabel Martínez de Vera, detenidora dels béns de l'escriptor heretats per Dalfina, fan donació a Úrsula, vídua de Miquel Vendrell, de totes les quantitats pecuniàries procedents del lloguer que ha de pagar d'una casa de dita Isabel -situada al carrer de la Verge Maria de Gràcia, i que afrontava amb altra casa d'Isabel Martínez de Vera i amb la casa de Jerònim Fenollar. Aquesta donació duraria fins que morira Pere Joan Vidal, fill del mercader Pere Vidal, i, en cas de morir, cessaria la donació però la vídua Vendrell hauria de percebre 8o lliures que, a Pere Joan Vidal, li donava Joan Roís de Corella segons constava en un memorial escrit de pròpia mà pel mestre en teologia. ${ }^{356}$

RCSCGV, protocols, no. Io942, not. Joan Bas.

374

I5OO, març, I. València.

Joan Caulet, llibreter veí de València, reconeix deure a Isabel Martínez de Vera, habitant de la dita ciutat, 157 lliures, 3 sous restants d'aquelles 237 lliures i 19 sous preu en què Isabel li va vendre 780 llibres "in lingua materna" anomenats Cartoxans. Aquest pagament es fa d'acord amb el contingut d'un escrit en castellà de Caulet inserit en aquesta escriptura notarial, on figura que ell lliuraria 50 lliures en el pròxim Tots Sants i la resta en un termini de tres anys a partir del 23 de gener de l'any 1498, data de firma del referit escrit en castellà.

Figuren com a testimonis Ramon d'Escrivà, llibreter, i Miquel Corberan, agricultor, residents a València. ${ }^{357}$

RCSCCV, protocols, no. 13874 , not. Pere Andreu.

356. Document esmentat en Riquer i964, 3, 259 .

357. Document esmentat en Almiñana I984-85, 412. 
375

I5OO, març, I. València.

Isabel Martínez de Vera cedeix a Solera de Ferrer, esposa de Lluís Ferrer, cavaller lloctinent del Governador General del regne de València, tots els drets que ella havia contra Joan Caulet, llibreter, en raó d'un deute format per 80 lliures que s'havien d'abonar en gener de 1501 i per 157 lliures, 3 sous que Caulet havia reconegut deure a Isabel.

Figuren com a testimonis d'aquest document Ramon d'Escrivà, llibreter, i Miquel Agramunt, escuder, habitants de València.

RCSCCV, protocols, no. ${ }^{38} 84$, not. Pere Andreu. ${ }^{358}$

376

I5OO, març, I. València.

Isabel Martínez de Vera reclama al cavaller Joan Martorell, senyor de Beniarbeig, el pagament d'una pensió de censal de 66 sous 8 diners.

RCSCGV, protocols, no. 13874 , not. Pere Andreu. ${ }^{359}$

377

I5OO, març, 20. València.

Lluís de Cavanyelles es dirigeix als ciutadans Honorat de Coblliure, Lluís Jeroni d'Alpicat, al cavaller de l'orde de Sant Jaume de l'Espasa mossén Jeroni de Vila-rasa i al donzell Joan Lluís de Vila-rasa, i els informa que el notari Mateu Salvador, com a procurador de Lluís Roís de Corella, li ha mostrada una escriptura notarial rebuda el 23 de desembre de 1492 pel notariJoan Rubiols segons la qual Honorat $i$ els altres carregaren 150 sous anuals de violari a na Violant de Soler -quant a l'usdefruit durant la vida d'ella-i a Lluís Roís de Corella -quant a la propietat i l'usdefruit després de l'òbit de Violant de Soler. El procurador de Lluís Roís de Corella reclama judicialment el pagament de 150 sous deguts de les pagues de juny i desembre de 1499.

ARV, Governació, no. I72, f. 418r.

$37^{8}$

I5OO, agost, 29. València.

Miquel Jordà, notari i ciutadà de València, com a procurador del monestir de Montaragó, a Aragó, "concedeix" a Isabel Martínez de Vera, habitant de València, una casa situada a la parròquia de Sant Martí, prop de la porta de Sant Vicent, sota cens de 14 sous anuals i el domini directe del monestir. Aquesta casa afrontava amb la de Margarita de Monsoriu-vídua del cavaller Baltasar Bou-, "cum muro vico medio et cum vico de Sanct Vicent et cum vico del Mur".

RCSCCV, protocols, no. 13874 , not. Pere Andreu.

358. Document esmentat en Almiñana I984-85, 4I2.

359. Document esmentat en Almiñana I984-85, 4I2.

Magnificat CLM I, 2OI4, III-377. ISSN 2386-8295 
379

I5Oo, agost, 29. València

Isabel Martinez de Vera, habitant de València, promet a Miquel Jordà, com a procurador del monestir de Montaragó, que, en el termini de quatre anys, quitarà els 14 sous censals establits sobre la casa de la parròquia de Sant Martí.

RCSCGV, protocols, no. 13874 , not. Pere Andreu.

$3^{80}$

I5OO, agost, 3I. València.

Isabel Martínez de Vera, habitant de València, Joan Roís de Corella i Estefania, fills ambdós d'ella, venen, conjuntament, a Miquel Nicolau i Isabel Desplà, La seua esposa, 45 sous censals per preu de zo lliures en raó de les 28 lliures que, els venedors, encara devien al matrimoni Nicolau d'un total de z8 lliures que restaven a pagar-los d'aquelles 128 lliures en què ells van vendre a Isabel Martínez de Vera una casa a la parròquia de Sant Martí per instrument rebut pel notari Pere Andreu el 15 d'octubre de 1498. Aquesta casa estava sota el domini directe del monestir de Montaragó - a cens de 14 sous anuals- i estava situada al carrer de Sant Vicent, prop la porta de la muralla.

RCSCGV, protocols, no. 13874 , not. Pere Andreu.

$38 \mathrm{I}$

I500, agost, 3I. València.

Miquel Jordà, notari de València, com a procurador de l'abad i canonges del monestir de Montaragó segons constava en escriptura notarial feta en dit monestir el 5 de gener de 1497, concedeix a Isabel de Vera, filla del difunt donzell Rodrigo [sic] de Vera, permís per a fer diverses obres en l'estructura arquitectònica de la casa venuda, darrerament, a la parròquia de Sant Martí, prop de la porta de Sant Vicent a la muralla, i que afrontava "ex una cum muro vico medio, duabus partibus cum domibus magnifice Margarite Bou et cum dicto vico de Sent Vicent".

RCSCCV, protocols, no. 13874 , not. Pere Andreu.

$3^{82}$

I5OO, setembre, I5. València.

Lluís de Cavanyelles es dirigeix a mossén Pere Martorell-senyor que era de Negrals-, a Caterina-la seua esposa-i a Francesc Miró-senyor actual de Negrals-i els comunica que el notari Mateu Salvador - com a procurador de Lluís Roís de Corella- li ha mostrat un document notarial rebut el 21 de febrer de 1442 pel notari Joan Sart segons els quals Pere Martorell, Caterina i Francesc Miró carregaren 583 sous, 4 diners censals anuals a mossén Ausiàs Roís de Corella-pare de Lluís Roís de Corella-i als seus. El8 de desembre de 1475, i per escriptura rebuda pel notari Antoni Barreda, aquest censal passà a mans de Lluís. Mateu Salvador, en nom de Lluís Roís de Corella, els reclamava un total de 27 lliures, 13 sous i 1 diners de pensions degudes. 
ARV, Governació, no. 176 , f. $455^{\mathrm{r}}$. $^{360}$

$3^{83}$

I5OO, desembre, 23. València.

Isabel Martínez de Vera i els seus fills -Joan Roís de Corella i Estefania, donzella-, habitants tots ells de València, venen a Melcior Demont, doctor en lleis i habitant també d'aquesta ciutat, 250 sous anuals rendals de violari durant les vides de Melcior Demont i d'Àngels Perpinyà, la seua esposa. El preu de venda va ser de 87 lliures, 10 sous. ${ }^{361}$

RCSCCV, protocols, no. 13874 , not. Pere Andreu.

384

I5OO, desembre, 23. València.

Isabel Martínez de Vera, habitant de València, Joan Roís de Corella-donzell-i Estefania donzella-llur fills i habitants de la mateixa ciutat, en raó de les pensions dels 250 sous anuals de violari venuts a Melcior Demont, doctor en lleis, per preu de 87 lliures, 10 sous tranfereixen a Demont tots els drets d'Isabel contra Garcia Gomis pel lloguer d'una casa d'ella situada al carrer anomenat de la Verge Maria de Gràcia, pel qual aquest havia de donar a ella 4 lliures, 11 sous i 8 diners en mars i setembre de 1501. Així mateix, també li cedeix tots els seus drets i accions contra Joan Martorell, donzell senyor de Çot, "ad exactione" de 66 sous i 8 diners que a Isabel havia de donar en abril de 1501 i en abril de 1502, en raó d'un censal que Jaume Martorell i la seua esposa Elionor vengueren a Saura d'Esplugues per 4 o lliures i que va ser carregat davant el notari de Gandia Pere Belsa el 21 d'abril de 1435. Aquest censal de Saura va passar a Ausiàs Roís de Corella d'acord amb el testament fet per ella en $1440^{362}$ a Gandia, en poder del notari Pere Belsa. Posteriorment, per mort d'Ausiàs Roís de Corella passà a mans del seu fill Joan Roís de Corella qui els va donar a sa mare Aldonça-per instrument davant el notari Antoni Barreda datat el 22 de desembre de 1450- qui va nomenar hereu universal el seu fill Joan Roís de Corella al seu darrer testament. El prosista i poeta va fer donació de tots aquests béns a la seua germana Dalfina, per instrument rebut pel notari Antoni Barreda el 7 de febrer del 1487, i ella li'ls va restituir el 27 de novembre de 1489. Finalment, Joan Roís de Corella va morir nomenant la seua germana Dalfina com a hereua universal i aquesta va donar tots els béns de Corella a Isabel Martínez de Vera per escriptura notarial feta davant el notari Jaume Albert el to de octubre de $149 \%$.

D’aquesta manera, Isabel cedeix a Demont tots els seus drets pel lloguer de la casa i pel censal referit.

RCSCCV, protocols, no. 13874 , not. Pere Andreu.

360. En ARV, Governació, no. 254, mà 8, f. 48 figura un altre procés, datat el 23 d'octubre de I5o8, de Lluís Roís de Corella per un censal, pertanyent a Ausiàs Roís de Corella, carregat sobre Negrals el 2I de febrer de I442.

36r. Document esmentat en Almiñana I984-85, 390 i 4 I2.

362. En aquest document, tan sols figura l'any de confecció i publicació del darrer testament de Saura d'Esplugues -I440-, mentre que les referències a mesos i dies estan en blanc. 
385

I5OO, desembre, 23. València

Isabel Martínez de Vera i els seus fills Joan Roís de Corella i Estefania, tots ells habitants de la ciutat de València, venen a Joan Martorell, donzell i senyor del lloc de Çot-a l'horta de Gandia-, 66 sous i 8 diners censals. Aquest censal havia pertangut a Saura d'Esplugues, esposa de Pere Roís de Corella, qui, al seu testament, el va llegar al seu fill Ausiàs Roís de Corella. Posteriorment, Ausiàs, al seu testament atorgat el 9 de febrer de 1443 davant el notari Joan Sart i publicat per aquest el 16 de gener de 1450, ordenà que fora lliurat al seu fill i hereu universal. Joan Roís de Corella.

RCSCCV, protocols, no. I3874, not. Pere Andreu.

$3^{86}$

I5OI, abril, 29. València.

Lluís de Cavanyelles es dirigeix a mossén Pere Martorell-senyor que era de Negrals-, a Caterina-la seua esposa-i a Francesc Miró -senyor actual de Negrals- i els comunica que el notari Mateu Salvador - com a procurador de Lluís Roís de Corella- li ha mostrat un document notarial rebut el 21 de febrer de 1442 pel notari Joan Sart segons el qual Pere Martorell, Caterina i Francesc Miró carregaren 583 sous, 4 diners censals anuals a mossén Ausiàs Roís de Corella-pare de Lluís Roís de Corella-i als seus. El8 de desembre de 1475, i per escriptura rebuda pel notari Antoni Barreda, aquest censal passà a mans de Lluís. Mateu Salvador, en nom de Lluís Roís de Corella, els reclamava un total de 24 lliures, 3 sous i 6 diners de pensions degudes.

ARV, Governació, no. I85, f. IO7r.

$3^{87}$

I5OI, maig, 25. València

Isabel Martínez de Vera lloga a Gaspar Joan de Monsoriu, donzell habitant de València, certes cases ubicades a la parròquia de Sant Martí, concretament al carrer anomenat de Mossén Corella, per temps de quatre anys - a partir de 1502-a raó de 12 lliures anuals. Aquestes cases afronten amb casa de Lluís Figuerola, séquia dels beguins i amb l'esmentat carrer de Corella.

RCSCGV, protocols, no. I3877, not. Pere Andreu.

388

I5OI, agost, I8. València.

Lluís Figuerola, Dalfina Roís de Corella i els seus fills Enric Joan i Bertomeu venen a la donzella Anna Çanoguera, filla del difunt Joan Çanoguera -senyor de Catarroja i Patraix-, 173 sous censals per preu de 133 lliures.

RCSCCV, protocols, no. 13877 , not. Pere Andreu. ${ }^{363}$

363. En un altra escriptura d'eixe mateix dia conservada en aquest protocol, figura que Enric Joan Figuerola si bé era habitant de València, en la dita data residia a Almenara, i que l’instrument nupcial de Lluís Figuerola i de Damiata Valleriola va ser fet davant el notari Ambrosi Alegret el 6 d'abril de I464, i que el testament de Damiata, mare d'Enric 
389

I5OI, desembre, I6. València

Isabel Martínez de Vera, Joan Roís de Corella -cavaller de Sant Jaume de l'Espasa- i Estefania Roís de Corella, fills seus, venen a Miquel Nicolau i Isabel Desplà, la seua esposa, diversos censals i violaris en raó de 55 lliures restants d'aquelles 128 lliures preu en què ells li van vendre una casa en la parròquia de Sant Martí, prop de la porta de la muralla.

RCSCCV, protocols, no. I3877, not. Pere Andreu

390

I5OI, desembre, I6. València.

Isabel Martínez de Vera i els seus fills Joan Roís de Corella, cavaller de Sant Jaume de l'Espasa, i Estefania, per preu de 175 lliures, venen 233 sous i4 diners censals al cavaller de València Nicolau Ferrando, com a tutor del seu fill el donzell Joan Jeroni-hereu de la seua difunta mare Beatriu Ferrer i de Ferrando. Aquests 233 sous i 4 diners censals, els carregaren sobre la casa d'Isabel Martínez de Vera al carrer de Sant Vicent

Figura una anotació segons la qual, l'i d'abril de 1514, el donzell Lluís Roís de Corella, germà del poeta Joan Roís de Corella, que posseïa en eixe moment el censal, es fa càrrec de quitar aquest censal de 3.500 sous de principal $i 68$ sous de prorrata en raó de 3 mesos i 15 dies. ${ }^{364}$

RCSCCV, protocols, no. IOO, , not. Pere Andreu.

$39 \mathrm{I}$

I5OI, desembre, 22. València.

Lluís de Cavanyelles es dirigeix als jurats de la Pobla de Vallbona i els informa que Lluís Roís de Corella, fill d'Aldonça Roís de Corella, ha reclamat davant la cort un total de 142 sous i 1 o diners deguts de la paga de juliol d'un censal per la mateixa quantitat que la seua mare li havia deixat al seu darrer testament. Aquest censal, originàriament, havia estat venut pels esmentats jurats de la Pobla de Vallbona i per les aljames de Paterna i de Benaguasil a Berenguer Minguet, ciutadà, com a tutor icurador del donzell Ramon Soler, fill i hereu del difunt cavaller Pere Soler.

ARV, Governació, no. I9o, f. 564 r.

392

I5O2, juny, I6. València.

Testament de Lluís Roís de Corella, donzell i habitant de València. Revoca els seus anteriors testaments inomena com a marmessors el dominic Pere de Sentandreu i el noble don Rodrigo de Borja, habitant de València, a qui nomena, també, hereu seu universal. Vol ser soterrat en el vas de les Ànimes del Purgatori que és al cantó del claustre al costat de l'església del monestir de Sant Domènec. Realitza

Joan Figuerola, fou escripturat pel notari Garcia d’Artés el i6 de febrer de I465 i publicat pel mateix notari l'Ii d'octubre de 1468 .

364. Document esmentat en Riquer I964, 3, 258 . 
diverses deixalles testamentaries: a la seua germana Dalfina, 50 lliures i lidemana el seu perdó per no deixar-li més, ja que no ho podia fer per l'escassetat dels seus béns; a Isabel Muntanyesa-esposa de Llàtzer, mestre d'esgrima - 10 lliures per qualsevol tipus d'obligació que tinguera amb ella, i a Jerònima Vives tots els mobles de la casa del testador més zo lliures pels serveis que, en alguna ocasió, li ha prestat. RCSCGV, protocols, no. ${ }_{3876} 6$, not. Pere Andreu.

393

I5O2, juny, I8. València.

Davant Jeroni Bayona, justícia civil de València, compareixen Dalfina Roís de Corella-esposa del cavaller Lluís de Figuerola- i Isabel Martínez de Vera i afirmen que Dalfina, com a hereua del seu germà Joan Roís de Corella, el dia 1o d'octubre de 1497 per escriptura notarial rebuda pel notari Jaume Albert havia fet donació inter vivos a Isabel de tots els béns, drets i càrrecs de l'herència del difunt. El valor d'aquesta herència, llevats els corresponents càrrecs, era menor de 5000 sous i, per això, aquesta donació s'havia fet sense el decret legal del justícia civil i com, ara o en el futur, algú podria dubtar de què aquesta donació no excedia de 500 florins demanen ambdues dones que, d'acord amb els furs, el justícia civil atorgue el seu vistiplau legal a la referida donació.

El justícia civil féu declarar sota jurament tant a Dalfina com a Isabel que la referida donació s'havia fet sense dol o en frau dels creditors. Posteriorment, l'oficial municipal va posar "en la dita donació ses auctoritat e decret". ${ }^{365}$

ARV, Justícia Civil, no. 937, mà 3ª , f. 25r.

ARV, Justícia Civil, no. 937, mà $9^{\mathrm{a}}$, f. 7r.

394

I5O2, agost, I3. València.

Darrer testament de Lluís Figuerola, cunyat de Joan Roís de Corella i espòs de Dalfina Roís de Corella. Fou publicat, a la casa del difunt, el 23 d'agost de 1502, tercer dia després de la mort del testador.

En aquest testament, nomen a marmessor fra Miquel Orts, confesor seu ifrare del monestir de Sant Agustí. Tria la seua sepultura en la capella dels Figuerola, existent a la parròquia de Sant Martí, on estan soterrats els seus pares. Nomena hereu universal el seu fill Bertomeu, nascut del seu matrimoni amb Dalfina Roís de Corella, i realitza diferents llegats als altres fills seus: a Beatriu, filla seua i de Dalfina, li deixa 360 florins; a Jerònim i a Lluis, fills seus i de Dalfina, els lliura 10 sous com a tota part en els seus béns; a Enric Joan, fill del difunt i de la seua primera esposa Damiata, li deixa els béns que restaven dels aportats per Damiata Valleriola al matrimoni.

Figuren com a testimonis d'aquest document, els preveres beneficiats en la Seu de València Jerònim Pla i Pere Jordà, i Bernat Ferreres, prevere de la diòcesi de Tortosa, tots ells habitants de la cüutat de València.

RCSCCV, protocols, no. ${ }_{38}^{8} 76$, not. Pere Andreu.

365. Document esmentat en Riquer I964, 3, 260; però donant com a signatura el volum 936 de la sèrie Justícia Civil. 
I5O2, agost, I6. València.

Codicil testamentari de Lluís Figuerola, cunyat de Joan Roís de Corella.

RCSCCV, protocols, no. I3876, not. Pere Andreu.

396

I5O2, setembre, 2. València.

Almoneda dels béns mobles del difunt Lluís Figuerola realitzada, al mercat de València, per Bernat Ferreres, prevere, procurador del donzell Bertomeu Figuerola, fill nascut del matrimoni de Lluís amb Dalfina Roís de Corella. Els béns venuts alcançaren un total de 132 sous, 11 diners.

RCSCCV, protocols, no. ${ }_{38} 86$, not. Pere Andreu.

397

I5O2, novembre, 26. València.

Bertomeu Figuerola, com a hereu testamentari de Lluís Figuerola, cunyat de Joan Roís de Corella, ven diversos béns de l'herència del difunt per a donar 5.028 sous, 7 diners a Dalfina Roís de Corella que restaven per pagar-li del seu dot i creix matrimonial després que Lluís Figuerola donara, el 24 d'octubre de 1485 davant el notari Joan Ramos, diverses quantitats a la seua dona. Entre els béns venuts per Bertomeu Figuerola consta "un libre appellat Cartoixà per tres sous".

RCSCCV, protocols, no. ${ }_{3876} 6$, not. Pere Andreu. ${ }^{366}$

398

I5O3, març, I8. València.

Dalfina Roís de Corella, vídua de Lluís Figuerola, ven un total de 75 sous censals per preu de 50 lliures a Bernat Fenollar-domer de la Seu-i a Joan Jerònim Fenollar-ocupant del benefici existent en l'església de Sant Llorenc sots invocació de la Verge Maria de la Salut establit pel domer Bernat Fenollar mitjançant escriptura del 10 de gener de 1497 davant el notari Felip Abella. Entre els censals venuts figuren un per valor de 22 sous i 6 diners carregat sobre una casa existent al carrer de Mossén Corella, sota domini directe de l'ofici de peraires a cens de g sous anuals, que afrontava amb casa d'Isabel Martínez de Vera, amb altra casa de Dalfina Roís de Corella "et cum dicto vico et a posteriori parte cum cequia et vico ex aliis partibus que domus, per reverendum magistrum Joannem Rö̈ de Corella, vendite michi fuerunt cum instrumento acto in posse discreti Genisï Barrot, notarium, die vicesima quarta mensis aprilis anni MCCCC octuagesimo octavi". La venda dels 75 sous censals fou realitzada per Dalfina per tal de pagar una part dels 18.000 sous que restaven donar a Enric Joan Figuerola, fill de Lluís Figuerola i de la seua primera esposa, dels prop de 5 o.ooo sous que Damiata Valleriola, mare d'Enric Joan, va portar com a dot al seu marit Lluís Figuerola.

El 24 de desembre de 1513, aquest censal va ser quitat per Jerònim Fenollar, a qui pertanyia en eixe

366. Document esmentat en Almiñana I984-85, 4II. En aquest mateix protocol i dia, figura l’àpoca de Dalfina pels referits 5.028 sous, 7 diners. 
moment.

RCSCCV, protocols, no. I3879, not. Pere Andreu.

399

I5O3, abril, I2. València.

Isabel Martínez de Vera, la seua germana Joana -beata-i els fills d'Isabel, Joan Roís de Corella cavaller de l'orde de Sant Jaume de l'Espasa-i Estefania-donzella-, habitants tots ells de València, en el nom seu propi i com a posseüdors dels béns de Joan Roís de Corella, cavaller i mestre en teologia, s’obliguen a Úrsula Vendrell, vídua de Miquel Vendrell, a donar-li, al llarg de set anys, 83 lliures, 15 sous i 4 diners a raó de 12 lliures anuals excepte l'últim any en què li donaran el que restara. Aquesta quantitat, es comprometen a donar-li-la per la bona memòria de Joan Roús de Corella qui, en el moment de la seu mort, va prometre lliurar a Pere Joan Vidal, nét de la dita Úrsula, si viu era o a Úrsula, si aquest moria, aquestes quantitats de diners per certes causes contingudes en un memorial escrit pel propi Corella. Com era fama pública a València que Pere Joan Vidal havia mort, es compremeten a donar a Úrsula les referides 83 lliures, 15 sous i 4 diners.

RCSCGV, protocols, no. 2IO35, not. Lluís Gomis.

400

I5O3, abril, 27. València.

Dalfina Roís de Corella, vídua de Lluís Figuerola -cavaller habitant de València-, ven a Francesc Bonfill certa botiga al Grau de València per preu de 105 sous.

RCSCCV, protocols, no. 23025, not. Guillem Exernit.

$4 \mathrm{OI}$

I5O3, maig, I5. València.

Lluís de Cavanyelles es dirigeix a Isabel Martínez de Vera, al cavaller Joan Roís de Corella comanador de l'orde de Sant Jaume de l'Espasa- i a la seua germana Estefania Roís de Corella i els informa que el procurador del cavaller mossén Nicolau Ferrando, pare i legútim administrador del donzell Joan Jeroni Ferrando -fill seu i hereu de la difunta Beatrü Ferrando, mare seua-, li ha mostrat un document notarial rebut el 16 de desembre de 1501 pel notari Pere Andreu segons el qual Isabel i els seus fills carregaren a Nicolau Ferrando i al seus 233 sous iz diners de violari anual. El procurador de Nicolau Ferrando els reclama judicialment 116 sous is diners deguts de la paga del desembre passat. ${ }^{367}$

ARV, Governació, no. 206, f. I6r.

$4 \mathrm{O} 2$

I5O3, maig, I6. València.

Lluís de Cavanyelles es dirigeix a Isabel Martínez de Vera, Joan Roús de Corella-comanador

367. Document esmentat en Almiñana 1984-85, 4I2. 
de l'orde de Sant Jaume de l'Espasa- i a la seua germana Estefania Roís de Corella i els informa que Beatriu Aguilona reclama, davant la cort de la Governació del regne de València, el pagament de 100 sous deguts de la paga d'un censal. ${ }^{368}$

ARV, Governació, no. 206, f. I7r.

403

I5O3, agost, 23. València.

Lluís de Cavanyelles es dirigeix a Isabel Martínez de Vera, Joan Roís de Corella-comanador de l'orde de Sant Jaume de l'Espasa-i a la seua germana Estefania Roís de Corella i els informa que el procurador de mossén Baltasar de Castellví li ha mostrat un document notarial rebut el 25 de juny de 1502 pel notari Joan Masó, segons el qual Isabel i els seus fills carregaren a Baltasar de Castellví6oo sous de violari anual pagadors, per meitat, el 26 de juny i de desembre. El procurador els reclama judicialment 300 sous deguts de la paga de juny passat.

ARV, Governació, no. 208, f. 6r.

404

I5O3, agost 23. València.

Felip Martín, procurador d'Àngela Perpinyà, reclama, davant la cort del Justícia Civil de València, a Joan Roís de Corella, comanador de Sant Jaume de l'Espasa, i al cavaller Lluís Carbonell el pagament d'una pensió de 60 sous de violari. ${ }^{369}$

ARV, Justícia Civil, no. 2609, mà 22, f. IIv,

405

I5O3, setembre, 4. València.

Lluís de Cavanyelles, Governador del regne de València, es dirigeix a Isabel Martínez de Vera, a mossén Joan Roís de Corella -cavaller de l'orde de Sant Jaume de l'Espasa-ia Estefania, donzella filla d'Isabel, i els informa que el notari Bertomeu Domínguez, procurador de Guillem Exernit, li ha mostrada una escriptura notarial rebuda el 3 de juny de 1503 pel notari Joan Monterde segons la qual Isabel $\mathrm{i}$ els seus fills carregaren a Guillem Exernit un total de 150 sous censals. El procurador d'Exernit els reclama judicialment un total de 150 sous deguts de diferents pagues.

ARV, Governació, no. 209, f. 2 or.

406

I5O4, maig, IO. València.

El Justícia Civil de València es dirigeix a Isabel Martínez de Vera i al seu fill Joan Roís de Corella, comanador de Sant.Jaume de l'Espasa, i els comunica que Mateu Salvador-com a procurador del

368. Document esmentat en Almiñana 1984-85, $4 \mathrm{I} 2$.

369. Document esmentat en Almiñana I984-85, 407 .

Magnificat CLM I, 2OI4, III-377. ISSN 2386-8295 
mercader Gabriel Andreu àlies Rosell- li ha mostrada una escriptura notarial rebuda pel notari Joan Sanc-major de dies-el 5 de gener de 1504 segons la qual Isabel i el seu fill reconegueren deure a Gabriel Andreu 7 lliures, 12 sous iz diners. Atés que mare ifill prometeren pagar-li el deute el passat 15 d'abrili això no ha ocorregut, el procurador Mateu Salvador reclama el pagament de l'esmentat deute.

ARV, Justícia Civil, no. 26Io, mà 8 , f. 45 v. ${ }^{370}$

407

I5O4, maig, 2O. València.

Lluís de Cavanyelles es dirigeix a Antoni Ciscar, veí de Pego, i li comunica que el notari Joan Sanc, com a procurador d'Isabel Martínez de Vera, li ha mostrada una escriptura notarial rebuda pel notari Bernat Sanç el 8 de novembre de 1487 segons la qual Antoni va reconéixer deure al cavaller i mestre en teologia Joan Roís de Corella i als seus g lliures i 10 sous. Posteriorment, aquest censal va passar a mans d'Isabel Martínez de Vera i als seus per escriptura rebuda pel notari Jaume Albert el io d'octubre de 1497. El procurador d'Isabel Martínez de Vera reclama a Antoni Ciscar un deute de g lliures i 1 o sous més els interessos corresponents i sol.licita que es venguen diversos béns d'Antoni Ciscar suficients per a pagar aquest deute.

ARV, Governació, no. 2I 7 , f. 7rv.

408

I5O4, juliol, Io. València.

Lluís de Cavanyelles es dirigeix a mossén Pere March, cavaller i senyor de Beniarjó, i al seu fill, Joan March, i els informa que el notari Joan Masó, com a procurador d'Isabel Martínez de Vera, li ha mostrada una escriptura notarial rebuda pel notari Ramon Dalmau el 21 de febrer de 1494 segons la qual els esmentats March carregaren a Joan Roís de Corella i als seus 500 sous censals pagadors anualment. Posteriorment, aquest censal va passar a mans d'Isabel Martínez de Vera ials seus per escriptura rebuda pel notari Jaume Albert el 1o d'octubre de 1497. El procurador d'Isabel Martínez de Vera reclama als March un total de 14.ooo sous per pagues degudes d'aquest censal.

ARV, Governació, no. 2I8, f. 4I6r.

I5O4, juliol, 22. València.

Testament de Dalfina Roís de Corella, germana i hereua universal de l'escriptor Joan Roís de Corella, cavaller i mestre en teologia. Va ser publicat el 6 de desembre de 1508 en la casa on visqué i morí la testadriu.

RCSCCV, protocols, no. 13883 , not. Pere Andreu.

Die XXII mensis julii Anno a nativitate Domini $M^{\circ} D^{o}$ IIII .

En nom de nostre Senyor Déu Jhesuchrist y de aquella alta reyna de paraís, mare de

370. Document esmentat en Almiñana I984-85, 413. 
misericòrdia, advocada de tots los peccadors molt piadosa. Com, quascú en carn possat a la mort corporal scapar no puga, e no sia cosa més certa que la mort e més incerta que lo dia e hora de aquella, per ço yo, na Dalfina Roïç de Corella y de Figuerola, vídua muller del magnífich mossén Luís Figuerola quòndam cavaller habitador de València, stant per gràcia de nostre Senyor Déu Jhesuchrist en aquells sa e sancer enteniment, memòria éntegra e loqüela manifesta, aquells que a la divina clemència li ha plagut acomanar-me, y revocant, cassant $\mathrm{e}$ anul-lant tots e qualsevolls testaments, etc.

Ara, de nou, faç e ordén aquest meu últim e darrer testament e la mia darrera voluntat ab lo qual pos, faç e legesch marmesors meus, e d'aquest meu últim e darrer testament execudors, los venerables mossén Pere Jordà, prevere rector de Burjaçot e beneficiat en la Seu de València, present, e en Berthomeu Figuerola, donzell fill meu, absent, als dos ensemps, e l'altre de aquells absent, mort o impedit, l'atre de aquell done licència, auctoritat etc.

E, primerament, vull e ordén que tots mos deutes, torts e injúries sien satisfets e pagats, aquells emperò aquelles que aparran mi ésser tenguda e obligada ab cartes, albarans, e totes cauteles, for de ànima y de bona consiència sobre les dites coses benignament observat.

E prench per ànima mia y de tots feels defuncts, vint lliures moneda reyals de València de les quals vull, quant a nostre Senyor Déu Jhesuchrist plaurà sia, en tal punct me sien liurats los Sancts Sagraments de Eucarestia y de Extremaunció, e quant la mia ànima haurà donat compte de sa vida, lo meu cors sia liurat a ecclesiàstica sepultura en lo vas de la capella del Corpus Christi, que és del dit marit meu, que és construïda dins la església de Sanct Martí de la dita ciutat. E vull ésser feta la dita mia sepultura ab aniversari e cap d'any a coneguda dels dits meus marmesors, tant simplament com fer se puga, sens pompa ni brogit degú. E que no sia soterrada que primerament no sia celebrada missa per ànima mia e sien sien [sic] dites aquelles cinch mises de les cinch plagues de nostre Déu e creador Déu Jhesuchrist, interposant la sua sanch preciosa entre lo seu juhí e mi, confiant en la sua infinida misericòrdia me perdonarà mos peccats. Axí mateix, vull me sien dites les mises [de] sanct Agostí, e les mises apellades de san[ct Amador] e ab ses candeles e offerta com és mester. E aquelles mises de les plagues e sanct Amador sien celebrades en la dita església e lo prevere o preveres que aquelles [cele] braran, sien tenguts de fer absolució sobre la dita [sepultura] mia. E, si res hi sobrarà, vull que sia distribuït per los dits meus marmesors en aquelles obres pies, sacrificis e almoynes que ells volran e elegiran. E, si en fer lo dessús dit, alguna cosa hi mancarà, vull que hi sia fet compliment dels altres béns meus.

Ítem, com ma voluntat sia que degú no·s senyale ne·s dolga de la mia mort corporal, ans deu fer gràcies a nostre Senyor Déu com me ha treta de pena, per ço vull que degú no porte dol per mi, ans simplament vaga ab sa clocha e caperó e, les dones, ab vel·ls tenats tant solament, com aquesta sia ma voluntat.

Ítem, leixe a Jerònima, criada mia, si en ma vida yo no li hauré donat e serà casada, deu lliures y totes les robes que ella té, axí noves com altres, e que li sia donat hun mantell dels meus. Lo qual legat li faç en paga de la servitut que ha fet en casa mia e no en altra manera. $\mathrm{E}$ si no-s tenia per contenta, en tal cars no vull que li sa donat lo dit legat, e sols haja lo que per justícia li serà jutgat.

Ítem, leixe a Isabeleta, serventa mia, francha e liure de tot jou de servitut e que aquella puga fer, tot lo que quascuna libera persona pot fer e servixcha a la amada na Beatriu, filla mia, fins que la dita Isabeleta haja complida edat de XX anys; los quals passats, sia e reste francha e, passat lo dit temps, la hereua mia dejús scrita sia tenguda donar-li X lliures per amor tota hora que aquella contractarà de matrimoni, a coneguda dels dits marmesors meus e filla mia, com axí a mi plàcia. 
Ítem, actés que, ab carta rebuda per lo discret en Luís Erau, notari, sots cert kalendari, yo haja comprat una casa, ab ort attinent a aquella, d'en Francí Monblanch y de na d'Eroles, jermana sua, per preu de sis mília CCC sous en los quals, pagant yo aquells, lo dit en Berthomeu Figuerola, fill meu, pagà quatre mília sous e yo paguí la resta, ab lo tros que vení de part del dit ort e en altra quantitat; la qual casa e ort es situda [sic] en la paròquia de Sanct Martí, en lo carrer appellat vulgarment de Mossén Corella. La qual casa e ort que huy resta és tenguda, sots directa senyoria de la confraria dels perayres, a cens de XVIIII sous, fadiga e loisme pagadors quascuns anys a Nadal, la qual afronta ab ort y stable de la spectable dona Elionor de Próxita, comtesa de Versa; ab lo dit carrer e ab casa que era del reverent e magnifich mossén Joan Roïç de Corella.

E, per ço, és de molta rahó que lo que lo [sic] dit fill meu ha fet per mi li sia remunerat, com yo ja, per la dita rahó, la part de la dita casa que davall li lexe e ort la y haja lexada francha de loguer eo verament en rata de l'interés que los dits quatre mília sous li porien guanyar. E, per tant, en paga e solució dels dits IIII mília sous e, per tot e qualsevoll dret de [...] e altre que en mos béns li pertanygua, done al dit en Berthomeu Figuerola, fill meu, la major part de la dita casa e l'ort que és huy [...] d'estable que és en aquella, ço és, la entrada entrant per la dita casa ab hun studi a part dreta, e la cambra damunt aquell, e part del portge dalt damunt la dita cambra, fins als pilars que són en lo dit porche, que són vers lo carrer de Sanct Vicent, e, dreta línea dalt a baix, lo [sic] dits pilars e paret on se refermen aquells, vull que la dita casa que lexe al dit en Berthomeu Figuerola, fill meu, plegue e sia e no passe més avant, e al dit respecte dels dits pilars e part devedeixcha la cuyneta que corespon al pou de la casa del dit mon fill.

Com la restant casa, ço és, dels dits pilars e paret on stan aquells e part de la dita cuyneta, vers lo carrer de Sanct Vicent, rechaen los patis e cambres següents, ço és, en lo porche dalt sols la scala e lo spay dels pilars, que seran $\mathrm{V}$ o sis palms, e la cambra per on se puga huy al dit porche; e, davall aquella, hun studi gran que trau finestra a la carrera e altra al corralet e sa entrada; e, damunt aquella, altra cambra e hun corralet descubert e, de la cuyneta, huns dotze palms. La qual casa axí designada, me retinch vers mi e vull que reste en la mia herència ab cens de sis sous tant solament, ab directa senyoria segons és dit.

E tot lo restant que serà començant als dits pilars e paret on stan aquells dreta linea fins a l'ort de la dita comtesa e al dit carrer de Mossén Corella, arreu que y haurà lo dit porche, recambra, cambra, mengador e terrat, dalt e baix, hun studi, entrada, ort, pou, stable e cuyna e coralet fins a la part e ort de la casa que era del dit mossén Corella, vull que sia del dit en Berthomeu Figuerola, ab càrrech de XIII sous de cens, fadiga e loisme a la dita confraria quascuns anys e perpetualment pagadors en la dita festa de Nadal. E, axí, vull que lo dit fill meu e sos hereus o tinguen, hajen e posseheixquen, e no en altra manera, com aquesta sia ma voluntat.

Ítem, a Luís Figuerola, fill meu legíttim e natural e del dit mossén Luís Figuerola meu [sic] quòndam, leixe una casa e ort que yo tinch e possehesch davant la casa e ort d'en Jacme Macip, mercader; e la qual fa de cens VI sous, VIIII als beguins, luïsme e fadiga. E si cars era que yo en ma vida la hauré venuda o donada a la dita filla mia en matrimoni, o altrament alienada, vull que en tal cars li leixe tots aquells XXIII sous, III diners censals o interés que a mi fa la muller del dit en Jacme Macip, En [blanc] Corcó e na Castellana, sa muller, per rahó del preu que resta de una casa del costat de la dita casa, los vení ab carta rebuda per lo discret en Francesch Badia, notari, lo primer de juny de l'any MD tres. Lo qual legat, li faç per tota part de legíttima e altre dret que en mos béns li pertanygua.

En tots los altres béns e drets meus, axí mobles com sehents, drets, veus e actions mies, a [mi] pertanyents e pertànyer podents e devents, de luny o prop, per qualsevoll títoll, causa, manera o rahó hereua mia pròpria e universal, e encara general, la dita na Beatriu Figuerola, 
donzella, filla mia e del dit marit meu legíttima e natural, faç e instituesch per dret de institució. Sots tal vincle e condició que, si la dita filla mia morrà quantquequant sens fills legíttims $\mathrm{e}$ naturals, en tal cars vull que, si lo dit Luís Figuerola, fill meu, viu serà, vull que la mitat dels dits béns meus torne e vinga al dit en Luís Figuerola, fill meu, e, de la altra part, aquella faça a ses voluntats. E si serà mort lo dit Luís, en tal cars, aquella puixa testar de tots los dits béns meus e fer-ne a ses voluntats.

Aquest és lo meu darrer testament etc.

Lo qual fonch fet en València, etc.

Presents foren per testimonis a la confecció del preinsert testament, pregats e demanats los venerables mossén Pere Jordà, prevere benificat en la Seu, e mossén Bernad Ferreres, prevere beneficiat en Sanct Andreu, e en Berthomeu Murrià, de Morella, studiant, qui conexien bé la dita testadriu e, yo, Pere Andreu, notari, conech aquella.

In super autem die intitulata sexta decembris anno a nativitate Domini $M^{\circ} D^{o} V I I I^{\circ}$, instants los magnífichs en Berthomeu Figuerola, donzell, y na Beatriu Figuerola, fills dels magnífichs mossén Loís Figuerola, quòndam cavaller, e de na Dalfina Roïç de Corella, testadriu dessús dita, lo dit testament, de la primera línea fins a la darrera inclusive, ab veu alta e intel-ligible que tots homs dien oyr y entendre, per mi, Agostí Agramunt, notari regent los libres del discret en Pere Andreu, quòndam notari, fonch lest e publicat. E, encontinent, la dita Beatriu dix que accepta la herència ab benefici de inventari e lo dit magnífich en Berthomeu Figuerola [dix que] acceptava lo càrrech de la marmessoria, e accepta lo legat, seguons stà en lo dit testament, protestant que en fer aquell temps no li precórrega. De les quals coses, los sobredits requeriren per mi, dit Agostí Agramunt, notari, ésser-los feta e rebuda carta pública; la qual los fonch feta e rebuda en la ciutat de València en la casa hon, segons se diu, la dita testadriu, quant vivia, stava e habitava e hon finí sos darrers dies, los prop dits dia, mes e any.

Testimonis, mossén Pere Frigola, rector, i en Johan Davo, habitants en València.

$4 \mathrm{IO}$

I5O4, agost 26. València.

El.Justícia Civil es dirigeix a Isabel Martínez de Vera i als seus fills Joan i Estefania i els comunica que el notari Antoni Cardona, com a procurador de Maria Magdalena de Crüllles -filla i hereua del ciutadà Bertomeu de Cruilles-, li ha mostrada una "carta pública executòria ab submissió de for" rebuda pel notari Pere Font segons la qual Isabel i els seus fills vengueren i carregaren a Bertomeu de Cruilles $i$ als seus 200 sous censals anuals. Cardona els reclama un total de 200 sous deguts en raó de la paga d'aquest censal.

ARV, Justícia Civil, no. 26II, mà I4, f. 2Ir. ${ }^{371}$

$4 \mathrm{II}$

I5O5, febrer, I9. València.

Dalfina Roís de Corella, vídua del cavaller i habitant de València Lluís de Figuerola, reconeix

37. Document esmentat en Almiñana I984-85, 4I2.

Magnificat CLM I, 2OI4, III-377. ISSN 2386-8295 
a Francesc Miró, ciutadà de València, i a la seua esposa el lliurament de 8o lliures que l'esmentat matrimoni devia a Lluís de Figuerola segons constava en escriptura notarial del 6 d'abril de 1484 feta davant el notari Mateu Esteban.

RCSCCV, protocols, no. II938, not. Pere Andreu

$4 \mathrm{I} 2$

I5O5, abril, 8. València.

Lluís de Cavanyelles, Governador General del regne de València, notifica a Dalfina Roís de Corella, vídua del cavaller Lluís de Figuerola, que el notari Jeroni Morest-com a procurador del donzell Enric Joan Figuerola-, li ha mostrat un document fet el 20 de març de 1503 rebut pel notari Pere Andreu on figura que Dalfina prometéi s'obligà al dit Enric a lluir i quitar, dins els dos anys següents a 1503, tots aquells 76 sous, 8 diners censals pagadors anualment que Enric Joan Figuerola i altres carregaren al notari de Morvedre Bernat Vesià segons constava per escriptura rebuda pel notari Bertomeu Garcia el 20 de juliol de 1500 . Jeroni Morest reclamava que Dalfina complira la seua promesa de quitació d'aquest censal i que, així mateix, pagara les pensions degudes del censal tal com Dalfina també s'havia obligat en l'escriptura notarial de l'any $1503 .{ }^{372}$

ARV, Governació, no. 226, f. 22r.

$4 \mathrm{I} 3$

I5O5, juny, 27. València.

Lluís de Cavanyelles, Governador del regne de València, comunica a Isabel Martínez de Vera i als seus fills, mossén Joan Roís de Corella -cavaller de l'orde de Sant Jaume de l'Espasa- i la donzella Estefania Roís de Corella, que davant la seua cort s'ha presentat el notari Miquel Valero, com a procurador del noble don Baltasar de Castellví, i ha reclamat 300 sous deguts de la paga del 25 de juny d'un violari carregat per Isabel i els seus fills al dit Castellví. Aquest violari havia un valor de 600 sous iva ser carregat el 25 de juny de 1502 davant el notari Joan Masó.

El18 de juny de 1505, un porter de la cort de la Governació notificà a Isabel Martínez de Vera $i$ als seus, personalment, a València aquest manament executori. Atés que Isabel i els seus no havien pagat el deute, Valero demana el g de juliol següent que s'ejecutara el deute en béns dels deutors. Eixe mateix dia, un porter anà a una casa a Meliana on figurava viven Isabel $i$ els seus fills i "no fonch trobat res". Posteriorment, el 31 de juliol el notari Jaume Pellicer-procurador de Baltasar de Castellví- esmentà davant la cort, com a béns d'Isabel i els seus fills, el lloguer o propietat d'algunes terres i cases -sota directa senyoria de Berenguer Amalric, a cens de 7 sous-situades totes elles en Meliana, i la propietat o lloguer d'una casa a la parròquia de Sant Martí "en lo carrer apellat de Sent Vicent confrontada ab lo portal de Sent Vicent, ab lo mur carrera pública en mig, e ab lo portal de la sglésia de Sent Agostí carrera pública en mig e ab casa de na Margarita Bou".

El zo d'agost un porter anà "a la casa dels obligats e, essent en aquella, no foren trobats béns alguns". Posteriorment, el 10 de setembre de 1505 el porter Pasqual Bernabeu anà a la casa del carrer de Sant Vicent on, a preguntes seues, una dona-probablement Estefania Roís de Corella-contestà "que la alqueria no és sua ni sap si la casa és sua".

372. Document esmentat en Almiñana 1984-85, 4II. Segons consta en aquest mateix document, hom el notificà personalment a Dalfina el to d'abril. 
$\mathrm{ARV}$, Governació, no. 228 , mà 45 , f. $25^{\mathrm{rv}}{ }^{373}$

$4 \mathrm{I} 4$

I5O5, juliol, II. València.

El notari Miquel Valero, com a procurador de Miquel Joan Monyino, reclama davant el Justícia Civil de València les quantitats degudes per la paga de juny de zoo sous de violari que, per escriptura notarial rebuda pel notari Jeroni Matalí el 16 de juny de 1502, Joan Roís de Corella, cavaller de l'orde de Sant Jaume de l'Espasa, Isabel Martínez de Vera i el flequer Domingo Pujol vengueren i carregaren a Monyino. El 12 d'agost de 1505 un porter i un notari es presentaren, a petició de Miquel Valero, a casa del flequer Pujoli li embargaren béns per valor de 15 lliures. ${ }^{374}$

ARV, Justícia Civil, no. 26r3, mà IO, f. 37r.

$4 \mathrm{I} 5$

I5O5, juliol, I5. València.

Lluís de Cavanyelles, Governador del regne de València, comunica a Isabel Martínez de Vera i als seus fills, mossén Joan Roís de Corella -cavaller de l'orde de Sant Jaume de l'Espasa-i la donzella Estefania Roís de Corella, que davant la seua cort s'ha presentat el notari Pere Calamocha, com a procurador del cavaller Nicolau Ferrando -tutor, curador i pare de Joan Jeroni Ferrando, fill i hereu de sa mare Beatriu Ferrer-, i ha reclamat 233 sous i 4 diners deguts de les pagues de desembre i juny d'un censal carregat per Isabel i els seus fills al dit Nicolau Ferrando "per obs del dit hereu [Joan Jeroni Ferrando]". Aquest censal havia un valor total de 233 sous i 4 diners i va ser carregat el 16 de desembre de 1501 davant el notari Pere Andreu.

El dia 22 de setembre de 1505 el notari Pere Calamocha, atenent que "Isabel Martínez alias de Vera" no havia pagat el deute esmentat i tampoc havia respost al requeriment del Governador del regne, demanà que "tots los béns mobles e semovents de la casa de aquella [...] ésser scrits e, aprés, venuts e dels preus de aquella ésser feta paga al dit seu principal". Tot seguit, Calamocha "offir, expon e met venal com a béns de aquella [Isabel Martínez de Vera] hun alberch situat e posat en lo carrer de Sent Vicent, davant la porta de Sent Agostí, està en la parròquia de Sant Martí tengut sota directa senyoria d'en [en blanc] a recens de do-ents XXXIII sous, IIII diners los quals se poden luir e quitar per preu de tres milia e cinch-cents sous si e segons se conté en lo dit manament executorifet en vostra cort a XV de joliol prop passat. Lo qual dit alberch e loguer de aquell requer ésser scrit e subastat per lo temps en lo fur statuhït e, aprés legítima subastació axí del dit loguer com del del.l [sic] alberch, ésser feta paga al dit seu principal de les dites quantitats, penes e messions". Aquesta petició va ser acceptada pel Governador que "provehí e manà que lo dit alberch e loguer de aquell sia scrit e adnotat e mès en libre de corredor, segons forma de fur statuhit".

ARV, Governació, no. 228 , mà 5 o, f. 24 rv.

373. Document esmentat en Almiñana I984-85, 4I3 però indicant que la mà és la 35 . 374. Document esmentat en Almiñana I984-85, 407. 
$4 \mathrm{I} 6$

I5O5, juliol I6. València.

Jeroni Moresc, procurador del noble Lluís Lladró-curador dels béns de la seua esposa Violant de Próxita-, reclama, davant la cort de la Governació del regne de València, el pagament, per Isabel Martínez de Vera i els seus fills Joan i Estefania Roís de Corella, de les pensions degudes de 100 sous de violari.

ARV, Governació, no. 228, mà 49, f. I2r. ${ }^{375}$

$4 \mathrm{I} 7$

I5O5, desembre, 3. València.

Lluís de Cavanyelles, Governador del regne de València, es dirigeix a Isabel Martínez de Vera, mossén Joan Roís de Corella-cavaller de l'orde de Sant Jaume de l'Espasa-i a Estefania, donzella filla d'Isabel, i els informa que el notari procurador del noble Lluís Lladró-en son nom propi i com a curador de Violant de Próxita, esposa seua- li ha mostrada una escriptura notarial rebuda el 26 d'abril de 1502 pel notari Damià Burgal segons la qual Isabel i els seus fills carregaren a misser Baltasar de Gallach, doctor en lleis i curador de Violant de Próxita, un total de 100 sous anuals de violari per a obs de la dita curadoria. El procurador de Lluís Lladró els reclama judicialment un total de 50 sous deguts de la paga d'octubre de 1505. El 1o de desembre es va lliurar aquesta notificació judicial a Pere Boredà, notari procurador d'Isabel Martínez de Vera.

ARV, Governació, no. 232, f. $35^{\text {r. }{ }^{376}}$

$4 \mathrm{IO}$

I5O5, desembre, 3 . València.

Lluís de Cavanyelles, Governador del regne de València, es dirigeix a mossén Joan Roús de Corella - comanador i cavaller de l'orde de Sant Jaume de l'Espasa- i al cütadà Joan Borrell i els informa que el notari Jerònim Navarro, procurador del noble Bernat de Rüusec-espòs d'Àngels Perpinyà- li ha mostrada una escriptura notarial rebuda el 26 de febrer de 1502 pel notari Francesc Vilar segons la qual ells vengeren a Àngels Perpinyà i als seus un total de 6o sous anuals de violari. El procurador de Bernat de Rüsec els reclama judicialment un total de 120 sous deguts de pensions.

ARV, Governació, no. 232, f. $35^{\text {r. }}{ }^{377}$

$4 \mathrm{I} 9$

I506, gener, 7. València.

Lluís de Cavanyelles, conseller reial i Governador General del regne de València, es dirigeix al mestre Daniel de Conca, obrer de vila, i a Joana, La seua esposa, a Antoni Alegret, fuster, a Pere Limós, peraire, i a Joan Bubesgues, pedrapiquer, i els comunica que Jeroni Morest, com a procurador

375. Document esmentat en Almiñana 1984-85, 407 . 376. Document esmentat en Almiñana 1984-85, 413. 377. Document esmentat en Almiñana 1984-85, 407. 
de Dalfina Roís de Corella, vídua, li ha mostrada una "carta" pública executòria amb submissió de for feta el 9 de novembre de 1490 segons la qual els esmentats vengueren i carregaren a Dalfina un violari anual per valor de 65 sous i 8 diners. Morest els reclama un total de 32 sous, 15 diners deguts de la paga del mes de novembre d'aquest violari.

ARV, Governació, no. 235, mà 2, f. I6r.

$42 \mathrm{O}$

I5o6, gener, 28. València.

Isabel Martínez de Vera, vídua [sic], ven a Joan Caulet, llibreter veí de València, per 4 lliures, 5 diners "tota la part dels libres que ella té en una ceda feta de mà del dit Caulet". Entre ells llibres esmentats en dita "ceda" figuren seixanta "Cartoixans", tres "Flors de virtuts", un "Vita Christi", quatre salteris en grec, una "Summa angelica", un "Ysopet", un "Compendio theologia", dos "Bernardos ad sororem", dotze hores franceses i un "Tirant lo Blanc". Aquests llibres eren d'Isabel Martínez de Vera, de Jerònim Pérez i de Bertomeu de Cars.

Isabel ven a Caulet la seua part "ab XXXV Cartoxans propris de la dita senyora los quals stan ab los dessús dits libres en una caxa que s tanca en manera que no.s veu on se ha de posar la clau si no.n saben. E si los dits XXXV Cartoxans no són en la dita caxa que, en tal cars, los dits Cartoxans no sien venuts sinó que sien de la dita senyora a on se vulla que sien e, si ni ha més dels dits XXXV Cartoxans en la dita caxa, que sien de la dita senyora".

ARV, protocols, no. II25, not. Mateu Gil.

$42 \mathrm{I}$

I506, maig, I5. València.

Isabel Martínez de Vera, vídua [sic], reconeix a Joan Caulet, llibreter veí de València, que es troba satisfeta de les quantitats que ell li devia d'acord amb un contracte establit entre ells dos en raó de certs exemplars del Segon del Cartoixà i d'altres objectes propietat d'Isabel que estaven en dos caixes que viatjaren a Nàpols i que, després de tornar a València, ara tenia Caulet en el seu poder.

ARV, protocols, no. II25, not. Mateu Gil.

422

I506, maig, I5. València.

Els jurats de València atorguen a Joan Roís de Corella, fill del cavaller i mestre en teologia Joan Roís de Corella, una concessió en exclusiva per a poder imprimir, durant espai de dos anys, una "bella obra sobre los Passis" que havia escrit son pare. Cap altra persona no podria imprimir-la sota pena de 10 lliures "e perdre la dita obra".

AMV, Manuals de Consells, A-53, f. I49v. ${ }^{378}$

Dicto die [divendres 15 de maig de 1506]

378. Document donat a conéixer per Carreres (I949, 625-626), però amb una transcripció parcial i defectuosa i, sobretot, amb una data i una localització arxivística errònies. 
Los magnífichs jurats et síndic [... $]^{379}$ en Johan Alegre, attenent que lo reverent mossén Johan Corella, quòndam, féu e ordenà una bella obra sobre los Passis, la qual lo fill de aquell vol fer estampar, per ço proveexen que nengú altre sinó aquell stampar e fer stampar aquella dita obra dins terme de dos anys, sots pena de X lliures e perdre la dita obra.

Testimonis, Agostí Mo[n]yós e Johan Noguera.

I506, juny, I7. València.

Lluís de Cavanyelles, conseller reial i Governador General del regne de València, es dirigeix a Isabel Martínez de Vera, al seu fill mossén Joan Roís de Corella -cavaller de l'orde de Sant Jaume de I'Espasa-i a Joan Borull, ciutadà, i els comunica que Nicolau de Bas, notari procurador de Brianda de Vilaragut i de Centelles-muller de Joan de Sentlir Centelles-, li ha mostrat una carta pública executòria amb submissió de for feta el 16 d'abril de 1504 davant el notari Joan Bas segons la qual Isabel, el seu fill i Borrull vengueren i carregaren a Brianda i als seus un violari anual per valor de 150 sous. Nicolau de Bas els reclama un total de 150 sous deguts de la paga del darrer mes d'abril.

ARV, Governació, no. 244, f. 2 r.

424

I5O7, agost, II. València.

Lluís de Cavanyelles, conseller reial i Governador General del regne de València, es dirigeix a Isabel Martínez de Vera i li comunica que Joan Alcanyis, notari procurador del noble don Lluís Lladró, li ha mostrat una carta pública executòria amb submissió de for feta el 24 de gener de 1506 davant el notari Pere Mercador segons la qual Isabel carregà a Lluís Lladró i als seus un censal per valor de 57 lliures i 10 sous. Alcanyís reclama a Isabel un total de 57 sous de pagues degudes.

ARV, Governació, no. 246, mà 5I, f. 2 or.

425

I5O 7 , agost, 20. València.

Lluís de Cavanyelles, conseller reial i Governador General del regne de València, es dirigeix a Isabel Martínez de Vera i als seus fills Joan i Estefania Roís de Corella i els comunica que Joan Çaburgada, notari procurador del cavaller Nicolau Ferrando - pare i legítim administrador del seu fill Joan Jeronim Ferrando-, li ha mostrat una carta pública executòria amb submissió de for feta el 16 de desembre de 1506 davant el notari Pere Andreu segons la qual Isabel i els seus fills carregaren a Nicolau Ferrando, a la seua esposa Beatriu Ferrando i als seus descendents un censal per valor de 233 sous i 4 diners. Çaburgada reclama a Isabel un total de 14 lliures i 7 sous de pagues degudes. Per a pagar aquest deute, el procurador de Ferrando sol.licita la subhasta, com a béns d'Isabel Martínez de Vera, d'una casa situada a la parròquia de Sant Martí, en el carrer de Sant Vicent, prop de la porta de la muralla i que estava sota el domini directe de l'abat de Montaragó a cens de 14 sous anuals $i$ a recens de 233 sous i 4 diners a Joan Jeroni Ferrando. Aquesta casa "confronta ab alberch de na

379. Paraula abreujada de lectura dificultosa. 
Margarida Bou de Monsoriu, ab lo mur e carrer en mig, e, a les spales, ab altre carrer del dit mur" ARV, Governació, no. 246 , mà 53 , f. 25 rv. ${ }^{380}$

ARV, Governació, no. 254, f. I677v.

426

I508, setembre, I4. València.

El Governador General del regne de València es dirigeix a Isabel Martínez de Vera, als seus fills Joan Roís de Corella i Estefania, i a Joana Martínez de Vera i els comunica que el procurador d'Isabel de Castellví ha interposat davant la seua cort una reclamació en raó de la manca de pagament de la paga de gener corresponent a un censal de 240 sous que ells varen carregar, davant el notari Joan Mascó, el 20 de gener de 1506 al doctor en lleis Joan Cirera.

ARV, Governació, no. 253, f. IO5r.

427

I509, gener, 8. València.

Lluís de Cavanyelles, conseller reial i Governador General del regne de València, es dirigeix a Isabel Martínez de Vera, ${ }^{381}$ a mossén Joan Roís de Corella -cavaller de l'orde de Sant Jaume de l'Espasa-i a Estefania Roís de Corella, fills d'ella, i els comunica que Lleonard Almenar, notari procurador del noble Lluís Lladró, li ha mostrat una carta pública executòria amb submissió de for feta el 28 d'abril de 1502 davant el notari Damià Burgal segons la qual els esmentats vengueren i carregaren a misser Baltasar de Gallach, doctor en lleis, com a curador de la noble Violant de

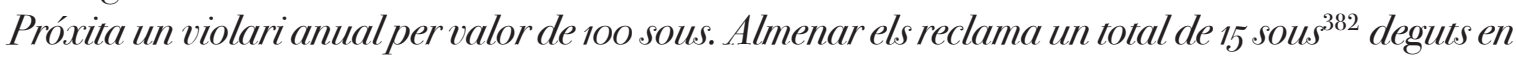
raó d'aquest violari. Per ordre del Governador General, el porter Pedro Delgado anà a casa d'Isabel Martínez de Vera i escripturà els següents béns: "Primo, en lo studi de la dita casa, hun mig coffre pintat buyt e una stora d'espart de peus e hun matal-lafet chich de lana ple. Item, en la entrada, hun pagès, altra stora d'espart, dos cadires de costelles. Diu la dita na Ysabel que són de na Lorisa, e l'altra roba és d'ella. La qual fonch scriturada en XV sous e acomanada ab jurament a la dita na Ysabel Martines [...] Requer e protesta na Joana Martines que los dits béns e altres són de sa filla Elena, donzella, ab acte reebut per en Francesc Valero, notari, lo primer dia de març any DVT'. El 13 de març de 1509, per ordre del Governador, el corredor de la cort Pere Mercer va vendre per 15 sous "hun mig coffre pintat, huna stora d'espart de peus e hun mattalafet chich de llana, hun pagès de fust e huna altra estora d'espart e dos cadires de costelles, com a béns de la dita na Ysabel Martines de Vera, al discret en Francesc Valero, notari [...] per fer pagua al dit noble don Luís Ladró"

ARV, Governació, no. 257, mà 2, f. 39rv.

428

I509, febrer, I. València.

380. Document esmentat en Almiñana 1984-85, 413.

38r. En el f. 39r se l'anomena Isabel Martínez àlies de Vera.

382. En el f. 39 r es diu I5 lliures però, tot seguit, sempre figura la quantitat de I5 sous.

Magnificat CLM I, 2OI4, III-377. ISSN 2386-8295 
Lluís de Cavanyelles, conseller reial i Governador General del regne de València, es dirigeix a Isabel Martínez de Vera, a la seua germana Joana Martínez de Vera i a mossén Joan Roús de Corella - comanador de l'orde de Sant Jaume de l'Espasa - i Estefania Roís de Corella, fills d'Isabel, i els comunica que Miquel Sart, notari procurador de la noble Anna Isabel de Castellví, li ha mostrat una carta pública executòria amb submissió de for feta el 20 de gener de 1506 davant el notari Joan Mascó segons la qual ells vengueren i carregaren, al doctor en lleis. Joan Cirera i als seus, 240 sous censals.

Miquel Sart els reclama un total de 240 sous deguts en raó de la paga del 20 de gener de 1509 d'aquest violari. El 7 de febrer de 1509, per ordre del Governador, un porter de la cort lliurà personalment la reclamaciójudicial a Joana i Isabel Martínez de Vera.

ARV, Governació, no. 257, mà IO, f. 37r.

I509, juliol, I8. València.

Lluís de Cavanyelles, conseller reial i Governador General del regne de València, es dirigeix a Isabel Martínez de Vera i als seus fills Joan Roís de Corella -cavaller de l'orde de Sant Jaume de l'Espasa-i Estefania Roís de Corella, i els comunica que Miquel Sisternes, notari procurador del cavaller Nicolau Ferrando - pare i legítim administrador de Joan Jerònim Ferrando, fill seu i de la seua difunta esposa Beatriu Ferrer, li ha mostrat una carta pública executòria amb submissió de for feta el 12 de desembre de 1501 davant el notari Pere Andreu segons la qual Isabel i els seus fills vengueren i carregaren Nicolau Ferrando i als seus, 233 sous i 4 diners censals. Miquel Sisternes els reclama un total de 5 lliures, 16 sous i 8 diners sous deguts en raó de la paga de juny de 1509.

Per a pagar aquest deute el procurador de Ferrando sol-licita la subhasta, com a béns d'Isabel Martínez de Vera, d'una casa situada a la parròquia de Sant Martí, en el carrer de Sant Vicent, prop de la porta de la muralla i que estava sota el domini directe de l'abat de Montaragó a cens de 14 sous anuals i a recens de 233 sous, 4 diners a Joan Jeroni Ferrando. Com, en dies passats, el noble Lluís Lladró havia demanat a la cort del Governador que aquesta casa d'Isabel també fóra subasthada, el procurador de Nicolau Ferrando demana que no es fera eixa subhasta sense tenir en compte els drets del seu representat.

ARV, Governació, no. 26I, f. I89r.

I5², juliol, 5. València.

Miquel Pérez, ciutadà de València i gendre de l'escriptor Joan Roís de Corella, arrenda a Pere Arbones $i$ Joan Jovell una alqueria i certes terres que ell havia a Campanar per 4 olliures anuals i un periode de quatre anys. Entre les condicions de l'arrendament figura que Miquel Pérez es reserva la possibilitat d'anul.lar l'arrendament per a vendre l'alqueria i les terres.

RCSCCV, protocols, no. II279, not. Jaume Albert.

I5I2, setembre, II. València.

Demanda hipotecària del plater Miquel Roig i Joana-vídua del notari Mateu Iviça-contra els 
fills i hereus de Saragossa -hereus del difunt notari Martí de Roda-en raó de la injusta possessió d'una casa i hort ubicat en el carrer de Santa Maria de Gràcia que Isabel Martínez de Vera i els seus fills veneren a Roda, el 13 de setembre de 1504 davant el notari Beromeu Iviça, per a quitar 200 sous de recens sobre la dita casa i hort, carregats per ells al ciutadà Bertomeu de Cruïlles. La casa, sota directa senyoria del difunt Bertomeu de Crü̈lles i ara de sa filla Magdalena de Crü̈lles, afrontava, en 1502, amb la casa de "na Johana Martines de Vera, beata, e huy, del noble don Baltazar de Castellví, de una part, e de l'altra part, ab casa del rector de Sant Thomàs, ab carrera pública de la Verge Maria de Gràcia, e l'ort, ab les matexes afrontacions, e a les spal.les, ab carrer dels Sans".

$\mathrm{ARV}$, Justícia Civil, no. 3804 , mà 4 , ff. $34 \mathrm{r}^{-} 37^{\mathrm{v}}{ }^{383}$

432

I5I6, juliol, 20. València.

Miquel Pérez, ciutadà de València i gendre de l'escriptor Joan Roís de Corella, reconeix a Joan Jovell el lliurament de 4 o lliures en raó de l'arrendament anual d'una alqueria i certes terres que ell havia a Campanar i que, en 1512, Pérez havia arrendat a Jovell $i$ a Pere Arbones.

RCSCCV, protocols, no. II28I, not. Jaume Albert.

383. Document esmentat per Riquer I964, 3, $25^{8}$ que el data en abril de I4I2. 
5 Arbres genealògics

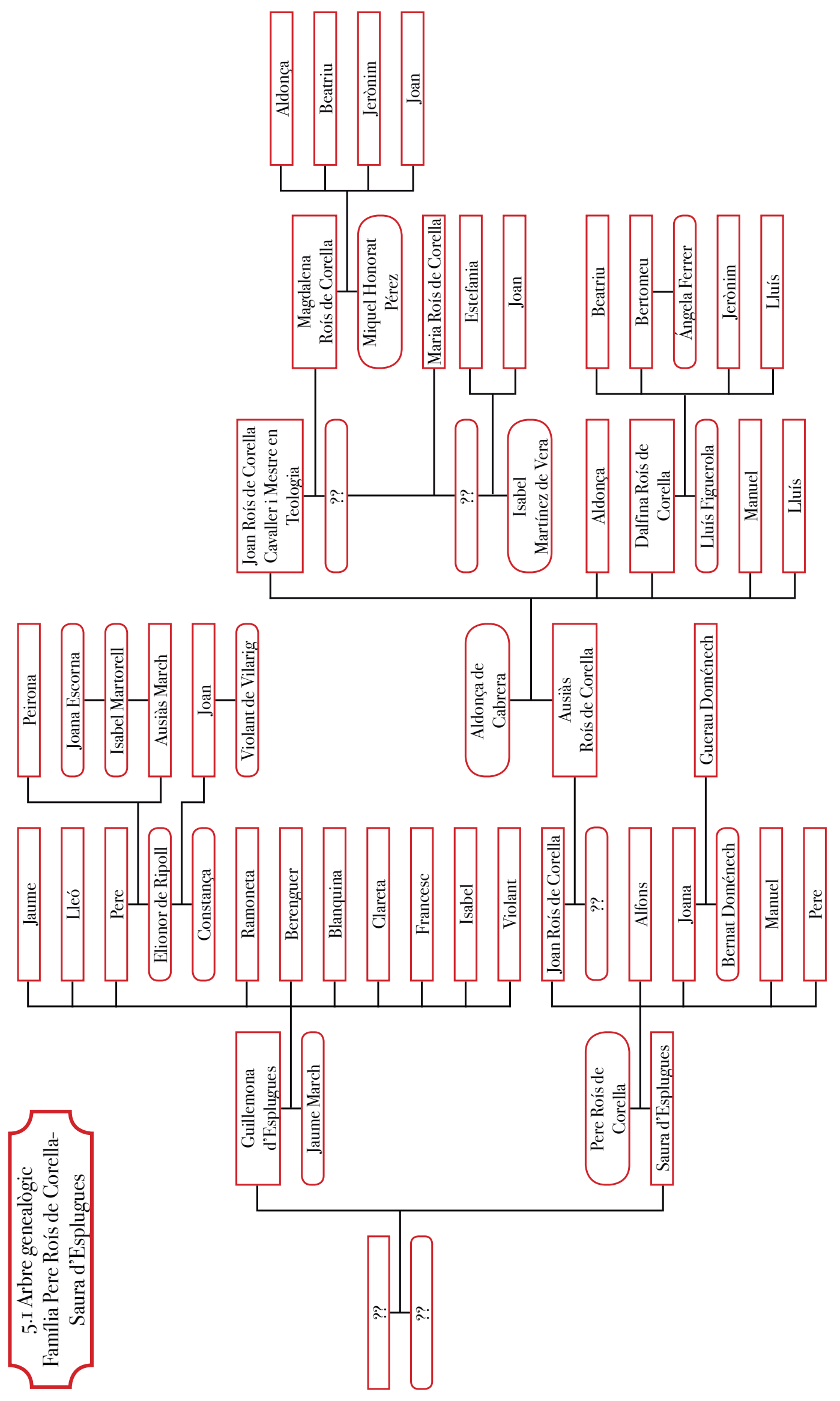

Magnificat CLM I, 2OI4, III-377. ISSN 2386-8295 


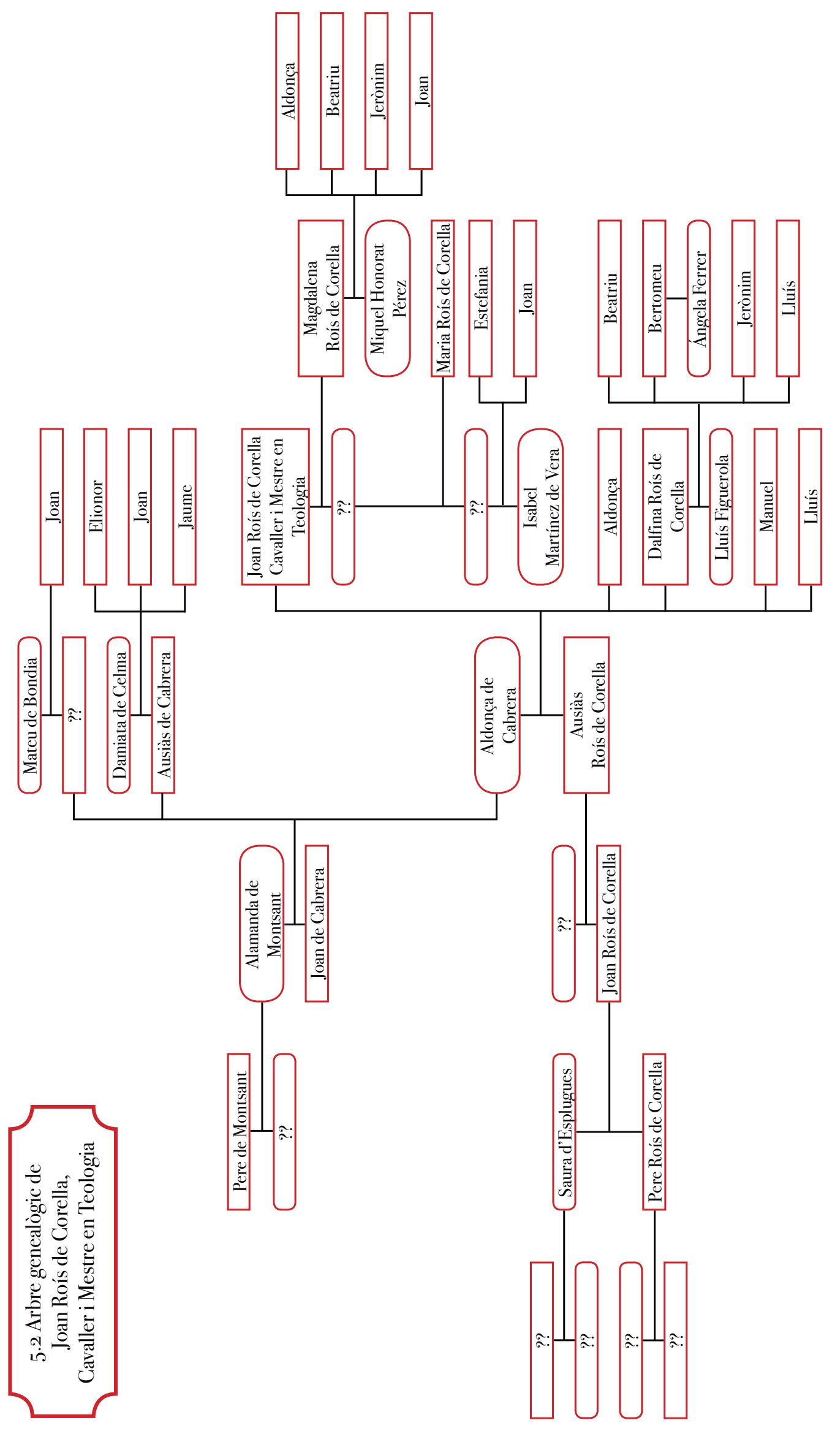

Magnificat CLM I, 2OI4, III-377. ISSN 2386-8295 

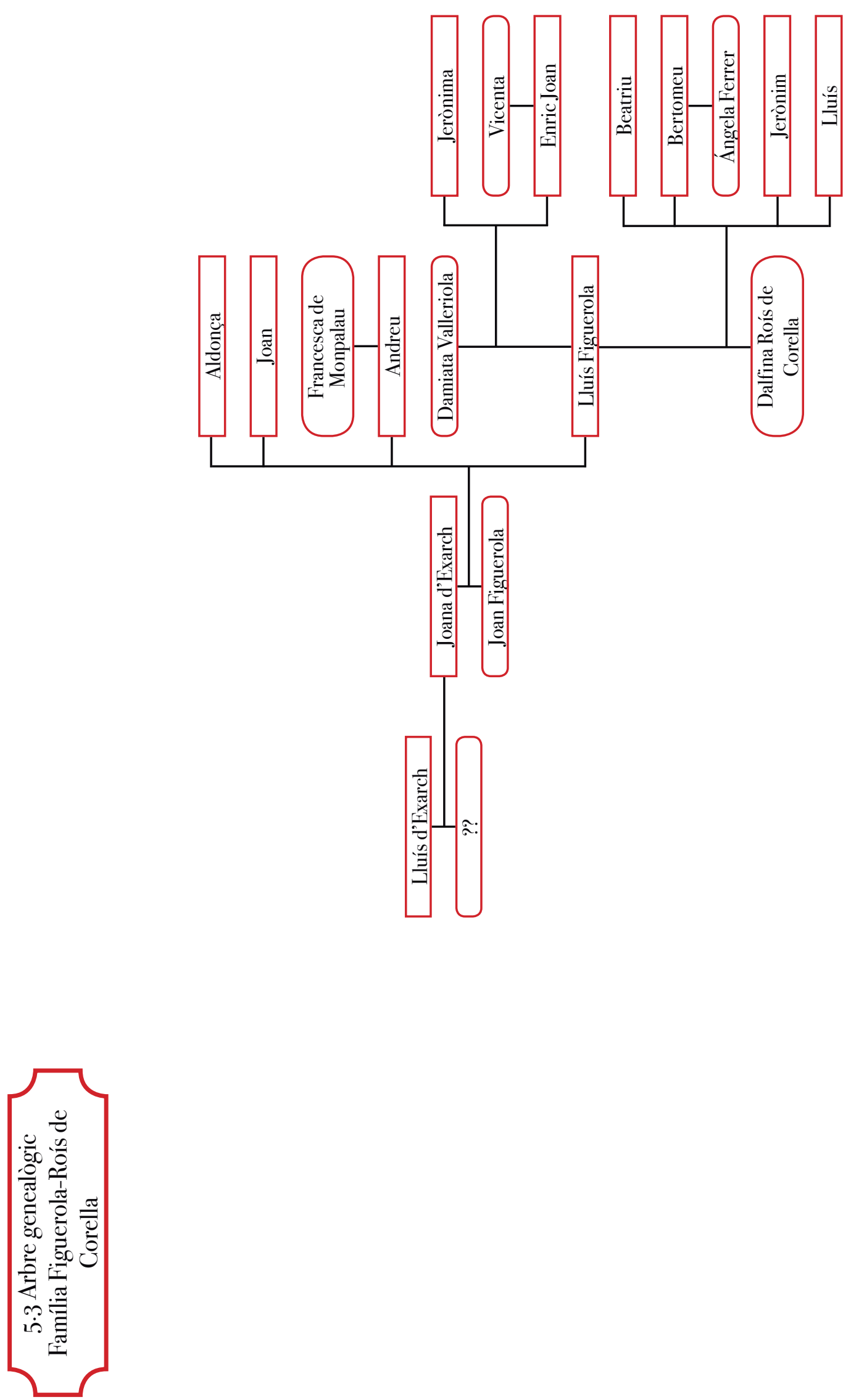


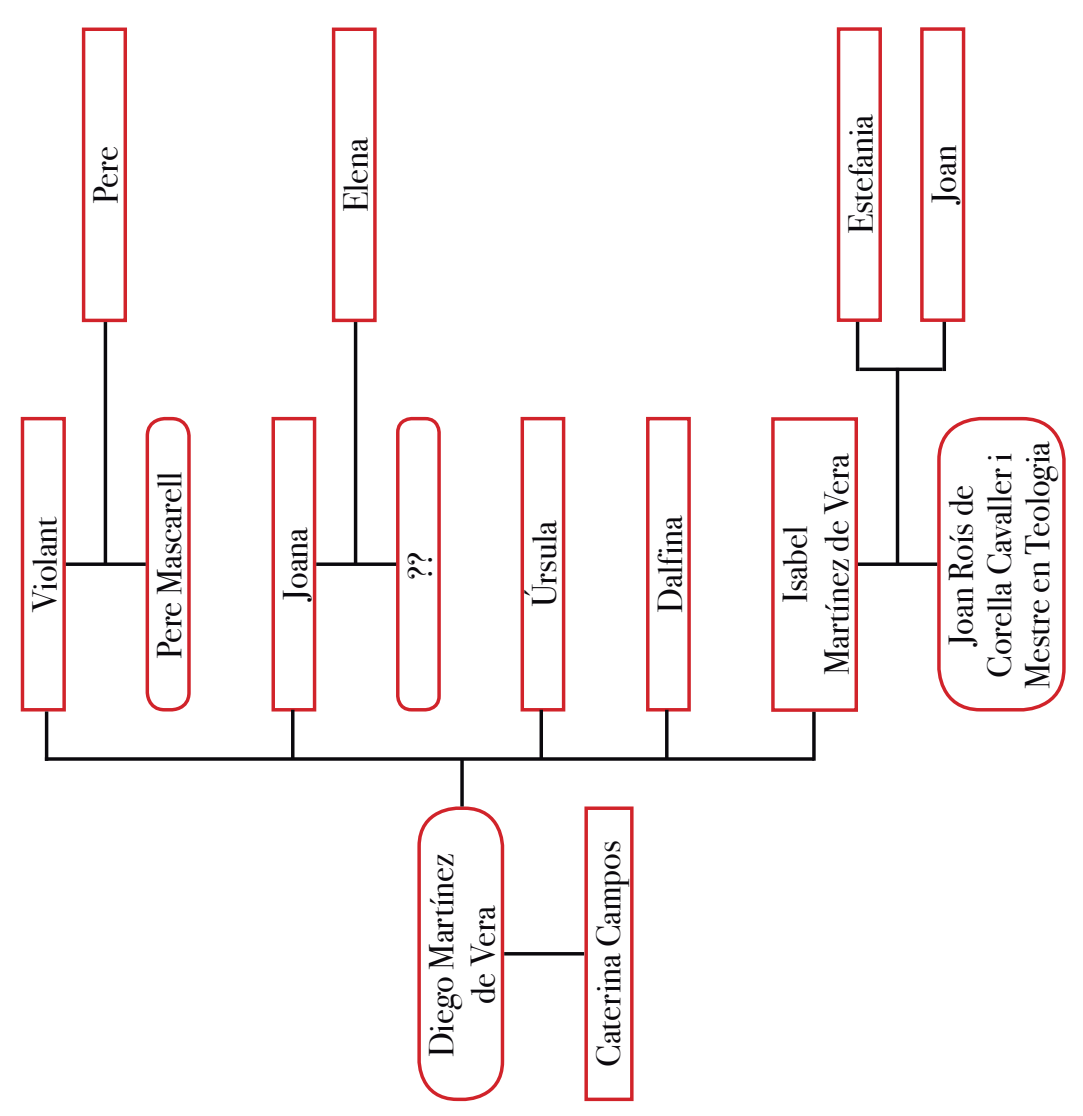

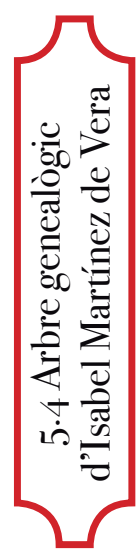



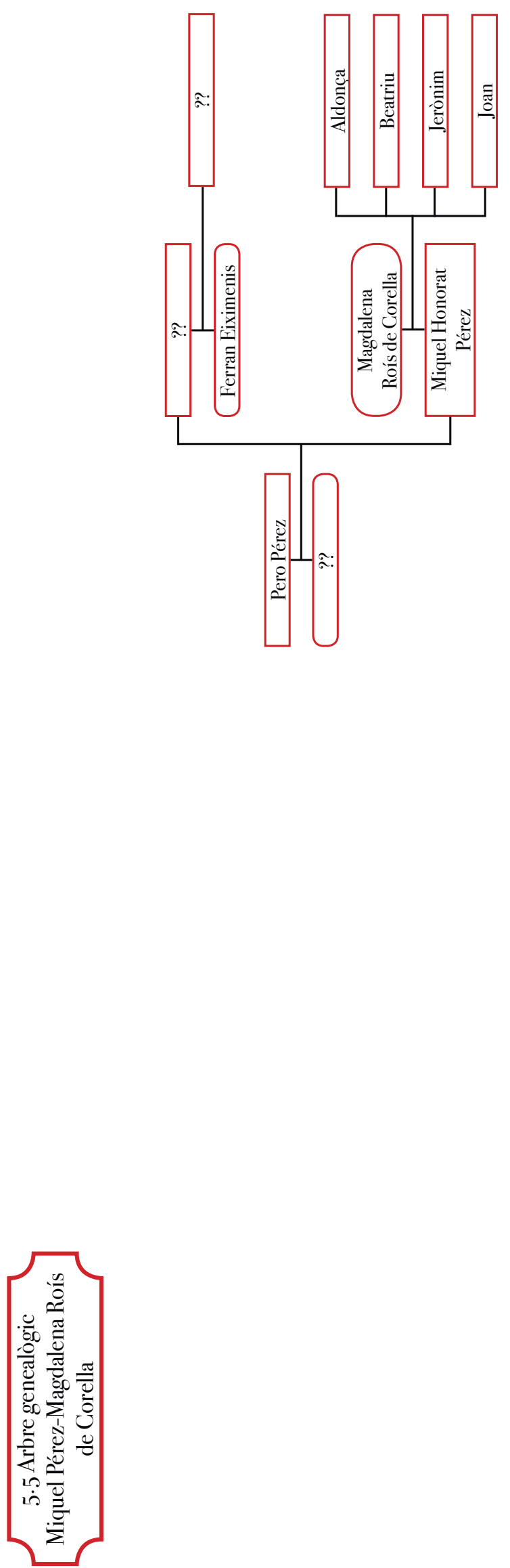


\section{Obres citades}

Almiñana Vallés, Josep, ed., 1984-85, Obres de Joan Roiç de Corella: edició facsímil del manuscrit de Mayans, vol. 2, València, Del Cénia al Segura.

Anzizu, Eulàlia, I897, Fulles històriques del Reial Monestir de Santa Maria de Pedralbes, Barcelona, Estampa de F. Xavier Altés.

Argente Vidal, Javier, I987, "Un libro de cuentas de las morerías del condado de Denia (I379)", Boletín de la Sociedad Castellonense de Cultura 63, 285-89.

Arronis Llopis, Carme, 20I2, La vida de la sacratíssima verge Maria, de Miquel Pérez: estudi $i$ edició, tesi doctoral, Alacant, Universitat d'Alacant.

Badia, Lola, I988, “'En les baixes antenes de vulgar poesia': Corella, els mites i l'amor”, al seu De Bernat Metge a Joan Roús de Corella, Barcelona, Quaderns Crema, I45-80.

Batllori, Miquel, r994, La família Borja, València, Tres i Quatre.

Belenguer Cebrià, Ernest, 20I2, Fernando el Católico y la ciudad de Valencia, València, Universitat de València.

Bellreguard = Ajuntament de Bellreguard, 20I4, "Història de Bellreguard", http://www. bellreguard.org/web/guest/historia (checked I4/II/2OI4).

Benito Goerlich, Daniel, ı998, El real monasterio de la Santísima Trinidad, València, Consell Valencià de Cultura.

Botinas i Montero, Elena; Cabaleiro i Manzanedo, Júlia; Duran i Vinyeta, Maria dels Àngels, 2002, Les beguines, Barcelona, Publicacions de l'Abadia de Montserrat.

Cabanes Pecourt, María de los Desamparados, 2008, Avecindados en la ciudad de Valencia en la época medieval: Avehinaments (1308-1478), València, Ajuntament de València.

Camarena Mahiques, José, I959-6r, Colección de documentos para la historia de Gandía y su comarca, vol. I, fascicle 3 .

Cantavella, Rosanna, I997, "Dames a l'aigua: el tema del debat entre el príncep de Viana i Joan Roís de Corella”, Anuari de l'Agrupació Borrianenca de Cultura 8, 37-45.

Carbonell, Jordi, I955-56, "Sobre la correspondencia literaria entre Roís de Corella i el Príncep de Viana”, Estudis Romànics 5, I27-39.

Carreres de Calatayud, Francisco de A., I949, "Noticias referentes a diversas obras literarias", Boletín de la Sociedad Castellonense de Cultura 35, 624-28.

Carreres Zacarés, Salvador, ed., I930-35, Libre de memories de diversos sucesos i fets memorables e de coses senyalades de la ciudad e Regne de Valencia (1308-1644), València, Acción Bibliográfica Valenciana, 2 vols.

Caruana Reig, José (Barón de San Petrillo), I932, Los Próxita y el estado de Almenara, València, Tipogr. Domènech.

Caruana Reig, José (Barón de San Petrillo), I94O, Las casonas solariegas, València, Tipogr. 
Domènech.

Castellano i Tresserra, Anna, 2003, "Les 'reformes' del monestir de Pedralbes al llarg dels segles XVI i XVII", Pedralbes 23, 72I-34.

Chabàs, Roque, I896, El altar de plata de la Catedral de Valencia, València, Imprenta de Francisco Vives Mora.

Chiner Gimeno, Jaume J., I99I, “El III Duque de Liria y su toma de posesión en I738”, Lauro 5, 77-IOO.

Chiner Gimeno, Jaume J., I992, "Batalla a ultrança per Joanot Martorell”, A sol post: Estudis de Llengua i Literatura 2, 83-І27.

Chiner Gimeno, Jaume J., I993, El viure novel-lesc: biografia de Joanot Martorell amb un fragment d'un manuscrit del "Tirant lo Blanc", Alcoi, Marfil.

Chiner Gimeno, Jaume J. I993-94, "Del testamento e inventario de bienes de Jaume Roig al autor del manuscrito del Spill: documentos y nuevas hipótesis", Boletín de la Real Academia de Buenas Letras de Barcelona 44, $175^{-2} 3^{2}$.

Chiner Gimeno, Jaume J., I994a, "Prevención y peste en la Valencia del siglo Xv: unas ordenanzas de I483" dins 1490 en el umbral de la modernidad: Mediterráneo europeo y las ciudades en el tránsito de los siglos XV-XVI, vol. 2, València, Consell Valencià de Cultura, 25-34.

Chiner Gimeno, Jaume J., I994b, “Aportació a la biografia de Joan Roís de Corella: noves dades sobre el seu naixement i la seua mort”, Caplletra I5, 49-62.

Chiner Gimeno, Jaume J., I997, Ausiàs March i la València del segle XV (140O-1459), València, Consell Valencià de Cultura.

Chiner Gimeno, Jaume J., I998, "Introducció” a Ludolphus de Saxonia Lo Quart del Cartoixà, aromançat per Johan Roiç de Corella, València, Ajuntament de València.

Chiner Gimeno, Jaume J., 20I3, "Joan Roís de Corella (l’autor)", dins Biblioteca Virtual Joan Lluís Vives, http://tinyurl.com/04jh7cj(checked 22-II-2OI4).

Cingolani, Stefano M., I998, Joan Roís de Corella: la importància de dir-se honest, València, Tres i Quatre.

Colón, Germà; Garcia, Arcadi, ed., I990, Furs de València, vol. 5, Barcelona, Barcino.

Conca, Maria; Guia, Josep, 20I2, “Obres de Corella en el Tirant lo Blanc: revisió de fonts i dates”, Catalonia II, I-33.

Cruselles, Enrique, 1989, El Maestre Racional de Valencia: función política y desarrollo administrativo del oficio público en el siglo XV, València, Alfons el Magnànim.

Cruselles Gómez, José Ma , I998, Els notaris de la ciutat de València: activitat profesional $i$ comportament social a la primera meitat del segle XV, Barcelona, Fundació Noguera.

Cuñat Císcar, Virginia Maria, 2005, "El archivo de la Casa de Alaquàs en la primera mitad del siglo XIX”, Quaderns d'Investigació d'Alaquàs 24, I9-230.

Demurger, Alain, 2005, Caballeros de Cristo: templarios, hospitalarios, teutónicos y demás ordenes militares en la Edad Media (siglos XI a XVI), Granada, Universidad de Granada.

Díaz Manteca, Eugenio, 1987, El "Libro de poblaciones" de la orden de Santa María de Montesa 
(1234-1426), Castelló, Diputació de Castelló.

Domènech, Josep Lluís; Martos, Josep Lluís; Domènech, Maria Pilar, 2OI4, Joan Roís de Corella i el seu temps, València, Acadèmia Valenciana de la Llengua.

Escartí, Vicent Josep, ed., 2OI4, Joan Roís de Corella Obra completa, València, Alfons el Magnànim.

Ferrán y Salvador, Vicente, I926, El castillo de Montesa: historia y descripción del mismo, precedida de un bosquejo histórico de la Orden Militar de Santa María de Montesa y San Jorge de Alfama, València, Imprenta Hijo de F. Vives Mora.

Ferrando Francés, Antoni, 20I3a, "Les relacions literàries de Joan Roís de Corella", Afers: Fulls de Recerca i Pensament 76, 635-59.

Ferrando Francés, Antoni, 20I3b, Sant Vicent Ferrer en la historiografia, la literatura, l'hagiografia $i$ l'espiritualitat al segle XV, València, Alfons el Magnànim.

Ferrando Francés, Antoni; Escartí, Vicent Josep, I998, “Impremta i vida literària a València en el pas del segle XV al XVI", Boletín de la Sociedad Castellonense de Cultura 74, I6I-I78.

Fullana Mira, Luis, I920, Historia de la villa y condado de Cocentaina, València, [s. n.].

Fullana Mira, Luis, I935-36, “Los caballeros del apellido March en Cataluña y Valencia: contribución documental para su estudio", Boletín de la Sociedad Castellonense de Cultura I6, 432-66; I7, IO7-72, 205-55, 297-322, 364-444.

Furió, Antoni; Mira, Antonio José; Viciano, Pau, r994, “L'entrada en la vida dels joves en el món rural valencià a finals de l'Edat Mitjana”, Revista d'Història Medieval 5, 75-Io6.

Fuster, Joan, I99I, Obres completes, vol. I: Llengua, literatura, història, Barcelona, Edicions 62.

Gallent, Mercedes, 1980, La asistencia sanitaria en Valencia (1400-1512), València, Universitat de València.

García Herrero, María del Carmen, I984, "La muerte y el cuidado del alma en los testamentos zaragozanos de la primera mitad del siglo Xv", Aragón en la Edad Media 6, 209-46.

Gavara Prior, Juan J., 2003, El plano de Valencia de Tomás Vicente Tosca (1704), València, Ajuntament de València.

Gómez-Ferrer Lozano, M. Mercedes, 1995, Arquitectura y arquitectos en la Valencia dels. XVI: el hospital generaly sus artífices, València, Universitat de València.

Gómez-Ferrer Lozano, M. Mercedes, 1998, Arquitectura en la Valencia del siglo XVI: el Hospital General y sus artifices, València, Albatros, 1998.

Gómez-Ferrer Lozano, M. Mercedes; Corbalán de Celis, Juan, 20o9, "La capilla funeraria de Joan de Vich en Valencia (I494-95): la participación de Joan Corbera, García de Vargas y Pablo Forment”, Archivo de Arte Valenciano 90, 45-53.

Graullera Sanz, Vicente, 1998, "Un jurista valenciano del siglo XV. Don Jaime García de Aguilar”, Quaderns d'Investigació d'Alaquàs I7, 9-22.

Graullera Sanz, Vicente, 2007, "La biblioteca de don Jaime García de Aguilar. La trayectoria intelectual de un jurista valenciano en el siglo XV", Quaderns d'Investigació d'Alaquàs 27, II-28.

Graullera Sanz, Vicente, 2009, Derecho y juristas valencianos en el siglo XV, València, Generalitat Valenciana. 
Guia, Josep, I999, Fraseologia i estil: enigmes literaris a la València del segle XV, València, Tres i Quatre.

Guia, Josep, 2002, "De Lo Cartoixà a l'Espill: concordances textuals i dades contextuals", Afers: Fulls de Recerca i Pensament 4I, I5I-89.

Guia, Josep, 2003, "Dades documentals d'interès literari (València, segle XV)", dins Momenti di cultura catalana in un millennio: atti del VII convegno dell'AISC, Napoli 20oo, Anna Maria Compagna Perrone, Alfonsina De Benedetto, Núria Puigdevall ed., Napoli, Liguori, vol. I, 2OI22. http://tinyurl.com/n7da2ql (checked 22-II-2OI4).

Guia, Josep, 2008, “Anotacions de Jaume Roig sobre Roderic de Borja, Joan Roís de Corella i ell mateix”, Afers: Fulls de Recerca i Pensament 6I, 625-36.

Guinot, Enric, I986, “Un precedent en la recuperació del patrimoni reial al País Valencià: la jurisdicció d'Onda, I393”, Saitabi 36, I37-53.

Hauf, Albert G., I99o, "El món cultural d'Isabel de Villena" al seu D'Eiximenis a sor Isabel de Villena: aportació a l'estudi de la nostra cultura medieval, València-Barcelona, IIFV-Publicacions de l'Abadia de Montserrat, 303-2I.

Hauf, Albert G., 1993, "Tirant lo Blanc: algunes qüestions que planteja la connexió corelliana”, dins Actes del novè Col-loqui Internacional de Llengua i Literatura Catalanes, Alacant-Elx 1991, Rafael Alemany Ferrer, Antoni Ferrando Francés, Lluís B. Meseguer ed., Barcelona, Publicacions de l’Abadia de Montserrat, vol. 2, 69-II6.

Igual, David, 2000, "La confraria dels genovesos de València: una associació interprofesional a les darreries de l'Edat Mitjana”, dins Organització del treball preindustrial: confrares i oficis, Lluís Virós i Pujolà ed., Barcelona, Publicacions de l’Abadia de Montserrat, 9I-IO2.

IIEB = Institut Internacional d'Estudis Borgians, 2006, "Formació del ducat borgià de Gandia", http://www.elsborja.org/borjao8.php (checked I4/II/2OI4).

Labarga García, Fermín, 1999, "La devoción a las Cinco Llagas y a la Sangre de Cristo en las cofradías riojanas de la Vera Cruz", Zainak I8, 381-92.

La Parra López, Santiago, 2006, "El nacimiento de un señorío singular: el ducado gandiense de los Borja”, Revista de Historia Moderna 24, 3 $3^{\mathrm{I}-66 .}$

Le Goff, Jacques; Schmitt, Jean-Claude, ed., 2003, Diccionario razonado del Occidente Medieval, Madrid, Akal.

Longère, Jean, 1983, La prédication médiévale, París, Études Augustiniennes.

Madurell Marimón, Josep Maria, I948, "Los contratos de obras en los protocolos notariales y su aportación a la historia de la arquitectura (siglos XIV-XV)", Estudios Históricos y Documentos de los Archivos de Protocolos I, I05-99.

Martínez Romero, Tomàs, I998, "Variacions sobre el tema 'Corella i els contemporanis valencians", Caplletra 24, 45-66.

Martínez Romero, Tomàs, 20I2, "Miquel Péreç i la posteritat de Corella", Revista de Literatura Medieval 24, I93-2IO.

Martínez Romero, Tomàs, 20I3, “L'obra literària de Joan Roís de Corella”, dins Biblioteca Virtual Joan Lluís Vives, http://tinyurl.com/pxg2wyq (checked 22-II-2OI4). 
Martos, Josep Lluís, ed., 20I3, Joan Roís de Corella Psalteri: edició crítica, València, Alfons el Magnànim.

Mata López, Manuel, 199I, Relación de limosnas para la construcción del monasterio de la Trinidad de Valencia, Zaragoza, Anubar.

Miranda Menacho, Vera-Cruz, 2005, "La estancia del príncipe de Viana en Mallorca (I459-I460)", Príncipe de Viana 235, 429-40.

Miranda Menacho, Vera-Cruz, 20II, El príncipe de Viana en la Corona de Aragón (1457-1461), tesi doctoral, Barcelona, Universitat de Barcelona.

Olaso Cendra, Vicent, I987, Catàleg de pergamins de l'Arxiu Municipal de Gandia (1268-1683), València, Generalitat Valenciana.

Pardo Molero, Juan Francisco, 2OI2, "Con maduro consejo: la carrera pública de Eximén Pérez de Figuerola”, dins Oficiales reales: los ministros de la Monarquía Católica (siglos XVI-XVII), Juan Francisco Pardo Molero, Manuel Lomas Cortés ed., València, Universitat de València.

Parisi, Iván, 2009a, "Els Escrivà, parents dels Borja: una continuació”, Revista Borja 2, 55-79.

Parisi, Iván, 2009b, "La verdadera identidad del comendador Escrivà, poeta valenciano de la primera mitad del siglo XVI", Estudis Romànics 3I, I4I-62.

Perea Rodríguez, Óscar, 2007, Estudio biográfico sobre los poetas del “Cancionero general”, Madrid, CSIC.

Pérez de Heredia y Valle, Ignacio, I994, Sínodos medievales de Valencia: edición bilíngüe, Roma, Instituto Español de Historia Eclesiástica.

Piles Ros, Leopoldo, I978, La población de Valencia a través de los Llibres de Avehinament, 14001449, València, Ajuntament de València.

Rabassa i Vaquer, Carles; Selma i Castell, Sergi, I994, "L'agregació del Molinell a Culla en I4II i l'inici d'un nou hidraulisme", dins Imatge de Culla: estudis recollits en el 750 aniversari de la carta de població (1244-1994), vol. 2, Culla, Comissió de Cultura de Culla per al 75 o Aniversari de la Carta de Població, 537-72.

Revest Corzo, Luis, 1952, "El epitafio de Perot Penyarroja", Anales del Centro de Cultura Valenciana 20, $173-80$.

Riquer, Martí de, I964, Història de la literatura catalana, vol. 3, Barcelona, Ariel.

Roca Traver, Francisco A., I973, "Pedro Juan Belluga", Estudios de la Edad Media de la Corona de Aragón 9, IOI-59.

Rodrigo Lizondo, Mateu, I975, "La Unión valenciana y sus protagonistas”, Ligarzas 7, I33-66.

Rodrigo Lizondo, Mateu, ed., 20II, Melcior Miralles Crònica i dietari del capellà d'Alfons el Magnànim, València, Universitat de València.

Rodríguez Risquete, Francisco J., 2002, "Del cercle literari del Príncep de Viana i unes poesies satiriques del Cançoner de Saragossa”, Estudi General 22, 365-9I.

Rodríguez Risquete, Francisco J., 2003, Vida y obra de Pere Torroella, Girona, Universitat de Girona.

Romeu i Figueras, Josep, I992, "Dos poemes de Joan Roís de Corella: A Caldesa i La sepultura" 
dins Miscel-lània Sanchis Guarner, vol. 3, IO9-38.

Rubio Vela, Agustín, I989, "Valencia y Torquemada: en torno a los comienzos de la Inquisición española (I482-I489)”, Boletín de la Sociedad Castellonense de Cultura 74, 77-I39.

Rubio Vela, Agustín, 2OI3, "El context històric de Joan Roís de Corella: tríptic documental sobre el seu entorn”, Afers: Fulls de Recerca i Pensament 76, 593-6I5.

Rubio Vela, Agustín, 20I4, "Joan Roís de Corella, el mundo de los caballeros y la guerra: notas de archivo sobre notas de lectura", eHumanista/IVITRA 5, 443-66.

Sales, Agustín, I76I, Historia del Real Monasterio de la Ssma. Trinidad, religiosas de Santa Clara, de la Regular Observancia, fuera los Muros de la Cüudad de València, València, Josef Estevan Dolz.

Samper, Hipólito, I669, Montesa ilustrada, primera part, València, Jerónimo Vilagrasa.

Sánchez Adell, José, I976, “La inmigración en Castellón de la Plana durante los siglos XV, XVI y XVII”, Cuadernos de Geografía I9, 67-Ioo.

Sánchez Gijón, Antonio, 1995, Pedro Luís Escrivà: caballero valenciano, constructor de castillos, València, Ajuntament de València.

Sanchis Sivera, José, I9o9, La Catedral de Valencia: guía histórica y artística, València, Francisco Vives Mora.

Sanchis Sivera, José, 1922, Nomenclator geográfico-eclesiástico de los pueblos de la diócesis de Valencia, València, Tipografia Moderna.

Sanchis Sivera, José, I93I-32, "Bibliología valenciana (siglos XV, XVI y XVII)", Anales del Centro de Cultura Valenciana 4, 89-I22; 5, 44-49, 89-II9.

Sanjust i Latorre, Cristina, 2009, L'obra del monestir de Pedralbes al segle Xv: aportació a l'estudi de les intervencions arquitectòniques a través de l'anàlisi dels llibres de comptes, Barcelona, Universitat de Barcelona.

Serrano Morales, José Enrique, I898-99, Reseña histórica en forma de diccionario de las imprentas que han existido en Valencia, València, Imprenta de F. Domènech.

Siete Iglesias, Marqués de, I957, "Catálogo de los caballeros y religiosos de la Orden de Montesa (I3I9-I7O0)”, Hidalguía 2I, I77-92.

Soler, Abel; Jordà, Rafa, 2005, Ròtova: geografia, història, patrimoni, Ròtova, Ajuntament de Ròtova.

Soler, Abel, 20I3, "Joan Roís de Corella enfront d’alguns problemes socials i polítics del seu temps", Afers: Fulls de Recerca i Pensament 76, 6r7-33.

Soler, Abel, 20I4, "Joan Roís de Corella i Miquel Pérez: relacions familiars”, Revista de Cancioneros, Impresos y Manuscritos 3, $\mathrm{I}^{2-}{ }^{-} 6$.

Soriano Triguero, Carmen, I995, "La reforma de las clarisas en la Corona de Aragón (ss. XV-XVI)", Revista de Historia Moderna I3/I4, I85-98.

Teixidor, José, I895, Antigüedades de Valencia, València, Librería de Pascual Aguilar.

Teixidor de Otto, María Jesús; Domingo Pérez, Concepción, I989, “Les séquies i els traçats urbans a València” dins Los paisajes del agua: libro jubilar dedicado al profesor Antonio López Gómez, València, Universitat de València, 287-30I. 
Tintó Sala, Margarita, 1979, Cartas del Baile General de Valencia Joan Mercader, al rey Fernando de Antequera, València, Alfons el Magnànim.

Tomás Botella, Bernardo, 2OI3, "En los orígenes de la hacienda inquisitorial valenciana: la inspección de las cuentas del receptor Joan Ram-Escrivà (I482-I487)”, dins En el primer siglo de

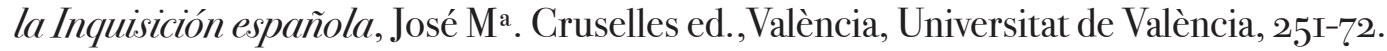

Torre y del Cerro, Antonio de la, 1924-25, "Precedentes de la Universidad de Valencia", Anales de la Universidad de Valencia 5, I75-303.

Torró, Jaume, ed., 2009, Sis poetes del regnat d'Alfons el Magnànim: Lluís de Requesens, Bernat Miquel, Martí Garcia, Rodrigo Dies, Lluís de Vila-rasa, Francesc Sunyer, Barcelona, Barcino.

Ventura, Jordi, I978, Inquisició espanyola i cultura renaixentista al País Valencià, València, Tres i Quatre.

Ventura, Jordi, I993, La Bíblia valenciana: recuperació de la història d’un incunable en català, Barcelona, Curial Edicions Catalanes.

Villalmanzo, Jesús, 1995, Joanot Martorell, biografía ilustrada y diplomatario, València, Ajuntament de València.

Villalmanzo, Jesús, I999, Ausiàs March: colección documental, València, Diputació de València.

Wittlin, Curt, I995, "Un text inèdit de Joan Roís de Corella: La Visió a la porta de la Senyora Nostra de Gràcia, del I487", A Sol Post 3, 257-68. 